\title{
Organizadores
}

Auxiliadora dos Santos Pinto

Bethânia Moreira da Silva Santos

Eva da Silva Alves

Márcia Dias dos Santos

Oziel Marques da Silva

\section{DIÁLOGOS ENTRE LUGARES II: língua(gem), educação e literatura}

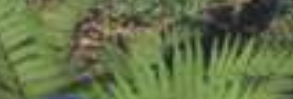

T. Temática

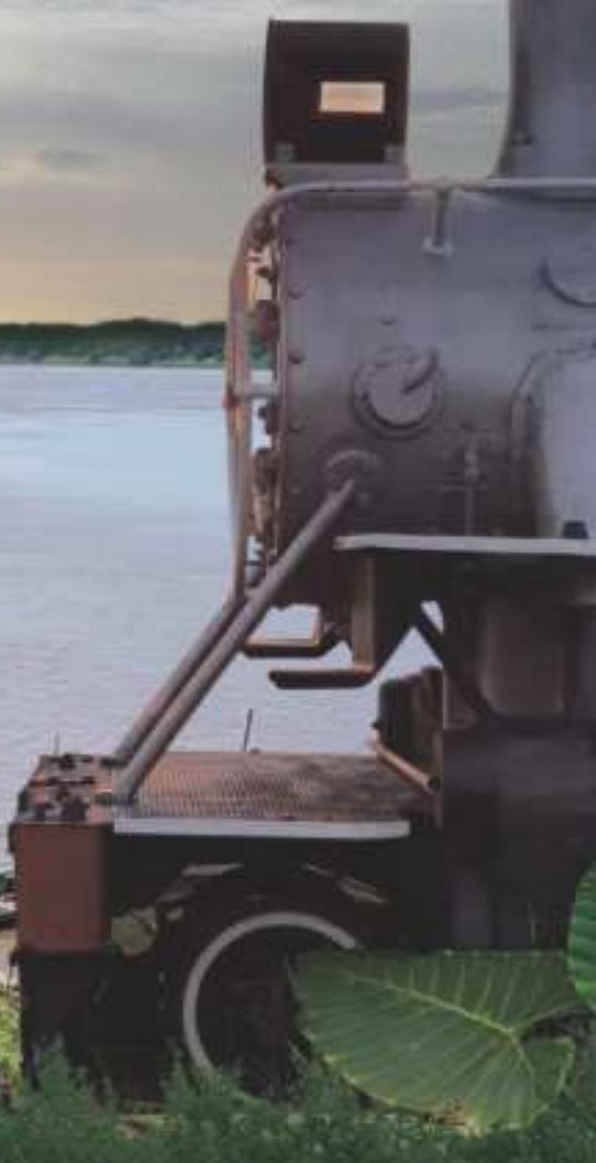




\section{DIÁLOGOS ENTRE LUGARES II: LÍNGUA(GEM), EDUCAÇÃO E LITERATURA}




\title{
Comissão científica
}

\author{
Antonella Gasbarri - Università degli Studi dell'Aquila \\ Carlos Alberto Bezerra Tomaz - Universidade Ceuma \\ Luiz Fernando Dias Pita - - UERJ \\ Maria Clotilde Henriques Tavares - UnB \\ Carlos Alberto Paraguassú-Chaves - UNIR
}

\section{Comissão editorial}

$\begin{array}{cc}\text { Eder Cassola Molina } & - \text { USP } \\ \text { Júlio César Barreto Rocha } & - \text { UNIR } \\ \text { Miguel Nenevé } & - \text { UNIR } \\ \text { Nair Ferreira do Amaral Gurgel } & - \text { UNIR } \\ \text { Valdir Vegini } & - \text { UNIR }\end{array}$




\author{
Auxiliadora dos Santos Pinto \\ Bethânia Moreira da Silva Santos \\ Eva da Silva Alves \\ Márcia Dias dos Santos \\ Oziel Marques da Silva \\ (Organização)
}

\title{
DIÁLOGOS ENTRE LUGARES II: LÍNGUA(GEM), EDUCAC̣ÃO E LITERATURA
}

Temática

Porto Velho - Rondônia

2021 
(C) by Auxiliadora dos Santos Pinto, Bethânia Moreira da Silva Santos, Eva da Silva Alves, Márcia Dias dos Santos, Oziel Marques da Silva

\author{
Temática Editora
}

Rua Mal. Deodoro, 1808

Centro Porto Velho-RO

(69) 9.9246-7839 tematicaeditora@gmail.com

\author{
Comissão Técnica \\ Preparação de originais e revisão \\ Abel Sidney \\ Rogério Mota \\ Capa
}

Dados Internacionais de Catalogação na Publicação (CIP)

D536

Diálogos entre lugares II : língua(gem), educação e literatura / organizadores: Auxiliadora dos Santos Pinto ... [et al.]. - 1. ed. - Porto Velho : Temática Editora, 2021.

ISBN 978-65-89078-25-8 (Livro digital)

1. Multiplicidade - educação. I. Pinto, Auxiliadora dos Santos, org. II. Santos, Bethânia Moreira da Silva, org. III. Alves, Eva da Silva, org. IV. Santos, Márcia Dias dos, org. V. Silva, Oziel Marques da, org. VI. Título.

CDD 370.11

CDU 37.01

Ficha catalográfica elaborada pela Bibliotecária Zane S. S. Santos CRB 11/1081 


\section{SUMÁRIO}

APRESENTAÇÃO 9

1 - A EDUCAÇÃO EM ARISTÓTEleS: UMA NECESSÁRIA VOLTA AOS CLÁSSICOS 21

Juliano Xavier da Silva Costa

Eva da Silva Alves

José Maiko Farias Amim

2 - A POLÍTICA PÚBLICA BRASILEIRA E O PERCURSO AVALIATIVO DO ENSINO SUPERIOR 39

Neidimar Vieira Lopes Gonzales

Tânia Regina Raitz

Verônica Gesser

3 - Perspectivas do programa Escola novo Tempo para PROMOÇÃO DA PLURALIDADE CULTURAL E LINGUÍSTICA EM RONDÔNIA:UM ESTUDO EM CONTEXTO ESCOLAR DA FRONTEIRA BRASIL-BOLÍVIA 56

Bethânia Moreira da Silva Santos

4 - FORMAÇÃO INICIAL DE PROFESSORES E MODALIDADE DA EDUCAÇÃO A DISTÂNCIA PARA A EDUCAÇÃO INCLUSIVA 85

Vera Mônica Queiroz Fernandes Aguiar Regina Célia Linhares Hostins

5 - A IMPORTÂNCIA DA LÍNGUA DE SINAIS PARA A FORMAÇÃO DA IDENTIDADE E CULTURA SURDA:DA TRAJETÓRIA HISTÓRICA À EXPERIÊNCIA EM JI-PARANÁ-RO 119

Maria de Lourdes Vargas

Maria Cecília Correa de Souza

Jaqueline Custodio Chagas Soares

6 - A FORMAÇÃO DOCENTE: UMA PRÁTICA REFLEXIVA PARA A TRANSFORMAÇÃO 157

Vera Mônica Queiroz Fernandes Aguiar 
7 - A VIRADA LINGUíSTICA E AS CONCEPÇÕES DE LÍNGUA E LINGUAGEM NUMA PERSPECTIVA FILOSÓFICA: CONTRIBUIÇÕES PARA OS ESTUDOS DA FILOSOFIA DA LINGUAGEM 179

Adriana Fernandes

Rita Nocetti

Selena Castiel

8 - ENSINO REMOTO NA EDUCAÇÃO BÁSICA: DESAFIOS, POSSIBILIDADES E PERSPECTIVAS DA PRÁTICA DOCENTE DAS ESCOLAS MULTISSERIADAS MUNICIPAIS DE NOVA MAMORÉ 204

Ely Sandra Carvalho de Oliveira

Leidiane Ferreira da Silva

9 - O CORPO COMO ESPAÇO DE INTERDISCIPLINARIDADE: O DIÁLOGO ENTRE A FILOSOFIA E A EDUCAÇÃO FÍSICA 218

Alyne de Fátima Lourenço dos Santos

Augusto Rodrigues de Sousa

João Paulo Silva Martins

10 - O TRABALHO DOCENTE NA CONSTRUÇÃO DO CONHECIMENTO: OS DESAFIOS ENFRENTADOS PELOS PROFESSORES 238

Edney Costa Souza

Tânia Regina Raitz

Fábio Rychecki Hecktheuer

11 - A PRÁTICA EDUCATIVA LÚDICA COMO FERRAMENTA DE LINGUAGEM PARA O PROCESSO DE ENSINO E APRENDIZAGEM 252

Deigna Lais Oliviak

Sâmia de Oliveira Brito Freire

Selena Castiel Gualberto Lima

12 - MAPAS CONCEITUAIS - UMA ABORDAGEM REFLEXIVO-ANALÍTICA A RESPEITO DA APRENDIZAGEM COM SIGNIFICADO 278

Daiany da Silva Ferreira 
13 - ESTUDANTES ENFERMOS: O DIREITO À ASSISTÊNCIA EDUCACIONAL HOSPITALAR E DOMICILIAR 293

Vera Mônica Queiroz Fernandes Aguiar

Regina Célia Linhares Hostins

14 - PROTEÇÃo DE RECURSOS HIDRÍCOS NA SUB-BACIA RIO CANDEIAS 316 Ocilene Gonçalves Soares

15 - IDENTIDADES SOCIOLINGUÍSTICAS E CULTURAIS: UM ESTUDO NA FALA DE MORADORES DO BAIRRO CRISTO REI, EM GUAJARÁ-Mirim(RO) 342 Auxiliadora dos Santos Pinto

Eunaia dos Santos Mercado

Diana da Silva Barroso

16 - MEMÓRIA E DESAFIOS CONTEMPORÂNEOS DE POPULAÇÕES NEGRAS NA AMAZÔNIA SUL-OCIDENTAL BRASILEIRA 367

Joely Coelho Santiago

Rosália Aparecida da Silva

17 - A BÍBLIA É A ESPADA DO ESPÍRITO E A HARPA CRISTÃ É O CANIVETE: O MOVIMENTO PENTECOSTAL E A SUA HINOLOGIA 394

Josué Passos de Melo

18 - FRAGMENTOS HISTÓRICOS DA EDUCAÇÃO TEOLÓGICA NO PENTECOSTALISMO BRASILEIRO NAS DUAS ÚLTIMAS DÉCADAS DO PERÍODO DA PRIMEIRA REPÚBLICA - 1910 A 1930: PRIMEIRAS TENTATIVAS METODOLÓGICAS 417

Josué Passos de Melo

19 - Catequese e assistencialismo no Vale do Guaporé/Mamoré (RO), FRONTEIRA BRASIL-BOLÍVIA 443

Auxiliadora dos Santos Pinto

Joely Coelho Santiago

Rosália Aparecida da Silva 
20 - A METAMORFOSE ANIMAL E ESPACIAL EM MISTERIOS DE LA SELVA AMAZÓNICA 467

Edimilson de Sousa Macedo

João Pedro da Silva Antelo

21 - NAVEGANDO PELA AMAZÔNIA ALÉM DAS FRONTEIRAS: UMA LEITURA DO IMAGINÁRIO TUPEBA E DA POÉTICA DE MARTA CORTEZÃO 481

Vânia Maria do S. Alvarez

22 - A DESCOlONIZAÇÃo EM GALVEZ, IMPERAdOR DO ACRE: MÁRCIO SOUZA E O DISCURSO IRÔNICO DA FACE DO COLONIZADOR 517

João Pedro da Silva Antelo

Mara Genecy Centeno Nogueira

23 - AS NARRATIVAS NAVEGANTES NAS ÁGUAS DO MAMORÉ: OS ENCANTAMENTOS NA VOZ DOS RIBEIRINHOS 530

Daiane de Castro Eurico

Ester Chao Ojopi Simo

Márcia Dias dos Santos

24 - O FEMININO NA OBRA NIKETCHE: UMA HISTÓRIA DE POLIGAMIA, DE PAULINA CHIZIANE 552

Jéssica Vivilane Pereira Freitas

Maria Viviane Pereira Freitas

Lisiane Oliveira e Lima Luiz 


\section{APRESENTAÇÃo}

\section{A coletânea Diálogos entre lugares II: Língua(gem),}

educação e literatura traz discussões que abordam várias áreas de estudos. Essa diversidade é compreendida como uma colaboração para um profícuo diálogo entre diferentes linguagens. Incide neste sentido, a relação dialogada desses lugares de pesquisa, de acontecimentos, de manifestações que se articulam para que se desdobrem em vozes que serão ouvidas, compreendidas e discutidas nos âmbitos acadêmicos e/ou outros lugares nos quais as condições de pesquisadores sejam reveladas como lugares múltiplos de reivindicações.

Compreendendo a importância desses diálogos, nossas discussões iniciais trazem o artigo A educação em Aristóteles: uma necessária volta aos clássicos, no qual, os pesquisadores Juliano Xavier da Silva Costa, Eva da Silva Alves e José Maiko Farias Amim apresentam reflexões acerca da concepção de educação em Aristóteles, esboçando as relações que o filósofo grego estabeleceu entre ética, política e educação. As reflexões apontam para a indispensável necessidade de se pensar uma educação integral, que veja o homem em todos os seus aspectos e, principalmente, o homem em relação com os outros, com a cidade, visto que a educação visa à formação de bons cidadãos, cujo resultado será sentido por todos, em todas as instâncias sociais. Daí a necessidade de uma volta à concepção clássica de educação: devemos (re) pensar a educação de forma a não a desvincular da ética e da política, buscando inserir em nossas reflexões e ações educacionais as inesgotáveis contribuições dos clássicos acerca da educação. 
No artigo A política pública brasileira e o percurso avaliativo do Ensino Superior as autoras Neidimar Vieira Lopes Gonzales, Tânia Regina Raitz e Verônica Gesser discutem sobre percurso da avaliação do ensino superior brasileiro. O objetivo foi compreender o processo inicial e o percurso das políticas públicas para avaliar o ensino superior no Brasil. Trata-se de uma pesquisa de revisão de literatura de caráter descritivo. Para embasamento teórico a pesquisa utilizou-se os estudos de Freitas e Verhine (2012), Vianna (2014) e Luft (2018). O estudo revela que as práticas avaliativas desenvolvidas nos diferentes países tornam possíveis compreender as mudanças referentes a educação que acontecem no mundo globalizado, uma vez que os governantes em âmbito nacional e internacional se valem das avaliações normativas e padronizadas como mecanismos para controlar (regular), fiscalizar e prestar contas, bem como reformar os seus sistemas educativos. Identificou-se que o Brasil tem investido em políticas públicas para a avaliação da educação superior, promovendo mudanças no processo avaliativo desde o ano de 1983 com a criação do Programa de Avaliação da Reforma Universitária (PARU) e outros, até a criação do Sistema Nacional de Avaliação da Educação Superior, o Sinaes, por meio da Lei n. 10.861, de 2004, que ainda está em vigor.

O artigo Perspectivas do Programa Escola Novo Tempo para promoção da pluralidade cultural e linguística em Rondônia: um estudo em contexto escolar da fronteira BrasilBolívia, da autora Bethânia Moreira da Silva Santos, apresenta resultados de uma pesquisa sobre as possibilidades de favorecimento de flexibilização de currículos da escolar de tempo integral para a Promoção da Pluralidade Cultural e Linguística em 
Rondônia. A pesquisa teve como objetivo geral: analisar as perspectivas do Programa Escola Novo Tempo e seu desenvolvimento no município de Guajará-Mirim fronteira com a Bolívia. A pesquisa de cunho bibliográfico, documental e de campo foi desenvolvida no período de agosto a novembro 2019. Subsidiaram as discussões, entre outros autores, Santos (2000); Walsh (2009); Santomé (2013). Os resultados apresentados evidenciam que a pedagogia da presença faz toda a diferença na mudança de comportamento dos estudantes e da comunidade escolar tornando-o bastante favorável para promoção da pluralidade cultural e linguística em Rondônia, em específico a escola da fronteira.

\section{O artigo Formação inicial de professores e modalidade da} educação a distância para a educação inclusiva, das pesquisadoras Vera Mônica Queiroz Fernandes Aguiar e Regina Célia Linhares Hostins, apresenta reflexões no sentido de que há muito a ser feito para que se consolidem políticas públicas de educação especial na escola e na sociedade. A Declaração de Salamanca demarcou princípios, políticas e práticas na área das necessidades educativas especiais. As discussões e análises foram baseadas nos estudos de Nóvoa (1992), Aguiar; Duarte (2005), Silva; Castro (2008), Mainardes; Marcondes (2009), Ball (2014), Grimm; Sossai; Segabinazzi (2016), André (2009) e Packer (2017).

Discussões sobre questões históricas, teóricas e metodológicas da educação de surdos, reforçando a importância da Língua Brasileira de Sinais no processo educativo, social, político e cultural são apresentadas no artigo A importância da língua de sinais para a formação da identidade e cultura surda: da trajetória histórica à experiência em Ji-Paraná-RO, das 
pesquisadoras Maria de Lourdes Vargas, Maria Cecília Correa de Souza e Jaqueline Custodio Chagas Soares. Entrelaçando a teoria com a prática, as autoras apresentam experiências sobre a inclusão de pessoas surdas no processo educacional do município de JiParaná-RO, ressaltando assim, a relevância do contato entre os estudantes surdos e a aprendizagem da Libras para o empoderamento e desenvolvimento da Comunidade Surda.

Em A formação docente: uma prática reflexiva para a transformação, a pesquisadora Vera Mônica Queiroz Fernandes Aguiar realiza uma análise sobre a formação do professor direcionada à prática reflexiva, conjecturando acerca da respectiva transformação que abrange o processo de aprendizagem. O texto debate que, para o sucesso do acadêmico, após o término do curso, devem concorrer diversas fontes, dentre elas a prática de um professor dotado de sabedoria intelectual, psicológica e espiritual, desde que a instituição prime pela qualificação de seu corpo docente. Em virtude das novas tendências atinentes ao sistema educacional e do mercado de trabalho, exige-se, por parte dos profissionais, habilidades, competência e compromisso.

As pesquisadoras Adriana Fernandes, Rita de Cássia Pessoa Nocetti e Selena Castiel, no artigo A virada linguística e as concepções de língua e linguagem numa perspectiva filosófica: contribuições para os estudos da Filosofia da Linguagem, apresentam algumas reflexões sobre a "virada linguística" ocorrida durante o século XX e as concepções de língua e linguagem numa perspectiva filosófica. Como proposta inicial, as autoras discutem sobre a virada através das proposições teórico-filosóficas desse contexto, considerando, principalmente, as contribuições de autores como Gadamer, Wittgenstein, Habermas, Austin, Saussure 
e Humboldt. Assim, como estratégia metodológica, as autoras realizam um percurso de leituras desde as primeiras investigações na história das línguas, a fim de interpretarem suas contribuições para os estudos da filosofia da linguagem. Para tanto, fundamentaram as discussões e análises em alguns pressupostos teóricos delineados por Mikhail Bakhtin, em especial no que diz respeito aos conceitos de língua e linguagem, numa perspectiva filosófica, e outros conceitos relacionados, considerados fundamentais para detectar a reflexão que deles resulta.

Nas discussões apresentadas no texto Ensino remoto na educação básica: desafios, possibilidades e perspectivas da prática docente das escolas multisseriadas municipais de Nova Mamoré, as pesquisadoras Ely Sandra Carvalho de Oliveira e Leidiane Ferreira Silva trazem resultados de uma pesquisa realizada sobre o ensino remoto ofertado para alunos da zona rural do município de Nova Mamoré-RO. Diante do contexto pandêmico causado pela Covid-19, verificaram que as dificuldades fizeram com que os professores ressignificassem suas práticas para ensinar sem a presença física do aluno.

O estudo realizado por Alyne de Fátima Lourenço dos Santos, Augusto Rodrigues de Sousa, João Paulo Silva Martins, O corpo como espaço de interdisciplinaridade: o diálogo entre a filosofia e a educação física, traz contribuições relevantes ao problematizar a interdisciplinaridade e a fragmentação curricular. Defende a Educação Integral como forma de integrar diferentes saberes e possibilidades de ser efetivo, como possibilidade de experiências de integração não só dos professores, mas, também, das instituições. A proposta almeja que as instituições de ensino possam ampliar os horizontes e superar a fragmentação curricular 
que impossibilita o relacionamento espontâneo entre o conhecimento do corpo com a vida cotidiana.

No artigo $\mathbf{O}$ trabalho docente na construção do conhecimento: os desafios enfrentados pelos professores, os autores Edney Costa Souza, Tânia Regina Raitz e Fábio Rychecki Hecktheuer, por meio de um estudo bibliográfico procuram evidenciar como o trabalho docente pode influenciar na construção de uma sociedade justa e igualitária. $\mathrm{O}$ artigo foi fundamentado nos estudos de Gadotti (1998), Nóvoa (2019), Cani e Segnini (2020). Refletindo sobre as características que preconizam o trabalho docente e a prática no dia a dia a pesquisa evidencia que o professor assume uma carga intensa de trabalho, pois além de desenvolver o seu trabalho com qualidade, necessita se desdobrar para atender as necessidades oriundas do sistema, que vão desde o planejamento de aulas a ações burocráticas administrativas. Dessa forma, os autores consideram a importância de as instituições terem um olhar humanizado frente as práticas docentes, no sentido de compreender que os professores, antes de ser um profissional, também é humano, com falhas, problemas pessoais. Diante disso o conhecimento e o trabalho docente devem ser pensados a partir de espaços democráticos, a fim de formar uma sociedade mais justa e igualitária.

Por meio da pesquisa bibliográfica, no artigo A prática educativa lúdica como ferramenta de linguagem para o processo de ensino e aprendizagem, as autoras Deigna Lais Oliviak, Sâmia de Oliveira Brito Freire e Selena Castiel Gualberto Lima discutem sobre a prática educativa lúdica como ferramenta de linguagem para o processo de ensino e aprendizagem. A autoras trazem evidências que o estímulo e a criatividade são pontes prazerosas 
para o desenvolvimento do ensino, consubstanciando a construção plena através do lúdico. Os resultados apontam que através das ferramentas pedagógicas baseadas no lúdico e num ambiente motivador, a aprendizagem ocorre de maneira mais estimuladora, vislumbrando o desenvolvimento de dimensões que possibilitam a integralidade dos saberes.

A pesquisadora Daiany da Silva Ferreira apresenta-nos interessantes reflexões sobre o uso dos mapas conceituais no ensino da Física. No artigo Mapas conceituais - uma abordagem reflexivo-analítica a respeito da aprendizagem com significado, a pesquisadora discute conceitos a partir de autores como Dantas, et al. (2018), Souza Junior et al. (2017), Rocha e Spohr (2016), Palandi (2011), Correia et al. (2010) e Moreira (2010), de modo a elucidar questões relacionadas à utilização de mapas conceituais para uma aprendizagem significativa sem realizar mudanças drásticas no processo didático.

No artigo Estudantes enfermos: o direito à assistência educacional hospitalar e domiciliar, as pesquisadoras Vera Mônica Queiroz Fernandes Aguiar e Regina Célia Linhares Hostins discutem que as classes escolares em hospitais consistem em alternativas de atendimento educacional para estudantes hospitalizados, as quais garantem que, no período de permanência no hospital, sejam providas suas necessidades educativas e direitos de cidadania, pelo processo de escolarização. Discute-se que as celeumas relativas à saúde não obstam a responsabilidade de oportunizar os processos educacionais. A educação e a saúde se cruzam por meio da pedagogia hospitalar, para que o médico e o pedagogo possam realizar as tarefas distintas e conexas. 
O artigo intitulado Proteção de recursos hídricos na subbacia rio Candeias, de autoria de Ocilene Gonçalves Soares, discute sobre a importância da proteção e/ou recuperação dos recursos hídricos. O texto destaca os impactos causados pelo verão amazônico no rio Candeias, manancial que abastece a cidade de Buritis-RO, e as ações implementadas pela Agência Reguladora de Serviços Públicos de Buritis (Agerb) na tentativa de proteger o referido manancial de forma contínua e envolvendo os diversos segmentos da sociedade. Os resultados da pesquisa demonstram a importância das ações implementadas pela Agerb, considerando, também, o que preconiza a Lei das águas do Brasil, a qual defende a gestão dos recursos hídricos de forma descentralizada e participativa, envolvendo o poder público, os usuários de recursos hídricos e as comunidades.

Identidades sociolinguísticas e culturais: um estudo na fala de moradores do bairro Cristo Rei, em Guajará-Mirim(RO), é uma pesquisa apresentada pelas autoras Auxiliadora dos Santos Pinto, Eunaia dos Santos Mercado e Diana da Silva Barroso, na qual, discutem sobre a constituição das identidades sociolinguísticas e culturais de moradores do bairro Cristo Rei, na Cidade de GuajaráMirim(RO), destacando-se a construção da Estrada de Ferro Madeira Mamoré e, posteriormente, a decadência do $2^{\circ}$ Ciclo da Borracha como processos históricos que contribuíram para a formação e povoamento do referido bairro. Devido a sua localização geográfica, o processo de ocupação deu-se com maior facilidade, sendo fatores determinantes: a área das margens do rio Mamoré, a proximidade do comércio da cidade e da própria construção da EFMM. Os resultados da pesquisa, do tipo sociolinguística, evidenciaram que as identidades sociolinguísticas 
e culturais dos moradores do bairro Cristo Rei foram constituídas por elementos históricos, culturais e simbólicos e contribuem para a constituição da histórica, linguística e cultural do município de Guajará-Mirim(RO).

Com a intenção de investigar e registrar o emergir de vozes de remanescentes de quilombos na região, que por muito tempo foram postos à invisibilidade, e marginalizados pelo Estado e silenciados pela História, assim como suas conquistas, lutas e desafios no cenário político atual, as pesquisadoras Joely Coelho Santiago e Rosália Aparecida da Silva no apresentam discussões no texto Memória e desafios contemporâneos de populações negras na Amazônia Sul-Ocidental brasileira. O estudo apresentado pelas pesquisadoras, além de ser uma importante fonte de dados é uma contribuição para a valorização e o reconhecimento de vozes marginalizadas por estruturas sociais, colocam em debate esse território de fronteira amazônica.

No artigo intitulado A Bíblia é a espada do espírito e a Harpa Cristã é o canivete: o movimento pentecostal e a sua hinologia, o autor Josué Passos de Melo, apresenta alguns elementos do Movimento Pentecostal e a sua hinologia de 1917 até a atualidade. A discussão é construída a partir da pesquisa bibliográfica, com utilização do método político-cultural. Os resultados da pesquisa demonstram que o Movimento Pentecostal teve dois ramos étnicos, um branco e outro negro e que a musicalidade do Pentecostalismo negro influenciou, significativamente, o contexto religioso e o contexto social.

No artigo intitulado Fragmentos históricos da educação teológica no pentecostalismo brasileiro nas duas últimas décadas do período da Primeira República - 1910 a 1930: 
primeiras tentativas metodológicas, Josué Passos de Melo apresenta discussões baseadas em textos narrativos produzidos pelos pioneiros do movimento pentecostal e em obras produzidas a partir dessas narrativas. Os resultados da pesquisa mostram que as principais estratégias utilizadas na formação de novas lideranças, conforme a doutrina do movimento, foram a utilização de materiais impressos e a realização de seminários presenciais, as quais contribuíram para a constituição da história da educação teológica do movimento pentecostal na Amazônia.

Catequese e assistencialismo no Vale do Guaporé/Mamoré(RO), fronteira Brasil-Bolívia, das pesquisadoras Auxiliadora dos Santos Pinto, Joely Coelho Santiago e Rosália Aparecida da Silva, é uma pesquisa em que as autoras destacam, a partir da análise da obra Memórias de Monsenhor Francisco Xavier: Dom Rey, de autoria de Izabel de Oliveira Assunção, alguns aspectos do trabalho de catequese e assistencialismo liderado pelo missionário Dom Rey nos Vales dos rios Mamoré-Guaporé. Os resultados da pesquisa evidenciam a importância do trabalho missionário de Dom Rey na formação religiosa, política e social dos referidos Vales, no contexto da Amazônia rondoniense.

Os pesquisadores Edimilson de Sousa Macedo e João Pedro da Silva Antelo trazem em A metamorfose animal e espacial em Misterios de la selva amazónica. A pesquisa norteada pela da teoria animal estudo visa apresentar uma análise do espaço como um recurso estético e de transformação na obra da escritora Gabby Cuellar Camacho buscando a aproximação dos seres humanos com os animais ou com animalidade. 
Em Navegando pela Amazônia além das fronteiras: uma leitura do imaginário tupeba e da poética de Marta Cortezão, Vânia Maria do S. Alvarez traz discussões sobre a poética da amazonense Marta Cortezão. O estudo tentar elucubrar o entrecruzar do fazer da autora que se deságua nos mitos gregos e as musas clássicas, reinterpretadas pela ação das guerreiras icamiabas e transborda em devaneios e contemplações dos cenários que a poeta viveu.

João Pedro da Silva Antelo e Mara Genecy Centeno Nogueira apresentam em sua pesquisa um olhar sobre o processo de descolonização tendo como corpus a voz de Márcio Sousa. No artigo A descolonização em Galvez, imperador do Acre: Márcio Souza e o discurso irônico da face do colonizador, os pesquisadores visam analisar marcas discursivas da colonização durante o processo da chamada Revolução Acreana promovida pela disputa do "ouro branco" da Amazônia, que era a borracha. O estudo é pautado a partir das ideias de autores do pós-colonialismo e do Decolonialismo, tais como: Said, Mignolo, Dussel e Aníbal Quijano.

Remando a canoa da pesquisa, as autoras Daiane de Castro Eurico, Ester Chao Ojopi Simo e Márcia Dias do Santos nos apresentam em As narrativas navegantes nas águas do Mamoré: os encantamentos na voz dos ribeirinhos, o registro de memória dos moradores das margens do rio Mamoré. As autoras nos fazem os registros de lendas e mitos e analisam como essas histórias atravessam e são atravessados por esses sujeitos.

As pesquisadoras Jéssica Vivilane Pereira Freitas, Maria Viviane Pereira Freitas e Lisiane Oliveira e Lima Luiz, no artigo $\mathbf{O}$ feminino na obra Niketche: uma história de poligamia, de 
Paulina Chiziane, apresentam uma análise da narrativa citada, da escritora moçambicana Paulina Chiziane. A pesquisa foi mediada pela discussão das teóricas Perrot (2008), Rocha-Coutinho (1994), entre outras e apresenta discussões sobre a figura feminina na narrativa como evidência do papel marginal que muitas tiveram/têm na sociedade.

Por fim, este livro nos provoca a refletir sobre os temas linguagem, literatura e educação em um contexto marcado pela pluralidade sociocultural e linguística, de onde ecoam vozes que são constituídas, cotidianamente, em um contexto muitas vezes marcado por um lugar descentralizado, que sobrevive nas/das margens. Trata-se de um livro destinado aos educadores e pesquisadores contemporâneos, especialmente, aos que têm interesse de compreender os discursos, as narrativas históricas, as práticas educacionais e culturais e as relações de poder instauradas entre os sujeitos que vivem na Amazônia brasileira.

Boas leituras,

As organizadoras e o organizador 


\title{
1 \\ A EDUCAÇÃo EM ARISTÓTELES: UMA NECESSÁRIA VOLTA AOS CLÁSSICOS
}

\author{
Juliano Xavier da Silva Costa ${ }^{1}$ \\ José Maiko Farias Amim² \\ Eva da Silva Alves ${ }^{3}$
}

\section{INTRODUÇÃO}

Este artigo discorre acerca da concepção de educação na Grécia antiga e a influência que Aristóteles recebeu dos homens de letras que o antecedeu. A partir de suas obras: A Política e Ética a Nicômaco, percebe-se muito bem o quanto Aristóteles preza pela educação do indivíduo, para que ele possa viver melhor em sua

1 Doutorando em Educação pelo Doutorado Interinstitucional em Educação Faculdade Católica de Rondônia (FCR) e Universidade do Vale do Itajaí (UNIVALI), Mestre em Filosofia pela Universidade Federal do Mato Grosso (UFMT) 2016, especialista em Metodologia do Ensino Superior (FCR) 2014, licenciado em Filosofia pela Faculdade Católica de Rondônia (FCR) 2013 e Pedagogia (UniSerra) 2018. E-mail: julianoxavier89@hotmail.com

${ }^{2}$ Graduado em Filosofia pela Faculdade Católica de Rondônia (FCR). Membro do Grupo de Pesquisa "Desafios Socioambientais, Saberes e Práticas na Amazônia" da Faculdade Católica de Rondônia (FCR).E-mail: jose.amim@sou.fcr.edu.br

${ }^{3}$ Doutoranda em Educação pela Universidade do Vale do Itajaí (Univali) - Dinter com a Faculdade Católica de Rondônia (FCR). Membro do Grupo de Estudos Interdisciplinares das Fronteiras Amazônicas (Geifa) da Universidade Federal de Rondônia (UNIR); membro do Grupo de Estudos e Pesquisa Interdisciplinares Afro e Amazônicos (Gepiaa), da UNIR; membro do Grupo de Estudos e Pesquisa Contextos da Educação da Criança, da Universidade do Vale do Itajaí (Univali) e membro do Grupo de Pesquisa Desafios Socioambientais, Saberes e Práticas na Amazônia, da Faculdade Católica de Rondônia (FCR). Bolsista da Faculdade Católica de Rondônia (FCR) e da Fundação de Amparo à Pesquisa de Rondônia (Fapero).E-mail: evaalvesgm@yahoo.com 
comunidade. Não é finalidade do presente artigo expor todos os elementos e categorias que constituem a educação clássica, por conta de tão vasta e complexa amplitude teórica que caracteriza a cultura grega, no entanto, pretende-se trazer presente alguns elementos importantes que contribuíram para a formação do pensamento clássico acerca do presente tema, especificamente, a educação em Aristóteles.

Antes de iniciar a reflexão direcionada à educação em Aristóteles, foi definido, de forma breve, o conceito de educação e, logo após, foi analisada a história da educação na Grécia Clássica.

Para iniciar uma reflexão acerca da educação em Aristóteles, faz-se necessário estabelecer alguns pontos acerca da educação clássica, visto que foi deste terreno fértil que Aristóteles retirou certos princípios direcionadores para a sua concepção de educação, através da Paideia. A educação grega era inteiramente voltada para a formação do bom cidadão; para tal, era utilizado todo o arcabouço cultural herdado dos poetas gregos. Política, ética, cultura e educação eram indissociáveis na Grécia Clássica. Aristóteles representa o ápice dessa relação.

Aristóteles tem influência de muitos elementos educacionais da Grécia antiga, como: o nascimento da filosofia, a retórica e a ciência política. $\mathrm{O}$ pensador estagirita busca, a partir de sua observação, moldar caminhos para que o cidadão possa ser feliz através da boa convivência em sociedade, partindo do indivíduo para o coletivo. A preocupação da educação em Aristóteles é responder de que maneira o homem pode se tornar virtuoso, contribuir para vida política e alcançar a felicidade.

Devemos lembrar também que o modelo de educação, proposto por Aristóteles, não depende exclusivamente do indivíduo, mas também do Estado. É o Estado responsável pela 
educação de seus cidadãos, e, com o agir de cada cidadão, este se torna virtuoso, consequentemente teremos um Estado virtuoso, através de uma ação coletiva.

O ponto forte da educação, portanto, está na práxis, na ação do dia a dia, em praticar coisas boas para que se torne bom, com isso o homem alcançará a felicidade proposta por Aristóteles, visto que, para este, o agir virtuoso consiste na repetição de boas ações. Tendo a educação a finalidade de formar indivíduos, deve ela estimular o bom agir, através de um ambiente que propicie o desenvolvimento ético.

Esta pesquisa se justifica pelo fato de que reflexões acerca da educação precisam levar em conta as contribuições filosóficas acerca do tema. Dessa forma, devemos lançar luz acerca de novas possibilidades para a educação, tomando de empréstimo certos pontos de direção estabelecidos por Aristóteles. A frutífera relação entre educação e ética deve ser repensada e restabelecida, visto que o professor é um agente de transformação social, portanto sua função exige ética. No que diz respeito à relação política, cultura e educação, esta precisa ser saneada e reafirmada.

Através da análise das categorias centrais da educação clássica, da perfeita relação entre ética, política e educação, estabelecida pelos gregos, e da concepção ética de Aristóteles sobretudo em se tratando da relação entre hábito e ética -, esperamos lançar questionamentos que proporcionem uma reflexão necessária acerca das infinitas possibilidades que a concepção aristotélica de educação pode oferecer a professores, pesquisadores e políticos, abertos ao diálogo e sedentos por uma transformação social, operada pela educação. 


\section{HISTÓRIA DA EDUCAÇÃo NA GRÉCIA ANTIGA}

Falar acerca da educação na Grécia antiga é tarefa estimulante, embora os conceitos que utilizamos hoje não sejam adequados para se referir ao que os antigos sábios concebiam como tal. Na Grécia antiga foi moldando suas peculiaridades culturais e investindo na educação de seus cidadãos. A Grécia tornou-se uma sociedade completa em organização social, onde a educação é marco norteador, sendo até hoje, para todos, referência clássica de democracia e cultura.

Aristóteles contribuiu, juntamente com os gregos, na dimensão da valorização e formação do homem 'grego', ou seja, uma formação de bons cidadãos para a cidade. O modelo de pólis, que os gregos criaram, está totalmente ligado com a forma de educação que eles mantinham. Para apresentar essa organização e formação do homem grego deve-se recorrer à Paideia, a base de todo pensamento 'pedagógico' grego.

O homem grego é cultivado por meio de uma ação virtuosa que o leva a dominar e a formar a si mesmo e, com isso, agir de forma reta, preservando a harmonia social de toda a pólis. Percebe-se que a educação, nos moldes da Antiguidade Clássica, está vinculada com o processo de formação do cidadão, ou seja, encontra-se voltada para o desenvolvimento da vida coletiva.

Poderíamos começar nos perguntando: qual seria o lugar dos Gregos na história da educação? O grau elevado da organização do cidadão na pólis está totalmente vinculado com a prática da educação, onde o homem deve chegar à excelência.

Uma das características da educação grega era educar a partir da poesia, os grandes contos da Ilíada, Odisseia, assumiam a posição de instrumentos de formação do caráter do homem grego: 
Já não deves viver como criança - diz Atena Telêmaco, tens idade demais para isso. Não soube da alta honra que Orestes conquistou no mundo inteiro por ter acabado com Egito, o pérfido assassino de seu pai? Também tu, meu amigo - bem vejo que és belo e desempenhado -, tens força suficiente para que um dia te exaltem as novas gerações (Jaeger, 2010, p. 58).

A passagem acima ilustra perfeitamente as possibilidades educativas que poderiam ser tiradas das obras dos grandes poetas antigos, neste caso, o espírito bélico, a honra e a coragem. Os jovens e a sociedade se orientavam e aprendiam com os poemas. Portanto, com isso depreende-se que "Sem dúvida, os verdadeiros representantes da Paideia grega não são os artistas mudos escultores, pintores, arquitetos -, mas os poetas e os músicos, os filósofos, os retóricos e os oradores, quer dizer, os homens de Estado.” (Jaeger, 2010, p. 18).

A educação grega está enraizada na dimensão poética, musical, filosófica, retórica e sobretudo o mais essencial para a formação cultural do homem de Estado. Essas dimensões fundamentam de forma muito concreta e eficaz o pensamento grego. Ao se juntar a estas dimensões as "condições sociopolíticas adequadas”, pode-se dizer que, na Grécia Antiga, havia a possibilidade para uma sociedade bem formada, com uma cultura vigorosa.

A educação grega elementar tinha como cerne as leituras dos autores gregos Homero e Demóstenes (Nunes, 1978, p. 22). E nessa dimensão, segundo Nunes (1978), os métodos educacionais ali estabelecidos consistiam basicamente em ler, decorar e declamar os grandes poemas sob a supervisão do mestre ou na presença de familiares e amigos. No entanto, Aristóteles usará a indagação como método educacional. 
Nas obras de Aristóteles, sobretudo em Ética a Nicômaco, a Poética e a Política, a presença, através de citações, a diversos personagens que fazem parte do imaginário grego. A presença de grandes nomes da poesia grega, no texto aristotélico, demonstra o quão presente era o pensamento destes personagens na sociedade grega e, portanto, o quão tradicional é útil era, para o filósofo, trazer para a sua argumentação algo da produção literária da época, seja para exemplificar uma teoria, seja para ilustrar uma lição de vida como forma de educar seus filhos; evidenciando, assim, o fato de não haver antagonismos entre uma rigorosa reflexão filosófica e uma primorosa criação artística. Portanto, a literatura passa a ter, para Platão, Aristóteles e outros, uma função especial dentro de sua argumentação filosófica.

A quem os gregos da época de Platão e Aristóteles recorriam para ilustrar certos comportamentos que deveriam ser seguidos ou reprimidos? Fica claro que eram aos grandes poetas. Platão, por exemplo, foi um dos primeiros a debater sobre esse assunto, tanto que, em sua obra a República, exclui de sua comunidade ideal os poetas (Platão, 2011, p. 397), visto que os mesmos desfrutavam dessa importância ímpar, apresentando-se como fomentadores de determinados atos que, na perspectiva platônica, apresentavam um perigo à sociedade, visto que poderiam enaltecer os sentimentos vis e os instintos selvagens, ao invés de lançar louvores aos atos virtuosos que denotavam honra (Russell, 2015, p. 150-151). Isso demonstra o quão enraizado era o agir educativo com a cultura herdada, representados aqui por seus poetas.

Assim, Platão afirma que para a arte ter lugar em sua comunidade ideal, ela deve estar a serviço do Bem, deve trabalhar ao lado do filósofo (Reale, 1990, p. 151). Aristóteles, por outro lado, vê a literatura com outros olhos e passa a fazer um bom uso desse mesmo material que seu mestre havia, de certa forma, condenado. 
Por fim, sem dúvida alguma, o contexto da educação grega trouxe muitos elementos importantes, do qual grandes pensadores souberam usar muito bem. Aristóteles, a partir dos gregos, desenvolve uma reflexão acerca do agir virtuoso que melhor desenvolva as potencialidades sociais, onde o cidadão é educado para viver e agir bem em sociedade, possibilitando ao indivíduo, e ao coletivo, buscar a sua felicidade.

Nesse tópico é enfatizado alguns elementos importantes da educação clássica, desenvolvida pelos gregos, analisada, complementada e reafirmada por Aristóteles. A partir de agora, analisaremos alguns elementos fundamentais para formação educacional em Aristóteles.

\section{A RELAÇÃo ENTRE ÉTICA, POLÍTICA E EDUCAÇÃO}

A ética de Aristóteles, também chamada de ciência prática, é classificada como 'teleológica', ou seja, ela estuda os fins a que tendem todas as ações, e é nessa perspectiva que surge, em sua ética, a questão da 'eudaimonia', ou seja, a felicidade (Reale, 1990, p. 203). Ele afirma que todas as ações humanas tendem a um fim, a soma dessas ações e fins resulta na busca do supremo bem; tudo que o homem faz é em busca de um bem, mesmo que, através de um erro de cálculo do agente, esse bem se revele um mal (Aristóteles, 2008, p. 18).

Ora, o sumo bem a que todas as ações tendem é a felicidade; todo homem quer ser feliz, e é responsabilidade da ciência prática estudar os meios, os instrumentos, que os homens devem utilizar para alcançar esse fim, que é autossuficiente (Reale, 1990, p. 203).E é aí que entra o agir político, que é a parte mais importante, pois traz as reflexões teóricas para o campo da prática cotidiana. 
O estudo desse agir político, na concepção aristotélica, é de suma importância, visto que ele almeja a felicidade do todo, do coletivo, da cidade; conhecendo sua finalidade dentro de uma determinada sociedade, os homens irão utilizar de todos os meios disponíveis para atingir determinado fim, e é essa a tarefa da educação - e em se tratando de Aristóteles, uma educação moral (Aristóteles, 2008, p. 18).

Isso demonstra, também, a importância da relação, indissociável, entre agir político e educação, visto que ambos funcionam como harmonizadores da sociedade, pois estimulam os homens a buscarem o fim último de suas vidas, proporcionando o pleno desenvolvimento de suas potencialidades, e reforçam a ideia do homem enquanto um animal político, ou seja, como parte essencial de um todo.

Portanto, a busca da felicidade representa não só o fim último do indivíduo, mas de toda a sociedade, visto que, da mesma forma que a política visa garantir a harmonia do coletivo, a educação, aliada à ética, vem para ajudar o indivíduo a fazer um bom uso dos meios com os quais buscará sua parcela de felicidade, construindo, coletivamente, uma felicidade 'geral', preservando assim a harmonia do todo, visto que felicidade para Aristóteles é viver bem e agir bem, mas esse viver e agir bem são sempre um viver/agir em relação com os outros, daí a indissociação entre agir político, ética e educação.

Aristóteles divide a alma em duas partes: uma racional, e outra irracional (vegetativa e apetitiva), sendo que a vegetativa também está presente nas plantas e a apetitiva nos animais, portanto, o que diferencia o homem dos outros seres seria essa capacidade de colocar sua parte irracional sob o controle da racional (Reale, 1990, p. 204). 
Aristóteles difere duas formas de virtude: a intelectual, que é aquela adquirida com os estudos, é, portanto, uma construção que leva uma vida inteira; e a virtude moral ou virtude prática, que é aquela adquirida pelo hábito, portanto, nos tornamos virtuosos habituando-nos a atos virtuosos (Reale, 1990, p. 204). Afirma Aristóteles: "Com efeito, as coisas que temos de aprender antes de poder fazê-las, aprendemo-las fazendo" (Aristóteles, 1991, p. 29). Neste mesmo sentido, afirma ainda que: "Pelos atos que praticamos em nossas relações com os homens nos tornamos justos ou injustos" (Aristóteles, 1991, p. 30).

Da mesma forma que uma pessoa se torna vil, não por uma propensão natural, mas por praticar atos ruins - atos estes que, sem dúvida alguma, também foram adquiridos pela habituação -, também os atos virtuosos fazem do indivíduo um homem virtuoso.

Logo, o hábito é importantíssimo para a construção do caráter moral do indivíduo, tendo os legisladores uma tarefa e tanto ao criar suas leis, visto que é através delas que se os cidadãos desenvolverão bons hábitos, propiciando assim um espaço onde seja possível buscar o bem supremo, acarretando a harmonia social, através da realização plena dos indivíduos que repercute, consequentemente, na felicidade do coletivo: "Sendo, pois de duas espécies a virtude, intelectual e moral, a primeira, por via de regra, gera-se, e cresce graças ao ensino, pois isso requer experiência e tempo; enquanto a virtude moral é adquirida em resultado do hábito" (Aristóteles, 1991, p. 29).

Nosso filósofo argumenta que os jovens, instigados pelas paixões, tendem a menosprezar os aspectos teóricos da vida virtuosa (Aristóteles, 2008, p. 19), correndo o risco de se deixar levarem por uma maré de infortúnios. 
Assim, exigir de um jovem uma total entrega às questões teóricas acerca da virtude seria inútil, mas é natural que assim aconteça, no entanto, ainda assim é possível torná-los virtuosos, pois o caráter se constrói através da virtude moral, que adquirimos pelos hábitos, isso faz dos pais (em uma família) os responsáveis pela construção moral desses jovens, como também os professores (em uma escola) são coadjuvantes na construção moral destes, através da educação; e assim como os legisladores (em uma sociedade) são responsáveis por fomentar bons hábitos em seus cidadãos, através de boas leis, que, com o uso contínuo, se transformará em hábitos. Isto é confirmado pelo que acontece nos estados: os legisladores tornam bons os cidadãos por meio de hábitos que lhes incutem. Esse é o propósito de todo legislador, e quem não logra tal desiderato falha no desempenho da sua missão (Aristóteles, 1991, p. 30).

Portanto, fica clara a importância que Aristóteles deposita na educação, amalgamando-a com a ética e a política, visto que estas ajudam: $1^{\circ}$ na premente necessidade de habituação dos jovens às ações virtuosas, e também, $2^{\circ}$ na importância de trabalhar os meios (legisladores, educação, leis) para que esses hábitos sejam apreciados, apreendidos, realizados e repetidos, assim: "e não é coisa de somenos que desde a juventude nos habituemos desta ou daquela maneira. Tem, pelo contrário, imensa importância, ou melhor: tudo depende disso" (Aristóteles, 1991, p. 30).

\section{ARISTÓTELES E A EDUCAÇÃo}

Aristóteles discute sobre a educação do cidadão, reafirmando o quanto esta é essencial para vida na pólis, conduzindo o indivíduo a uma formação para o agir bem, cuja finalidade é a felicidade. Os livros Ética a Nicômaco e A Política são 
duas obras com princípios que enfatizam, entre outras coisas, o papel da educação na vida do cidadão, da cidade ou do Estado. Pode-se dizer que a Ética a Nicômaco nos ajudará a refletir acerca de alguns princípios pedagógicos que norteiam uma formação pela virtude, ou seja, uma pedagogia que propõem uma busca pela excelência, ajudando o indivíduo a potencializar-se. Em A Política pode-se encontrar certas bases teóricas para um processo educativo que capacite o indivíduo à busca da felicidade.

A educação do homem, em Aristóteles, é entendida como uma necessidade de "transformar a práxis humana em eupraxia (boa ação)”, (Santos; Esteves; Fragoso, 2012, p. 4). É a partir do hábito cotidiano que o cidadão vai se educando, sendo assim, é com a boa educação que o ser humano desenvolve a política, tornandose capaz de bem governar a pólis, a si mesmo e à família. "A cidade equilibrada não é obra do acaso, mas do conhecimento e da vontade" (Aristóteles, 1998, p. 531). A formação do homem em Aristóteles está totalmente vinculada ao coletivo, a educação forma o indivíduo para se tornar um cidadão, além disso, Aristóteles consagra a educação como uma das vias, um dos meios, que o homem utiliza para ser digno da felicidade, ou seja, para sua plena realização.

No livro Ética a Nicômaco, Aristóteles desenvolve uma profunda reflexão, direcionada a seu filho Nicômaco, onde se encontra uma análise sobre a excelência humana, afirmando que, para alcançar essa excelência, o indivíduo deve passar pelo processo de educação. Para Aristóteles pode-se dizer que a boa educação é a partir daquele que passou por várias etapas, começando desde criança e chegando até a fase adulta. Nesse sentido, adverte seu filho sobre a importância de uma boa educação. 
Outra característica da educação aristotélica é a preocupação com a formação voltada para coletivos. O legislador deve estar atento, segundo Aristóteles, para o êxito da educação coletiva. O legislador "deverá assegurar que os cidadãos se tornem bons, averiguar as atividades que produzirão esse resultado, e qual o fim da vida melhor" (Aristóteles, 1998, p. 537). A formação do cidadão é importante para o ser social, no entanto, se não visar o bem viver da pólis ou Estado, não tem sentido completo.

De fato, Aristóteles afirma que a constituição melhor é aquela que realiza o bem viver, a felicidade dos cidadãos, isto é, que realiza o próprio fim pelo qual a sociedade política é constituída. A esse respeito evoca a concepção da felicidade exposta na Ética a Nicômaco, segundo a qual os bens externos e os corpóreos, embora necessários, são inferiores aos da alma, isto é, à virtude, e entre as virtudes, as éticas são inferiores às dianoéticas, por isso a felicidade consiste essencialmente em viver segundo as virtudes dianoéticas, isto é, no exercício da inteligência mediante a pesquisa, o estudo e a cultura (Berti, 2012, p. 203).

Aristóteles defende que o querer viver bem é natural da existência social humana, todos anseiam pelo bem viver. Para viver bem, na concepção aristotélica, é necessário agir bem. Não é suficiente que o ser humano só pense de forma teórica em viver bem, é necessário à práxis (ação).É nesse sentido, do cidadão buscar agir bem em seu grupo de convivência, tendo bons comportamentos na Pólis e participação ativa na política, que a vida vai se tornando um bem viver, e a virtude torna-se presente na vida dos indivíduos. Nesse sentido, Aristóteles, em Ética a Nicômaco, estabelece reflexões acerca da ética e sua imprescindível relação com a educação, estimulando e direcionando o indivíduo a se tornar um homem virtuoso. 
No livro A Política, Aristóteles dedica dois capítulos especiais, embora todo seu livro seja formativo, para trabalhar mais a fundo a dimensão da educação do indivíduo, contudo, seu objetivo é formar bons cidadãos para a Pólis. $\mathrm{O}$ pensamento aristotélico enfatiza muito bem que a possibilidade da cidade (pólis) se tornar melhor é a partir da educação que seus legisladores dão aos seus jovens.

Para alcançar a perfeita educação, dentro do processo formativo do caráter humano, Aristóteles destaca três dimensões que devemos estar atentos, que são: a natureza, o hábito e o exercício. Estes fatores devem estar sintonizados no indivíduo.

Aristóteles observa a natureza humana e chega à conclusão que deve se buscar o que é necessário à vida humana. É nesse sentido que Aristóteles estabelece a clássica definição do homem como um "animal político" e não há como escapar disso, o homem é condicionado por natureza a viver em sociedade. Aristóteles entende como uma questão inata do ser humano a necessidade de se desenvolver no convívio na pólis, visto que, como bem disse ele, o homem não se basta a si.

Com a preocupação de bem organizar a cidade, desde muito cedo devem, os legisladores e mestres, pensar e desenvolver uma prática de educação para as crianças, pois, quanto mais cedo o indivíduo adentra um processo educativo, mais chances eles têm de criar bons hábitos e assim, tornar-se um sujeito autônomo, habituado a agir de forma correta, tornando virtuosa sua cidade, incutindo bons comportamentos.

No processo de educação clássica dos jovens, a primeira dimensão a ser aprimorada era o corpo, não demasiadamente, e só depois de um certo período vinha o cuidado com a alma. Com isso, Aristóteles estabelecia um equilíbrio educacional, corpo e alma, 
defendendo que esta era a melhor forma de "suprir as deficiências naturais".

Para Aristóteles, o indivíduo é formado com a finalidade de ser um bom cidadão, contribuindo politicamente com a sua cidade podendo ter acesso e participar ativamente das decisões para o melhor governo da cidade, tendo o entendimento e "as prescrições para uma educação que prepara as pessoas para a vida comunitária são as regras produtivas da excelência moral como um todo" (Aristóteles, 1985, p. 95).

No entanto, lendo as obras de Aristóteles, percebe-se que, apesar de as crianças, mulheres, os escravos e os velhos, serem habitantes da cidade, estes não são considerados cidadãos, portanto, não são aceitos na participação ativa do Estado e nem têm participação no processo educativo, visto que este é reservado aos futuros homens do Estado. Portanto, este processo educativo revela uma face cruel do pensamento aristotélico: os escravos eram necessários para este processo de formação, visto que os senhores e seus filhos - necessitavam de tempo livre para uma efetiva dedicação aos estudos, daí a necessidade dos escravos. Como poderiam os homens do Estado se dedicaram às questões da política se tivessem que fazer trabalhos fúteis e pesados? Os escravos são na perspectiva aristotélica -, por natureza, condicionados ao trabalho duro. Daí nasce a 'perfeita harmonia'.

A educação em Aristóteles tem o compromisso na formação para bem viver em sociedade, uma visível união entre o caráter e os bons hábitos, melhor para o indivíduo e melhor para a sociedade. É importante ressaltar que a educação em Aristóteles não é individualista - no sentido moderno de atomização -, pelo contrário, ela visa o pleno desenvolvimento do todo, acarretando na 
felicidade coletiva. $\mathrm{O}$ homem virtuoso tem como fim a vida em sociedade e não a vida individual.

Por fim, a educação em Aristóteles é uma prática constante na busca do aperfeiçoamento da natureza humana. Aristóteles tem claro que somos feitos para sermos felizes, e isso acontece na prática de uma educação virtuosa e coletiva, proporcionando um bem viver na sociedade, através do bem agir do cidadão, resultando assim na felicidade da pólis.

\section{CONSIDERAÇõES FINAIS}

A educação é um conceito instigante, nos provoca uma constante busca por melhorarias em nossa natureza humana, nas relações sociais e na política. O presente artigo está marcado por uma preocupação de demonstrar o quanto Aristóteles trabalhou para elaborar princípios que o ajudassem a contribuir para uma melhoria da pólis. A organização da cidade, com a política e a ética, da qual os cidadãos devem ser educados, leva o homem a buscar uma formação integral de suas potencialidades, tornando-se virtuoso e feliz.

Portanto, conclui-se que, para Aristóteles, a educação é um meio entre a teoria e a prática, entre a ética e a política, onde a formação do cidadão e a construção de uma sociedade mais harmoniosa para todos são as finalidades almejadas. De Aristóteles podemos aprender que a educação é a questão chave de toda sociedade. Nesse sentido, temos muito a aprender com a organização dos gregos, visto que até seus poemas tinham a característica educativa, ou seja, a educação não era algo fechado e apartado da sociedade civil, pelo contrário, a produção desta era condição primeira para aquela. 
A pesquisa demonstra perfeitamente a importância da tradição, da volta aos clássicos, para a formação dos indivíduos. Isto se dá pelo fato de os gregos enaltecerem seu passado de glória, suas conquistas e tradições. Daí a importância dos poetas para ilustrar um ideal de comportamento, seja para enaltecê-lo ou para condenálo.

Por fim, finalizamos ratificando a tese de que a sociedade grega tem muito a nos ensinar, no que tange à relação entre ética, política e educação, visto que estes são os pilares basilares de qualquer sociedade que busque desenvolver-se culturalmente, ajudando seus indivíduos a potencializar seus talentos, evidenciando a absoluta importância de garantir uma efetiva formação dos homens. A educação, com sua característica singular, busca os melhores meios para a formação dos indivíduos.

A discussão acerca de métodos, práticas e diretrizes educacionais, deve ater-se, caso realmente deseje formar integralmente os indivíduos, em olhar para o passado, para a tradição ocidental, e colher seus princípios norteadores, visto que eles foram, durante séculos, o chão em que se ergueu a civilização ocidental. Faz-se necessário não desprezarmos a tradição, os filósofos e seus tratados acerca da ética e política e, também, os grandes homens de letras que moldaram a cultura clássica.

Devemos realizar uma volta aos clássicos como forma de sintonizar os pilares que possibilitaram a realização da extraordinária civilização grega: ética, política e educação. Somente restabelecidas estas relações poderemos efetivar uma educação integral, humanista, clássica, e somente com esta formação clássica poderá o indivíduo viver e agir bem em sociedade, contribuindo socialmente para a harmonia do tecido social. 


\section{REFERÊNCIAS}

ARISTÓTELES. Ética a Nicômaco. Tradução de Mário da Gama Kury. Brasília: Editora Universidade de Brasília, 1985.

ARISTÓTELES. Ética a Nicômaco. Tradução de Antônio de Castro Caeiro. São Paulo: Atlas, 2009.

ARISTÓTELES. Política. Tradução de Antônio Campelo Amaral e Carlos Gomes. Lisboa: Editora Vega, 1998. Edição bilíngue. Coleção Vega Universidade/Ciências Sociais e Políticas.

BERTI, Enrico. Perfil de Aristóteles. São Paulo: Paulus, 2012.

HOBUSS, João. Aristóteles e a possibilidade da mudança de caráter. Dois pontos: Curitiba-PR (UFPR), São Carlos-SP (UFSCar), v. 10, n. 2, p. 291-313, outubro, 2013.

JAEGER, Werner Wilhelm. Paidéia: formação do homem grego. Tradução Artur M. Parreira. Adaptação do texto para a edição brasileira Mônica Stahel. Revisão do texto grego Gilson César Cardoso de Souza. 5. ed. São Paulo: Editora WMF Martins Fontes, 2010.

LAET, Sávio de Barros Campos. A política em Aristóteles: educação para a virtude e contemplação. Disponível em: $<$ http://filosofante.org/filosofante/not_arquivos/pdf/Aristoteles _Politica.pdf $>$.

NUNES, Ruy Afonso da Costa. História da educação na antiguidade cristã: o pensamento educacional dos mestres e escritores cristãos no fim do mundo antigo. São Paulo: Ed. da Universidade de São Paulo (EPU), 1978.

PLATÃO. A República. Rio de janeiro: Editora Nova Fronteira. 2011. 
RUSSELL, Bertrand. História da filosofia ocidental: a filosofia antiga. Rio de janeiro: Editora Nova Fronteira. 2015.

SANTOS, Lenilson Alves dos; ESTEVES, Julio Cesar Ramos; GONÇALVES, Carolina Fragoso. Ética, política e educação em Aristóteles. Congresso Internacional Interdisciplinar em Sociais e Humanidades. Niterói: ANINTER-SH/PPGSD-UFF, 3 a 6 de setembro de 2012, ISSN 2316-266x. 


\section{A POLÍTICA PÚBLICA BRASILEIRA E O PERCURSO AVALIATIVO DO ENSINO SUPERIOR}

Neidimar Vieira Lopes Gonzales ${ }^{4}$

Tânia Regina Raitz ${ }^{5}$

Verônica Gesser ${ }^{6}$

\section{INTRODUÇÃo}

A avaliação consiste num processo heterogêneo que deve proporcionar aos docentes informações para a organização da ação pedagógica atendendo os(as) alunos(as) em suas diversidades, desenvolvendo a sua capacidade investigativa e reflexiva diante dos fatos que vivenciam no seu dia a dia, especialmente no desempenho de suas atividades laborais no mundo do trabalho. Por isso, avaliar é um processo complexo e abstrato que exige que o/s avaliador/es conheça/m os pressupostos teóricos da avaliação educacional para desenvolver uma prática avaliativa condizente com a realidade do/s avaliado/s.

${ }^{4}$ Doutoranda em Educação pela Universidade do Vale do Itajaí-SC (Univali). Mestre em Educação. Pedagoga com habilitação em Orientação Educacional. Bacharel em Direito. Professora Adjunta da Fundação Universidade Federal de Rondônia (UNIR). E-mail: neidimar1@yahoo.com.br.

${ }^{5}$ Doutora em Educação pela Universidade Federal do Rio Grande do Sul. Desenvolveu estudos pós-doutorais em educação na Universidade de Barcelona, na Espanha. Professora nos cursos de graduação, mestrado e doutorado em Educação da Universidade do Vale do Itajaí (Univali).

${ }^{6}$ Pós-doutora em Educação, Currículo e Ensino pela Barry University, na FlóridaEUA (financiamento da Capes). Doutora em Educação, Currículo e Ensino na citada universidade acima. Diretora do Centro de Educação da Univali. Professora e coordenadora do Programa de Pós-Graduação Stricto Sensu em Educação (mestrado e doutorado) da Universidade do Vale do Itajaí (Univali). 
Nesta perspectiva, com este trabalho pretendemos levantar reflexões acerca da avaliação do ensino superior brasileiro. $\mathrm{O}$ objetivo é compreender o processo inicial e o percurso das políticas públicas para avaliar o ensino superior no Brasil. Trata-se de uma pesquisa de revisão de literatura de caráter descritivo. Para embasamento teórico usamos os estudos de Freitas e Verhine (2012), Vianna (2014) e Luft (2018).

Ao final é possível destacar que as políticas públicas de avaliação do ensino superior no Brasil têm avançado, no entanto, é perceptível que os resultados trazem informações sobre os estudantes e as instituições de ensino superior de modo que são classificados para fins de ranqueamento com o intuito de alcançar as metas internacionais. Desta forma, as discussões acerca da avaliação não são recentes, os estudos e publicações têm crescido consideravelmente a partir dos anos 1960, contudo, ainda não há uma como defini-la ou conceituá-la desconsiderando a sua complexidade.

Neste sentido, este trabalho levanta reflexões acerca do percurso da avaliação do ensino superior brasileiro por meio das políticas públicas, tendo como referencial os estudos de Heraldo Marelim Vianna, um dos pioneiros da avaliação educacional no Brasil, sendo o primeiro homenageado pela Associação Brasileira de Avaliação Educacional (Abave), com atuação relevante no período de 1965 e 1990 na direção da Fundação Carlos Chagas, uma instituição importante no que se refere a avaliação educacional no Brasil ${ }^{7}$. Sua preocupação centra-se nos elementos teóricos e contextualizados que auxiliam na compreensão desta temática.

7 Estudos em avaliação educacional. Contribuições de Fundação Carlos Chagas vol. 25 n. 60, dez. 2014 [número especial]. 
Antônio Alberto da Silva Monteiro de Freitas e Robert Evan Verhine tratam das modalidades e tendências da avaliação da educação superior no cenário internacional, destacando as características de universalidade e especificidades das práticas avaliativas, considerando os modelos predominantes de avaliação. Já Isabel Cristina Miorando Luft traz o percurso das políticas públicas e o processo de avaliação das instituições de ensino superior brasileiro ao analisar as contribuições do Programa de Avaliação Institucional das Universidades Brasileiras (Paiub), para o Sistema Nacional de Avaliação da Educação Superior (Sinaes).

\section{A GÊNESE DA AVALIAÇÃO DO ENSINO SUPERIOR NO BRASIL}

Para situar acerca da temática, inicialmente trazemos o conceito do termo política que segundo Gesser (2011, p. 34) "surge no contexto da Política e da Administração e significa um modo de orientação para tomada de decisões coletivas. [...] As políticas públicas também podem ser entendidas como o Estado em ação”. A autora destaca ainda, que há diferenças entre decisões políticas e políticas públicas, considerando que nem todas as decisões políticas são concretizadas como uma política pública.

Com relação a avaliação, Vianna (2014) aponta que o seu conceito se limita à mensuração do desempenho escolar, ou, então, é concebida segundo um modelo simplista, baseado na apresentação de objetivos comportamentais, construção e aplicação de instrumentos, análise dos resultados e elaboração de um relatório final.

Quanto ao conceito e definição, avaliar em educação é de modo geral, entendido como medir os resultados do rendimento escolar. Medir é uma operação de quantificação, em que se 
atribuem valores numéricos, segundo critérios preestabelecidos. Contudo, alguns aspectos importantes acerca do contexto social, a diversidade de interesses e de valores do/s avaliado/s nem sempre são considerados durante $\mathrm{o}$ ato de avaliar.

Vianna (2014) destaca que a avaliação tinha como propósito inicial avaliar o aluno e sua aprendizagem, estava relacionado a problemas de microavaliação e como área de investigação científica passa a investigar grupos, programas, materiais instrucionais e até mesmo o sistema educacional.

Ralph Tyler (1942) foi o precursor da avaliação educacional e responsável por difundir o conceito de avaliação como um processo que permite comparar o desempenho do estudante com os objetivos de ensino previamente estabelecidos pelo professor. A partir de 1974 Payne começa a investigar questões de macroavaliação (as avaliações externas, que no Brasil são: a Prova Brasil, Exame Nacional do Ensino Médio (ENEM), Exame Nacional do desempenho do Estudante (Enade) e avaliação institucional entre outras que compõem o Sistema Brasileiro de avaliação em larga escala).

Com relação às macroavaliações, a avaliação em larga escala no Brasil, deve ser analisada criticamente, bem como os modelos avaliativos utilizados em todos os níveis e modalidades de educação, destacando os dados resultantes destas avaliações e o que eles trazem para o cenário nacional que merece ser considerado. Vianna (2014) entende que a avaliação educacional não deve ser uma responsabilidade exclusiva dos professores, uma vez que são variados os fatores que poderão contribuir, dificultar ou impedir para que se alcance bons resultados. 
As complexas funções do avaliador educacional (nas esferas macro e micro) mostram que este deve possuir grande maturidade e ampla experiência de ensino ou equivalente; por outro lado, exigem também uma formação profissional aprofundada e constante, não somente por parte do docente, mas de toda a equipe escolar, por meio de discussões e análises acerca da avaliação/ões que será/ão empregada/as e dos resultados que esta/s apontará/ão. E, a partir dos resultados, será possível traçar metas e ações para a melhoria da oferta e qualidade da educação.

No Brasil, o Sistema Nacional de Avaliação da Educação Superior (Sinaes) foi criado após o aumento vertiginoso da oferta de cursos de graduação na década de 1990. Neste cenário, é promulgada a Lei de Diretrizes e Bases da Educação Nacional n. 9394 de 1996, que já estabelece no seu art. 46 a necessidade de avaliar as IES: "A autorização e o reconhecimento de cursos, bem como o credenciamento de instituições de educação superior, terão prazos limitados, sendo renovados, periodicamente, após processo regular de avaliação".

O Sinaes (sistema integrado de avaliação) é a política de avaliação em vigor no país desde o ano de 2004, centrando-se no controle, credenciamento e regulamentação das instituições de ensino superior, avaliando além da infraestrutura, a gestão e a responsabilidade social.

Ristoff e Giolo (2006) destacam que a Constituição Federal do Brasil de 1988, já traz em seu bojo a preocupação com avaliação da Educação Superior em larga escala e, que o Sistema Nacional de Avaliação da Educação Superior (Sinaes) teve início a partir de uma proposta política do Governo Lula no ano de 2002. Trata-se da 
Proposta 12 que destaca a necessidade de rever o sistema atual de avaliação da educação superior, que naquele momento era o Exame Nacional de Cursos ENC ou Provão e implantar um sistema nacional de avaliação institucional a partir da experiência do Programa de Avaliação Institucional das Universidades Brasileiras (Paiub).

A proposta 12 indicava os programas vigentes que antecederam ao Sinaes, sendo eles: o Programa de Avaliação da Reforma Universitária (PARU), criado em 1983; o Grupo Executivo para a Reforma da Educação Superior (Geres) instituído em 1985; o Programa de Avaliação Institucional das Universidades Brasileiras (Paiub) de 1994, o Exame Nacional de Cursos (ENC); a Avaliação das Condições de Oferta/Ensino e a Avaliação de Centros Universitários implantados em 1996.

As políticas públicas de avaliação da educação superior que antecederam ao Sinaes não tiveram a eficácia e o sucesso esperado, no entanto, é perceptível a influência destas nas políticas vigentes. Segundo Dias, Horiguela e Marchelli (2006) o PARU foi um programa que tinha como metodologia o uso de questionários aplicados aos membros da comunidade acadêmica, inclusive aos professores com a finalidade de encontrar dados sobre a estrutura da instituição de ensino.

Com a intenção de fazer uma reforma em todo o sistema de funcionamento das instituições federais de ensino superior, o Ministério da Educação (MEC) cria no ano de 1987 o Grupo Executivo para a Reformulação da Educação Superior (Geres). E no ano de 1993 instituiu e nomeou uma Comissão Nacional de Avaliação das Universidades Brasileiras, delegando a esta, a 
responsabilidade pela estruturação do Programa de Avaliação Institucional das Universidades Brasileiras, e em 1994 dá publicidade à proposta. $\mathrm{O}$ Paiub pode ser considerado um ensaio para a organização do sistema nacional de avaliação da educação superior no Brasil (Giolo, 2009).

Outra política pública de avaliação para as IES foi a Lei $n$, 9.131 de 1995, que instituiu o Conselho Nacional de Educação CNE e criou o Exame Nacional de Cursos (ENC), uma avaliação obrigatória e quantitativa também chamada de Provão. Este Exame teve início em 1996 e finalizou em 2003, era realizado por meio de uma prova escrita, aplicada aos iniciantes e concluintes de cursos de graduação, e foi considerado por Barreyro e Rothen (2006) como uma forma de regulação por parte do Estado. Os critérios deste formato de avaliação atendiam aos interesses do mercado, pois os resultados estimulavam a concorrência entre os pares e constituíam o ranking das universidades.

Segundo Luft (2018) houve transformação nas IES, uma vez que estas reformularam os currículos adequando-os aos conteúdos do provão, legitimando o seu caráter regulatório. A repetição anual do provão em todo o âmbito nacional, causou impacto em toda a estrutura das IES no que se refere a organização acadêmica e nos cursos, promovendo a unificação curricular e induzindo as ações tanto administrativas quanto pedagógicas para elevar $\mathrm{o}$ desempenho do estudante e, consequentemente o ranqueamento, tornando o provão um instrumento informativo para o setor privado com fins mercadológicos para a educação superior.

Diante deste cenário, com a intenção de organizar um sistema integrado de avaliação para evitar que diversos setores do 
MEC utilizassem procedimentos metodológicos e instrumentos diferentes para avaliar as IES, foi designada pelas Portarias MEC/SESu n. 11, de 28 de abril de 2003 e Portaria n. 19, de 27 de maio de 2003, a Comissão Especial da Avaliação da Educação Superior (CEA) para levantar um diagnóstico da avaliação nacional realizada no país, apresentar um relatório e elaborar uma proposta de avaliação para a educação superior do Brasil. A síntese dos estudos realizados pela CEA, destacava o provão como um instrumento avaliativo cujos fins não eram acadêmicos e sim apresentava características mercadológicas e reguladoras fugindo ao que se propunha.

A partir disto, cria-se a proposta de um Sistema Nacional de Avaliação da Educação Superior o Sinaes, por meio da Lei n. 10.861, de 2004, que traz um sistema integrado de avaliação e delega ao Instituto Nacional de Estudos e Pesquisas Anísio Teixeira (INEP) a responsabilidade pela realização das mesmas. A CEA também sugeriu a criação da Comissão Nacional de Avaliação da Educação Superior (Conaes) para coordenar e supervisionar o Sinaes. Vale destacar que a lei que institui o Sinaes permanece em vigência neste ano de 2020.

Contudo, no ano de 2012 as dimensões de análise do SINAES foram reformuladas para melhorar a avaliação aplicada em todo o país e, no ano de 2014 o MEC publica a Nota Técnica n. 14/2014 CGACGIES/DAES/INEP/MEC, apontando os cinco eixos de análise do Sinaes que entram vigor a partir de então. Vejam os cinco eixos destacados na figura 1. 
Diálogos entre lugares II

Figura 1: Os cinco eixos de análise do Sinaes

\section{Eixo 1 - Planejamento e Avaliaçđo Institucional}

- Considera a dimensào 8 do Sinaes (Planejamento e Avaliação). Incluí também um Relato Institucional, que descreve e evidencia os principais elementos do seu processo avaliativo (interno e externo) em relaçào ao Plano de Desenvolvimento Institucional (PDI), incluindo os relatórios emanados pela Comissào Própria de Avaliaçào (CPA), do periodo que constituiu o objeto de avaliaçăo.

\section{Eixo 2 - Desenvolvimento Institucional}

- Contempla as dimensões 1 (Missão e o Plano de Desenvolvimento Institucional) e 3 (Responsabilidade Social da Instituição) do Sinaes.

\section{Eixo 3 - Políticas Acadêmicas}

-Abrange as dimensões 2 (Políticas para o Ensino, Pesquisa e Extensão), 4 (Comunicação com a Sociedade) e 9 (Políticas de Atendimento aos Discentes) do Sinaes.

\section{Eixo 4 - Políticas de Gestão}

- Compreende as dimensões 5 (Políticas de Pessoal), 6 (Organização e Gestão da Instituição) e 10 (Sustentabilidade Financeira) do Sinaes.

\section{Eixo 5 - Infraestrutura Física}

• Contempla a dimensão 7 (Infraestrutura Física) do Sinaes.

Fonte: Adaptado (Brasil, 2014, p. 3)

O objetivo do Sinaes conforme o que está disposto no artigo $1^{\circ}$ da Lei n. 10.861 de 2004 que o institui é melhorar a qualidade da educação superior no país e para isso, a avaliação deve considerar a infraestrutura (funcionamento da IES) ocorrendo por meio da autoavaliação; o projeto pedagógico do curso (sua aplicação) avaliado por uma equipe multidisciplinar com membros externos; e o desempenho dos estudantes (aprendizagem) que ocorre por meio 
do Enade com instrumento avaliativo aplicado aos estudantes ingressantes e concluintes de cursos de graduação. Ao final, estas avaliações devem trazer dados que possibilitem identificar os pontos fortes e as fragilidades para que possam ser melhorados.

No entendimento de Polidori, Marinho-Araújo e Barreyro (2006) o Sinaes modificou os modelos avaliativos no Brasil, uma vez que os anteriores desencadeavam a construção de rankings entre as universidades, e a proposta de avaliação do Sinaes é formativa incluindo a autoavaliação das IES articulada à regulação do próprio sistema. Este posicionamento é controverso, não sendo aceito por parte de alguns estudiosos, porém não é objeto deste estudo.

O Sinaes embora tenha uma proposta mais completa em comparação às propostas anteriores, requer alguns ajustes no campo prático para atingir os fins a que se propõe.

\section{AVALIAÇÃO: CONTROLE, QUALIDADE E GLOBALIZAÇÃo}

As práticas avaliativas desenvolvidas nos diferentes países tornam possíveis compreender as mudanças referentes a educação que acontecem no mundo globalizado, uma vez que os governantes em âmbito nacional e internacional se valem das avaliações normativas e padronizadas como mecanismos para controlar (regular), fiscalizar e prestar contas, bem como reformar os seus sistemas educativos.

Com relação às modalidades e tendências da avaliação da educação superior em âmbito internacional, Freitas e Verhine (2012) entendem que o melhor caminho é a integração e complementaridade da avaliação externa padronizada e a interna, que respeita a diversidade institucional. Considerando que há interesses diversos subjacentes a tais avaliações, vale destacar que a educação superior passa a ser um bem mundial. 
Gonzales (2020) ao mencionar o saber pós moderno, com base nos estudos de Lyotard (1988), destaca que na pósmodernidade o saber (técnico-científico), não é apenas usado pelos poderes como um mecanismo para melhorar a educação, torna-se um instrumental que serve à lógica do capital e do consumo, se expressa por meio das ciências em geral, se transformando em mercadoria, gerando lucro/riqueza, e por sua vez passa a ser comercializado, invertendo os papéis de controle do Estado, sendo controlado pelo poder econômico e científico globalizado.

Além do interesse global mercadológico pela educação superior, Freitas e Verhine (2012) destacam que a educação como bem mundial de interesse global, cria interlocutores públicos e privados externos aos órgãos oficiais das nações. Qiang (2003) apresenta os motivos que tornam importante a internacionalização da educação superior, uma vez que os interesses não se limitam apenas aos conteúdos básicos de determinada profissão ou ciência, mas aos requisitos acadêmicos e profissionais concernentes a língua, a cultura e habilidades interculturais. No entanto, é preciso considerar que a internacionalização da educação superior modifica o modelo, a função e a missão das instituições de educação superior, uma vez que há expansão da oferta de cursos de graduação de baixa qualidade por instituições privadas. Para Freitas e Verhine (2012, p. 27):

O modelo de avaliação, baseado em sistemas predominantemente quantitativos, remete à questão da eficiência ou ineficiência das instituições. Nessa linha, a avaliação se realiza como atividade predominantemente técnica, que busca a mensuração dos resultados produzidos pelas instituições em termos de ensino, pesquisa e prestação de serviços à comunidade. Sua ênfase recai sobre indicadores quantitativos, padronização de testes de conhecimento, respeito das medidas físicas (como áreas construídas), titulação de professor, 
descrição do corpo docente, discente etc. Esses procedimentos permitem o estabelecimento de "rankings" de instituições, com efeitos diretos nas políticas de alocação de recursos financeiros e como organizadores sociais de estudantes e de instituições.

Para Unesco (1999) as avaliações em larga escala geram dados e informações que tornam possíveis a realização de pesquisas nacionais e internacionais com finalidade de comparar os indicadores sobre os funcionamentos dos sistemas educacionais e o reflexo destes resultados quanto aos desenvolvimentos sociais, políticos e econômicos do/s país/es.

Entretanto, a avaliação em larga escala padronizada externa torna-se reguladora quando ocorre por intermédio do compromisso assumido entre o MEC e as instituições proponentes e articula a eficiência, a qualidade, o desempenho dos estudantes e a prestação de contas para quantificar, mensurar e comparar os resultados, denotando o cumprimento dos critérios e padrões mínimos de qualidade estabelecidos nos documentos legais. Contudo, quando não considera as especificidades locais no que se refere às condições financeiras, estruturais da IES e culturais dos estudantes, se torna insuficiente e injusta.

Para Freitas e Verhine (2012) a avaliação com a finalidade de regulação estatal (em larga escala) necessita de procedimentos que maximizam a objetividade das informações e dos julgamentos, desta forma, será possível comparar a qualidade das IES e dos cursos. Esse modelo de avaliação amplia o poder de controle dos Estados sobre as IES, por meio de mecanismos centrados na concepção de produtividade destas. E consequentemente, desencadeiam novos processos de gestão universitária, de organização do trabalho docente e de formação profissional.

Os autores destacam ainda, que a evolução histórica das teorias educacionais influencia as variadas tendências e 
modalidades da avaliação, sendo estas (avaliações) híbridas envolvendo paradigmas com abordagens qualitativas e quantitativas. Diante desta realidade é necessário que instituições de educação superior entendam que haverá o aumento do controle e regulação quanto aos padrões de qualidade dos critérios não atendidos adequadamente.

E, nesta perspectiva de busca pela qualidade e controle, todos os envolvidos no processo avaliativo tanto externo quanto interno devem assumir com responsabilidade sua função, uma vez que o ato de avaliar em si gera tensão, e as pressões decorrentes das cobranças e exigências são desconfortáveis e pode desencadear uma situação ameaçadora.

Considerando o modelo de avaliação global, Contera (2002, apud Freitas e Verhine, 2012, p. 28) aborda esse modelo sob três pontos de vista:

Figura 2: Modelo de avaliação global conforme Contera

Modelo de avaliação global sob o ponto de vista filosófico

-Esse modelo orientado por uma racionalidade instrumental, con interesse técrico, a qualidade a eficácia onde os meios e os processos nào têm mais significaçâo em si, o importante é a função instrumental para conseguir os objetivos apresentados.

\section{Modelo de avaliação global sob o ponto de vista politico}

- A intencionalidade explicita é a de que as universidades públicas prestem contas do uso do orcamento usado. Essa finalidade se inscreve no surgimento do Estado controlador e se sustenta nos valores de competitividade, esforço individual e produtividade, próprios do mereado.

Modelo de avaliação global sob o ponto de vista metodológico

- O modelo enfatiza a busca de indicadores de rendimento, a fixaçào de padróes, provas e testes.

Fonte: Adaptado (Freitas e Verhine, 2012)

Considerando a avaliação global, a avaliação padronizada, a internacionalização da educação superior e a sua qualidade é 
importante mencionar a acreditação que é uma prática para garantir a qualidade. No entendimento de Sobrinho (2008) a acreditação é uma forma de certificar se a qualidade da instituição, de um curso ou de um programa está de acordo com os critérios e padrões externos.

A acreditação é que permite convalidar os estudos realizados em instituições localizadas em outros países. As metas de cada país no que tange aos fatores sociais, econômicos e políticos estão diretamente ligadas as reformas educacionais, o que torna a avaliação um instrumento necessário e apropriado para o alcance de tais metas.

\section{CONSIDERAÇÕES FINAIS}

Ao final deste estudo é possível destacar que avaliação de forma geral, requer alguns cuidados diante de sua complexidade e abstração, para não incorrer no julgamento injusto e prejudicial que envolve todos os atores e instituições a ela ligados.

E, que a partir da década de 80, expande os seus propósitos de microavaliação (relacionada a aprendizagem do aluno) passa a investigar no âmbito da macroavaliação (dos grupos, programas, materiais instrucionais e o sistema educacional).

Identificou-se que o Brasil tem investido em políticas públicas para a avaliação da educação superior, promovendo mudanças no processo avaliativo desde o ano de 1983 com a criação do Programa de Avaliação da Reforma Universitária (PARU) e outros, até a criação do Sistema Nacional de Avaliação da Educação Superior, o Sinaes, por meio da Lei n. 10.861, de 2004 que está em vigor até o ano atual 2020. 
Este estudo permitiu identificar a avaliação como uma ferramenta importante para as reformas educacionais, já que ela produz mudanças de âmbito curricular, metodológico, de organização, formação, gestão e até mesmo nas estruturas de poder das instituições e nos modelos educativos, ou seja, está diretamente relacionada com as transformações desejadas não somente na Educação Superior, mas na sociedade como um todo.

\section{REFERÊNCIAS}

BARREYRO, Gladys Beatriz; ROTHEN, José Carlos. "SINAES" contraditórios: considerações sobre a elaboração e implantação do Sistema Nacional de Avaliação da Educação Superior. Educação e Sociedade, Campinas, v. 27, n. 96, Especial, p. 955-977, out. 2006.

BRASIL, Lei de Diretrizes e Bases da Educação Nacional n. 9394/96. Brasília: MEC, 1996.

BRASIL. Portarias MEC/SESU 11, de 28/04/2003 e 19, de 27 de maio de 2003. DOU de 30 de abril de 2003, seção 2.

BRASIL. Lei n. 10.861, de 14 de abril de 2004. DOU n. 72, Seção 1, de 15 de abril de 2004.

BRASIL, Nota Técnica n. 14/2014

CGACGIES/DAES/INEP/MEC, de 7 de fevereiro de 2014.

CONTERA, Cristina. Modelos de avaliação da educação superior. In: SOBRINHO; José Dias; RISTOFF (Org.). Avaliação democrática. Florianópolis: Insular, 2002.

DIAS, Carmen Lúcia; HORIGUELA, Maria L; MARCHELLI, Paulo S. Políticas para a avaliação da qualidade do Ensino Superior no Brasil: um balanço crítico. Educação e Pesquisa, v. 32, n. 3, p. 435-464, set./dez. 2006. Disponível em: <www.researchgate.net/publi 
cation/250988242_Politicas_para_avaliacao_da_qualidade_do_En sino_Superior_no_Brasil_um_balanco_critico $>$. Acesso em: 18 nov. 2020.

FREITAS, Antônio A. S. M. de. VERHINE, Robert E. A avaliação da educação superior: modalidades e tendências no cenário Internacional. Revista Ensino Superior Unicamp, 2012.

GIOLO, Jaime. A avaliação da Educação Superior na legislação brasileira. In: NUNES, Ana Karin (org.). Universidade comunitária e avaliação: os quinze anos do PAIUNG. Santa Cruz do Sul: EDUNISC, 2009, p. 28-41.

GONZALES, Neidimar Vieira Lopes. HOSTINS Regina Célia Linhares. O saber na sociedade pós-moderna: o olhar de Lyotard. IN: PINTO, Auxiliadora dos Santos et al. Diálogos entre lugares: educação, literatura e memória. Porto Velho: Temática Editora, 2020.

LUFT, Isabel Cristina M. Do PAIUB ao SINAES: aproximações entre as políticas públicas de avaliação da educação superior. Dissertação de Mestrado: UFFS, 2018.

PAYNE, David A. Toward a characterization of curriculum evaluation. In: PAYNE, Est. Aval. Educ., São Paulo, v. 25, n. 60, p. 74-84, n. especial, dez. 2014.

POLIDORI, Marlis M.; MARINHO-ARAÚJO, Claisy; BARREYRO, Gladys B. SINAES: Perspectivas e desafios na avaliação da Educação Superior brasileira. Revista Ensaio: Avaliação e políticas públicas em Educação, Rio de Janeiro, v. 14, n. 53, p. 425436, out./dez. 2006. 
QIANG, Zha. Internationalization of Higher Education: towards a conceptual framework. Policy Futures in Education, Toronto, v. 1, n. 3, 2003.

RANGHETTI, Diva Spezia. GESSER, Verônica. Currículo escolar das concepções histórico-epistemológicas: a sua materialização na prática dos contextos escolares. 1. ed. Curitiba, PR: Editora CRV, 2011.

RISTOFFI, Dilvo. GIOLO, Jaime. O SINAES como sistema. Revista Brasileira de Pós-Graduação - RBPG. Brasília, v. 3, n. 6, p. 193-213, dez. 2006. Disponível em: <www.researchgate.net/publication/ 228349227_O_Sinaes_como_sistema>. Acesso em: 18 nov. 2020.

SOBRINHO, José Dias. Qualidade, avaliação: do Sinaes a índices. Avaliação. Revista de Avaliação da Educação Superior, Campinas/Sorocaba, v. 13. n. 3, 2008.

TYLER, R. W. General statement on evaluation. Journal of Educational Research, n. 35, 1942.

UMA ESCOLA do tamanho do Brasil. Programa de Governo do Candidato Lula, 2002.

UNESCO - Organização das Nações Unidas para Educação, Ciência e Cultura. Política de mudança e desenvolvimento no ensino superior. Trad. Laura Ferrantini Fusaro. Rio de Janeiro: Garamond, 1999.

VIANNA, Heraldo Marelin. Estudos em avaliação educacional. Contribuições de Fundação Carlos Chagas. v. 25, n. 60, número especial, dezembro, 2014. 


\section{Perspectivas do Programa Escola Novo Tempo para PROMOÇÃO DA PLURALIDADE CULTURAL E LINGUÍSTICA EM RONDÔNIA: UM ESTUDO EM CONTEXTO ESCOLAR DA FRONTEIRA BRASIL-BOLÍVIA}

Bethânia Moreira da Silva Santos ${ }^{8}$

\section{INTRODUÇÃo}

A Agenda de 2030 para o Desenvolvimento Sustentável coloca a desigualdade no centro de todos os objetivos e metas. No caso da educação, isso explica em virtude de estarmos num período em que o conhecimento sobre as disparidades por razão de gênero, localização e riqueza eles aumentaram rapidamente (Unesco, 2017/2018, p. 210, tradução nossa). A desigualdade é um problema global que requer soluções integradas

[...]Solo el 66\% de los países han logrado la paridad de género en la enseñanza primaria, el $45 \%$ en el primer ciclo de la enseñanza secundaria y el $25 \%$ en el segundo ciclo de la enseñanza secundaria. [...] En 2009, solo el 13\% de las instituciones de enseñanza superior de 27 países de la UE estaban dirigidas por mujeres[...] La situación es incluso peor para los más pobres de los países de bajos y medianos ingresos (54 por cada 100) y de los países de bajos ingresos (14 por cada 100). Mientras que la tasa

8 Doutoranda em Educação pela Universidade do Vale do Itajaí (Univali)/Faculdade Católica de Rondônia (FCR). Mestre em Ciências da Linguagem pela Fundação Universidade Federal de Rondônia (UNIR). Graduada em Letras Língua Portuguesa pela UNIR/Câmpus de Guajará-Mirim. Professora da Rede Estadual de Ensino de Rondônia (Seduc-RO). Membro do Grupo de Estudos Interdisciplinares das Fronteiras Amazônicas (Geifa). Email: bethaniamssantos@gmail.com 
mundial de finalización fue del $69 \%$, solo el $12 \%$ de los hombres más pobres y el $8 \%$ de las mujeres más pobres terminaron el primer ciclo de la enseñanza secundaria. [...] es difícil estimar el porcentaje de alumnos que reciben enseñanza en su lengua familiar [...] (Unesco, 2017/2018, p. 210-216)

Nesse contexto, a educação inclusiva e equitativa de qualidade é projetada como objetivos em diferentes planos de ação global de educação, a fim de promover igualdades de oportunidades de aprendizagem ao longo da vida para todos.

Desde 2000, houve enorme progresso na promoção do acesso universal à educação primária para as crianças ao redor do mundo. Para além do foco na educação básica, todos os níveis de educação estão contemplados no objetivo de desenvolvimento sustentável 4, que enxerga como fundamental a promoção de uma educação inclusiva, igualitária e baseada nos princípios de direitos humanos e desenvolvimento sustentável. A promoção da capacitação e empoderamento dos indivíduos é o centro deste objetivo, que visa ampliar as oportunidades das pessoas mais vulneráveis no caminho do desenvolvimento (Plataforma Agenda 2030) $)^{9}$.

Em Rondônia, o Ensino em Tempo Integral configura-se como uma, das mais recentes, alternativas para o contínuo avanço da qualidade da educação. Regido pela Portaria n. 1.145, de 10 de outubro de 2016 as Escolas de Tempo Integral oferecem a ampliação da jornada escolar e a formação integral e integrada do estudante.

${ }_{9}^{9}$ Plataforma Agenda 2030. Disponível em: <www.agenda2030.org.br/ods/4/>. Acesso em: 12 dez. 2019. 
Estudos revelam, como o de Marques (2017), que o tempo escolar estendido além de possibilitar ampliação de oportunidades aos estudantes apontam resultados positivos na valorização dos profissionais docentes, uma vez que os professores terão prioritariamente dedicação exclusiva, salários diferenciados e menos carga horária de trabalho docente, o que significa trabalhar com maior motivação.

Acerca do trabalho dos profissionais docentes, a Lei Complementar n. 958/2017 prevê em seu parágrafo $1^{\circ}$ que:

Aos professores lotados nas escolas participantes do Programa Escola do Novo Tempo, em decorrência da integração entre as áreas de conhecimento da base nacional comum e da parte diversificada do Programa, poderá ser atribuída carga horária inferior a 32 (trinta e duas) horas-aula, sem prejuízos das gratificações e auxílios instituídos por esta Lei Complementar e pela Lei Complementar n. 680, de 7 de setembro de 2012, desde que seja cumprida integralmente a carga horária na unidade escolar de sua lotação, bem como desenvolvida a Matriz Curricular (Lei Complementar n. 958/2017).

Lotta e Bauer (2018), enfatizam que a formação docente também é um fator determinante, uma vez que é ofertada com foco no Modelo Escola da Escolha. Contudo, observa-se que durante as últimas décadas os sistemas educativos têm sido objeto de legislação, da imposição de filosofias educativas e de orientação práticas que descuidam aspectos de crucial importância como a seleção da cultura por meio da qual se pode compreender melhor um mundo cada vez mais globalizado e no qual se produzem muitas transformações [...] (Santomé 2013, p. 10-11).

Os estudantes das Escolas de Ensino Médio em Tempo Integral (EMTIs), segundo Lotta e Bauer (2018) têm a possibilidade 
de aprofundamento nas quatro áreas de conhecimento por meio das disciplinas eletivas. $\mathrm{O}$ que permite a flexibilização do currículo da base comum com a parte diversificada. As aulas de Projeto de Vida são consideradas, pelos estudantes, como "as melhores, hoje, na escola”, considerando que por elas, "os alunos se conhecem melhor" e se projetam para o futuro (Lotta; Bauer, 2018).

Ao realizar um estudo sobre a política curricular adotada pela Secretaria de Estado da Educação de Rondônia (Seduc-RO) e os currículos das escolas de ensino fundamental da rede estadual das cidades fronteiriças: Guajará-Mirim e Nova Mamoré, Uchôa (2019), constata que:

[...] a negação da cultura boliviana no currículo das escolas fronteiriças tem contribuído para a propagação do preconceito e da discriminação ao imigrante boliviano, uma vez que a rejeição do Outro e ao que é inerente a ele: língua, história e identidade geram, por conseguinte, o desprezo, a exploração e a expropriação, o que se observa de forma latente nesta região, pautada na ideia de uma suposta superioridade cultural dos brasileiros em relação aos bolivianos (Uchôa, p. 1, 2019).

$\mathrm{Na}$ fronteira Guajará-Mirim/Guayaramerín os hábitos culturais, a língua, a cor, a etnia, os costumes são elementos que contribuem para a constituição sociohistórica das cidades gêmeas, assim chamadas porque em línguas diferentes, adotam o mesmo nome. Concordamos com a autora ao considerar que essa região necessita da implantação de políticas públicas que voltadas aos interesses da comunidade local, valorizando sua realidade geográfica, econômica, social, cultural e educacional.

A língua é considerada um fenômeno dinâmico, de natureza sociocultural, que permite explicar, através dos estudos sociolinguísticos, as dimensões da historização das ideias 
linguísticas. Essa singularidade da região fronteiriça, não pode ficar aquém das políticas públicas, sobretudo aquelas que refletem na educação (Uchôa, p 2019).

O relatório Global Education Monitoring Report. 2017/2018 traz indicadores educacionais de paridade/igualdade entre homens e mulheres, áreas rurais e urbanas, quintis de riqueza situações de "grupos marginalizados" como os deficientes, os povos indígenas e migrantes, abordando também indicadores temáticos como diversidade etnolinguística e situações do ensino na língua materna, o que induz a reflexão sobre a realidade local da fronteira.

Em âmbito mundial, os resultados apontam que, houve o aumento da desigualdade em relação ao: gênero, localização e riqueza. Enfatiza que a política de ensino da língua pode ser a chave para tornar a educação mais inclusiva para os grupos desfavorecidos/vulneráveis. Considera a difícil estimativa da percentagem de estudante que recebe o ensino em seu idioma familiar. As dificuldades são diferentes nos países de alta renda com grandes populações de imigrantes, em comparação com países de baixa e média renda com ampla diversidade etnolinguística (Relatório GEM, 2016).

Dados sobre a situação educacional dos grupos desfavorecidos e marginalizados criam consciência pública sobre sua desigualdade, bem como entre os decisores políticos. Determinam a magnitude da discriminação e cria uma base de informações que favorece políticas mais inclusivas (Simon; Piché, 2012).

Vale ressaltar que a prática pedagógica no contexto educacional, como é o caso da fronteira contexto de pesquisa, exige a necessidade de diminuir a distância entre o discurso e a prática, pois ensinar exige humildade, tolerância e luta em defesa dos 
direitos dos educandos e exige também a compreensão da realidade. Ensinar requer a plena convicção de que a transformação é possível porque a história deve ser encarada como uma possibilidade e não como uma coisa moldada pronto e inalterável. A implantação da nova BNCC e as práticas pedagógicas na fronteira Brasil/Bolívia requer constante reflexão crítica, analítica e rigorosa do processo formativo identitário e curricular, que considere o contexto multicultural das vivências dos alunos.

O tema desta pesquisa é relevante porque compreendemos que a educação no contexto da fronteira Brasil-Bolívia deve promover o respeito à diversidade sociocultural e linguística, pois a preservação da identidade cultural não pode ser vinculada à ideologia da cultura dominante.

No plano pessoal esta pesquisa é relevante porque ao decorrer da atuação profissional de uma das pesquisadoras, foi possível identificar algumas lacunas da prática educativa que precisam ser repensadas, como, por exemplo, a promoção da pluralidade linguística cultural, pensada de forma intercultural, no Estado de Rondônia e em Guajará-Mirim, pois essa é uma cidade de Fronteira e precisa que sejam observadas questões próprias de fronteira na formação e prática de educadores para posteriormente serem introduzidas na elaboração do currículo, vejo esse contexto propício a investigações e reflexões críticas.

Diante disso, a lacuna que orientou esse estudo consistiu na falta de discussões sobre as perspectivas da Escola de Ensino Médio em Tempo Integral na promoção da pluralidade cultural e linguística, em específico no município de Guajará-Mirim(RO). O objetivo da pesquisa foi analisar as perspectivas do Programa Escola Novo Tempo para Promoção da Pluralidade Cultural e 
Linguística em Rondônia, e seu desenvolvimento no município de Guajará-Mirim-RO fronteira do Brasil com a Bolívia.

A pesquisa foi norteada pelas seguintes problematizações: quais as perspectivas da Escola Novo Tempo para promoção da pluralidade cultural e linguística na fronteira? Como se constitui a educação na contemporaneidade, e as políticas de promoção pluralidades culturais e linguísticas na Educação Básica? Como se constitui o Programa Escola Novo Tempo em Rondônia? Quais as concepções da gestão escolar da Escola de Ensino Médio em Tempo Integral sobre a pluralidade cultural e linguística na fronteira?

O estudo do tema é relevante porque embora já se reconheça a contribuição ${ }^{10}$ das Escolas em Tempo Integral para com a Política de Educação Integral e melhoria da qualidade da educação no Brasil, observa-se que ainda há poucas discussões em torno da abertura que a Escola Novo Tempo traz para promoção da pluralidade linguística em contexto de fronteira. Diante disso, acreditamos que os estudos voltados ao Programa Escola em Tempo Integral em Rondônia, em particular do nosso contexto de investigação, nos permitirão refletir sobre as potencialidades que esse espaço escolar traz para elaboração de currículos interculturais. Assim sendo, definimos como objetivos específicos: a) discutir sobre a educação na contemporaneidade, políticas, currículos e diferenças culturais na educação; b) descrever sobre as premissas normativas que institui o Programa Escola Novo Tempo em Rondônia articulando com as iniciativas de desenvolvimentos do Ensino Médio em tempo Integral em Rondônia, descrita por Lotta e Bauer (2018) no relatório de Mapeamento do Ensino Médio

${ }^{10}$ Castro, Adriana de; Lopes, Roseli Esquerdo. A escola de tempo integral: desafios e possibilidades. In. Ensaio: aval. pol. públ. Educ., Rio de Janeiro, v. 19, n. 71, p. 259-282, abr./jun. 2011. 
em Rondônia; d) registrar e analisar as experiências da gestão escolar frente ao Programa Escola Novo Tempo, as concepções sobre a pluralidade cultural e linguística na fronteira.

$\mathrm{O}$ artigo será organizado em quatro partes, a saber: na primeira parte deste texto, nos detemos a reflexões sobre a educação na contemporaneidade: currículo, políticas públicas e diferenças culturais e linguísticas na educação. Na segunda parte, esboçaremos sobre os aportes legais sobre as Escolas de Ensino Médio em Tempo Integral, implantação e iniciativas de flexibilização do Programa Escola Novo Tempo - Ensino Médio em Tempo Integral em Rondônia. Na terceira parte, nos deteremos à descrição do contexto de pesquisa, o histórico e caracterização da instituição em estudo. A quarta parte traz os registros dos dados da pesquisa, apresentando os resultados obtidos através dos registros de experiências da gestão escolar, e por fim as Considerações Finais sobre as ponderações sobre os impactos educacionais e sociais gerados pela Educação em Tempo Integral em Guajará-Mirim(RO), município limítrofe com a Bolívia.

\section{EDUCAÇÃO NA CONTEMPORANEIDADE: POLÍTICAS, CURRÍCULOS E DIFERENÇAS CULTURAIS NA EDUCAÇÃO}

Na obra Por uma outra globalização: do pensamento único à consciência universal Santos (2000) traz inquietações sobre o entendimento do que hoje é o espaço geográfico e o mundo na pósmodernidade. Ao propor uma reflexão sobre a realidade contemporânea e os fundamentos materiais e políticos da Globalização, afirma que só é possível compreender o papel da ideologia na produção, na reprodução e na manutenção do discurso político da Globalização atual, através da compreensão dos princípios fundamentais de sua existência (a globalização como 
fábula), suas linhas de fraquezas (a globalização como perversidade) e de forças (a globalização como possibilidade).

Para o autor a globalização sustenta-se na convicção da relevância da política para mudança da realidade histórica (o estado das técnicas e o estado da política) que constitui o mundo contemporâneo - "desenhos globais de poder, capital e mercado" dominado por um pequeno número de atores globais que em benefício exclusivo, utilizam discursos simbólicos de unificação da técnica (difusão da técnica da informação), dando a impressão de estreitamento de fronteiras culturais, sociais e econômicas, onde através do discurso regulador do Estado, segmentam mercados, encadeiam a perversidade do progresso técnico (espaço unipolar de dominação), a tirania do dinheiro e da informação (concentração do capital e do poder), polarizando riquezas, dando a impressão da democratização global, mínima intervenção e incapacidade do Estado na regulação da vida coletiva.

Pode-se inferir que em sua abordagem sobre uma nova consciência universal o papel atual da ideologia na produção da história é determinada pelo "[...] extraordinário progresso das ciências e das técnicas", isto porque os fatores que contribuem para explicar a arquitetura da globalização atual, são: a unicidade da técnica (técnica da informação), a convergência dos momentos (unicidade do tempo), a cognoscibilidade do planeta (conhecimento dos acontecimentos globais) e a existência de um motor único na história (ações igualmente globais), representado pela mais-valia globalizada.

A técnica da informação instala e busca espalhar-se na produção e no território, atuando no uso do tempo, permitindo, em todos os lugares, a convergência dos momentos, a simultaneidade das ações, aceleração do processo histórico. Fundamenta-se na 
avaliação e ação de atores hegemônicos. A convergência dos momentos, a cognoscibilidade do planeta possibilita o conhecimento dos acontecimentos globais. A história é comandada pelos grandes atores desse tempo real, os donos da velocidade e os autores do discurso ideológico.

Santos (2000), ao tratar da globalização como perversidade aborda a tirania da informação/ violência da informação (manipulada pelo poder) e do dinheiro (concentração do capital) e o atual sistema ideológico (política comandada pelas empresas). "Essas técnicas da informação são apropriadas por alguns Estados e por algumas empresas, aprofundando os processos de desigualdades".

Observa-se que a contemporaneidade é marcada pela imposição de filosofias de orientação práticas que descuidam aspectos de crucial importância como a seleção da cultura por meio da qual se pode compreender melhor um mundo cada vez mais globalizado e no qual se produzem muitas transformações.

Santos (2000) também propõe que o discurso ideológico da Globalização traz possibilidade para a construção de uma nova consciência universal. Sustenta-se na ideia de que as cidades possam ser "espaços de liberdades" para a luta dos oprimidos. Sua abordagem está voltada a emergências de temáticas relacionadas a países periféricos (cultura popular em oposição à cultura de massas), até então, pouco estudada, que de certa forma, segundo o autor poderá servir, de alicerce para o surgimento de "uma nova humanidade", "uma nova consciência" (conscientização e riqueza da nação passiva), possibilitando a construção de "novos valores simbólicos”, nova política, uma nova globalização.

Para Santomé (2013), nas últimas décadas os sistemas educativos têm sido objeto de legislação, da imposição de filosofias 
educativas e de orientação práticas que descuidam aspectos de crucial importância como a seleção da cultura por meio da qual se pode compreender melhor um mundo cada vez mais globalizado e no qual se produzem muitas transformações [...] (Santomé, 2013, p. 10-11).

A Agenda Global $2030^{11}$ prevê em seu escopo, objetivos e metas que poderão ser desenvolvidos por meio de ação integradas em diferentes países, que ao se espelharem nas grandes potências econômicas mundiais, trazem a abertura para restruturação de currículos e o desenvolvimento de práticas inclusivas que se equilibram nas três dimensões do desenvolvimento sustentável: a econômica, a social e a ambiental.

Catherine Walsh (2009), na obra Interculturalidade crítica e pedagogia decolonial, já se pronunciava sobre a influência neoliberal de perspectiva capitalistas na educação e as dificuldades do contexto latino-americano em ler criticamente o mundo, intervir na reinvenção da sociedade, e viabilizar a desordem absoluta do que ela chama de "descolonização". Segunda a autora, embora desde os anos 90, a diversidade cultural na América Latina tenha se tornando um tema em moda. Considera-se ainda nas políticas públicas a ideia de "raça" como instrumento de classificação e controle social e o desenvolvimento do capitalismo mundial (moderno, colonial, eurocêntrico), que se iniciou como parte constitutiva da constituição histórica da América.

Embora se possa argumentar que essa dificuldade seja fruto do resultado das lutas dos movimentos sociais-ancestrais e suas demandas por reconhecimento e direitos, pode ser vista, ao mesmo

11 Disponível em: <https://nacoesunidas.org/pos2015/agenda2030/>. Acesso em: 8 ago. 2019. 
tempo, de outra perspectiva: a que a liga aos desenhos globais do poder, capital e mercado, visivelmente latente nas categorias binárias, que se apresentam: oriente-ocidente, primitivo-civilizado, irracional-racional, mágico/mítico-científico e tradicionalmoderno, reiterando a superioridade e a inferioridade - razão e não razão, humanização e desumanização colocando o eurocentrismo como perspectiva hegemônica.

De acordo com Walsh (2009) essa retórica e ferramenta não apontam para a criação de sociedades mais equitativas e igualitárias, mas para o "controle do conflito étnico" e "a conservação da estabilidade social”, com o fim de impulsionar os imperativos econômicos do modelo neoliberal de acumulação capitalista, agora "incluindo" os grupos historicamente excluídos.

A interculturalidade crítica é apontada pela autora como ferramenta pedagógica que questiona continuamente a racialização e subalternização dos sujeitos, capaz de viabilizar maneiras diferentes de ser, viver e saber, buscando não só compreender as condições e dialogar com as diferenças num marco de legitimidade, dignidade, igualdade, equidade e respeito, mas que, ao mesmo tempo, alentam a criação de modos "outros", de pensar, ser, estar, aprender, ensinar, sonhar viver que cruzam fronteiras.

Para Santomé (2013), a justiça curricular é o resultado da análise do currículo que é elaborado, colocado em ação, avaliado e investigado levando em consideração o grau em que tudo aquilo que é decidido e feito em no contexto escolar respeita e atende às necessidades e urgências de todos os grupos sociais. Nesse contexto, vale salientar que o currículo é parte importante da organização educacional, se constitui através de ações políticapedagógica de cada sistema, envolve não só a relação de conteúdo, mas também questões de poder, tanto nas relações professor-aluno 
como também escola comunidade. Por isso ele deve ser pensado de forma que considere as peculiaridades existentes no contexto escolar, objetivando intervenções políticas sociais necessárias para o envolvimento das relações de classe sociais, questões raciais, étnicas e de gênero no intuído de construir um mundo mais humano, justo e democrático.

Levando em consideração que as instituições não são sempre projetadas para a diversidade, evidencia a necessidade dos professores, e da escola suscitarem questões reflexivas e críticas sobre o modelo neoliberal capitalista, analisando, com os alunos, as consequências decorrentes desse modelo político a fim de garantir a todos os estudantes à educação de qualidade, independentes das capacidades intelectuais, físicas ou sensoriais, de suas crenças religiosas ou culturais e de suas características étnicas, de gênero ou de classe social.

Tomando como base o cenário educacional espanhol, Santomé (2013) enfatiza a necessidade de superação do "cavalo de troia dos currículos", que reproduzem as formas dominantes do discurso neoliberal capitalista, a exemplo: a segregação, a desconexão e a infantilização. A segregação consiste, em agrupar os estudantes de acordo com características comuns, como, por exemplo, sexo, idade, origem étnica, classe social ou mesmo habilidades. Dessa forma, é possível negar, as mesmas oportunidades educacionais aos educandos e a interação entre ambos. No Brasil temos como exemplo a classificação por turmas, que é a efetivação da política de prevenção de distorção idade ano; e a matrícula por localização geográfica, que favorece o agrupamento de alunos oriundos de classes econômicas similares e grupo social e cultural no mesmo contexto educacional. A desconexão está fundamentada, especialmente, em duas estratégias 
pedagógicas: "o dia de" e "a segmentação curricular por disciplinas". No que se refere a segmentação curricular por disciplinas, verificasse a obrigatoriedade de disciplinas voltadas ao desenvolvimento econômico como matemática, ciências, tecnologia e língua estrangeira, por exemplo. Sobre a infantilização Santomé (2013), afirma ser currículo do turista. O currículo do turista é a forma de apresentar a realidade cultural subalterna como os turistas em geral experimentam. Assim o enfoque limita-se aos hábitos alimentares, as vestimentas, práticas cerimoniais, etc. Outra forma é a representação das diferentes culturais por meio de um desenho distanciando da realidade. Fica evidente a urgência de favorecer o debate, em sala de aula, e permitir que a diversidade, presente na vida real, participe, também, do currículo escolar.

É importante salientar que Paulo Freire (1996) No livro Pedagogia da autonomia: saberes necessários à prática educativa, já apontava a formação docente entrelaçada com a reflexão sobre a prática educativa como favorável a autonomia do ser dos educandos. Afirmando que os educadores não podem escapar a rigorosidade ética. A rigorosidade ética pode ser entendida como o confronto a toda e qualquer ação discriminatória de raça, de gênero e de classe. Ainda como qualquer afronta ao "achismo da prática educativa" sem análise da verdade, ou por meio da distorção da verdade em detrimento ao ser indefeso partícipe da prática formadora.

O professor e aluno devem, portanto, ser sujeitos ativos no processo de ensino e aprendizagem. Não se podem reduzir a objetos um do outro. $O$ professor não pode ser apenas a figura que ensina $o$ aluno, e o aluno a figura que aprende com o professor, ambos juntos. Ensinar, portanto, não é simplesmente transferir conhecimento. A criticidade é um fator importante no processo educativo. 


\section{O Programa Escola Novo Tempo em RondôNia}

A Portaria n. 1.145, de 10 de outubro de 2016 institui o Programa de Fomento à Implementação de Escolas em Tempo Integral, criada pela Medida Provisória n. 746, de 22 de setembro de 2016.

O Programa Escola Novo Tempo fortalece Ensino Médio Integral como política pública em Rondônia. Vinculado a Secretaria de Estado de Educação (Seduc), tem por objetivo "o planejamento, o desenvolvimento e a execução de um conjunto de ações inovadoras relativas ao currículo e gestão escolar, por meio da implementação de políticas públicas para o ensino médio em tempo integral no Estado" (Lei Complementar n. 940/2017).

Rondônia, desde 2016, vem apresentando iniciativas de mudanças, na modalidade de Ensino Médio em Tempo Integral (EMTI), que se materializam na prática em "iniciativas de flexibilização, com a possibilidade de escolhas de disciplinas, e de formação integral, como o projeto de vida” (Lotta; Bauer, 2018). A reorganização do currículo, por áreas de conhecimento, competências e habilidades dão oportunidade ao estudante a sua formação integral.

Os resultados do Índice de Desenvolvimento da Educação Básica (IDEB) de 2017 evidenciam que de onze escolas de tempo integral em Rondônia, cinco delas destacaram-se como melhores em resultados de proficiência.

De acordo com a Lei Complementar n. 940/2017:

O Programa Escola do Novo Tempo tem por finalidade integrar as ações desenvolvidas nas escolas estaduais de ensino médio em tempo integral em todo o Estado, oferecendo atividades que influenciem no 
processo de aprendizagem e enriquecimento cultural (Lei Complementar n. 940/2017).

Em Rondônia, o programa Escola Novo tempo conta com a parceria do Instituto de Corresponsabilidade pela Educação (ICE), Instituto Sonho Grande e Instituto Natura. O ICE, entidade sem fins lucrativos, criada por um grupo de empresário em Recife, tem objetivo de construir um novo modelo de escola, onde os padrões de excelência sejam reconstituídos.

De acordo com Lotta e Bauer (2018), o Ensino Médio em Tempo Integral em Rondônia se materializa por um conjunto de iniciativas de mudanças e flexibilização que contam com: Formação Integral, Protagonismo do Estudante, Inovações Curriculares e Novos Formatos de Ensino. Na Formação Integral e Protagonismo do Estudante os alunos têm a possibilidades de escolher disciplinas, desenvolver o projeto de vida, com o aprofundamento em alguma área do conhecimento e atividades orientadas e tutoria. Nas Inovações Curriculares e Novos Formatos de Ensino o currículo é organizado por áreas de conhecimento, por competências e habilidades. A Educação Profissional e Técnica trabalha com projeto, matriz curricular ou componente que incorpore práticas associadas ao mundo do trabalho modalidade de educação profissional e técnica articulada integrada em um único turno escolar. A formação docente entrelaça a integração de disciplinas, $\mathrm{O}$ projeto de vida com as metodologias inovadoras para promoverem protagonismo do estudante e suas competências/habilidades socioemocionais.

Dessa forma, o Programa Escola do Novo Tempo tem por objetivo o planejamento, o desenvolvimento e a execução de um conjunto de ações inovadoras relativas ao currículo e gestão escolar, por meio da implementação de políticas públicas para o 
Ensino Médio em Tempo Integral. Deve dessa forma, ser implantado e desenvolvido em unidades escolares de ensino médio da rede pública estadual de ensino conforme regulamentadas do Decreto do Poder Executivo para funcionar em tempo integral.

\section{APRESENTAÇÃo lócus E ANÁlise doS RESUltados DA PESQUISA}

\section{O LÓCUS DA PESQUISA DE CAMPO}

A pesquisa foi desenvolvida na fronteira Brasil/Bolívia do estado de Rondônia, especificamente em uma Escola de Ensino Médio em Tempo Integral da rede estadual de ensino na cidade de Guajará-Mirim(RO).

Até o início do século XIX, "Guajará-Mirim era apenas uma indicação geográfica para designar o ponto brasileiro à povoação boliviana de Guayaramerim". Foi somente a partir da construção da Estrada de Ferro Madeira Mamoré que uma grande miscigenação de pessoas instalou-se no município, trazendo para a região suas contribuições culturais, que hoje auxiliam na compreensão da formação da identidade, da linguagem e da sociedade local. De acordo com Bispo (2010 p. 81) esses grupos chegavam às terras guaporeanas para participar da construção da estrada ou eram seduzidos pela oportunidade de produzirem borracha que seriam escoadas pela ferrovia. A partir desse período iniciou-se progressivamente o processo de colonização, ocupação e povoamento do município.

Guajará-Mirim foi elevado à categoria de município em 1928 e instalado pelo governo do estado do Mato Grosso em 10 de abril 
de 1929, sendo integrado ao Território Federal do Guaporé12, em 1943.

A característica da população do município é a mestiçagem de várias raças com os nativos (indígenas aculturados), resultando numa população tipicamente amazônica. Os perfis sociais observáveis no município são: indígenas, agricultores, seringueiros, pescadores, ribeirinhos, bolivianos, indianos, chineses, gregos, barbadianos, cubanos, espanhóis, norte-americanos, libaneses, portugueses, alemães e ainda uma forte migração decorrente da região nordeste brasileira.

Conforme dados do Instituto Nacional de Geografia e Estatística (IBGE) ${ }^{13}$, a população estimada de Guajará-Mirim em 2019 é de 46.174 mil pessoas, em uma área de 24.855,724 km², e densidade demográfica de 1,68 habitantes por quilômetro quadrado, registrando no censo 2010, 93,1\% de pessoas escolarizadas de 6 a 14 anos.

A economia de Guajará-Mirim está assentada no funcionalismo público, resultante do aparelhamento estatal na faixa de fronteira, com a presença de diversos órgãos públicos, como: Exército, Marinha, Aeronáutica, Receita Federal, Justiça Federal, Incra, Suframa, além dos órgãos das esferas estadual e municipal presentes na localidade (Uchôa, 2019 p. 4).

\footnotetext{
${ }^{12}$ No ano de 1956 o Território Federal do Guaporé passou a ser denominado Território Federal de Rondônia, em homenagem ao Marechal Cândido Mariano da Silva Rondon, responsável pela missão telegráfica que ligou a região ao restante do país. Rondônia se constitui Estado em 1981.

13 Disponível em: <www.ibge.gov.br/cidades-e-estados/ro/guajaramirim.html>. Acesso em: 25 nov. 2019.
} 


\section{DISCUSSÕES E ANÁLISE DOS DADOS COLETADOS}

Para atingir os objetivos propostos realizamos estudos documentais e entrevistas com a equipe gestora da Escola em Tempo Integral no município de Guajará-Mirim, fronteira com a Bolívia. As perguntas que nortearam os estudos foram: Quais as perspectivas da Escola Novo Tempo para promoção da pluralidade cultural e linguística na fronteira? Quais os desafios da prática educativa da gestão escolar na promoção da pluralidade cultural e linguística na fronteira? Quais as impressões que a gestão da Escola de Ensino Médio em Tempo Integral tem em relação aos alunos da fronteira?

Para a gestora da Escola contemplada com o Programa Novo Tempo em Guajará-Mirim "às perspectivas para promoção da pluralidade cultural e linguística na fronteira estão pautadas no currículo da escola, onde a centralidade do modelo é o jovem e o seu projeto de vida [...]" (Gestora, 2019).

De acordo com Silva (1996, p. 23): “o currículo é um dos locais privilegiados onde se entrecruzam saber e poder, representação e domínio, discurso e regulação. O currículo corporifica relações sociais" (Silva, 1996, p. 23). Pode-se inferir que é nele que se condensam relações de poder que são cruciais para o processo de formação de subjetividades sociais e reconhecimento das identidades sociais.

Dessa forma, o currículo da escola contemplada pelo Programa Escola Novo Tempo é mais estendido, por ser integral, assim é constituído a partir de três eixos formativos que são importantes na formação dos estudantes são eles: excelência acadêmica, formação para a vida e formação de competência para o século XXI, que estão aí sendo trabalhada nessa parte diversificada. 
A parte diversificada tem a função de fortalecer a base comum, dessa forma, tudo que é feito na parte diversificada tem relação com a base comum e isso é muito legal que não é uma coisa desassociada tem uma relação bem próxima um com outro (Gestora, 2019).

A formação de excelência acadêmica está relacionada ao cognitivo, ao aprender, o aluno relaciona o conteúdo ao "pilar ser", dentro do "pilar conhecer cognitivo". "A gente precisa de resultados, a gente precisa de indicadores para poder trabalhar o eixo de formação para a vida” (Gestora, 2019). O eixo de formação para a vida está muito relacionado com esse pilar do ser:

Preciso me conhecer pra me relacionar porque o ser humano é um ser relacional então a escola novo tempo ela vem trabalhar dentro desse eixo de formação para a vida entendendo que eu sou um ser social eu preciso entender a importância disso, no eixo formativo de competência pro século XXI eu vou ter lá várias habilidades sendo desenvolvidas que vão me ajudar a ser um bom profissional, assim uma pessoa que eu vou me descobrir nesse mercado que seja exigente e eu preciso ter algumas aptidões como alto regulação (Gestora, 2019).

Nessa perspectiva a Escola Novo Tempo em contexto de Fronteira traz possibilidade para a promoção da pluralidade linguística na escola, às vezes ocultadas em escolas com outras realidades. "Nós temos muitas diversidades e a escola novo tempo ela traz essa abertura para promoção dessa pluralidade cultural” (Gestora). Isto, porque, segundo a gestora:

Dentro da parte diversificada, as disciplinas eletivas abrem a possibilidade de desenvolvimento de projetos bem interessantes que vão trabalhar essa pluralidade cultural linguística, nós temos, 
por exemplo, as eletivas na área de Língua Espanhola, que trabalha muito cultura espanhola (Gestora, 2019).

Dessa forma,

[...] Sempre a gente vai ter uma eletiva que vai tratar da cultura espanhola, na parte cultural na parte da culinária, musical, então a gente sempre tem essa afinidade, essa proximidade, a escola dá uma possibilidade de acolhimento muito grande e esse acolhimento ele é fundamental para que eles aprendam a conviver com diferenças porque eles são incluídos nos grupos, quando a gente trata de eletivo, por exemplo, eu vou ter um grupo de trabalho que vai ter menino de $2^{\circ}, 3^{\circ}$ ano envolvido no mesmo projeto (Gestora, 2019).

Verifica-se que a interação no contexto escolar ela é muito importante para o desenvolvimento desse estudante independente da questão cultural dele. Ao falar sobre a experiência que tem como gestora da escola de Ensino Médio em Tempo Integral e as impressões linguísticas que têm em relação aos alunos da fronteira (bolivianos em relação aos brasileiros e dos alunos de GuajaráMirim em relação aos bolivianos), a gestora afirma:

[...] há três anos ocupando a função de gestora [...], passeando nessa realidade dos estudantes, que formam a comunidade estudantil nessa escola, a g ente percebe que há um grande avanço no sentido de que você percebe estudantes menos tímidos, porque eles conseguem se sentir parte desse processo, quando eles se sentem parte, eles realmente fazem acontecer, e eu falo assim muito da pedagogia da presença de ser gestor da escola novo tempo [...] quando eu vi que essa escola colocava o estudante como o centro e que eu tinha que entender a centralidade do modelo [...] (Gestora, 2019). 
Verifica-se que a pedagogia da presença faz toda a diferença na mudança de comportamento dos estudantes e da comunidade escolar, de acordo com a gestora o estudante "ao se importar um com o outro a forma de como ele é recebido ele passa receber também", o espaço que ele ganha quando se fala de protagonismo faz com que ele se sinta "um ser dotado de capacidade de fato e não alguém que tá ali só pra receber um conhecimento, ele faz parte desse crescimento da escola do novo tempo ele faz parte diretamente quando ele decide, quando ele avalia, quando ele planeja [...]" (Gestora, 2019).

Ao retomar sobre as perspectivas do Programa Escola Novo Tempo para promoção da pluralidade cultural e linguística na fronteira a gestora afirma:

Os princípios do programa estão pautados nos quatro pilares da educação, educação interdimensional e protagonismo [...] são princípios negociáveis dentro do programa [...] se o estudante é autônomo ele consegue verificar, ele vai ter dificuldades como qualquer outro estudante, mas ele vai conseguir visualizar menos soluções problemáticas, sem desistir dos seus objetivos [...] vejo como ponto positivo isso, esses princípios que são estabelecidos que infelizmente eles ainda não são de fato trabalhados em todas as escolas, em todos os âmbitos educacionais. O Programa Escola Novo Tempo, abre possibilidades de intervir dentro da escola com uma metodologia capaz de identificar as fragilidades até então não trabalhada [...] (Gestora, 2019).

Ao ser questionada sobre a importância da gestão educacional no desenvolvimento da proposta pedagógica da instituição na qual atua e na promoção da pluralidade cultural e linguística na fronteira a gestora afirma que: 
A pedagogia da presença foi algo que como gestora me enriqueceu muito [...] a gente tem toda comunidade envolvida nessa pedagogia, desde o porteiro até a merendeira [...] o acolhimento ao aluno é realizado por todos. Saber trabalhar a pedagogia da presença é de fundamental importância (Gestora, 2019).

A linguagem é um fator interessantíssimo na relação de fronteira. Desse modo, procurou encaminhar as entrevistas às questões relacionadas ao intercâmbio de informações entre brasileiros e bolivianos falantes de línguas diferentes.

Em relação aos alunos da fronteira (bolivianos) qual língua é utilizada para a comunicação a gestora afirma:

A gente gosta muito de brincar com os alunos da fronteira [...] os bolivianos quando eles chegam eu cumprimento eles em espanhol, fortalecendo isso porque muitas vezes o que acontece, eles têm vergonha de falar a língua deles em público porque são bolivianos [...] a equipe gestora procura muito falar com eles, trabalho na escola desde 2007, percebo que tinha muito preconceito linguístico em relação em relação aos meninos que eram bolivianos, eles quase não falavam, por causa que falavam meio portunhol mas hoje não percebo assim essa timidez em relação a isso (Gestora, 2019).

O portunhol no contexto de Guajará-Mirim e Guayaramerín serve como estratégia linguística para facilitar a comunicação e foi definido pelos informantes como: falar a sua língua materna utilizando alguns termos, da língua portuguesa ou espanhola, que já estão familiarizados. Com isso registramos uma dupla informação: língua de contato sendo a materna, português ou espanhol, de cada falante e/ou língua intermediária o "portunhol”. 
Nesse sentido, prevalece à ideia que no contexto escolar da "Escola da Escolha" perceber a diferenciação linguística não é prática impassível, o acolhimento ao aluno imigrante é importante nesse processo, visto promover sua identidade cultural e linguística. "A interação é muito importante para o desenvolvimento total desse estudante independente da questão cultural dele" (Gestora, 2019).

Para Freire (1996) o diálogo com educando permite a consideração e compreensão saberes construídos pelos alunos em suas comunidades. Valorização e compressão da história do aluno para construção de saberes significante. $\mathrm{O}$ professor precisa ser crítico e humilde, e relação de esperança.

Os alunos das escolas públicas na fronteira Brasil-Bolívia possuem características linguísticas e socioculturais singulares que se constituem e se reconstituem na multiculturalidade e no plurilinguismo, pois além dos inúmeros falares e dialetos, as culturas indígena, boliviana e africana contribuíram, de forma significativa, para a constituição da linguagem e da cultura dessa região. Nesse contexto, o desafio da prática docente nas escolas da fronteira é oferecer uma educação includente, possibilitando aos indivíduos das classes sociais estigmatizadas a valorização de suas singularidades e de suas identidades.

Ainda em relação à língua a gestora afirma:

Alguns alunos têm um pouquinho de dificuldade na língua, mas isso aí a gente identifica através da tutoria e o tutor conversa com os professores eles sempre ganham uma chance a mais para ter mais paciência com ele, pois ele tem mais dificuldade, mas no dia a dia a gente fala assim dentro da língua pra valorizar que é da cultura dele e eles se sentem (Gestora, 2019). 
Na obra Pedagogia da autonomia: saberes necessários à prática educativa Freire (1997) propõe os saberes indispensáveis à prática formativa do professor, enquanto mentor e guia no processo educativo-social, conscientizado e conscientizando os educandos de todas as camadas sociais. Ensinar exige tanto a criticidade do professor como a do aluno, "Quanto mais se exercita criticamente a capacidade de aprender, mais se constrói a curiosidade epistemológica, sem a qual não alcançamos o conhecimento do objeto" (Freire, 1996). O conteúdo não pode ser estudado passivamente, é necessário, portanto, uma reflexão crítica sobre ele. Nesse processo é importante a valorização do conhecimento prévio dos alunos que estão baseados em experiências e em conhecimentos de processos formais, passando a ter a visão crítica da realidade.

Ao ser questionada se a EEEFMTI na qual atua já desenvolveu alguma ação para promoção da pluralidade cultural e linguística na fronteira, a gestora reponde:

Todo semestre tem as eletivas que trata da pluralidade cultural, principalmente da língua espanhola, então sempre vai ter uma eletiva voltada pra essa área, percebemos que e eles gostam muito, pois valoriza muito a questão da culinária da cultura deles [...], quando se trata da dança de fazer os pratos de aprender mais sobre o idioma eles participam bastante, não tem nenhum preconceito em relação a isso.[...] além da eletiva nós temos uma disciplina chamada pós médio e projeto de vida, nós já fomos algumas vezes na Bolívia visitar a faculdade e o centro cultural [...] (Gestora, 2019).

Nesse sentido, o protagonismo é fortalecido, visando a promoção dos estudantes a jovens autônomos, solidários e competentes e consequentemente a realização dos seus projetos de 
vida sempre alicerçados nos três eixos fundamentais do Projeto da Escola da Escolha: Formação Acadêmica de Excelência, Formação para a Vida e Formação para o Desenvolvimento das Competências do Século XXI e nos quatro pilares da educação: aprender a ser, aprender a conhecer, aprender a fazer, aprender a conviver.

\section{CONSIDERAÇõES FINAIS}

Este trabalho teve o intuito analisar as perspectivas do Programa Escola Novo Tempo para Promoção da Pluralidade Cultural e Linguística em Rondônia, e seu desenvolvimento no município de Guajará-Mirim, fronteira do Brasil com a Bolívia.

Durante o estudo, destacamos sobre alguns aspectos sobre educação, políticas, currículos e diferenças culturais na contemporaneidade. Observa-se que a contemporaneidade é marcada pela imposição de filosofias de orientação práticas que descuidam aspectos de crucial importância como a seleção da cultura por meio da qual se pode compreender melhor um mundo cada vez mais globalizado e no qual se produzem muitas transformações, que não consideram a pluralidade linguística cultural.

Os estudos sobre as normativas que institui o Programa Escola Novo Tempo em Rondônia e análise das iniciativas de desenvolvimentos do Ensino Médio em tempo Integral em Rondônia, descrita por Lotta e Bauer (2018) nos permitiram compreender como se institui o Programa Escola Novo Tempo em Rondônia e como se dá a flexibilização do Programa no referido estado.

Nossas discussões nos levam a compreender que as possibilidades de flexibilização de currículos tornam o contexto escolar de tempo integral bastante favorável para promoção da 
pluralidade cultural e linguística em Rondônia, em específico a escola da fronteira, realidade diferente da escola que não possui tempo adicional.

Os registros das experiências da gestão escolar frente ao Programa Escola Novo Tempo, nos permitiram identificar as concepções que o contexto escolar possui sobre a pluralidade cultural e linguística na fronteira.

A prática docente em um contexto de fronteiras exige do professor o conhecimento e a compreensão das variedades linguísticas, sociais e culturais dos alunos, pois uma sociedade multicultural tem suas especificidades e suas relações identitárias internas interculturais.

O portunhol no contexto de Guajará-Mirim e Guayaramerín serve como estratégia linguística para facilitar a comunicação e foi definido pelos informantes como: falar a sua língua materna utilizando alguns termos, da língua portuguesa ou espanhola, que já estão familiarizados. Com isso registramos uma dupla informação: língua de contato sendo a materna, português ou espanhol, de cada falante e/ou língua intermediária o "portunhol".

Verifica-se que a pedagogia da presença faz toda a diferença na mudança de comportamento dos estudantes e da comunidade escolar, de acordo com a gestora o estudante "ao se importar um com o outro a forma de como ele é recebido ele passa receber também", o espaço que ele ganha quando se fala de protagonismo faz com que ele se sinta "um ser dotado de capacidade de fato e não alguém que tá ali só pra receber um conhecimento, ele faz parte desse crescimento da escola do novo tempo ele faz parte diretamente quando ele decide, quando ele avalia, quando ele planeja [...]” (Gestora, 2019). 
Verifica-se que a interação no contexto escolar de pesquisa é muito importante para o desenvolvimento desse estudante independente da questão cultural que está inserido.

$\mathrm{Na}$ fronteira Brasil-Bolívia, devemos considerar que a presença de diferentes sujeitos amazônidas é construída diariamente e é constituída por múltiplas linguagens, possibilitando estudos e pesquisas no campo educacional, a fim de oferecer uma educação que favoreça o multiculturalismo existente nas escolas. Dessa forma, esta pesquisa não se finda. Pretendemos investigar de que forma acontece a prática docente nos diversos âmbitos da prática educativa, considerando, também, as diversidades interculturais e as histórias dos povos que contribuíram para a constituição social da fronteira Brasil-Bolívia.

\section{REFERÊNCIAS}

BRASIL. Ministério da Educação. Portaria n. 1.145, de 10 de outubro de 2016. Disponível em: $<$ http://portal.mec.gov.br/index.php?option=com_docman\&view =download $\&$ alias=49121-port-1145-11out-pdf\& category_slug= outubro-2016-pdfEItemid=30192>.

CALVET, Louis-Jean. As políticas linguísticas. São Paulo: Parábola, 2007.

FREIRE, Paulo. Pedagogia da autonomia: saberes necessários à prática educativa. São Paulo: Paz e Terra, 1997.

LOTTA, Gabriele; BAUER, Marcela. Mapeamento das iniciativas de desenvolvimento do ensino médio nos estados brasileiros. Brasília: Consed, 2018. 
RONDÔNIA. Conselho Estadual de Educação. Resolução n. 1238/2018. Disponível em: <www.diof.ro.gov.br/data/uploads/ 2018/09/Doe_04_09_2018.pdf>.

. Decreto de criação das escolas - n. 22.234/2017. Disponível em: $\quad<$ http://ditel.casacivil.ro.gov.br/COTEL/Livros/ Files/D22234.pdf >.

Lei Complementar 940/2017. Disponível em:

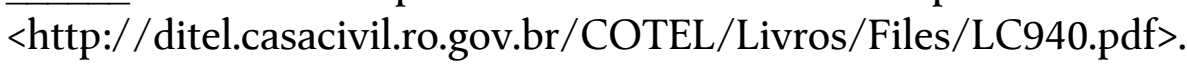

Lei Complementar 958/2017. Disponível em:

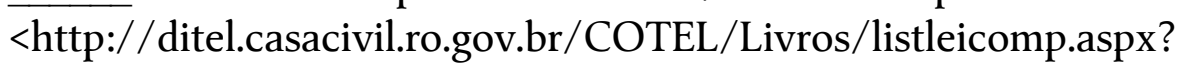
ano $=2017>$.

SANTOS, Milton. Por uma outra globalização: do pensamento único à consciência universal. São Paulo: Saraiva, 2000.

TORRES SANTOMÉ, Jurjo. Currículo escolar e justiça social: o cavalo de Tróia da educação. Porto Alegre: Penso, 2013.

UCHÔA, Márcia Maria Rodrigues. Currículo na fronteira Brasil/Bolívia de Rondônia. Revista Culturas \& Fronteiras, vol. 1, Edição Especial, 2019 Disponível em: <www.periodicos.unir.br/ index.php/index/user>.

UNESCO. Global Education Monitoring Report. 2017/2018.

WALSH, Catherine. Interculturalidade crítica e pedagogia decolonial: in-surgir, reexistir e re-viver. In. CANDAU, Vera Maria (Org.). Educação intercultural na América Latina: entre concepções, tensões e propostas. Rio de Janeiro: 7 Letras, 2009. p. $12-43$ 
FORMAÇÃO INICIAL DE PROFESSORES E MODALIDADE DA EDUCAÇÃO A DISTÂNCIA PARA A EDUCAÇÃO INCLUSIVA ${ }^{14}$

\author{
Vera Mônica Queiroz Fernandes Aguiar ${ }^{15}$
}

Regina Célia Linhares Hostins ${ }^{16}$

\title{
INTRODUÇÃo
}

Ao considerar que o Brasil é signatário da Declaração de Salamanca, e que há muito a ser feito para que se consolidem as políticas públicas de educação especial no ambiente escolar e na sociedade, entende-se que o envolvimento de governos, grupos de advocacia, comunidades, professores e pais, e em particular de organizações de pessoas com deficiência é relevante para as que políticas possam ser traduzidas no contexto da prática de maneira mais efetiva. Há que se encontrar formas de melhorar o acesso à educação, reconhecendo que todos devem ter seus direitos assegurados para conviver em sociedade.

Assim sendo, os sistemas educacionais têm sido designados a implementarem alguns programas educacionais de acesso a todos na escola regular por meio de uma pedagogia centrada na criança, capaz de satisfazer às necessidades de aprendizagem de todos. Buscam-se escolas regulares que possuam orientação inclusiva

\footnotetext{
${ }^{14}$ Artigo apresentado à Universidade do Vale do Itajaí (Univali). Pró-reitora de pesquisa, pós-graduação, extensão e cultura. Programa de Pós-Graduação Stricto Sensu em Ciência da Educação. Curso de Doutorado em Educação. Doutorado Interinstitucional. Faculdade Católica de Rondônia como requisito avaliativo.

${ }^{15}$ Doutoranda em Educação pela Univali.

16 Professora Doutora da Univali, ministrante da disciplina Epistemologia no curso de doutorado em Educação.
} 
como um dos meios eficazes de combater atitudes discriminatórias criando-se comunidades acolhedoras, construindo uma sociedade inclusiva. É preciso também oferecer a segurança de uma educação para todos; além disso, tais escolas proveem uma educação efetiva com eficiência e, em última instância, o custo da eficácia de todo o sistema educacional, com políticas públicas que garantam a modernização para o desenvolvimento humano.

João Serapião de Aguiar e Édison Duarte (2005, pp. 227 e 228) enfatizam que:

A presença do deficiente na escola pressupõe uma mudança radical no interior da mesma, seja nos procedimentos de ensino, na avaliação, no currículo, enfim, em todas as áreas do sistema escolar. Pode-se mesmo dizer, que há múltiplos aspectos a serem considerados para a implementação de uma escola inclusiva. Dentre esses estão o oferecimento de cursos de reciclagem para capacitação de docentes; a importância da existência de um corpo técnico especializado (composto por psicólogo, fonoaudiólogo e psicopedagogo); o apoio da família do aluno com necessidades especiais; o número de alunos na classe; a eliminação de barreiras arquitetônicas; a revisão pela sociedade civil da concepção sobre a pessoa com necessidades especiais; o apoio da sociedade política; a destinação de verbas; a adequação de currículos, metodologias de ensino, recursos didáticos e materiais e sistemas de avaliação (ARANHA, 2000; BERALDO, 1999; BUENO; RESA, 1995, CARDOSO, 1992; DAMIÃO, 2000; JANNUZZI, 1993; LÜSCHER, 1999; MACHADO, SOUSA, SAYÃO, 1997; MANTOAN 1989, 1997, 1998, 2003; MARTINS, 1996; MAZZOTA, 1993, 1994; MENDES, 1999, 2000; MRECH, 1999; SANTOS, 1992; SASSAKI, 1999; STAINBACK; STAINBACK, 1999). 
Com o princípio da Inclusão, a Educação Física escolar deve ter como eixo fundamental o aluno e, sendo assim, deve desenvolver as competências de todos os discentes e dar aos mesmos condições para que tenham acesso aos conteúdos que propõe, com participação plena, adotando para tanto estratégias adequadas, evitando a exclusão ou alienação.

Sendo assim, com a legislação, no contexto da prática, em que as políticas são traduzidas e adquirem novos contornos, acredita-se que existam contribuições para aprimorar e ampliar as atividades docentes, além de propiciar reflexões importantes do cotidiano escolar, como a necessidade de os projetos políticopedagógicos incorporarem em seus textos políticas, culturas e práticas inclusivas, tais como a formação pela modalidade a distância. Outro aspecto importante é a necessidade de mudança do trabalho pedagógico na escola para atender com qualidade a singularidade de cada estudante, uma vez que esta se movimenta para promover ensino, de tal modo que todos aprendam.

Adriana Rocha da Silva e Alda Maria Duarte Araújo Castro (2008, p. 189) destacam:

Na atualidade, a necessidade de qualificação do profissional docente está articulada às seguintes necessidades: a) superar os problemas ou as lacunas existentes na prática docente; b) promover a introdução de um novo repertório de conhecimentos de natureza teórica ou prática, decorrente da produção de novos saberes nas diferentes áreas de conhecimento. Tais aspectos justificam a importância da formação realizada no exercício da prática profissional, no entanto, essa formação, de modo geral, acaba acontecendo sem uma sólida base teórica, pois visa, apenas, ao desenvolvimento de habilidades técnicas. Essa visão aligeirada e fragmentada não permite que o futuro profissional seja 
formado para atuar numa perspectiva que o permita compreender as relações sociais que perpassam os saberes escolares.

Desse jeito, denota-se que as autoras entendem que a formação inicial de professores tem ocorrido observando-se todos os critérios previstos em normas disciplinadas pelo Ministério da Educação por meio de programas das instituições superiores públicas e privadas. Contudo, há necessidade de se primar pela qualificação profissional que, muitas vezes, depende de superar as celeumas comuns da prática docente e incluir novos conhecimentos teórico-práticos para produzir novos saberes na diversidade inerentes à educação.

\section{CONCEITOS E CONTEXTOS LEGAIS}

De acordo com a Política Nacional de Educação Especial na perspectiva da educação inclusiva, publicada em 2008, o atendimento educacional especializado (AEE) identifica, elabora e organiza recursos pedagógicos e de acessibilidade que eliminem as barreiras para a plena participação dos estudantes, considerando suas necessidades específicas. As atividades desenvolvidas no AEE diferenciam-se das realizadas na sala de aula comum, não sendo substitutivas à escolarização, cujo atendimento complementa e/ou suplementa a formação dos estudantes visando sua autonomia e independência na escola e na sociedade. O AEE tem como função identificar, elaborar e organizar recursos pedagógicos e de acessibilidade que eliminem as barreiras para a plena participação dos alunos, considerando suas necessidades específicas.

A Secretaria de Educação Especial instrui que os sistemas de ensino matriculem os alunos com deficiência, os com transtornos globais do desenvolvimento e os com altas 
habilidades/superdotação nas escolas comuns do ensino regular e ofertem o AEE, com o fito de promover o acesso e as condições para uma educação de qualidade. As diretrizes operacionais da educação especial preconizam que para o atendimento educacional especializado na educação básica, a oferta do AEE deve constar no projeto pedagógico da escola de ensino regular, prevendo:

a. Sala de recursos multifuncional: espaço físico, mobiliários, materiais didáticos, recursos pedagógicos e de acessibilidade e equipamentos específicos; b. Matrícula do aluno no AEE: condicionada à matrícula no ensino regular da própria escola ou de outra escola; c. Plano do AEE: identificação das necessidades educacionais específicas dos alunos, definição dos recursos necessários e das atividades a serem desenvolvidas; cronograma de atendimento dos alunos; d. Professor para o exercício da docência do AEE; e. Profissionais da educação: tradutor e intérprete de Língua Brasileira de Sinais, guia-intérprete e outros que atuam no apoio às atividades de alimentação, higiene e locomoção. f. Articulação entre professores do AEE e os do ensino comum. g. Redes de apoio: no âmbito da atuação intersetorial, da formação docente, do acesso a recursos, serviços e equipamentos, entre outros que contribuam para a realização do AEE (Brasil, 2008, p. 3)

Na perspectiva de direitos, reconhecer as diferenças para a garantia da aprendizagem irrestrita em quaisquer circunstâncias é importante para a inclusão. No entanto, impõem-se novos desafios e formas de trabalho aos educadores. Além da necessidade de atualização constante, considerando as grandes mudanças e transformações no sistema educacional brasileiro e no mundo, analisar o próprio fazer pedagógico no cotidiano da escola é condição obrigatória para o desenvolvimento de práticas pedagógicas inclusivas. A análise documental se torna importante para que sejam observados os dispositivos legais e atendidas as 
demandas de currículo, ementas e direitos digitais e todos os componentes que se referem à formação, à prática pedagógica e à aprendizagem.

Jefferson Mainardes e Maria Inês Marcondes (2009, p. 305), quando entrevistaram Stephen Ball, assinalam que o autor ao abordar o ciclo de políticas considera que as leis situam-se no contexto de produção de texto. Trata-se de uma alternação entre modalidades, sendo a primária, que é a textual, pois as políticas são escritas, enquanto a prática é ação, incluem o fazer coisas. A prática das políticas converte ou transforma essas duas modalidades, entre a modalidade da palavra escrita e a da ação, e isto é algo difícil e desafiador de se fazer.

O que isto envolve é um processo de atuação, a efetivação da política na prática e através da prática. É quase como uma peça teatral. Temos as palavras do texto da peça, mas a realidade da peça apenas toma vida quando alguém as representa. Este é um processo de interpretação e criatividade; as políticas também são assim.

Viviane Grimm, Fernando Cesar Sossai e Marília Segabinazzi no artigo intitulado "Globalização, redes políticas e neoliberalismo: as contribuições de Stephen Ball para pensar sobre políticas educacionais na atualidade" (2016, p. 852) ressaltam que:

Nesse contexto, as políticas educacionais estão sendo feitas "[...] em novas localidades, em diferentes parâmetros, por novos atores e organizações", requerendo dos investigadores " $[\ldots]$ novos métodos e conceitos e novas sensibilidades de pesquisa", superando o "territorialismo metodológico" (Ball, 2014, p. 27).

Para as autoras é importante frisar que Ball (2014), quanto às políticas públicas direcionadas à educação, cita inúmeros projetos e programas que, mesmo estando revestidos de 
promissores desígnios, corroboram num modelo gerencialista que vem se estabelecendo em nosso meio social e se enraizando no pensamento dos educadores.

Quanto ao Decreto n. 7.611/11, este estabelece as diretrizes do AEE e reitera as garantias estabelecidas pela Política nacional e assim novas ideias constituíram a educação especial. Entretanto, é necessário compreender de fato qual o papel do professor do AEE, que tem como um de seus espaços de atuação a sala de recursos multifuncionais (SRM), frisando-se que, em primeiro lugar, é o caráter complementar ou suplementar do AEE.

A Lei n. 13.005/2014 foi sancionada no dia 25/2014. O art. $1^{\mathrm{o}}$, que aprova o Plano Nacional de Educação (PNE), com vigência por 10 (dez) anos, a contar da publicação da Lei n. 13.005/2014, na forma do anexo, visa ao cumprimento do disposto no art. 214 da Constituição Federal. $\mathrm{O}$ art. $2^{\circ}$ apresenta as diretrizes do PNE, que são a erradicação do analfabetismo, a universalização do atendimento escolar, a superação das desigualdades educacionais, com ênfase na promoção da cidadania e na erradicação de todas as formas de discriminação, melhoria da qualidade da educação.

O PNE garante a formação para o trabalho e para a cidadania, com ênfase nos valores morais e éticos em que se fundamenta a sociedade, promoção do princípio da gestão democrática da educação pública, promoção humanística, científica, cultural e tecnológica do Brasil, estabelecimento de meta de aplicação de recursos públicos em educação como proporção do Produto Interno Bruto (PIB), que assegure atendimento às necessidades de expansão, com padrão de qualidade e equidade, 
valorização de profissionais da educação, promoção dos princípios do respeito aos direitos humanos, à diversidade e à sustentabilidade.

$\mathrm{O}$ art. $3^{0}$ estabelece que as metas previstas no artigo da lei serão cumpridas no prazo de vigência do PNE, desde que não haja prazo inferior definido para metas e estratégias específicas. $\mathrm{O}$ art. $4^{\circ}$ define as metas previstas em Lei que deverão ter como referência a Pesquisa Nacional por Amostra de Domicílios (PNAD), o censo demográfico e os censos nacionais da educação básica e superior atualizados, disponíveis na data da publicação da Lei.

O PNE é importante e deve ser debatido para ser executado. Dentre as metas, cita-se a Meta 4, que propõe universalizar, para a população de 4 a 17 anos com deficiência, transtornos globais do desenvolvimento e altas habilidades ou superdotação, o acesso à educação básica e ao atendimento educacional especializado, preferencialmente na rede regular de ensino, com a garantia de sistema educacional inclusivo, de salas de recursos multifuncionais, classes, escolas ou serviços especializados, públicos ou conveniados.

Há dezenove estratégias para consecução de objetivos essenciais para atender a demanda do sistema educacional inclusivo. Elas especificam pontos a serem analisados para obter resultados com as condições para a escola, o professor e o estudante.

Vejamos as estratégias das Meta 4, no Quadro 1: 
Quadro 1: Estratégias do Plano Nacional de Educação (PNE)

\begin{tabular}{|l|l|l|}
\hline \multicolumn{2}{|c|}{ Meta 4 } \\
\hline \multirow{2}{*}{ Estratégia } & \multicolumn{1}{|c|}{ Proposta } & \multicolumn{1}{|c|}{ Viabilidade } \\
\hline \multirow{4}{*}{4.1} & $\begin{array}{l}\text { Contabilizar, para fins do } \\
\text { repasse do Fundo de } \\
\text { Manutenção e } \\
\text { Desenvolvimento da } \\
\text { Educação Básica e de } \\
\text { Valorização dos } \\
\begin{array}{l}\text { Profissionais da Educação } \\
\text { (Fundeb), as matrículas da } \\
\text { educação regular da rede } \\
\text { pública. }\end{array}\end{array}$ & $\begin{array}{l}\text { Atendimento educacional } \\
\text { especializado } \\
\text { complementar e } \\
\text { suplementar, sem prejuízo } \\
\text { do cômputo dessas } \\
\text { matrículas na educação } \\
\text { básica regular. }\end{array}$ \\
\hline \multirow{4}{*}{4.2} & $\begin{array}{l}\text { Universalização do } \\
\text { atendimento escolar à } \\
\text { demanda manifesta pelas } \\
\text { famílias de crianças de zero } \\
\text { a três anos com deficiência, } \\
\text { transtornos globais do } \\
\text { desenvolvimento e altas } \\
\text { habilidades ou } \\
\text { superdotação. }\end{array}$ & $\begin{array}{l}\text { Observância à Lei n. } \\
9.394 / 96 .\end{array}$ \\
\hline $\begin{array}{l}\text { Implantação de salas de } \\
\text { recursos multifuncionais e } \\
\text { fomento da formação } \\
\text { continuada de professores } \\
\text { para o atendimento } \\
\text { educacional especializado } \\
\text { nas escolas urbanas, do } \\
\text { campo, indígenas e de } \\
\text { comunidades quilombolas. }\end{array}$ & $\begin{array}{l}\text { Observância à Lei n. } \\
9.394 / 96 .\end{array}$ \\
\hline
\end{tabular}




\begin{tabular}{|c|c|c|}
\hline 4.4 & $\begin{array}{l}\text { Garantir atendimento } \\
\text { educacional especializado } \\
\text { em salas de recursos } \\
\text { multifuncionais, classes, } \\
\text { escolas ou serviços } \\
\text { especializados, públicos ou } \\
\text { conveniados, nas formas } \\
\text { complementar e } \\
\text { suplementar, aos estudantes } \\
\text { com deficiência, transtornos } \\
\text { globais do desenvolvimento } \\
\text { e altas habilidades ou } \\
\text { superdotação, matriculados } \\
\text { na rede pública de educação } \\
\text { básica (dependendo da } \\
\text { necessidade). }\end{array}$ & $\begin{array}{l}\text { Observância à Lei n. } \\
\text { 9.394/96 e demais } \\
\text { legislações específicas. }\end{array}$ \\
\hline 4.5 & $\begin{array}{l}\text { Criar centros } \\
\text { multidisciplinares de apoio, } \\
\text { pesquisa e assessoria, } \\
\text { articulados com instituições } \\
\text { acadêmicas e integrados por } \\
\text { profissionais das áreas de } \\
\text { saúde, assistência social, } \\
\text { pedagogia e psicologia. }\end{array}$ & $\begin{array}{l}\text { Apoiar os professores que } \\
\text { atuam com estudantes } \\
\text { com deficiência, } \\
\text { transtornos globais do } \\
\text { desenvolvimento e altas } \\
\text { habilidades ou } \\
\text { superdotação. }\end{array}$ \\
\hline 4.6 & $\begin{array}{l}\text { Manter e ampliar programas } \\
\text { suplementares que } \\
\text { promovam a acessibilidade } \\
\text { nas instituições públicas, } \\
\text { para garantir o acesso e a } \\
\text { permanência de estudantes } \\
\text { com deficiência com } \\
\text { adequação arquitetônica, } \\
\text { oferta de transporte } \\
\text { acessível e disponibilização } \\
\text { de material didático próprio } \\
\text { e de recursos de tecnologia } \\
\text { assistiva para todos. }\end{array}$ & $\begin{array}{l}\text { Em etapas, níveis e } \\
\text { modalidades de ensino, a } \\
\text { identificação de estudantes } \\
\text { com altas habilidades ou } \\
\text { superdotação). }\end{array}$ \\
\hline
\end{tabular}




\begin{tabular}{|c|c|c|}
\hline 4.7 & $\begin{array}{l}\text { Ofertar educação bilíngue, } \\
\text { em Língua Brasileira de } \\
\text { Sinais (Libras) como } \\
\text { primeira língua e na } \\
\text { modalidade escrita da língua } \\
\text { portuguesa como segunda } \\
\text { língua, a estudantes surdos e } \\
\text { com deficiência auditiva até } \\
\text { os dezessete anos, em } \\
\text { escolas e classes bilíngues e } \\
\text { em escolas inclusivas. }\end{array}$ & $\begin{array}{l}\text { Art. } 22 \text { do Decreto n. } \\
\text { 5.626/05 e dos arts. } 24 \text { e } 30 \\
\text { da Convenção sobre os } \\
\text { Direitos das Pessoas com } \\
\text { Deficiência. Adoção do } \\
\text { Braille de leitura para } \\
\text { cegos e surdos-cegos. }\end{array}$ \\
\hline 4.8 & $\begin{array}{l}\text { Ofertar educação inclusiva, } \\
\text { vedada a exclusão do ensino } \\
\text { regular sob alegação de } \\
\text { deficiência }\end{array}$ & $\begin{array}{l}\text { Com articulação } \\
\text { pedagógica entre o ensino } \\
\text { regular e o atendimento } \\
\text { educacional especializado. }\end{array}$ \\
\hline 4.9 & $\begin{array}{l}\text { Fortalecer o } \\
\text { acompanhamento e o } \\
\text { monitoramento do acesso à } \\
\text { escola e ao atendimento } \\
\text { educacional especializado, } \\
\text { bem como da permanência e } \\
\text { do desenvolvimento escolar } \\
\text { de estudantes com } \\
\text { deficiência, transtornos } \\
\text { globais do desenvolvimento } \\
\text { e altas habilidades ou } \\
\text { superdotação. }\end{array}$ & $\begin{array}{l}\text { Beneficiários de programas } \\
\text { de transferência de renda, } \\
\text { com o combate às } \\
\text { situações de discriminação, } \\
\text { preconceito e violência. } \\
\text { Condições adequadas ao } \\
\text { sucesso educacional. }\end{array}$ \\
\hline 4.10 & $\begin{array}{l}\text { Fomentar pesquisas para o } \\
\text { desenvolvimento de } \\
\text { metodologias, materiais } \\
\text { didáticos, equipamentos e } \\
\text { recursos de tecnologia } \\
\text { assistiva, para promover o } \\
\text { ensino e da aprendizagem e } \\
\text { condições de acessibilidade }\end{array}$ & \\
\hline
\end{tabular}




\begin{tabular}{|c|c|c|}
\hline & $\begin{array}{l}\text { dos estudantes com } \\
\text { deficiência, transtornos } \\
\text { globais do desenvolvimento } \\
\text { e altas habilidades ou } \\
\text { superdotação; }\end{array}$ & \\
\hline 4.11 & $\begin{array}{l}\text { Desenvolver pesquisas } \\
\text { interdisciplinares para } \\
\text { subsidiar a formulação de } \\
\text { políticas públicas } \\
\text { intersetoriais que atendam } \\
\text { as especificidades } \\
\text { educacionais de estudantes } \\
\text { com deficiência, transtornos } \\
\text { globais do desenvolvimento } \\
\text { e altas habilidades ou } \\
\text { superdotação que requeiram } \\
\text { medidas de AEE. }\end{array}$ & \\
\hline 4.12 & $\begin{array}{l}\text { Articular intersetores de } \\
\text { órgãos e políticas públicas } \\
\text { de saúde, assistência social e } \\
\text { direitos humanos, em } \\
\text { parceria com as famílias, } \\
\text { para desenvolver modelos } \\
\text { de atendimento de } \\
\text { continuidade do } \\
\text { atendimento escolar, na } \\
\text { educação de jovens e } \\
\text { adultos, das pessoas com } \\
\text { deficiência e transtornos } \\
\text { globais do desenvolvimento } \\
\text { com idade superior à faixa } \\
\text { etária de escolarização } \\
\text { obrigatória. }\end{array}$ & $\begin{array}{l}\text { Assegurando a atenção } \\
\text { integral ao longo da vida. }\end{array}$ \\
\hline
\end{tabular}




\begin{tabular}{|l|l|l|}
\hline 4.13 & $\begin{array}{l}\text { Ampliar equipes de } \\
\text { profissionais da educação } \\
\text { para atender à demanda do } \\
\text { processo de escolarização } \\
\text { de estudantes com } \\
\text { deficiência, transtornos } \\
\text { globais do desenvolvimento } \\
\text { e altas habilidades ou } \\
\text { superdotação, garantindo a } \\
\text { oferta de professores AEE. }\end{array}$ & $\begin{array}{l}\text { Profissionais de apoio ou } \\
\text { auxiliares, tradutores (as) e } \\
\text { intérpretes de libras, guias- } \\
\text { intérpretes para surdos- } \\
\text { cegos, professores de } \\
\text { libras, prioritariamente } \\
\text { surdos, e professores } \\
\text { bilíngues. }\end{array}$ \\
\hline 4.14 & $\begin{array}{l}\text { Definir, no segundo ano de } \\
\text { vigência deste PNE, } \\
\text { indicadores de qualidade e } \\
\text { política de avaliação e } \\
\text { supervisão para o } \\
\text { funcionamento de } \\
\text { instituições públicas e } \\
\text { privadas. }\end{array}$ & $\begin{array}{l}\text { Instituições que prestam } \\
\text { atendimento a alunos com } \\
\text { deficiência, transtornos } \\
\text { globais do } \\
\text { desenvolvimento e altas } \\
\text { habilidades ou } \\
\text { superdotação. }\end{array}$ \\
\hline $\begin{array}{l}\text { Promover, por iniciativa do } \\
\text { Ministério da Educação, nos } \\
\text { órgãos de pesquisa, } \\
\text { demografia e estatística } \\
\text { competentes, a obtenção de } \\
\text { informação detalhada sobre } \\
\text { o perfil das pessoas com } \\
\text { deficiência, transtornos } \\
\text { globais do desenvolvimento } \\
\text { e altas habilidades ou } \\
\text { superdotação de zero a } \\
\text { dezessete anos. }\end{array}$ & Pelo censo escolar. \\
\hline
\end{tabular}




\begin{tabular}{|c|c|c|}
\hline 4.16 & $\begin{array}{l}\text { Incentivar a inclusão nos } \\
\text { cursos de licenciatura e nos } \\
\text { demais cursos de formação } \\
\text { para profissionais da } \\
\text { educação, inclusive em nível } \\
\text { de pós-graduação. }\end{array}$ & $\begin{array}{l}\text { Caput do art. } 207 \text { da } \\
\text { Constituição Federal, dos } \\
\text { referenciais teóricos, das } \\
\text { teorias de aprendizagem e } \\
\text { dos processos de ensino- } \\
\text { aprendizagem } \\
\text { relacionados ao AEE. }\end{array}$ \\
\hline 4.17 & $\begin{array}{l}\text { Promover parcerias com } \\
\text { instituições comunitárias, } \\
\text { confessionais ou } \\
\text { filantrópicas sem fins } \\
\text { lucrativos, conveniadas com } \\
\text { o poder público, }\end{array}$ & $\begin{array}{l}\text { Condições de apoio ao } \\
\text { AEE integral das pessoas } \\
\text { com deficiência, } \\
\text { transtornos globais do } \\
\text { desenvolvimento e altas } \\
\text { habilidades/superdotação } \\
\text { da rede pública de ensino. }\end{array}$ \\
\hline 4.18 & $\begin{array}{l}\text { Promover parcerias com } \\
\text { instituições comunitárias, } \\
\text { confessionais ou } \\
\text { filantrópicas sem fins } \\
\text { lucrativos, conveniadas com } \\
\text { o poder público, visando a } \\
\text { ampliar a oferta de } \\
\text { formação continuada e a } \\
\text { produção de material } \\
\text { didático acessível, assim } \\
\text { como os serviços de } \\
\text { acessibilidade necessários } \\
\text { ao pleno acesso. }\end{array}$ & $\begin{array}{l}\text { Participação e } \\
\text { aprendizagem dos } \\
\text { estudantes com } \\
\text { deficiência, transtornos } \\
\text { globais do } \\
\text { desenvolvimento e altas } \\
\text { habilidades ou } \\
\text { superdotação da rede } \\
\text { pública de ensino. }\end{array}$ \\
\hline 4.19 & $\begin{array}{l}\text { Promover parcerias com } \\
\text { instituições comunitárias, } \\
\text { confessionais ou } \\
\text { filantrópicas sem fins } \\
\text { lucrativos, conveniadas com } \\
\text { o poder público. }\end{array}$ & $\begin{array}{l}\text { Porque pode favorecer a } \\
\text { participação das famílias e } \\
\text { da sociedade na } \\
\text { construção do sistema } \\
\text { educacional inclusivo. }\end{array}$ \\
\hline
\end{tabular}

Adaptado do Plano Nacional de Educação (PNE) (2014) 
$\mathrm{O} \S 2^{\mathrm{O}}$ estabelece que a cada 2 (dois) anos, ao longo do período de vigência deste PNE, o Instituto Nacional de Estudos e Pesquisas Educacionais Anísio Teixeira (INEP) terá publicação de estudos para aferir a evolução no cumprimento das metas estabelecidas no Anexo desta Lei, com informações organizadas por ente federado e consolidadas em âmbito nacional, tendo como referência os estudos e as pesquisas de que trata o art. $4^{\mathrm{o}}$, sem prejuízo de outras fontes e informações relevantes, em especial, na educação a distância. Segundo o art. 58, entende-se por educação especial, para os efeitos desta Lei, a modalidade de educação escolar oferecida preferencialmente na rede regular de ensino, para educandos com deficiência, transtornos globais do desenvolvimento e altas habilidades ou superdotação.

Senão vejamos:

$\S 1^{\circ}$ Haverá, quando necessário, serviços de apoio especializado, na escola regular, para atender às peculiaridades da clientela de educação especial.

$\S 2^{\circ} \mathrm{O}$ atendimento educacional será feito em classes, escolas ou serviços especializados, sempre que, em função das condições específicas dos alunos, não for possível a sua integração nas classes comuns de ensino regular.

Essas ações endossam a ideia de necessidade de cumprimento da legislação pelos planos de governo. As políticas públicas para a Educação inclusiva ser prioridade em políticas de Estado, a fim de se consumar as práticas de ensino e aprendizagem par amparar escolas, professores e estudantes.

A Conferência Mundial sobre Necessidades Educacionais Especiais, datada no período de 7 e 10 de junho de 1994, na cidade espanhola de Salamanca - a Declaração de Salamanca demarcou 
princípios, políticas e práticas na área das necessidades educativas especiais. A Declaração de Salamanca ressalta que a educação inclusiva possui características específicas para estudantes com alguma deficiência física, sensorial ou cognitiva, cujo intuito foi o de dar mais especificidade para ações no âmbito da educação especial.

Durante o evento em Salamanca, estabeleceu-se que "toda criança tem direito fundamental à educação, e deve ser dada a oportunidade de atingir e manter o nível adequado de aprendizagem, ou seja, o direito da igualdade para aquisição do conhecimento", reconhecendo também que "toda criança possui características, interesses, habilidades e necessidades de aprendizagem que são ímpares".

A legislação por si não garante os direitos desse público, pois outros fatores estão envolvidos quando a política é traduzida na escola, são necessárias políticas públicas de educação especial, para atender dignamente os estudantes e ampliar as conquistas sociais.

\section{FORMAÇÃO INICIAL DE PROFESSORES}

A formação docente no contexto da educação inclusiva resulta da vivência e da interação cotidiana com os estudantes, com e sem deficiência, a partir de uma prática pedagógica dinâmica que reconhece e valoriza as diferenças. Desenvolver ao máximo as potencialidades de cada estudante implica considerar os assuntos ou atividades lhes interessam e mobilizam.

Marli E. D. A. André (2009, p. 45) quanto à formação inicial dos professores ressalta:

Formar, em sentido amplo, significa desenvolver; portanto, formação pressupõe continuidade. Nesse 
sentido, a formação inicial é um momento importante na socialização profissional, mas o aprendizado da docência deve seguir um longo caminho de educação continuada. (...) $\mathrm{O}$ autor que serviu de referência para analisar as relações entre formação e profissionalização docente foi Nóvoa (1992), que destaca três dimensões distintas, mas interdependentes, na formação de professores: o desenvolvimento pessoal, o desenvolvimento profissional e o desenvolvimento organizacional. $\mathrm{O}$ autor argumenta que a formação deve estimular uma perspectiva críticoreflexiva, que favoreça um pensamento autônomo e facilite uma dinâmica de auto formação participada. E complementa "estar em formação implica um investimento pessoal, um trabalho livre e criativo sobre os percursos e os projetos próprios, com vista à construção de uma identidade que é também uma identidade profissional" (André, 2009, p. 45).

Nessa perspectiva, a autora sustenta que Nóvoa (1992) defende práticas de formação que considerem as dimensões coletivas a fim de contribuir para o crescimento profissional e autonomia dos docentes. Ressalta que é importante articular a formação dos professores com os projetos das escolas, insistindo que algumas mudanças devem ocorrer no seu local de trabalho, segundo o que preceitua a Lei de Diretrizes e Bases da Educação Nacional (LDB).

$\mathrm{O}$ art. 58 da LDB estabelece que educação especial - a modalidade de educação escolar, oferecida preferencialmente na rede regular de ensino, para educandos portadores de necessidades especiais.

Devem ser cumpridos rigorosamente os dispositivos legais de que trata a lei: 
$\S 1^{\circ}$ Haverá, quando necessário, serviços de apoio especializado, na escola regular, para atender as peculiaridades da clientela de educação especial.

$\S 2^{\mathrm{o}} \mathrm{O}$ atendimento educacional será feito em classes, escolas ou serviços especializados, sempre que, em função das condições específicas dos alunos, não for possível a sua integração nas classes comuns de ensino regular.

$\S 3^{0}$ A oferta de educação especial, dever constitucional do Estado, tem início na faixa etária de zero a seis anos, durante a educação infantil.

Dentre tantos aspectos a se cumprir, destacam ainda: art. 59, o qual estabelece que os sistemas de ensino assegurarão aos educandos com necessidades especiais: como currículos, métodos, técnicas, recursos educativos e organização específicos, para atender as necessidades. Há também a terminalidade específica para quem não puderem alcançar o nível exigido para a conclusão do ensino fundamental, em virtude de suas deficiências, e aceleração para concluir em menor tempo o programa escolar para os superdotados, entre outros.

A LDB estabelece que sejam cumpridas as previsões de atendimento às pessoas com deficiência em suas demandas físicas, psicológicas, sociais e educacionais.

\section{EDUCAÇÃO INCLUSIVA - FORMAC̣ÃO INICIAL PEDAGÓGICA EM EAD}

Em relação aos aspectos pertinentes à política de formação de professores buscou-se nesse estudo identificar o que a produção científica tem analisado sobre essa questão e suas correlações com a política de educação inclusiva. Um dos aspectos que tem merecido estudos é a política de Educação a Distância que tem predominado 
na oferta de cursos na área de pedagogia e dos cursos de licenciatura em geral.

Nesse sentido, Figueiredo (2009, p. 13) assinala que o Brasil vem promovendo um intenso processo de implantação de programas de formação inicial e continuada de professores, desde a década de 1990 pela modalidade de Educação a Distância (EaD), como estratégia de acesso e expansão do ensino, havendo uma massificação de cursos de formação superior.

A autora salienta que "a utilização da $\mathrm{EaD}$ na formação inicial dos professores vem também privilegiando a ampliação do espaço privado entre o público e o privado com alocação de verbas públicas para o financiamento de instituições privadas”.

Desta maneira, convém analisar o que prevê a legislação. A Lei n. 13.146/2015 e a Base Nacional Comum Curricular (BNCC) (2017) preveem que um planejamento com foco na equidade também exige um claro compromisso de reverter a situação de exclusão histórica colocam grupos à margem social tais como indígenas originários e populações das comunidades remanescentes de quilombos e demais afrodescendentes. Além destes, as pessoas que não puderam estudar ou completar sua escolaridade na idade própria.

A BNCC define as aprendizagens essenciais às quais todos os estudantes têm direito. Ou seja, quando dizemos que todos, sem exceção, têm direito à educação (frisamos aqui a inclusão) não estamos nos referindo somente ao acesso. A perspectiva inclusiva indica que qualquer estudante tem o direito de acessar o mesmo currículo para o pleno exercício da cidadania e a consequente inclusão social.

Na concepção de Bourdieu (1990), 
para que sejam desfavorecidos os mais favorecidos, é necessário e suficiente que a escola ignore, no âmbito dos conteúdos do ensino que transmite, dos métodos e técnicas de transmissão e dos critérios de avaliação, as desigualdades culturais entre as crianças das diferentes classes sociais. Tratando todos os educandos, por mais desiguais que sejam eles de fato, como iguais em direitos e deveres, o sistema escolar é levado a dar sua sanção às desigualdades iniciais diante da cultura (Bourdieu, 1990).

Assim, requer o compromisso com os alunos com deficiência, reconhecendo a necessidade de práticas pedagógicas inclusivas e de diferenciação curricular, conforme estabelece a Lei Brasileira de Inclusão da Pessoa com Deficiência. Esta seria a grande justificativa de elaborar cursos on-line para formar professores. $\mathrm{O}$ alcance poderia ser amplo e atender as demandas na educação especial.

$\mathrm{O}$ aspecto complementar da formação dos estudantes com deficiência e/ou com transtorno do espectro autista (TEA). Isso significa trabalhar com os recursos que possibilitem ao aluno transpor barreiras impostas à sua aprendizagem na classe comum. São muitos os exemplos que podem ser dados: aos estudantes com deficiência visual, cego, por exemplo, é imprescindível o ensino do Sistema Braille, a adaptação de materiais para se tornarem táteis, o ensino do sorobã para os cálculos matemáticos, entre ouras adaptações.

Os alunos com deficiência intelectual necessitam que o professor possa focar em comunicação, memória, localização espacial e temporal, resolução de problemas, etc. $\mathrm{O}$ professor do AEE tem como objetivo trabalhar a aprendizagem de conceitos e a organização do pensamento do aluno, na classe comum, eles se beneficiarão dos conteúdos trabalhados. 
Para os alunos com deficiência física, o atendimento educacional especializado visa a confecção de materiais para que ele possa, por exemplo, se comunicar com autonomia, como é o caso das pranchas de comunicação alternativa. É importante ensiná-lo a utilizar as tecnologias assistivas necessárias, entre outras atividades pedagógicas.

Organizado dessa forma, o AEE não deve se constituir como reforço escolar, uma vez que não é objetivo de o professor da sala de recursos ensinar os conteúdos que foram ministrados na classe comum, mas auxiliar na eliminação de barreiras, as quais, lembramos, não estão no aluno, mas no ambiente que o cerca.

É fundamental que o professor do atendimento educacional especializado realize um trabalho articulado com o docente da classe comum, para que essas ações não se atenham apenas à sala de recursos, mas a toda escolarização do aluno. O desafio é levantar dados sobre a formação de professores para atua na educação especial na região Norte do Brasil. Isto porque os avanços são lentos.

O Ministério da Educação trata da formação docente com muitas atribuições. Dentre elas, citam-se:

Identificar, elaborar, produzir e organizar serviços, recursos pedagógicos, de acessibilidade e estratégias considerando as necessidades específicas dos alunos público-alvo da educação especial; b. Elaborar e executar plano de atendimento educacional especializado, avaliando a funcionalidade e a aplicabilidade dos recursos pedagógicos e de acessibilidade; c. Organizar o tipo e o número de atendimentos aos alunos na sala de recursos multifuncional; d. Acompanhar a funcionalidade e a aplicabilidade dos recursos pedagógicos e de acessibilidade na sala de aula comum do ensino regular, bem como em outros ambientes da escola (...). 
Assim, vê-se que a instituição educacional deve se envolver com as responsabilidades do professor para que o atendimento se desenvolva de maneira satisfatória. O AEE é um serviço destinado a estudantes com deficiência, transtorno do espectro autista (TEA) e altas habilidades/superdotação. É desenvolver práticas pedagógicas inclusivas e atividades diversificadas para eliminar barreiras no processo de ensino-aprendizagem e garantir o pleno acesso e participação desses alunos na escola regular. Por esse motivo, o AEE configura como uma das principais estratégias de acessibilidade no contexto educacional brasileiro.

Trata-se de um serviço complementar e/ou suplementar ao processo de escolarização para a autonomia e independência desses alunos na escola e fora dela, não devendo ser substitutivo, nem acontecer isoladamente. Recomenda-se que o AEE seja realizado no contraturno das aulas regulares, preferencialmente na mesma escola e em salas de recursos multifuncionais (SRM). É fundamental que haja articulação entre o atendimento educacional especializado, as equipes pedagógicas e as famílias dos alunos atendidos por esse serviço.

Há recursos técnicos e financeiros provenientes da União para a implantar e ofertar esse serviço a todos os estudantes público-alvo da educação especial, como o Fundo de Manutenção e Desenvolvimento da Educação Básica e de Valorização dos Profissionais da Educação (Fundeb). $\mathrm{O}$ atendimento educacional especializado é obrigatório pelos sistemas de ensino nas etapas, níveis e modalidades, ao longo de todo o processo de escolarização, de forma complementar ou suplementar à formação dos estudantes no ensino regular.

Segundo o Ministério da Educação, outras atribuições dos professores e das escolas são estabelecer parcerias com as áreas 
intersetoriais com estratégias e disponibilização de recursos de acessibilidade. Outra: orientar professores e famílias sobre os recursos pedagógicos e de acessibilidade utilizados pelo aluno.

O MEC estabelece que é necessário

[...] ensinar e usar recursos de Tecnologia Assistiva, tais como: as tecnologias da informação e comunicação, a comunicação alternativa e aumentativa, a informática acessível, o soroban, os recursos ópticos e não ópticos, os softwares específicos, os códigos e linguagens, as atividades de orientação e mobilidade entre outros; de forma a ampliar habilidades funcionais dos alunos, promovendo autonomia, atividade e participação. Estabelecer articulação com os professores da sala de aula comum, visando a disponibilização dos serviços, dos recursos pedagógicos e de acessibilidade e das estratégias que promovem a participação dos alunos nas atividades escolares. i. Promover atividades e espaços de participação da família e a interface com os serviços setoriais da saúde, da assistência social, entre outros (Brasil, 2008).

Dessa perspectiva, compreende-se que um dos principais objetivos do atendimento é criar ou encontrar estratégias pedagógicas alternativas que possibilitem a participação e a aprendizagem em sala de aula, criatividade é outra característica bem-vinda. E, finalmente, apostar no potencial de cada um dos estudantes atendidos, buscando sua autonomia na escola e fora dela, para o pleno desenvolvimento de seu potencial.

Quando não há atendimento educacional especializado na própria escola, é preciso tomar providências. Se a escola é pública, a melhor estratégia é procurar a Secretaria de Educação local para averiguar se existe a possibilidade de o serviço passar a ser oferecido lá mesmo, por meio da instalação de Salas de Recursos Multifuncionais (SRM). Caso não seja possível fazer isso no curto 
prazo, o AEE deve ser oferecido em, como uma escola próxima ou um centro, e o transporte, garantido para todos.

Se, no entanto, as tentativas de diálogo com a escola se esgotarem, é possível contatar o Ministério Público (MP), exigindo que a escola cumpra suas obrigações em relação aos estudantes público-alvo da educação especial. Lembrando que o direito à educação inclusiva não se restringe ao acesso (matrícula e presença), compreendendo também o desenvolvimento de suas potencialidades para a plena participação em igualdade de condições.

Além disso, o processo educacional não se encerra no ambiente escolar, é imprescindível que a família e a escola estabeleçam uma parceria efetiva, com estratégias complementares para alcançar os objetivos de aprendizagem e a promoção da autonomia, na escola e fora dela. A educação inclusiva parte do princípio de que a diferença é uma condição humana, isto é, todos somos distintos uns dos outros. Então, os processos de aprendizagem de cada estudante são também distintos entre si.

Gestores públicos e escolares devem estabelecer espaços coletivos de formação na rotina das instituições de ensino, dos quais, além da equipe pedagógica, todas as pessoas envolvidas possam participar. Apesar das atribuições e formação, não há um perfil específico para o exercício da função, porém, considerando o caráter interativo e interdisciplinar de sua atuação em relação à sala de aula na qual cada um dos alunos atendidos está matriculado, é fundamental que o professor do AEE tenha facilidade para trabalhar de modo cooperativo. 


\section{Projeto PedAGógico do CURSO (PPC)}

Um currículo inclusivo nada mais é que a coesão da base curricular comum com o contexto da sala de aula, ou seja, de cada um dos estudantes que a compõe. Para que isso seja possível, é importante que o professor e a equipe pedagógica conheçam os alunos, suas características sociais, culturais e individuais e as levem em consideração ao elaborar o planejamento pedagógico.

Adriana Michela Cardoso Packer $(2017$, p. 7) aduz que é necessário oportunizar aos professores a percepção e intervenção na preparação do currículo, que adquire dimensões de um projeto cultural e social. Na organização curricular, a escola proporciona uma base curricular comum, obrigatória em nível federal, e uma parte diversificada com características específicas da cultura dos alunos, de acordo com seu Projeto Pedagógico (PP).

A legislação prevê a:

Acessibilidade arquitetônica: eliminação de barreiras ambientais físicas nas residências, nos edifícios, nos espaços e equipamentos urbanos, nos meios de transporte individuais ou coletivos; Acessibilidade comunicacional: eliminação de barreiras na comunicação interpessoal (oral, língua de sinais), escrita (jornal, revista, livro, carta, apostila etc., incluindo textos em Braille e o uso de computador portátil) e virtual (acessibilidade digital); Acessibilidade metodológica: eliminação de barreiras nos métodos e técnicas de estudos (escolar), de trabalho (profissional), de ação comunitária (social, cultural, artística etc.) e de educação familiar; Acessibilidade instrumental: eliminação de barreiras para o acesso e manuseio de instrumentos, utensílios e ferramentas de estudos (escolar), de trabalho (profissional), de lazer e recreação (comunitária, turística, esportiva etc.); Acessibilidade programática: eliminação de barreiras 
“invisíveis" embutidas em políticas públicas (leis, decretos, portarias etc.), normas e regulamentos (institucionais, empresariais etc.); Acessibilidade atitudinal: eliminação de preconceitos, estigmas, estereótipos e discriminações nas pessoas em geral.

Neste sentido, há questões fundamentais que devem orientar a escola, mas também a formação dos professores, pois a acessibilidade representa o elo para a inclusão. Por ela, todos têm as mesmas condições de chegar, de sair, de buscar, de encontrar, etc. Será que a formação inicial para professores poderia trazer mais caminhos para a interação e inclusão?

\section{MATRIZ CURRICULAR}

O currículo corresponde ao conjunto de conteúdos que devem ser abordados pelos educadores em cada nível de ensino. Um currículo fundamentado na perspectiva inclusiva precisa estar alinhado com a Base Nacional Comum Curricular (BNCC) e, ao mesmo tempo, dialogar com as particularidades sociais, culturais, regionais e os diferentes modos de aprender de cada estudante.

Assim, a importância do currículo deve orientar a formação docente e guiar as práticas. Os resultados de um processo de envolvimento e participação das famílias e da comunidade, referem-se, entre outras ações, segundo a BNCC (2019) a:

Contextualizar os conteúdos dos componentes curriculares, identificando estratégias para apresentá-los, representá-los, exemplificá-los, conectá-los e torná-los significativos, com base na realidade do lugar e do tempo nos quais as aprendizagens estão situadas; decidir sobre formas de organização interdisciplinar dos componentes curriculares e fortalecer a competência pedagógica das equipes escolares para adotar estratégias mais dinâmicas, 
interativas e colaborativas em relação à gestão do ensino e da aprendizagem; selecionar e aplicar metodologias e estratégias didático-pedagógicas diversificadas, recorrendo a ritmos diferenciados e a conteúdos complementares, se necessário, para trabalhar com as necessidades de diferentes grupos de alunos, suas famílias e cultura de origem, suas comunidades, seus grupos de socialização etc.(...) (BNCC, 2019).

Conceber e pôr em prática situações e procedimentos para motivar e engajar os alunos nas aprendizagens, além de construir e aplicar avaliação formativa de processo ou de resultado que considerem os contextos e as condições de aprendizagem, com registros para melhorar o desempenho da escola, de estudantes e professores. É preciso selecionar, produzir, aplicar e avaliar recursos didáticos e tecnológicos que apoiam o processo de ensinar e aprender. Deve-se ainda criar e disponibilizar materiais de orientação para os professores.

As Diretrizes Nacionais para a Educação Especial na Educação Básica, recomendam:

A educação escolar dos alunos que apresentam necessidades educacionais especiais e requeiram atenção individualizada nas atividades da vida autônoma e social, bem como ajudas e apoios contínuos e flexibilizações e adaptações curricular estão significativas que a escola comum não tenha conseguido prover - pode efetivar-se em escolas especiais, assegurando-se que o currículo escolar observe as diretrizes curriculares nacionais para as etapas e modalidades da Educação básica e que os alunos recebam os apoios de que necessitam (Brasil, 2001).

O currículo deve ser amplamente apontado como uma das principias barreiras - bem como um dos mais importantes facilitadores - à educação inclusiva. Pontua-se que o currículo é não 
somente importante, mas determinante na garantia do direito de todos, e de cada um, à educação. Quando o currículo é préformatado, fundamentado em expectativas homogeneizantes, que não considera o contexto, ou seja, as características da comunidade onde a escola se localiza e de cada um dos estudantes individualmente gera a exclusão.

Para que se desenvolvam as potencialidades de cada estudante ao máximo, é preciso tornar a experiência da aprendizagem relevante e significativa. Vê-se que se delineia um desafio colaborativo e criativo: conectar as características e os interesses de cada um dos alunos à base curricular comum, para que todas as áreas do conhecimento sejam trabalhadas a partir e por intermédio dos pressupostos internalizados por cada um (já sabem) ou gostariam de saber.

\section{OS CONTEÚDOS}

O Atendimento educacional especializado (AEE) é fundamental para o aluno e para o professor. As cinco dimensões da educação inclusiva são interdependentes entre si e são permeadas por temas transversais, como conteúdo curricular, formação, acessibilidade e outros. Por isso, os conteúdos, ou os conhecimentos privilegiados na formação de professores na modalidade $\mathrm{EaD}$ deve favorecer a organização para a prática com instrumentais capazes de alcançar a melhor forma de trabalhar com o conhecimento na educação inclusiva.

A expectativa - e, portanto, o critério ao escolher cursos e bibliografia - deve ser de sempre primar pelo desenvolvimento de práticas pedagógicas atualizadas acessíveis a todos, considerando diferenças de credo, raça, gênero, condição econômica, social, cultural, física, mental, intelectual, sensorial ou linguística. 
A desigualdade pode ser um elemento excluso do contexto educacional quando se trata da educação especial. Assim, requer o compromisso com os alunos com deficiência, reconhecendo a necessidade de práticas pedagógicas inclusivas e de diferenciação curricular, conforme estabelece a Lei Brasileira de Inclusão da Pessoa com Deficiência, que seria a justificativa de elaborar cursos on-line para formar professores na modalidade $\mathrm{EaD}$. O alcance poderia ser amplo e atender as demandas na educação especial.

\section{CONSIDERAÇÕES FINAIS}

Os estudos da legislação realizados permitem observar que a agenda educacional brasileira priorizou, durante os anos 80 , a expansão quantitativa da oferta e ampliou o acesso com a expansão da rede física, em detrimento do aspecto qualitativo. Com a falta de qualidade atribuída ao sistema escolar, foi associada à insuficiência de recursos para a educação, à centralização das decisões, à burocratização do sistema educacional.

Veio a ideia da privatização e clientelização da política educacional, fator que gerou o fenômeno da exclusão da comunidade e profissionais dos processos decisórios e de gestão do sistema. Vistos como obstruidores dos processos de modernização do setor educacional, tais aspectos orientaram as reformas que tinham como eixo a democratização da educação.

O desenvolvimento da educação em plataformas digitais encaminhou-se para novas necessidades e indicou o fato desses procedimentos serem utilizados não para complementar os processos formativos presenciais dos professores, mas sim para realizar a formação inicial. Há consenso também que esses termos apoiam o processo de formação no modelo da racionalidade técnica, que, além de separar a formação inicial da continuada 
considerando a atividade do profissional como instrumental, dirigida apenas para a solução de problemas mediante a aplicação rígida de técnicas pedagógicas.

Dessa perspectiva, infere-se que a formação inicial deve se fundamentar em experiências de campo que precedem o trabalho em cursos acadêmicos, as experiências precoces incluídas nos cursos acadêmicos e as práticas de ensino e os programas de iniciação.

O estudo mostrou, ainda, que a formação continuada em $\mathrm{EaD}$ realiza-se por um processo de compreensão pelo professor das concepções implícitas às suas práticas docentes, o comprometimento explícito com a mudança e com a construção contínua de sua formação, buscando dar significado ao trabalho do professor e à realização dos saberes dos alunos.

A temática foi incorporada pela agenda educacional dos anos 90, em razão das políticas educacionais globais que instituíram a reformas educacionais e nela o predomínio da concepção de que a educação precisava (re) assumir uma posição de destaque nas perspectivas da cidadania e da formação para o trabalho, associada à perspectiva de retomada do crescimento nacional.

Com a crescente incorporação de inovações tecnológicas, da demanda por novas qualificações e/ou competências, e razão das consequências de uma economia que vem se globalizando, há quase um consenso quando se trata de apontar que o sistema educacional brasileiro não vem respondendo às necessidades do novo perfil de qualificação da mão de obra.

Nessa direção, um conjunto de ações orienta a busca da melhoria da qualidade do sistema educacional, tais como: iniciativas de caráter pedagógico voltadas à diminuição da repetência e evasão no ensino fundamental; implantação de 
sistemas de avaliação; adequação dos conteúdos à população-alvo; redução do número de alunos por sala; investimentos no corpo docente, o que inclui capacitação, melhoria salarial e melhores condições de trabalho; fornecimento de equipamentos básicos e formação continuada.

Desafios surgem e são muito grandes. Entretanto, o processo, que é coletivo, exigirá disposição para compreender que todos fazem parte de uma unidade nacional para os avanços em prol da qualidade com equidade, focalizada no direito de cada cidadão, para que as políticas educacionais tenham empenho significativo junto à escola pública, pois é nela que se projetam as mudanças para se alcançar os objetivos e metas.

A proposta de inclusão parece ter surgido primeiramente nas leis e nas práticas da escola pública e, depois passou a ser preocupação dos espaços acadêmicos. Atualmente, a proposta é alcançar a qualidade educacional para que cumpra com o papel que lhe foi reservado constitucionalmente.

Os objetivos dos Planos de Educação que primam pela ampliação do acesso e melhoria da qualidade do ensino em ambos os níveis, nas etapas e modalidades combinadas com valorização profissional, dão especial relevo à necessidade da instituição do Sistema Nacional de Educação, e, com ele a modernização e investimentos na educação a distância para formar professores e assim, atuarem na educação especial. Os planos recém-elaborados devem ser aprimorados e aperfeiçoados pelos mecanismos de monitoramento e avaliação a fim de vislumbrar desdobramentos da educação a distância e avanços na área da educação inclusiva.

É essencial que haja efetivo comprometimento de todos Estado, família e sociedade para gerar melhoria da educação e a implementação das políticas educacionais e educação, pois assim 
podemos analisar que o papel do sistema de ensino age na consagração das divisões sociais e consolida um novo modo de dominação, tornando-se um desafio até para os acadêmicos mais ousados que compõem as plataformas da educação a distância.

\section{REFERÊNCIAS}

AGUIAR, JS. Duarte E. Educação inclusiva: um estudo na área da educação física. Rev Bras Educ Espec. 2005;11(2):223-40.

ANDRÉ, M. E. D. A. A produção acadêmica sobre formação de professores: um estudo comparativo das dissertações e teses defendidas nos anos 1990 e 2000. Form Doc. 2009; 1 (1). Disponível em: <http://formacaodocente.autenticaeditora.com.br/artigo/ exibir/1/7/1> Acesso em: 10 jul. 2020.

BALL, Stephen J. Educação Global S.A. Novas redes políticas e o imaginário neoliberal. Tradução de Janete Bridon. Ponta Grossa: UEPG, 2014.

BOURDIEU, P. Coisas ditas. Trad. de Cássia R. da Silva e Denise Moreno Pegorim. São Paulo: Brasiliense, 1990.

BRASIL. Ministério da Educação. Diretrizes nacionais para a educação na educação básica. Secretaria de Educação Especial MEC; SEESP, 2001.

. Base Nacional Comum Curricular - BNCC. Brasília, 2017.

. Constituição da república federativa do Brasil. Brasília: República Federativa do Brasil, 1988.

. Ministério da Educação Secretaria de Educação Especial. Diretrizes operacionais da educação especial para o atendimento educacional especializado na educação básica. 
Disponível em: <http://portal.mec.gov.br/index. php?>. Acesso em: 10 ago. 2020.

. Lei n. 9.394, de 20 de dezembro de 1996. Estabelece as diretrizes e bases da educação nacional. Brasília: MEC, 1996. 12.

Parâmetros curriculares nacionais: Adaptações Curriculares. Secretaria de Educação Fundamental. Secretaria de Educação Especial. Brasília: MEC/SEF/SEESP, 1998.

. Resolução CNE/CP n. 1, de 15 de maio de 2006. Institui Diretrizes Curriculares Nacionais para o Curso de Graduação em Pedagogia, licenciatura. Brasília: MEC, 2006.

. Resolução CNE/CEB n. 2, de 11 de setembro de 2001. Institui Diretrizes Nacionais para a Educação Especial na Educação Básica. Brasília: MEC, 2001.

. Resolução n. 4, de 2 de outubro de 2009. Institui Diretrizes Operacionais para o Atendimento Educacional Especializado na Educação. Brasília: MEC, 2009.

.Política nacional de educação especial na perspectiva da educação inclusiva. Documento elaborado pelo Grupo de Trabalho nomeado pela Portaria Ministerial n. 555, de 5 de junho de 2007, prorrogada pela Portaria n. 948, de 9 de outubro de 2007. Brasília: MEC, 2007.

FIGUEIREDO, S. B. Formação de professores a distância: análise crítica a partir de um curso de pedagogia. 2009. 147 f. Dissertação (Mestrado em Educação) - Universidade Federal de Sergipe, São Cristóvão, 2009. Disponível em: <https://ri.ufs.br/handle/ riufs/4923>. Acesso em: 21 jul. 2020. 
GRIMM, V.; SOSSAI, F. C.; SEGABINAZZI, M. Globalização, redes políticas e neoliberalismo: as contribuições de Stephen Ball para pensar sobre políticas educacionais na atualidade. Práxis Educativa, Ponta Grossa, p. 850-854, v. 11, n. 3, set./dez. 2016. Disponível em: <revistas2.uepg.br/index.php/praxiseducativa $>$.

MAINARDES, J.; MARCONDES, M. I. Entrevista com Stephen J. Ball: um diálogo sobre justiça social, pesquisa e política educacional. Educação \& Sociedade. Campinas, v. 30, n. 106, p. 303-318, jan./abr. 2009. DOI: <10.1590/s0101-73302009000100015>.

NÓVOA, Antonio. A Formação de professores e profissão docente. In: NÓVOA, A. Os professores e a sua formação. Lisboa: Publicações Don Quixote, 1992.

PACKER, A. M. C. Currículo e prática docente: uma experiência de uma escola internacional. Dissertação (Mestrado em Educação). Itajaí, Univali, 2017.

SILVA, A. R.; CASTRO, A. M. D. A. Formação continuada de professores: uma nova configuração a partir da lógica do mercado. Quaestio Revista de Estudos em Educação, Sorocaba, vol. 10 n. 1, (2008), p. 185-208. 


\title{
A IMPORTÂNCIA DA LÍNGUA DE SINAIS PARA A FORMAÇÃO DA IDENTIDADE E CULTURA SURDA: DA TRAJETÓRIA HISTÓRICA À EXPERIÊNCIA EM JI-PARANÁ-RO
}

\author{
Maria de Lourdes Vargas ${ }^{17}$ \\ Maria Cecília Correa de Souza ${ }^{18}$ \\ Jaqueline Custodio Chagas Soares ${ }^{19}$
}

\section{INTRODUÇÃO}

Falar uma língua não significa apenas expressar nossos pensamentos mais interiores e originais; significa também ativar a imensa gama de significados que já estão embutidos em nossa língua e em nossos sistemas culturais.

Stuart Hall (2006)

17 Licenciada em Pedagogia pela Universidade Federal de Rondônia (2002). Especialista em Libras pela Faculdade Interamericana de Porto Velho-RO (2008). Especialista em Pedagogia Gestora: Administração, Orientação e Supervisão escolar pelo Instituto Superior do Acre (2004). Especialista em Ciências da Educação pela Faculdade de Pinheiros, FAP Brasil. Mestra em História e Estudos Culturais da Universidade Federal de Rondônia (UNIR), Professora de Libras da Secretaria Municipal de Educação de Ji-Paraná-RO.

18 Licenciada em Pedagogia pela Universidade Federal de Rondônia (1999). Especialista em Psicopedagogia e Educação Especial (2003); Especialista em Educação de Surdos e Déficit Cognitivo (2010). Especialista em Libras pela Faculdade São Bráz (2018). Especialista em Psicopedagogia (2019). Mestranda em Educação Matemática pela Universidade Federal de Rondônia (UNIR), Gerente de Educação Especial da Secretaria Municipal de Educação de Ji-ParanáRO.

${ }^{19}$ Licenciada em Pedagogia pelo Centro Universitário Luterano de Ji-Paraná Ceulji/Ulbra (2009). Especialista em Tradução e Interpretação da Libras (2018). Especialista em Educação Infantil e Alfabetização (2013). Professora dos Anos Iniciais do Ensino Fundamental da Secretaria Municipal de Educação de JiParaná-RO. 
Nas últimas décadas muitas discussões foram geradas em torno de assuntos relacionados ao empoderamento e conquista do lugar da pessoa surda na sociedade. Geralmente estas questões são levantadas pela própria comunidade surda que reconhece os direitos políticos, culturais e linguísticos. Também estudiosos de línguas, intérpretes e pessoas de convivência mais próximas aos surdos, buscam conhecer e entender a cultura surda e os diversos artefatos que são produzidos, e que constituem a realidade do lugar de vivência e convivência em comunidade.

Este artigo apresenta temas pertinentes à língua, à cultura e à educação de pessoas surdas e assim oferece uma oportunidade de reflexão sobre a nossa percepção em torno do assunto, e, quem sabe, motivar-nos a buscar mais conhecimento e preparação para contato tanto educacional, como social, com as pessoas que usam a Língua Brasileira de Sinais e outros artefatos da Cultura Surda. Nesta perspectiva, faz sentido efetuar um levantamento históricocrítico de teorias pedagógicas, responsáveis por uma perspectiva da educação de surdos, procurando contextualizar e compreender as representações que esteve ou ainda permanecem na base das práticas do Oralismo, Comunicação Total e Bilinguismo, direcionando a discussão para o mundo da Cultura e Identidade Surda. Assim sendo, consideramos importante apresentar a Educação de Surdos a partir da aceitação da Língua Brasileira de Sinais, compreender as influências das representações da surdez que impedem a formação educacional, cultural e social das pessoas surdas.

Partindo para o campo da vivência na prática e tendo como um norte as bibliografias consultadas, procurou-se observar uma realidade mais próxima. Através das experiências das coautoras educadoras, que possuem significativos espaços de tempo da trajetória profissional dedicados ao trabalho na secretaria 
municipal e escolas de Ji-Paraná, na área da Educação Inclusiva, foi possível identificar a trajetória inicial e chegar até a atualidade, destacando assim o processo inclusivo, o desenvolvimento da comunidade surda ji-paranaense, o crescimento e empoderamento a partir do reconhecimento da identidade surda e da Língua Brasileira de Sinais, tanto pela própria comunidade, quanto pelos órgãos públicos responsáveis pela educação e inclusão escolar.

\section{EDUCAÇÃO DE SURDOS E A ORIGEM DA LIBRAS}

A história da educação de surdos teve um marco importante ainda na idade moderna, no perídoo de 1501-1576, em que Girolamo Cardano, médico, filósofo, afirmava que a mudez e a surdez não eram consideradas impedimento para desenvolver a aprendizagem. Segundo ele, a melhor maneira para o desenvolvimento da aprendizagem desse sujeito era a escrita.

De 1712-1789, o francês Charles Michel de l'Épée apresentou importante contribuição no desenvolvimento da educação de surdos, tanto para a Europa, quanto para as Américas. Foi com ele que o ensino, até então ministrado individualmente, passou a ser institucionalizado e coletivo, com a criação do Instituto de Surdos-Mudos de Paris, em 1771. Podemos dizer que sua atuação não se restringiu apenas às instruções educativas, mas alcançou proporções políticas e culturais influenciando o contexto histórico daquele período. Efetivamente a qualidade da educação francesa atingiu os objetivos ao desenvolver a capacidade de seus estudantes, preparando-os para ultrapassarem as fronteiras espalhando, inclusive, para outro continente a origem da língua de sinais. Assim, educadores surdos franceses vieram para as Américas, sendo Laurent Clerc para os Estados Unidos no ano de 1817, e Hernest Huet em 1856 para o Brasil. Desta forma, é possível afirmar que a educação brasileira para pessoas surdas teve suas 
bases fundadas no modelo utilizado na França. Com a organização do ensino francês a base gestual foi considerada, impulsionando assim, a efetivação e a propagação da língua de sinais. Historicamente a Educação de Surdos no Brasil, está registrada a partir da chegada do primeiro educador de surdos no ano de 1856, dando início à primeira escola para pessoas com surdez no Brasil. Era também o início da construção de uma língua que representaria para os surdos brasileiros o direito de comunicar, expressar sentimentos, pensamentos e adquirir conhecimentos necessários para o usufruto dos bens culturais e sociais considerados como direito de todos.

No período imperial de D. Pedro II, Huet desejoso de fundar um instituto para surdos, obteve a autorização do imperador. Emigrou para a Corte Portuguesa no Brasil em 1855, fundou o Imperial Instituto de Surdos-Mudos em $1^{\circ}$ de janeiro de 1856 , no Rio de Janeiro, mas, posteriormente, de acordo com a Lei n. 939 que regulamentou a fundação do instituto, passou a vigorar como data de criação o dia 26 de setembro de 185720 . Relacionar estas datas torna esclarecedor o motivo de diferenças, tendo em vista que, conforme as diferentes fontes bibliográficas podem divergir entre os anos 1956 e 1957.

Fernanda Bouth Pinto (2006, p. 3), em uma publicação na revista Fênix de História e Estudos Culturais, apresenta uma pesquisa na qual analisa documentos dos acervos do Instituto Nacional de Educação de Surdos (INES) e coloca que: "A criação do Imperial Instituto dos Surdos Mudos, em 1856, estava associada ao Projeto Saquarema de implementação da instrução pública na

${ }^{20}$ PINTO, Fernanda Bouth. O silencioso despertar do mundo surdo brasileiro. Revista de História e Estudos Culturais, vol. 3, n. 2, ano III, abril/maio/junho, 2006. 
Corte". Havia um empenho político conservador em garantir um Estado forte, que procurava em sua organização a centralização do poder.

Nesse período, somavam-se ainda muitos excluídos do direito à instrução. As próprias leis criavam os empecilhos, visto que o sistema educacional ainda não abarcava todo o contingente populacional que necessitava de escolarização. Hernest Huet reivindica e consegue o apoio do imperador para fundar a primeira escola de surdos no Brasil.

O Decreto n. 1.331-A, de fevereiro de 1854, que regulamentou a reforma de ensino primário e secundário do município da corte, implementado pelo Ministro Luiz Pedreira do Couto Ferraz, em seu Artigo 69 continha a seguinte redação: “Não serão admitidos à matrícula, nem poderão frequentar as escolas: $\S$ $1^{\circ}$ Os meninos que padecem moléstias contagiosas. $\S 2^{\circ}$ Os que não tiverem sido vacinados. § Os escravos" (Brasil, 1854, p. 45 Vol. 1 pt I). Ao analisar o conteúdo do artigo encontramos menção sobre os que estavam eminentemente proibidos de efetuarem matrículas em instituição de ensino. No artigo 64 deste mesmo decreto, encontramos que, as pessoas da família, tutores ou outros que mantivessem em sua companhia meninos maiores de sete anos sem impedimento físico ou moral, que não estiverem matriculados no ensino do primeiro grau, incorreriam em multa conforme as circunstâncias. As palavras "impedimento físico" por muito tempo foram designadas para caracterizar as pessoas com surdez. Assim, esta expressão registrada no decreto, desmotivava as pessoas surdas a procurarem a instrução escolar, pois revelava uma ideia de que só as pessoas que não apresentassem alguma deficiência teriam a oportunidade de estudar. 
Em consideração ao fato dos surdos, por possuírem um impedimento físico, não lhes serem obrigados a frequentar a escola, também era condição para que seus pais ou responsáveis se sentissem desobrigados de inseri-los no sistema educativo formal. Dessa forma, a atuação de Huet foi decisiva para conquistar a atenção dos pais e das autoridades enquanto Comissão Promotora do Instituto, considerando que educação até então era privilégio de poucos, talvez dos grupos e classes dominantes. Fernanda Bouth Pinto comenta que:

Por determinação do Imperador D. Pedro II, foi organizada uma comissão com figuras importantes do Império para promover a fundação da escola para surdos. O Instituto dependeu da ação de alguns ilustres homens públicos, pois sem seu esforço o Instituto não sobreviveria. Estes homens pertencentes à elite, à "boa sociedade", exerceram o papel de incentivadores e difusores da instrução pública (Pinto, 2006, p. 8).

Assim, cabe indagar os objetivos da criação da escola para surdos. No caso do Imperial Instituto de Surdos Mudos do Rio de Janeiro, podemos inferir que Hernest Huet contava com o sentimento da caridade advinda de sua experiência religiosa, por ser também surdo possuía requisitos para o ensino dos sinais de sua língua e como professor tinha um programa de ensino para o desenvolvimento de seus estudantes. Porém, com o regime de internato e estudantes que não pertenciam às famílias com condições de mantê-los financeiramente, só lhe restava recorrer ao sistema de apadrinhamento para poder contar com as pensões fornecidas pelas autoridades desejosas de se consagrarem politicamente como benfeitoras da sociedade e da instrução pública. 
A inspeção era feita por uma comissão que monitorava e tomava as providências necessárias "devendo manter informado o imperador do estado em que se encontrava o Instituto, suas despesas e dívidas, assim como o andamento do ensino, seu progresso e os métodos de ensino utilizado" (Pinto, 2006, p. 11).

Com relação aos conteúdos trabalhados, havia o desenvolvimento de atividades práticas separado por gênero, como o ensino da agricultura para os meninos, e costuras e bordados para as meninas. Eram desenvolvidos o ensino de leitura e escrita, bem como a gramática da língua nacional. As dificuldades de aprendizagem deveriam ser vencidas pelos estudantes, pois, assim como era o costume na França, modelo concebido inicialmente por l'Épée, para que se tornasse conhecida a eficácia de seu método aplicado ao ensino de surdos, o professor Huet manteve também aqui no Brasil, a demonstração pública da aprendizagem alcançada durante o ano. Uma espécie de apresentação avaliativa dos bons resultados às autoridades financiadoras do estudo dos Surdos e assim conseguir a manutenção destas parcerias. Os fins econômicos para a manutenção do asilo, enquanto preocupação do diretor, fora externalizada verbalmente quando afirmava que o Instituto não "sobreviveria" sem a ajuda das autoridades e do Estado.

Sobre as lições de pronúncia, de articulação e de leitura, no contexto da leitura oral, analisada a partir do escrito no documento acima, e considerava as aptidões para a realização desses exercícios. Essa referência requer uma análise anterior e posterior ao fato para contextualização, considerando ser ainda, nos dias atuais, motivos de conflito na educação da pessoa surda. Referente ao passado, os surdos começaram a ser reconhecidos em alguns direitos pela capacidade da oralização, sendo, na maioria das vezes, os filhos dos nobres que necessitavam da fala para serem considerados herdeiros de títulos de nobreza e/ou de heranças familiares. Assim, podemos 
pensar que o princípio educacional esteve ligado ao treino da oralidade.

No período de instalação da escola de surdos no Rio de Janeiro, o ensino já havia progredido, aceitando assim que se incluísse a língua gestual, embora existissem algumas escolas extremamente oralistas. Huet vinha de instituições francesas que defendiam também o uso dos sinais. Para aplicação do ensino de pronúncia e articulação da fala, por ser praticamente optativa, era aplicada conforme a aptidão de seu alunado. Uma hipótese seria o fato de os estudantes brasileiros pertencerem à classe econômica explorada, não havendo assim uma cobrança unânime da fala, haja vista não se enquadrarem nos moldes da antiga necessidade da fala como parâmetro de legitimação de direitos. Igualmente, a dificuldade encontrada no processo do treino da oralização para pessoas com surdez profunda poderia dificultar o convencimento de pais e estudantes a prosseguirem os estudos no Instituto. Melhor seria, no entanto, uma flexibilidade como garantia de autonomia na condução do ensino para poder consolidar o processo conforme as características encontradas através da permanência dos estudantes na Instituição Nacional de Surdos-Mudos no Brasil.

Quanto à educação de surdos no Brasil, tendo como precursor o professor Surdo francês Hernest Huet (1856-1961), aconteceu no momento histórico em que poucas pessoas tinham acesso à escolarização, a conquista do espaço social foi atingida, bem como os objetivos de apresentar à sociedade como as pessoas com surdez poderiam e deveriam receber instruções educacionais. Assim sendo, a constituição da Comunidade Surda e da Língua Brasileira de Sinais teve seu momento embrionário com a vinda de Huet e a criação do Imperial Instituto de Surdos-Mudos, atual Instituto Nacional de Educação de Surdos (INES), que desenvolveu, além das bases do ensino, a contribuição para a formação das 
identidades surdas brasileiras, considerando que é na reunião de pessoas surdas, e interação entre as mesmas, que a língua de sinais torna-se prática de comunicação, criação e vivência em suas diferenças culturais, conquistando o espaço em uma sociedade que, constitui-se de falantes das línguas orais. Hoje, a Libras é oficialmente reconhecida como língua da comunidade surda brasileira, pela Lei n. 10.436, de 24 de abril de 2002.

\section{AS DIFERENTES ABORDAGENS NA EDUCAÇÃO DE SURDOS}

É importante mencionar que algum tempo posterior, precisamente em 1880, como resultado do Congresso de Milão ${ }^{21}$, o desenvolvimento da oralidade tornou-se mundialmente obrigatório, e institui-se o "Oralismo". É abolida por cerca de um século a língua de sinais do contexto escolar. Talvez esta tenha sido a mais cruel tentativa de eliminação das diferenças individuais, ou seja, a negação do sujeito que foge aos parâmetros de normalidade por não conseguir beneficiar-se da audição e da fala, privando-o dos direitos linguísticos e consequentemente de suas diferenças individuais e culturais.

Atualmente, a opção pela oralização do aluno surdo não faz parte dos objetivos educacionais no sentido escolar. Os pais de crianças surdas têm o direito de requererem, através de órgãos públicos da área de saúde, o atendimento de fonoaudiologia, que pode ser trabalhada sem prejuízo ao desenvolvimento da Língua Brasileira de Sinais, tendo em vista que os cursos que formam os fonoaudiólogos têm incluído na grade curricular a formação em

${ }^{21} \mathrm{O}$ Congresso de Milão foi uma conferência internacional de educadores de surdos, realizada em 1880. Declarou que a educação oralista era a mais apropriada para a educação de surdos. Proibiu língua gestual e aprovou a resolução que preferencialmente seria utilizado o uso da língua oral nas escolas. 
Libras, e muitos profissionais da área têm adotado a língua de sinais como base para o desenvolvimento da escrita e da língua oral. Assim sendo, as condições de aceitabilidade e desenvolvimento da criança devem ser levadas em consideração para que não se exija algo que não esteja ao alcance, contribuindo assim para a melhoria de condição da vida social e educacional do Surdo, bem como um direito de optar somente pela utilização da língua sinalizada da comunidade e cultura surda.

Por volta dos anos de 1960, uma nova abordagem, denominada de Comunicação Total, passou a fazer parte do ensino para surdos. Teve seu início nos Estados Unidos e, paulatinamente, ganhou espaço também no Brasil. Segundo Gladis Perlin e Karin Strobel (2009, p. 20):

A Comunicação Total inclui uma gama de instrumentos linguísticos, ou seja: língua de sinais, língua oral, gestos, fala, leitura labial, alfabeto manual, leitura da escrita, ritmo, dança. Em sua prática incorpora ainda o desenvolvimento da fala mediante uma atividade com repetição ritmada, dos restos auditivos com o treinamento do som para estimular através de uso constante, por um longo período de tempo, aparelhos auditivos individuais e/ou sistemas de alta fidelidade para amplificação em grupo. Visa desenvolver as habilidades de fala, mediante treino rítmico corporal e articulação ritmada. Para isto se serve de qualquer artefato, mesmo a língua de sinais é usada com a intenção de ensino da fala ou do português.

Sobre esses pressupostos, Perlin e Strobel descrevem as práticas que passaram a constituir o cotidiano das salas de aula e, embora a oralização ainda fizesse parte das atividades desenvolvidas na escola, as mãos já iam ganhando liberdade no longo processo de consolidação da língua, considerando assim, um período de transição na constituição do ambiente escolar. 
As críticas a esta forma de trabalho baseiam-se no argumento de ser prejudicial ao desenvolvimento da Libras, conforme Perlin e Strobel, uma vez que "Essa modalidade mista produziu um problema que é até hoje contestado pelos surdos, ou seja, a mistura de duas línguas, a língua portuguesa e a língua de sinais resultando numa terceira modalidade que é o "português sinalizado" (2009, p. 21).

De acordo com as políticas de inclusão, considerando que nem todos os profissionais atuantes com surdos recebem formação adequada, pode acontecer de não se aplicar conscientemente uma abordagem definida. O pouco domínio da Libras, e das metodologias inapropriadas, poderá fazer com que o professor lance mão do que lhe é disponível, seja oralização, ou língua de sinais fora da estrutura gramatical, o que dificulta a compreensão da informação mesmo quando o sujeito surdo já possui uma base linguística formada, ou seja, o pleno domínio da língua de sinais. Caso seja um estudante surdo, vindo de família ouvinte, que não obteve os referenciais da língua usada na comunidade surda, pode acontecer que as dificuldades somente sejam reconhecidas quando confrontadas em situação real de uso com os pares mais experientes em Língua Brasileira de Sinais. Nesse segundo caso, além da falta de compreensão, pode ocorrer deformação de aprendizagem. Nas duas situações há comprometimento na apreensão dos conteúdos trabalhados, onde o domínio da língua na qual a informação está sendo colocada é primordial para bons resultados.

Em relação à situação dos estudantes surdos Ronice Müller de Quadros (1997, p. 23) afirma que:

Apesar de não haver um levantamento exaustivo sobre o desempenho escolar de pessoas surdas brasileiras, os profissionais e a sociedade surda reconhecem as defasagens escolares que impedem o adulto surdo de 
competir no mercado de trabalho. Nas escolas brasileiras é comum terem surdos com muitos anos de vida escolar nas séries iniciais sem uma produção escrita compatível com a série. Além disso, há defasagens nas demais áreas previstas para as séries considerando o currículo escolar.

Não há como esperar melhorias na qualidade do ensino sem investimentos na educação. Concordamos com a existência de leis que garantam a formação, mas também existem escolas brasileiras que ainda não contam com o quadro de professores e intérpretes especializados. Os cursos de graduação, ou mesmo os de formação continuada, oferecidos pelo Estado, nas Secretarias de Educação, nem sempre são suficientes para um maior aprofundamento, sendo preciso, na maioria das vezes, uma busca por complementação, seja com esforço e recursos próprios, ou em contato com as comunidades surdas, considerando que a aprendizagem de uma língua exige um tempo de maior dedicação, não suficientemente encontrada nas disciplinas de curta duração ou de formação descontínua.

Outra questão que deve ser considerada por sua influência na aprendizagem da Libras, não somente em suas formas estruturais, o que irá fazer diferença para pessoas ouvintes que têm internalizada a estrutura do português e também para o surdo que precisa constituir-se a partir de referências identitárias e linguísticas, refere-se à presença de professores surdos nas escolas inclusivas, para o devido estabelecimento da comunicação entre surdos e ouvintes usuários da língua de sinais.

Nesse sentido, Fernandes (2003, p. 41), entende que se deve ter "o reconhecimento do espaço prioritário dos adultos e profissionais surdos no processo educacional, favorecendo a formação da identidade das crianças e a vivência de aspectos culturais da comunidade surda”. Assim sendo é extremamente 
importante para as crianças que pertencem a famílias ouvintes o contato com pessoas surdas para reconhecimento de identidade e como modelo cultural.

Das propostas pedagógicas desenvolvidas na educação de surdos, vimos até aqui que o poder ouvintista impôs quase um século de proibição mundial da língua de sinais, utilizando-se do método "Oralismo Puro”. Representando o início de um processo educativo mais flexível, a "Comunicação Total” lançou mão de todos os recursos no sentido de facilitar a entrada do surdo para a comunidade ouvinte. Já o "Bilinguismo" é a mais recente proposta educacional no Brasil, e vem ganhando espaço pelo forte movimento da comunidade surda para que seja consolidada. Essa proposta é usada por escolas que se propõem a tornar acessível à criança duas línguas no contexto escolar, ou seja, para que o ensino seja considerado bilíngue, deve ser oferecido ao aluno surdo a aprendizagem da Libras e da Língua Portuguesa na modalidade escrita. Conforme o Decreto 5.626/2005, Art. 22, § $1^{\circ}$ "São denominadas escolas ou classes de educação bilíngue aquelas em que a Libras e a modalidade escrita da Língua Portuguesa sejam línguas de instrução utilizadas no desenvolvimento de todo o processo educativo".

Quanto à organização educacional que adote a proposta bilíngue, não se enfatiza que devem estudar nesta escola somente alunos surdos. Os estudantes ouvintes poderão estar matriculados, desde que estejam de acordo com o processo de ensino que se utiliza da língua portuguesa na modalidade escrita e a Libras como língua de instrução, interação e comunicação. Acredita-se ser possível valorizar a inclusão educacional e social ao despertar no estudante ouvinte o desejo de aprender a língua de sinais. Para além de uma ação afirmativa, trata-se também de uma ação inclusiva reivindicada pela comunidade surda, familiares e profissionais da 
área que consideram legítima tal reivindicação. $\mathrm{O}$ trecho a seguir faz parte da justificativa do Projeto de Escola Pública Integral de Educação de Surdos ${ }^{22}$ liderado pelo Movimento Nacional em Favor da Educação e da Cultura e Feneis, do Distrito Federal.

Nos últimos anos, a inclusão dos surdos à sociedade abriu-lhes uma grande possibilidade de exercerem a cidadania. Por isso, todos nós queremos a inclusão, mas não podemos nos esquecer de que a diversidade humana precisa ser respeitada, mesmo nos espaços inclusivos. Uma política de educação inclusiva para os surdos precisa, contudo, levar em consideração suas especificidades linguísticas, culturais e identitárias. A diversidade para a unidade e a diferença para a equidade são marcas importantíssimas para tornar acessíveis as relações sociais e o conhecimento humano adquirido ao longo dos milhares de anos de existência da humanidade (2011, p. 3).

Com relação ao desenvolvimento da oralidade, tão aclamada nos dois métodos pedagógicos que vigorou anteriormente, não se faz presente nos objetivos da educação bilíngue para surdos. Quadros (1997) faz referência à sugestão apresentada por Ferreira Brito (1995) ao afirmar ser mais interessante trabalhar na aquisição de conceitos e desenvolvimento do sistema semântico, ou seja, criar significados internalizados. A discussão acima suscita uma reflexão mais profunda, e talvez, mais difícil de ser analisada do ponto das condições de aceitação das diferenças linguísticas e de identidade. Ao receber o estudante ouvinte, a escola bilíngue que tem a língua

\footnotetext{
${ }^{22}$ Projeto elaborado pela Feneis-DF, tendo como diretor regional Messias Ramos Costa, contando-se com a participação de outros colaboradores. Disponível em: <www.sinprodf.org.br/wp-content/uploads/2013/06/projeto_escolabil\%C3\%8Dngue-feneis.pdf $>$. Acesso em: 8 set. 2017.
} 
de sinais como primeira língua, realiza o processo inclusivo destes estudantes no ambiente cultural e linguístico visual-espacial. Dessa forma, há uma real necessidade de aceitação e negociação entre os falantes pela utilização da língua de sinais no processo de aprendizagem e de conversação.

No entanto, considerando as diferenças individuais, deve ser respeitado o direito de o aluno surdo desenvolver a língua oral e escolher a oralização e leitura labial como forma de comunicação para estabelecer o diálogo e a compreensão, inclusive sendo facultado o direito de optar pela educação em escola bilíngue ou escola inclusiva no ensino regular, desde que também seja oferecido o conhecimento das diferenças culturais. É, nesse sentido, um respeito às diferenças e à liberdade, como preconiza os direitos da humanidade, como também pode ser um recurso a mais, colocado em favor do desenvolvimento do pensamento crítico próprio e da comunidade. Vendo por este viés, a surdez não pode ser motivo para impedir o indivíduo de participar ativa e politicamente dos ambientes, desenvolvendo assim, a capacidade crítica de entender as necessidades tanto do meio surdo, e o relacionamento com a comunidade ouvinte, valorizando os artefatos culturais da comunidade surda, mas também reivindicando a acessibilidade para o usufruto de outros ambientes culturais que é de domínio e direito das humanidades.

\section{EDUCAÇÃO DE SURDOS E A PERSPECTIVA POLÍTICO-CULTURAL}

Conforme já abordamos, estas são as propostas de ensino que permearam ou ainda permeiam a educação de surdos, sendo elas o oralismo, a comunicação total e o bilinguismo. Tomando por base a história dos surdos, quando relacionadas a estas abordagens educacionais, percebemos as inúmeras situações de imposição da cultura escolar ouvintista. No entanto, as pessoas surdas buscam, 
através de movimentos, de participação nas discussões políticas, no engajamento social e de pesquisas educacionais, alcançar o lugar de direito a ser ocupado pelas comunidades surdas. Teceremos algumas considerações sobre o posicionamento reflexivo com relação a algumas teorias educacionais.

Para as pesquisadoras surdas Perlin e Strobel, as teorias que se vinculam com o princípio universal focado na formação das pessoas, não inclui o Surdo neste modelo. Segundo as autoras:

A educação moderna visa um objetivo, visa fazer do surdo um não surdo. $\mathrm{E}$ a teoria moderna em educação apresenta uma visão de instrução, de sala de aula, de aprendizados objetivos, conteúdos uniformizados, de modelos a serem copiados. Ela mantém um aprendizado imparcial que neutraliza as posições de poder, política e cultura surda (Perlin; Strobel, 2009, p. 9).

Os surdos dependem de um espaço de flexibilidade cultural, de política para uma educação que considere a língua de sinais e a cultura surda, porém encontram dificuldades para vivenciarem sua alteridade. Conforme o processo educativo que a eles são oferecidos, diminuem as possibilidades de construírem identidades autônomas. Assim sendo, na concepção ouvintista, ou os surdos aceitam o processo de ensino marcado pela oralização, ou ficam excluídos dos sistemas escolares. Nas duas situações, o sujeito da cultura surda sofrerá a invisibilidade social.

O pensamento de Perlin e Strobel, na citação acima, leva-nos a identificar uma proximidade com as ideias do educador Paulo Freire; quando este defendia que a educação deve ser emancipadora, um ato político e apresentava clara rejeição à imposição dos conteúdos desconectados da realidade social, cultural e política. Na obra Pedagogia do oprimido, o autor se refere 
à "educação bancária" que não considera as experiências, as diferenças culturais do aluno, e que o conhecimento será igualmente repassado a todos os estudantes como forma de doação, ou seja, "o 'saber' é uma doação dos que se julgam sábios aos que julgam nada saber". O autor enfatiza que esta visão de educação está fundamentada em "manifestações instrumentais da ideologia da opressão - a absolutização da ignorância, que constitui o que chamamos de alienação da ignorância, segundo o qual esta se encontra sempre no outro" (Freire, 1987, p. 33).

Em tempos atuais, não podemos admitir uma educação que exclui o aluno das questões políticas, inclusive no direito de usufruir o direito a participar das questões discutidas em sala de aula, de entendê-las e manifestar suas opiniões, ou seja, participando da construção do próprio saber. No entanto, para participar deste processo não pode haver ignorância ou preconceito às línguas utilizadas no ato pedagógico e comunicativo. Por isso, há a necessidade da língua de sinais para que a educação de surdos faça a diferença enquanto promotora de participação ativa, política, cultural, ou seja, desenvolvida com autonomia.

Numa sociedade constituída em sua grande maioria por pessoas ouvintes, a presença do surdo pode representar o novo, a nova forma de comunicação, e com isto o novo jeito de ensinar. Para Paulo Freire "ensinar exige risco, aceitação do novo e a rejeição a qualquer forma de discriminação" (1996, p. 39). Neste sentido, o autor salienta que qualquer prática discriminatória ofende a substantividade do ser humano e nega radicalmente a democracia.

Considerando que o ato reflexivo pode manter uma relação com o ato interativo e comunicativo, buscamos as palavras de Paulo Freire quando expressa que: 
Pensar certo implica a existência de sujeitos que pensam mediados por objeto ou objetos sobre que incide o próprio pensar dos sujeitos. Pensar certo não é que-fazer de quem se isola, de quem se "aconchega" a si mesmo na solidão, mas um ato comunicante. Não há por isso mesmo pensar sem entendimento e o entendimento, do ponto de vista do pensar certo, não é transferido, mas coparticipado (Freire, 1996, p. 41).

Ao situar a educação como um ato reflexivo, que envolve a relação entre os sujeitos, o modelo de escola "bancária” não reúne condições de desenvolvimento deste sujeito pensante, seja ele surdo ou ouvinte. Também, da mesma forma a escola que tem a presença de estudantes surdos, não pode desconsiderar a importância da língua de sinais, pois é através desta língua visualespacial que acontece a compreensão e interação dos sujeitos surdos com os outros sujeitos, o desenvolvimento do pensamento e entendimento da realidade social e, por conseguinte, tirando o sujeito do isolamento. Conforme Freire, o pensar certo não pode ser transferido e sim coparticipado.

As palavras de lutas em prol do ensino, currículo, cultura, educação, comunicação e transformação estão ligadas ao compromisso ético e político do educador e da educação emancipadora. Com este sentido acontecem também as reivindicações da comunidade surda pelo reconhecimento do espaço educacional, social e cultural, que constitui o fazer de um povo que tem uma língua em comum, que vive, que interpreta e que interage com o mundo carregando em si seus significados e ressignificando a partir do contato com a comunidade ouvinte.

Como na educação de surdos deve-se priorizar a Língua Brasileira de Sinais, também para a inserção no trabalho se faz necessária. Nesse caso, no ambiente de trabalho de uma pessoa 
surda são necessárias, além do uso da Libras, a presença do intérprete para a tradução e interpretação das palestras, reuniões e outros eventos. Com os avanços tecnológicos há maiores possibilidades de trocas de informações e comunicações com a utilização de recursos que promovem tal acessibilidade, como, por exemplo, a comunicação visual, mensagem de textos, sinalização luminosa, internet com os aplicativos que facilitem a comunicação. Porém, a maior importância da língua está no fato de ser a mediadora na relação dos sujeitos. Segundo Paulo Freire:

O diálogo não é um produto histórico, é a própria historicização. É ele, pois, o elemento constitutivo da consciência que, abrindo se faz a infinitude, vence intencionalmente as fronteiras da finitude e, incessantemente, busca reencontrar-se além de si mesma. Consciência do mundo, busca-se ela a si mesma num mundo que é comum; porque é comum esse mundo, busca-se a si mesma comunicar-se com o outro (Freire, 1987, p. 9).

Nessa perspectiva, podemos considerar como parte da história da educação as reflexões sobre as diferentes teorias e sua manifestação na educação de surdos, considerando que as escolhas interferem na produção dos significados e consequentemente nos resultados. Assim sendo, o diálogo, que com o uso da língua é conferido ao surdo, precisa estar inserido na realidade das práticas educativas, tanto como pela interação subjetiva dos sujeitos, como para o conhecimento dos objetivos que se pretendem alcançar, sendo uma questão de direito e de respeito, que faz a diferença quando a escola oferece as condições de acessibilidade por meio da língua de sinais e outros recursos visuais. 


\section{TEORIAS PEDAGÓGICAS E MATERIAIS CULTURAIS}

Os conteúdos culturais são transversais e constituem os domínios de conhecimento incorporados pela humanidade, por isso, reavaliados permanentemente, revitalizados e atualizados face às realidades sociais. As reclamações dos surdos em relação à escola da sociedade ouvintista estão no fato desta não contemplar a cultura surda. Na escola, mesmo considerada inclusiva, há uma predominância de aulas expostas por meio da oralidade. Sabemos que, mesmo com a presença do intérprete de Libras, muitas informações podem tornar-se bem mais significativas para o estudante surdo se for complementado com materiais ilustrativos, ou seja, com recursos visuais. Quanto à reivindicação por escolas bilíngues, na qual a Libras ocupa o lugar reservado a primeira língua, ou seja, os conteúdos são ministrados em sinais e a Língua Portuguesa utilizada na modalidade escrita, pelo fato de a aula já estar sendo pensada e planejada para o aluno que faz uso da língua visual espacial, a proposta curricular e pedagógica já dispõe de materiais culturais que normalmente são favoráveis à experiência linguística, tornando assim o conteúdo mais expressivo visualmente.

Conforme os objetivos estabelecidos na Constituição Federal de 1988 e na Lei de Diretrizes e Bases da Educação Nacional, LDBEN, Lei n. 9.394/1996, a educação visa o desenvolvimento pleno da pessoa, portanto pressupõe que a leitura (em sinais) a escrita (em língua portuguesa) sejam instrumentos para que o estudante surdo possa se desenvolver, incluindo a autonomia de acesso aos mais diversos textos e contextos representados na história, na literatura, na arte, nos materiais impressos como jornais, revistas e por meios da internet, que pode reunir desde os recursos da escrita, como em vídeo, priorizando as 
imagens e movimentos, bem como a interpretação por meio da língua de sinais, para que não se perca o sentido da educação. Parece estar se referindo ao óbvio, entendendo que estes objetivos são comumente desenvolvidos pela escola. Ou seja, deveriam ser também para os estudantes surdos, mas o contexto real da educação desses estudantes tem apresentado grande defasagem dos conhecimentos. Mesmo quando se trata de ter direitos ao conhecimento e participação em manifestações culturais, sente-se em desigual condição de apreciação, ou mesmo de produção, pela falta de acessibilidade visual, de comunicação, e de compreensão dos materiais escritos numa língua com estrutura diferente da língua manualmente sinalizada ou escrita em sinais.

As lutas pelo acesso aos diferentes conhecimentos estão intimamente relacionadas ao direito de acessibilidade de comunicação. Sobre a importância do ato educativo, Dermeval Saviani expõe que:

A educação, para além de se constituir em determinado tipo de direito, o direito social, configura-se como condição necessária, ainda que não suficiente, para o exercício de todos os direitos, sejam eles civis, políticos, sociais, econômicos ou de qualquer outra natureza (Saviani, 2013, p. 745).

Quando o autor fala que o direito à educação é condição necessária para o exercício de todos os direitos, podemos situar os surdos como dependentes também de políticas públicas que garantam o direito básico e fundamental da fruição de Cultura. Saviani (1986, p. 80) afirma que "no processo de autoproduzir-se o homem produz cultura" e "isso significa que grande parte da população que participa da produção da cultura, não participa da fruição", ou seja, as condições econômicas barram muitos brasileiros a terem acesso aos bens culturais, como também a falta 
de acessibilidade torna-se empecilho para que as pessoas com deficiência possam ter acesso aos eventos culturais, pois dependem dos tipos de acessibilidades necessárias, citando alguns exemplos como: as adaptações arquitetônicas para deficientes físicos, de voz e tátil para os deficientes visuais e de interpretação em língua de sinais para os surdos.

A atividade cultural quando apresentada com o recurso da língua oral, irá solicitar a presença do tradutor e intérprete da língua de sinais, enquanto o material cultural escrito exigirá o domínio da língua portuguesa escrita, que para os surdos representa um alto nível de complexidade em decorrência das diferenças linguísticas. Nas duas modalidades, o conhecimento prévio da história de sua constituição fará grande diferença na apreensão dos significados para relacionar com o conhecimento do mundo ao redor, também pelo fato de ter adquirido conhecimentos por meio de conteúdos escolares.

\section{EXPRESSÕES DA CULTURA SURDA PELOS ARTEFATOS CULTURAIS}

A realidade social está caracterizada por diferentes culturas, considerando os diferentes grupos de pessoas que se organizam em comunidades e formam sociedades. Assim sendo, não há como falar em cultura sem referir-se também a um processo social efetivo.

Numa sociedade mais elitizada, o termo "cultura" estava relacionado à forma clássica. Para ser considerada uma pessoa dotada culturalmente exigia-se formação específica e alto grau de instrução, onde o ideal de ser humano era, portanto, aquele que conhecia todas as artes e todas as ciências. Já os Estudos Culturais, que teve como seus principais fundadores Raymond Williams, Richard Hoggart e Edward Thompson, pretendiam romper com o 
positivismo científico da objetividade sociológica e concentrar-se na "subjetividade". Consolidaram um referencial teórico que levou à compreensão da cultura como a esfera do sentido que unifica os setores da produção e das relações sociais e pessoais. Segundo Cevasco (2003, p. 64): "A posição teórica dos estudos culturais se distingue por pensar as características da arte e da sociedade em conjunto, não como aspectos que devem ser relacionados, mas como processos que têm diferentes maneiras de se materializar".

Para Pierre Bourdieu a cultura são valores e significados que orientam e dão personalidades ao grupo social. Ele introduz a metáfora "Capital Cultural" referindo-se a cultura na sociedade introduzida pelo sistema capitalista, ou seja, a sociedade dividida em classes, que pode acentuar as diferenças e até mesmo transformar em instrumentos de dominação da classe dominante em relação à classe dominada, no qual percebendo tal dinâmica, denominou-a de "arbitrário cultural".

Ao transpor essa ideia para a educação, Bourdieu aponta que a escola reforça a cultura dominante ao ser transmitida igualmente aos estudantes que dominam os códigos culturais e aos que não tiveram, no âmbito familiar, o "capital cultural" na forma de livros e acessos às informações disponíveis aos estudantes mais favorecidos economicamente. O que se observa é que a escola trata todos os estudantes igualmente, não considerando os conhecimentos prévios dos estudantes que nela ingressam, ignorando que, tanto social como culturalmente, existem diferenças nas experiências vivenciadas anteriormente ao ingresso da criança na instituição escolar. Nesta visão, a escola não cobra dos estudantes apenas aquilo que lhes foi ensinado e sim habilidades previamente desenvolvidas para uns, bem como, estranhas para outros. Neste contexto, podemos considerar a situação da inclusão do aluno surdo em sala de aula para ouvintes; cobra-se deste aluno o domínio 
que ele não adquire espontaneamente, como é o caso da língua portuguesa que precisa ser trabalhada como uma segunda língua, portanto na modalidade escrita; já a língua de sinais, embora também deva ser aprendida, torna-se mais natural diante de pessoas que se utilizam especialmente do sentido visual. Considerando que a maioria dos estudantes surdos são de famílias ouvintes, onde o ambiente cultural familiar é organizado também pelas/para pessoas ouvintes, torna-se mais agravante pelo fato de não se adquirir habilidades prévias de comunicação que resultam num melhor desenvolvimento interacional e desempenho escolar.

Quando abordamos questões relacionadas à comunidade de pessoas surdas, é comum aparecer dúvidas e espantos em relação à "identidade surda" e "cultura surda". Normalmente isto acontece por falta de contato que gera o conhecimento, ou até mesmo por uma questão de negação da surdez. O contrário acontece com pessoas engajadas politicamente em movimentos a favor da cultura surda, sendo que:

A partir de uma visão dos Surdos, o ato politizado de alegar uma surdez "nativa" - ou seja, uma surdez de nascença - está ligado à identidade positiva de não estar "contaminado" pelo mundo dos que ouvem e suas limitações epistemológicas do som seqüencial. A "pureza" do conhecimento dos Surdos, a verdadeira Surdez, que vem da expulsão desta distração, é, na cultura dos Surdos, uma marca de distinção (Wrigley, 1996, p. 15).

O termo derivado do "ser surdo" não representa, neste contexto, um problema ou uma deficiência, mas agrega a identificação com o que é visual. Embora pareça contraditória esta afirmação, podemos observar que a doutora surda Karin Strobel escreve em seu livro "As imagens do outro sobre a cultura surda" (2015, p. 29) conceituando que: 
Cultura surda é o jeito de o sujeito surdo entender o mundo e modificá-lo a fim de torná-lo acessível e habitável, ajustando-o com as suas percepções visuais, que contribuem para a definição das identidades surdas e das "almas" das comunidades surdas. Isto significa que abrange a língua, as ideias, as crenças, os costumes e os hábitos do povo surdo.

Para Strobel, o que define o pertencimento à cultura surda, tem muito a ver com os esforços que o sujeito faz para habitar no país que majoritariamente usa uma língua pouco compreensível ao sujeito surdo, e que para torná-lo habitável necessita de ajustar-se, perceber por meio da visão o que os ouvintes percebem em sua maioria por meio da audição. E neste ato de transformação dos meios de percepção, os surdos podem também ajustar-se a uma compreensão da cultura dominante, porém dentro dos modelos experimentados na cultura surda.

Mesmo sendo óbvio que os surdos assimilam aspectos da cultura dominante que os circunda, deve-se entender que estes são experimentados e compreendidos a partir da experiência legítima, nativa da surdez. Dentro da cultura maior, aquela que organiza seu comportamento (modo de vestir, de comer, de andar etc.), o surdo tem outros códigos de cultura que dão sentido à sua vida, que lhe dão valores simbólicos diferenciados enquanto pessoa surda (Sá, 2006, p. 315).

Conforme a afirmação de Sá, embora os surdos estejam inseridos na comunidade majoritária ouvinte, a relação dele com o mundo que o cerca vem da experiência nativa da surdez e é na comunidade surda que vai encontrar as condições para constituírem-se como sujeitos dentro de um processo social com seus pares surdos, modelos identitários e culturais da experiência visual, da linguística, da literatura surda, da vida social e esportiva, 
das artes, da política e outros. Strobel, (2015, p. 43-44) baseada em teorias do campo dos Estudos Culturais, conceitua que: "artefatos não se refere apenas a materialismos culturais, mas àquilo que na cultura constitui produções do sujeito que tem seu próprio modo de ser, ver, entender e transformar o mundo". Assim sendo, a língua de sinais é um dos principais artefatos da cultura surda que identifica o povo surdo. Essa língua é expressamente visual e a partir dela o surdo comunica-se e adquire conhecimentos, tanto formais como os universais.

Sobre o desenvolvimento da linguagem da pessoa surda, Strobel (2015, p. 53) explica que:

Quando um bebê nasce surdo, ele desenvolve inicialmente as mesmas fases de linguagem que o bebê ouvinte; grito de satisfação, choro de dor e fome, sons sem significados, até mais ou menos seis meses de idade. Quando chega à fase do balbucio é que começa a ser diferenciado do outro. Porque o bebê ouvinte, podendo ouvir sons do ambiente ao redor de si, tenta se comunicar emitindo sons, enquanto o bebê surdo não ouve os sons do ambiente e, por isto, as primeiras "palavras" não surgem. Consequentemente, fica com a aquisição de linguagem atrasada e limitada por falta de continuidade e acesso aos conhecimentos e informações externas.

Levando em consideração a exposição da autora, podemos considerar que o reconhecimento da surdez precocemente, quando aceita como uma possibilidade do ser sujeito surdo, pode indicar o momento de iniciar a língua de sinais, ou seja, no mesmo momento em que a criança ouvinte começa adquirir as primeiras palavras. Infelizmente, é comum observar o contrário: a primeira atitude quando a família ouvinte descobre que o filho é surdo, e não aceitam a surdez, é procurar especialistas da área da saúde, buscando 
resolver o problema e iniciá-lo o quanto antes na cultura ouvintista. Já quando a criança surda nasce de pais também surdos, a iniciação linguística se dá naturalmente e a criança adquire a língua de sinais espontaneamente no contato com a família surda e posteriormente na comunidade surda, onde acessará outros artefatos da vida social, esportiva e artística da cultura surda.

Relacionado à cultura surda podemos considerar artefatos da literatura que (Strobel, 2015, p. 68) “... traduz a memória das vivências surdas através de várias gerações dos povos surdos. A literatura se multiplica em diferentes gêneros: poesia, história de surdos, piadas, literatura infantil, clássicos, fábulas, romances, lendas..." e outros. Assim como na literatura, também as artes são constituídas por sinais e expressões culturais visuais, com criações que apresentam as emoções e a subjetividade da cultura surda.

A "política" também é considerada um artefato cultural, e está relacionada à militância pelas causas importantes para conquistas de direitos das pessoas com surdez. Um dos pontos importantes para reunir pessoas e tornar legítima as reivindicações do grupo é estarem legalmente constituídos em associações. Segundo Strobel, é mediante as associações que se formam as lideranças e conscientizam-se de seus deveres e direitos, encampam suas lutas pela causa surda e promovem a cultura.

Nessas organizações juntam-se sujeitos surdos em reuniões e assembleias para compartilhar dos interesses comuns, lutando pelos seus direitos judiciais e de cidadania, em uma determinada localidade, geralmente em uma sede própria, alugada ou cedida pelo governo (2015, p. 89).

Assim como podemos perceber, os locais de associações são espaços com finalidade definida, como um local, também, do 
exercício da cidadania de sujeitos surdos, que optam por defender uma espécie de território onde a língua de sinais é a língua usada, onde a cultura visual prevalece, formando assim uma comunidade em que seus membros possuam identidade e cultura surda.

\section{TRAJETÓRIA E PERSPECTIVA EDUCACIONAL E POLÍTICO- CULTURAL: COMUNIDADE SURDA DO MUNICÍPIO DE JI- PARANÁ}

Até a presente página deste artigo buscou-se apresentar questões relacionadas à educação de surdos, à origem da Língua Brasileira de Sinais, aos movimentos culturais que se encontram referenciados teoricamente por pesquisadores surdos e ouvintes. Esta importante contribuição das pesquisas brasileiras sobre a surdez, em um sentido mais amplo, abre a oportunidade para analisar as realidades mais próximas, que neste caso, trata-se da comunidade surda do município de Ji-Paraná. Para isto, buscou-se conhecer inicialmente a trajetória educacional e assim traçar um paralelo, especialmente em relação às abordagens pedagógicas que vigoravam na época, contrastando com o tipo de educação que era ofertada em nível nacional.

A história inicial da educação de surdos ji-paranaenses não se diferencia muito do contexto de outras localidades da região Norte, especialmente de outros municípios do Estado de Rondônia. Geralmente contam com os esforços de pessoas surdas e ouvintes, engajadas em movimentos sociais e/ou educacionais, que "descobrem" as singularidades de uma pedagogia e língua visual e espacial, ou então são estimulados pelas políticas do Ministério da Educação e Cultura (MEC) e secretarias estaduais e municipais através de projetos de inclusão. 
Segundo a pesquisa, na última década do século $\mathrm{XX}$, os surdos que conseguiam estudar, encontravam-se matriculados nas escolas regulares e eram orientados a observarem a leitura labial para que acontecesse a aprendizagem. Os surdos que não conseguissem se enquadrar na proposta ouvintista, eram encaminhados para a Associação de Pais e Amigos dos Excepcionais (APAE) com a intenção de receberem ali algum atendimento que as escolas dos estudantes ouvintes ainda não estavam capacitadas a oferecer. Por este processo passaram a maioria dos estudantes com surdez, ou seja, pelo fato de o aluno não aprender como os ouvintes, eram considerados deficientes. Perlin e Strobel $(2009$, p. 10) pesquisadoras surdas relatam que:

No caso, o objetivo da pedagogia é direcionado a nós surdos e consiste em nos apresentar o homem ouvinte, falante, capaz de entender e incorporar todos os significados de uma língua oral. Nele se percebe que o objetivo é ensinar os surdos a serem ouvintes.

Em 1998, o MEC organizou um Programa de Especialização em Informática na Educação (Proinfo). O referido curso foi executado pela Unama/PA, na cidade de Belém, no período de 1998/1999 pela Universidade do Pará. A Prefeitura de Ji-ParanáRO encaminhou uma professora para participar, que posteriormente estaria incumbida de montar uma Equipe de Professores Multiplicadores responsáveis pela disseminação do Programa e capacitação dos professores das escolas contempladas com laboratórios de informática. A necessidade de envolver todos os educandos na aprendizagem e uso das ferramentas tecnológicas proporcionou aos surdos matriculados na rede regular de ensino, não somente o uso das novas tecnologias, mas também o encontro com outros estudantes surdos e a partir de então a fruição da língua de sinais. Assim surge a necessidade de comunicação, ocasionada pelo contato entre o professor e estudantes surdos, motivando 
assim, parcerias entre as secretarias municipal e estadual, núcleos de tecnologias e universidade, culminando com o desenvolvimento do projeto "O Surdo e o computador", nos anos de 2001 a 2005 estabelecendo assim o processo inclusivo.

Na sequência dos anos, as pessoas surdas foram se encontrando e formando assim a comunidade de Ji-Paraná. Inseridos nesta comunidade, vários profissionais da educação, ouvintes e simpatizantes da Libras deram suporte e desenvolveram a aprendizagem, inicialmente com os recursos tecnológicos em vídeos (DVDs) produzidos pelo Instituto Nacional de Educação e Integração dos Surdos (INES), Rio de Janeiro. Foi também neste instituto, responsável pela iniciação da educação de surdos e origem da Libras, já mencionado neste artigo, que alguns professores de Rondônia, e especialmente a professora iniciadora do processo educacional de estudantes surdos de ji-Paraná, realizaram cursos de estudos adicionais para professores na área da Deficiência Auditiva, com carga horária de $800 \mathrm{~h}$, objetivando compreender as necessidades específicas e a complexidade de aprendizagem da pessoa com surdez. Assim sendo, o ensino pautado no conhecimento das especificidades de uma pedagogia para as pessoas com surdez, foi responsável não somente pela inclusão do estudante surdo, mas também do surgimento e fortalecimento da comunidade surda, da aprendizagem da Língua Brasileira de Sinais e disseminação dessa língua.

Como o objetivo principal desta escrita está em destacar a importância da Libras para o desenvolvimento da identidade e cultura surda, temos argumentos suficientes para afirmar que o empoderamento da comunidade surda de Ji-Paraná foi resultado também da comunicação possibilitada pelo uso desta língua. Atualmente, encontram-se surdos nas universidades, como profissionais Instrutores de Libras que são responsáveis tanto na 
formação educacional e linguística de crianças surdas, como também pelas formações nos cursos de Libras oferecidos pelas secretarias de ensino à comunidade em geral. É importante ressaltar que a convivência grupal e a compreensão do mundo ao redor, desvendado pelos códigos linguísticos, despertaram nos membros desta comunidade o lado militante pelas causas surdas, simbolizado como um artefato político-cultural. Assim foi criada a associação de surdos, aqui denominada de Associação dos Surdos e Familiares de Ji-Paraná (Asfjipa) e pelas afirmações de Strobel (2015, p. 88-89):

Historicamente o povo surdo brasileiro transmitiu muitas tradições em suas organizações das comunidades surdas. $\mathrm{O}$ espaço cultural mais conhecido de todos são as associações de surdos. [...] Atualmente, um dos maiores objetivos das associações de surdos é a política.

É resultado de surdos politizados, organizados em associações, as crescentes reivindicações pelos direitos à acessibilidade linguística, seja cultural, social e/ou educacional. Entre vários documentos que asseguram às pessoas o direito à acessibilidade, destaca-se e requer uma maior observância, o que diz a Lei n. 13.146, de 6 de julho de 2015, em seu Art. 28, onde estabelece a incumbência do poder público em assegurar, criar, desenvolver, implementar, incentivar, acompanhar e avaliar; e para os estudantes surdos, segundo o Inciso XI, deverá haver formação e disponibilização de professores para o atendimento educacional especializado, de tradutores e intérpretes da Libras, de guias intérpretes e de profissionais de apoio. Em consonância com a Lei e outros documentos, a Secretaria Municipal de Educação de JiParaná-RO através da Gerência de Educação Especial, buscou alternativas para a implementação dessas políticas voltadas à educação de pessoas surdas, como, por exemplo, a elaboração e aprovação municipal do Projeto de Lei n. 2144 de 29 de abril de 
2011, criando a Gerência de Ensino de Alunos Surdos e a Coordenação de Ensino da Libras. Como resultado desse projeto foi possível desenvolver ações que possibilitaram o acesso, permanência e a aprendizagem de estudantes surdos. Passou-se a oferecer anualmente os cursos básico, intermediário e avançado de Libras para o atendimento dos professores e familiares de estudantes surdos da rede municipal de educação, tanto na sede da secretaria de educação, como nas escolas onde tem estudantes surdos matriculados. Outra ação foi o Atendimento Educacional Especializado, realizado semanalmente, para esses estudantes na escola em que estavam matriculados.

Em 2017, a Secretaria Municipal de Educação de Ji-Paraná, como forma de implementação das políticas educacionais de inclusão e educação de surdos, iniciou o Projeto Piloto no CMEIEF Ruth Rocha de Sala Bilíngue para o ensino dos estudantes surdos da rede municipal. O projeto destinou-se a atender, de forma coletiva, os estudantes surdos matriculados no Ensino Fundamental das áreas urbana e rural que recebiam o atendimento semanalmente, por um período de três horas, onde o ensino era realizado pelos instrutores surdos, com a orientação das professoras de Libras, visando a aquisição e aprimoramento da Língua de Sinais Brasileira, a troca de experiências e comunicação de estudantes surdos com seus pares.

O projeto surgiu da necessidade primária da oferta bilíngue e fundamenta-se entre outros documentos, nas Diretrizes Curriculares Nacionais da Educação Básica, como se lê:

No caso dos estudantes que apresentem necessidades diferenciadas de comunicação, o acesso aos conteúdos deve ser garantido mediante a utilização de linguagens e códigos aplicáveis, como o sistema Braille, a Língua Brasileira de Sinais (Libras), bem como a garantia 
da tecnologia assistiva, facultando-lhes e às suas famílias a opção pela abordagem pedagógica que julgarem adequada, ouvidos os profissionais especializados em cada caso, voltada à garantia da educação de qualidade (Brasil, 2013, p. 452).

As atividades realizadas nesses encontros proporcionaram muita interação e participação das crianças, que demonstravam prazer e entusiasmo nesse ambiente. As atividades realizadas eram caracterizadas como expressões e artefatos da cultura surda. Por se tratar de alunos dos primeiros anos do ensino fundamental, os gêneros textuais infantis, que estão disponíveis à cultura ouvinte, tais como: contação de histórias, dramatização, confecção de maquetes e brincadeiras envolvendo jogos pedagógicos eram adaptados para a Libras, valorizando muito a expressão facial e corporal, naturalmente desenvolvidas nas comunidades surdas. Este contato proporcionado pelo projeto de educação bilíngue, alcançavam tanto o desenvolvimento linguístico e cognitivo, como também a identificação com seus pares surdos e desenvolvimento da identidade surda, considerando que estes alunos vinham de famílias ouvintes e necessitavam de modelos culturais. Em virtude da dificuldade de locomoção das famílias em levar e buscar os estudantes até o local de ensino, em dezembro de 2018, o projeto foi encerrado.

No ano de 2017, a Prefeitura Municipal de Ji-Paraná realizou um concurso público para o cargo de pedagogos ouvintes e especialistas em Libras para assumirem suas funções, passando a serem mediadores na comunicação entre os estudantes surdos e demais pessoas ouvintes na comunidade escolar. Os professores da Libras são responsáveis por organizar em parceria com o professor de classe comum e o instrutor surdo, atividades e recursos didáticos que facilite a aprendizagem e a comunicação do estudante surdo, 
bem como o atendimento educacional especializado (AEE) no contraturno e ensino da Libras para os estudantes da turma regular em que os estudantes surdos estão matriculados.

Atualmente (2020), devido à pandemia do coronavírus, o atendimento aos estudantes surdos passou a ser realizado de forma remota, pelos professores do ensino regular, professores da Libras e com a colaboração dos instrutores surdos. As atividades são realizadas por meio de vídeos explicativos, grupos no WhatsApp e contam também com a entrega de atividades impressas.

Graças aos recursos das novas tecnologias foi possível continuar o trabalho educacional, levando os estudantes surdos a prosseguirem em seu processo de desenvolvimento num ambiente em que surdos e ouvintes aprendem a conviver e aceitar as diferenças, construindo, para além das aprendizagens escolares, um convívio harmonioso e respeitoso.

\section{CONSIDERAÇõES FINAIS}

Falar em cultura e educação de surdos abre muitas possibilidades de reflexão sobre como a escola e a sociedade têm reconhecido os direitos culturais e linguísticos das pessoas surdas. Neste artigo objetivamos apresentar uma pequena contribuição para identificar e compreender um pouco da história da educação dos surdos, referenciando sobre as abordagens educacionais, concepção de sujeito, comunidade e identidade que se identificam na Cultura Surda. Balizados pelas bibliografias consultadas, procurou-se observar uma realidade mais próxima. Através das experiências das coautoras educadoras, que há mais de décadas vêm desenvolvendo o trabalho na secretaria municipal e escolas de Ji-Paraná, foi possível identificar a trajetória inicial e chegar até a atualidade, destacando assim $\mathrm{o}$ processo inclusivo, o 
desenvolvimento da comunidade surda ji-paranaense, o crescimento e empoderamento a partir do reconhecimento da identidade surda e da Língua Brasileira de Sinais, tanto pela própria comunidade, quanto pelos órgãos públicos responsáveis pela educação e inclusão escolar.

Sobre o conceito de cultura debatido neste contexto, consideramos haver um embate entre as representações dos sujeitos surdos e ouvintes em relação à surdez, o vínculo entre os processos sociais, políticos e culturais, especialmente as representações políticas de aceitação das diferenças e do crescimento das comunidades surdas brasileiras. Reconhecemos as conquistas obtidas pelas comunidades surdas, que através de movimentos sociais obtiveram o reconhecimento da Língua Brasileira de Sinais, mas lamentamos a pouca socialização, considerando a língua de sinais ainda ser pouco utilizada pelos ouvintes no processo comunicativo com as pessoas surdas.

Assim, concluímos que o conhecimento sobre a cultura surda, o respeito à identidade surda e a fluência na Língua Brasileira de Sinais podem contribuir para que a sociedade seja menos excludente, portanto, convido você, leitor, a continuar com leituras relacionadas, e a buscar o contato com pessoas da comunidade surda. Dessa forma, estará permitindo uma maior interação e garantindo aos surdos, através da aprendizagem da Libras, o direito à comunicação.

\section{REFERÊNCIAS}

BOURDIEU, P.;PASSERON, J. A Reprodução: elementos para uma teoria do sistema de ensino. Rio de Janeiro: Francisco Alves, 1970.

BRASIL. Lei n. 13.146, de 6 de julho de 2015. Institui a Lei Brasileira de Inclusão da Pessoa com Deficiência (Estatuto da 
Pessoa com Deficiência). Disponível em: <www.planalto.gov.br/ CCIVIL_03/_Ato2015-2018/2015/Lei/L13146.htm> Acesso em: 2 dez. 2020.

. Constituição (1988). Constituição da República Federativa do Brasil. Brasília: Biblioteca Digital da Câmara dos Deputados, 2012. Disponível em: <http://bd.camara.gov.br/bd/handle/ bdcamara/15261> Acesso em: 3 out. 2020.

. Decreto 5.626 de 22 de dezembro de 2005. Regulamenta a Lei n. 10.436, de 24 de abril de 2002, que dispõe sobre a Língua Brasileira de Sinais - Libras, e o art. 18 da Lei n. 10.098, de 19 de dezembro de 2000. Disponível em: <www.planalto.gov.br /ccivil_03/_Ato2004-2006/2005/Decreto/D5626.htm>. Acesso em: 27 nov. 2020.

. Decreto n. 1.331-A de 17 de fevereiro de 1854. Aprova o Regulamento para a reforma do ensino primário e secundário do Município da Côrte. Coleção de Leis do Império do Brasil - 1854, Página 45 Vol. 1 pt I (Publicação Original). Disponível em: $<$ https://www2.camara.leg.br/legin/fed/decret/1824-1899/decre to-1331-a-17-fevereiro-1854-590146-norma-pe.html> Acesso em: 27 nov. 2020.

. Lei n. 13.146, de 6 de julho de 2015. Institui a Lei Brasileira de Inclusão da Pessoa com Deficiência (Estatuto da Pessoa com Deficiência). Disponível em: <www.planalto.gov.br/CCIVIL_03/_ Ato2015-2018/2015/Lei/L13146.htm> Acesso em: 2 dez. 2020.

. Lei n. 10.436, 24 de abril de 2002. Dispõe sobre a Língua Brasileira de Sinais - Libras e dá outras providências. Brasília. 2002. Disponível em: <www.planalto.gov.br $>$. Acesso em: 3 nov. 2020.

. Lei n. 9.394 de 20 de dezembro de 1996. Estabelece as diretrizes e bases da educação nacional. Disponível em: 
<www.planalto.gov.br/ccivil_03/LEIS/L9394.htm>. Acesso em: 27 nov. 2020.

Ministério da Educação. CNE/CEB. Diretrizes curriculares nacionais para a educação. Brasília, 2013.

CEVASCO, Maria Elisa. Dez lições sobre estudos culturais. São Paulo: Boitempo Editorial, 2003.

FERNANDES, Sueli de Fátima. Educação bilíngue para surdos: Identidades, Diferenças, Contradições e Mistérios, 2003. Tese (doutorado), Universidade Federal do Paraná. Curso de PósGraduação em Letras, Setor de Ciências Humanas, Letras e Artes. Curitiba, 2003.

FREIRE, Paulo. Pedagogia da autonomia: saberes necessários à prática educativa. 11. ed. São Paulo: Paz e Terra, 1996.

.Pedagogia do oprimido. 17. ed. Rio de Janeiro: Paz e Terra, 1987.

HALL, Stuart. A identidade cultural na pós-modernidade. 11. ed. Rio de Janeiro: DP\&A, 2006.

PERLIN, Gladis. Identidades Surdas. In: SKLIAR, C. (Org). A surdez: um olhar sobre as diferenças. Porto Alegre: Mediação, 1998.

PERLIN, Gladis; STROBEL, Karin. Teorias da educação e estudos surdos. Licenciatura e Bacharelado em Letras-Libras na Modalidade a Distância. UFSC: Florianópolis, 2009. Disponível em: $<$ www.libras.ufsc.br/colecaoLetrasLibras/eixoFormacaoEspecifica /teoriasDaEducacaoEEstudosSurdos/assets/257/TEXTOBaseTeo ria_da_Educacao_e_Estudos_Surdos_pronta.pdf > Acesso em: 14 out. 2020. 
PINTO, Fernanda Bouth. O Silencioso Despertar do Mundo Surdo Brasileiro. Revista de História e Estudos Culturais. Vol. 3. Ano III, n. 2. abril/maio/junho, 2006. Disponível em: <www.revistafenix. pro.br/PDF7/03\%20ARTIGO\%20FERNANDAPINTO.pdf $>$. Acesso em: $1^{\mathrm{O}}$ out. 2020.

QUADROS, Ronice Müller de. Educação de surdos: a aquisição da linguagem. Porto Alegre: Artmed, 1997.

SÁ, Nidia Regina Limeira de. Cultura, poder e educação de surdos. São Paulo: Paulinas, 2006.

SAVIANI, Dermeval. Vicissitudes e perspectivas do direito à educação no Brasil: abordagem em história e situação atual. Educ. Soc., Campinas, v. 34, n. 124, p. 743-760, jul.-set. 2013. Disponível em: <www.scielo.br/pdf/es/v34n124/06.pdf> Acesso em: 16 outubro de 2020.

. Educação: do senso comum à consciência filosófica. São Paulo: Cortez Editora: Autores Associados, 1986.

STROBEL, Karin. A imagem do outro sobre a cultura surda. 3. ed. rev. Florianópolis: Ed. da UFSC, 2015.

WRIGLEY, O. Política da surdez. Washington: Gallaudet University Press, 1996. 


\title{
A FORMAÇÃo DOCENTE: UMA PRÁTICA REFLEXIVA PARA A TRANSFORMACุ̃̃O ${ }^{23}$
}

\author{
Vera Mônica Queiroz Fernandes Aguiar ${ }^{24}$
}

\section{INTRODUÇÃo}

O presente artigo tem como escopo realizar uma análise sobre a formação do professor e a chamada prática reflexiva, refletindo acerca da respectiva transformação que envolve o processo de aprendizagem. A considerar que os docentes recémformados enfrentam uma realidade inóspita e complexa, espera-se destes profissionais - que estão iniciando na área da educação - um posicionamento ético e crítico em relação à realidade sócioeducacional, no entanto, nem sempre estes profissionais recebem uma formação adequada para lidar com este contexto caótico. Desta falha na formação docente resultam inúmeros problemas.

Os desafios do sistema educacional e a formação dos professores devem problematizar a própria formação docente, as práticas pedagógicas e as questões sociais, visto que estas refletem a possibilidade para a formação do indivíduo humano. Falamos aqui de uma formação que pense o homem de forma integral, ou seja, em seus aspectos: físicos, psíquicos, afetivos, culturais, econômicos, etc. As escolas brasileiras são um mosaico de situações, a formação docente deve priorizar uma reflexão acerca dos problemas inevitáveis que uma realidade plural como esta deve desencadear,

${ }^{23}$ Artigo para publicação e consecução de pontos obrigatórios referentes ao curso de doutorado em Educação, 2020. O artigo foi publicado na Revista Prática Jurídica, ano V, n. 55, 31 de outubro de 2006, p. 32-35.

${ }^{24}$ Doutoranda em Educação pela Universidade do Vale do Itajaí (Univali). 
incutindo no professor uma atitude de permanente crítica, pois o referido profissional não poderá se acomodar, mas sim buscar se aprimorar, mesmo sabendo que o início da carreira na docência nem sempre é privilegiada.

No início da carreira o docente poderá se deparar com demandas e necessidades peculiares, ressaltando que este momento pode ser vivenciado de forma mais fácil ou mais árdua, a depender da acolhida, do apoio ou do local em que passe a exercer a sua profissão. A falta de condições dignas para exercer a profissão e a ausência de disciplina, por parte dos discentes, podem levar o docente à solidão, à ansiedade, à insegurança e até mesmo ao medo. Trata-se das principais características e/ou dificuldades que marcam o início da carreira do docente. Destes inconvenientes resulta a postura de 'derrotado' por parte dos professores. Desamparados, abandonam o prazer por construir-se, por dar-se integralmente à profissão. Morre aí o espírito de formação permanente, o espírito crítico de transformação.

Daí a importância de uma formação profissional que defenda a permanente formação docente, efetivando a autonomia intelectual e moral, através de mecanismos, como: a prática de pesquisa, de produção de conhecimento, de reflexão conjunta, coletiva, fatores estes que podem, e devem lançar luz sobre a prática pedagógica, 'reformando' a educação de forma pacífica e profunda, e efetivando uma formação permanente, atenta às transformações.

A metodologia utilizada neste artigo foi uma pesquisa com método de abordagem dedutivo, através de uma revisão bibliográfica. O objetivo da pesquisa será explicativo e o ponto de vista qualitativo.

No diálogo com a empiria, este artigo se beneficia das contribuições de autores, a exemplo de: Nóvoa (2019), ao estudar 
que, na seara da formação inicial ou continuada do professor, o exercício da docência poderá se materializar com a proposta de remodelação da área que abarca a formação de professores. Barreto (1998), quando se reporta à atuação do professor, enfatiza que ser mais humano, comum a todos, se realiza pela educação. Moretto (2003), que passa a atribuir ao professor o ônus pela mediação do conhecimento, atinentes às substâncias de sua disciplina e ao campo de pesquisa. Perrenoud (1999), que ajuda a compreender que toda competência se encontra, de forma fundamental, atrelada a uma prática social complexa. Piaget (1986), ao tratar da inteligência, aduz que esta não germina num determinado momento do desenvolvimento mental humano.

\section{A FORMAÇÃo DOCENTE, A ESCOLA E AS RUPTURAS NECESSÁRIAS}

Para o sucesso do acadêmico, após a conclusão do curso, devem convergir inúmeras fontes, dentre elas a prática de um professor dotado de sabedoria intelectual, psicológica e espiritual, isto, claro, desde que a instituição prime pela qualificação de seu corpo docente. Se fôssemos nos reportar a uma escola moderna seriam necessários argumentos diversos para apresentar a instituição escolar como fator político e socioeconômico.

A partir da concepção de Nóvoa (2019, p. 3) depreende-se que

A escola assenta num contrato social e político que lhe atribui a responsabilidade pela formação integral das crianças e num modelo organizacional bem estabelecido. No início do século XXI começou a tornar-se claro que este contrato e este modelo precisam de ser profundamente repensados. Já não se trata de melhorias ou de aperfeiçoamentos ou mesmo de inovações, mas de uma 
verdadeira metamorfose da escola. Fazer esta afirmação é, também, reconhecer as mudanças que, inevitavelmente, atingem os professores e a sua formação.

Neste sentido, o autor faz abordagem à questão de transformação da escola e o seu indisfarçável vínculo com o papel importantíssimo da formação de docentes e o seu respectivo desempenho no processo de ensino-aprendizagem. Nóvoa (2019, p. 6) enfatiza que acredita que "compromisso público com a educação e metamorfose da escola, partem também de um diagnóstico crítico, mas para reforçar e valorizar as dimensões profissionais" [...].

Vê-se que o autor salienta que, no âmbito da formação inicial ou continuada, o exercício da docência se dá pelo trabalho coletivo com os demais colegas da profissão, que poderá se consolidar, segundo o autor, com a sua proposta de renovação da área que envolve a formação de professores.

Nóvoa (2019) pesquisou e descobriu os indicadores de inovação que mais se sobressaíram, tais como: a ruptura com costumes tradicionais de ensinar e aprender, a possibilidade de realizar rupturas com dualidades entre a teoria e a prática, a restauração de valores como respeito, autoestima, alteridade e a mediação docente, direcionadas a aprendizagens significativas.

É preciso que haja também vocação para atuar como professor. A despeito disso, Barreto (1998, p. 54) analisa que "ser mais, isto é, ser mais humano, comum a todos homens e mulheres, se realiza pela Educação. Mas esta vocação de ser mais deixa de concretizar-se quando as relações entre os homens se desumanizam”, sabendo-se que nos comportamentos deve existir ética, compreensão e responsabilidade para desempenhar as funções no trabalho. 
Segundo Barreto (1998, p. 55), “a consciência de ser inacabado dá às pessoas a possibilidade de irem além delas” e esta é uma das marcas dos seres humanos. Esta visão permite engrandecer a produção do conhecimento, ideia defendida por Moretto (2003), que atribui ao professor a responsabilidade pela mediação do conhecimento, concernentes aos conteúdos de sua disciplina e do campo de pesquisa.

Barreto (1998), ao fazer citações às ideais de Freire, destaca que a ação da pessoa humana sobre o mundo muda também os sujeitos envolvidos no processo de desenvolvimento profissional. $\mathrm{Na}$ construção do mundo, as pessoas se completam e se humanizam. A autora lembra que o ato de infinitude do ser humano ou a sua inconclusão é peculiar da experiência vital, em que há inacabamento.

A autora ainda faz a abordagem sobre a transcendência do ser humano em que destaca a raiz da finitude do homem, que possui a consciência de que a vida é finita. Para ela, "do ser inacabado que é e cuja plenitude se acha na ligação com seu Criador, cuja ligação que, pela própria essência, jamais será de dominação ou de domesticação, mas sempre de libertação".

A autora - referindo-se a Freire, que faz alusão ao poder da vida - enfatiza: "é exatamente a vida que, aguçando nossa curiosidade, nos leva ao conhecimento; é o direito de todos à vida que nos faz solidários; é a opção pela vida que nos torna éticos." (Barreto, 2019, p. 11).

Com isso, compreende-se que o papel da Instituição de Ensino Superior (IES), que pretende se estruturar como modelo social e educacional, deve seguir os ditames da Carta Magna, em seu art. $3^{\circ}$, incs. II e IV, ao afirmar que constitui-se, respectivamente, como um dos objetivos fundamentais da República Federativa do 
Brasil a garantia do desenvolvimento nacional e o alcance do bem de todos, sem convencionalismos de origem, raça, sexo, cor, idade e quaisquer outras formas de discriminação.

Ademais, deve-se trazer à discussão o texto do art. 205 da Constituição Federal in verbis:

Art. 205. A educação, direito de todos, é dever do Estado e da família, será solicitada e incentivada com a colaboração da sociedade, visando ao pleno desenvolvimento da pessoa, seu preparo para o exercício da cidadania e sua qualificação para o trabalho.

Denota-se que a Carta Magna do Brasil assegura que a educação trata-se de dever do Estado e da família, devendo ser estabelecida com o incentivo da sociedade, culminando no desenvolvimento pleno do cidadão, incluindo o seu preparo à cidadania e preparação para o mundo do trabalho.

A formação oferecida pela instituição, ao seu corpo docente, deve atender às exigências das normas e legislação inerentes à educação, auxiliando o profissional a se qualificar. Em razão disso, o acadêmico receberá informações que permitam a construção do seu próprio conhecimento, enaltecendo a instituição de ensino e contribuindo para o sucesso mútuo.

\section{DESAFIOS DO SISTEMA EDUCACIONAL}

Antes de tudo, dedicação e conhecimento não são suficientes para promover o sucesso do aluno, da instituição educacional e do seu próprio profissional: o professor precisa ser dotado de espírito de sabedoria, o qual lhe permitirá discernir, compreender e acolher aqueles que estão em busca da construção do saber, envolvendo objetivos comuns inerentes ao grupo. 
Para Morin (2003, p. 118), “o processo de conhecer não é mero reflexo das coisas ou do mundo externo, pois todas as percepções são, ao mesmo tempo, traduções e reconstruções cerebrais com base em estímulos ou sinais captados e codificados pelos sentidos". No primeiro saber, a educação deve enfrentar o problema inerente ao conhecimento, que é o risco do erro e da ilusão. Para tanto, é imprescindível fazer conhecer o que é conhecer, que significa estudar as características psíquicas e culturais que constituem o conhecimento da pessoa humana.

Quando se expressa a ideia de formação do homem, como pessoa de sua pessoa única, responsável, autêntica e sujeito da sua própria história, compreende-se que deve haver um equilíbrio entre o pensar, o sentir e o agir. Este deveria ser o perfil do educador dos dias atuais. Seu compromisso com o crescimento profissional e pessoal reflete no desempenho de outras pessoas que têm atitudes de participação, de fraternidade, de justiça, de igualdade e solidariedade.

Além disso, não podemos esquecer que os desafios propostos pelo sistema educacional ao professor são inúmeros e ocorrem de forma constante. A cada dia, dentro ou fora da sala de aula, essa função torna-se relevante e necessária, não somente para o sistema, mas, também para seus alunos, isso compõe outras veredas a serem trilhadas, acoplando teoria e prática.

Em virtude das novas tendências referentes ao sistema educacional e do mercado de trabalho, exige-se habilidade, competência, responsabilidade, compromisso, por parte dos profissionais, assim como a dignidade humana de forma recíproca. É preciso que o professor esteja sintonizado com o tempo para que realize um trabalho qualificado, construindo uma disciplina pessoal que o ajude a crescer como ser humano, operacionalizando o amor 
no convívio diário, dispondo de tempo para estudar e cuidar da sua competência profissional.

Vivemos em uma época de mudanças rápidas e o nosso desempenho precisa acompanhar a evolução ou corremos risco de fossilização precoce das nossas ideias e da nossa prática. É importante salientar que para acontecer o sucesso da instituição e de seus acadêmicos, precisamos ser facilitadores da mudança significativa em nossas maneiras de atuar competências para efetivarmos uma educação de qualidade, resultando na formação de um profissional capacitado para o mercado de trabalho.

Perrenoud (1999, p. 37), a respeito da competência, preleciona que:

Toda competência está, fundamentalmente, ligada a uma prática social de certa complexidade. Não a um gesto dado, mas sim a um conjunto de gestos, posturas e palavras, inscritos na prática que lhes confere sentido e continuidade. Uma competência não remete, necessariamente, a uma prática profissional, e exige ainda menos que quem a ela se dedique seja um profissional completo.

\section{REFERÊNCIAS PARA A FORMAÇÃO DO PROFESSOR E A SUA PRÁTICA}

Para toda e qualquer atividade formativa é indispensável à presença de diretrizes que estabeleçam compromissos e relações teleológicas (que tendam a um objetivo específico). Tais compromissos, no caso da educação, devem ainda carregar em si os porquês das relações e os porquês dos objetivos a serem alcançados.

Para isso, faz-se necessário uma análise da realidade concreta em que se inserem os atores que participarão, direta ou 
indiretamente, deste processo. É neste ponto que se estabelecem os Parâmetros, e é neste sentido que os Parâmetros Curriculares Nacionais (2002, p. 33) ressaltam, entre outras coisas:

A importância da participação da sociedade no cotidiano escolar, como forma de promover o exercício da cidadania; a necessidade de articulação e integração entre o MEC, Secretarias Estaduais e Municipais de Educação e escolas; o sentido e o significado da aprendizagem, estimulando nos alunos o compromisso e a responsabilidade; a importância da apropriação de conhecimentos elaborados como base para a construção da cidadania; a importância da elaboração do projeto educativo da escola; a importância da ampliação da visão de conteúdo para além dos conceitos, inserindo procedimentos, atitudes e valores.

Vê-se que os PCNs se preocuparam em abordar assuntos sociais primordiais, tais como: Ética e Convívio Social, Meio Ambiente, Pluralidade Cultural, Saúde, Sexualidade, Consumo e Trabalho, que não se enquadravam nas disciplinas habituais ou que extrapolassem os seus limites; a valorização do trabalho do professor, ressaltando o valor de sua atuação, a considerar a diversidade existente entre os alunos e seus conhecimentos anteriores; o fortalecimento da escola, como fonte de aprendizagem e de convívio na sociedade, embasado no diálogo, no respeito recíproco, na solidariedade, desencadeando a aprendizagem dos conteúdos característicos, imperiosos ao desenvolvimento e à inclusão dos discentes no mundo complexo que lhes foi ofertado para viver.

De forma específica, os profissionais que atuam no ensino superior devem nortear os caminhos do estudante durante sua formação nestas direções, o que deverá ser prolongado após a conclusão do curso. Observa-se que muitos profissionais, ao 
ingressarem no mercado de trabalho, estão desprovidos de tais conhecimentos e por isto fazem um julgamento equivocado, por não terem a teoria que respalde a prática no desempenho de suas atribuições. Com isso, deparamo-nos com pessoas heterônomas que, conforme Kamii (1991), são aquelas que vivem a ser governadas por outrem.

Percebe-se que muitos alunos, ao saírem da faculdade, não estão aptos a lidar com os diversos aspectos da vida em sociedade. A diretora irmã Maria Terezinha Almeida afirma, em sua dissertação Educar pela transversalidade do conhecimento (1998), quanto à heteronomia cega, nos ensina

que induz ao servilismo, a autonomia incondicional acarreta à soberba. Aspira-se sob a luz do Espírito Santo, fonte de toda sabedoria humana, alistar-se as persuasões de ordem pessoal com o que o mundo exterior tem a nos pronunciar e, dessa forma, aproximar-se da "ontonomia", ou seja, da lei que nasce do ser. Posto que o ser humano é insuficiente para ser ele mesmo. O homem, por sua índole, é um ser em analogia, melhor explicando, consigo mesmo, com o seu próximo, com o cosmo e com Deus.

O vínculo do professor com os saberes não se especifica a um ofício de transmissão de conhecimentos; na sua prática é necessário um conjunto de múltiplos saberes e de diferentes relações. Por isso, são imprescindíveis as assertivas do outro diante dos saberes docentes, quer dizer, o que sustenta o professor é [...] "sua capacidade de dominar, integrar e mobilizar tais saberes enquanto condições para a sua prática" segundo analisa (Tardif, 2007, p. 39).

Na concepção de Tardif (2007), o saber profissional do professor reside em uma amálgama de diferentes saberes, originados de diversas fontes, em que o ato de formar apoia-se em 
uma dinâmica, no qual, sua resultante é a proposição de experiências no docente.

Portanto, as práticas educativas constituem um campo complexo de atuação, cabendo ao professor ter um conhecimento necessário acerca de como se constroem as autonomias moral e intelectual.

Nem todo autônomo intelectual é detentor de autonomia moral. Considerando esses dois aspectos da autonomia, pode-se dizer que o profissional, ao desempenhar suas atividades com autonomia, é capaz de conscientizar o aluno a construir sua própria condição de ser autônomo. A autonomia moral considera o respeito recíproco e, no que se refere ao professor, tolerância e afetividade. Neste ponto, Kamii (1991) enfatiza que a formação docente deve estar pautada numa visão crítico-reflexiva para atingir a autonomia, participando de forma consistente no grupo social do qual faz parte.

Nóvoa (2019, p. 10), corroborando do mesmo pensamento de Kamii (1991), aduz que:

Esta possibilidade é ainda mais urgente hoje do que no passado. Ninguém se integra numa profissão sozinho, isoladamente. Ninguém constrói novas práticas pedagógicas sem se apoiar numa reflexão com os colegas. Ninguém, sozinho, domina completamente a profissão, como tantas vezes nos tem alertado Sérgio Niza (2012). Precisamos dos outros para nos tornarmos professores.

Depreende-se da fala de Nóvoa que a formação dos professores não se edifica por ajuntamentos de cursos, sejam de conhecimento ou de técnicas, contudo por meio de um trabalho de reflexão coletiva, e também envolvendo críticas sobre as práticas, possibilitando uma reconstrução que deve ser contínua, investindo 
sempre no educador que está em busca de experiências positivas e crescentes.

Com relação à autônoma intelectual, está deveria ser inerente à prática do professor, pois é por meio dela que ele pode ser facilitador e multiplicador, respectivamente, da construção do conhecimento, sendo que para isto haja uma mediação na formação da personalidade dos alunos e alunas.

É importante assinalar que o professor deve manter, no dia a dia, sua criatividade e espírito inovador, canalizando informações pertinentes aos valores humanos. A sua atitude frente a uma sala de aula deverá sempre ser pautada na calma e no equilíbrio, caso contrário, passará aos seus alunos, que poderão afetar o pleno desenvolvimento da formação intelectual dos mesmos. Se autonomia intelectual possui o sentido de autogoverno, a pessoa que a possui será convicta de suas próprias conclusões acerca de fatos que acredita serem passiveis de credibilidade.

Segundo Piaget (1986, p. 23), a inteligência não brota, de forma alguma, numa determinada ocasião do desenvolvimento mental do homem, como um mecanismo inteiramente preparado e radicalmente diverso dos que o antecederam. Proporciona, diversamente, uma enorme continuidade com os processos alcançados ou até mesmo inatos concernentes à agregação habitual e ao reflexo, processos estes sobre os quais ela vem se nortear, ao mesmo tempo em que passa a adotá-los.

Partindo desses pressupostos, é possível entender o contexto que deve ser preconizado pelo professor - mesmo para acadêmicos - visto que a aquisição de conhecimento se distingue da sua construção, tornando necessária a criação de um espaço propício onde o aprendiz possa interagir, questionando, recriando, 
estabelecendo relações de aprendizagem e, futuramente, efetivar a produção do conhecimento obtido.

O diálogo com a teoria que defende a autonomia do ser humano não implica em inventar um método ou desprezar outro, mas a autonomia como finalidade de educação implica uma nova conceituação de objetivos, os quais devem ser traçados pelo professor que deseja o sucesso dentro da sala de aula ou no convívio social fora dela. Com isso, devem surgir respostas produzidas autonomamente para os questionamentos, por convicção pessoal e não porque são previamente elaboradas.

Os Parâmetros Curriculares Nacionais (PCN, 2002, p. 43) ressaltam ainda que os profissionais da educação, e de demais áreas da sociedade, têm posto em debate o ponto de vista da educação, o papel da escola, a relação entre o conhecimento escolar e a vida sociocultural e, consequentemente, o trabalho do professor. Da mesma forma que se sugere uma nova educação escolar, um novo papel para o professor está sendo idealizado, a contar de novas práticas pedagógicas, do desempenho da categoria e da demanda em nossa sociedade.

Russini et al. (2018) argumenta acerca do fator que singulariza o professor em meio a esse contexto, utilizando-se de alguns dados reveladores que expõem, entre outras coisas, que do alto número de "funções docentes", $85 \%$ são exercidas em escolas públicas e apenas $15 \%$ em estabelecimentos privados. Baseado nestes dados e na análise dos PCN, conclui que:

Uma proposta de formação docente à luz dos PCN busca uma formação pautada em uma participação ativa que promova, principalmente, a reflexão, valorizando as trajetórias formativas individuais e permitindo, dentro do ambiente escolar, a oportunidade do diálogo e a produção do conhecimento. Desta forma, a proposta de formação 
busca superar modelos formativos descontextualizados à realidade do ambiente escolar e, principalmente, permitir, aos docentes, aperfeiçoamento coerente com os pressupostos humanísticos necessários ao contexto educacional atual (Russini et al., 2018, p. 175).

Também nos PCN (2002, p. 98), constam ideias quanto ao desenvolvimento de capacidades, tais quais: de relação interpessoal, as cognitivas, as afetivas, as éticas, estéticas de inserção social, torna-se possível mediante o processo de construção de conhecimentos.

Confirmando a necessidade de um desenvolvimento integral, conforme indicado nos PCN, Wadsworth (1997, p. 23), ao tratar do desenvolvimento intelectual, aduz que:

$\mathrm{O}$ aspecto afetivo tem uma profunda influência sobre o desenvolvimento intelectual. Ele pode acelerar ou diminuir o ritmo de desenvolvimento. Ele pode determinar sobre que conteúdos a atividade intelectual se concentrará.

Nesse sentido, precisamos de acadêmicos que estejam ativos, que aprendam desde cedo a trabalhar-se de forma integral, desenvolvendo potencialidades e construindo novas possibilidades de atuação, além de descobrir novos caminhos a fim de atuarem nos diversos campos de trabalho, efetivando profissionalmente esta gama de descobertas. O professor, na sua prática pedagógica, lança mão de vários instrumentos para a organização do pensamento do aprendiz. Além da sua autonomia e sua vocação, é necessário que haja a construção de suas competências e habilidades para sua realização profissional.

Perrenoud (1999, p. 15) ensina que: 
Aceitar uma abordagem por competências é, portanto, uma questão ao mesmo tempo de continuidade - pois a escola jamais pretendeu querer outra coisa - e de mudança, de ruptura até, pois as rotinas pedagógicas e didáticas, as compartimentações disciplinares, a segmentação do currículo, o peso da avaliação e da seleção, as imposições da organização escolar, a necessidade de tornar rotineiros o ofício de professor e o ofício de aluno têm levado a pedagogias e didáticas que, às vezes, não contribuem muito para construir competências, mas apenas para obter aprovação em exames...

Uma boa situação para o aprendizado acontece quando o educador tem visão de que o aprendiz é o sujeito que reconstrói seu próprio conhecimento, proporcionado, aos acadêmicos, situações desafiadoras, ou seja, as mais difíceis possíveis.

Quando o professor se dispõe a orientar seus alunos a executarem métodos científicos, estes tornam-se capazes de construir, por meio de seus próprios esforços, ideias inovadoras, respaldadas em teorias. A grande alavanca capaz de impulsionar o educador é a consciência de estar trabalhando para formar o ser humano pleno, solidário, contribuindo para elevar o patamar cultural e a politização da humanidade. Há necessidade de envolvimento dos professores em questões de práticas pedagógicas com profundidade, em estudos e pesquisas relacionados à escola, ao currículo, à inovação, ao ensino, à aprendizagem e a sua formação, e com isso conquistar autonomia na sua atividade docente.

Se os professores permanecerem à espera de esclarecimentos e diretrizes dos especialistas para saber o que fazer na sua ação docente, não vão ocorrer transformações tão necessárias para alcançar a edificação de seu ofício docente e, em consequência, o grau e o tempo hábil de autonomia, 
principalmente, em relação ao Estado, será cada vez menor (Contreras, 2002; Santos, 2013).

A formação científica deveria ser incentivada, da educação infantil ao ensino superior, não importa se atuamos no ensino básico ou no curso superior, somos profissionais, somos educadores, precisamos proporcionar aos alunos oportunidade para a construção de novos saberes.

Barreto (1988, p. 61), fazendo alusão ao pensamento de Paulo Freire, enfatiza que:

Assim sendo, “o papel do educador não é propriamente falar ao educando, sobre sua visão de mundo ou lhe impor esta visão, mas dialogar com ele sobre a sua visão e a dele. Sua tarefa não é falar, dissertar, mas problematizar a realidade concreta do educando, problematizando-se ao mesmo tempo".

Nessa perspectiva, faz-se necessário olhar, também, para o outro lado, observar e refletir o fato de que existem vários fatores que interferem, de forma negativa, na vida profissional, tais como: jornada excessiva de trabalho, baixa remuneração, condições precárias de estabelecimentos e outros. No entanto, apesar desses obstáculos, o professor deve estar consciente da importância de sua atuação como agente que busca formar cidadãos capazes de interferir criticamente na realidade, contemplando o desenvolvimento de capacidades que possibilitem adaptações às complexas condições e alternativas de trabalho.

Dessa forma, os professores exercem papel crucial no processo, pois, mesmo sendo precárias as condições para o professor desempenhar uma função mais determinante na criação e desenvolvimento das políticas públicas educacionais, existem 
meios capazes de avançar e transformar a realidade com o apoio da escola e da sociedade.

Os novos caminhos da educação apontam para a busca de formação de um novo profissional e de um novo cidadão. E na orientação de um novo profissional e de um cidadão renovado, a própria escola abre espaços para mudanças, para uma metamorfose, que refletirá diretamente no espaço da sala de aula.

É preciso que tanto a instituição como os educadores, individual e coletivamente, tenham clareza quanto ao papel da instituição, apropriando-se do conhecimento e organizando trabalho pedagógico, sendo que para tanto, é fundamental que se sensibilizem com as especificidades, as potencialidades, os saberes, os limites, as possibilidades dos educandos com os desafios de uma formação voltada para a cidadania, a autonomia e a liberdade responsável de aprender a aprender de maneira positiva.

\section{LEI DAS DIRETRIZES E BASES DA EDUCAÇÃO NACIONAL}

A Lei n. 9.394, de 20 de dezembro de 1996, que estabelece as diretrizes e bases da educação nacional, preconiza no caput do seu art. $1^{\circ}$, que a educação engloba os processos formativos, os quais se desenvolvem na vida familiar, na convivência humana, nas instituições de ensino e pesquisa, nos movimentos sociais e organizações da sociedade civil e nas manifestações culturais.

Nos $\S \S 1^{\circ}$ e $2^{\circ}$ do art. $1^{\circ}$, a Lei das Diretrizes e Bases da Educação Brasileira disciplina a educação escolar, que se desenvolve, de forma precípua, por intermédio do ensino, em instituições próprias, devendo a educação escolar vincular-se ao mundo do trabalho e à prática social. 
Em comentário aos arts. 65 e 66 da aludida Lei, o professor Moaci Alves Carneiro (2000) aborda, de forma enfática, que, para a formação do professor, há a necessidade da junção criativa de teoria e prática, e sendo o professor um indivíduo, é um ser particular, acumulando uma vivência que o marca como sujeito social, por conseguinte, exigem-se para o desempenho das suas funções profissionais qualificados, principalmente porque no ensino universitário lida-se com ciência e consciência social.

\section{CONSIDERAÇõES FINAIS}

Considerando o campo da construção do conhecimento um vasto e fecundo ambiente que se apresenta como uma das principais molas propulsoras do progresso sociocultural, e percebo este campo como um ambiente de trocas de conhecimento e de relações éticas, entende-se que o professor é um agente importante neste processo.

Presumimos que o ato de refletir sobre a atuação docente aponta possibilidades de construir novas práticas quanto à formação e exercício profissional do docente, mesmo compreendendo que a reflexão pode ser um esforço incalculável por parte do professor, embora a prática se torne ferramenta essencial no processo de atuação e convívio no ambiente escolar. Além disso, o vínculo do professor com os saberes não se especifica a um ofício de transmissão de conhecimentos; na sua prática é necessário um conjunto de múltiplos saberes e de diferentes relações. Por isso, são imprescindíveis as diversas áreas de conhecimento para uma real e efetiva prática docente, visto que o professor é constantemente chamado a atualizar-se e repaginar seus conhecimentos, acompanhando as transformações que ocorrem nos diversos setores da educação. 
A partir da discussão de ideias pertinentes à formação do professor, logo implica compreender que um resultado satisfatório, no que diz a respeito à qualidade de aprendizagem do educando, bem como no sucesso da instituição que oferece o ensino, só é possível através de uma análise reflexiva do professor pelo professor. Portanto, para resultados, precisa-se de atuações vinculadas às novas competências por parte do professor, sejam elas quais forem: formação continuada, atualização de currículo, pesquisa, etc.

Além disso, na resolução de conflitos, a análise dos fatos relacionados à docência também é indispensável, utilizando-se do conhecimento das teorias e suas práticas que direcionam e sistematizam o exercício da profissão de professor. Ante este contexto, visibiliza-se que o conhecimento dos desafios da atuação do professor no processo ensino-aprendizagem pode contribuir para reflexões e discussões acerca do tema, oferecendo para a escola e para o poder público subsídios para entender e orientar a melhor forma para alcançar os resultados a que todos almejam.

Portanto, os processos de formação docente, pautados na busca da autonomia, na valorização das experiências profissionais, a fim de produzir conhecimento e com perspectivas à inclusão de estudantes em novo paradigma educacional, são necessários e indispensáveis no cenário educacional atual.

Em virtude de tantas mudanças ocorridas com o desenvolvimento das ciências da educação durante o século XX, os instrumentos de atuação profissional já não são os mesmos, e tampouco são suficientes. É nesse contexto que a atuação do professor está inclusa, trazendo à tona discussões acerca de tomadas de decisões frente aos conflitos éticos, profissionais e de saúde decorrentes do exercício da profissão, visto que a própria 
importância do profissional de educação já não é mais considerada, acarretando desestímulo e descrédito pelo seu trabalho.

Por isso faz-se necessário, e indispensável, um novo cenário educacional, que priorize os processos de formação docente, direcionado os profissionais da educação aos trilhos da autonomia, pautando a reflexão na valorização das experiências profissionais, no desenvolvimento de práticas pedagógicas transformadoras, na produção de conhecimento sob perspectivas inovadoras, com a participação dos estudantes e da sociedade, em um novo paradigma para o vasto campo da educação.

Portanto, a reflexão acerca da formação docente é imprescindível, visto que esse tema tem uma natureza multirreferencial. Isso significa que, havendo investimento nos profissionais, havendo uma reflexão crítica por parte deste profissional acerca de sua profissão, havendo formação continuada, havendo uma metamorfose na escola e havendo participação da sociedade neste processo, perfaz-se um caminho, o qual poderá ser escolhido como novo parâmetro para que haja um desempenho efetivo do educador, a posteriori.

\section{REFERÊNCIAS}

ALMEIDA, Ir. Maria Terezinha. Educar pela transversalidade do conhecimento: relato de uma experiência de 20 anos. Dissertação (Mestrado em Educação) - Universidade Mackenzie, São Paulo, 1998.

BARRETO, Vera. Paulo Freire para educadores. São Paulo: Arte $\&$ Ciência, 1998. 
BRASIL, Ministério da Educação. Ensino fundamental de nove anos de anos: orientações para a inclusão da criança de seis anos de idade, Brasília, FNDE, Estação Gráfica, 2006.

- Constituição da República Federativa do Brasil.

Disponível em: <www.planalto.gov.br/ccivil_03/constituicao/ constituicao.htm > Acesso: 28 nov. 2020.

Brasil. Ministério da Educação. Secretaria de Educação Fundamental. Políticas de Melhoria da Qualidade da Educação. Um Balanço Institucional. Brasília. MEC/SEF, 2002.

. Parâmetros curriculares nacionais. Introdução. Brasília, MEC/SEF, 2001.

. Terceiro e quarto ciclos do ensino fundamental. Temas Transversais, Secretaria de Educação fundamental, Brasília, MEC/SEF, 2001.

CARNEIRO, Moaci Alves. LDB fácil - leitura crítico-compreensiva artigo a artigo. Petrópolis, Vozes, 2000.

CONTRERAS, J. Autonomia docente. Tradução de Sandra Trabucco Valenzuela. São Paulo: Cortez, 2002.

KAMII, Constance. A criança $\mathbf{e}$ o número: implicações educacionais da teoria de Piaget para atuação junto a escolas de 4 a 6 anos. 1991. Tradução: Regina A. de Assim, 11. ed. Campinas, São Paulo. Papirus, 1990.

MORETTO, Vasco Pedro. Construtivismo: a produção do conhecimento em aula. Rio de Janeiro, DP\&A, 2003.

MORIN, Edgar. Os sete saberes necessários à educação do futuro. Tradução de Catarina Eleonora F. da Silva e Jeanne Sawaya; revisão 
técnica de Edgard de Assis Carvalho. 8. ed. São Paulo: Cortez, Brasília, DF: Unesco. 2003.

NÓVOA, Antônio. Os professores e a sua formação num tempo de metamorfose da escola. Educação \& Realidade, Porto Alegre, v. 44, n. 3, e84910, 2019. Disponível em: $<$ http://dx.doi.org/10.1590/2175-623684910>. Acesso: 28 nov. 2020.

PERRENOUD, Philippe. Construir as competências desde a escola. Trad. Bruno Charles Magne. Porto Alegre. Editora Artmed, 1999.

RUSSINI, Augusto; HARTMANN, Emerson; CARLAN, Rodrigo Braz; SANTOS, Eliane Aparecida Galvão dos. A formação docente: os parâmetros curriculares nacionais para a área de ciências humanas e suas tecnologias. Artigo. Disponível em: <www. cmsm.eb.mil.br/images/revista_schola_2018/.pdf >Acesso: 28 de nov. 2020.

SANTOS. E.G. A dinâmica de ações extensionistas na formação continuada de professores municipais de Santa Maria/RS: a tessitura de processos formativos. Tese de doutorado. Universidade Federal de Santa Maria. Programa de Pós-Graduação em Educação, 2013.

WADSWORTH, Barry J. Inteligência e afetividade da criança na teoria de Piaget: Fundamentos do Construtivismo. 5. ed. São Paulo: Pioneira, 2000. 
A VIRADA LINGUíSTICA E AS CONCEPÇõES DE LÍNGUA E LINGUAGEM NUMA PERSPECTIVA FILOSÓFICA: CONTRIBUIÇÕES PARA OS ESTUDOS DA FILOSOFIA DA LINGUAGEM $^{25}$

\author{
Adriana Fernandes ${ }^{26}$ \\ Rita Nocetti ${ }^{27}$ \\ Selena Castiel ${ }^{28}$
}

\title{
INTRODUÇÃO
}

Ao longo dos séculos, a linguagem humana exerceu e exerce um papel primordial no pensamento e o estudo das línguas passou a ser objeto de investigação nas mais variadas áreas de interesse: no âmbito sagrado, que motivou o estudo do sânscrito ${ }^{29}$, na Índia, cuja

${ }^{25}$ Artigo produzido para a disciplina de Estudos Avançados em Epistemologia, ministrada pela Profa. Dra. Regina Célia Linhares Hostins, do Programa de PósGraduação Stricto Sensu Doutorado Interinstitucional em Educação (Dinter Univali/FCR).

${ }^{26}$ Doutoranda em Educação do Programa de Pós-graduação da Univali/FCR. Docente do Ensino Superior da Faculdade Católica de Rondônia (FCR-RO). Email: adriana.fernandes@fcr.edu.br

${ }^{27}$ Doutoranda em Educação do Programa de Pós-graduação da Univali/FCR. Docente do Ensino Superior da Faculdade Católica de Rondônia (FCR-RO). Email: ritanocetti@gmail.com

${ }^{28}$ Doutoranda em Educação do Programa de Pós-graduação da Univali/FCR. Docente do Ensino Superior da Faculdade Católica de Rondônia (FCR-RO). Email: selena.castiel@fcr.edu.br

${ }^{29}$ As primeiras manifestações de interesse pelo sânscrito no Brasil datam da década de 50 a 60, quando o grande romanista Professor Theodoro Henrique Maurer Júnior, em suas aulas de Glotologia Clássica na Faculdade de Letras da Universidade de São Paulo, utilizava-se de elementos da gramática sânscrita para comparações com o grego e o latim, na tentativa de reconstrução do indoeuropeu. 
história tem cerca de cinco mil anos e é sobremaneira interessante no desenvolvimento da cultura indiana; na Grécia de Platão (429347 a.C.) e Aristóteles (384-322 a.C.) $)^{30}$, onde especulava-se a origem dos nomes; já, no pós-renascimento, há um interesse voltado para a pesquisa filológica, cujo surgimento, segundo Bueno (1954), "remonta à escola de Alexandria, aos textos de Homero". Um ponto importante a ser destacado sobre a Filologia é que tal ciência foi criada pelos gregos na época helenística (séculos III e II a.C.), com o intuito de recuperar o formato dos textos da mitologia e da religião helena, que, deixados na tradição oral, estavam caindo no esquecimento. Tal ciência da linguagem procura fazer um estudo comparado das línguas indo-europeias, e seu grande mérito foi abrir um campo vasto e fecundo na história das línguas.

Na época moderna, precisamente por volta do século XIX, a história da constituição da ciência da linguagem teve um importante marco, o estudo das gramáticas comparadas. Esta perspectiva, que surge da ruptura do modelo gramatical do século XVII, conhecida como Gramática Geral (conhecida por Gramática de Port Royal), descentraliza o pensamento de um ideal universal e abre um extraordinário campo de pesquisas nos estudos linguísticos.

30Platão, no seu diálogo Crátilo, considera que a linguagem pode ser um medicamento ou até um remédio para o conhecimento, porque através dela podemos estabelecer diálogo, discursos e pela comunicação, conseguimos descobrir a nossa sabedoria e a ignorância de aprender dos outros e perguntavase se as palavras significariam intrinsecamente alguma coisa ou se seriam apenas símbolos convencionais. Aristóteles, por sua vez, em suas obras Categorias e $D a$ interpretação, postula que a linguagem se refere ao mundo através das significações e, por isso, podemos nos relacionar com a realidade através da palavra. A linguagem se relaciona com os sentidos já existentes e cria sentidos novos e, por isso, podemos nos relacionar com o pensamento através das palavras. 
Na última metade do século XIX, temos caracterizada a época dos neogramáticos, que constituiu uma nova geração de linguistas relacionados com a Universidade de Leipzig (Alemanha) e que, ao questionar certos pressupostos tradicionais da prática histórico-comparativa, estabeleceu uma orientação metodológica diferente e um conjunto de postulados teóricos para a interpretação da mudança linguística (Faraco, 2005).

Já no século XX, surge em cena o linguista suíço Ferdinand de Saussure, que propôs um novo paradigma para a compreensão da linguagem humana - o Estruturalismo. O conceito de língua adotado por Saussure (1916) instaura a autonomia da Linguística como ciência. Sua obra - Curso de Linguística Geral - representa o marco inicial da linguística moderna, o grande "divisor de águas" entre as pesquisas diacrônicas (comparativismo) e a moderna ciência da linguagem - a linguística.

É, portanto, no século XX que ocorrem muitas transformações nas diversas áreas do conhecimento humano. A filosofia, por exemplo, percorreu um longo caminho reflexivo (dos gregos antigos, que se perguntavam sobre a realidade, até os modernos, com Descartes, que passaram a questionar sobre o conhecimento da realidade) até criar a dualidade sujeito/objeto que transformara a filosofia em epistemologia - submetendo-a à teoria do conhecimento.

Consequentemente, a filosofia da linguagem também ganha um grande impulso neste século e seus questionamentos e reflexões ainda constituem um ponto central na contemporaneidade, uma vez que o pensamento predominante é o de que a mente humana não consegue explorar a realidade sem a linguagem, pois esta não representa apenas a expressão de pensamentos e, sim, é o próprio 
pensamento; é a única forma pela qual acessamos o nosso pensamento e de outrem.

Nesse contexto, eis o cenário que surge: todas as atenções estão centradas na linguagem. A virada linguística ou giro linguístico é, portanto, a denominação adotada para o "novo rumo" que a filosofia da linguagem ganhou no século XX. Ela representa importante marco do desenvolvimento da filosofia ocidental, cuja principal característica é a relação entre a filosofia e a linguagem.

Dessa forma, para esse estudo, propomos realizar um ensaio teórico, a partir de um percurso de leituras desde as primeiras investigações filosóficas na história das línguas até os estudos contemporâneos sobre a ciência da linguagem - Linguística. Para realizar tal empreitada, a metodologia utilizada foi uma abordagem analítica, utilizando-se fonte secundária a partir de pesquisa bibliográfica.

Muitas são as referências históricas centrais, desde o início do século XX, quando outros pensadores ${ }^{31}$, como Ludwig Wittgenstein (1889-1951), ${ }^{32}$ definem a problemática da filosofia da

${ }^{31}$ Autores como Frege, Russel e Wittgenstein são fundamentais para esse estudo,
uma vez que são, historicamente, considerados os fundadores da Filosofia
analítica; logo, o estudo dos seus escritos funciona como uma iniciação à Filosofia
da linguagem contemporânea.
${ }^{32}$ O legado de Wittgenstein é dividido em dois momentos, comumente chamados
de primeiro e segundo Wittgenstein. O primeiro Wittgenstein é representado na
obra Tractatus Logico Philosophicus, que inaugura sua trajetória de escritos sobre
os principais temas e problemas da filosofia da linguagem contemporânea. No
segundo momento, que compreende o período de 1929 até o ano de sua morte,
em 1951, Wittgenstein produziu um grande volume de escritos e, dentre essas
obras, entretanto, escolheu a obra Investigações Filosóficas para ser publicada
postumamente (dois anos após seu falecimento, em 1953), tornando-se 
linguagem, a que se pode chamar de contemporânea, passando a se preocupar com a análise dos conceitos, sua função e sentido como motor do pensamento que agora surge.

Neste cenário de muitos debates, um texto muito interessante, que realiza um estudo sobre essa nova forma de olhar para a linguagem, numa perspectiva filosófica, é o de Segatto (2011). Em seu trabalho, o autor propôs examinar a recolocação e a transformação da questão da harmonia entre linguagem, pensamento e realidade na segunda fase da produção filosófica de Wittgenstein. Para Segatto, essa harmonia é uma questão filosófica fundamental tão antiga quanto à própria filosofia. Conforme o autor, "sua perenidade deve-se, em boa medida, ao vínculo estreito que mantém com outra questão lógico-filosófica: a possibilidade da representação enunciativa ou proposicional da realidade".

Assim, embora como ressonâncias de um passado distante, entendemos que o estudo das proposições de teorias e conceitos clássicos é essencialmente atemporal, visto que são parte constitutiva de nossa realidade atual. É nesse sentido que buscamos entender o pensamento filosófico sobre a linguagem e a sua relação com o mundo: "o querer dizer" concretizado em ideias e pensamentos. Enfim, a compreensão dos conceitos analisados é, portanto, o principal propósito deste estudo: conhecer o contexto da virada linguística, bem como as concepções de língua e linguagem numa perspectiva filosófica, a fim de interpretar suas contribuições para os estudos da filosofia da linguagem.

rapidamente um clássico, especialmente para o grupo da filosofia da linguagem ordinária. 


\section{ABORDAGENS FILOSÓFICAS DA LINGUAGEM}

É válido dizer que as pesquisas sobre hermenêutica são ainda relativamente incipientes se comparadas com o andamento de outras abordagens filosóficas. Nesse sentido, para contribuir com este estudo, optamos por trazer algumas postulações da hermenêutica filosófica cunhada por Hans-Georg Gadamer (1991).

O referido teórico fundamenta uma concepção ontológica da linguagem calcada na finitude da existência humana. Afirma Gadamer que a linguagem humana é universal ${ }^{33}$ e constitui, pelas estruturas de interação e compreensão que lhe são próprias, as formas de sociabilidade humana. Seu estudo somente ganha destaque no cenário filosófico a partir do século XIX, principalmente como uma reação ao idealismo transcendental ${ }^{34} \mathrm{de}$ matriz kantiana. Esse movimento da filosofia contemporânea rumo a uma crítica da linguagem redundará no nascimento de uma "filosofia da linguagem”, que tem como concepção básica a análise da linguagem e do processo de significação, seja por uma corrente "analítica", que estuda a linguagem ideal, ou por uma corrente "pragmática" que investiga a linguagem ordinária e seu uso efetivo nos diversos contextos cotidianos.

\footnotetext{
${ }^{33}$ Gadamer defende a universalidade da linguagem na célebre afirmação de que "o ser que pode ser compreendido é a linguagem". Com base na universalidade da linguagem, ele argumenta a favor da tese da universalidade do ponto de vista hermenêutico.

${ }^{34} \mathrm{O}$ idealismo transcendental kantiano é a concepção de um sistema dado como síntese e superação das duas correntes da filosofia - racionalismo e empirismo. $\mathrm{O}$ pensamento de Kant é uma etapa decisiva, sua fecundidade está longe de esgotarse e foi ponto de partida para a filosofia moderna. Desse modo, o pensamento kantiano marcou diversos outros pensadores posteriores a sua época. Suas obras são referência fundamental para diversas correntes filosóficas. Ver mais em (Pascal, 1999).
} 
Como proposta inicial, temos que a abordagem tradicional da filosofia da linguagem apresenta como essência da linguagem, entre os vários papéis que ela pode cumprir, uma atividade dita comunicacional, qual seja a de representar a realidade. Nessa direção, vale dizer que esse novo olhar para a linguagem, numa perspectiva filosófica (contemporânea), traz mudanças profundas ao pensamento ocidental: a visão platônica de mundo; ou seja, o pressuposto de que existe uma separação, e mesmo uma oposição, entre a realidade "nua" e a representação linguística dessa realidade, passa a ser questionada. Isso porque a concepção tradicional de Platão compreende a linguagem como mero suplemento das ideias, incapaz, portanto, de expressar a essência das coisas. ${ }^{35}$

Dito de outra forma, a identidade da filosofia contemporânea, pós-kantiana, está em grande medida ligada, de um lado, à reflexão sobre o conhecimento e a ciência, de outro, à reflexão sobre a linguagem e sobre a lógica, temas que, muitas vezes, se sobrepõem e se tornam indistintos. Nesse contexto, a reflexão sobre a linguagem é marcada de maneira singular pelo surgimento de uma "nova" lógica que trouxe consigo a revisão (questionamentos e outros pontos de vista) de concepções centrais da filosofia. É nesse contexto que surge o novo debate sobre a filosofia da lógica e da linguagem que se elabora em meio a todas essas transformações. "Nela encontramos a reflexão sobre a lógica e a linguagem associadas de maneira direta à ontologia, à teoria do conhecimento, à ética, à filosofia da ciência”; conceitos estes que continuam sendo a grande fonte das reflexões filosóficas mais frutíferas sobre a linguagem.

\footnotetext{
${ }^{35}$ Segundo Marcondes, a primeira formulação filosófica dessa impossibilidade do conhecimento imediato da realidade encontra-se no diálogo Teeteto de Platão e pode ser resumido no "paradoxo do Teeteto". Ver em Marcondes (2006).
} 
Não se pode negar que o século XX marcou o vínculo entre a filosofia e a linguagem e, por isso, está na raiz da criação da "filosofia da linguagem". Inicialmente, tal vínculo é essencialmente lógico: é pela análise lógica ${ }^{36}$ da linguagem que, primeiramente, se interessou pela filosofia da linguagem contemporânea. Num segundo momento, a empreitada filosófica de uma investigação acerca do entendimento humano se dá com a investigação do entendimento das palavras; assim, o que muda em relação às investigações filosóficas clássicas é "para onde" devemos olhar quando falamos em "entendimento": devemos olhar para "a práxis, o uso da linguagem".

No passo dessa nova forma de pensamento, Marcondes (2006) identifica, de modo geral, duas grandes vertentes desse novo contexto da filosofia: a Escola Analítica de Cambridge, que resultará no positivismo lógico do Círculo de Viena, e a Escola de Oxford, também conhecida como filosofia da linguagem ordinária também caracterizada pela expressão "virada linguística" do século XX. Essa segunda vertente será o principal foco de análise deste estudo.

A partir das leituras realizadas, é possível dizer que são dois os traços fundamentais da virada: em primeira análise, ela é considerada como elemento constitutivo do pensamento e do conhecimento e, nessa medida, é entendida como condição de

\footnotetext{
${ }^{36}$ A chamada "filosofia analítica", em sua primeira fase, é marcada pelo logicismo, que consiste na visão de que as verdades da aritmética são redutíveis à lógica, isto é, os enunciados aritméticos podem ser expressos em termos puramente lógicos, e, consequentemente, os teoremas da aritmética podem ser derivados de axiomas estritamente lógicos. Autores como G. Frege e B. Russell inauguraram temas e formularam problemas que se tornaram clássicos pontos de partida para as discussões ulteriores acerca da simbolização da realidade pela linguagem, segundo os paradigmas da nova lógica. Ver em Carvalho e Cornelli (2013).
} 
possibilidade tanto da objetividade da experiência quanto da intersubjetividade da comunicação, como consequência da superação da concepção tradicional da linguagem enquanto "instrumento", enquanto simples meio para a expressão de pensamentos pré-linguísticos. Em segundo lugar, essa nova concepção de linguagem conduz a uma destranscendentalização da razão: a linguagem manifesta-se sempre em línguas particulares e históricas e não permite, por isso, uma separação estrita entre o transcendental e o empírico, entre o a priori e o a posteriori. E o que impulsionou essa transformação foi a crítica à razão "pura" kantiana, como podemos notar na seguinte passagem dos escritos de Habermas (1985):

Já Hamann levantará contra Kant a censura do 'purismo da razão'. Não há uma razão que só posteriormente vestiria roupagens linguísticas. A razão é originalmente uma razão encarnada tanto nos contextos de ações comunicativas como nas estruturas do mundo da vida.

A virada linguística rompeu com "o modelo linear fechado do fazer filosófico” (Cuter, 2010), sobretudo, com a influência de muitos estudiosos, surgiram novos pressupostos que serviram de base para se embrenhar em novas reflexões. A linguagem, a partir desse contexto, é relacionada diretamente com a noção de uso. As regras de uso da linguagem, antes construídas num sistema lógico, dão espaço para as regras construídas pragmaticamente pelos usuários da língua em espaço social - são os chamados “jogos de linguagem" ${ }^{37}$.

\footnotetext{
${ }^{37} \mathrm{~A}$ teoria dos jogos de linguagem de Wittgenstein abriu o campo para olhar a variedade linguística com intenso interesse e a publicitação das regras de uso
} 


\section{A VIRADA LINGUíSTICA E A DIMENSÃo PRAGMÁTICA ${ }^{38}$ DA LINGUAGEM}

Em linhas gerais, a virada linguística traduz todo um contexto de mudanças no que se refere à centralidade da linguagem. Esta passa a dominar o pensamento contemporâneo, uma vez que é considerada, prioritariamente, uma atividade capaz de "moldar" a realidade e não simplesmente uma representação de fatos e coisas.

A esse respeito, Habermas (2004, p. 39) escreve o seguinte:

A linguagem e a realidade interpenetram-se de uma maneira indissolúvel para nós. Cada experiência está linguisticamente impregnada, de modo que é impossível um acesso à realidade não filtrado pela linguagem. Esta descoberta constitui um forte motivo para atribuir às condições intersubjetivas de interpretação e entendimento mútuo linguísticos o papel transcendental que Kant reservara para as condições subjetivas necessárias da experiência objetiva. No lugar da subjetividade transcendental da consciência entra a intersubjetividade destranscendentalizada do mundo da vida.

seria fundamental para seu funcionamento eficiente e coerente. Ver em: Wittgenstein (1999).

${ }^{38} \mathrm{O}$ termo "pragmática" é uma classificação proposta por Morris em 1938 e adotada por diversos pensadores da linguagem, tanto da vertente analítica como da ordinária. Considerando a linguagem humana como um conjunto de signos, Morris divide o fenômeno da significação em três áreas distintas: sintaxe, semântica e pragmática. Dentro dessa tipologia, a pragmática é definida como a parte da semiologia que estuda a relação entre os signos e seus usuários; a sintaxe estuda apenas a relação entre os signos; e a semântica restringe-se a investigar a relação entre os signos e o mundo. Sob o ponto de vista pragmático, o estudo da linguagem pretende dar conta das experiências práticas, concretas da linguagem, do contexto e da multiplicidade de usos da linguagem cotidiana. 
A partir dos anos 1940, desenvolveu-se uma nova teoria para a concepção da linguagem. Autores como Wittgenstein e Austin veem a ciência linguística como uma das formas possíveis na relação com o real. De acordo com Marcondes (2017), "a linguagem passa a ser vista como uma prática social e examinada sempre a um contexto de uso." Assim, surgem os chamados jogos de linguagem (de Wittgenstein), que valorizam a prática concreta do caráter interativo e intersubjetivo da linguagem. Em outros termos, falante e ouvinte interagem de acordo com o contexto e os usos da linguagem. A semântica dá lugar à pragmática, isto é, à consideração da linguagem como uso, como práxis, nas palavras de Wittgenstein em sua obra Investigações filosóficas. Assim, a dimensão pragmática da linguagem, impulsionada pela virada linguística, proporcionou uma análise da razão crítica da modernidade numa perspectiva comunicativa e discursiva. Desta forma, é constituído o novo paradigma pós-positivista: o caráter performativo da linguagem (Marcantonio, 2007).

Vale ressaltar que a noção dos atos de fala como atos performativos surge com J. L. Austin (1976), responsável por sua introdução no campo da filosofia da linguagem. A partir de Austin, de modo geral, o ato de fala, ou o próprio uso da linguagem passa a ser caracterizado como ato performativo, na medida em que a linguagem é entendida como ação. Essa valorização da dimensão performativa/comunicativa da linguagem trouxe inúmeras consequências para os estudos linguísticos em geral.

Conforme já mencionado, a virada linguística alterou os paradigmas de linguagem que a reduziam a um instrumento de transmissão de informações ou simples representante do mundo objetivo (Marcantonio, 2007), centrando-se em questões ontológicas e epistemológicas sobre a verdade. A linguagem, portanto, passou a ser vista não como idealizada, com contornos 
perfeitos, sintonizados num mecanismo lógico e artificial, mas, sim, o pensamento contemporâneo busca pela valorização da linguagem em seu contexto real de uso.

Nesse contexto, as teorias do discurso causaram uma grande influência no pensamento contemporâneo, visto que fundamentaram a ideia de linguagem como uma forma de ação no real, uma prática social concreta, na qual as estruturas de interação social se refletem na própria linguagem. Assim, a linguagem sofre uma redefinição e passa a ser considerada indissociável do social e da interação.

Segundo essa nova concepção, cada afirmação feita por um falante pode ser tomada como parte de um processo social interativo que supõe ou antecipa uma resposta a ser dada potencialmente por um interlocutor. Dessa maneira, a identidade do falante e do ouvinte/interlocutor pressupõe uma identidade coletiva do grupo social que ambos fazem parte. É a partir daí, que a relação entre linguagem e mundo real é considerada indissociável.

Com efeito, numa perspectiva filosófica, a relação entre a linguagem e o mundo - o que é central nos estudos da semântica não pode ser explicada logicamente, pois o "mundo" é linguagem. Em outros termos, a linguagem sempre já é anterior a toda pergunta específica sobre qualquer coisa no mundo, ela "abre o mundo" e tem papel constitutivo na nossa relação com ele.

O movimento filosófico rumo ao estudo da linguagem - a virada linguística - também foi foco das investigações de Wilhelm von Humboldt ${ }^{39}$. O referido teórico propôs uma compreensão da

${ }^{39}$ Wilhelm von Humboldt (1767-1835), filósofo, nascido na Alemanha, viveu a virada do século XVIII fortemente marcado pelo idealismo filosófico alemão. 
linguagem não apenas como um sistema acabado, mas como atividade. Em suas palavras: "é preciso considerar a linguagem não como um produto morto, mas, sobretudo, como uma produção (...) Em si mesma, a linguagem não é um produto (Ergon), mas uma atividade (Energeia)" (Humboldt, 2002).

É importante destacar, para essa compreensão de linguagem como atividade, que seu aspecto criador comparece tanto em um ponto de vista semântico quanto pragmático. E é justamente esse fato que faz das reflexões propostas por Humboldt um marco importante não apenas para a linguística, mas também para a filosofia contemporânea. Sobre a grande contribuição de Humboldt, Cristina Lafont diz o seguinte:

Humboldt leva a cabo uma mudança de paradigma que afeta não apenas a linguística, cujo desenvolvimento no século XX revela as consequências dessa mudança de maneira bastante clara, mas também a filosofia, para a qual a linguagem (vista como sistema de signos objetificados) nunca teve uma dimensão filosófica. Além disso, a mudança de paradigma levada a cabo por Humboldt ocorre em duas dimensões diferentes. Em sua dimensão cognitivo-semântica, essa mudança consiste em encarar a linguagem não como um mero sistema de signos, não como algo objetificável (intramundanamente), mas como algo constitutivo da atividade de pensar, como a própria condição de possibilidade dessa atividade. A linguagem é, então, elevada a um estatuto quasi-transcendental, que

Estudioso de extrema perspicácia e sutileza, contribuiu não somente com ensaios no campo da filosofia da linguagem, mas também no campo da política e da educação, sendo um dos fundadores e reitor da Universidade de Berlim, instituição modelo no século XIX. Como um homem de seu tempo, suas obras linguísticas buscaram, desde cedo, demonstrar a relação existente entre a estrutura de uma língua e a estrutura mental dos usuários desta língua, tematizando como cultura e língua se refletem um no outro. 
reivindica contra a subjetividade a autoria das operações constitutivas da visão de mundo do sujeito (...) Em sua dimensão comunicativo-pragmática, a mudança consiste em ver esse caráter constitutivo da linguagem como o resultado de um processo ou atividade: especificamente, a atividade de falar. Nesse sentido, a linguagem se torna a garantia da intersubjetividade da comunicação, a condição de possibilidade do entendimento entre falantes (Lafont, 1999, p. 17-18).

$\mathrm{Na}$ esteira desse pensamento, Humboldt vem sendo identificado como um dos vanguardistas de uma nova visão sobre a linguagem, justamente porque propõe uma nova maneira de conceber as relações entre pensamento, razão e linguagem. Com efeito, ele é considerado por muitos o primeiro filósofo a referir-se, explicitamente, à dimensão comunicativa da linguagem e, nesse sentido, pode ser considerado pioneiro na abertura do campo ‘pragmático’ da linguagem, para além da função apenas designativa, visto que a sua concepção inovadora não se limita a apontar a característica de ‘abertura de mundo’ da linguagem, mas também destaca o seu caráter essencialmente comunicativo e, portanto, intersubjetivo e dialógico ${ }^{40}$.

Humboldt é o primeiro a ressaltar que a linguagem apresenta, além de sua função cognitiva e expressiva, a função comunicativa. A linguagem é definida como uma ação, uma atividade humana, um processo contínuo que não pode ser analisada como um objeto, mas sim, compreendida pelos seus usuários (falantes que dela participam). Conforme observa o

${ }^{40} \mathrm{~A}$ noção de intersubjetividade como um processo dialógico que ocorre na comunicação linguística inaugura, dessa forma, a dimensão comunicativapragmática da linguagem que encontrará, por sua vez, ampla recepção por parte de diversos autores contemporâneos, estabelecendo, assim, um diálogo profícuo com os estudos linguísticos. 
teórico: "A linguagem só existe na fala continuada, a gramática e o léxico são apenas comparáveis com seu esqueleto morto”. E prossegue afirmando o seguinte: "Uma vez que a linguagem vive na boca do povo, ela é uma produção e reprodução progressiva da capacidade geradora de palavras no seu uso cotidiano de fala" (Humboldt, apud Lafont, 1993, p. 54 e 55).

Vale dizer que uma das teses centrais das reflexões de Humboldt é a de que em cada língua encontra-se uma perspectiva de mundo particular. Nessa linha de pensamento, ao considerar as línguas em sua função de abertura do mundo, e sendo tais línguas plurais e historicamente modificáveis, as perspectivas de mundo subjacentes a elas também o serão.

Além disso, Habermas nos lembra que Humboldt examina a linguagem sob dois pontos de vista distintos: semântico, no qual assume proeminência o papel de organização de conteúdos linguísticos compartilhados por uma determinada comunidade; e pragmático, no qual assume proeminência o papel de médium do entendimento mútuo entre interlocutores. Segundo Habermas (2004, p. 65):

Enquanto a análise semântica se concentra na visão de mundo linguística, para a análise pragmática a conversação está em primeiro plano. Enquanto lá Humboldt trata a função cognitiva da linguagem em conexão com os traços expressivos da mentalidade e da forma de vida de um povo, ele aqui tematiza a mesma função na conexão com discursos em que os participantes podem oferecer respostas e contradizer.

Sendo assim, de acordo com a concepção humboldtiana, a linguagem só pode existir em sociedade e apenas se desenvolve no uso contínuo da fala que tem lugar na 'boca do povo'. Ela aparece como condição de possibilidade da intersubjetividade e do diálogo 
e, portanto, da comunicação entre sujeitos; ela pertence, na verdade, a todo gênero humano, em suas dimensões cognitiva, expressiva e comunicativa. Nesse sentido, os pressupostos de Humboldt inauguram um novo campo de estudo da linguagem.

\section{CONCEPÇÕES DE LÍNGUA E LINGUAGEM NUMA PERSPECTIVA SÓCIO-HISTÓRICA}

Conforme já mencionado, o propósito principal que motiva o presente estudo é a análise dos conceitos essenciais dos estudos da linguagem no contexto da virada linguística, bem como as concepções de língua e linguagem, numa perspectiva filosófica, a fim de interpretar suas contribuições para os estudos da filosofia da linguagem. Isso porque, partimos do pressuposto de que o pano de fundo histórico da filosofia da linguagem trouxe (e ainda traz) reflexos decisivos para a ciência linguística, visto que seu estudo, numa abordagem filosófica, possibilita uma maior reflexão sobre o que faz da linguagem um objeto filosófico, fazendo emergir, de forma concreta, aquilo que é especificamente filosófico nos estudos linguísticos - as questões semântica e pragmática em torno do sentido e da verdade. Assim, entendemos que conhecer os conceitos linguístico-filosóficos vistos a partir da filosofia da linguagem nos permite reconhecer a relação da linguagem com a tradição linguística, filosófica e cultural.

Entretanto, antes de promover qualquer discussão, é necessário fazer uma breve explanação sobre alguns pressupostos teóricos que contribuíram para esta análise. Dentre os conceitos fundamentais referentes aos estudos linguísticos, a concepção de língua e linguagem passa a ser central. Isso se justifica pelo fato de que a forma como se concebe a linguagem determina os processos de interação, socialização e individuação dos sujeitos. Nessa 
direção, para este estudo, será apresentada a perspectiva sóciohistórica, de linha bakhtiniana, que concebe a interação verbal como o lugar da produção da linguagem e da constituição dos sujeitos.

É importante ressaltar que a perspectiva sócio-histórica delineada por Bakhtin constitui uma corrente de pensamento que não se encaixa propriamente na perspectiva da virada linguística. Ela é de matriz moderna, marxista, focada no social e no histórico. Todavia, as concepções de língua e linguagem e as ideias defendidas por Bakhtin contribuem para a discussão da filosofia da linguagem, no sentido de compreender a linguagem como condição de possibilidade da intersubjetividade e do diálogo e, portanto, da comunicação entre sujeitos.

A linguagem, para Bakhtin (1929\1986), é entendida como um trabalho de construção e produção de sentidos apoiado nas relações discursivas (dialógicas) empreendidas por sujeitos historicamente situados. Pensar a linguagem nessa perspectiva é, portanto, compreender a indissolúvel relação existente entre língua, linguagem, história e sujeitos.

Os postulados bakhtinianos apontam para uma concepção de linguagem na qual ela é entendida não como um sistema de categorias gramaticais abstratas, nem como um ente gramatical homogêneo, mas como uma realidade axiologicamente saturada como um fenômeno sempre estratificado pelos índices sociais de valores (Faraco, 2003). Em outras palavras, a perspectiva sócio- 
histórica de linha bakhtiniana apresenta uma concepção de linguagem que focaliza o social e o histórico ${ }^{41}$.

À luz da teoria bakhtiniana, a língua apresenta-se como uma corrente evolutiva ininterrupta. Tal corrente é concreta, realiza-se através do diálogo, dos enunciados, da comunicação efetiva entre os usuários da língua. $\mathrm{O}$ pensamento bakhtiniano não concebe, portanto, uma língua que não cumpra seu papel comunicativo, carregado em sua essência social e ideológica. Tal pensamento define a língua como sendo multifacetada, como a própria materialização das ideologias, como arena da luta de classes, como instrumento de dominação ou de libertação, dada sua característica fundamentalmente ideológica.

Ao tratar da verdadeira substância da língua, Bakhtin postula que esta se constitui fundamentalmente pelo fenômeno social da interação verbal, realizada através da enunciação ou das enunciações. Assim, este é o aspecto social da língua: só se concretiza na materialidade do discurso, através de suas relações dialógicas (Bakhtin, 1929\1986, p. 123). A língua constitui um conjunto infinito de vozes sociais e possui a propriedade de ser dialógica. Isso implica concebê-la, portanto, como um sistema contínuo que se constrói e evolui historicamente pelo processo interativo da comunicação verbal concreta.

Em outras palavras, no seu uso prático, a língua é inseparável de seu conteúdo ideológico: "Assim, na prática viva da língua”, ou seja, no seu uso efetivo, "a consciência linguística do locutor e do

\footnotetext{
${ }^{41} \mathrm{Em}$ sua leitura da obra de Bakhtin, Faraco (2003, p. 105-6) salienta que, a partir da perspectiva teórica do pensamento bakhtiniano, "a linguagem verbal não é vista primordialmente como sistema formal, mas como atividade, como um conjunto de práticas socioculturais [...] que estão atravessadas por diferentes posições avaliativas sociais (concretizam diferentes vozes sociais)”.
} 
receptor nada tem a ver com um sistema abstrato de formas normativas, mas apenas com a linguagem no sentido de conjunto dos contextos possíveis de uso de cada forma particular" (Bakhtin, $1929 \backslash 1986$, p. 95). Na visão do teórico, “a língua materna não chega ao nosso conhecimento a partir de dicionários e gramáticas, mas de enunciações concretas que nós mesmos ouvimos e nós mesmos reproduzimos na comunicação discursiva viva com as pessoas que nos rodeiam” (Bakhtin, 1952-53\1992).

Ainda na proposta de Bakhtin, “a utilização da língua efetuase em forma de enunciados (orais e escritos), concretos e únicos, que emanam dos integrantes duma ou doutra esfera da atividade humana”. E acrescenta que "qualquer enunciado considerado isoladamente é, claro, individual, mas cada esfera da utilização da língua elabora seus tipos relativamente estáveis de enunciados, sendo isso que denominamos gêneros do discurso". Nessa linha de pensamento, "os enunciados e o tipo a que pertencem são as correias de transmissão que levam da história da sociedade à história da língua” e "em cada época de seu desenvolvimento, a língua escrita é marcada pelos gêneros do discurso" (Bakhtin, 1952$53 \backslash 1992$, p. 285). Estes, segundo Tonácio (2003, p. 104), “são a própria linguagem em atividade, que se move continuamente em fronteiras nunca delimitadas com rigor e precisão”.

No que diz respeito aos sujeitos que participam dessas relações, estes, ao produzirem a linguagem, vão se constituindo ao mesmo tempo que constituem a própria linguagem. Diante disso, pensar no sujeito dialógico, nessa perspectiva, é entender que este nasce de uma complexa realidade linguística e é nessa atmosfera heterogênea da linguagem que o sujeito passa a se constituir discursivamente, visto que está inserido nas múltiplas relações da interação socioideológica. É pensar que este sujeito se constitui como um ser social de ponta a ponta - pelas múltiplas vozes sociais 
e suas relações dialógicas e, ao mesmo tempo, um ser singular de ponta a ponta - na medida em que cada indivíduo se constitui como "um evento único do ser" (Faraco, 2003).

Para Travaglia (1998), conforme essa visão da linguagem, o que o sujeito faz ao usar a língua não é tão-somente traduzir e exteriorizar um pensamento, ou transmitir informações a outrem, mas, sim, realizar ações, agir sobre o interlocutor (ouvinte/leitor). Já, no dizer de Koch, diferentemente das outras concepções de linguagem, na perspectiva interacional/dialógica da língua, os sujeitos são vistos não mais como (pré)determinados pelo sistema linguístico, mas, sim, como atores/construtores sociais, sujeitos ativos que - dialogicamente - se constroem e são construídos no texto, considerado o próprio lugar da interação, ou seja, da constituição dos interlocutores (Koch, 2000).

Assim, nessa concepção, a linguagem, seja ela escrita, oral ou gestual, processa-se por meio de enunciados que se materializam em diversas interações, como esclarece Bakhtin (1929\1986):

A enunciação é o produto da interação de dois indivíduos socialmente organizados e, mesmo que não haja um interlocutor real, este pode ser substituído pelo representante médio do grupo social ao qual pertence o locutor. A palavra dirige-se a um interlocutor: ela é função da pessoa desse interlocutor (...). "Não pode haver interlocutor abstrato; não teríamos linguagem comum com tal interlocutor, nem no sentido próprio nem no figurado" (...) a enunciação enquanto tal é um puro produto da interação social, quer se trate de um ato de fala determinado pela situação imediata ou pelo contexto mais amplo que constitui o conjunto das condições de vida de uma determinada comunidade linguística. 
É nessa linha de pensamento que comungamos do princípio de que a relação entre a linguagem e o mundo é indissolúvel e intrínseca. Nosso contato com a realidade encontra-se, desde sempre, linguisticamente estruturado. Não há como escapar da linguagem, não existe estarmos "fora dela", assim como não existem pensamentos "pré-linguísticos". Todas as proposições que estruturam nosso pensamento são proposições linguísticas. $\mathrm{O}$ "mundo da vida", entendido como o conjunto de referências possíveis, como "rede de interlocução", esse mundo é linguisticamente estruturado; ele aparece de forma paradigmática quando pensamos sobre a linguagem. É assim que, para Habermas (2004, p. 126), seguindo o caminho trilhado por Humboldt, a linguagem abre o acesso ao mundo. Ela contribui para os processos de interação, socialização e individuação do sujeito.

Sendo assim, nesta parte derradeira de nosso trabalho, apresentaremos não considerações finais, mas algumas considerações/reflexões; pois, conforme elucida Brait, para o pensamento bakhtiniano, nossa atitude diante do conhecimento:

significa um contato dialógico com o corpus selecionado, ou seja, com esse contínuo dinâmico, cujo acabamento, mesmo que visível, é sempre inconcluso. Assim, a cada conceito mobilizado a partir das propostas bakhtinianas é preciso levar em conta que ele forma, com os demais, uma rede e que dificilmente poderá dela dissociar-se (Brait, 2005).

\section{Algumas CONSIDERAÇões}

No decorrer deste ensaio teórico, buscamos apresentar como as reflexões epistemológicas da chamada "virada linguística" foram fundamentais para se compreender a importância das abordagens teóricas da Filosofia da linguagem e das concepções de 
língua e linguagem no que se refere ao papel central que ela (linguagem) ocupa na formação dos sujeitos enquanto um ser social e individual.

A virada linguística, movimento desencadeado no fim do século XIX, marcou profundamente o século XX, uma vez que ressaltou o caráter específico da relação entre filosofia e linguagem no pensamento contemporâneo, bem como contribuiu para a formação de uma visão mais abrangente da filosofia como discurso múltiplo, combatendo visões reducionistas. Tudo isso provocou uma mudança paradigmática na Filosofia e nas Ciências Humanas e Sociais, visto que trouxe uma ressignificação na forma como o homem compreende a realidade, o mundo e a ele mesmo (Ibáñez, 2004, p. 19).

A Filosofia da Linguagem pode ser entendida, portanto, como uma filosofia sobre o conhecimento, voltada à interpretação e visão de mundo por meio da linguagem, que passa a representar “a questão central” da filosofia contemporânea. Nesse viés, a linguagem passa a ser o novo paradigma; não como o objeto da filosofia, mas como o seu fundamento. Tal filosofia, no dizer de Searle (2007), passa a se ocupar da relação entre a realidade, a linguagem, e o sentido; sendo a linguagem "a questão central" das escolas filosóficas e da filosofia contemporânea.

\section{REFERÊNCIAS}

AUSTIN, John. L. How to do things with words. 2. ed. Oxford: Oxford University Press, 1976.

BAKHTIN, Mikhail. Marxismo e filosofia da linguagem. Tradução Michel Lahud e Yara Frateschi Vieira. 10. ed. São Paulo: Hucitec, 1929/1986. 
. Os gêneros do discurso. In: Estética da criação verbal.

Tradução Paulo Bezerra. São Paulo: Martins Fontes, 1952-53/1992. p. 277-289.

BRAIT, Beth (org.). Bakhtin, dialogismo e construção do sentido. 2. ed. rev. Campinas: Editora da Unicamp, 2005.

BUENO, F. S.. Estudos de filologia portuguesa. 2. ed. São Paulo: Saraiva, 1954.

CUTER, João Vergílio Gallerani. Wittgenstein e eu. Discurso Departamento de Filosofia da FFLCH DA USP, v. 38, p. 215-238, 2010.

FARACO, Carlos Alberto. Linguagem $\&$ diálogo: as idéias do Círculo de Bakhtin. Curitiba: Criar Edições, 2003.

FARACO, Carlos Alberto (1950). Linguística histórica: uma introdução ao estudo da história das línguas. São Paulo: Parábola Editorial, 2005. Na ponta da língua, v. 12

GADAMER, Hans-Georg. Verdad y método: fundamentos de una hermenéutica filosófica. Tradução por Ana Agud Aparicio e Rafael de Agapito. 4. ed. Salamanca: Sígueme, 1991.

HABERMAS, Jürgen. Der philosophische Diskurs der Moderne. Frankfurt am Main: Suhrkamp, 1985, p. 374 (trad.: HABERMAS, J. O discurso filosófico da modernidade. São Paulo: Martins Fontes, 2000, p. 447).

HABERMAS, Jürgen. Verdade e justificação. São Paulo: Edições Loyola, 2004. 
HABERMAS, J. "Filosofia hermenêutica e filosofia analítica: duas versões complementares da virada lingüística”. In: . Verdade e justificação. São Paulo: Edições Loyola, 2004, p. 65).

HUMBOLDT, Wilhelm von. Escritos sobre a filosofia da linguagem (Obras III). Darmstadt: Sociedade Científica do Livro, 2002.

IBÁÑEZ, T. O giro linguístico. In: IÑIGUEZ, L. Manual de análise do discurso em ciências sociais. Petrópolis: Vozes, 2004.

KOCH, Ingedore Villaça. A inter-ação pela linguagem. São Paulo: Contexto. 5. ed., 2000.

LAFONT, Cristina. The linguistic turn in hermeneutic philosophy. Cambridge: MIT Press, 1999, p. 17-18.

MARCANTONIO, Jonathan Hernandes. A virada linguística e os novos rumos da Filosofia. Revista da Faculdade de Direito (São Bernardo do Campo), v. 4, p. 114-132, 2007.

MARCONDES, Danilo. Duas Concepções de Análise na Filosofia Analítica. In: Linguagem e construção do pensamento. Casa do psicólogo, São Paulo, 2006.

SAUSSURE, Ferdinand (1916). Curso de linguística geral. Tradução de Antônio Chelini, José Paulo Paes e Izidoro Blikstein. 26. ed. São Paulo: Cultrix, 2006.

SEARLE, John. Filosofia da Linguagem: uma entrevista com John Searle. ReVEL, v. 5, n. 8, 2007. Disponível em: $<$ www.revel.inf.br/files/entrevistas/revel_8_entrevista_john_searl e.pdf>. Acesso em: out. 2015. 
SEGATTO, Antonio Ianni. Wittgenstein e a questão da harmonia entre linguagem, pensamento e realidade. São Paulo, $2011.170 \mathrm{f}$. Tese (Doutorado) - Faculdade de Filosofia, Letras e Ciências Humanas da Universidade de São Paulo.

TONÁCIO, G. M. Os gêneros discursivos e as propostas curriculares de ensino da Língua Portuguesa nos currículos documental e docente: um entrelaçamento de vozes. Dissertação (Mestrado em Educação). Universidade Federal de Juiz de Fora, Minas Gerais 2003.

TRAVAGLIA, Luiz Carlos. Gramática e interação: uma proposta para o ensino de gramática no $1^{\circ} \mathrm{e} 2^{\circ}$ graus. São Paulo: Cortez, 1998.

WITTGENSTEIN, L. Investigações filosóficas. Tradução: José Carlos Bruni. São Paulo: Editora Nova Cultural, 1999. 


\section{ENSINO REMOTO NA EDUCAÇÃO BÁSICA: DESAFIOS, POSSIBILIDADES E PERSPECTIVAS DA PRÁTICA DOCENTE DAS ESCOLAS MULTISSERIADAS MUNICIPAIS DE NOVA MAMORÉ ${ }^{42}$}

Ely Sandra Carvalho de Oliveira ${ }^{43}$ Leidiane Ferreira da Silva ${ }^{44}$

\section{INTRODUÇÃO}

A sociedade contemporânea tem passado por significativas mudanças, sobretudo com o advento das tecnologias digitais da informação e comunicação, nesse cenário está inserido também mudanças de paradigmas na educação. As práticas tradicionais de ensino, estão cada dia mais ultrapassadas, em virtude das crianças, jovens e adolescentes estarem imersos a esse universo de informações e interação.

Diante desse contexto, são impostos aos docentes novas práticas alinhadas não somente às tecnologias, mas que vão além da transmissão de conteúdos.

Com todos esses desafios que são impostos à educação ao longo dos anos, 2020 foi um ano que trouxe, talvez o maior desafio dos últimos tempos, o mundo foi acometido pela pandemia Covid19, impondo o isolamento social. De uma hora para outra os

\footnotetext{
${ }^{42}$ Prefeitura Municipal de Nova Mamoré-RO.

43 Mestranda em Educação do Programa Pós-graduação Scricto Sensu em Educação, Mestrado Acadêmico em Educação.

${ }^{44}$ Mestra em Educação do Programa Pós-graduação Scricto Sensu em Educação, Mestrado Acadêmico em Educação.
} 
docentes tiveram que transformar sua sala de aula em uma sala virtual.

A pandemia da Covid-19 trouxe profundas mudanças para a sociedade, a humanidade teve que se adequar as tecnologias digitais da informação e comunicação. Muitos já estavam acostumados no seu dia a dia a lidarem com as tecnologias, outros lidavam de forma menos formal.

Nesse cenário com as restrições ocasionadas pela pandemia, devido ao distanciamento social vivenciado pela sociedade, de uma hora para outra, empresas, prestadoras de serviços, igrejas, restaurantes e outros segmentos da sociedade tiveram que se apropriar das tecnologias digitais para ofertar os seus serviços.

E escola não foi diferente, os docentes tiveram que reinventar e ressignificar suas práticas a partir do ensino remoto com a utilização das tecnologias digitais da informação e comunicação.

Nessa perspectiva a presente pesquisa estuda sobre as práticas docentes nas escolas multisseriadas do campo do município de Nova Mamoré, com o objetivo de analisar as dificuldades e desafios encontrados pelos docentes no tocante à reinvenção de suas práticas a partir do ensino remoto.

\section{O USO DAS TECNOLOGIAS NA EDUCAÇÃO EM TEMPOS DE ENSINO REMOTO}

Com os avanços científicos, sobretudo das tecnologias digitais da comunicação e informação (TDIC) mudanças profundas ocorreram na sociedade.

É notório que as tecnologias provocaram mudanças no modo de vida, alterando comportamentos e o modo de interação 
entre as pessoas. Os jovens, adultos, crianças e idosos estão conectados a todo momento, vivenciado desse modo o acesso as mais variadas informações.

Nesse sentido, como não podia ser diferente o processo educacional também se altera com o advento das tecnologias e com seus reflexos sociais, econômicos, culturais, uma vez que a escola se constitui também como fonte de comunicação e produção do conhecimento.

Desse modo, as tecnologias, sobretudo as digitais, oferecem hoje aos professores uma infinidade de recursos que podem ampliar a relação ensino-aprendizagem. Elas possibilitam aos educadores, ultrapassar o ambiente físico da sala de aula e atingir outros espaços, que são muitas vezes bem mais interessantes e atrativos.

É importante destacar que as tecnologias devem ser pensadas como uma nova metodologia, na perspectiva de promover a interação dos alunos de forma ativa com o conteúdo de ensino.

Nessa perspectiva Moran (2015),

As metodologias precisam acompanhar os objetivos pretendidos. Se queremos que os alunos sejam proativos, precisamos adotar metodologias em que os alunos se envolvam em atividades cada vez mais complexas, em que tenham que tomar decisões e avaliar os resultados, com apoio de materiais relevantes. Se queremos que sejam criativos, eles precisam experimentar inúmeras novas possibilidades de mostrar sua iniciativa (Moran, 2015, p. 3).

Como podemos constatar o autor enfatiza a importância de se adotar metodologias em que os alunos são desafiados a pensar, criar, interagir e refletir durante a produção e construção do conhecimento. 
Sobre essa questão Freire (2013) destaca a necessidade de superação da concepção de educação bancária, onde o conteúdo é apenas depositado na cabeça do aluno.

Sabemos que em uma sociedade onde há circulação de informações de forma aberta, e que é possível aprender de diversas formas, com várias pessoas e com horários flexíveis, é inconcebível os métodos tradicionais que privilegiam a transmissão de conhecimento.

Essa realidade foi alterada nas instituições educacionais com as mudanças intensas causadas pela crise da pandemia do Coronavírus, a educação teve que ser reinventada para que os alunos não ficassem sem aula e as atividades educacionais fossem mantidas.

De uma hora para outra os professores tiveram que adaptar seus conteúdos para um formato on-line, no entanto, muitas dúvidas surgiram quanto ao caminho a ser seguido, pois nenhum sistema estava preparado para tal mudança.

O Conselho Nacional de Educação (CNE) editou medidas através da publicação do Parecer 05/2020, de 5 de abril de 2020, o qual traz orientações sobre o cômputo de carga horária pedagógica com atividades não presenciais e também a reorganização dos calendários escolares, os quais devem trabalhar com a carga horária mínima de 800 horas.

Sobre atividades não presenciais o Parecer propõe "a realização de atividades pedagógicas não presenciais (mediadas ou não por tecnologias digitais de informação e comunicação), e considera que "são aquelas a serem realizadas pela instituição de ensino com os estudantes quando não for possível a presença física destes no ambiente escolar." (CNE, p. 6) 
Com isso o parecer visa minimizar os impactos do acesso às aulas ocasionadas pelo isolamento social. Em seu bojo o referido parecer traz também a preocupação da dificuldade de acesso aos meios digitais por muitos alunos, propondo a oferta de atividades mediadas pelas mídias digitais e quando não for possível o acesso pelos alunos, a escola deverá propor atividades impressas, etc.

Essa realidade pode ser reforçada pelos dados apresentados a seguir, em que confirmam que;

De acordo com um levantamento realizado pela Pesquisa Nacional por Amostra de Domicílios Contínua Tecnologia da Informação e Comunicação (Pnad Contínua TIC) em 2018, 46 milhões de brasileiros não possuem acesso à internet. Dados que representam, uma parcela da população não acessa por não saberem manusear, por falta de interesse e conhecimento, além da acessibilidade devido ao alto custo financeiro ou por não possuir os equipamentos necessários para utilizá-la (Tokarnia, 2020).

Como podemos constatar os desafios são muitos, dentre eles a falta de acesso à internet por parte de muitos alunos, muitas famílias não possuem equipamentos como computador, a dificuldade de manusear os aplicativos por falta de conhecimento, etc.

Um outro desafio vivenciado neste contexto da pandemia foi o ensino de uma maneira geral precisou se ressignificar pensando assim, em uma prática pedagógica permeada pelas tecnologias digitais. Dentre os desafios e incertezas professor e professoras tiveram que aprender a utilizar plataformas digitais, aplicativos, redes sociais e outros. 
Para fazer o uso eficaz tiveram que buscar iniciativas para selecionar as formas tecnológicas que levassem o conhecimento aos seus alunos, pois:

Os professores têm um papel de destaque na preparação dos alunos para lidarem com essa quantidade de informação de maneira crítica. A integração das TIC na Educação, por si só, não garante eficácia pedagógica (Campos; Paula, 2020, p. 7).

Mediante todos os 'bombardeios' provocados pela Covid-19, a educação precisou, em pleno século XXI, criar um 'abrigo' elaborado e, com trabalhos de 'escavação', fazer 'trincheiras' para poder permitir a circulação do conhecimento, que não pode 'morrer (Oliveira; Silva; Silva; 2020, p. 31).

Deste modo, foi necessário repensar a prática pedagógica, aprender a utilizar as tecnologias digitais e integrá-las ao ensino. E a escola, teve que reformular sua proposta pedagógica e calendário escolar de 2020.

Considerando, a emergência de adotar medidas de enfrentamento da Covid-19 e, ao mesmo tempo, garantir o direito a educação e a aprendizagem a todos estudantes, que o ensino remoto foi normatizado em todo o Brasil com intuito de não disseminar o vírus a um grupo vasto de professores e alunos de norte a sul, tanto provenientes de escolas públicas como privadas.

Desta forma, iniciou uma longa trajetória a cegas de ter que pensar quais as tecnologias ou recursos digitais e impressos poderiam ser utilizado para que se chegasse o ensino nas casas de todos os alunos. 


\section{ENSINO REMOTO NA PRÁTICA DOCENTE NAS ESCOLAS MULTISSERIADAS DO MUNICÍPIO DE NOVA MAMORÉ}

Em Nova Mamoré, essa realidade ainda é mais peculiar nas escolas multisseriadas do campo, onde o acesso à internet é, na maioria dos casos, via rádio, o que torna o acesso mais lento.

Conforme informações do Setor Pedagógico da Secretaria Municipal de Educação (Semed), o município tem 38 escolas multisseriadas, com o total de 402 alunos matriculados em 2020. 358 alunos foram atendidos remotamente; 29 alunos foram atendidos presencialmente e apenas 10 alunos não foram atendidos (Nova Mamoré, 2020).

Vale ressaltar que essas escolas são distantes da zona urbana, funciona com alunos da educação infantil e fundamental I juntos na mesma sala.

Sem dúvida, os desafios para os professores dessas turmas ainda são maiores do que das turmas não multisséries, pois além de terem que repensarem suas práticas a partir do uso de tecnologias e metodologias que possam atender ao ensino remoto, os docentes ainda têm que administrar o seu tempo de planejamento para atender às diversas séries da turma.

Para atender às exigências da legislação emanada pelo CNE, a Resolução n. 69/2020-CME/NM/2020 expedida pelo Conselho Municipal de Educação de Nova Mamoré, normatizou a organização do calendário escolar 2020 e as aulas não presenciais. A Secretaria Municipal de Educação de Nova Mamoré, após o posicionamento do Conselho emitiu de abril a novembro de 2020, (3) três instruções normativas que orientou as escolas nas questões administrativas e pedagógicas. 
Estes documentos nortearam as ações que se desenvolveram como o preparo de material impresso a ser entregue aos pais ou responsáveis dos alunos. E quando se trata de escolas multisseriadas os desafios são ainda maiores, primeiro por estar localizadas na zona rural do município, segundo os alunos não têm acesso à internet o que se descartaria a possibilidade de plataformas digitais como o Google Classroom, Zoom, Google Meet, etc.

Neste sentido, o professor mesmo sem tempo para pensar precisou agir mesmo sem os aparatos tecnológicos, diante da suspensão das aulas.

O presente estudo irá a seguir, fazer uma análise dos principais desafios e possibilidades encontradas e enfrentadas pelos professores dessas escolas multisseriadas durante as aulas remotas.

\section{Metodologia ADOTADA}

Foi realizada uma pesquisa qualitativa, por meio de revisão bibliográfica. Sobre a pesquisa qualitativa, Bogdan e Biklen (1994, p. 16), destacam que:

Os dados recolhidos são designados por qualitativos, o que significa ricos em pormenores descritivos relativamente a pessoas, locais e conversas, e de complexo tratamento estatístico. As questões a investigar não se estabelecem mediante a operacionalização de variáveis, sendo, outrossim, formuladas com o objetivo de investigar os fenómenos em toda a sua complexidade e em contexto natural [...] privilegiam, essencialmente, a compreensão dos comportamentos a partir da perspectiva dos sujeitos da investigação.

Como podemos constatar essa abordagem de pesquisa possibilita ao pesquisador analisar o objeto de estudo com maior 
profundidade, uma vez que permite evidenciar suas causas, efeitos e relação com o meio ao qual está inserido.

A pesquisa bibliográfica consistiu na leitura minuciosa de livros e artigos científicos sobre o tema pesquisado.

Utilizou-se como técnica para coleta de dados questionários virtuais com 5 questões abertas e fechadas, aplicados para 10 professores de escolas multisseriadas do município de Nova Mamoré-RO. Responderam ao questionário 7 professoras.

\section{AMOSTRA COM OS PROFESSORES DE ESCOLAS MULTISSERIADAS}

Para coleta da pesquisa foi aplicado questionário online com questões abertas e fechadas, no que se refere aos dados pessoais participaram 7 professoras.

Ao perguntarmos sobre qual o tipo de internet que as professoras utilizam para as aulas remotas, obtivemos as seguintes respostas, 50\% usam via Rádio, 16,7\% Fibra Óptica, 16,7\% Banda Larga e 16,7\% dados móveis.

Figura 1: Qual o tipo de internet que utiliza para as aulas remotas?

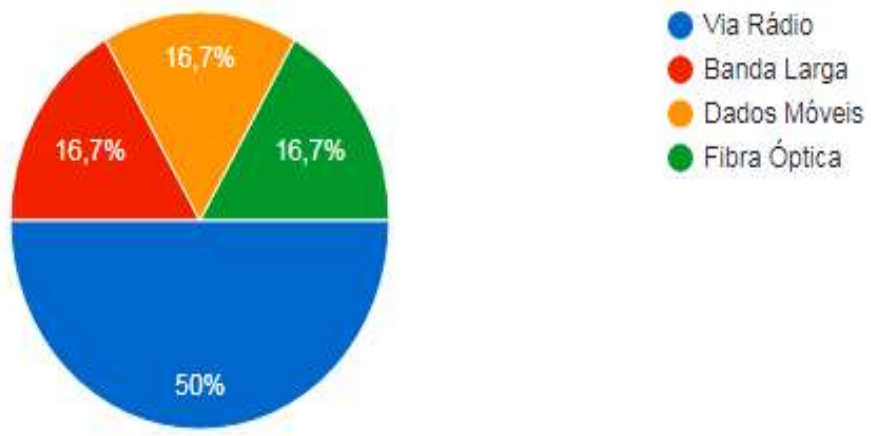

Fonte: dados das pesquisadoras 
A saber, "[...] a Internet se constituiu como um poderoso recurso de informação e comunicação, que vem transformando o modo de vida e as relações humanas em todas as suas dimensões, tais como política, social, econômica e inclusive educacional [...] (Campos; Paula, 2020, p. 6).

De 2017 para 2018, o percentual de utilização da Internet nos domicílios subiu de 74,9\% para 79,1\%. O crescimento mais acelerado da utilização da Internet nos domicílios rurais, em todas as regiões - de $\mathbf{4 1 , 0} \%$ em 2017 para 49,2\% em 2018 - ajudou a reduzir a diferença em relação à área urbana, onde a utilização da internet subiu de 80,2\% para 83,8\% (Agência IBGE Notícias, 2020).

Ademais, com a suspensão das aulas presenciais e a necessidade de aulas remotas, acreditamos que estes números tenham se elevado. Educação, por si só, não garante eficácia pedagógica (Campos; Paula, 2020, p. 7).

Podemos pontuar pelas respostas obtidas que a maior dificuldade é o acesso à internet devido à má conexão na região, não temos dados confirmativos de indicadores de qualidade, mas podemos afirmar como cliente deste sistema. Em se tratando daqueles residentes na zona rural da Amazônia Ocidental, assim que se encontra estas bravas rondonienses professoras de escolas multisseriadas.

Dando continuidade, perguntamos sobre quais os recursos tecnológicos que usam para encaminhar as atividades e aulas, dentre as opções tinha livro didático e atividades impressas, Youtube e aplicativo de conferências e por último WhatsApp, as professoras poderiam marcar mais de uma resposta logo, obtivemos os seguintes resultados: duas professoras marcaram as três opções, 
uma professora marcou Youtube e aplicativo de conferências e outra professora marcou duas opções, livros e atividades impressas.

Ressaltamos que houve duas respostas não registradas no formulário online, devido uma correção que fizemos. A ordem das respostas foi alterada e as professoras, na ocasião, já tinham respondido, logo o sistema não registrou.

Neste sentido, "o desafio do professor, portanto, é observar essas mudanças para compreendê-las, no âmbito de seu trabalho pedagógico, a fim de que possa ressignificá-lo, atualizá-lo" (Oliveira; Silva; Silva, 2020, p. 31).

Dando continuidade, perguntamos o que você destacaria de aprendizado neste período de aulas remotas. Destacaremos a fala das professoras, mas não atribuímos nenhuma identificação.

Socialização Cultural e Superação em práticas tecnológicas;

A capacidade de ensinar sem a presença física do educando;

Uso de novos aplicativos no celular, novas ferramentas no computador. Desenvolvimento de atividades por vídeos e por áudio;

O manuseamento da tecnologia;

A oportunidade de novos conhecimentos referente as novas tecnologias que muitas das vezes não era usada com tanta frequência no ensino presencial.

Podemos concluir, que as aulas remotas fizeram com que muitos professoras e professores fossem obrigados a desbravar o desconhecido mesmo sem as armas, pois muito não tinha computadores, celulares e internet. Certamente neste campo de batalhas sem as trincheiras, muitos criaram suas armas ou adaptaram, tudo pensando no ensino e aprendizado do alunado. 
Neste emaranhado de erupções vulcânicas de informações, o professor tem o papel imprescindível de mediador para que este aluno não perca o vínculo com a escola e assim seja garantido o direito ao aprendizado.

\section{CONSIDERAÇÕES FINAIS}

O objetivo desta pesquisa foi analisar as dificuldades e desafios encontrados pelos docentes das escolas multisseriadas do município de Nova Mamoré para a realização do ensino remoto.

Com a presente pesquisa mapeamos as dificuldades quanto ao tipo de internet que os professores utilizam para dar suas aulas remotas, e deste quais os maiores desafios, como também, quais os recursos didáticos para realização das atividades e aulas e qual o aprendizado se poderia ser destacado neste período de ensino remoto.

Observamos pelo questionário online que as maiores dificuldades é o acesso à internet, aliado a possuir equipamento tecnológico para o preparo das aulas e ter de construir habilidades a sós, pois muitas tiveram que aprender, de modo isolado, a manusear cada recurso tecnológico.

Em suma, podemos aferir as dificuldades destes professores rurais de escolas multisseriadas. As demandas a serem atendidas exigirão esforço contínuo, pois estão a problematizar, mediar e incentivar a construção do conhecimento para atender alunos de maneira a formar sujeitos críticos e reflexivos da sociedade da qual pertence e que não será a mesma no pós-Covid.

Muito ainda precisa ser feito para o devido atendimento na modalidade de ensino remoto. Primeiro, deve ser disponibilizado computadores ou notebook aos professores e alunos de baixa 
condição financeira. Segundo, que os professores tenham acesso à internet, disponilizado por meio de recursos públicos, pois a maioria não tinha e se viram obrigados a contratar, com recursos próprios, operadoras de internet para terem acesso e assim dar suas aulas remotas.

Deste modo, esperamos que nossos desbravadores de terras desconhecidas possam ter formação continuada; que consigam reconstruir teorias e práticas e assim ressignificar sua prática integrando tecnologia e aprendizado.

Ao finalizar este artigo destacamos que não tivemos a pretensão de esgotar o assunto. Recomendamos que futuros trabalhos possam dar continuidade à pesquisa, ampliando-a.

\section{REFERÊNCIAS}

AGÊNCIA IBGE NOTÍCIAS. PNAD Contínua TIC 2018: Internet chega a 79,1\% dos domicílios do país. Publicado em 29 de abril de 2020. Disponível em: <https://agenciadenoticias.ibge.gov.br/>.

ALVES, Lynn. Educação remota: entre a ilusão e a realidade. Interfaces Científicas. Aracaju v. 8, n. 3, p. 348-365, 2020.

BOGDAN, R.; BIKLEN, S. Investigação qualitativa em educação: fundamentos, métodos e técnicas. Portugal: Porto Editora, 1994.

BRASIL, CONSELHO NACIONAL DE EDUCAÇÃO. Reorganização do Calendário Escolar e da possibilidade de cômputo de atividades não presenciais para fins de cumprimento da carga horária mínima anual, em razão da Pandemia da COVID-19.

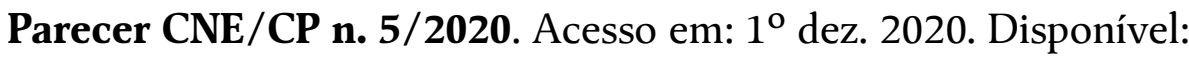
$<$ http://portal.mec.gov.br/index.php?option=com_docman\&view $=$ download $\&$ alias $=14511-$ pcp005-20\&category_slud $=$ marco 2020-pdf 8 Itemid $=30192>$. 
CAMPOS, Cesar Ferraz; PAULA, Luciano Bernardes de. O uso da internet na educação e o panorama brasileiro atual. Elocução/Revista Científica da Faex, edição 17, ano 9, 2020.

FREIRE, Paulo. Pedagogia da autonomia: saberes necessários à prática educativa. 13. ed. Rio de Janeiro: Paz e Terra, 20013.

MORAN, José. Mudando a educação com metodologias ativas. In Coleção Mídias Contemporâneas. Convergências Midiáticas, Educação e Cidadania: aproximações jovens. Vol. II] Carlos Alberto de Souza e Ofelia Elisa Torres Morales (orgs.). PG: Foca FotoPROEX/UEPG, 2015. Disponível em: <www2.eca.usp.br/ moran/wpcontent/uploads/2013/12/mudando_moran.pdf $>$. Acesso em: 2 dez. 2020.

OLIVEIRA, Sidmar da Silva; SILVA, Obdália Santana Ferraz; SILVA, Marcos José de Oliveira. Educar na incerteza e na urgência: implicações do ensino remoto ao fazer docente e a reinvenção da sala de aula. Interfaces Científico, Aracaju, v. 10, n. 1, p. 25-40. Número Temático, 2020.

TOKARNIA, Mariana. A Pesquisa Nacional por Amostra de Domicílios Contínua - Tecnologia da Informação e Comunicação (Pnad Contínua TIC) 2018. Disponível em $<$ https://agenciabrasil.ebc.com.br/economia/noticia/202004/um-em-cada-quatro-brasileiros-nao-tem-acesso-internet>. Acesso em: 30 nov. 2020. 


\title{
9
}

\section{O CORPO COMO ESPAÇO DE INTERDISCIPLINARIDADE: $O$ DIÁLOGO ENTRE A FILOSOFIA E A EDUCAÇÃo FÍSICA}

\author{
Alyne de Fátima Lourenço dos Santos ${ }^{45}$ \\ Augusto Rodrigues de Sousa ${ }^{46}$ \\ João Paulo Silva Martins ${ }^{47}$
}

\section{INTRODUÇÃo}

Há alguns anos temos nos confrontado com o imenso desafio de proporcionar processos educativos que sejam significativos na vida e na atuação profissional dos estudantes. A experiência de outros países na concretização da educação integral enfatiza como a pedagogia brasileira, apesar da vasta produção literária, na prática, ainda reproduz processos educacionais herdados dos jesuítas e do militarismo ${ }^{48}$.

A anedota que se conta é de que se descongelássemos um médico do século XVI e o deixássemos a sós em uma sala de

45 Mestra em Psicologia pela Universidade Federal de Rondônia. Docente no Instituto Federal de Rondônia (IFRO). Contato: Alyne.santos@ifro.edu.br.

46 Mestre em Educação Profissional e Tecnológica pelo Instituto Federal de Rondônia (IFRO). Contato: augustodb@gmail.com.

47 Mestre em Filosofia pela Universidade Federal de Mato Grosso (UFMT). Docente junto à Secretaria de Estado de Educação e Qualidade de Ensino (SEDC) do Amazonas. Contato: joao.filoss@gmail.com.

48 Ao propor o mapeamento das teorias de aprendizagem, Milhood (2013) tece uma teia de diversas abordagens e destaca como o "instrucionismo" além de não se relacionar com nenhum pensador ou campo de conhecimento educacional, é a base de práticas de doutrinação, isto é, transmissão de conhecimentos sem a necessidade de ampliar a capacidade crítica e dialógica dos estudantes. Todas as demais teorias da aprendizagem se pautam no princípio da relação entre professor e aluno e na autonomia intelectual do estudante. 
cirurgias atual, ele se sentiria perdido e não teria sequer noção do local em se que se encontrava. Se a mesma experiência fosse reproduzida com um professor do mesmo século, descongelado em uma sala de aulas atual, ele continuaria a aula exatamente do ponto em que parou há séculos atrás, sem sequer notar que os alunos mudaram. A estrutura da sala de aulas, a forma de organização dos conteúdos e o padrão do professor como detentor de todo conhecimento continua a mesma (Leitão, 2015).

A própria filosofia moderna hegemônica e colonizadora se pauta na ideia de fragmentação do real como ponto de partida do conhecimento, tal como se preconiza no método científico hegemônico. Desse modo, a disciplina se apresenta como "a forma histórica de produzir e organizar conhecimento” que se materializa em sala de aula na disposição linear, sequencial e dosada do saber organizado (Moraes; Kuller, 2016).

Nesse sentido, romper com a hegemonia da modernidade e do conhecimento linear e abrir-se para a complexidade do mundo e para a assunção de um paradigma do conhecimento como complexidade e interligação é o imenso desafio que os complexos problemas ambientais, sociais e políticos convidam a escola a assumir (Morin, 2003).

Já no início do século XX, o filósofo pragmático John Dewey (1979) propunha a possibilidade de integração dos conhecimentos escolares em vista do fortalecimento da democracia e do progresso social. Para Dewey, a educação deve ser integral porque a vida real assim o exige, ou seja, no cotidiano, os desafios não se apresentam divididos em disciplinas, mas exigem da pessoa a capacidade de integrar diferentes saberes e ser efetivo na resolução de problemas.

Para Santomé (1998), a interdisciplinaridade é cada vez mais urgente diante do processo de globalização e complexificação do 
mundo do trabalho. No passado, a revolução industrial favoreceu a fragmentação do conhecimento a partir da praticidade da linha de montagem, no qual o trabalhador não necessitava conhecer todo o processo produtivo, mas apenas executar atividades pontuais.

No cenário atual, marcado pela automatização de procedimentos simples, o mundo do trabalho começa a exigir profissionais cada vez mais qualificados e com a capacidade de utilizar múltiplas inteligências e conhecimentos na resolução de problemas. Desse modo, ao considerar que um dos objetivos da educação seja preparar para o mundo do trabalho, não faz sentido continuar reproduzindo modalidades de ensino que não correspondem mais às necessidades do cenário atual.

É preciso reconhecer, no entanto, que "a interdisciplinaridade é um objetivo nunca completamente alcançado e por isso deve ser permanentemente buscado" (Santomé, 1998, p. 66) e exige a redescoberta de dimensões intelectuais satanizadas pelo racionalismo e positivismo modernos, tais como a imaginação, a criatividade, a intuição, a incerteza, o encanto, etc.

Ao buscar apresentar as modalidades possíveis de interdisciplinaridade, Santomé (1998) faz uma rica revisão bibliográfica de uma série de autores que contribuíram para se pensar o conceito, mas salienta que de todas as classificações possíveis a que se tornou mais conhecida e divulgada foi a proposta por Erich Jantsch no Seminário da OCDE de 1979, que considera as seguintes modalidades de integração de conhecimentos:

A multidisciplinaridade: nível mais baixo de integração, que consiste na mera justaposição de matérias diferentes; 
A pluridisciplinaridade: a justaposição de disciplinas mais ou menos próximas que trabalham de forma cooperativa acerca de um tema.

A disciplinaridade cruzada: uma disciplina toma para si conceitos, métodos, procedimentos, etc. de outras áreas, mas continua sendo a matéria principal;

A interdisciplinaridade propriamente dita, no qual as disciplinas se põem em contato e passam a depender claramente umas das outras;

A transdisciplinaridade: modalidade em que desaparecem as fronteiras entre as disciplinas e já se pode falar do aparecimento de uma nova macrodisciplina que integra todas as demais em um sistema unificado.

Santomé (1998) salienta que a experiência indica como a fragmentação disciplinar faz com os alunos não consigam relacionar espontaneamente os conhecimentos entre si e com a vida cotidiana, enquanto a interdisciplinaridade favorece que os alunos se tornem mais motivados no processo de aprendizagem e resolvam problemas complexos que exigem a interligação de diferentes saberes.

No Brasil, tem-se promovido com bastante ênfase a implementação de currículos integrados como principal modalidade de interdisciplinaridade, especialmente na educação profissional. Acredita-se que, dessa forma, se oferece uma educação mais ampla e integral para a classe trabalhadora, possibilitando a emancipação dos sujeitos e melhor inserção no mundo trabalho. Entretanto, o que se tem notado na prática é que as modalidades de ensino integrado têm se materializado na simples justaposição de disciplinas da educação básica com disciplinas técnicas, enquanto as poucas experiências de integração têm-se dado mais pela 
atuação espontânea de educadores do que por esforço institucional, que oficialmente mantém a estrutura disciplinar na grade curricular e nas modalidades de avaliação (Moraes; Kuller, 2016). A proposta do projeto aqui apresentado trata-se exatamente de mais um desses esforços espontâneos que visa ajudar a instituição a ampliar os horizontes e assumir mais concretamente o que se propõe teoricamente.

\section{UM OBJETO DE ESTUDO EM COMUM: O SER HUMANO}

Partindo da premissa de que a interdisciplinaridade é uma ótima estratégia para tornar os processos educativos mais humanizados, cabe refletir a respeito do que nos torna "ser humano" e fazer algumas considerações sobre o conceito de homem. Para nos ajudar nessa reflexão vale trazer as contribuições de Duarte (2013), que ao discorrer sobre o gênero humano (categoria histórica) a distingue de espécie humana (categoria biológica). Explicita, ainda, sobre o processo de transposição da hominização para humanização. Entende-se por hominização as transformações genéticas ocorridas na espécie humana ao longo da história, que desde o homo sapiens não se observa modificações expressivas. Por outro lado, em termos comportamentais, o gênero humano passou por mudanças significativas, as diversas maneiras de organização social, a apropriação dos instrumentos pertinentes a cada um desses modelos, e a mediação estabelecida entre os indivíduos de forma coletiva, contribuíram para a formação do psiquismo humano. Esse processo histórico, social e dialético denomina-se humanização. $\mathrm{O}$ autor não descarta a importância dos aspectos físicos, porém enfatiza que esses elementos são direcionados através da prática social. Pelo disposto podemos afirmar que é no coletivo que nos tornamos humanos, e constituímos nossa individualidade. 
A reflexão sobre o que é ou quem é o homem no ambiente escolar fica a cargo das humanidades que, cada componente curricular a seu modo, discorrerá sobre a temática. No entanto, quando se descreve o homem como "animal racional", por exemplo, não conseguimos atender à complexidade do que é o ser humano, $\mathrm{e}$ ainda que - aos modos da Antropologia de Kant - definíssemos separadamente as categorias da animalidade e da racionalidade um elemento fundamental ainda ficaria por ser considerado, a saber, a cultura. Compreender o conceito e a aplicabilidade da cultura fazse fundamental para que consigamos compreender o ser humano. Como nos indica Laraia fazendo referência a Confúcio: "a natureza dos homens é a mesma, são seus hábitos que os mantêm separados” (1986, p. 10).

Para o pensador indígena Ailton Krenak (2019), a ideia de "ser humano" é uma conceituação criada como autorretrato do sujeito moderno colonizador. Desse modo, a humanidade se apresenta como um clube muito restrito, que durante muitos séculos foi fechado para diversos sujeitos e povos e limitado ao pleno acesso de homens-brancos- europeus-cristãos. Negros, indígenas, judeus, mulheres, não tinham acesso total ao clube da "humanidade" numa escala valorativa e cromática (de melanina) que determinava o quanto os corpos se aproximavam dos animais ou dos "humanos". A indicação de Krenak nos convida a ampliar a carga conceitual de humanidade e reconhecer que o Ocidente construiu essa categoria a partir de suas próprias lógicas de dominação, materializadas na colonização, no racismo e no patriarcado.

Quando pontuamos a necessidade de ampliação conceitual, falamos em reconhecer outras possibilidades de concepção do ser humano, visto que, no decorrer da história, apenas o homem 
europeu foi tomado como referência e parâmetro para se avaliar o que é ou não uma característica humana.

Peixoto (2012, p. 46), ao apresentar as definições de homem à luz da fenomenologia de Merleau-Ponty, além do conceito nos apresenta uma sinopse da ideia de homem no decorrer da história da filosofia:

[Merleau-Ponty] considera que o ser humano é constituído por duas substâncias distintas: a substância pensante, de natureza espiritual, que é o pensamento; e a substância extensa, de natureza material, que é o corpo. Mantém, com isso, o dualismo psicofísico instituído por Platão. Difere deste por tratar o corpo como corpo-objeto, associado à ideia mecanicista do ser humano-máquina. Platão defende o pressuposto de que a alma, antes de ser introduzida no corpo, teria vivido no mundo puramente espiritual, mundo perfeito, mundo das ideias. Ao se unir ao corpo, ela se degrada, vindo a ter influência do mundo dos sentidos. Com isso, ela passa a ter duas dimensões: uma superior (a alma intelectiva) e outra inferior (a alma do corpo). Esta última é irracional e está dividida em duas partes: a irascível, que é impulsiva, localizada no peito; e a concupiscível, centrada no ventre e voltada para os desejos de bens materiais e apetite sexual.

Além do que foi destacado, é importante considerar que enquanto a dualidade corpo e alma revela o trauma do sujeito ocidental, cindido em si mesmo (Birman, 2001), aos demais sujeitos o colonizador não impõe a dualidade, visto que os considera destituídos de alma/mente. Dessa forma, ao negro e ao indígena, a destituição da alma e da racionalidade, realizada como um processo de epistemicídio, isto é, de apagamento da racionalidade e, consequentemente de humanidade, permitiu a animalização e exploração total sem escrúpulos. É tão verdade, que inclusive 
luminares do humanismo ocidental moderno, tais como Kant e Voltaire, descrevem o negro como incapaz de qualquer pensamento sofisticado, puro corpo, sensualidade, fetiche, força brutal, enfim, animalidade.

\section{POR QUE O CORPO IMPORTA?}

Para Richard Sennett (2001), a civilização ocidental apresenta uma história conturbada em relação ao corpo, inicialmente desvalorizado pela exacerbada ênfase na racionalidade e no desrespeito à diversidade e dignidade dos corpos considerados diversos; e atualmente hipervalorizado por conta da acelerada acumulação do capital e dos padrões de consumo. Nesse ambiente, o corpo se torna o centro de todos os esforços e o sujeito, insuflado pela velocidade, principal elemento da pós-modernidade, não tem tempo de construir identidade, mas apenas de modelar aparências, materializadas em corpos ideais, mesmo que em detrimento da saúde física e mental e do equilíbrio espiritual.

Por outro lado, o corpo não é negado em outros grupos humanos, nem compreendido em luta com a racionalidade e a alma. Muniz Sodré (2014) salienta como na cosmovisão africana, não possuímos um corpo, mas somos um corpo e mais ainda, que a própria racionalidade é corpórea. $\mathrm{O}$ corpo, nesse sentido, não se sujeita ao capitalismo e sua exploração no consumo e na força de trabalho, nem ao paradigma europeu do racionalismo que nega a corporeidade ou a separa das identidades individuais.

Nas culturas tradicionais apresenta-se o "si mesmo corporal", ou seja, o corpo é um microcosmo no qual se interligam elementos físicos, químicos, minerais, afetos, relações, ancestrais. Por ser microcosmo, o corpo está necessariamente ligado à comunidade e ao cosmos total, a pessoa está indissociavelmente 
ligada à totalidade comunitária e sagrada. Nesse sentido, pode-se compreender como o samba, por exemplo, não se trata apenas de um gênero musical, mas de uma tecnologia de agregação do corpo e da comunidade através do ritmo.

Para a pensadora afro-americana bell hooks ${ }^{49}$ (2017, p. 253), como professores somos formados na herança da dualidade metafísica ocidental, aceitando sem questionamentos a cisão entre corpo e mente. De fato, "crendo nisso, as pessoas entram em sala de aula para ensinar como se apenas a mente estivesse presente e não o corpo".

Assumir a corporeidade como instrumento pedagógico é, nesse sentido, uma prática decolonial e de resistência dos subalternos, que acreditam na inteligência corporal e na capacidade de transformar o ato pedagógico em um ato "erótico" no sentido que envolve não apenas racionalidade, mas paixão, entusiasmo e afeto nas relações criadas em sala de aula.

\section{ALGUMAS INDICAÇõES SOBRE PRÁTICA INTERDISCIPLINAR: Projeto CoRPoral-Mente}

Ao assumir a prática da interdisciplinaridade e a temática do corpo como campo de encontro entre a filosofia e a educação física, assumimos a necessidade de se compreender dimensões até então excluídas do espaço escolar, como salientado por Santomé (1998) e bell hooks (2017): a criatividade, a brincadeira, a descontração, a ternura, a espontaneidade, etc. Nesse sentido, reforça-se que o projeto não se resumiu tão somente em "falar sobre" o corpo, mas

\footnotetext{
${ }^{49}$ bell hooks é o pseudoanônimo da educadora feminista Gloria Jean Watkins, é escrito em letras minúsculas para deslocar o foco da figura autoral para as ideias que ela propõe.
} 
vivenciar e refletir a própria corporeidade a partir das práticas propostas: a dança regional, as brincadeiras de infância, o toque terno no colega, a integração do corpo e da mente na prática de yoga, dentre outras.

Educação Física e Filosofia presumivelmente parecem trilhar caminhos opostos, numa visão dicotômica, estabelece-se um antagonismo quanto à natureza das mesmas, pressupõe-se que uma seja de competência teórica e a outra prática. Nesse sentido resgatase o antigo paradoxo corpo X mente. Logo, o desafio na elaboração do projeto foi encontrar um ponto de conexão entre as ciências supramencionadas, diante da problemática elegeu-se a corporeidade e seus desdobramentos como objeto de estudo.

Após identificação do eixo norteador do trabalho a ser desenvolvido, o projeto foi realizado numa turma de 38 alunos de $2^{\circ}$ ano do Curso Técnico em Edificações do Instituto Federal de Educação, Ciência e Tecnologia de Rondônia - Porto Velho Calama, tendo como objetivo a integração das disciplinas, a fim de desvelar o questionamento sobre a insatisfação com a imagem corporal, fenômeno recorrente na adolescência, e assim propor a discussão sobre concepção de corpo, com o intuito de conduzir os discentes à desconstrução e reelaboração de conceitos, à ampliação das vivências corporais, destarte provocar a autognose e constituição de identidade. A execução do projeto decorreu entre os meses de maio e novembro de 2018, com três aulas semanais ininterruptas ministradas com a presença dos dois professores (Educação Física e Filosofia) simultaneamente. Fato inédito para a turma envolvida, o que reverberou positivamente em razão da atenuação da quantidade de instrumentos avaliativos, do resgate dinâmico de conceitos filosóficos, da reflexão crítica da corporeidade e do fortalecimento de pertencimento do grupo. 
A fim de atender o calendário acadêmico do câmpus o planejamento do projeto foi organizado por bimestres, tendo início a partir do segundo bimestre letivo no qual, os professores propuseram a reflexão sobre a insatisfação com a imagem corporal, esmiuçaram este conceito e ponderaram a respeito da construção social em torno dessa temática.

Desse modo, para o desenvolvimento da proposta tivemos a exibição de filmes, estudos aprofundados de textos relacionados e debates com intuito de desvelar e fomentar o conhecimento da imagem corporal pessoal e comunitária na turma.

Mediante primeiro contato, foi apresentado o filme Teoria de Darwin no qual os alunos puderam observar uma percepção diversa, de caráter científico, do surgimento (evolutivo) desse corpo e de suas percepções. Baseado no filme foi possível trabalhar a questão da autoimagem no jogo das percepções corporais e com a atividade denominada "Espelho" os alunos foram orientados a falar um pouco de si mesmo, culminando numa discussão intitulada "quem sou eu". A atividade proporcionou um momento de forte interação grupal e melhor conhecimento interpessoal.

Dentre os filmes reproduzidos refletimos a questão da insatisfação corporal e da construção da sexualidade embasado no drama "A garota dinamarquesa". No debate em grupo, os alunos destacaram como esses temas ainda permanecem como um tabu em nossos ambientes sociais, marcados por uma percepção de mundo e dos corpos numa perspectiva cristã, burguesa, branca, heteronormativa e padronizada.

A reflexão da percepção do corpo na sociedade e da influência das construções sociais e culturais sobre as imagens 
corporais foi aprofundada a partir da leitura do livro "Sociologia do Corpo". Os alunos, divididos em grupo, ficaram responsáveis por capítulos específicos da obra. Dessa forma foi pedido para que cada grupo grifasse as partes mais importantes ou que lhe chamassem atenção e produzissem um resumo final. E ainda de maneira individual e com o suporte da disciplina OP3 (Orientação para Prática e Pesquisa) cada discente elaborou uma resenha crítica, que serviu como ferramenta avaliativa para os três componentes curriculares, fortalecendo assim o caráter interdisciplinar do projeto.

No início do terceiro bimestre, foram recapitulados os caminhos pedagógicos percorridos até aquele momento e abriu-se espaço para que os alunos avaliassem o percurso traçado e sugerissem algumas atividades.

O ponto de partida da proposta desse bimestre foi a exibição do documentário The mask you live, que discutia a pressão da sociedade com aquilo que pode ou não ser considerado "masculino". Foram propostas ainda atividades mais práticas, na intenção de valorizar e vivenciar aspectos culturais da Região Norte e também experimentar vivências corporais, como brincadeiras tradicionais, relacionando-as com as novas tendências de exercícios e sua aplicabilidade em condutas relacionadas à saúde e estética.

O desenvolvimento das práticas corporais foi iniciado com a oficina de dança contemporânea, que aplicou algumas dinâmicas para desenvolver a percepção do corpo no meio social. Num dado momento, os alunos se dispuseram em duas filas paralelas formando um corredor, e cada indivíduo devia passar no meio, guiado por outro colega, ao final cada aluno contou sua experiência, relatando como se sentiu inseguro em depender do outro para chegar ao final do trajeto. 
Outra atividade proposta foi a criação de coreografias: cada discente criou um movimento e depois apresentou à turma, logo após, a professora organizou grupos e pediu que montassem as coreografias formando uma apresentação única. Com essa experiência conduziu-se a reflexão sobre como os corpos se comportam de modo diferente quando associados em grupo em busca de um objetivo comum.

Com relação às vivências da cultura da Região Norte, inicialmente foi realizada uma pesquisa das brincadeiras mais populares, de modo que os alunos realizaram entrevistas informais com pessoas de mais idade acerca das brincadeiras mais executadas antigamente. Após essa sondagem e com orientação dos professores, foi sugerida realização de um seminário com os resultados, no qual cada grupo apresentou os relatos e elegeu a brincadeira que mais se destacou em suas investigações, conduzindo a prática da mesma. Dentre as brincadeiras realizadas destacaram-se: rouba-bandeira, pipa (papagaio) e peteca.

Após esta etapa, foram desenvolvidas práticas de vivência cultural e corporal nortista por meio das danças regionais, como Carimbó, Boi-Bumbá e Jequitaia. Tal prática foi realizada com o propósito de enaltecer a cultura corporal tão presente na região, por conseguinte, os alunos puderam descobrir e valorizar aspectos culturais até então negligenciados por eles, embora muitos destes fossem naturais da região.

No último bimestre, seguindo o cronograma, foram realizadas atividades fundamentadas no exercício de despertar e alargar "o olhar", a visão de mundo, a percepção filosófica de si mesmos e do contexto social no qual estão inseridos. Tais exercícios foram realizados através de ações práticas, como o teatro e a fotografia, somados à leitura de textos filosóficos. 
A oficina de teatro foi conduzida por um servidor convidado, que tem formação em artes cênicas. Este orientou o exercício de encenação de clássicos da literatura infantil a partir de óticas diversas, diferentes pontos de percepção, não abordados normalmente. A leitura do texto "O corpo utópico" de Michel Foucault contribuiu para aprofundar o debate sobre a possibilidade de ver além da simples realidade, tomando os elementos simbólicos de prolongamento da nossa capacidade de ver o mundo.

Uma das propostas finais do projeto foi que a turma apresentasse um produto sobre a temática do projeto, a escolha foi uma produção imagética. Para auxiliar o grupo, realizou-se uma oficina de fotografia, onde a turma recebeu auxílio quanto à produção e manipulação das imagens. Nessa oportunidade propôsse uma atividade para despertar o olhar, recapitulando um pouco do assunto anterior. A turma foi orientada a sair pela instituição com uma moldura para que enquadrassem seu olhar para as pessoas e para o mundo a partir dela, como se o olhar fosse a lente fotográfica.

Por fim tivemos a exibição das imagens produzidas numa exposição fotográfica, intitulada: "corpo: tenho ou sou?" na qual cada grupo apresentou um "corpo" segundo sua percepção e explicou por meio das narrativas o conceito de corporeidade consolidado e agregado nas fotografias.

\section{AVALIAÇ̃̃o}

O método avaliativo utilizado foi a avaliação participativa. No segundo bimestre tivemos a leitura do livro de maneira compartilhada e depois cada aluno de maneira individual fez a resenha crítica, além de serem avaliados dos aspectos do projeto, educação física e filosofia, foi usado também como instrumento avaliativo da disciplina de OP3, uma vez que a matéria é justamente 
para ensinar os alunos a usarem a metodologia científica. Além disso, sempre era observado à proatividade dos alunos em sala.

Os alunos no terceiro bimestre foram indicados a fazer uma pesquisa sobre as atividades que eram vivenciadas em décadas passadas e depois apresentaram em sala de aula os resultados dessas pesquisas, do mesmo modo fizeram depois a vivência dessas brincadeiras, e ainda foi realizado um paradoxo das vivências de antigamente com as contemporâneas.

No quarto bimestre os alunos escolheram fazer uma produção imagética, a turma foi dividida em grupos e elegeram uma temática, os alunos tiveram que entregar no final do bimestre dez imagens, com uma narrativa sobre o processo criativo. Desta maneira procedeu o processo avaliativo do projeto, sendo prezada pela integração das avaliações para redução do quantitativo e assim fomentar uma educação não balizada no processo quantificável do aprendizado, mas numa aprendizagem marcada pelas vivências e promoção da criticidade dos alunos.

\section{RESUltados ALCANÇAdOS}

O projeto Corporal-mente se diferencia dos demais por ser interdisciplinar, por isso trouxe benefícios tanto para a turma quanto para os professores, obtendo ao longo do desenvolvimento do projeto a oportunidade de diminuição de avaliações, em uma turma que conta com 17 provas bimestrais, podendo assim fazer um único exame, para duas ou três disciplinas.

Desde modo o projeto corporal-mente sempre procurou fazer das atividades algo prazeroso de se participar. Todas as atividades foram bem desenvolvidas, trazendo um ótimo resultado. Logo de início o projeto começou com a temática de investigação do nível de insatisfação corporal, no qual a insatisfação com a 
imagem tornou-se nítido que a turma apresentava um nível crítico com sua imagem corporal. A cada atividade realizada, a cada fala dos alunos isso era expresso de maneira enfática, apontando para o fato de que a adolescência é uma fase de muito conflito e insegurança, fortalecendo a insatisfação, o que ainda é ampliado pela mídia e redes sociais quando reforçam um apelo estético padronizado.

No terceiro bimestre os alunos puderam vivenciar práticas típicas de outros momentos histórico, de outras culturas e regiões. No qual conseguiram experimentar brincadeiras típicas, danças da região norte e jogos. A experiência da turma em praticar tais atividades foi muito gratificando, podendo encontrar o "eu" do corpo, assim vendo as infinitas possibilidades que o corpo tem em descobrir.

No quarto bimestre a turma escolheu fazer uma produção de imagem, quando se buscou saber como se pode sentir, perceber o próprio corpo, a partir das expressões faciais e outros modos de expressar. Cada grupo mostrou na sua concepção o que seria o corpo.

No último dia do projeto passamos um questionário de avaliação, com escalas no qual os alunos pudessem avaliar o projeto. Dentre as notas, tivemos, onde $66,66 \%$ avaliaram o projeto com nota $10,22,22 \%$ avaliaram com nota $9,11 \%$ avaliaram com nota 8 . Dentre as perguntas respondidas, eles descreveram que o projeto ajudou no seu autoconhecimento, também ressaltaram a desconstrução de um corpo ideal, aprendendo assim a amar o seu próprio corpo e sabendo lidar com as diferenças. Citaram a ocorrência de maior aproximação entre os integrantes da sala, alunos e professores; perceberam um amadurecimento em conjunto. O projeto ganhou grande visibilidade na instituição. Está 
previsto uma continuação em 2019, porém com as matérias de educação física e sociologia. Todos disseram sim para a pergunta sobre o projeto continuar.

\section{CONSIDERAÇÕES FINAIS}

Diante dos desafios da educação contemporânea, educadores bem como toda a equipe de profissionais da educação são chamados a refletir sobre as práticas pedagógicas e o próprio fim da educação escolar. Pensar sobre a interdisciplinaridade e possibilitar a sua prática faz-se necessário para alcançar uma educação integral que fuja de uma arcaica visão conteudista sobre o processo de formação escolar.

Ao propormos um diálogo interdisciplinar, buscamos romper com a classificação das disciplinas em teóricas e práticas, visto que, numa compreensão mais apurada, todas as disciplinas são teóricas, pois trabalham com a construção e aplicação de conceitos; por outro lado, toda disciplina é também prática, pois é na vida cotidiana que o conhecimento se aplica e transforma a realidade daquele que aprende.

Refletir sobre o corpo em sua integralidade transcende qualquer reflexão filosófica sobre os conceitos e suas aplicações em cada período da história. Todavia, transcende também a prática da educação física, pois esta carece do olhar crítico sobre suas temáticas e conteúdos. Assim, objetivamos como a presente pesquisa - e sua aplicação no projeto Corporal-mente - uma práxis pedagógica que pudesse partir dos ensinamentos da filosofia da educação propondo uma educação filosófica, ou seja, uma educação que reflita sobre os problemas atuais e possibilite aos educadores e educandos descontruir seus pressupostos e avançar rumo a uma 
maturidade intelectual que venha a configurar numa atuação social e política mais ativa e participativa.

Frente ao que foi desenvolvido no decorrer do presente trabalho, é importante perceber que, se a negação do corpo se apresenta como o ápice da dualidade corpo-mente na modernidade/colonialidade, ao mesmo tempo em que a fragmentação do conhecimento se constituiu como paradigma hegemônico da epistemologia desse período, assumir o corpo como tema central de uma prática interdisciplinar materializa um processo duplamente decolonial.

Debater sobre o corpo é valorizar a diversidade humana, é descontruir paradigmas e questionar os padrões preestabelecidos no que diz respeito ao ser humano como um ser biológico, histórico, político e cultural, possibilitando a reflexão sobre os próprios hábitos e crenças e, ao tomar consciência da realidade, encontrar na própria educação instrumentos para transformá-la.

\section{REFERÊNCIAS}

A GAROTA DINAMARQUESA. Direção: Tom Hoope, Produção: Tim Bevan. (DE): Universal Pictures, 2016, EUA/Alemanha/Reino Unido.

BIRMAN, Joel. Mal-estar na atualidade: a psicanálise e as novas formas de subjetivação. 3. ed. Rio de Janeiro: Civilização Brasileira. 2001.

DESAFIO DE DARWIN. Direção: Jon Bradshaw, Produção: Michael Mahoney. (DE Paramount Pinctures, 2009, EUA/Canadá/Japão. 
DEWEY, John. Como pensamos: como se relaciona o pensamento reflexivo com o processo educativo: uma reexposição. São Paulo: Companhia Editora Nacional, 1979.

hooks, bell. Ensinando a transgredir: a educação como prática da liberdade. Tradução de Macelo Brandão Cipolla. São Paulo: Editora WMF Martins Fontes, 2017.

KRENAK, Ailton. Ideias para adiar o fim do mundo. São Paulo: Companhia das Letras, 2019.

LARAIA, Roque de Barros. Cultura um conceito antropológico. Rio de Janeiro: Zahar, 1986.

LE BRETON, D. Sociologia do corpo. 4. ed. Rio de Janeiro: Vozes, 2010.

LEITÃO, Míriam. Caminhos e tropeços da educação: a maior das tarefas. In. História do futuro: o horizonte do Brasil no século XXI. Rio de Janeira: Intrínseca, 2015. p. 116-157.

MILHOOD, Richard. Learning Theorie Maps. HoTEL: Holistic Aproach to Technology Enhanced Learning, 2013. Disponível em: $\quad<$ http://hotel-project.eu/content/learning-theories-maprichard-millwood $>$. Acesso em: 25 nov. 2020.

MORAES, Francisco de; KÜLLER, José Antônio. Currículos integrados no ensino médio e na educação profissional: desafios, experiências e propostas. São Paulo: Editora SENAC, 2016.

MORIN, Edgar. A cabeça bem-feita: repensar a reformar, reformar o pensamento. Tradução de Eloá Jacobina. Rio de Janeiro: Bertrand Brasil, 2003. 
SANTOMÉ, Jurjo Torres. Globalização e interdisciplinariedade: o currículo integrado. Porto Alegre: Artes Médicas, 1998.

SENNETT, Richard. Carne e pedra: o corpo e a cidade na civilização ocidental. Rio de Janeiro: Record, 2003.

SODRÉ, Muniz. Cultura, Corpo e Afeto. Dança, Salvador, v. 3, n. 1, p. 10-20, jan-jul 2014. Disponível em <https://portalseer.ufba.br/ index.php/revistadanca/article/view/13161/9318>. Acesso em: 26 nov. 2020. 


\title{
10 \\ O TRABALHO DOCENTE NA CONSTRUÇÃO DO CONHECIMENTO: OS DESAFIOS ENFRENTADOS PELOS PROFESSORES
}

\author{
Edney Costa Souza ${ }^{50}$ \\ Tânia Regina Raitz ${ }^{51}$ \\ Fabio Rychecki Hecktheuer ${ }^{52}$
}

\section{INTRODUÇÃO}

O exercício da docência exige do profissional em educação atitudes que colaborem para a expansão do conhecimento, isto é, o profissional em educação que exerce a docência precisa ter em mente que em suas práticas educacionais há de haver critérios que permitam ao discente a apreensão do conhecimento, pois ensinar e aprender é uma característica inerente ao ofício docente.

$\mathrm{Na}$ prática docente o profissional avalia todas as possibilidades que possam contribuir para a realização do seu

${ }^{50}$ Doutorando em Educação pela Universidade do Vale do Itajaí (Univali), em 2019. Mestre em Planejamento e Desenvolvimento Regional pela Universidade de Taubaté-SP. Bacharel em Administração. Professor e Coordenador do MBA em Gestão de Pessoas e dos cursos de graduação em Administração, Gestão Comercial e Gestão Hospitalar do Centro Universitário Aparício Carvalho (Fimca).

51 Doutora em Educação pela Universidade Federal do Rio Grande do Sul. Docente nos cursos de graduação, mestrado e doutorado em Educação Universidade do Vale do Itajaí (Univali).

52 Doutor em Desenvolvimento psicológico e aprendizagem pela Universidad Autónoma de Madrid (2001). Mestre em Filosofia pela Pontifícia Universidade Católica do Rio Grande do Sul (1993). Graduado em Educação Física pela Universidade Federal de Pelotas (1986) e em Filosofia pela Universidade Católica de Pelotas (1988). Reitor e professor da Faculdade Católica de Rondônia desde o dia 13 de fevereiro de 2007. 
trabalho, principalmente quando se trata da formação cidadã, em que é possível fazer a diferença na vida das pessoas. Neste sentido, ser docente significa levar o aluno à reflexão de suas atitudes, posturas e posicionamentos, sabendo que sua formação depende da busca pelo conhecimento de forma a permitir a utilização desse conhecimento para o bem comum.

Ao mesmo tempo, para a formação de uma sociedade justa e igualitária no funcionamento do princípio da isonomia, em que os direitos e deveres sejam afrontados como atitude rotineira. Desta maneira, é possível dizer que a prática docente passa a fazer sentido, posto que as responsabilidades atribuídas ao docente podem transformar a vida e as práticas cotidianas, pelas quais se forma uma sociedade livre e consciente.

O estudo teve como objetivo analisar o trabalho docente e sua contribuição na construção do conhecimento, assim como os desafios enfrentados pelos professores. Diante deste objetivo a pesquisa procurou demonstrar por meio de objetivos específicos como o trabalho docente pode influenciar na construção de uma sociedade justa e igualitária, contextualizando à docência como espaço de trabalho, as características que preconizam o trabalho docente e a prática no dia a dia.

A metodologia utilizada para desenvolver o presente artigo foi o levantamento bibliográfico, tendo como base as ideias de autores como Cani, Gadotti, Nóvoa e Segnini.

A justificativa desta pesquisa reside no fato de que a educação tem passado por um tempo de novas práticas educacionais e o docente teve que adaptá-las a esse novo momento de aprender e ensinar. Portanto, se faz mister abordar sobre o reinventar docente, no sentido de não apenas valorizar a profissão que contribui para a formação de quase todas as outras profissões, 
mas também para demonstrar que há uma necessidade premente de reconhecer o trabalho docente como algo imprescindível.

\section{O TRABALHO DOCENTE}

Para exercer seu trabalho o docente precisa antes de tudo compreender que sua prática deve estar voltada para a formação de um cidadão crítico, que saiba dos seus direitos e dos seus deveres. Nesse sentido, Gatti (2017) diz que pensar e fazer a formação de professores envolve considerar condições situacionais e conscientizar-se das finalidades dessa formação, considerar os porquês, o para quê e o para quem é realizada essa formação, assumindo compromissos éticos e sociais. Isto representa que para exercer sua função como docente o professor deve estar sempre buscando formação e informação, no sentido de construir sua identidade profissional. Sobre o trabalho exercido pelo docente, Segnini (2000, p. 73) diz que:

A educação e a formação profissional aparecem hoje como questões centrais, pois a elas são conferidas funções essencialmente instrumentais, ou seja, capazes de possibilitar a competitividade e intensificar a concorrência, adaptar trabalhadores às mudanças técnicas e minimizar os efeitos do desemprego.

É fato que a formação educacional tem passado por mudanças significativas, especialmente em função do atual cenário imposto pela pandemia de Covid 19, doença que acometeu uma quantidade considerável da população mundial, e o setor educacional, juntamente com o setor de saúde, tiveram que adaptar suas práticas, tornando o trabalho bem diferenciado. Nesse contexto, podemos destacar a colocação de Raitz (2003, p. 43) que assevera: 
Numa sociedade que demanda um esforço incrível para entender a complexidade que se apresenta diariamente perante nossos olhos, nos encontramos envolvidos em uma pluralidade de pertencimentos que brota da multiplicação das posições sociais, das redes associativas, dos grupos de referências. Nossas entradas e saídas dos sistemas e relações ocorrem com muito mais frequência que no passado.

Ainda sobre o assunto supramencionado, Cani et al. (2020) explicam que ensinar tornou-se mais um desafio diante de tantas incertezas sobre como viver o dia a dia, e surge então a necessidade de reinventar a escola. Para tanto, o trabalho do professor se expande, para muitos por paragens desconhecidas, e assim, ele tem que criar mecanismos de atuação.

Sobre este aspecto, Nóvoa (2019, p. 6) explica em seu trabalho "Tornar-se professor $\{. .$.$\} obriga a refletir sobre as$ dimensões pessoais, mas também sobre as dimensões coletivas do professorado. Não é possível aprender a profissão docente sem a presença, o apoio e a colaboração dos outros professores”. Isto significa que não dá para exercer o magistério sem estar devidamente imbuído em participar do processo educativo, pois a educação só acontece com a participação de todos, irmanados num mesmo propósito.

\section{CARACTERÍSTICAS DO TRABALHO DOCENTE}

Para atuar em sala de aula o professor, antes de tudo, precisa passar por formação inicial e continuada (profissional), como finalidade se capacitar para o exercício do magistério. A academia é, portanto, o espaço em que o professor acorre para se formar e informar sobre sua atuação como docente. Nesse sentido, Oliveira (2011, p. 117) contribuiu sobre o modelo de competência, 
O modelo de competência teve reflexo da reorganização do modo de produção e de organização do trabalho, que vem exigindo novos perfis do trabalhador, novos arranjos de gestão das organizações e novas formas de pensar a realidade social, do trabalho e da formação profissional.

É fato que a escola é um dos espaços que mais passou por novas adaptações, tendo que reorganizar, em tempo recorde, as suas novas formas de atuação e competência. Segundo Tardif (2002), o objeto do trabalho docente são os seres humanos que possuem características peculiares; são características como individualidade e a heterogeneidade, isto é, as pessoas têm diferentes histórias, ritmos, interesses necessidades e afetividades, e assim o ambiente educacional convive com situações de ensino complexas, únicas, imprevisíveis e incabíveis em generalizações ou esquemas pré-definidos de ação. Para Morgado (2011, p. 796),

A profissão docente tem sofrido transformações significativas ao longo das últimas décadas, sendo hoje exigida, na generalidade dos países, uma formação de nível superior para se poder leccionar quer no Ensino Básico, quer no Ensino Secundário.

É fato que na atualidade o professor precisa se reinventar, buscar qualificação, aprender novas maneira de ministrar sua aula, embora não tenha o auxílio necessário para buscar essa qualificação em seu ambiente de trabalho. Deste modo, Morgado (2011, p. 798) esclarece que

A construção da identidade docente não pode dissociar-se dos valores de cada indivíduo, nem das experiências vividas ao longo da sua formação e da forma como cada pessoa constrói a sua história de vida, o que permite compreender que a identidade profissional se 
constrói e transforma num processo contínuo, podendo assumir características diferentes em distintos momentos da vida.

É através dessa construção identitária que o professor irá desenvolver o seu trabalho, atribuindo-lhe características que tornem esse trabalho um momento de aprendizagem e ensino. Para isto acontecer alguns aspectos devem ser levados em consideração, como a criatividade, ou seja, o professor tem que ser criativo. Sobre esse aspecto, Oliveira e Alencar (2012, p. 543) dizem que:

O professor constitui elemento chave para facilitar o desenvolvimento do potencial criador dos alunos. Para tanto, a escola precisa ser um espaço que cultive e valorize as ideias originais de seus educadores, oportunizando o desenvolvimento e o desabrochar de habilidades que muitas vezes esse profissional desconhece possuir.

A criatividade é, portanto, um aspecto que a escola deve fomentar no professor, como forma de tornar seu trabalho atraente. Outra característica inerente ao trabalho docente é a interatividade, principalmente, atualmente, dada a forma adotada de ensino e aprendizagem em que os ambientes virtuais se transformaram em espaços de saber educativo. Sobre interatividade Veraszto e Garcia (2011, p. 93) explicam que:

A interatividade precisa que o sistema virtual seja dinâmico, forneça possibilidades variadas de escolha e feedbacks, com auxílio de animações, filmes, músicas, hipertextos, jogos, simulações, holografias e verossimilhança com o meio real, permitindo ainda que usuário tenha capacidade de imersão no meio virtual de forma passiva ou ativa, individual ou coletiva, com opções de transformar o ambiente de forma livre, em consonância com sua vontade, suas preferências, crenças e valores. 
Mediante os aspectos elencados por estes autores a interatividade não depende apenas da prática educativa do professor, mas de todo o aparelhamento colocado à sua disposição. O professor é também um ser social denotando outra característica atribuída à função do professor. Nesta perspectiva Ruiz (2003) diz que os engajados em um processo de transformação social necessitam acreditar na educação, pois sozinha ela não transforma a sociedade, entretanto, sem ela nenhuma mudança profunda se realiza.

Isto representa que o professor como um ser social precisa compreender que sozinho não consegue os objetivos do fazer educativo, é necessário socializar as ideias, para que alcancem a finalidade de educar. No desenvolvimento de sua atividade docente deve também agir com ética, sendo esta uma característica que deve permear o trabalho que ele realiza. Sobre ética como característica do trabalho do professor, Oliveira (2014, p. 113) esclarece,

O tratamento das questões éticas, na escola, pede um trabalho integrado entre docentes, gestores e responsáveis pelos alunos. A construção de uma escola plural, democrática e comprometida com processos formativos voltados para a constituição de uma visão crítica sobre a realidade passa pelo respeito às diferenças de natureza filosófica, política, religiosa, etc., que caracterizam os sujeitos, pela compreensão de que há distâncias a negociar, pois o contexto escolar não é imune às relações de poder hierarquizadas existentes na sociedade, nem às influências das redes de interesse que a permeiam.

Assim, no ambiente educacional todos devem estar engajados em ações éticas, que respeitem todas as diversidades, sejam essas de qualquer natureza. Para que possamos ter uma 
escola que realiza seu trabalho objetivando o bem comum ao tratar a todos com isonomia.

\section{REFLEXÕES SOBRE A PRÁTICA DOCENTE}

Neste tópico traremos reflexões acerca da prática docente e iniciamos com uma passagem em que Piovezan e Dal Ri (2019, p. 3) abordam sobre a flexibilização do trabalho do professor, que

é caracterizada pela ampliação das competências e funções que devem ser realizadas por este profissional no interior da escola e fora do recinto escolar. [...] Os docentes devem participar de projetos que estimulam a prática de atividades esportivas dos alunos, da organização de festas típicas e de eventos e campanhas realizadas pela escola. [...] Além de os afazeres que fogem da alçada de formação dos professores, a burocracia é apontada como outro elemento da flexibilização do trabalho, tendo em vista a necessidade de elaborar, inclusive em horários de descanso e fora da escola.

Como podemos observar a carga de trabalho do professor é altamente cansativa, portanto, requer dele uma entrega que muitas vezes o prejudica física e emocionalmente.

\footnotetext{
Chakur (1995, p. 37) esclarece sobre a função do docente dizendo que:
}

As preocupações do professor com o seu trabalho, em sala de aula, são de várias ordens e nem sempre suficientemente claras e bem definidas. São exemplos de suas atribuições diárias: chegar ao final do programa dentro do prazo previsto; suprir as dificuldades de aprendizagem dos alunos; escolher recursos didáticos adequados à apresentação do conteúdo; elaborar tipos de atividades e formas de avaliação dos alunos; e, principalmente entre professores recém-formados, 
encontrar estratégias apropriadas ao desenvolvimento do conteúdo e à consecução dos objetivos propostos.

Para Gadotti (1998) o professor deve assumir uma postura crítica, dada a sua condição como profissional humano, social e político, tomando partido e não sendo omisso, neutro, contudo, definindo para si de qual lado está. Isto quer dizer que o professor precisa se posicionar quanto às suas atribuições, contribuindo, é lógico, para o bem-estar da comunidade escolar, porém, sem prescindir da sua própria vida como ser humano que é. Nesse sentido, Ruiz (2003) aduz que o professor pode ascender à sociedade usando a educação como instrumento de luta, levando a população a uma consciência crítica que supere o senso comum, todavia não o desconsiderando. É preciso, portanto, levar em consideração sua condição humana.

\section{O TRABALHO DOCENTE E A SOCIEDADE}

O trabalho docente no desenvolvimento da prática pedagógica é fundamental para o desenvolvimento de uma sociedade justa e igualitária. Por meio do trabalho docente a sociedade pode compreender seus direitos e deveres, isto significa que um trabalho educativo bem realizado alcança os objetivos propostos pelo ato de educar. Desta forma, a escola, juntamente com o corpo docente e todos os outros envolvidos com educação, poderão cumprir com a sua real função: educar com responsabilidade, propagando a democracia como um regime que deve permear o trabalho desenvolvido pela escola, logo com a participação do trabalho docente.

Oliveira e Alencar (2012) asseveram que o professor é o elemento facilitador do desenvolvimento potencial e criativo dos alunos. Isto é, cabe ao docente facilitar que o aluno desenvolva toda 
a sua criatividade; ainda segundo os teóricos supracitados, a escola é o espaço que deve cultivar e valorizar as ideias de seus educadores, oportunizando o desenvolvimento e o desabrochar de habilidades que muitas vezes o docente desconhece possuir.

Entretanto, é necessário levar em consideração a carga trabalhista atribuída aos docentes, posto que tantas vezes esse cumpre carga horária em dois regimes trabalhistas, além de serem pais, cônjuges, estudantes, e tantas outras atribuições que permeiam a vida dos docentes.

Piovezan e Dal Ri (2019) abordando sobre o processo de flexibilização do trabalho dos docentes explicam que esse é caracterizado pela ampliação das competências, bem como das funções que devem ser realizadas por este profissional, que devem participar de projetos que estimulem os alunos, além de afazeres que fogem da alçada de formação dos professores. Além daquelas há a burocracia, que toma um tempo considerável no trabalho dos professores, tais como diários de classe, relatórios, correção de avaliações, planos de aulas, planejamento de atividades extracurriculares, maratonas, simpósios, e muito mais.

Assim, é salutar que no desenvolvimento de seu trabalho o professor tenha a compreensão de que pode muitas atividades, mas não tudo, é preciso que o seu trabalho seja realmente realizado com compromisso, dedicação, todavia, não deve afetar sua vida pessoal, de modo a levá-lo a adoecer, causando prejuízo tanto a si mesmo, como no desenvolvimento do seu trabalho, pois um trabalhador adoecido não produz conforme a sua capacidade plena.

\section{Conclusão}

Mediante aos aspectos elencados pelos teóricos constantes neste estudo bibliográfico sobre o trabalho docente, é possível 
perceber que o professor assume uma carga exaustiva de trabalho, pois além de ter que desenvolver o seu trabalho com qualidade, ainda precisa se desdobrar para atender todas as tarefas que lhes são repassadas. Estas vão desde a confecção de relatórios até o preenchimento dos diários de classe, passando pelos planos e planejamento de aulas, e ainda por reuniões administrativas e pedagógicas, além de formação e informação em tempo real, portanto, um calhamaço de trabalho que não para, mesmo quando, cansado, o professor volta para casa.

É preciso, portanto, refletir sobre as práticas docentes, no sentido de compreender que os professores são seres humanos, com falhas, problemas pessoais, com todas as características inerentes às outras pessoas que não têm sua atividade. Não dá para cobrar pleno desenvolvimento das atividades no trabalho de professores, até porque o poder público não está comprometido com o aparelhamento que permita ao professor acessar e compartilhar seus conhecimentos, principalmente no atual momento vivido no contexto escolar.

As cobranças relacionadas ao trabalho desenvolvido pelo professor são deveras pesadas, tomando como exemplo as novas adaptações surgidas após o contexto da pandemia. Não é segredo que os professores mundo afora estão se adaptando a duras penas a um contexto desconhecido, ou seja, estão tendo que se aventurar em uma messe nova, cheia de compreensões e momentos totalmente diversos dos vividos, até então, em sala de aula presencial.

A sociedade precisa fazer a sua parte no entendimento das limitações que fazem parte do trabalho docente que, neste momento tão inusitado, tem permeado seu trabalho. À sociedade cabe, juntamente com a família e o poder público, prover meios de possibilitar recursos para facilitar o trabalho desenvolvido pelos 
docentes. Não tem sido fácil para os docentes exercerem suas atividades pelos motivos listados ao longo deste artigo.

Portanto, para que o trabalho docente seja exercido com competência e desenvoltura torna-se fundamental que as aprendizagens permitam a construção de espaços democráticos, a fim de formar uma sociedade mais justa e igualitária, exigindo a participação de todos, desde os pequenos, que buscam a escola para desenvolver o processo de aprendizagem, aos que buscam a escola para inserção no mercado de trabalho ou para transitar por diversos espaços. A participação de todos expande o processo democrático e o real compromisso com a educação.

\section{REFERÊNCIAS}

CANI, Josiane Brunetti. Educação e Covid-19: a arte de reinventar a escola mediando a aprendizagem "prioritariamente" pelas TDIC. Revista Ifes-Ciência. Vol. 6. Ed. Especial. n. 1, 2020. Disponível em: <www.researchgate.net/publication/342223833_educacao_e_cov id-19_a_arte_de_reinventar_a_escola_mediando_a_aprendizagem _prioritariamente_pelas_tdic $>$. Acesso em: 10 nov. 2020.

CHAKUR, Cilene Ribeiro de Sá Leite. Fundamentos da Prática Docente: por uma pedagogia ativa. Paideia, FFCLRP-USP, Ribeirão Preto: fev./ago. 1995. Disponível em: <www.scielo.br/pdf/paideia /n8-9/04.pdf >. Acesso em: 11 nov. 2020.

GADOTTI, Moacir. Pedagogia da práxis, 2. ed., São Paulo, Cortez, 1998.

GATTI, Bernardete Angelina. Formação de professores, complexidade e trabalho docente. Rev. Diálogo Educ., Curitiba, v. 17, n. 53, p. 721-737, 2017. Disponível em: <http://dx.doi.org/ 10.7213/1981-416X.17.052.AO01>. Acesso em: 11 nov. 2020. 
MORGADO, José Carlos. Identidade e profissionalidade docente: sentidos e (im)possibilidades. Ensaio: aval. pol. públ. Educ., Rio de Janeiro, v. 19, n. 73, p. 793-812, out./dez. 2011. Disponível em: <www.scielo.br/pdf/ensaio/v19n73/04.pdf>. Acesso em: 10 nov. 2020.

NÓVOA, António. Os Professores e a sua Formação num Tempo de Metamorfose da Escola. Educação \& Realidade, Porto Alegre, v. 44, n. 3, e84910, 2019. Disponível em: <http://dx.doi.org/10. 1590/2175-623684910>. Acesso em: 11 nov. 2020.

OLIVEIRA, Edileusa Borges Porto. ALENCAR, Eunice Maria Lima Soriano de. Importância da criatividade na escola e no trabalho docente segundo coordenadores pedagógicos. Estudos de Psicologia I Campinas I 29(4) I 541-552 I outubro - dezembro 2012. Acesso em: <www.scielo.br/pdf/estpsi/v29n4/v29n4a 09.pdf. Acesso em: 11 nov. 2020.

OLIVEIRA, Patrícia Whebber Souza de. Construção de identidades profissionais: da formação profissional à vivência da inserção no mercado de trabalho. Revista LABOR n. 6, v.1, 2011. Disponível em: <www.periodicos.ufc.br/labor/article/view/9306>. Acesso em: 10 nov. 2020.

OLIVEIRA, Renato José. Reflexões sobre a Ética na Educação Escolar. Educação, Santa Maria: v. 39 | n. 1 | p. 105-116 | jan./abr. 2014. Disponível em: <http://dx.doi.org/10.5902/198464449189>. Acesso em: 10 nov. 2020.

PIOVEZAN, Patricia Regina. DAL RI, Neusa Maria. Flexibilização e Intensificação do Trabalho Docente no Brasil e em Portugal. Educação \& Realidade, Porto Alegre, v. 44, n. 2, e81355, 2019. Disponível em: <http://dx.doi.org/10.1590/2175-623681355>. Acesso em: 13 nov. 2020. 
RAITZ, Tânia Regina. Jovens, trabalho e educação: rede de significados dos processos identitários na Ilha de Santa Catarina. UFRGS. Porto Alegre: 2003.

RUIZ, Maria José Ferreira. O papel social do professor: uma contribuição da Filosofia da Educação e do pensamento freireano à formação do professor. Revista Iberoamericana de Educación. N. 33, 2003. Disponível em: <https://rieoei.org/historico/ documentos/rie33a03.PDF>. Acesso em: 10 nov. 2020.

SEGNINI, Liliana Rolfsen Petrilli. EDUCAÇÃO E TRABALHO: uma relação tão necessária quanto insuficiente. São Paulo em Perspectiva, 2000. Disponível em: <www.scielo.br/pdf/spp/ v14n2/9791.pdf >. Acesso em: 10 nov. 2020.

TARDIF, M. Saberes docentes e formação profissional. Petrópolis: Vozes, 2002.

VERASZTO, Estéfano Vizconde. GARCÍA, Francisco García. INTERATIVIDADE E EDUCAÇÃO: reflexões acerca do potencial educativo das TIC. Interciência \& Sociedade, 2011. Disponível em: <https://intercienciaesociedade.francomontoro.com.br/cole cao/impressa/v1_n1/interatividade_e_educacao.pdf $>$. Acesso em: 12 nov. 2020. 


\title{
11 \\ A PRÁTICA EDUCATIVA LÚDICA COMO FERRAMENTA DE LINGUAGEM PARA O PROCESSO DE ENSINO E APRENDIZAGEM
}

\author{
Deigna Lais Oliviak ${ }^{53}$ \\ Sâmia de Oliveira Brito Freire ${ }^{54}$ \\ Selena Castiel Gualberto Lima ${ }^{55}$
}

\section{Introdução}

O presente artigo objetiva promover uma discussão sobre a prática educativa lúdica como ferramenta de linguagem para o processo de ensino e aprendizagem, no sentido de proporcionar uma reflexão das estratégias de criatividade, interação e motivação na ampliação e desenvolvimento da aprendizagem.

Não obstante, independentemente de ser criança ou adulto, o brincar é uma necessidade interior para promover a linguagem entre os indivíduos, de forma que norteia expertises e viabiliza as potencialidades para compreensão do mundo ao seu redor, e

53 Mestranda em Educação pela Universidade do Vale do Itajaí (Univali). Especialista em Avaliação Psicológica pelo IPOG- Instituto de pós-graduação e graduação. Graduada em Psicologia pela Faculdade de Rolim de Moura-RO (Farol).

${ }^{54}$ Doutoranda em Educação pela Universidade do Vale do Itajaí (Univali). Mestra em Processos Construtivos e Saneamento Urbano pela Universidade Federal do Pará (UFPA). Especialialista em Docência do Ensino Superior pela Universidade Federal de Rondônia (UNIR). Especialialista em Gestão de Pessoas pela Faculdade São Lucas (FSL). Graduada em Administração de Empresas pela Faculdade Porto Velho (FIP).

${ }^{55}$ Doutoranda em Educação pela Universidade do Vale do Itajaí (Univali). Mestre em Educação pela Universidade Federal de Rondônia (UNIR). Especialista em Docência do Ensino Superior pela FGF. Graduada em Psicologia pelo Instituto Luterano de Ensino Superior (Ulbra). Graduada em Direito pela Faculdade de Rondônia (FARO). 
delinear o desenvolvimento socioemocional e o cognitivo. Assim, lúdico deve ser entendido como uma ferramenta que colabora na prática pedagógica e educativa que envolve os educandos, visto que os jogos e as brincadeiras permitem a autonomia, o raciocínio lógico e as mudanças de atitude por intermédio da aquisição de saberes.

Nesse escopo, cabe ao professorado planificar a ludicidade como instrumento de mediação do processo de ensino e aprendizagem, mediante o universo de encantamento e da realidade que favorece a concentração e, ao mesmo tempo, o desenvolvimento cultural, social e a construção racional do pensamento.

Nessa direção, este estudo buscou nortear aportes epistemológicos que consubstanciem o entendimento da aplicabilidade do lúdico na prática pedagógica de maneira a contribuir para a integralização do conhecimento para as proposituras formativas do indivíduo de forma plena. Dessa forma, o objetivo consistiu em analisar a prática educativa lúdica como ferramenta de linguagem para o processo de ensino e aprendizagem. Para tanto, a metodologia utilizada foi de natureza qualitativa, utilizando-se fonte secundária a partir de levantamento bibliográfico acerca da temática por intermédio de uma abordagem de cunho analítico para nortear a compreensão da estratégia lúdica para aquisição e desenvolvimento do conhecimento.

Diante do exposto, organizou-se este artigo de forma que o leitor possa visualizar uma sistematização na compreensão do objeto, iniciando primeiramente com uma introdução que situa os aportes descritos; posteriormente, na segunda seção, menciona-se a ciência que denomina o campo conceitual do lúdico como estratégia educativa. A terceira seção norteou a ludicidade como ferramenta para a linguagem; e a quarta seção deu ênfase na 
relevância do lúdico na educação infantil e suas diferentes formas da linguagem. Por fim, na parte derradeira do estudo, seguem as considerações finais acerca da temática abordada.

\section{CONCEITUANDO O LÚDICO COMO ESTRATÉGIA EDUCATIVA}

Em conformidade com Oliveira (2010, p. 11), para desenvolver a aprendizagem, deve-se ter a compreensão de que é um processo integrado para provocar a transformação qualitativa na estrutura mental daquele que aprende; para tanto, o desconhecido necessita ser ministrado com bases que provoquem além da ampliação dos cognitivos pressupostos afetivos para busca prazerosa dos saberes. Diante deste contexto, o lúdico colabora para a ação professoral como uma estratégia para desencadear a assimilação do conhecimento mediante uma prática pedagógica consciente e motivacional para elevar o psiquismo humano, tornando-se, assim, um mecanismo rico para construir novas experiências para o universo social.

Não obstante, segundo Oliveira (2012), os primeiros enunciados sobre o lúdico decorrem de uma prática desde o século I d.C. quando na Grécia Antiga, Platão foi o sistematizador do jogo, inserindo a brincadeira nessa época, pois ele considerava ambas as atividades importantes para o valor educativo que tinha que ser dado, para elaboração de aprendizagens e formação do caráter e personalidade.

Doravante em tempos modernos, a partir do século XVI, diante do movimento Humanista, os colégios jesuítas promoveram a inserção do lúdico em uma tratativa de valorizar o ato educacional dos jogos e brincadeiras através de uma prática pedagógica que colaborasse significativamente para desenvolver as aprendizagens do currículo da época. Nessa direção, denota-se que as práticas 
educativas voltadas para o lúdico contribuem efetivamente para o desenvolvimento do processo de ensino e aprendizagem, uma vez que suas diferentes formas de linguagem constituem uma importante ferramenta de estratégia educativa na educação infantil. Assim, cabe ao professor, independente da faixa etária que atua, mediar os saberes por meio das brincadeiras, dos jogos, dos materiais audiovisuais coloridos como uma práxis que viabiliza a criação, a experimentação, o aprendizado sobre as regras e limites.

É importante frisar que a atividade lúdica é a primeira forma que o ser humano encontra para descobrir o mundo; afinal, a criança não nasce sabendo brincar ou jogar, ela aprende com a mãe e os familiares na medida em que eles utilizam o lúdico como suporte para o desenvolvimento físico e para as construções mentais do bebê.

Normalmente, as primeiras atividades lúdicas têm como característica a repetição de ações apenas por prazer. É desse primeiro contato com o lúdico que começa a ser gerado o raciocínio, e sua contínua utilização propicia a ampliação dos conhecimentos (Souza, 2012, p. 83). Nesse sentido, deve-se conhecer a práxis conceitual como um ato estratégico para uma ação de desenvolvimento, sendo assim, tornar-se-á necessário compreender que a ludicidade oferece significativos indícios a respeito dos aspectos emocionais envolvidos no processo de conhecer e de aprender que podem contribuir para a autonomia dos cidadãos e conhecimento generalizado de mundo. possibilita:

Para Macedo, Petty e Passos (2005, p. 121), o lúdico

Compreender os processos e estruturas psicológicas graças às quais o ser humano produz conhecimento; do ponto de vista prático, possibilita-nos 
analisar criticamente as situações que são mais favoráveis para isso. Jogos regras e de construção são essencialmente férteis o sentido de criarem um contexto de observação e diálogo, sobre processos de pensar e construir conhecimentos.

Assim, Vygotsky (2001) mensura que há a necessidade de se usar a ludicidade com mais intensidade, pois a brincadeira é universal e é própria da saúde. $\mathrm{O}$ brincar facilita o crescimento e conduz aos relacionamentos grupais. Além disso, para o teórico, a ludicidade possibilita aos educandos um espaço recreativo para reorganizar experiências, tornando possível construir conhecimento no ato da brincadeira remetendo-se às soluções dos problemas (Vigotsky, 1989). Nesse contexto, entende-se que promover atividades lúdicas possibilita conduzir as crianças à autoexpressão e à socialização, proporcionando, de fato, uma grande contribuição para a aprendizagem na educação infantil.

Sobrepujando essa práxis, se torna imprescindível reconhecer que o lúdico colabora para as questões do desenvolvimento humano, conforme alude Silva (2011):

O lúdico passou a ser reconhecido como traço essencial de psicofisiologia do comportamento humano. De modo que a definição deixou de ser o simples sinônimo de jogo. As implicações da necessidade lúdica extrapolaram as demarcações do brincar espontâneo. Passando a necessidade básica da personalidade, o lúdico faz parte das atividades essenciais da dinâmica humana. Caracterizando-se por ser espontâneo funcional e satisfatório (Silva, 2011, p. 16).

O ensino deve ser, portanto, mensurado por práticas educativas que envolvam o educando no processo, pois o pertencimento estimula o ser humano a buscar o conhecimento 
através de atividades dinâmicas. Nessa direção, Fernandes (2013, p. 3) ressalta que "[...] a atividade lúdica é um "fazer" humano mais amplo, que se relaciona não apenas à presença das brincadeiras ou jogos, mas também a uma atitude verdadeira do sujeito envolvido na ação". Assim, o lúdico proporciona prazer para o aprender e delineia para a construção da identidade do indivíduo, sendo algo que deve ser inserido desde o iniciar do desenvolvimento humano. E deve ser uma pauta no trabalho pedagógico para evidenciar significados.

Conforme menciona Barros (2006, p. 2),

A ludicidade é assunto que tem conquistado espaço num contexto educacional significativo. Brincar é uma coisa agradável. Traz-nos sensações agradáveis, prazerosas e sua utilização em determinados trabalhos pedagógicos possibilitam por meio de procedimento metodológicos a produção de um conhecimento.

Como discorrido, todo mecanismo que colabore para uma ação delimitada para assegurar o desenvolvimento pleno do ser humano visa municiar aportes integrais para a aprendizagem. Para tanto, cabe ao professor, ao propor uma atividade lúdica, deixar a liberdade entre os educandos para a troca de experiências com os colegas, para a vazão da criatividade e a busca de soluções, pois assim, a criança será capaz de construir seu próprio conhecimento (Sales, 2010).

Dessa maneira, planificar atividades que envolvem o lúdico exige do professor uma organicidade para que, ao executar a ministração do conhecimento, os educandos possam ser estimulados para experimentar, descobrir a autoconfiança, o desenvolvimento da linguagem e a concentração como ações essenciais para autonomia. 
Para Maluf (2008, p. 42), as atividades lúdicas são:

instrumentos pedagógicos altamente importantes, mais do que apenas divertimento, são um auxílio indispensável para o processo de ensino aprendizagem, que propicia a obtenção de informações em perspectivas e dimensões que perpassam o desenvolvimento do educando. A ludicidade é uma tática insubstituível para ser empregada como estímulo no aprimoramento do conhecimento e no progresso das diferentes aprendizagens.

Diante dessa afirmativa do autor, configura-se que o uso do lúdico não é apenas uma forma de diversão, é uma atividade que perfaz a formação do ser humano em qualquer idade com a intencionalidade de ampliação dos conhecimentos.

Para Piers e Landau (1990, p. 43), “o lúdico por meio do brincar desenvolve a criatividade, a competência intelectual, a força e a estabilidade emocionais, sentimentos de alegria e prazer: o hábito de ser feliz!” Proporciona alegria e divertimento à medida que cria uma atitude alegre em relação à vida e à aprendizagem.

Além disso, é imprescindível ter o entendimento de que o recurso pedagógico lúdico não pode ser delineado como uma estratégia que estimule somente o prazer para aprender mediante um ato de brincadeiras ou jogos, mas o seu significado promove o real conhecimento que levará a contextualização da aprendizagem acerca de um determinado objeto.

\section{O LÚDICO E A LINGUAGEM DE APRENDIZAGEM}

Desde os primórdios, o ser humano se reinventa em todas as etapas de sua vida, em permanente processo de aprendizado sendo uma característica nata; isso acontece por influência do meio que vive e através de seus semelhantes. Dessa forma, pode se dizer que 
tal processo advém de aprendizados e descobertas desde as simples até as mais complexas, garantindo sua persistência e adaptação na sociedade, sendo interativo, crítico e criativo. É através desta ação conjunta, que desfruta de uma linguagem cooperativa e comunicativa em torno do saber, a qual chamamos de educação.

O processo de educar é amplo e diversificado, pois através deste pode-se obter diferentes representações dentro do âmbito escolar, seja na matemática, língua portuguesa entre outras. Tal processo permeia a vida de crianças e adolescentes, com intuito de obter conhecimento engajado no processo de ensino e aprendizagem; porém, é de grande relevância pontuar que o processo educativo permeia diferentes facetas que não se restringem apenas a livros e tarefas, mas também a atividades lúdicas, que são igualmente importantes.

Nesse contexto, é de grande significância descrever sobre a infância, sendo considerada uma das fases mais satisfatórias, pois vem carregada de conteúdos lúdicos.

A infância é a idade das brincadeiras. Acreditamos que por meio delas a criança satisfaz, em grande parte, seus interesses, necessidades e desejos particulares, sendo um meio privilegiado de inserção na realidade, pois expressa a maneira como a criança reflete, ordena, desorganiza, destrói e reconstrói o mundo. Destacamos o lúdico como uma das maneiras mais eficazes de envolver o aluno nas atividades, pois a brincadeira é algo inerente na criança, é sua forma de trabalhar, refletir e descobrir o mundo que a cerca (Dallabona; Mendes, 2004, p. 107).

Em se tratando da história, Silva e Matias (2019) descrevem que "a palavra lúdico tem origem na palavra latina ludos que quer dizer "jogo”. Porém, seu significado tem por finalidade descrever que se trata de atividades que possibilitam o desenvolvimento de 
diversas funções sendo possível a obtenção de conhecimentos. Dessa forma, o lúdico é uma ferramenta de grande relevância para o processo de ensino e aprendizagem, pois tem por objetivo proporcionar uma compreensão dos significados através do brincar; sendo que, por meio de uma análise mais focal, pode-se obter diversas informações sobre o desenvolvimento da criança e sua autonomia.

É válido dizer que, a partir de atividades lúdicas (jogos, brinquedos, brincadeiras), são muitas as possibilidades de adquirir competências importantes como atenção, memória entre outras habilidades que as crianças desenvolvem por meio das brincadeiras. Ademais, a ação educativa intencional é de suma importância no que se refere a seu percurso individual, como o criar artístico, que aguça a imaginação, e o contato com objetos que é fundamental para a leitura das imagens. Portanto, o lúdico tem como objetivo proporcionar, dentro do processo de alfabetização, um conhecimento significativo na prática educacional, promovendo ganho no rendimento escolar em suas respectivas características voltadas ao conhecimento de mundo, a fala, o pensamento e o sentimento (Salomão; Martini; Jordão, 2007).

Mas, em se tratando do lúdico, é primordial descrever qual a sua origem na prática: como sendo uma ferramenta pedagógica de grande valia para melhor analisar, compreender e interpretar os conteúdos que são descritos através do brincar.

Sobre a utilização de atividades lúdicas no contexto escolar, Peixoto et al. propõem o seguinte:

Na escola, as atividades lúdicas são um meio de oferecer às crianças um ambiente de aprendizagem prazeroso, motivador e planejado, com possibilidades de aprendizagem de várias habilidades. Os docentes acabam 
por focar somente na alfabetização tradicional esquecemse de que cada criança possui um desenvolvimento e precisam de estímulos, para alcançar a alfabetização, acabam por deixar essas atividades de lado esquecendo-se que estes são instrumentos importantes de alfabetização. As atividades lúdicas ainda geram regras, tempo e atenção. Muitas vezes, as atividades são encaradas como brincadeira pelas crianças, o que torna o desenvolvimento das mesmas muito mais leve. As brincadeiras permitem que o professor trabalhe com o concreto ou abstrato, inúmeras maneiras das crianças realizarem determinadas atividades, prevalecendo um aprendizado significativo e divertido (Peixoto et al., 2019, p. 222-223).

A partir destas considerações, pode-se observar que o brincar livremente é carregado de significados, pois a criança se sente livre para se expressar. Em se tratando de uma sala de aula, o educador tem um papel fundamental, qual seja: o de auxiliar apenas quando necessário, observando o que ocorre com os comportamentos das crianças, pois para criar ou construir, as mesmas se embasam em características associadas ao brinquedo, através se seu simbolismo adjunto da realidade. O professor, dessa forma, deve estar ciente de que as informações relacionadas ao comportamento das crianças frente à escolha livre são fundamentais, pois é nas situações não estruturadas que elas desenvolvem diversas funções que as mantêm atuantes.

De acordo com Santanna e Nascimento (2011), o emprego do lúdico na educação perpassa a ideia em torno do desenvolvimento de aprendizagem embasado apenas em teorias, indo além com questões mais atrativas, com enfoque na busca histórico-cultural destas atividades, possibilitando um momento em torno do reconhecimento histórico familiar e a cultura regional, lembrando que o lúdico sempre foi vivenciado de forma natural, 
como também sendo uma ferramenta educacional voltada ao desenvolvimento do indivíduo. Assim,

Brincar é uma das atividades fundamentais para o desenvolvimento da identidade e da autonomia. $\mathrm{O}$ fato de a criança, desde muito cedo, poder se comunicar por meio de gestos, sons e mais tarde representar determinado papel na brincadeira faz com que ela desenvolva sua imaginação e conviva favoravelmente no meio em que está inserida, tendo uma vida pessoal alegre e positiva (Niles; Socha, 2014, p. 86).

A partir desse contexto, mesmo diante das informações que permeiam sobre a importância do lúdico na vida da criança, é relevante apresentar a sociedade atual, descrita como sociedade contemporânea, e como se comporta frente aos recursos tecnológicos tais como a televisão, computador, internet entre outros, enriquecendo a imaginação, fazendo com que, através da criatividade, a criança possa transparecer seus sentimentos, compartilhar vivências, personagens preferidos; enfim, tudo isso, estando embasado na criatividade, é o que arte do brincar proporciona (Barbosa; Gomes, 2011).

Dessa forma, pode-se observar que o lúdico colabora para o desenvolvimento da criança de forma eficaz, e cabe aos educadores estimular essa prática, com intuito de uma aprendizagem divertida, através de jogos e brincadeiras. Sendo assim,

no processo de ensino e aprendizagem, para que a atividade lúdica seja uma proposta pedagógica relevante é necessário quebrar os paradigmas do ensino tradicional, o que pressupõe organizar o trabalho pedagógico sob uma perspectiva teórica, que possibilite o aluno assumir um papel ativo nessa dinâmica e o professor um papel 
mediador, fazendo uso de metodologias que favoreçam uma aprendizagem (Moratori, 2003, p. 2).

Além disso, no processo de ensino e aprendizagem, as atividades lúdicas contribuem para que a criança desenvolva suas competências, visto que correspondem a uma ferramenta fundamental que permite deixar a criança agir livremente, respeitando suas ações criativas, permitindo a aquisição do desenvolvimento de suas competências físicas, mentais e emocionais, sendo importante valer-se de um ambiente adequado e motivador, contando com pessoas que compreendam as facetas das atividades lúdicas.

Na esfera escolar, portanto é imprescindível que educadores e gestores sejam absolutamente conhecedores da maneira pela qual os alunos aprendem. Afinal o foco na educação hoje é o aprender a aprender e o papel do professor é de ser um desestabilizador e direcionador. $\mathrm{O}$ ambiente lúdico é o campo fértil para que essa aprendizagem significativa ocorra. Ao sondar os conhecimentos prévios dos alunos, problematizar os fatos e fornecer ferramentas que auxiliem os alunos a sistematizar este conhecimento, em um espaço propício, munidos de ferramentas que permitam o jogo simbólico, a expressão da criatividade e da fantasia não há como negar a ocorrência de uma aprendizagem de fato (Sacchetto et al., 2011, p. 31).

Assim, por meio de atividades lúdicas, os professores poderão observar melhor as etapas do desenvolvimento da aprendizagem das crianças, possibilitando-lhes brincadeiras que despertem nelas cada vez mais a construção de diferentes linguagens. 
A esse respeito, Barbosa e Gomes (2011) afirmam que "ao brincar, a criança se socializa, se movimenta, busca parceiros, explora o ambiente e situações cotidianas, fortalece seu eu e se expressa com uma rica linguagem lúdica infantil”. Essa linguagem proporciona na criança um maior segurança, pois surge de comportamentos espontâneos, fazendo com que a criança se sinta livre no que consiste ao imaginário infantil.

Por sua vez, Alvin e Novaes (2019) salientam que cada indivíduo vivencia o processo de ensino e aprendizagem de maneiras diferentes; isso acontece devido às particularidades no que tange ao processamento cognitivo frente às informações recebidas, de forma excêntrica, retratando comportamentos e conhecimentos atuais.

De acordo com Calicchio (2015), “o lúdico tem uma grande importância no processo de ensino aprendizagem, visto que a educação lúdica ajuda e influencia no desenvolvimento integral do aluno". Logo, através da ludicidade, se pode diagnosticar as possíveis dificuldades e trabalhar de maneira que se possa agregar o lúdico neste processo, com intuito de sanar as dificuldades para que ocorra o processo de ensino-aprendizagem de forma íntegra, acarretando êxito na arte de educar.

Segundo Morais (2016), “o lúdico infantil há algum tempo vem sendo reconhecido como facilitador do processo de ensino e aprendizagem, uma vez que é promovido o despertar do interesse pela aula, assim, logo surgem os resultados positivos". O embasamento nas concepções lúdicas é de grande relevância descrever sua importância, fazendo uma comparação a questões corriqueiras do dia a dia como o ato de comer e dormir, contribuindo, assim, para o desenvolvimento infantil. 
Portanto, o lúdico e sua linguagem de aprendizagem são fundamentais no desenvolvimento da criança. É através do brincar que o aprendizado se concretiza, pois tal ato tem por objetivo explorar o potencial e o desenvolvimento de suas habilidades, já que a brincadeira faz parte do mundo da criança, tornando-se, assim, um facilitador no processo de ensino e aprendizagem.

\section{A RELEVÂNCIA DO LÚDICO NA EDUCAC̣ÃO INFANTIL}

Com embasamento em estudo aprofundado acerca da educação infantil, encontra-se por várias obras um assunto que, muitas vezes, vem à tona juntamente com outros temas relevantes na área da pedagogia: o lúdico. O que de fato questiona-se, muitas vezes, é se realmente a prática de atividades lúdicas na educação infantil influencia diretamente no aprendizado das crianças. Não há como negar que o estudo do lúdico vem crescendo nas pesquisas de âmbito acadêmico, buscando responder tais questões e seus impactos, como a indagada anteriormente. Vygotsky (1984, p. 81) nos mostra que:

O lúdico influencia enormemente $\mathrm{o}$ desenvolvimento da criança. É através do lúdico que a criança aprende a agir, sua curiosidade é estimulada, adquire iniciativa e autoconfiança, proporciona o desenvolvimento da linguagem, do pensamento e da concentração.

É sabido que o lúdico deve acompanhar a criança em todos os aspectos e fases de sua vida, em especial nas séries iniciais da Educação Infantil, em conformidade com a Lei de Diretrizes e Bases da Educação n. 9.394/96, em seu art. 29, onde afirma-se que a educação infantil, primeira etapa da educação básica, tem como 
finalidade o desenvolvimento integral da criança de até 5 (cinco) anos, em seus aspectos físico, psicológico, intelectual e social, complementando a ação da família e da comunidade. Pode-se afirmar, portanto, que no momento em que a criança estabelece relação com o lúdico, ocorre um despertar de entendimento dela para com o mundo real, com situações vivenciadas na sua rotina, mas que se tornam distantes ao adentrar na sala de aula. É como se a criança fizesse um link da sua vivência na escola a partir do desenvolvimento do lúdico com o seu ambiente familiar, doméstico, seu lar. Para Borges (1987), a pré-escola

[...] é um recurso benéfico, enquanto se propõe a ser um ambiente intermediário, entre o lar e a escola, no período de vida em que a personalidade começa a se formar. Cabe ao professor proporcionar um ambiente agradável que facilite a adaptação da criança, nesse primeiro contato com a escola, demonstrando que gosta dela e se interessa por ela, uma vez que a transição dá um impacto muito grande e, por isso mesmo, exigirá, tanto do professor como dos pais, grande compreensão e paciência (Borges, 1987, p. 3).

Apesar de o lúdico mostrar-se diretamente relacionado a brincadeiras e jogos, é interessante evidenciar que, ao mesmo tempo em que a criança brinca, desenvolve também habilidades, permitindo o aprendizado de uma forma mais dinâmica, criativa e prazerosa. A questão importante que se destaca também no contexto de brincar é que a criança aprenda a relacionar-se consigo mesma e com todos que estão ao seu redor no ambiente escolar, e que, posteriormente, ao retornar ao seu lar, ela possa interagir melhor com seus familiares a partir do que aprendeu na escola.

A respeito do ato de brincar, Friedmann (1996) aponta que 
O brincar atualmente é uma ação considerada lúdica na qual trabalha na criança seu desenvolvimento cognitivo, motor, social e afetivo, principalmente por ser uma ação no qual proporciona a socialização e interação com outras crianças, estimulando consecutivamente a autonomia, curiosidade, criatividade, raciocínio, ou seja, ela prende brincando, se divertindo, pois a brincadeira proporciona as crianças uma aprendizagem alegre e prazerosa (Friedmann, 1996, p. 71).

Ressalta-se que o brincar está diretamente relacionado à atividade pedagógica, que deve ser desenvolvida na educação infantil, uma vez que é a partir de tal vivência, que a criança inicia o entendimento de mundo e se sente acolhida e pertecente ao mesmo. Nesse sentido, Wajskop (2001, p. 25), afirma que: “essa definição de brincadeira, como atividade social específica e fundamental que garante a interação [...] é que faz estabelecer um vínculo com a função pedagógica da Educação Infantil”. O brincar é agradável por si mesmo, aqui e agora. Na perspectiva da criança, brinca-se pelo prazer de brincar, e não porque suas consequências sejam eventualmente positivas ou preparadoras de alguma outra coisa (Macedo; Petty; Passos, 2005). Assim, quando são proporcionadas às crianças atividades pedagógicas que envolvem brincadeiras, elas engajam-se nas atividades de maneira mais prazerosa, trazendo, assim, benefícios ao processo de ensino e aprendizagem.

Ademais, evoca-se que o lúdico pode ser desenvolvido de forma interdisciplinar para as crianças, pois percebe-se que tal prática pedagógica aperfeiçoa o aprendizado, de modo a compreender como as brincadeiras devem ser utilizadas em momentos oportunos e mais propícios a ensinar. 
O brincar deveria funcionar como um eixo importante na educação das crianças, mesmo porque o brincar, o sonhar, e o fantasiar, assim como o aprender, o estudar e o trabalhar, não são coisas independentes, estão entrelaçadas psiquicamente, uma influenciando as outras (Farias, 2008, p. 36).

Nesse sentido, o lúdico pode ser considerado uma estratégia para a aprendizagem infantil. Salientamos, ainda, que a forma de abordagem do lúdico, principalmente com as crianças da educação infantil, é que irá nortear para o sucesso ou não do processo de aprendizagem, transpondo a responsabilidade para o condutor da estratégia traçada, o professor.

O professor que trabalha com a Educação Infantil precisa desenvolver seu trabalho focado nas brincadeiras, estar atento à faixa etária das crianças, para que cada atividade trabalhada possibilite ao professor atingir os objetivos propostos, além de materiais coerentes e necessários. O professor precisa trabalhar em sala com o lúdico, utilizando-se da participação, ser crítico, trabalhar com as experiências trazidas pelos alunos no seu dia a dia, ações estimulantes e incentivadoras, ser mediador no processo ação-reflexão, incentivar a criatividade (Silva, 2014, p. 20).

Considerando que o lúdico é composto por brincadeiras que possuem papéis distintos no que tange ao objetivo a ser alcançado junto às crianças, podemos listar algumas atividades dentre as mais trabalhadas na educação infantil, onde cada uma foca desenvolver habilidades diferentes das crianças, são elas: 
Quadro 1: Atividades lúdicas e desenvolvimento

\begin{tabular}{|c|c|}
\hline \multicolumn{2}{|c|}{ EDUCAÇÃO INFANTIL } \\
\hline Atividade Lúdica: & Desenvolve na criança: \\
\hline Pintura & Criatividade e coordenação motora. \\
\hline Oficinas & $\begin{array}{l}\text { Interação com as pessoas e } \\
\text { desenvolvimento intelectual. }\end{array}$ \\
\hline Circuitos lúdicos & $\begin{array}{l}\text { Desenvolvimento psicomotor, } \\
\text { social e emocional. }\end{array}$ \\
\hline Gincanas diversas & Espírito de equipe. \\
\hline Massinha & $\begin{array}{l}\text { Criatividade e desenvolvimento } \\
\text { intelectual. }\end{array}$ \\
\hline Quebra-cabeças & $\begin{array}{l}\text { Concentração, paciência e } \\
\text { percepção visual. }\end{array}$ \\
\hline Mímicas & Expressão corporal e linguagem. \\
\hline Fantoches & $\begin{array}{l}\text { Construção de identidade da } \\
\text { criança. }\end{array}$ \\
\hline Jogos de tabuleiro & $\begin{array}{l}\text { Raciocínio lógico, imaginação e } \\
\text { criatividade. }\end{array}$ \\
\hline
\end{tabular}

Fonte: Freire, 2020

Partindo da interpretação do exposto no quadro 1, pode-se afirmar que o lúdico é de grande valia para o ensino na educação infantil, visto que, consequentemente, apresenta uma expressiva participação no desenvolvimento da linguagem das crianças, entendendo que as atividades de cunho lúdico norteiam para a linguagem infantil.

Diversas vezes quando citamos linguagem, é comum generalizar e remeter à linguagem verbal e escrita, que não deixam também de exercer sua importância para o desenvolvimento infantil. Porém, algumas escolas, gestores e professores insistem 
ainda, nos dias atuais, em abordar a linguagem sob essas duas formas na educação infantili; e em decorrência dessa forma restrita de pensar, as crianças são impedidas de vivenciar novas experiências, partindo de experiências que possam expandir o aprendizado. Nesse sentido, Gonçalves e Antônio (2007, p. 2) estabelecem que:

A educação infantil vem buscando superar esse entendimento de linguagem e considerando que a criança se comunica e se expressa por meio de múltiplas linguagens, $[\ldots]$ quatro das múltiplas linguagens presentes no cotidiano da educação infantil, são elas, a linguagem oral, a contação de história, a linguagem audiovisual e a linguagem por meio das artes visuais (pintura, colagem, modelagem).

Conforme o que afirmam os autores acima, vale salientar as quatro linguagens, apontando suas características.

Quadro 2: Os 4 tipos de linguagens, conforme Gonçalves e Antônio (2007):

\begin{tabular}{|l|l|}
\hline \multicolumn{1}{|c|}{ Tipos de linguagem } & \multicolumn{1}{c|}{ Características } \\
\hline Linguagem oral & $\begin{array}{l}\text { Comunicação oral, habilidade de } \\
\text { narrar e relação interpessoal. }\end{array}$ \\
\hline Contação de história & Imaginação e construção subjetiva. \\
\hline Linguagem audiovisual & $\begin{array}{l}\text { Linguagem temporal, diversão, } \\
\text { desenvolvimento da narrativa e da } \\
\text { fala letrada. }\end{array}$ \\
\hline $\begin{array}{l}\text { Linguagem por meio das artes } \\
\text { visuais (pintura, colagem e } \\
\text { modelagem) }\end{array}$ & $\begin{array}{l}\text { Forma de comunicação e } \\
\text { representação do que vêem e } \\
\text { sentem. }\end{array}$ \\
\hline
\end{tabular}

Fonte: Adaptado Gonçalves e Antônio (2007, p. 2) 
Com relação às mais diversas formas de abordagem das linguagens pautadas na educação infantil, Gonçalves e Antônio (2007, p. 21) afirmam que:

A educação vem avançando e superando desafios no que tange o trabalho com as múltiplas linguagens presentes na educação das crianças. Esperamos num tempo não muito distante uma pedagogia que trabalhe no cotidiano das crianças por meio das brincadeiras e das interações, todas as múltiplas dimensões: corporal, expressivas, estética, lúdica, sexual, psicológica, social, afetiva, cognitiva e as múltiplas linguagens possíveis: musical, plástica, corporal, dramática, oral, proporcionando as crianças à construção de suas identidades da forma mais rica possível.

Nesse compasso, enfatiza-se que a atividade lúdica também pode tornar-se uma aliada no reconhecimento de dificuldades enfrentadas pela criança no ambiente escolar, uma vez que educadores podem ter uma percepção quando a criança não se entrega totalmente à prática da atividade proposta, haja vista tais atividades despertam interesse no âmbito infantil.

\section{CONSIDERAÇÕES FINAIS}

A realização deste estudo teve como base similar a importância do lúdico no desenvolvimento do processo de aprendizagem. Considera-se que o ato de brincar e os jogos lúdicos atuam como influenciadores diretos na linguagem na educação infantil. Através da ludicidade, as crianças se sentem estimuladas a aprender, uma vez que coliga com o prazer de brincar agregado a uma forma mais agradável de aprender, e, muitas vezes, sem perceber que se está assimilando conhecimento. Tais atividades estimulam o raciocínio lógico, desenvolvem capacidades, 
determinam limites, trazem à tona a realidade de mundo, tornandose, assim, recursos fundamentais de cunho pedagógico para o desenvolvimento da linguagem, inseridos no processo de aprendizagem.

Ademais, o estudo da influência do lúdico no âmbito da educação infantil é inesgotável, haja vista, a todo momento, surgem problemáticas que colocam à prova a eficácia da atividade lúdica. Isso se deve às diversas tecnologias que despontam diariamente à nossa frente.

Diante do exposto ao longo do presente artigo, pôde-se afirmar, através das análises científicas de estudiosos, que o lúdico permanece como ferramenta de estratégia de ensino na educação infantil, não somente pelo fato de se preocupar com o aprendizado, mas por englobar também a preocupação com as questões emocionais, afetivas, sociais e cognitivas da criança.

Por fim, ressalta-se que as outras formas de linguagens pesquisadas, que não se limitam somente à oral e escrita, são diferentes formas que as crianças, na educação infantil, já utilizam; porém, muitas vezes, nem os professores ou gestores escolares se atentam para o fato de que tal atividade desenvolvida trata-se de um tipo diferenciado de linguagem, onde a criança está buscando comunicar-se.

\section{REFERÊNCIAS}

ALVIM, A. S.; NOVAES, M. P. Os jogos e as atividades lúdicas na construção da aprendizagem. 2019. Disponível em: <www.psicologia.pt/artigos/textos/A1341.pdf >. Acesso em: 10 nov. 2020 
BARBOSA, R. F. M.; GOMES, C. F. Brincadeira e desenho animado: a linguagem lúdica da criança contemporânea. In: Anais do $\mathbf{X}$ Congresso Nacional de Educação-EDUCERE e I Seminário Internacional de Representações Sociais, Subjetividade e Educação-SIRSSE. Pontifícia Universidade Católica do Paraná. Curitiba, Paraná, Brasil. 2011. Disponível em: <https://educere.bruc.com.br/CD2011/pdf/5656_3458.pdf>. Acesso em: 29 out. 2020.

BARROS, P. C. de. A prática pedagógica do professor de educação física e a inserção do lúdico como um meio de aprendizagem. Dissertação (Mestrado em Educação). Pontifícia Universidade do Paraná. Curitiba, 2006.

BORGES, C. J. Educação física para o pré-escolar. Rio de Janeiro: Sprint, 1987.

BRASIL. Lei n. 9.394, de 20 de dezembro de 1996. Dispõe sobre Diretrizes e Bases da Educação Nacional. Disponível em: <www.planalto.gov.br/ccivil_03/leis/19394.htm>. Acesso em: 12 nov. 2020.

CALICCHIO, R. S. A contribuição do lúdico nos processos de ensino e de aprendizagem. 2015. Disponível em: $<$ http://repositorio.roca.utfpr.edu.br/jspui/bitstream/1/14118/1 /MD_EDUMTE_II_2014_124.pdf >. Acesso em: 2 de nov. 2020.

DALLABONA, S. R.; MENDES, S. M. S. O lúdico na educação infantil: jogar, brincar, uma forma de educar. Revista de divulgação técnico-científica do ICPG, v. 1, n. 4, p. 107-112, 2004. Disponível em: <www.inesul.edu.br/professor/arquivos_alunos/doc_131162 7172.pdf>. Acesso em: 26 out. 2020.

FARIAS, A. G. O brincar na psicanálise e na educação. Cuiabá: UFMT, 2008. 
FARIA, A. R. de. $\mathbf{O}$ desenvolvimento da criança e do adolescente segundo Piaget. São Paulo: Ática, 1995.

FERNANDES, V. de J. L. A ludicidade nas práticas pedagógicas da Educação Infantil. Revista Científica Eletrônica de Ciências Sociais Aplicadas da EDUVALE. 104. ed. 80 Cadernos de Educação: Ensino e Sociedade, Bebedouro-SP, 3 (1):p. 66-80, 2013.

FREIRE, P. Pedagogia da autonomia: saberes necessários à prática pedagógica. São Paulo: Paz e Terra, 1996.

FRIEDMANN, A. O direito de brincar: a brinquedoteca. São Paulo: Abrinq, 1998.

GIRARDELLO, G. Voz, Presença e imaginação: a narração de histórias e as crianças pequenas. (s.d.).

GONÇALVES, C. J.; ANTONIO, D. A. As múlptiplas linguagens no cotidiano das crianças. Revista ZERO-A-SEIS (Jul./Dez. 2007), v. 9, n. 16. Disponível em: <https://periodicos.ufsc.br/index.php/ zeroseis/article/view/853>. Acesso em: 12 nov 20.

GUTIERREZ, F. Linguagem total: uma pedagogia dos meios de comunicação. São Paulo: Summus, 1978.

KISHIMOTO, T. M. Jogos infantis: o jogo, a criança e a educação/ Tizuko Morchida Kishimoto. Petrópolis, RJ: Vozes, 2006.

KOHL, M. de O. Pensamento e linguagem. In: . Vygotsky. São Paulo: Scipione, 1995.

LIBÂNEO, J. C. Didática. São Paulo: Cortez, 1994.

MACEDO, L.; PETTY, A. L. S.; PASSOS, N. C. Os jogos e o lúdico na aprendizagem escolar. 2. ed. Porto Alegre. Artmed, 2005. 
MALUF, A. C. M. Brincar: prazer e aprendizado. Petrópolis, RJ: Vozes, 2009.

MALUF, A. C. M. Atividades lúdicas para Educação Infantil: conceitos, orientações e práticas. Rio de Janeiro: Vozes, 2008.

MATIAS, A. M. J.; DA SILVA, N. W. As contribuições do lúdico na Educação Infantil. Revista de Pós-graduação Multidisciplinar, v. 1, n. 6, p. 111-122, 2019. Disponível em: <http://fics.edu.br/index.php/rpgm/article/view/851>. Acesso em: 14 de nov. 2020.

MOLON, S. I. Subjetividade e Constituição do Sujeito em Vygotsky. Petrópolis, RJ: Vozes, 2003.

MORAIS, P. H. V. de S. A importância do lúdico no processo de ensino-aprendizagem. 2016. Trabalho de Conclusão de Curso. Universidade Federal do Rio Grande do Norte. Disponível em: $<$ https://monografias.ufrn.br/jspui/bitstream/123456789/2570/ 3/AImport\%C3\%A2nciaDoLudicoEnsinoAprendizagem_Artigo_ 2016.pdf>. Acesso em: 30 out. 2020.

MORATORI, P. B. Por que utilizar jogos educativos no processo de ensino aprendizagem. UFRJ. Rio de Janeiro, p. 4, 2003. Disponível em: <www.nce.ufrj.br/ensino/posgraduacao/ strictosensu/ginape/publicacoes/trabalhos/t_2003/t_2003_patri ck_barbosa_moratori.pdf $>$. Acesso em: 13 nov. 2020.

NEVES, B. A.; OLIVEIRA, A. de; PINTO, E. A. T.;SANTOS, V. R. dos. Possibilidades de ensino por meio da ludicidade na escola pública de educação básica. Seminário Institucional PIBID. Residência Pedagógica. Dezembro/2019. Disponível em: <https://unisagrado.edu.br/custom/2008/uploads/anais/pibid_r esidencia-pedagogica/2019/trabalhos/residencia-pedagogicaensino-de-portugues-e-matema.pdf $>$. Acesso em: 13 nov. 2020. 
NILES, R. P.; SOCHA, K. A importância das atividades lúdicas na educação infantil. ÁGORA: Revista de divulgação científica, v. 19, n. 1, p. 80-94, 2014. Disponível em: <www.periodicos.unc.br/ index.php/agora/article/view/350>. Acesso em: 14 nov. 2020.

OLIVEIRA, F. dos S. Lúdico como instrumento facilitador na aprendizagem da educação infantil. Universidade Candido Mendes. Araioses: Maranhão, 2010.

OLIVEIRA, Z. M. R. Educação infantil: fundamentos e métodos. São Paulo: Cortez, 2012.

PIERS, M. W.; LANDAU, G. M. O dom de jogar e porque as crianças não podem prosperar sem ele. São Paulo: Cortez, 1990.

SACCHETTO, K. K. et al. O ambiente lúdico como fator motivacional na aprendizagem escolar. Cadernos de PósGraduação em Distúrbios do Desenvolvimento, v. 11, n. 1, 2011. Disponível em: <www.mackenzie.br/fileadmin/OLD/47/ Graduacao/CCBS/PosGraduacao/Docs/Cadernos/Volume_11/K aufmann-Sacchetto_et_al_v_11_n_1_2011artigo_2.pdf $>$. Acesso em: 9 nov. 2020.

SALES, F. O papel das atividades lúdicas no processo de desenvolvimento e aprendizagem. UERJ, 2010. Disponível em: $<$ www.educador.brasilescola.com/trabalho-docente/o-papel-dasatividades-ludicas-noprocesso-desenvolvimento.htm $>$. Acesso em: 23 out. 2020.

SAlOMÃO, H. A. S.; MARTINI, M.; JORDÃO, A. P. M. A importância do lúdico na educação infantil: enfocando a brincadeira e as situações de ensino não direcionado. Portal de Psicologia, 2007. Disponível em: <www.psicologia.pt/artigos/ textos/A0358.pdf>. Acesso em: 24 out. 2020. 
SANTANNA, A.; NASCIMENTO, P. R. A história do lúdico na educação. In: REVEMAT Revista Eletrônica de Educação Matemática. v. 6, n. 2, p. 19-36, 2011. Disponível em: <https://periodicos.ufsc.br/index.php/revemat/article/view/198 1-1322.2011v6n2p19/21784>. Acesso em: 8 nov. 2020.

SILVA, A. G. da. Concepção de lúdico dos professores de educação física infantil. Universidade Estadual de Londrina. Londrina: SC, 2011.

SILVA. N. Z. da. A importância do lúdico na educação infantil. Monografia (Especialização em Educação). Universidade Tecnológica Federal do Paraná. Paranavaí, 2014.

SOUZA, P. do C. O lúdico e o desenvolvimento infantil. Revista do NUPE (Núcleo de Pesquisas e Extensão) do DEDC I/UNEB. Universidade do Estado da Bahia. v. 1.n. 1. 2012.

VYGOTSKY, L. S. Psicologia pedagógica. São Paulo: Artes Médicas, 2001.

VYGOTSKY, L. S. A Formação social da mente. São Paulo: Martins Fontes, 1989.

WAJSKOP, G. Brincar na pré-escola. São Paulo: Cortez, 2001. 


\section{MAPAS CONCEITUAIS - UMA ABORDAGEM REFLEXIVO- ANALÍTICA A RESPEITO DA APRENDIZAGEM COM SIGNIFICADO}

Daiany da Silva Ferreira ${ }^{56}$.

\section{INTRODUÇÃO}

Este trabalho é resultado dos estudos realizados pelos autores Dantas et al. (2018), Souza Junior et al. (2017), Rocha e Spohr (2016), Palandi (2011), Correia et al. (2010) e Moreira (2010), que tratam sobre o que são mapas conceituais e respectivamente quanto ao uso dos mesmos no processo educacional de ensino. A proposta deste trabalho consiste em pesquisar e realizar uma reflexão analítica sobre o uso de mapas e como deve acontecer essa utilização em sala de aula pelos professores. Seguindo a perspectiva da pesquisa bibliográfica, os dados obtidos foram através de consultas digitais de artigos publicados em revistas pedagógicas, notadamente as voltadas ao ensino de física.

Os mapas conceituais surgem como proposta didática alternativa para complemento na aprendizagem, ideia proposta inicialmente por Joseph Novak, como citado por Souza Junior et al. (2017) o mapa conceitual é uma ferramenta utilizada como recurso para alcançar a aprendizagem significativa, contribuindo à construção hierárquica dos conceitos a partir dos conhecimentos prévios dos alunos.

56 Mestrado Nacional Profissional em Ensino de Física junto à Universidade Federal de Rondônia (UNIR). E-mail: daianysf@gmail.com. 
De acordo com Moreira (2010), de modo geral, mapas conceituais, ou mapas de conceitos, são apenas diagramas indicando relações entre conceitos, ou entre palavras que usamos para representar conceitos que podem ser usados como ferramenta de aprendizagem significativa, como a proposta por David Paul Ausubel, uma aprendizagem com significado ocorre quando o aluno consegue relacionar situações do seu cotidiano com o objeto de estudo levando em consideração todo conhecimento prévio adquirido ao longo de sua existência.

Conforme Palandi (2011), os mapas conceituais não são abordados nos livros didáticos, os professores repassam os conceitos prontos puramente formais, o que distancia ainda mais da realidade dos alunos com relação à temática abordada. A partir desse prisma foi feito um estudo na Universidade de Santa Maria em 2011, durante um projeto de extensão, quando foram analisados mapas conceituais disponibilizados na internet, levando em consideração critérios especiais como hierarquia na disposição dos conceitos, clareza e simplicidade na estruturação espacial e inclusividade em relação aos conceitos essenciais e complementares. Posterior a análise conclui-se que os mapas prontos não atendiam as expectativas, propuseram então que outros mapas fossem produzidos pelos bolsistas de iniciação participantes do projeto onde futuramente serviriam como instrumento de aplicação em sala de aula, ou mesmo como método de avaliação.

Os mapas conceituais podem ser utilizados também como forma de avaliação. De acordo com Souza Junior et al. (2017), o professor pode avaliar diferentes aspectos como, por exemplo, se o 
aluno apresenta algum conceito equivocado, sua habilidade de organização e estruturação, a profundidade sobre a mobilização de um conceito, se faz diferenciação progressiva e reconciliação integrativa. $\mathrm{O}$ fato de os alunos produzirem seus próprios mapas conceituais e não simplesmente seguirem um modelo pronto faz com que haja aprendizagem significativa, uma vez que durante a produção há uma associação dos conhecimentos já adquiridos às novas informações, organizadas de forma clara e hierárquica.

Esse fato nos remete ao artigo de Palandi (2011) que analisaram mapas prontos disponibilizados na internet, mas que nenhum estava de forma completa e clara em relação ao tema central e desenvolvimento dos mesmos, o que nos faz pensar sobre o resultado positivo em os alunos construírem os mapas conceituais à sua maneira, de modo a obter uma maior compreensão sobre o que construíram, pois partem de ideias criadas por si só, e o que não tiver coerência poderá ser ajustado no processo de avaliação.

No decorrer deste artigo iremos abordar algumas das propostas de utilização de mapas conceituais como ferramenta pedagógica com ênfase no ensino de Física, bem como essa ferramenta pode ser abordada em sala de aula e os impactos na aprendizagem dos alunos. Conceitualmente, trabalharemos no âmbito da aprendizagem significativa proposta por Ausubel através de análise bibliográfica reflexiva-analítica.

\section{DeSENVOLVIMENTO}

A aprendizagem significativa ou teoria cognitivista de aprendizagem desenvolvida por Ausubel acontece quando, segundo Moreira (2010, p. 18): "uma nova informação (conceito, 
ideia, proposição) adquire significados para o aprendiz através de uma espécie de ancoragem", ou seja, a nova informação ou o novo conhecimento para ser aprendido é necessário fixar ou de acordo com o autor ancorar interagir juntamente ao existente. Esse conhecimento já existente na estrutura cognitiva do indivíduo é chamado por Ausubel como "subsunçores".

Para acontecer realmente uma aprendizagem com significados é necessário obter condições apropriadas como "a predisposição para aprender, a existência de conhecimentos prévios adequados, especificamente relevantes e materiais potencialmente significativos" (Moreira, 2010 p. 4). Na realidade, os pontos máximos seria a predisposição no aprendizado do indivíduo e os materiais a serem utilizados de forma significativa, no qual está internalizado com os conhecimentos prévios. Desta maneira esse novo conhecimento deve acontecer de forma não arbitrária, ou seja, deve conter significados pessoais de acordo com Moreira (2010):

Aprender significativamente implica atribuir significados e estes têm sempre componentes pessoais. Aprendizagem sem atribuição de significados pessoais, sem relação com o conhecimento preexistente, é mecânica, não significativa. Na aprendizagem mecânica, o novo conhecimento é armazenado de maneira arbitrária e literal na mente do indivíduo (Moreira, 2010, p. 18).

Essa aprendizagem não arbitrária significa que a relação com o conhecimento prévio não acontece com qualquer conceito, mas sim com algum conhecimento que seja especificamente relevante Moreira (2010). 
Figura 1: Mapa conceitual - uma síntese da aprendizagem significativa de Ausubel

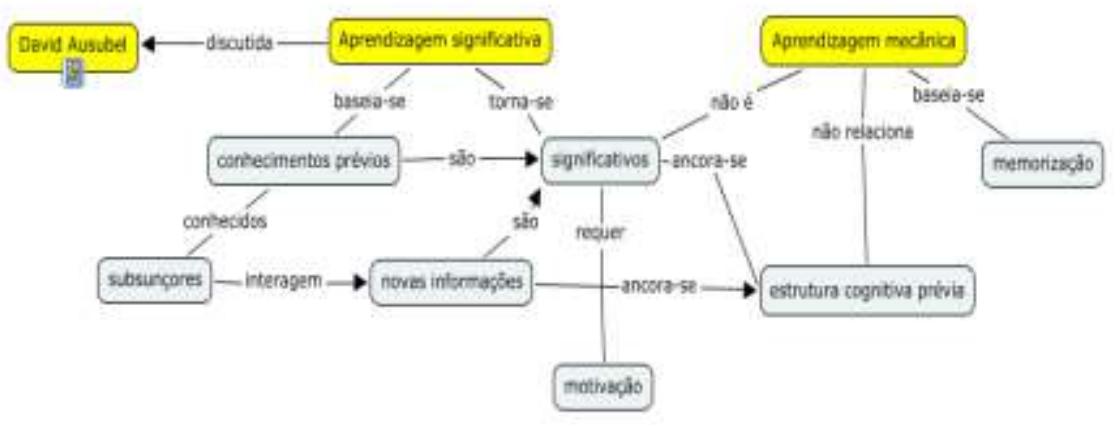

Fonte: Martins (2015)

\section{MAPAS CONCEITUAIS}

Quando se fala em mapas conceituais, logo se remete à teoria de aprendizagem significativa proposta por Ausubel. Entretanto, de acordo com Souza Junior et al. (2017, v. 13, p. 4 apud Novak, 2005). "Os mapas conceituais foram desenvolvidos em 1972, dentro do programa de pesquisa realizado por Novak na Universidade de Cornell, no qual ele buscou acompanhar e entender as mudanças na maneira como as crianças compreendiam a ciência”.

Essa relação entre os mapas e a aprendizagem significativa acontece devida a utilização de mapas como um recurso didático que se relaciona com as etapas necessárias para obter uma aprendizagem por meios de significados. Moreira (2010) realiza uma análise no currículo da aprendizagem ausubeliana e classifica em cinco etapas que implicam bem essa teoria:

1) identificar a estrutura de significados aceita no contexto da matéria de ensino; 2) identificar os 
subsunçores (significados) necessários para a aprendizagem significativa da matéria de ensino; 3) identificar os significados preexistentes na estrutura cognitiva do aprendiz; 4) organizar sequencialmente o conteúdo e selecionar materiais curriculares, usando as ideias de diferenciação progressiva e reconciliação integrativa como princípios programáticos; 5) ensinar usando organizadores prévios, para fazer pontes entre os significados que o aluno já tem e os que ele precisaria ter para aprender significativamente (Moreira, 2010, p. 22).

Mas o que realmente é um mapa conceitual? Segundo Moreira (2010) mapas conceituais é diagramas que apontam interrelações de conceitos, entre palavras que podem ser representadas por eles. Os mapas possuem uma organização hierárquica e que em sua maioria das vezes possuem setas e diagramas em seu esboço, mas segundo Moreira (2010, p. 11) "tais diagramas não devem ser confundidos com organogramas ou diagrama de fluxo, pois não implicam sequência, temporalidade ou direcionalidade”. Neste sentindo, os mapas conceituais não classificam, mas sim relaciona e hierarquiza conceitos.

A utilização de mapas conceituais é algo bem diversificado, pois o mapeamento não está preso a um único tema ou apenas uma situação, os mapas possuem diversas finalidades "instrumento de análise do currículo, técnica didática, recurso de aprendizagem, meio de avaliação” (Moreira, 2010, p. 16 apud Moreira e Buchweitz, 1993).

"Os mapas perpassam variados graus de generalidade e exclusividade” Moreira (2010), ou seja, pode ser utilizado em uma única aula, ou pode ser utilizado como uma atividade de avaliação, ou pode ser realizado para um curso, ou para um programa educacional, seus conteúdos podem específico ou não enfim os 
mapas podem ser utilizados para mostrar aprendizagem significativa, conforme a figura 2.

Mas Moreira deixa um alerta que os mapas conceituais não são autointuitivos os professores precisam explicar como os mapas funcionam e como devem ser realizados atividades por meio deles. Por isso é necessário que os alunos estejam familiarizados com os mapas para que sejam um instrumento de grande potencialidade na aprendizagem significativa, caso contrário os mapas se tornam uma ação mecânica realizada pelo aluno de forma arbitrária.

Figura 2: Mapa conceitual sobre "o que são mapas conceituais"

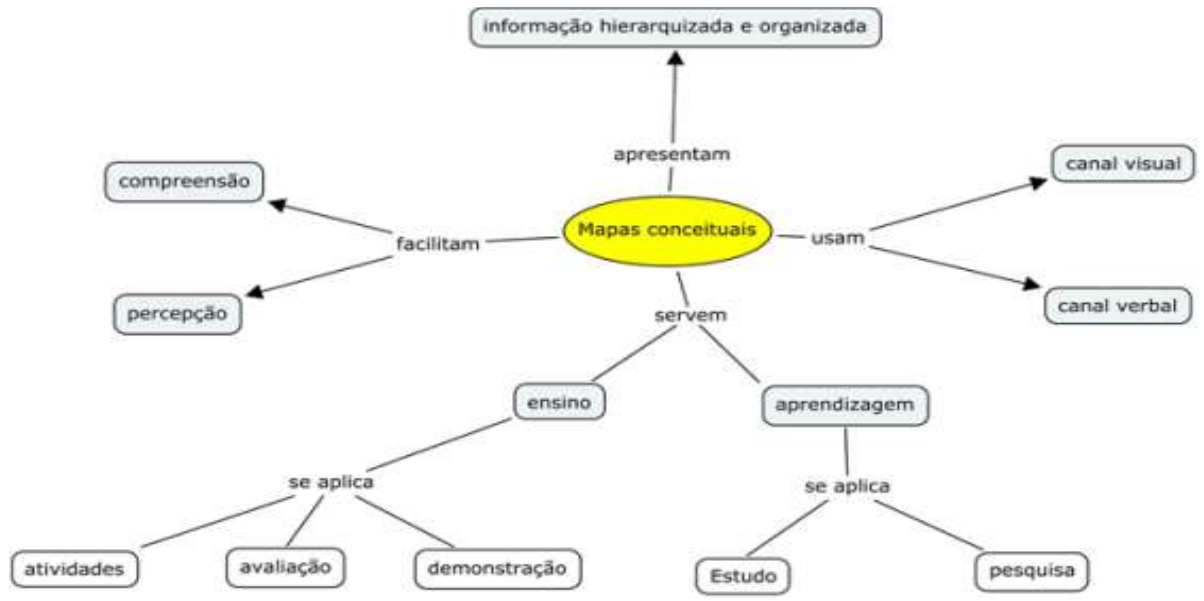

Fonte: Audy (2014)

\section{MAPAS CONCEITUAIS NO ENSINO DE FÍSICA}

Os desafios no ensino de física se tornam cada vez mais frequente em sala de aula, os problemas e dificuldades que a física sofre não é algo novo no sistema de ensino, desta maneira um dos pontos altos de várias discussões em relação a essa problemática ocorre devido à forma que as escolas empregam seu ensino de "forma tradicional que proporciona separações na área do 
conhecimento. No Ensino de Física quando os conceitos são repassados aos alunos em forma de blocos - mecânica, ótica, eletricidade, etc. -, percebe-se que essas divisórias não se tornam claras aos alunos; eles não conseguem relacionar os conhecimentos repassados e as aulas tornam-se complexas e difíceis, entre outros fatores relacionados (Souza Junior et al., 2017, p. 3).

É necessário, portanto, que o professor busque ferramentas que possa deixar suas aulas não mecânicas e que os alunos realmente conseguem interpretar, discutir, relacionar os novos conhecimentos em sala de aula. Desta maneira os mapas conceituais tornam-se uma alternativa de ferramenta educacional. Como já sabemos o mapa conceitual é uma ferramenta gráfica que obtém uma organização e representação de assuntos, características que proporciona e pode ser redirecionado ao ensino de física "como se organiza o pensamento científico, em postulados, axiomas e teoremas" (Dantas, et al., 2018, p. 191).

Essa configuração hierárquica do pensamento científico pode ser facilmente evidenciada com o uso dos mapas, eles também podem representar relações entre grandezas e conceitos físicos, ponto crucial no estudo dos fenômenos físicos, vale ressaltar que conceitos iguais podem assumir funções hierárquicas diferentes dependendo do temo abordado. Em segundo lugar, por eles serem uma representação da estrutura cognitiva do indivíduo e por serem fundamentados em uma teoria solida da aprendizagem (Dantas, et al., 2018, v. 3, p. 191).

Atualmente podemos encontrar diversas propostas de mapas conceituais no ensino de física, que ocorre em assuntos específicos (a figura 3 traz um assunto específico, a transferência de calor, que normalmente se encontra nos conteúdos sobre calor nos livros didáticos) ou até mesmo numa forma geral dos conteúdos (a 
figura 4 que mostra um mapa conceitual sobre o conteúdo de óptica, que é proposto em capítulos nos citados livros).

Figura 3: Mapa conceitual sobre transferência de calor

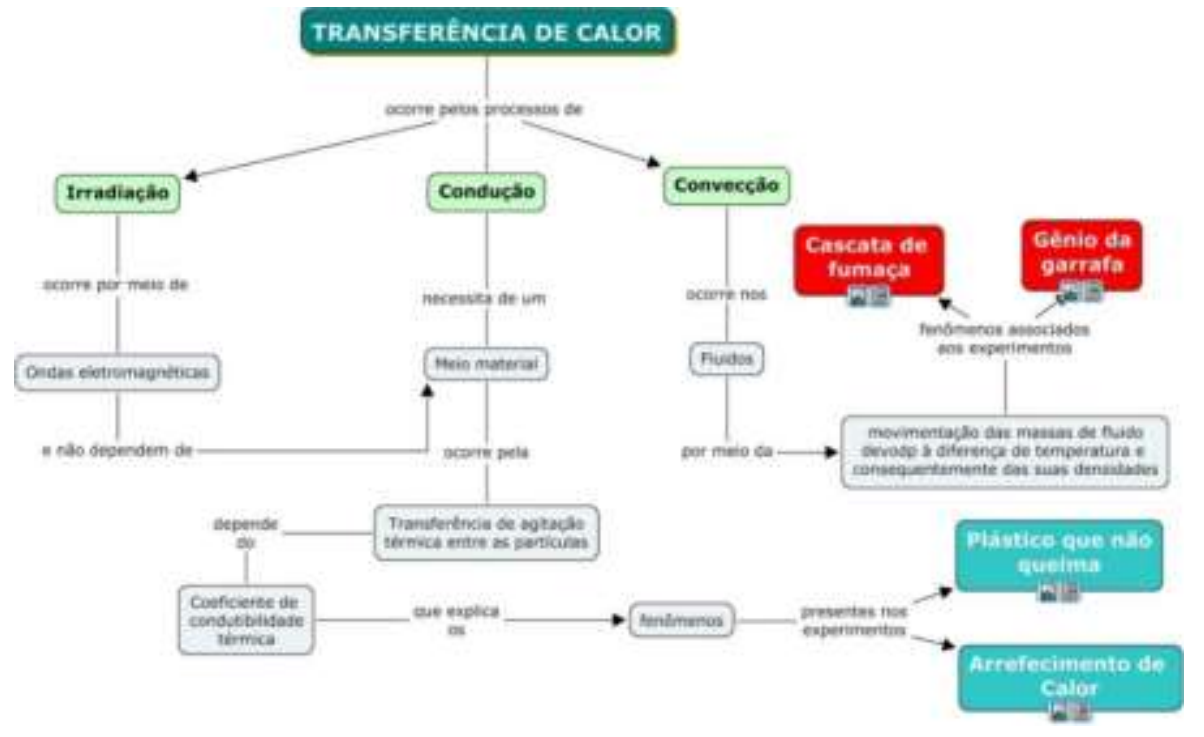

Fonte: Experimentando Física (2012) 
Figura 4: Mapa conceitual sobre óptica

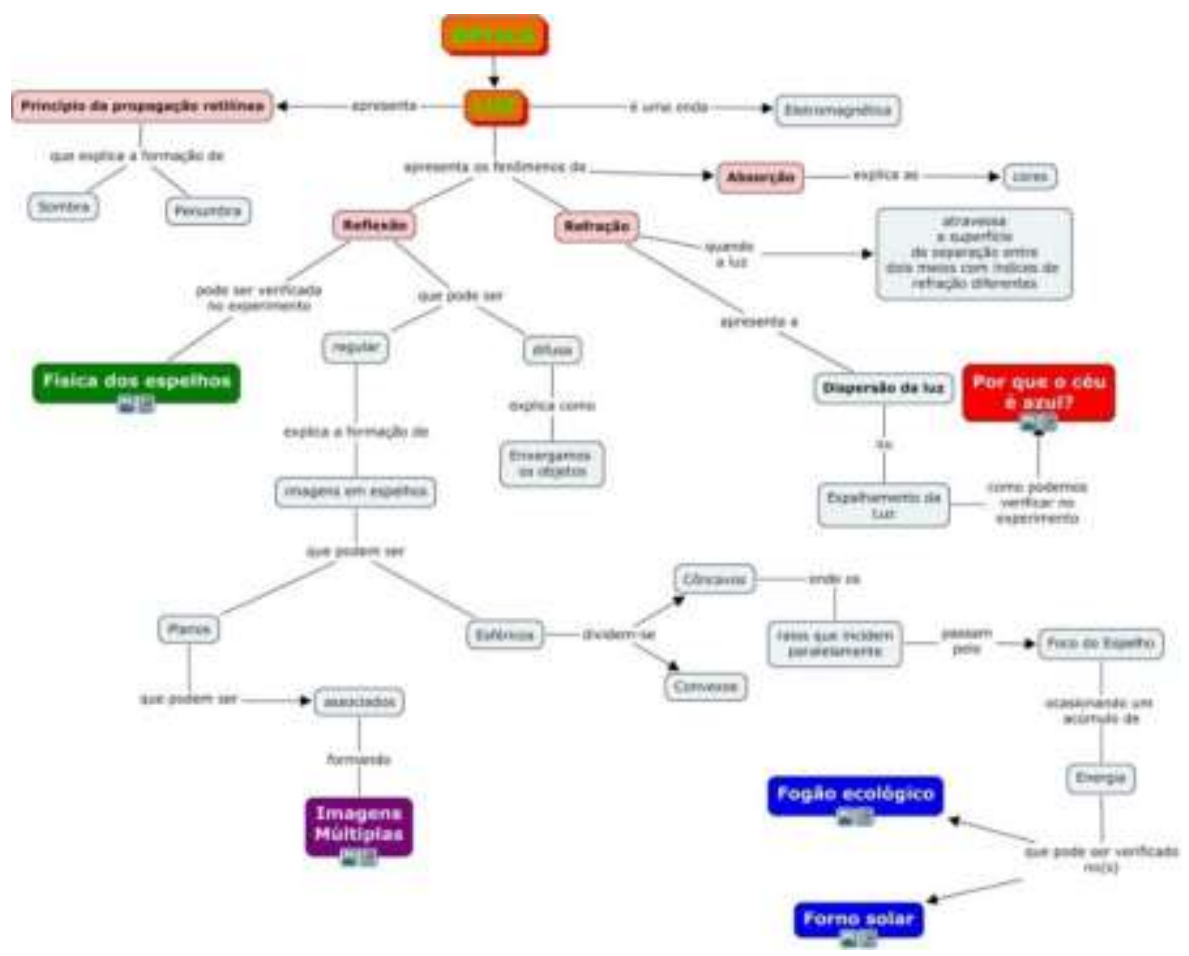

Fonte: Experimentando Física (2012)

O uso de mapas conceituais pode ocorrer de várias maneiras e essa utilização pode ser diferenciada quando relacionamos alunos versus professores de acordo com Dantas, et al. (2018, p. 193), os objetivos para o uso de mapas para alunos e professores são:

Para os alunos os mapas conceituais podem ser usados, por exemplo, para fazer anotações, trocar ideias sobre um tema, resolver problemas, planejar o estudo e/ou a redação de grandes relatórios, fazer síntese de um texto, preparar-se para avaliações, apresentar trabalho e identificar integração entre tópicos. Para os professores, eles podem ser uma ferramenta poderosa para auxiliar em 
tarefas rotineiras do ensino, como por exemplo, ensinar um novo tópico, reforçar a explicação, analisar currículos, organizar o conteúdo e avaliar a aprendizagem (Dantas, et al., 2018, p. 193).

E não podemos esquecer que os mapas conceituais também podem ser utilizados como uma ferramenta de avaliação durante o processo de ensino e aprendizagem.

\section{MAPAS CONCEITUAIS COMO FERRAMENTA DE AVALIAÇÃO}

A utilização de mapas conceituais em salas de aulas como uma ferramenta de avaliação é uma das maneiras que professor pode utilizar para realizar as devidas organizações e avaliações na grande curricular de acordo com Correia et al. (2010).

Os MCs são frequentemente utilizados para identificar os conhecimentos prévios dos alunos, para acompanhar o processo de mudança conceitual ao longo da instrução, para verificar a organização dos conceitos numa disciplina e para avaliar grades curriculares (Correia et al., 2010, p. 1).

Essas avaliações podem ocorrer de diversas maneiras como, identificar o grau de conhecimento dos alunos, analisar como os alunos estabelecem as relações hierárquicas que os mapas exigem ou como os alunos estabelecem as inter-relações entre a realização dos mapas conceituais com o conteúdo desenvolvido pelo professor, acontecendo em uma única aula ou podendo ser estendido a todos os conteúdos que serão trabalhados durante toda duração do curso (Rocha; Spohr, 2016, p. 28).

No entanto, quando se é trabalhado mapas conceituais dentro de um sistema de avaliação deve ser lembrado que não existem mapas errados ou que o aluno errou ao desenvolver a 
atividade, mas que cada mapa é distinto, ou seja, exclusivo dentro da compreensão desenvolvida pelo discente, de acordo com Rocha e Spohr (2016, p. 28, apud Moreira, 2006b).

Um dos pontos importantes quando se fala de MCs é que ele não deve ser visto como único, pois não existe uma única forma de organização e o mesmo assunto pode assumir apresentações distintas entre diferentes MCs, ou seja, cada mapa é apenas mais uma das inúmeras possíveis representações de uma estrutura conceitual (Rocha; Spohr, 2016, p. 28 apud Moreira, 2006b).

De fato, o ato de avaliar não deve ser algo vazio sem nenhum conhecimento teórico é necessário que o professor tenha uma base de concepções bem atribuídas em sua maneira de avaliar seus alunos, os mapas trazem um teórico distinto e perceptivo quando se é aplicado devidamente dentro do processo ensino aprendizagem e traz consigo seu desempenho satisfatório.

A partir da análise de artigos, evidencia-se uma gama aplicações no ensino de física através dos mapas conceituais. Essas aplicações ocorrem em diversos ramos da física e possuem um resultado significativo no processo educacional dos alunos e também no aperfeiçoamento de professores de acordo Palandi e colaboradores (2011), utilizou os mapas conceituais para o aprendizado da física dos fluidos no ensino médio onde tal atividade aconteceu através de um projeto desenvolvido com os professores do Programa Ciência Viva Integração Ciências \& Sociedade (Proext, 2010, edital n. 5).

Os mapas podem ser trabalhados com assuntos gerais, mas também específicos como podemos encontrar no trabalho realizado por Souza Junior e colaboradores (2017) onde utilizaram os mapas no ensino de física abrangendo conteúdos básicos de 
ondas, som e luz aos alunos do $9^{\circ}$ ano do ensino fundamental como uma ferramenta de avaliação. Podemos verificar Prado e Ferracioli (2014) a utilização dos mapas através do assunto de Termodinâmica, atividade realizada com os alunos do ensino médio no processo de avaliação. Moreira (2004) trabalha mapas conceituais com assuntos introdutórios sobre partículas elementares e interações fundamentais que são representadas de uma forma mais simples e acessível ao entendimento do aluno.

A utilização dos mapas é interdisciplinar e pode ser utilizado em vários ramos científicos não somente no ensino de física, mas em diferentes níveis de ensino, Lorenzetti e Virginia (2018) realizaram a utilização dessa ferramenta educacional com alunos do $4^{\mathrm{O}}$ ano do ensino fundamental de uma escola pública, trabalhando assuntos de ciências com esses alunos.

\section{CONSIDERAÇÕES FINAIS}

Frente às reflexões a aprendizagem significativa só acontece quando as novas ideias (conceitos) interagem de forma acentuada com as ideias pré-existentes. O conhecimento prévio do aluno é imprescindível e relevante para que novo assunto seja compreendido. Para que isso possa acontecer se faz necessário pensar que tipo de ferramenta deve ser utilizado nesse processo educacional. Desta maneira, os mapas conceituais se integram perfeitamente a essa teoria, tornando-se associados à mesma.

Os mapas se tornam uma ótima alternativa em sala de aula, mas, ao mesmo tempo, se o professor não souber utilizar os mesmos, a aprendizagem significativa não acontece, ao contrário se torna algo sem sentido ao aluno que simplesmente o reproduz mecanicamente. Quando os mapas são trabalhados de forma adequada se obtém um resultado positivo, mas para que isso 
aconteça é necessário que os alunos estejam familiarizados com mapas, e que compreendem bem como devem ser realizados e utilizados em sala de aula.

O uso de mapas em sala de aula pode ocorrer como uma forma de avaliação pelo professor, que pode utilizá-los para determinar as relações do conhecimento adquirido pelo aluno. Nesse sentido, através da pesquisa realizada por esse artigo, podemos concluir que a utilização de mapas conceituais realmente conduz a uma aprendizagem significativa sem realizar mudanças drásticas em sala de aula.

\section{REFERÊNCIAS}

CORREIA, Paulo Rogério Miranda; SILVA, Amanda Cristina da; JUNIOR, Jerson Geraldo Romano. Mapas conceituais como ferramenta de avaliação na sala de aula. [S.1.]:v. 32, n. 4, 4402. rev. Brasileira de Ensino de Física, 2010.

DANTAS, M. P.; SILVA, F. U; BORGES, J. C. S. Uso de mapas conceituais como ferramenta de avaliação qualitativa, com ênfase no ensino de física. [S.l.]: v. 3. Holos, 2018.

LORENZETTI, Leonir; SILVA, Virginia Rotters da. A utilização dos mapas conceituais no ensino de ciências nos anos iniciais. Passo Fundo, RS. v. 25, n. 2. rev. Espaço Pedagógico, 2018.

MOREIRA. Marcos Antonio. Mapas conceituais e aprendizagem significativa. [S.l.]: Editora Centauro, 2010.

PALANDI, Joecir. et al. Mapa conceitual da física dos fluidos. Santa Maria, RS. v. 3, n. 1. Revista de Extensão, 2016. 
PRADO, Ramon; FERRACIOLI, Laércio. Utilização mapas conceituais na avaliação do conteúdo de termodinâmica. Santos, SP. Concept Mapping to Learn and Innovate, 2014.

ROCHA, Cecília Elenir dos Santos. SPOHR, Beatriz. O uso de mapas conceituais como instrumento didático para identificar indícios de aprendizagem significativa em diferentes níveis de ensino. Investigações em Ensino de Ciências (IENCI) v. 21, n. 3, 2016. Disponível em: <www.if.ufrgs.br/cref/ojs/index.php/ienci/ article/view/219>.

SOUZA JUNIOR, M.V. et al. Mapas conceituais no ensino de física como estratégia de avaliação. Scientia Plena, v. 13, n. 1, 2017. 


\title{
ESTUDANTES ENFERMOS: O DIREITO À ASSISTÊNCIA EDUCACIONAL HOSPITALAR E DOMICILIAR ${ }^{57}$
}

\author{
Vera Mônica Queiroz Fernandes Aguiar ${ }^{58}$ \\ Regina Célia Linhares Hostins 59
}

\section{INTRODUÇÃO}

Classes escolares em hospitais são alternativas de atendimento educacional para estudantes hospitalizados, as quais buscam assegurar que no período de permanência no hospital sejam supridas suas necessidades educativas e direitos à cidadania, pelo processo de escolarização.

Por ser a educação um direito de todos e dever do Estado e da família, este deve ser expresso como direito à escolarização, por isto a proposta deste artigo é promover a discussão sobre esses direitos, dada à grande necessidade atual no Brasil, em que cresce o número de alunos-pacientes.

A abordagem não é específica da educação especial, mas em dados publicados pela Secretaria de Educação Especial no livro

\footnotetext{
${ }^{57}$ Artigo elaborado para fins de publicação e obtenção de créditos como exigência da matriz curricular da Universidade do Vale do Itajaí - Univali. Pró-Reitoria de Pesquisa, Pós-Graduação, Extensão e Cultura. Programa de Pós-Graduação Stricto Sensu em Ciência da Educação. Curso de Doutorado em Educação. Doutorado Interinstitucional. Faculdade Católica de Rondônia (FCR).

${ }^{58}$ Doutoranda em Educação da Universidade do Vale do Itajaí (Univali).

${ }^{59}$ Orientadora da pesquisa, docente do Curso de Doutorado em Educação da Univali.
} 
Classe hospitalar e atendimento pedagógico domiciliar: estratégias e orientações, a classe hospitalar é descrita como

Uma sala para desenvolvimento das atividades pedagógicas com mobiliário adequado e uma bancada com pia são exigências mínimas. Instalações sanitárias próprias, completas, suficientes e adaptadas são altamente recomendáveis e espaço ao ar livre adequado para atividades físicas e ludo-pedagógicas. Além de um espaço próprio para a classe hospitalar, o atendimento propriamente dito poderá desenvolver-se na enfermaria, no leito ou no quarto de isolamento, uma vez que restrições impostas ao educando por sua condição clínica ou de tratamento assim requeiram. $\mathrm{O}$ atendimento pedagógico poderá também ser solicitado pelo ambulatório do hospital onde poderá ser organizada uma sala específica da classe hospitalar ou utilizar-se os espaços para atendimento educacional (Brasil, 2002, p. 22).

Dessa perspectiva, entendemos que o direito à saúde e à educação pode ser resguardado, a fim de que o estudante possa se recuperar de alguma enfermidade sem que haja prejuízos em sua vida educacional.

Tyara Carvalho de Oliveira (2013) destaca que as classes hospitalares surgem no contexto mundial, em meados do século $\mathrm{XX}$, quando se observou que, em países como Inglaterra, Canadá e Estados Unidos, orfanatos, asilos e instituições infantis violavam aspectos básicos do desenvolvimento emocional infantil de estudantes e podiam levá-los a condições psiquiátricas sérias com riscos de sequelas na vida adulta.

Pesquisas sobre classes hospitalares relatam que nas primeiras décadas do século XX, a Europa registrava o surgimento de algumas atividades educativas de hospitais que podem ser 
consideradas o início do que hoje se conhece como classe hospitalar.

Paula (2011) ensina que na França, a primeira classe hospitalar foi implementada em 1929, por Marie Luoise Imbert, contudo, Vasconcelos (2005) assinala que a classe hospitalar em 1935 se iniciou na França e posteriormente, alguns países europeus e Estados Unidos, que atendiam crianças com tuberculose.

Oliveira (2013) salienta que

O Centro Nacional de Estudos e de Formação para a Infância Inadaptada (CNEFEI) de Suresnes, cidade periférica de Paris, foi criado em 1939 com o objetivo de formar professores para o trabalho em institutos especiais e em hospitais. Nesse mesmo ano é criado o cargo de professor hospitalar junto ao Ministério da Educação na França. Esse Centro funciona até hoje. A formação de professores para as classes hospitalares no CNEFEI tem duração de dois anos. O Centro tem como missão até hoje mostrar que a escola não é hermeticamente fechada. $\mathrm{O}$ CNEFEI promove estágios, em regime de internato dirigido a professores e diretores de escolas; a médicos de saúde escolar e a assistentes sociais. Desde 1939, o CNEFEI já formou mais de mil professores. Isso faz com que todos os hospitais públicos na França tenham em seu quadro docente quatro professores: dois de ensino fundamental $\mathrm{e}$ dois do ensino médio. Eles trabalham em turnos diferentes de segunda a sexta (Oliveira, 2013a, p. 13).

Nessa direção, a autora relata que nos anos 40, criou-se a associação Animation Loisirs à L Hôpital (Animação, Lazer no Hospital), sendo que na década de 80 fundou-se a Associação para a melhoria das condições de hospitalização das crianças (Apache) vinculada, segundo Paula (2011), à European Association for 
Children in Hospital (Associação Europeia para Crianças em Hospital).

Essa conquista histórica foi importante, pois os direitos das crianças e adolescentes internados foram assegurados para obter atendimento de professores aposentados, professores da rede pública oficial e voluntários, como continuidade à escolarização da criança e adolescente hospitalizados, recebendo o devido acompanhamento nos hospitais, permitindo-se a alta hospitalar, antes do retorno à escola regular. Essa associação conta com mais de três mil professores (Paula, 2011).

$\mathrm{O}$ atendimento pedagógico hospitalar é recente em muitos lugares no mundo. Na Espanha, por exemplo, Oliveira (2013) analisa que hospitais infantis e de reabilitação; aqueles que tiveram serviços pediátricos permanentes, da administração do Estado, dos órgãos, comunidades autônomos e hospitais particulares que ocupem, no mínimo, a metade de suas camas com doentes e atendimento médico que dependam de recursos públicos deverão dispor de uma seção pedagógica para prevenir e evitar a marginalização do processo educacional dos alunos em idade escolar internados nesses hospitais. Dessa maneira, na esfera mundial, vê-se que a criança em idade escolar acometida por enfermidade possui atendimento com profissionais preparados. A Declaração dos Direitos da Criança Hospitalizada de 1987, na Espanha faz alusão ao processo de ensino-aprendizagem da criança doente e/ou hospitalizada e/ou convalescente, destacando entre outros aspectos, o direito, que as crianças têm, de continuar a sua vida escolar durante o tempo de permanência no hospital e de se beneficiar do ensino dos professores e do material didático que as autoridades escolares disponibilizem (Camaru; Goldani, 2004).

Oliveira (2013) destaca: 
A Carta da Criança Hospitalizada de Portugal, de 2000, inspirada nos princípios da Carta Europeia da Criança Hospitalizada, aprovada pelo Parlamento Europeu em 1986, demonstra as preocupações com projetos de humanização nos hospitais, com o bem-estar da criança hospitalizada e os aspectos educativos. O princípio sete da Carta de Portugal propõe que o "Hospital deve oferecer às crianças um ambiente que corresponda às suas necessidades físicas, afetivas e educativas, quer no aspecto do equipamento, quer no de pessoal e da segurança. (Oliveira, 2013b, p. 13).

Depreende-se, nesse histórico, que outros países se preocuparam com a garantia do direito de aprender das crianças hospitalizadas e assim é necessário que no Brasil se ampliem as políticas públicas de educação hospitalar e implemente-se o atendimento a crianças com necessidade de atendimento hospitalar.

No Brasil, as políticas públicas educacionais norteiam o desenvolvimento da pesquisa, dos saberes e de todas as questões que envolvem a produção científica. A aplicabilidade das políticas de educação tem sido satisfatória no âmbito da educação, contudo são necessários muitos ajustes por parte do poder público para que sejam efetivadas.

A Constituição Federal de 1988 assegura nos artigos 205 e 206 o que segue:

Art. 205. A educação, direito de todos e dever do Estado e da família, será promovida e incentivada com a colaboração da sociedade, visando ao pleno desenvolvimento da pessoa, seu preparo para o exercício da cidadania e sua qualificação para o trabalho. 
Art. 206. O ensino será ministrado com base nos seguintes princípios:

I - igualdade de condições para o acesso e permanência na escola;

II - liberdade de aprender, ensinar, pesquisar e divulgar o pensamento, a arte e o saber;

III - pluralismo de ideias e de concepções pedagógicas, e coexistência de instituições públicas e privadas de ensino;

IV - gratuidade do ensino público em estabelecimentos oficiais;

V - valorização dos profissionais da educação escolar, garantidos, na forma da lei, planos de carreira, com ingresso exclusivamente por concurso público de provas e títulos, aos das redes públicas;

VI - gestão democrática do ensino público, na forma da lei;

VII - garantia de padrão de qualidade.

VIII - piso salarial profissional nacional para os profissionais da educação escolar pública, nos termos de lei federal.

A Lei Maior garante educação a todos e deve ser acessível aos cidadãos, a fim de ser promovida e incentivada com a colaboração coletiva, primando pelo desenvolvimento da pessoa humana para exercer a cidadania, possibilitando a sua qualificação sem prejuízos no seu intelecto independente das condições em que se encontre o indivíduo. $\mathrm{O}$ artigo $1^{\circ}$ da lei preconiza que a República Federativa do Brasil, organizada pela união indissolúvel dos Estados e Municípios e do Distrito Federal, constitui-se em Estado Democrático de Direito e tem como fundamento no inciso II a dignidade da pessoa humana e o caput do seu artigo $5^{\circ}$ estatui que todos são iguais perante a lei, fazendo jus a tratamento igual e digno. 
A Carta Política também corrobora que o ensino será ministrado com fundamento em princípios, sendo alguns como da igualdade de condições para o acesso e permanência na escola, isto é, todos têm direito à educação. Já o princípio da liberdade de aprender, ensinar, pesquisar e divulgar o pensamento, a arte, o saber indica que todos podem usufruir as benesses contempladas pelo conhecimento. O princípio do pluralismo de ideias e de concepções pedagógicas, e coexistência de instituições públicas e privadas de ensino possibilita a todos a expressão livre do pensamento.

Quanto à gratuidade do ensino público em estabelecimentos oficiais a Constituição Federal garante o acesso gratuito à educação a fim de que todos possam ser alcançados. Lalo Watanabe Minto (2018) assinala que o princípio da gratuidade do ensino público deve ser explanado de forma extensiva para que a expressão ensino englobe as atividades norteadoras, propiciando o ensino, posto que embora ensino seja o fim, os meios que permitem o acesso a ele, lhes são próprios, pois amparam e dão suporte e até condição a fim de concretizar o acesso ao ensino público e gratuito.

Cabe aqui chamar a atenção para o desenvolvimento desta temática que versará sobre a pessoa que se encontra em ambiente hospitalar no que concerne à escolarização obrigatória prevista em nosso ordenamento jurídico pátrio. Sabe-se que é importante a formação de professores e profissionais da educação para exercer funções no ambiente hospitalar, visto que a legislação garante estas políticas públicas de saúde e educação.

Eneida Simões da Fonseca et al. (2018) no artigo Atendimento Escolar Hospitalar: Trajetória Pela Fundamentação Científica e Legal aduz quanto ao tema que

É mister destacar que, apesar das legislações citadas, muitos estados não têm ofertado o atendimento 
escolar hospitalar tal qual apregoa a normatização jurídica brasileira. [...]. A ausência do atendimento escolar ao doente configura exclusão social na medida em que um processo de enfermidade afasta o indivíduo da escola, devido à reclusão hospitalar ou ao tratamento da doença (Fonseca et al., 2018, p. 110).

Nesse sentido, a autora alude ao tipo de atendimento como um mecanismo que equipara oportunidades aos estudantes que, por questões de saúde, necessitam de afastamento temporário da escola regular. Para ela, é preciso haver a possibilidade de amparo às crianças e aos adolescentes doentes a fim de que estes não sofram prejuízos em sua vida estudantil por se afastar da escola em razão de doença.

Há que se repensar as políticas educacionais, a complexidade do conhecimento pela crítica, pela reflexão-ação, pelo currículo com estratégias criativas e inovadoras de educação para o atendimento àquele que tem direito ao ensino na classe hospitalar, conforme regula a legislação. A não observância a esse direito implica infringir o inciso II do artigo $5^{\circ}$ da Constituição Federal, ou seja, o princípio da legalidade, que tem por função precípua o papel de proteger o cidadão contra os poderes constituídos, defendendo os direitos individuais e a autonomia de vontade das pessoas que integram o Estado. Com essas considerações é que se pretende realçar o ensino em classe hospitalar como parte importante da educação no Brasil.

\section{CONTEXTO EDUCACIONAL HOSPITALAR PARA CRIANÇAS E ADOLESCENTES}

Carmem Lucia Artioli Rolim (2019) no ensaio Educação hospitalar: uma questão de direito informa que os jesuítas direcionaram os ensinamentos para a educação de classe, com as 
características distintas da aristocracia rural brasileira, indo do período colonial e imperial até o período republicano, sem modificações estruturais, mesmo quando a demanda social de educação começou a aumentar, atingindo as camadas mais baixas da população e obrigando a sociedade a ampliar sua oferta escolar.

Rolim (2019) analisa que pertencer à escola é integrar-se a um grupo social. A instituição escolar como um espaço cultural que se encaminha ao desenvolvimento particular dos sujeitos envolvidos em suas práticas. (...) A escola se define como um espaço social de trabalho conjunto que permite a apropriação recíproca dos sujeitos, segundo relações assimétricas na definição situação e na compreensão da lógica de distribuição de posições subjetivas.

Nesse sentido, passa-se a construir uma cultura de valorização escolar que não está limitada à aquisição de conhecimento e de desenvolvimento humano, incluir-se na instituição educacional consiste em socializar-se e desenvolver ações de pertencimento para integrar determinado grupo a fim de alcançar o sucesso socioeconômico no âmbito histórico-cultural.

Rolim (2019) assinala que pertencer ao ambiente escolar não garante o sucesso, porém viabiliza possibilidades; é movimento que aposta na vida e em seu desenvolvimento. $O$ contexto que situa a escola como espaço de direito da criança, local de progresso cognitivo, ambiente saudável está relacionado às expectativas sociais positivas. Ser estudante e integrar os contextos escolares é estar incluído (a) no aparato cultural e socioeconômico, que normatiza e estabelece o que tem valor legítimo e o que se vê como algo comum.

A escola possui normatizações e oferece ambientes de possibilidades, em contrapartida, ser excluído (a) desse contexto consiste em subtrair as oportunidades de manter um lugar possível 
à ascensão social. Muitas causas podem gerar o afastamento do alunado do sistema escolar, todavia, neste estudo, centrar-se-á atenção no atendimento educacional escolar no ambiente hospitalar para crianças e adolescentes que apresentarem alguma patologia, que requeira internação mediante exigência médica.

\section{Classe hospitalar E ATENDimento PEDAgógico DOMICILIAR}

$\mathrm{O}$ atendimento pedagógico domiciliar e hospitalar estão previsto expressamente nas orientações esboçadas na Lei $n$. 9.394/1996 (LDB), que sofreu alterações por meio da Lei $n$. 13.716/2018, incluindo o artigo $4^{\circ}-\mathrm{A}$, que preconiza: "é assegurado atendimento educacional, durante o período de internação, ao aluno da educação básica internado para tratamento de saúde em regime hospitalar ou domiciliar por tempo prolongado, conforme dispuser o Poder Público em regulamento, na esfera de sua competência federativa”.

Rolim (2019, p. 7) enfatiza que na internação hospitalar, quando as atividades peculiares da infância saudável, brincadeiras e estudos não são o principal ponto no desenvolvimento do alunado e a saúde é colocada como única necessidade à criança é à maneira de um "exilado da própria vida".

Ao tratar a saúde desqualificando a continuidade educacional, podemos condenar a criança a vivenciar uma situação ínfima na esfera educacional. O espaço hospitalar é necessário para a manutenção da vida, ao passo que o ambiente educacional é considerado imprescindível elemento sociocultural para a continuidade da condição do desenvolvimento humano.

Assim sendo, a saúde e a educação são fatores constitutivos do decurso vital, processos de direito da criança e do adolescente 
que precisam ser oportunizados se forem acometidos por qualquer enfermidade durante o período regular da educação formal. Reconhecer tal direito não é justo e legal, a garantia de saúde e de educação configuram benefícios já consagrados nos ordenamentos jurídicos nacionais e internacionais.

A Organização das Nações Unidas (ONU), em 1948, com a Declaração Universal dos Direitos do Homem, considerado um documento marco na história dos direitos humanos, reconhece que

Art. XXV - Todo ser humano tem direito a um padrão de vida capaz de assegurar a si e à sua família saúde, bem-estar, inclusive alimentação, vestuário, habitação, cuidados médicos e os serviços sociais (...).

Art. XXVI - Todo ser humano tem direito à instrução. A instrução será gratuita, pelo menos nos graus elementares e fundamentais. A instrução elementar será obrigatória. (...) A instrução será orientada no sentido do pleno desenvolvimento da personalidade humana e do fortalecimento do respeito pelos direitos do ser humano e pelas liberdades fundamentais (ONU, 1948).

O direito à saúde e à educação em 1993, segundo a Organização da Nações Unidas, consolida-se, a exemplo do que estabelece o artigo 24 que recomenda como de vital importância a proteção de direitos aos grupos considerados vulneráveis:

Deve ser dada grande importância à promoção e à proteção dos Direitos Humanos de pessoas pertencentes a grupos que se tenham tornado vulneráveis [...]. Os Estados têm uma obrigação de adotar e manter medidas adequadas a nível nacional, sobretudo nos domínios da educação, da saúde e da assistência social, com vista à promoção e proteção dos direitos das pessoas pertencentes a sectores vulneráveis das suas populações, e a garantir a participação das que, de entre elas, se mostrem 
interessadas em encontrar uma solução para os seus próprios problemas (ONU, 1993).

Nessa perspectiva, a Declaração da ONU considera a promoção e a proteção dos Direitos Humanos como sendo condições prioritárias para que todos recebam o mesmo tratamento como oportunidade única de analisar o sistema internacional de Direitos Humanos e os mecanismos de proteção destes direitos, a fim de incentivar e promover o respeito à dignidade de uma forma justa e equilibrada.

$\mathrm{Na}$ esfera do direito nacional a norma estatuída na Declaração da ONU já era contemplada na Constituição Federal de 1988, em seu artigo 196: “A saúde é direito de todos e dever do Estado, garantido mediante políticas sociais e econômicas que visem à redução do risco de doença e de outros agravos e ao acesso universal e igualitário às ações e serviços para sua promoção, proteção e recuperação.” (Brasil, 1988).

Como foi citado alhures, o artigo 205 da Carta Magna valorizou a educação tanto quanto à saúde, e, como tal deve ser respeitado e cumprido, como forma de promover e incentivar o envolvimento social, culminado com o pleno desenvolvimento da pessoa humana, com sua capacitação para o exercício da cidadania e sua qualificação para o trabalho.

Frise-se que o Estatuto da Criança e do Adolescente (ECA), Lei n. 8.069/1990, no que tange ao direito à educação e à saúde resguarda a integridade da pessoa humana em idade infantil e na adolescência.

Vejamos o que preconiza o artigo $4^{\circ}$ do aludido Estatuto:

Art. $4^{\circ}$ É dever da família, da comunidade, da sociedade em geral e do poder público assegurar, com 
absoluta prioridade, a efetivação dos direitos referentes à vida, à saúde, à alimentação, à educação, ao esporte, ao lazer, à profissionalização, à cultura, à dignidade, ao respeito, à liberdade e à convivência familiar e comunitária.

O parágrafo único do artigo $4^{\circ}$ do Estatuto da Criança e do Adolescente - ECA prevê a garantia de prioridade à criança e ao adolescente nas seguintes premissas:

a) primazia de receber proteção e socorro em quaisquer circunstâncias;

b) precedência de atendimento nos serviços públicos ou de relevância pública;

c) preferência na formulação e na execução das políticas sociais públicas;

d) destinação privilegiada de recursos públicos nas áreas relacionadas com a proteção à infância e à juventude.

Rolim (2019) ensina que tratar de celeumas atinentes à saúde não impede a responsabilidade de oportunizar os processos educacionais, pois a educação e a saúde se cruzam por meio da pedagogia hospitalar, processo que visa preservar os direitos das crianças e dos adolescentes independentemente do espaço ou situação que vivenciam.

Desta feita, na impossibilidade de frequência à escola, durante o período sob tratamento de saúde ou de assistência psicossocial, a criança e o adolescente carecem de cuidados que devem ser previstos nas políticas públicas como formas alternativas de organização e oferta de ensino para cumprir normas referentes aos direitos à educação e à saúde. 
Nesse contexto, o atendimento educacional hospitalar e domiciliar se institui como possibilidade de desenvolvimento à medida que é resguardado o direito da criança e do adolescente ao direito de aprendizagem, "que escolhe atividades e aprende, ao passo que, na condição de paciente, é inevitavelmente tratada sem opinar, envolvida pela fria rotina hospitalar." (Rolim, 2008, p. 95).

A pedagogia hospitalar poderá ser um caminho de atenção em que o atendimento educacional no contexto hospitalar se desenvolva. Isto emerge da necessidade de responder às crianças e aos jovens hospitalizados ou em tratamento psiquiátrico ou domiciliar ao seu exercício educacional e ao acompanhamento durante seu processo de enfermidade, com a finalidade de promover a qualidade de vida e de garantir os direitos de aprendizagem.

A autora do ensaio salienta que se a atividade hospitalar é indispensável para o restabelecimento do organismo infantojuvenil, a atividade escolar é primordial à aprendizagem e ao desenvolvimento intelectual. Dessa forma, a pedagogia hospitalar pode contribuir para o restabelecimento da criança e do adolescente.

Rolim (2008), ao refletir sobre a criança e o adolescente enfermos, admite que a educação deve relacionar-se ao tratamento e à esfera da pedagogia terapêutica. Há que se juntar esforços entre a gestão hospitalar e escolar, para que o médico e o pedagogo possam realizar as tarefas distintas e integradas. Não se pode traçar uma delimitação das medidas terapêuticas e educativas frequentemente, mas é possível promover a cura da criança doente sem prejuízos à educação.

Entende-se que o atendimento hospitalar e domiciliar é um direito da criança e do adolescente em situação de enfermidade, que 
envolve a saúde e a educação, áreas do conhecimento humano que necessitam trabalhar de forma convergente quando houver benefício à criança e ao adolescente amparado legalmente.

\section{Profissionais PARA O ATENDIMENTO hOSPITALAR E DOMICILIAR}

Ao considerar que a educação no ambiente hospitalar deve contar com professor habilitado, o ideal é que se trabalhassem ainda na formação superior disciplinas focadas no atendimento ao aluno no hospital. No Brasil, a estrutura da educação no ambiente hospitalar e domiciliar, tanto na esfera pública e privada, nas áreas da educação e da saúde, depende de muitos estudos, investimentos, pesquisas, práticas, cumprimento das normas e formação de profissionais com as habilitações específicas.

Nessa linha, denota-se que a educação brasileira, sendo pública ou privada, cresce, contudo, não corresponde à necessidade da sociedade, principalmente no âmbito hospitalar, posto que não existe qualidade na educação com políticas públicas eficazes para o acesso pleno do alunado por inúmeras razões, tais como: gestão dos investimentos, baixo índice de desenvolvimento humano e ausência de investimentos de pesquisa (Rolim, 2019).

O Relatório de Monitoramento da Unesco (2017) indica que a qualidade no ensino em ambientes hospitalares e domiciliares se refere tanto ao alcance das metas de aprendizagem, quanto ao processo de alcançá-los. Qualidade, garantia versus gestões escolares e hospitalares, por sua vez, envolvem monitoramento e avaliação, programas educacionais, características do corpo docente, capacidade de apoiar a aprendizagem, a pesquisa e os resultados dos alunos que se encontrarem em ambientes hospitalares e domiciliares. 
Embora o ensino brasileiro tenha tido considerável autonomia, historicamente, a qualidade deve ser cada vez mais avaliada, pois o acesso à educação se expande globalmente. Os processos de garantia de qualidade fornecem informações aos decisores políticos detalhados sobre o sistema e o desempenho. Os resultados podem ser usados para justificar mudanças para o financiamento e criação de programas ou consolidação de políticas de educação de classes hospitalares e domiciliares.

\section{ASSISTÊNCIA EDUCACIONAL EM CLASSES HOSPITALARES}

Depois de contextualizar as ponderações relatadas pela Unesco (2017) no âmbito da educação de classes hospitalares é salutar discutir as características do atendimento educacional nas classes hospitalares, dado ser esse um direito preservado pela Lei de Diretrizes e Bases da Educação Nacional (LDB), Lei n. 9.394/96, alterada recentemente pela Lei n. 13.716/2018, que introduziu o artigo $4^{\mathrm{o}}$-A, o qual especifica a modalidade de atendimento educacional hospitalar e domiciliar.

A pedagogia hospitalar e domiciliar é um modo de ensino da educação hospitalar que visa à ação do educador nos hospitais, clínicas ou residências para atender crianças ou adolescentes com necessidades educativas especiais transitórias, isto é, quem por meio de doença precisa de atendimento escolar diferenciado e especializado. O hospital e a escola devem buscar alternativas e métodos qualificados que possibilitem aos pacientes receber atendimento educacional com abordagens educativas por um determinado espaço de tempo.

Este novo espaço de educação nos hospitais é desenvolvido para suprir a necessidade de crianças afastadas da escola e também é um espaço de ajuda nos transtornos emocionais, causados pela 
internação, como raiva, insegurança, incapacidades e frustrações que podem prejudicar na recuperação do paciente.

Andrieli Silva (s.d.), em seu artigo "o papel do pedagogo hospitalar - qual é a importância do pedagogo no ambiente hospitalar"? A autora assinala que há impressão que, para as crianças e os adolescentes em ambientes hospitalares e domiciliares, o estudo surge como um bem que eles podem resgatar para si mesmos como um vetor de saúde no desenvolvimento da vida, mesmo em fase do adoecimento e da hospitalização.

Silva (s.d.) ensina que a pedagogia hospitalar se processa alternativamente, pela educação, pois ultrapassa os métodos tradicionais da escola e do estudante, buscando formas de apoiar o paciente no hospital na esfera da educação. É um atendimento que pode auxiliar no processo de recuperação do paciente, caracterizado como uma nova modalidade educacional.

Na pedagogia hospitalar há situações desafiadoras, em que o profissional de educação desenvolve atividades com pacientes prejudicados na sua escolarização. A educação no hospital ou na residência tem como princípio, atender o educando seguindo uma proposta pedagógica com as necessidades com critérios que permitem abordagem segundo a patologia do paciente.

Dependendo da gestão hospitalar, pode-se levar objetos pessoais das crianças como brinquedos, jogos educativos, revistas, dentre outros, que contribuirão para o desenvolvimento psicológico e emocional da criança e do adolescente durante o seu período de internação. Segundo Matos (1998, p. 4), o educador que faz atendimentos hospitalares ou domiciliares necessariamente buscará em si mesmo o verdadeiro sentido de educar e deve converter sua profissão numa atividade cooperadora do engrandecimento da vida. 
Dessa feita, deve ter habilitação acadêmica, pesquisar, inovar e incrementar os seus conhecimentos na referida área, procurando conhecer e desenvolver ambientes educacionais inovadores que amenizem e possibilitem a ação educativa. Daí surge a necessidade de transferência do local comum de aprendizagem - a escola - para o hospital ou a residência do aluno dependendo de cada caso.

Assim, a classe hospitalar deve constituir um espaço que necessita de um professor ou pedagogo que atenda crianças e adolescentes a fim de não perderem o ano letivo por se encontrarem hospitalizados. Pensando neste problema, o profissional de educação deverá atuar no espaço onde as condições de aprendizagem se distanciam do ambiente escolar, posto que no hospital tende-se a ignorar alunos e estes são vistos unicamente como pacientes.

\section{CONSIDERAÇÕES FINAIS}

De acordo com os aspectos legais e pedagógicos levantados neste estudo, as possibilidades legais que amparam o atendimento de estudantes na classe hospitalar se constituem por um direito consagrado no artigo $6^{\circ}$ da Lei Maior de nosso País, preconiza que são direitos sociais a educação, a saúde, a alimentação, o trabalho, a moradia, o transporte, o lazer, a segurança, a previdência social, a proteção à maternidade e à infância, a assistência aos desamparados.

Denota-se que o artigo $6^{\circ}$ da Constituição Federal reconhece a educação como um direito fundamental de natureza social e sua proteção tem uma dimensão que ultrapassa, e muito, a consideração de interesses puramente individuais, posto que deve abranger a coletividade num todo. Assim, os governos têm a 
responsabilidade de desenvolver políticas de atendimento a estudantes em faixa etária escolar que necessitam de internação, combinando o direito de aprendizagem ao direito à saúde, em programas flexíveis que correspondam às necessidades dos alunos.

Quando há estudantes necessitados de internação, a escola e o hospital devem providenciar a assistência pedagógica; depois é preciso mapear os interesses de cada um a fim de desenvolver o trabalho com temas de várias disciplinas dentro do que é indicado para aquela faixa etária. As atividades devem fazer parte de uma ficha de tutoria e no final da internação, esse parecer pode ser transformado em nota pela instituição de origem e justificativa de ausência em sala de aula.

As aulas em ambiente hospitalar podem reunir crianças que estão em um mesmo quarto ou que vão até a sala de aula do setor pediátrico e podem ser compartilhados os conhecimentos. Por causa da condição física das crianças e dos adolescentes, a frequência não pode ser imposta. A legislação prevê atendimento dentro das condições de cada paciente, que poderá garantir a continuidade dos estudos e bons resultados.

A pedagogia hospitalar é desafiadora, porém permite um trabalho humanizado que auxilia alunos-pacientes prejudicados na sua escolarização, propicia conhecimento e qualidade de vida ao paciente. A educação no hospital tem como princípio o atendimento personalizado ao educando na qual se trabalha uma proposta pedagógica com as necessidades, estabelecendo critérios que respeitem a patologia do paciente.

No hospital, a criança está longe do seu cotidiano da escola, por isso é fundamental a atenção do educador em articular atividades para o paciente, na situação de internação. O professor adapta-se à realidade da criança hospitalizada a fim de realizar as 
atividades lúdicas pedagógicas, recreativas; densidade de leitos na enfermaria pediátrica e dinâmica da utilização do espaço; adaptar agenda de horários.

As crianças e adolescentes estudantes que permanecem em internação precisam de amparo físico e emocional; o pedagogo pode contribuir para que o aluno-paciente se sinta bem, para que haja a possibilidade de aliviar a ansiedade da criança por intermédio de suas práticas pedagógicas, envolvendo a família neste processo de cura e recuperação.

\section{REFERÊNCIAS}

BRASIL. Ministério da Educação. Classe hospitalar e atendimento pedagógico domiciliar: estratégias e orientações. Secretaria de Educação Especial. Brasília, Brasil: MEC; SEESP, 2002.

- Constituição federal brasileira. Disponível em: <www.planalto.gov.br/ccivil_03/constituicao/constituicao.htm>. Acesso em: 24 fev. 2020.

. Lei de diretrizes e bases da educação brasileira. Brasília, MEC, 1996.

. Estatuto da criança e da adolescência. Disponível em: <www.planalto.gov.br/ccivil_03/leis/l8069.htm> Acesso em: 24 fev. 2020.

. Classe hospitalar e atendimento pedagógico domiciliar: estratégias e orientações. / Secretaria de Educação Especial Brasília: MEC; SEESP, 2002. Disponível em: <http:// http://portal.mec.gov.br/seesp/arquivos/pdf/livro9.pdf >. Acesso em: 24 fev. 2020. 
CAMARU, T.; GOLDANI, M. Os direitos da criança hospitalizada no hospital de clinicas de Porto Alegre. Revista do Hospital de Clinicas de Porto Alegre. Porto Alegre, vol. 24, p. 5-13, abril, 2004.

CLASSES HOSPITALARES: ensino na saúde e também na doença. Disponível em: <https://novaescola.org.br/conteudo/ 2806/classes-hospitalares-ensino-na-saude-e-tambem-na-doenca - Luise Takashina - 01 de Junho/2012>. Acesso em: 24 fev. 2020.

FONSECA, E. S. Atendimento escolar hospitalar: trajetória pela fundamentação científica e legal. Disponível em: <www.scielo.br/pdf/rbee/v24nspe/1413-6538-rbee-24-spe>. Acesso em: 24 fev. 2020.

MATOS, E.L.M; PAVÃO, Z. M. O desafio ao professor universitário na formação do pedagogo para atuação na educação hospitalar. Dissertação (Mestrado) - Pontifícia Universidade Católica do Paraná, Curitiba, 1998. Disponível em: $<$ http://bdtd.ibict.br/vufind/Record/P_PR_6630b 2003fa53d5b2fe53dc29097 33a0 > Acesso em: 24 fev. 2020.

MINTO, L.W. Gratuidade do ensino superior em estabelecimentos oficiais: precisão e implicações. Disponível em: <www.scielo.br/pdf/es/v39n142/ 1678-4626 -es-es010173302018181580.pdf> Acesso em: 24 fev. 2020.

OLIVEIRA, D; et al. Políticas educacionais e a reestruturação da profissão do educador. Perspectivas globais e comparativas. Rio de Janeiro: Petrópolis, 2019.

OLIVEIRA, T.C. Um breve histórico sobre as classes hospitalares no Brasil e no mundo. Disponível em: $<$ https://educere.bruc.com.br/ANAIS2013/pdf/9052_5537.pdf >. Acesso em: 24 fev. 2020. 
. Declaração e programa de ação. (1993). Disponível em: <www.dhnet.org.br/direitos/anthist/viena/viena.html>. Acesso em: 24 fev. 2020.

PAULA, E.M.A.T. A pedagogia de projetos nas escolas dos hospitais: estratégia coletiva de construção de conhecimentos. In: SCHILKE, Ana Lúcia, NUNES, Lauane Baroncelli, AROSA, Armando C. (Orgs). Atendimento escolar hospitalar: saberes e fazeres. Niterói Ed Intertexto, 2011. p. 57-65.

ROLIM, C. L. A. Entre escolas e hospitais: o desenvolvimento de crianças em tratamento hospitalar. Pro-Posições, 26(3), 129-144. Doi: <https://dx.doi.org/10.1590/0103-7307201507806,2015> Acesso em: 24 fev. 2020.

. Educação hospitalar: uma questão de direito. 2019. Disponível em: <www.scielo.sa.cr/scielo.php?pid=S1409-470320 190001007008 script=sci_arttext->. Acesso em: 24 fev. 2020.

. A criança em tratamento de câncer e sua relação com o aprender: experiências num programa educacional em ambiente hospitalar. Tese para obter o grau de Doutora em Educação) Universidade de Piracicaba-SP, 2008. Disponível em: <unimep.br/phpg/bibdig/pdfs/2006/OXMURLEbQVLKA.pdf>. Acesso em: 24 fev. 2020.

SILVA, A. O papel do pedagogo hospitalar. Disponível em: $<$ https:// meuartigo.brasilescola.uol.com.br/ educacao/o- papelpedagogo-hospitalar.htm> Acesso em: 24 fev. 2020.

UNIDAS, organización de las naciones para la educación, la ciencia y la cultura. Capítulo 15. Place de Fontenoy. Primera edición. Publicado en 2017 por París: 2017. 
UNIDAS, Organização das nações. Declaração universal dos direitos humanos. (1948). Disponível em: <https://nacoes unidas.org/wp-content/uploads/2018/10/DUDH.pdf>. Acesso em: 24 fev. 2020.

VASCONCELOS, S. Classe hospitalar no mundo: um desafio à infância em sofrimento. In: REUNIÃO ANUAL DA SBPC, 57, Fortaleza, 2005. Anais. Reunião anual da SBPC, 57, Fortaleza. 2005. Disponível em: <www.sbpcnet.org.br/ livro/57ra/programas/ CONF_SIMP/textos/sandramaia-hospitalar.htm>. Acesso em: 25 mar. 2020. 


\section{4 \\ PRoteÇÃo de RECURSOS hÍDRICOS NA SUb-BACIA RIO \\ CANDEIAS}

Ocilene Gonçalves Soares ${ }^{60}$

\section{Introdução}

A água é essencial para a sobrevivência humana, como afirma a Declaração Universal dos Direitos da Água, de 1992: “A água é a seiva do nosso planeta. Ela é a condição essencial de vida de todo ser vegetal, animal ou humano (...)". Juntando-se a essa declaração, existem leis, decretos, portarias, normas, documentários, eventos e muitos outros demonstrando que, ao longo dos anos, a situação da água no planeta vem sendo abordada. Embora o volume de água existente na terra seja de aproximadamente 1,35 milhões de quilômetros cúbicos, somente $\mathbf{2 , 5 \%}$ (dois vírgula cinco por cento) é água doce, e a maior parte se encontra congelada. Disponível para o consumo da humanidade, restam apenas $0,3 \%$ (zero vírgula três por cento).

Considerando o acima exposto, é necessário que o ser humano, de qualquer lugar do planeta, se ocupe de forma responsável com a água na Terra e com a garantia de qualidade

60 Especialista em Psicopedagogia Clínica e Institucional pela Unijipa, JiParaná-RO; em Planejamento Educacional e Docência do Ensino Superior pela FAAR/Iesur, Ariquemes-RO e em Visão Interdisciplinar em EducaçãoGestão, Supervisão, Orientação e Inspeção Escolar pela Unesc, Cacoal-RO, Graduada em Pedagogia pela UNIR. Diretora Presidente da Agência Reguladora dos Serviços Públicos Delegados do Município de Buritis-Agerb, Vice-Presidente do Comitê de Bacias Hidrográficas do Jamari-CBH-Jamari, Coordenadora Municipal de Proteção e Defesa Civil. 
dessa água para o consumo humano e a realização das atividades de sobrevivência, como a produção de alimentos, dentre outras.

No Brasil, a Política Nacional de Recursos Hídricos, o Sistema Nacional de Gerenciamento de Recursos Hídricos (Singreh), o regulamento do inciso XIX do artigo 21 da Constituição Federal foram estabelecidos pela Lei n. 9.433/97 (Lei das águas do Brasil), em que está determinado que a gestão dos recursos hídricos no país deve ser realizada de forma descentralizada e participativa, envolvendo o poder público, os usuários de recursos hídricos e as comunidades. Teoricamente, pode-se afirmar que os recursos hídricos no Brasil e, consequentemente, no estado de Rondônia e seus respectivos municípios estão protegidos.

Porém, na prática cotidiana das ações individuais com resultados/consequências coletivas é que se "esculpe" a história da sociedade, de seus arranjos e modos de vida nas organizações públicas, privadas e/ou do terceiro setor com as nuances e aspectos sociocultural, político, econômico. É nessa prática que se apresentam problemas, bem como impulsiona pesquisas, estudos, projetos e ações na busca das soluções dos mesmos.

Ocorre, na região (sub-bacia rio Candeias), a degradação de áreas de preservação permanente (matas ciliares e nascentes), em nome do desenvolvimento econômico local (agropecuária). Os indivíduos afetam de maneira negativa os mananciais, gerando situações a degradação que podem trazer consequências sérias e difíceis de serem revertidas. Segundo documentos da Agência Reguladora dos Serviços Públicos Delegados do Município de Buritis (Agerb), em 2019, o nível das águas do rio Candeias, manancial que abastece a cidade de Buritis-RO, baixou assustadoramente levando os técnicos da agência, em parceria com outros órgãos, pessoas e instituições públicas e privadas a tomar 
iniciativas, construindo propostas com ações que foram imediatas, de curto, médio e longo prazos para a identificação do problema, propostas de solução, execução e acompanhamento dessas ações.

Dito isto, a proposta aqui é expor as iniciativas com o objetivo de analisar essas iniciativas tomadas pela Agerb frente ao desafio de agregar pessoas, ideias, instituições em torno da urgência que é preservar e/ou recuperar os recursos hídricos (mananciais, as nascentes e matas ciliares), os quais produzem a água para o abastecimento da cidade de Buritis, e apresentar, naturalmente, as conclusões resultantes da análise, que poderão ser utilizadas pela Agerb e outros órgãos como validação, considerando os aspectos técnicos, legais e outros das respectivas ações.

Para entender o problema e a busca da solução apresentados pela Agerb, foi realizada a pesquisa numa abordagem qualiquantitativa, através do método hipotético-dedutivo, visando a análise cujo resultado possibilita até mesmo a validação ou não das ações já realizadas e as que estão em desenvolvimento pela Agerb, tendo como referência a legislação vigente. As naturezas: a) exploratória (leitura dos documentos/registros referentes à II Semana da Água de Buritis “Água é vida" - Projetos relatórios, textobase, vídeos e outros) e b) explicativa (descrição do que foi realizado, organizado, sistematizado), levaram a pesquisa a passar pelos seguintes procedimentos: a) bibliográfico (leitura de livros com assuntos afins); b) documental (estudo de legislação, filmes, vídeos, etc.) e c) levantamento de dados junto aos atores envolvidos, em especial gestores da Agerb que coordenam e realizam os projetos e possuem uma relação direta e/ou indireta com os órgãos públicos responsáveis pela questão de proteção de recursos hídricos, com prestadores e reguladores de serviços da área de saneamento básico e outros usuários de água que atuam na região da sub-bacia rio Candeias. 
A seguir, far-se-á uma breve contextualização da situação da água numa dinâmica que possibilite o entendimento da responsabilidade individual, local que gera consequência coletiva e global, no mínimo (O planeta água pode morrer de sede). A exposição descrita resumida das atividades da Agerb para a proteção e/ou recuperação dos recursos hídricos (A Agerb e a proteção de recursos hídricos na sub-bacia Rio Candeias). A análise das atividades/iniciativas da Agerb passadas pelo "filtro" da legislação vigente, dentre elas, a Lei das águas do Brasil (Lei n. 9433/97) e as conclusões com as manifestações e sugestões.

\section{O PLANETA ÁGUA PODE MORRER DE SEDE}

Trata-se, aqui, de uma breve contextualização da situação da água numa dinâmica que possibilite o entendimento da responsabilidade individual e local que gera consequência coletiva e global, no mínimo.

Como já foi abordado, no primeiro parágrafo da introdução desse trabalho, o planeta Terra, que por várias vezes é chamado de Planeta Água, tem um volume de água de aproximadamente 1,35 milhões de quilômetros cúbicos, desse total, somente 2,5\% (dois vírgula cinco por cento) é água doce e a maior parte dessa água doce se encontra congelada, restam apenas $0,3 \%$ (zero vírgula três por cento) disponível para consumo da humanidade.

Nesse cenário, o Brasil conta com generosos 12\% (doze por cento) da água doce disponível mundialmente, o que o deixa numa situação confortável, se comparado a outros países. Mesmo com toda essa abundância, algumas regiões sofrem com a escassez, dada a distribuição irregular, tanto do bem natural (água), quanto da concentração da população. Conforme dados levantados pelo Instituto Trata Brasil, a Amazônia tem a menor concentração 
populacional e dispõe de $80 \%$ (oitenta por cento) da água superficial existente no Brasil, bem como escreve também Célia J. A. Victorino.

O Brasil é um país privilegiado em termos de disponibilidade de água, pois conta com $28 \%$ da disponibilidade sul-americana e de $12 \%$ das reservas de água do mundo. Em território brasileiro, $72 \%$ da água está localizada na bacia amazônica. O rio Amazonas tem 6.885 quilômetros de extensão e é o maior do mundo em volume de água, despejando 175 milhões de litros por segundo no Oceano Atlântico (Victorino, 2007, p. 21).

Considerando os dados acima citados, parece estranho falar da redução significativa do volume de água na sub-bacia rio Candeias, que está exatamente na região amazônica, identificando que a nascente do rio em questão (rio Candeias) se encontra no Parque Nacional Pacaas Novos, que é uma reserva nacional no estado de Rondônia.

Olhando a história, é possível verificar que o comportamento humano em relação ao uso da água ao longo dos anos demonstra inadequações. Há muito tempo, o ser humano apresenta uma preocupação que não foi e ainda não é suficiente para gerar um equilíbrio entre homem e natureza, que acaba por criar cenários de "autodestruição". Na citação abaixo é possível observar que a prática de milhares de anos atrás se identifica muito com os tempos atuais, tanto do ponto de vista da preocupação com criação de "atos normativos" quanto da degradação:

O homem sempre se preocupou com a água. Já há 4.000 anos a.C., as primeiras leis que se tem conhecimento eram códigos que regulavam o uso das águas, escritas pelos sumérios. Mas, nem todas as civilizações foram cuidadosas quanto a isso. Os Maias tiveram que 
abandonar a cidade de Tical, localizada em plena mata tropical, onde se encontram as ruínas da Pirâmide do Sol, porque não souberam armazenar corretamente a água, além de produzirem erosões cada vez maiores e grandes desmatamentos (Victorino, 2007, p. 19).

É fundamental que se estabeleça uma cultura de preservação da água com capacidade de transcender e interagir entre comunidades, entre povos (sem fronteiras), entre gerações, entre classes sociais, entre pessoas e instituições, entre o individual e o coletivo, entre o público e o privado. Trata-se de uma necessidade básica natural para a sobrevivência que por si só já deveria ser suficiente para tomadas de decisões, o que hoje é obrigação legal, como preconiza a Lei das águas do Brasil, Lei 9433/97, com destaque para os Fundamentos e Objetivos nos Artigos $1^{\circ}$ e $2^{\circ}$ :

Art. $1^{\circ}$ A Política Nacional de Recursos Hídricos baseia-se nos seguintes fundamentos:

I - a água é um bem de domínio público;

II - a água é um recurso natural limitado, dotado de valor econômico;

III - em situações de escassez, o uso prioritário dos recursos hídricos é o consumo humano e a dessedentação de animais;

IV - a gestão dos recursos hídricos deve sempre proporcionar o uso múltiplo das águas;

$\mathrm{V}$ - a bacia hidrográfica é a unidade territorial para implementação da Política Nacional de Recursos Hídricos e atuação do Sistema Nacional de Gerenciamento de Recursos Hídricos;

VI - a gestão dos recursos hídricos deve ser descentralizada e contar com a participação do Poder Público, dos usuários e das comunidades. 
Art. $2^{\mathrm{o}}$ São objetivos da Política Nacional de Recursos Hídricos:

I - assegurar à atual e às futuras gerações a necessária disponibilidade de água, em padrões de qualidade adequados aos respectivos usos;

II - a utilização racional e integrada dos recursos hídricos, incluindo o transporte aquaviário, com vistas ao desenvolvimento sustentável;

III - a prevenção e a defesa contra eventos hidrológicos críticos de origem natural ou decorrentes do uso inadequado dos recursos naturais.

Constata-se nos mais diversos documentos e de várias instituições a manifestação que por sua vez assume o "protagonismo" de uma determinada atividade tratando da proteção dos recursos hídricos o que é um alento.

A Organização das Nações Unidas (ONU) lançou em 2015 os 17 Objetivos do Desenvolvimento Sustentável (ODS), uma agenda de sustentabilidade adotada pelos países-membros da ONU para ser cumprida até 2030. O objetivo de número 6 é “Assegurar a disponibilidade e gestão sustentável da água e saneamento para todos”. Neste objetivo, estão definidas como metas a distribuição de água de forma igualitária para a população mundial, a melhoria da qualidade da água, o fim da defecção a céu aberto e a garantia de saneamento para todos.

A Carta Seworld, do $8^{\circ}$ Fórum Mundial da Água, realizado em Brasília, escrita em 22 de março de 2018, aborda os desafios elencados no $2^{\circ}$ Fórum, que aconteceu no ano 2000 :

(...) sete "desafios principais" à consecução da segurança hídrica: 1 . Satisfação das necessidades básicas; 2. Garantia do abastecimento de alimentos; 3. Proteção aos ecossistemas; 4. Compartilhamento de recursos 
hídricos; 5. Gerenciamento de riscos; 6. Valorização da água; e 7. Controle racional da água.

Para vencermos esses desafios, que dezoito anos depois ainda são atuais, a sociedade como um todo necessita rever seus conceitos e suas ações. Por essa razão, os gestores de recursos hídricos têm revisitado a questão dos reservatórios de acumulação. Posto que é preciso ser previdente, aproveitando os períodos climáticos favoráveis para acumular água para os períodos desfavoráveis (Carta Seworld, 2018, p. 3 e 4).

Programas como o "Produtor de Água”, criado pela Agência Nacional de Águas - ANA para incentivar o produtor rural a investir em ações que ajudem a preservar a água, usam o conceito de Pagamento por Serviços Ambientais (PSA), estimulando os produtores a investirem no cuidado do trato com as águas, recebendo apoio técnico e financeiro para implementação de práticas conservacionistas.

E ainda recentemente, a Lei 14.119/2021, de 13 de janeiro de 2021, que "Institui a Política Nacional de Pagamento por Serviços Ambientais (...)”.

Art.1 ${ }^{\circ}$ (...) define conceitos, objetivos, diretrizes, ações e critérios de implantação da Política Nacional de Pagamento por Serviços Ambientais (PNPSA), institui o Cadastro Nacional de Pagamento por Serviços Ambientais (CNPSA) e o Programa Federal de Pagamento por Serviços Ambientais (PFPSA), dispõe sobre os contratos de pagamento por serviços ambientais.

A lei acima citada se apresenta nesse cenário como um importante incentivo para a proteção dos recursos hídricos em todo país, fortalecendo o trabalho dos Comitês de bacias. 
Poderia citar aqui inúmeras iniciativas que vão desde ações individuais realizadas por indivíduos que já entenderam seu papel em relação à proteção da água como bem essencial para a vida, até a criação de leis, projetos, programas. Embora se tenha muitas iniciativas, ainda parece estar distante de ser uma prática natural, uma cultura de todos os povos o cuidado com água.

Todo conjunto de leis, planos, projetos e outros garantem segurança jurídica, mas, por si só, não garantem a prática necessária para proteção das águas com qualidade para o consumo humano. "As coisas não são feitas nem por dinheiro, nem por papel dos projetos, as coisas são feitas por homens e mulheres que decidem fazê-las" (Sociólogo Clodomir Santos de Moraes).

Segundo dados do IBGE, a maioria dos municípios brasileiros tem problemas ambientais comuns: assoreamento dos corpos d'água, esgoto a céu aberto, desmatamentos, queimadas, poluição da água, inundações, deslizamentos de encostas, secas e erosão.

\section{A AGERB E A PROTEÇÃo de RECURSOS HÍDRICOS NA SUB- BACIA RIO CANDEIAS}

O propósito aqui é fazer uma exposição descrita e resumida das atividades da Agerb para a proteção e/ou recuperação dos recursos hídricos, antes, porém, considera-se importante fazer uma rápida apresentação do que é a Agerb.

A Agerb é uma agência reguladora, especificamente a Agência Reguladora de Serviços Públicos Delegados do Município de Buritis, instituída em 22 de outubro de 2014 pela Lei 870/2014, sob regime especial, dotada de autonomia orçamentária, financeira, funcional e administrativa. A natureza de autarquia conferida à Agerb é caracterizada pela independência decisória. Tem como 
objetivo regular, fiscalizar e orientar a prestação dos serviços públicos concedidos, bem como editar normas técnicas, econômicas e sociais para a sua regulação e fiscalização.

A área de atuação da Agerb compreende acompanhar, regular e fiscalizar o ciclo completo do uso da água, com especial atenção na sua captação, tratamento e distribuição, bem como o sistema de redes de esgotamento sanitário (saneamento básico) do município de Buritis.

Conta com três colegiados: Comitê Técnico de Regulação (Trabalho Técnico e deliberativo/conclusivo), Conselho Consultivo e Conselho Municipal de Saneamento Básico, os dois últimos exercem o controle social e têm natureza apenas consultiva. Em suas atividades, a Agerb necessita do envolvimento e a participação da sociedade para garantir a qualidade e o atendimento dos serviços a todos os cidadãos, com tarifas moderadas e a manutenção do equilíbrio econômico-financeiro de contratos com as prestadoras de serviços.

Tem sua fundamentação legal na Lei Municipal 870/2014, que por sua vez atende a Lei Federal $n^{0}$ 11.445/2007 (Política Nacional de Saneamento Básico) e, segundo a Diretoria Executiva/Agerb, com a aprovação da Lei Federal 14.026/2020 a Agerb se reafirma como ente regulador dos serviços de Saneamento Básico.

Apresentada a Agerb responsável pelas atividades a serem descritas, segue o registro, matéria publicada no site da Agerb, que demonstra de forma sucinta, porém, bastante completa do ponto de vista do que se propõe o estudo em questão:

Na manhã de quinta-feira (19), os funcionários Marcio - Eng. Ambiental/Diretor Técnico-Agerb e Gerson - Concessionária/Águas de Buritis realizaram 
visita técnica ao manancial rio Candeias para monitorar e acompanhar as ações que vem sendo realizadas com o objetivo de garantir o abastecimento de água na cidade e informam que o desassoreamento feito hoje é suficiente para garantir esse abastecimento e tomam providências para fazer um desassoreamento maior no próprio local (atual) de captação o quanto antes, uma vez que o nível do Rio pode continuar baixando, considerando o histórico do mesmo para esse período.

A Agerb, e também a Concessionária, obrigatoriamente, se pautam em dados e estudos técnicos e históricos, e não em postagens que circulam nas redes sociais, que por vezes têm como objetivo somente causar sensacionalismo.

Hoje se pode afirmar, sem dúvidas, que o manancial (rio Candeias) tem potencial abundante para manter o abastecimento de água, necessitando apenas de ações pontuais imediatas no local de captação, que seja o desassoreamento e/ou a adição de mangotes, para o remanejamento das bombas da vazante onde se encontra para o leito do rio, onde a água é abundante. Já se tem em mãos, também, a Autorização Ambiental No 147.797, concedida pela SEDAM para a ação de desassoreamento.

É bom informar também que outras ações de curto, médio e longo prazo vêm sendo trabalhadas em parceria com órgãos e departamentos ambientais, Executivo, Legislativo Municipal, Agerb e Concessionária Águas de Buritis para preservação, recuperação e manutenção do manancial rio Candeias: recuperação de nascentes, matas ciliares e etc.

A Agerb, juntamente com a Defesa Civil do Município, por determinação do Executivo Municipal, Prefeito Ronaldi e solicitação da Câmara Municipal através de seu Presidente, Vereador Marcelo, se colocam à disposição, envidando todos os esforços necessários para manter a regularidade no 
abastecimento de água em nossa cidade (Comunicação/Agerb.19/09/2019).

Nota-se, pelo registro acima, que houve um envolvimento de diversos atores na ocasião do evento onde aparece a informação sobre ações de curto, médio e longo prazos que já estavam sendo trabalhadas. Diversos documentos como ofícios, relatórios, atas demonstram inequivocamente um trabalho de busca de parcerias junto às autoridades e órgãos competentes.

O problema apresentado na citação acima deu origem ao tema da II Semana da Água em Buritis, em 2020, projeto trabalhado pela Agerb em alusão ao Dia Mundial da Água.

A II Semana da Água, com tema: ÁGUA É VIDA, tem como finalidade realizar ações de proteção/preservação, recuperação e manutenção de mananciais (nascentes e matas ciliares) com o objetivo de fortalecer no consciente coletivo o entendimento de que "ÁGUA é VIDA" e que vida e água coexistem desde sempre, buscando "construir" um comprometimento integral cotidiano que seja capaz produzir mudanças simples e naturais nos costumes e comportamentos das pessoas e instituições que compõem a comunidade, com expectativa em resultados positivos de curto, médio e longo prazos, tomando por base experiências locais de preservação e proteção de nascentes, valorizando ideias e projetos já pensados pela própria comunidade (pessoas e/ou instituições), visando garantir às futuras gerações o acesso a esse bem indispensável para a sobrevivência, que é a água, em conformidade com a Lei 9433/1997 (Projeto Água é Vida/Agerb, 2020, p. 6).

O projeto foi organizado didaticamente com a proposta de ser realizado do dia 16 ao dia 22 de março de 2020 , contendo programação com datas horários, atividades, locais, regulamentos, 
premiações, patrocinadores e outros parceiros. Principais atividades:

1- I Seminário Intermunicipal de Proteção dos Recursos Hídricos da Sub-bacia Rio Candeias. (Buritis e Campo Novo de Rondônia);

2) Palestras nas Escolas Estaduais e Municipais: II Semana da Água em Buritis. Tema: “Água é Vida”. Como estamos cuidando desse bem imprescindível para a vida?

3) Workshop: Saúde Pública/Saneamento: água tratada e o serviço do Agente Comunitário de Saúde no Desenvolvimento do Município;

4) Concurso de Redação: (Desenhos, frases e textos) $2^{\mathrm{a}}$ Semana da Água em Buritis - Tema: “Água é Vida”. Ficou a critério de cada escola definir subtemas de acordo com a realidade.

5) Visitas à Estação de Tratamento de Água. Programa Portas Abertas. O Programa é de responsabilidade da Concessionária Águas de Buritis;

6) I Corrida da Água em Buritis.

Embora parte dessas atividades tenha sido suspensas em função da pandemia da Covid-19, que também ficou registrada no projeto através dos documentos oficiais e em diversas mídias, cada atividade acima relacionada tem sua relevância dentro do contexto da proposta do projeto e corrobora todo esforço do ponto de vista legal para que o cuidado com água se torne uma prática no cotidiano de todos, como pode ser conferido em trecho do texto de abertura/lançamento do Concurso de Redação que foi gravado em vídeo e enviado para as escolas utilizarem nas suas atividades. 
(...) Estamos iniciando a $2^{\text {a }}$ Semana da Água em Buritis com o tema "ÁGUA É VIDA".

Dentro desse tema, queremos dar ênfase à Proteção de Recursos hídricos aqui no lugar onde moramos, da água que mata nossa sede, da água que molha as plantas que nos alimentam e embelezam nossas casas, da água do banho... Proteção da água que está aqui ao nosso alcance! Durante toda essa semana queremos falar e ouvir sobre a ÁGUA nossa de cada dia.

O CONCURSO DE REDAÇÃO proposto, mais do que a premiação, pretende proporcionar esse debate. $\mathrm{O}$ tema é transversal, pode ser abordado em todas e por todas as disciplinas. As escolas podem e devem escolher seus subtemas de acordo com a realidade de cada faixa etária e de cada situação vivenciada pelos próprios alunos e comunidade escolar. Nesse sentido, quero deixar aqui algumas sugestões de subtemas, dentre muitos outros: 1) Lei das águas do Brasil - 9433/97 (os fundamentos no Artigo $1^{\circ}$ ); 2) O rio Candeias que abastece nossa cidade. $\mathrm{O}$ que sabemos dele, como está sendo cuidado como ficou seu volume de água no verão amazônico de 2019; 3) O rio São Domingos, trecho que corta nossa cidade, como está sendo cuidado, os alagamentos e o que pode ser feito; 4) Nascentes na zona urbana de Buritis, quantas são, como estão ou não estão sendo cuidadas e o que se pode fazer nessas áreas, podem falar também sobre o "Canal da cidadania”; 5) A água na composição do corpo humano; 6) A água e as futuras gerações. Será que do jeito que cuidamos da água hoje estamos garantindo esse bem para as futuras gerações? 7) $\mathrm{O}$ ciclo da água na natureza; 8) Água e as atividades econômicas (lazer, agropecuária) (...) (Projeto Água é Vida/Agerb, 2020, anexo III).

Para o objetivo do presente trabalho, que é analisar ações que tratam da proteção dos recursos hídricos propostas pela Agerb (realizadas ou em andamento), utilizando como "filtro" para essa 
análise a legislação vigente, em especial a Lei n. 9.433/97, o conteúdo do I Seminário Intermunicipal de Proteção dos Recursos Hídricos da Sub-bacia Rio Candeias (Buritis e Campo Novo de Rondônia), que foi realizado gerando o chamado é suficiente.

O I Seminário Intermunicipal de Proteção dos Recursos Hídricos da Sub-bacia Rio Candeias aconteceu no dia 16 de março de 2020, foi presidido e moderado pela Diretora Presidente da Agerb e seus auxiliares, contou com a participação de 32 (trinta e duas) pessoas, dentre elas representantes do Executivo e Legislativo do município de Buritis, dos colegiados da Agerb, da SEDAM, da Concessionária AEGEA Saneamento - Unidade Águas de Buritis, Dallan Açaí, Secretaria Municipal de Meio Ambiente, Secretaria Municipal de Agricultura, Secretaria Municipal de Educação, Mestrando do Profágua, Emater, Comitê da Bacia Hidrográfica do Rio Jamari - CBH-Jamari-RO, imprensa local.

O objetivo proposto no referido seminário foi o de criar espaços para consolidação de parcerias entre pessoas e instituições para, visando a realização de um diagnóstico da atual situação da sub-bacia rio Candeias, propor ações de curto médio e longo prazos envolvendo todos os atores pertinentes, em especial a comunidade, conforme texto-base:

O I Seminário Intermunicipal de Proteção dos Recursos Hídricos da Sub-bacia é uma das atividades da $2^{\mathrm{a}}$ Semana da Água, com Ttma: ÁGUA É VIDA, tem como finalidade colocar em debate questões relacionadas à PROTEÇÃO de RECURSOS HÍDRICOS, tais como: preservação, recuperação e manutenção de mananciais (nascentes e matas ciliares). Feito isso, o objetivo é criar espaços para consolidação de parcerias entre instituições e pessoas que compõem a comunidade, na expectativa de que o resultado de um trabalho integrado (em parceria) 
seja capaz de produzir mudanças simples e naturais nos costumes e/ou culturas da população local, no comportamento cotidiano em curto, médio e longo prazos.

Neste sentido, trazer para o debate a Proteção dos Recursos Hídricos, a partir do que se conhece pela vivência diária é uma simples, exequível e necessária tarefa para o momento. Não há mais espaço para espera, não há mais discurso que preencha a ausência da prática, não há mais inocentes entre nós e é vergonhosa a culpabilidade descarada que se costuma praticar ou assistir. O que podemos fazer hoje, a partir do copo de água, da torneira, do poço, da nascente, do rio que está mais próximo de cada um de nós? O assunto é abrangente e envolve a vida humana individual e social em todas as áreas, portanto, a soma de esforços na mesma direção e responsabilidade pode, até mesmo, e principalmente, iniciar identificando cases de sucesso (experiências) locais que possam ser replicados, valorizando ideias e projetos já pensados pela própria comunidade (pessoas e/ou instituições), "onde se encontra o problema, na maioria dos casos, encontra-se também a solução", seguramente este é um assunto que afeta a todos, sem distinção de classe social, raça ou credo. Buritis, precisa continuar se abastecendo do manancial rio Candeias e essa $2^{\text {a }}$ Semana da Água em Buritis é uma das iniciativas nessa direção. Necessário é que todos se envolvam, visando garantir às futuras gerações o acesso a esse bem indispensável para a sobrevivência, que é a água, em conformidade com a Lei das águas do Brasil (Projeto Água é Vida/Agerb, 2020, anexo IV).

Do I Seminário Intermunicipal de Proteção dos Recursos Hídricos da Sub-bacia rio Candeias resultaram a produção e publicação de um documento denominado "Tratado de Buritis" e a construção de várias parcerias. 
O "Tratado de Buritis" é um documento oficial de fácil leitura e interpretação que delibera ações diretas, simples e exequíveis, conforme pode ser conhecido na íntegra a seguir:

O presente TRATADO resulta do I Seminário Intermunicipal de Proteção dos Recursos Hídricos da Subbacia Rio Candeias proposto, presidido e moderado pela Agência Reguladora de Serviços Públicos Delegados do Município de Buritis - Agerb como uma das atividades alusivas à $2^{\text {a }}$ Semana da Água em Buritis, com o Tema: “Água é Vida”, e realizado pelos municípios de Buritis e Campo Novo de Rondônia, nesse Ato representados pelos seus respectivos prefeitos: Excelentíssimo Senhor Ronaldi Rodrigues de Oliveira - Buritis/RO e a Excelentíssima Senhora Valdenice Domingos Ferreira - Campo Novo de Rondônia/RO. Neste ato, a prefeita justificou sua ausência por telefone informando que estava em viagem e que não enviou representante, considerando a situação que ora se instalou em função do novo coronavírus. Apoio: Concessionária Águas de Buritis, Câmara de Vereadores, Dallan Açaí e ACIB.

Objetivos do TRATADO DE BURITIS: a) Consolidar parcerias entre pessoas e instituições; b) Realizar diagnóstico da atual situação das nascentes, cursos de água, Áreas de Preservação Permanente (matas ciliares) na sub-bacia rio Candeias; c) Propor e realizar ações de curto médio e longo prazos envolvendo todos os atores pertinentes, em especial a comunidade.

Seguem compromissos específicos assumidos:

A PREFEITURA DE BURITIS, através de seu responsável, prefeito Ronaldi Rodrigues de Oliveira, assume o compromisso de apoiar as ações de Proteção dos Recursos Hídricos e disponibilizará a área necessária para implantação de viveiro para produção de mudas visando a recuperação de áreas de AAPs que se encontram degradadas na sub-bacia rio Candeias, considerando todas 
as nascentes e cursos de água que alimentam o manancial (rio Candeias) que abastece a cidade de Buritis.

1) A SEMMAS - Secretaria Municipal de Meio Ambiente e Sustentabilidade, SEMAGRI - Secretaria Municipal de Agricultura e SEDAM - Secretaria Estadual de Desenvolvimento Ambiental, através de seus representantes legais, juntamente com o Técnico em Agropecuária e Gestor Ambiental, Vereador João Orlando, se comprometem em elaborar o projeto completo de viveiro, com planilhas contendo os materiais, custos e outros e protocolar na sede da Agerb no prazo de 30 (trinta) dias, a contar da data de aprovação desse Tratado.

2) A SEMMAS - Secretaria Municipal de Meio Ambiente e Sustentabilidade: se compromete em realizar o mapeamento das nascentes, cursos de água, Áreas de Preservação Permanente - APP (matas ciliares) fazendo a identificação, isolamento, se for o caso, começando pela zona urbana, envolvendo outros órgãos públicos e comunidade. Identificar e catalogar experiências de sucesso existentes na comunidade e desenvolver um projeto-piloto envolvendo, no mínimo, 1 (uma) nascente na zona urbana e outra na zona rural, com objetivo de consolidar experiências que possam ser replicadas em outros locais da sub bacia em questão.

3) OS PARTICIPANTES do I Seminário Intermunicipal de Proteção dos Recursos Hídricos da Subbacia Rio Candeias, autores e coautores do presente Tratado, são todos os que assinam a lista de presença do Seminário acima citado, com direito à voz e voto, devendo ser comunicados, consultados, convidados e/ou convocados, sendo assegurada a participação nas modalidades presencial e/ou online, sempre que necessário e com autonomia para ampliar e consolidar novas parcerias, visando atingir e envolver o maior número de pessoas e organizações comprometidas com 
questão da proteção dos recursos hídricos da Sub-bacia rio Candeias.

4) A CONCESSIONÁRIA Águas de Buritis, através de seu representante legal, Sr. Arlindo Pinto Sales, se compromete em entregar estrutura completa para implantação de um viveiro com sistema de irrigação, sombreamento, tubetes, badejas, sacolinhas, pulverizadores, EPIs, ferramentas e outros, de acordo com o projeto.

5) A CONCESSIONÁRIA Águas de Buritis, se responsabiliza de, a cada dois meses, fazer uma reportagem a respeito das nascentes e igarapés no município de Buritis. Realizar campanhas educativas, palestras em parceria com setores educacionais e órgãos afins com acompanhamento dos órgãos responsáveis pela questão ambiental no município.

6) A Agerb se responsabiliza por: a) inserir o Seminário Intermunicipal de Proteção dos Recursos Hídricos da Sub-bacia Rio Candeias como uma das atividades alusivas à Semana da Água realizada anualmente no Município Buritis; b) Dialogar com o Município de Campo Novo de Rondônia, instituições e pessoas convidadas que justificaram suas ausências devido às limitações impostas em função do novo coronavírus; c) Divulgar o Tratado de Buritis; d) Coordenar as ações aprovadas instituindo Comissão de Coordenação das Ações do Tratado de Buritis, composta por pessoas participantes desse ato e, essa comissão deverá elaborar a proposta de trabalho, visando atingir os objetivos propostos (Tratado de Buritis, 2020, p. 6).

Algumas das parcerias podem ser observadas no próprio texto do "Tratado de Buritis" acima citadas, mas, outras parcerias de igual importância também foram consolidadas, dentre elas a parceria com o "Programa Tracoá” se apresenta como sendo "uma 
iniciativa pessoal para o bem coletivo", colocando-se como uma alternativa mitigadora dos efeitos da degradação ambiental descontrolada que ocorre ao entorno do Parque Nacional Pacaás Novos.

A tarefa de preservação/recuperação das matas ciliares e solo nas bacias hidrográficas é uma atividade que depende grandemente da participação de todos. Como nem sempre há uma percepção de que os ganhos com esta prática são a longo prazo, o programa também visa incentivar os executores dos projetos em curto e médio prazo, considerando que os mesmos podem gerar externalidades positivas: benefícios sociais, ambientais, econômicos, culturais e etc., com trabalhos realizados dentro das escolas, dentro das comunidades até as fronteiras das propriedades e dos municípios. A ênfase está em incentivar a conservação e preservação do meio ambiente fora das áreas de reserva (Programa Tracoá, 2018, p. 4).

Na parceria com o Programa Tracoá a Agerb assumiu o compromisso de contribuir na articulação com outros órgãos e na elaboração de cronogramas de trabalho, etc.

\section{ANÁLISE DAS ATIVIDADES E INICIATIVAS REALIZADA PELA AGERB}

A análise das atividades/iniciativas da Agerb passadas pelo "filtro" da legislação vigente, dentre elas a Lei das águas do Brasil (Lei 9433/97), é uma tentativa de identificar o alinhamento entre o que propõe as obrigações legais através das leis e as iniciativas práticas, independentemente de serem ações imediatas, de curto, médio ou longo prazos, considerando a região da Sub-bacia rio Candeias e as estratégias utilizadas que, diga-se em tempo, nesse contexto, não se espera ações acabadas, mas, é necessário perceber 
e identificar instrumentos e/ou procedimentos que viabilizem o acompanhamento (gerenciamento) das ações e/ou iniciativas propostas ao longo de um período significativo, quando se trata de proteger e/ou recuperar danos causados aos mananciais de recursos hídricos, com especial foco em áreas de preservação permanente (matas ciliares e nascentes).

Do ponto de vista legal, pode-se afirmar que todos os documentos analisados guardam em si a fundamentação de legislação restando, portanto, agora, a analisar as estratégias utilizadas para realização e gerenciamento das ações.

Considerando o I Seminário Intermunicipal de Proteção de Recursos da Sub-bacia Rio Candeias consolidado no "Tratado de Buritis", em que um dos objetivos é “b) Realizar diagnóstico da atual situação das nascentes, cursos de água, Áreas de Preservação Permanente (matas ciliares) na Sub Bacia Rio Candeias", constatase duas ações significativas já realizadas sendo um georreferenciamento e a outra um estudo técnico da região.

O georreferenciamento foi feito pela Secretaria Estadual de Meio Ambiente (Sedam) em setembro de 2019, nas proximidades da área de captação de água bruta para o abastecimento da cidade de Buritis, margem esquerda do rio Candeias, onde nas imagens (mapas) é demonstrado o polígono da Área de Preservação Permanente (APP) e dessa área, 260,385 hectares estão degradados e precisam ser restaurados.

O Estudo Técnico foi apresentado pelo "Programa Tracoá" e demonstra as principais características da sub-bacia em questão: ciclo hidrológico, atividades econômicas realizadas (pecuária, agricultura familiar, piscicultura, pesca, agroindústria, extração de recursos naturais); geologia em torno das nascentes; clima, vegetação, características dos solos no município; municípios da 
sub-bacia rio Candeias. O descrito nesse parágrafo são apenas os tópicos, o estudo completo traz detalhes com números, coordenadas, etc.

Na sub-bacia do Baixo Candeias, são frequentemente encontradas atividades garimpeiras de exploração de cassiterita, localizadas no município de Campo Novo de Rondônia. Outras atividades existentes são captação de água para irrigação das lavouras de características permanentes, incluindo dois sistemas de captação para o abastecimento público de água tratada: um localizado no Baixo Candeias, para o abastecimento de água no município de Campo Novo de Rondônia, e o outro localizado no Alto Candeias, para o abastecimento de água no município de Buritis. As atividades de extração de cassiterita são frequentes nas sub-bacias do rio Candeias, estendendo-se até a foz do rio Jamari, no município de Candeias do Jamari (Programa Tracoá, 2018, p. 9 e 10).

Essas duas ações diagnósticas já realizadas são bases para a construção de outras ações para a realização do "Tratado de Buritis". O Viveiro previsto no item 2 foi elaborado considerando as informações diagnósticas. O terreno já disponibilizado pelo município contém as características técnicas específicas para construção e funcionamento de um viveiro (planilhas orçamentárias, plantas e etc) e foi denominado "Projeto de recuperação de nascentes e matas ciliares; Viveiro Municipal” e já protocolado junto à Concessionária Águas de Buritis, que é a responsável pela execução.

Ainda analisando as ações previstas no "Tratado de Buritis", a Agerb inseriu o Seminário Intermunicipal de Proteção de Recursos Hídricos da sub-bacia rio Candeias como uma das atividades alusivas à Semana da Água em Buritis, uma vez que consta no Projeto da III Semana da Água 2021; encaminhou cópia 
do Tratado de Buritis ao Executivo de Campo Novo de Rondônia e instituiu a Comissão de Coordenação das Ações do Tratado de Buritis (Portaria 008).

Considerando o que foi analisado, pode-se afirmar que todas as ações, sem exceção, de acordo com a legislação vigente, em especial a Lei das águas do Brasil, seus fundamentos e objetivos retratam uma inciativa (prática) baseada na necessidade de proteção dos recursos hídricos sinalizada pelo evento da redução do volume de água do rio Candeias, manancial que abastece a cidade de Buritis, em 2019.

Quanto à identificação de instrumentos e estratégias para garantir a continuidade das atividades, conta-se com a criação de uma comissão já citada, que tem como função criar instrumentos de gerenciamento, fortalecendo os procedimentos que naturalmente ocorrem quando da realização dos projetos, dadas as parcerias realizadas.

\section{CONSIDERAÇÃo FINAIS}

Concluindo, pode-se afirmar que a análise realizada, objetivo desse trabalho, demonstra os resultados esperados, considerando as ações da Agerb na tentativa de contribuir para proteção e/ou recuperação dos recursos hídricos da sub-bacia rio Candeias.

Acrescenta-se que a Agerb, ou quem quer seja, poderá utilizar os resultados desse estudo como certificação e/ou validação de cada atividade realizada e as que estão em andamento, considerando os parâmetros legais, em especial a Lei das Águas do Brasil (Lei 9.433/97) e até mesmo se considerar a possibilidade de aplicar a Lei n. 14.119/2021 que visa o Pagamento por Serviços Ambientais. 
É notório o esforço na busca da consolidação de parcerias, o que é fundamental, pois, sem a participação, sem a cumplicidade e o compromisso dos que utilizam esse bem essencial para vida, que é a água, os projetos, as ideias, as iniciativas, até mesmo os recursos técnicos e financeiros são insuficientes.

Há que se fortalecer cada vez mais os procedimentos de gerenciamento das ações de forma que seja capaz de fazer as intervenções e dar suporte aos envolvidos diretos nas ações, incentivando, motivando a melhoria na interação entre os parceiros, buscando apoio técnico, financeiro através de articulação para viabilização de recursos junto a diversos órgãos, com destaque para os Comitês de Bacias, nesse caso, especialmente o $\mathrm{CBH}$ JAMARI, bem como, criar os meios necessários para aplicar a Lei 14.119 de 13 de janeiro de 2021 que Institui a Política Nacional de Pagamento por Serviços Ambientais, tornando-se uma forte aliada para captação de recursos e manutenção das ações propostas, além do Fundo Municipal de Meio Ambiente de Buritis. Portanto, é fundamental que a Comissão de Coordenação das Ações do Tratado de Buritis cumpra seu calendário de reuniões ordinárias, mantendo atualizado o andamento das ações.

\section{REFERÊNCIAS}

ADAMY, Amilcar. Geodiversidade do estado de Rondônia. Porto Velho: CPRM, 2010.

AGERB. Notícias. Monitoramento do nível de água do Rio Candeias. Buritis: Agerb, 2019. Disponível em: <http://agerb. buritis.ro.gov.br/noticias/item/373-monitoramento-do-nivel-deagua-do-rio-candeia>. 
AGERB. Tratado de Buritis. Buritis: Agerb, 2020. Disponível em: $<$ https://transparencia.agerb.buritis.ro.gov.br/media/arquivos/att achments/TRATADO_DE_BURITIS>. Acesso em: 18 jan. 2021.

ANA. Manual operativo programa produtor de águas. Brasília: ANA, 2008. Disponível em: <http://produtordeagua.ana.gov.br/ Portals/0/DocsDNN6/documentos/MANUAL\%20OPERATIVO \%20-\%20PROGRAMA\%20PRODUTOR\%20DE\%20\%C3\%81 GUA>. Acesso em: 17 de jan. 2021.

BRASIL. Lei n. 9.433, de 8 de janeiro de 1997. Institui a Política Nacional de Recursos Hídricos, cria o Sistema Nacional de Gerenciamento de Recursos Hídricos. Diário Oficial da União.

BRASIL. Lei n. 11.445, de 5 de janeiro de 2007. Estabelece as diretrizes nacionais para o saneamento básico; cria o Comitê Interministerial de Saneamento Básico. Presidência da República, Casa Civil. Atos do Poder Legislativo.

BRASIL. Lei n. 14.119, de 13 de janeiro de 2021. Institui a Política Nacional de Pagamento por Serviços Ambientais. Diário Oficial da União.

BURITIS. Lei n. 870, de 22 de outubro de 2014. Institui a Agência Municipal de Serviços Públicos Delegados do Município de Buritis.

COELHO, Marcio de Santana. Recuperação de áreas de APP e nascentes no Município de Buritis-RO. Artigo Científico. Unufran, 2018.

EOS. Descubra qual a situação da água no Brasil. Rio de Janeiro: Blog, 2019. Disponível em <www.eosconsultores.com.br/descubraqual-a-situacao-da-agua-no-brasil/>. Acesso em: 17 dez. 2020. 
GODOY, Christiane; et. al. Plano local de desenvolvimento sustentável. Agenda 21. Pilar do Sul. Instituto ecoar. 2007.

ICMBIO. Unidades de Conservação. Disponível em: $<$ www.icmbio.gov.br/portal/unidadesdeconservacao/biomasbrasileiros/amazonia/unidades-de-conservacao-amazonia/1978parna-de-pacaas-novos>. Acesso em: 10 fev. 2019.

INSTITUTO TRATA BRASIL. Saneamento básico e educação. Disponível em: <www.tratabrasil.org.br/blog/2008/09/01/ saneamento-basico-e-educacao/>. Acesso em: 16 jan. 2021.

MAIFREDE, Pedro Ozeis; et. al. Programa Tracoá. Buritis. Parceria técnica para educação e sustentabilidade. 2018.

ONU. Declaração dos Direitos da Água-Eco-92. Rio de Janeiro, ONU, 1992.

SOARES, Ocilene G; et. al. Projeto “Água é vida” - $2^{\mathbf{a}}$ Semana da água em Buritis. Buritis: Agerb, 2020.

VICTORINO, Célia Jurema Aito. Planeta água morrendo de sede: Uma visão analítica na metodologia do uso e abuso dos recursos hídricos. Disponível em: <www.pucrs.br/edipucrs/online/ planetaagua.pdf $>$. Acesso em: 19 jan. 2021. 


\title{
IDENTIDADES SOCIOLINGUÍSTICAS E CULTURAIS: UM ESTUDO NA FALA DE MORADORES DO BAIRRO CRISTO REI, EM GUAJARÁ-MIRIM(RO) ${ }^{61}$
}

\author{
Auxiliadora dos Santos Pinto ${ }^{62}$ \\ Eunaia dos Santos Mercado ${ }^{63}$ \\ Diana da Silva Barroso ${ }^{64}$
}

\section{INTRODUÇÃo}

Este artigo apresenta resultados de um estudo sobre alguns aspectos das identidades sociolinguísticas e culturais evidenciadas na fala de moradores do bairro Cristo Rei, na área ribeirinha urbana, no município de Guajará-Mirim, Rondônia, na fronteira Brasil/Bolívia.

A pesquisa foi norteada pelos seguintes questionamentos: quais os principais aspectos históricos e geográficos do processo de formação e ocupação do bairro Cristo Rei? Quais os principais

61 Artigo publicado no $3^{0}$ volume da Revista Culturas e Fronteiras. $<$ www.periodicos.unir.br>. ISSN 26751011.

62 Dra. Auxiliadora dos Santos Pinto, Professora na Universidade Federal de Rondônia (UNIR); residente na cidade de Guajará-Mirim(RO), Brasil. E-mail: auxiliadorapinto@unir.br. URL Currículo Lattes: <http://lattes.cnpq.br/ 9380284076167461>.

${ }^{63}$ Graduada em Letras e suas respectivas literaturas, pela Universidade Federal de Rondônia (UNIR); residente na cidade de Guajará-Mirim(RO), Brasil. E-mail: eunaia_msantos@hotmail.com. URL currículo Lattes: <http://lattes.cnpq.br/ 8291648888878678>.

${ }^{64}$ Graduada em Letras e suas respectivas literaturas, pela Universidade Federal de Rondônia (UNIR); residente na cidade de Guajará-Mirim(RO), Brasil. E-mail: diana_sbarroso@hotmail.com. URL Currículo Lattes: <http://lattes.cnpq.br/ 8804217586838307>. 
aspectos sociais e econômicos do processo de formação e ocupação do bairro Cristo Rei? Qual a origem dos primeiros moradores do referido bairro? Atualmente, como é a constituição das identidades sociolinguísticas e culturais do bairro Cristo Rei?

O desenvolvimento desta pesquisa é relevante porque contribui para uma melhor compreensão do processo de constituição das identidades sociolinguísticas e culturais dos moradores do bairro Cristo Rei, no município de Guajará-Mirim.

Vale ressaltar que este estudo privilegia um momento histórico importante para a constituição da linguagem, da cultura e da identidade guajará-mirense, uma vez que, na época da construção da EFMM, ocorreu um intenso fluxo migratório no povoado de Esperidião Marques, atual município de GuajaráMirim, e a consequente ocupação da área ao longo das margens do rio Mamoré onde, atualmente, localiza-se bairro Cristo Rei. Nesse sentido, a pesquisa também contribuirá para a formação de um banco de dados sobre os falares ribeirinhos urbanos do município de Guajará-Mirim.

O objetivo da pesquisa foi registrar e analisar alguns aspectos das identidades sociolinguísticas e culturais evidenciadas na fala de moradores do bairro Cristo Rei, na área ribeirinha urbana de Guajará-Mirim, na fronteira Brasil/Bolívia.

Para alcançar o objetivo proposto, estabelecemos os seguintes objetivos específicos: identificar alguns aspectos constituidores das identidades sociolinguísticas na fala de moradores, destacando-se os aspectos semânticos-lexicais próprios dos falares urbanos ribeirinhos; mostrar alguns aspectos constituidores das identidades culturais na fala de moradores do referido bairro; destacar elementos linguísticos e extralinguísticos que contribuem/contribuíram para o processo de constituição da 
fala do referido grupo e contribuir para o registro das identidades sociolinguísticas e culturais dos moradores do referido bairro.

\section{LINGUAGEM, CULTURA E IDENTIDADE: ALGUNS CONCEITOS}

O estudo e análise desta temática foram fundamentados pelos pressupostos teórico-metodológicos da Sociolinguística Variacionista e da História Oral, tendo-se como base os estudos dos seguintes autores: Mollica e Braga (2012) que na obra Introdução à Sociolinguística discutem sobre o tratamento da "variação"; Bagno (2007), que descreve os fenômenos de variações linguísticas e extralinguísticas, e estágios formativos dos estudos variacionista; Halbwachs (1990), que discute sobre memória e modos de subjetivação; Laraia (2011), que apresenta um conceito antropológico de cultura; Hall (2016), cuja obra discute sobre os temas: representação, cultura, linguagem e sentido; Fraxe (2004), que discute sobre a cultura rural-ribeirinha, destacando os mitos, as lendas e a transculturalidade; Abdala Junior (2002), que discute sobre a mescla e hibridismo cultural, como uma interação construída e/ ou reconstruída individualmente ou coletivamente sempre constituída de interações múltiplas; Portelli (2016), que concebe a História Oral como arte da escuta e usos da memória, nos afirmando que eventos históricos é uma linha interconectada sobre o que se passou, o que está se passando, e a interconexão de ambos em uma única narrativa e outros.

Conforme Mollica e Braga (2012), a construção da linguagem de uma determinada região ou comunidade é constituída por marcas sociolinguísticas heterogêneas. Assim, elas definem e fazem distinções sobre as variações linguísticas que podem ocorrer nos eixos diatópico e diastrático: “[...] no primeiro, as alternâncias se expressam regionalmente, [...] no segundo, elas se 
manifestam de acordo com os diferentes estratos sociais, levandose em conta fronteiras sociais.” (Molica; Braga, 2012, p. 12).

Nos estudos das variações linguísticas observa-se a ocorrência de traços distintos e inconstantes que apresentam marcadores regionais e sociais a partir de diferentes níveis de monitoração linguística nos indivíduos de áreas distantes e/ou isolamento da comunidade em áreas rurais ou urbanas.

[...] Nota-se que, além de traços descontínuos, identificados nos polos rural e urbano [...] O grau de isolamento geográfico e social concorre para a gama de traços que definem uma estratificação descontínua, assim como as relações sociais [...] São considerados também os estilos formais e informais [...] da produção linguística (Mollica; Braga, 2012, p. 12 e 13).

Desse modo, partindo dos pressupostos teóricometodológicos propostos por Mollica e Braga (2012), podemos afirmar que: "[...] se cada grupo apresentasse comportamento linguístico idêntico, não haveria razão para se ter um olhar sociolinguístico das sociedades."

Bagno (2007) nos afirma que: “[...] dizer que a língua apresenta variação significa dizer, mais uma vez, que ela é heterogênea [...] debaixo do guarda-chuva chamado língua, no singular, se abrigam diversos conjuntos de realizações possíveis dos recursos expressivos que estão à disposição dos falantes (Bagno, 2007, p. 39).

Assim, compreendemos que nas línguas naturais existe uma heterogeneidade linguística, pressupondo a existência de variantes e variáveis, de natureza interna ou externa, concebidos por fatores sociais ou estruturais. 
Halbwachs (1990), afirma que além de abordar como essa memória individual e coletiva, sofre pelo aspecto confratário pelo próprio indivíduo, no processo de rememoração e fragmentada implícita, o que ocasiona em alguns momentos de esquecimentos, precisando do cruzamento de depoimentos, para fortalecer o fato descrito.

[...] nossa impressão pode apoiar-se não somente sobre nossa lembrança, mas também sobre a de outros, nossa confiança na exatidão de nossa evocação será maior, como se uma mesma experiência fosse começada, não somente pela mesma pessoa, mas por várias. [...] (Halbwachs, 1990, p. 25).

O sentido maior de rememoração é que podemos encontrar um alicerce entre o passado e o presente, através de narrativas para que possamos reconstruir uma história viva, em um "quadro" de sustentação. É como se o tempo fosse algo abstrato que permite à nossa lembrança constituir uma cadeia de recordações e o espaço fica como algo concreto onde há a possibilidade do indivíduo ou até mesmo de um grupo deixar suas marcas em um determinado lugar e de seus costumes, isso é que dá sentido à memória. Laraia (2011), explica que ao abordarmos o termo cultura sob o aspecto antropológico, evidenciamos a existência de várias formas de expressões, além da linguística, que estão subjacentes.

O fato de que o homem vê o mundo através de sua cultura tem como consequência a propensão em considerar o seu modo de vida como o mais correto e o mais natural. Tal tendência, denominada etnocentrismo, é responsável em seus casos extremos pela ocorrência de numerosos conflitos sociais (Laraia, 1986, p. 72 e 73). 
Corroborando as ideias de Laraia (2011), Hall (2016) afirma que:

A cultura [...] está envolvida em todas essas práticas que não são geneticamente programadas em nós, [...], mas que carregam sentido e valores para nós, [...] A cultura, desse modo, permeia toda sociedade. Ela que é o que diferencia o elemento "humano" na vida social daquilo que é biologicamente direcionado (Hall, 2016, p. 21).

Por este contexto, o entendimento da constituição da cultura é algo que passa pelo estudo diacrônico e antropológico. Sob este aspecto, o indivíduo reconhecendo-se como cognoscente da própria existência de sujeito-pensante, e que se molda pelas relações sociais e linguísticas da qual convive na sociedade.

Ao discutir sobre a cultura rural ribeirinha Fraxe (2004) destaca os mitos, as lendas e a transculturalidade. No contexto ribeirinho-urbano, esses elementos são constituídos de misticismos, crendices, e a constante beleza e mistérios das águas. Estas que além de mistérios, serve de ponto de referência para o reconhecimento de pertença de um povo.

Abdala Junior (2002), aborda o processo de hibridização cultural como uma interação construída e/ ou reconstruída, individualmente ou coletivamente, sempre constituída de interações múltiplas, por este viés, emerge o sentido da construção dialógica da cultura manifestada pelas vivências sociais do sujeito, ou seja, é preciso entender como o sujeito falante constitui a identidade individual e coletiva.

Dessa forma, a partir das concepções teóricas apresentadas, inferimos que tentar demarcar a identidade como algo de simples categorização imutável é um equívoco, pois ela está em constante processo de (re)construção. 


\section{Procedimentos Metodológicos DA PESQUISA}

A pesquisa, de natureza bibliográfica e de campo, foi desenvolvida no período de agosto a dezembro de 2017. A coleta de dados foi realizada com uma amostra de dez (10) moradores do bairro Cristo Rei, levando-se em consideração as seguintes variáveis internas e externas: faixa etária superior a 50 anos, pois é possível observar variações de formas antigas do léxico, como também reconstituição da memória afetiva e social do objeto de pesquisa; sexo, anos de escolarização, classe social, procedência geográfica, motivo da migração/imigração e tempo de residência no bairro Cristo Rei e outros.

Na coleta de dados, foram utilizadas as seguintes técnicas: conversas informais, visando identificar as variações semânticolexicais na fala dos entrevistados; realização de entrevistas a partir de gravação de áudios e aplicação de questionários, para obtenção de informações concisas sobre questões históricas, sociais, econômicas e culturais dos moradores do bairro Cristo Rei.

Assim, as entrevistas foram feitas durante pesquisa de campo, de autoria própria, e realizadas nas residências dos sujeitos, conforme sugestões de Mollica e Braga (2012). Considerando que, o uso da língua é heterogêneo, e a partir das interações sociais, o uso linguístico sofre por aspectos modificadores, internos ou externos do sistema linguístico, sendo assim, as variações linguísticas não acontecem de formas desordenadas:

[...] o pressuposto básico do estudo da variação no uso da língua é o de que a heterogeneidade linguística, tal como a homogeneidade, não é aleatória, mas regulada, governada por um conjunto de regras. Em outras palavras [...] existem condições ou regras mudáveis que funcionam para favorecer ou desfavorecer [...] o uso de uma ou outra 
das formas em cada contexto. Na língua [...] deve ser possível identificar uma série de categorias [...] internas ao sistema linguístico ou externas a ele (Mollica; Braga, 2012, p. 15).

A partir da asserção de modelos categóricos na língua, é necessário considerar a dimensão quantitativa a ser pesquisada, e buscar uma amostra relevante para alcançar resultados mais próximos da realidade linguística de uma comunidade e/ou sociedade. Essa tarefa não é fácil, devido a vários fatores que são inerentes às regras categorizadas, entretanto, ao almejar a aproximação da realidade linguística de um determinado lugar a escolha dos sujeitos falantes deve ser, prioritariamente, alguém de representatividade para a constituição do corpus.

[...] Tendo em vista que comunidades de fala, em geral, são compostas por centenas ou milhões de indivíduos, não temos outra opção a não ser coletar os dados referentes ao comportamento linguístico de uma comunidade apenas a partir de alguns de seus componentes [...] isso não chega a ser uma limitação à pesquisa [...] mas representativa - da comunidade é tudo o que precisamos (Coelho et al., 2015, p. 100).

Para a estratificação do universo da amostra, adotamos alguns dos modificadores variáveis para essa pesquisa, utilizamonos das variações dialetais existentes entre os fatores de faixa etária superior a 50 anos, possibilitando a análise de uma linguagem mais clássica, possivelmente adquirida ainda na primeira faixa etária - 15 a 24 anos, como exemplifica Coelho et al. (2015) quanto a distribuição planificada em quadro no que se refere à idade.

Segundo Mollica e Braga (2012), fatores relacionados a variações entre sexo feminino e masculino, podem ser relacionados e analisados a fatores de escolarização e classe social. De modo 
amplo, as variações existentes entre os sujeitos falantes do sexo feminino e masculino, são considerados a partir da forma inovadora quanto ao valor social.

Na realização das entrevistas, utilizamos as técnicas da História Oral, propostas por Portelli (2010), que concebe a história Oral como arte da escuta, dialogia e usos da memória.

A história oral, então, é primordialmente uma arte da escuta. Mesmo quando o diálogo permanece dentro da agenda original [...]. É comum, aliás, que a informação mais importante se encontre para além daquilo que tanto o historiador quanto $\mathrm{o}$ narrador consideram historicamente relevante (Portelli, 2016, p. 10).

A reconstituição da memória pelas técnicas de escuta requer a relação que pressupõe a ação dialógica entre o entrevistador e o entrevistado, de tempo e espaço temporal e, historiografia. Dessa forma, o autor apresenta a arte da escuta como algo que, “[...] não se demostra respeito, desligando o gravador como que para anunciar ao entrevistado que daquele momento em diante você não está interessado no que ele pode ter a dizer." (Portelli, 2016, p. 11).

A técnica dialógica da escuta almejando a rememoração de acontecimentos vivenciados pelo indivíduo entrevistado, mostrase como fonte importante para se obter significados e indícios de características linguísticas particularizadoras. Esta técnica, é tida pelos historiadores tradicionalistas como algo passível de “distorções”. Contudo, Portelli (2010) nos assegura que através de cruzamentos de informações é possível verificar se elas são verdadeiras e não apenas subjetivas de quem as narra.

Quando trabalhamos com fontes orais, então, devemos traçar [...] três níveis distintos, mas interconectados: um fato passado (o evento histórico), um 
fato do presente (a narrativa que ouvimos) e uma relação fluida, duradoura (a interação entre os dois fatos) [...] (Portelli, 2016, p. 18).

Ao tratarmos da representatividade linguística de uma comunidade, ressaltado no sentido não só de área geográfica, mas também comunidade de sentimentos, a força dialógica em uma história oral carrega mais que um simples discurso consciente, ela permeia a identidade do falante, dando ênfase à própria complexidade da linguagem.

Na história oral, o fazer empírico de dados linguísticos requer técnicas-metodológicas, das quais adotamos para o objeto de pesquisa do presente artigo: conversas informais, realização de entrevistas, gravação de áudio, e questionário. Coelho et al. (2015) explica que, a melhor forma de investigação sociolinguística que transmiti dados fidedignos do léxico de um falante é através da gravação de áudio sem muitas interferências e ruídos.

A melhor forma de coletar bons dados - que reflitam de forma fidedigna e em boa qualidade sonora o vernáculo-é a gravação de entrevistas individuais, procurando sempre minimizar a interferência de ruídos externos [...] No decorrer da entrevista, os dados mais interessantes provêm de narrativas de experiências pessoais. [...] o entrevistador faz com que o informante desvie a atenção de sua própria fala, deixando o vernáculo emergir (Coelho et al., 2015, p. 103).

Outra técnica utilizada foi a produção de questionário ou roteiro de entrevista. Ela auxiliou na elucidação de narrativas das vivências dos entrevistados, para a coleta de dados e identificação das variações linguísticas. O entrevistador pode se valer de estímulos verbais para obtenção de dados para produção do estudo linguístico. Desta forma Coelho (2015, p. 103) propõe que “[...] Nas 
entrevistas, além de estimular narrativas, o entrevistador pode conduzir perguntas".

$\mathrm{O}$ que devemos observar durante a entrevista sociolinguística é o aspecto metalinguístico, pois, o entrevistado tende a monitorar a fala quando o assunto da narrativa são questões que requerer opinião, havendo um maior cuidado do sujeito entrevistado ao expressar-se, é a partir desses dados registrados que podem emergir os traços linguísticos identitários.

Podemos pressupor que, "a arte da escuta”, requer do pesquisador um olhar minucioso das representações linguísticas que permeiam uma comunidade, pois é através do processo da dialogia nas narrativas que os aspectos constituidores de significados individuais e sociais fragmentados pela técnica de rememoração, faça emergir a identidade regional e sociocultural.

Os dados coletados foram analisados à luz da Teoria da Sociolinguística variacionista e foram organizados em tabelas com as classificações dos fenômenos de variações linguística e extralinguísticas identificados na fala de moradores da área ribeirinha-urbana do bairro Cristo Rei. Também foram destacados fragmentos das entrevistas para mostrar aspectos das identidades culturais e dos modos de vida dos moradores do bairro Cristo Rei.

\section{APRESENTAC̣ÃO E ANÁLISE DOS RESULTADOS DA PESQUISA}

O bairro Cristo Rei foi criado, oficialmente, através da Lei $n$. 363/GAB/PMGM, no dia 10 de dezembro de 1990, abrangendo os seguintes logradouros: 12 de outubro, Beira Rio, Benjamin Constant, Boucinhas de Menezes, Constituição, Costa Marques, Dom Pedro II, Firmo de Matos, Madeira Mamoré, Marcílio Dias, Mendonça Lima travessa Nicolau Jorge, Pedro Eleothério Ferreira, Pimenta Bueno, Porto Carreiro, Presidente Dutra, e Quintino 
Bocaiúva. É um espaço marcado pelas variedades linguísticas rural e urbana, situando-se em um contínuo rurbano.

Historicamente, o referido bairro foi povoado por trabalhadores da Estrada de Ferro Madeira Mamoré (EFMM) e, ao longo dos anos, foi sendo ocupado, também, por pessoas provenientes de comunidades rurais-ribeirinhas e por imigrantes e migrantes da zona rural, da Bolívia e de outros estados brasileiros. Devido a sua localização geográfica, o processo de ocupação deu-se com maior facilidade, sendo fatores determinantes: a área das margens do rio Mamoré, a proximidade do comércio da cidade, e da própria construção da EFMM Outro fator importante foi o ciclo da borracha, um dos mais promissores movimentos econômicos da região norte, que também despertou o interesse de migrantes e imigrantes em busca do "eldorado" na selva brasileira, e anseio de melhores condições de vida.

Após a expansão do município de Guajará-Mirim, fechamento da EFMM e a decadência dos seringais, a área ribeirinha urbana onde situa-se o bairro Cristo Rei foi ocupada tanto pelos ex-seringueiros, como por imigrantes bolivianos e população ribeirinha procedentes de outras localidades. Atualmente, a identidade sociolinguística e cultural do bairro Cristo Rei é constituída pela mistura de povos, prevalecendo, principalmente, os imigrantes bolivianos.

As formações sociais do bairro expressam o caráter próprio das identidades linguísticas e culturais dos moradores e estão relacionadas às condições sócio-históricas do local. Essas formações dão sentido aos modos de apropriação que cada comunidade constrói, sendo transmitidas por tradições populares a partir dos vários processos de constituição pelo qual passou a região com as relações de trabalho, educação, religião e outros. 
Ao pensarmos em "grupo social", temos uma gama de possibilidades de variações linguísticas, que vão desde a pronúncia diferenciada, região, ou até mesmo um léxico decorrente dos ancestrais do falante. Por essa asserção, podemos afirmar que independentemente das variações e variantes dialetais entre os falantes, é possível estabelecer uma comunicação dialogia. Nesse sentido, neste trabalho daremos ênfase às palavras ou expressões com traços ou características semântico-lexicais evidenciadas na fala de moradores da área ribeirinho urbano do bairro Cristo Rei, conforme apresentaremos na Tabela 2.

Tabela 1: Variações semântico-lexicais

\begin{tabular}{l|l|l}
\hline \multirow{2}{*}{ Entrevistado } & \multicolumn{1}{|c|}{$\begin{array}{c}\text { Palavras ou } \\
\text { expressões }\end{array}$} & \multicolumn{1}{c}{ Contextos de uso } \\
\hline \multirow{4}{*}{ A.B. } & Baixava & Descer o rio \\
\cline { 2 - 3 } & Comboi & $\begin{array}{l}\text { Muita gente aglomerada } \\
\text { em um mesmo espaço }\end{array}$ \\
\hline \multirow{4}{*}{ M.I.M } & Socou & Ficar \\
\cline { 2 - 3 } & Arranjou & Casar \\
\cline { 2 - 3 } & Ver o trem correr & $\begin{array}{l}\text { Ver o trem passar; se } \\
\text { movimentar }\end{array}$ \\
\cline { 2 - 3 } & Fundura & Fundo; buraco bem fundo \\
\cline { 2 - 3 } & Pilar & Alicerce \\
\cline { 2 - 3 } & Cacimbas & Poço \\
\cline { 2 - 3 } & Escovado & Lavar com bucha \\
\cline { 2 - 3 } & Pestana & $\begin{array}{l}\text { Corte vertical na } \\
\text { seringueira }\end{array}$ \\
\cline { 2 - 3 } & Quebra barranco & $\begin{array}{l}\text { Corte feito ao final da } \\
\text { pestana para encaixar uma } \\
\text { tigela }\end{array}$ \\
\hline
\end{tabular}




\begin{tabular}{|c|c|c|}
\hline & Mata bruta & Mata fechada \\
\hline & Taquara & Flechada \\
\hline & Fera & Boa \\
\hline & Mel na chupeta & Fácil \\
\hline & Bocado & Quantidade \\
\hline & Folha de pau & $\begin{array}{l}\text { Ideia de algo em grande } \\
\text { quantidade }\end{array}$ \\
\hline & Era piolho & $\begin{array}{l}\text { Frequentava muito algum } \\
\text { lugar }\end{array}$ \\
\hline & Buiá & Submergir \\
\hline & Misura & $\begin{array}{l}\text { Muitas histórias } \\
\text { assombradas }\end{array}$ \\
\hline & Matar burro & $\begin{array}{l}\text { Pau colocado com } \\
\text { distância de } 20 \\
\text { centímetros de um para os } \\
\text { outros }\end{array}$ \\
\hline & Trolho & $\begin{array}{l}\text { Espécie de carro movido } \\
\text { por pessoas para a } \\
\text { manutenção da EFMM }\end{array}$ \\
\hline \multirow{7}{*}{ J.M.L } & Trecho & Parte de uma estrada \\
\hline & Dormentes & $\begin{array}{l}\text { Madeira da parte de baixo } \\
\text { do trilho - EFMM }\end{array}$ \\
\hline & Cassaco & $\begin{array}{l}\text { Trabalha por contrato por } \\
\text { espaço/ ou área } \\
\text { determinada }\end{array}$ \\
\hline & Bocado & Muitas pessoas \\
\hline & Cargueiro & Vagão de carga \\
\hline & Pulista & $\begin{array}{l}\text { Pessoa responsável por } \\
\text { colocar lenha na caldeira } \\
\text { do trem }\end{array}$ \\
\hline & Trecho & Parte de uma estrada \\
\hline
\end{tabular}




\begin{tabular}{l|l|l}
\hline Dormentes & $\begin{array}{l}\text { Madeira da parte de baixo } \\
\text { do trilho - EFMM }\end{array}$ \\
\cline { 2 - 3 } & Bocado & Muitas pessoas \\
\cline { 2 - 3 } Cargueiro & Vagão de carga \\
\cline { 2 - 3 } & Pulista & $\begin{array}{l}\text { Pessoa responsável por } \\
\text { colocar lenha na caldeira } \\
\text { do trem }\end{array}$ \\
\hline
\end{tabular}

Fonte: Dados da pesquisa

Na tabela 3 destacamos palavras e expressões faladas pelos moradores do bairro Cristo Rei. Conforme descreve as transcrições das entrevistas, facilitando a percepção das identidades linguísticas dos moradores, pois, assim, podemos observar em que contexto eles utilizam essas palavras.

Tabela 2: Palavras utilizadas no contexto da fala

\begin{tabular}{l|l|l}
\hline Entrevistado & \multicolumn{1}{|c}{$\begin{array}{c}\text { Palavras ou } \\
\text { expressões }\end{array}$} & \multicolumn{1}{c}{ Contextos de uso } \\
\hline A.N.S & Gapozal & $\begin{array}{l}\text { "Quando chegamos aqui } \\
\text { não tinha nada, a gente teve } \\
\text { que fazer escavação pra } \\
\text { botar água, teve que ajudar } \\
\text { pra botar luz que não tinha, } \\
\text { tudo isso ai, nós lavava nos } \\
\text { poços que tinha aqui num } \\
\text { gapozal, porque nós não } \\
\text { tinha água, bebia até a água } \\
\text { daí do gapozal porque nós } \\
\text { não tinha água. [...].” }\end{array}$ \\
\hline A.B. & Comboi & $\begin{array}{l}\text { "Naquele tempo não tinha } \\
\text { médico não tinha colégio } \\
\text { era dentro do mato mesmo } \\
\text { era o comboi que levava } \\
\text { aqueles animais que como }\end{array}$ \\
\hline
\end{tabular}




\begin{tabular}{|c|c|c|}
\hline & & $\begin{array}{l}\text { burro, que ia deixar a viação } \\
\text { [..]." }\end{array}$ \\
\hline E.S.S. & & $\begin{array}{l}\text { "Quando eu cheguei aqui } \\
\text { não tinha nem essa sede ai, } \\
\text { quando eu já tive meus } \\
\text { filhos, quando meus filhos já } \\
\text { tavam rapaizinhos eles já } \\
\text { ajudavam [...] porque ai era } \\
\text { um buraco, era um buracão } \\
\text { feio ai, [...] e pra levantar } \\
\text { todo mundo cooperava, } \\
\text { quando eu era mocinha ali } \\
\text { era só um caminho [...]." }\end{array}$ \\
\hline M.I.M & $\begin{array}{l}\text { Gapó } \\
\text { Sapezal }\end{array}$ & $\begin{array}{l}\text { “A naquele negócio de } \\
\text { construção do bairro, aquela } \\
\text { sede ali tem mais ou menos } \\
\text { nada nada não que uns } 6 \\
\text { metros de fundura, de pilar } \\
\text { porque ali também era um } \\
\text { gapó, nós gastemo mais ou } \\
\text { menos na fundação do chão } \\
\text { uns } 50 \text { saco de cimento pra } \\
\text { poder chegar em cima[...]”. }\end{array}$ \\
\hline J.M.L & $\begin{array}{l}\text { Cassaco } \\
\text { Matagal } \\
\text { Lagoa }\end{array}$ & $\begin{array}{l}{ }^{2} \text { Tinha, naquela época que } \\
\text { era empeleitero chamava } \\
\text { cassaco, né naquela época aí } \\
\text { ficou assim cassaco que era } \\
\text { esses pessoal que dava } \\
\text { manutenção na linha, na } \\
\text { estrada de ferro. }\end{array}$ \\
\hline
\end{tabular}

Fonte: Dados da pesquisa

Além das variações linguísticas semântico-lexicais destacadas na Tabela acima, identificamos, na fala dos entrevistados, alguns fenômenos extralinguísticos. Dentre eles, destacamos o uso recorrente de palavras diminutivas: "Quando eu cheguei aqui não tinha nem essa sede ai, quando eu já tive meus 
filhos, quando meus filhos já tavam rapaizinhos eles já ajudavam [...] porque ai era um buraco, era um buracão feio ai, [...] e pra levantar todo mundo cooperava, quando eu era mocinha ali era só um caminho [...]" (Entrevistada: E.S.S).

Também destacamos que os entrevistados utilizam uma linguagem própria dos falares rurais-ribeirinhos, sendo identificados o uso de rotacismos, ditongação, monotongação, juntura vocabular, eliminação do R em final de palavras, eliminação dos plurais redundantes, palatalização dentre outros.

O bairro Cristo Rei é marcado por características geográficas típicas de um espaço ribeirinho urbano, que foi sendo modificado ao longo dos anos. A princípio, foi demarcado pelos trilhos da EFMM e, por situar-se na parte central da cidade e às margens do rio foi sendo ocupado rapidamente.

\section{Tabela 1 - Fragmentos para caracterização geográfica do bairro DESCRIÇÃO DO ESPAÇO GEOGRÁFICO DO BAIRRO CRISTO REI}

"Moro atrás do cemitério, perto da linha de ferro, com o rio Mamoré com a praia do Acácio, bem na linha do trilho de ferro, muro com o cemitério." (Entrevistada: A.N.S).

"Eu moro atrás do cemitério entre o cemitério e o rio no meu quintal fica o trilho né do trem e é um bairro que não desenvolve." (Entrevistada: A.B.).

"Eu nasci e me criei aqui no bairro, sobre a estrada de ferro madeira Mamoré?”. (Entrevistado: M.I.M.).

"O bairro aqui é mais parado do que num sei o que, aqui não vai nada avante, nada chega coisa pra cuidar do bairro cabar não faz nada olha o matão ai não vai avante é nada aqui.” (Entrevistada: E.S.S.).

Fonte: Dados da Pesquisa. 
Nas adjacências, também foi construído o cemitério municipal. A infraestrutura do bairro sempre foi precária, porém, as proximidades com o rio e a existência de terras férteis foram atrativas para os moradores em sua maioria provenientes de áreas rurais, ribeirinhas e de comunidades da fronteira Brasil-Bolívia. Atualmente, o bairro possui uma infraestrutura básica: água potável, energia elétrica, facilidade de acesso aos demais bairros, igrejas, campo de futebol, pequenos comércios, bares e outros.

$\mathrm{O}$ rio, para muitos moradores, é fonte de renda e alimentação, ponto de partida e de chegada para conexões que eram instigadas pelas necessidades socioeconômicas e culturais das pessoas e, ocasionou uma mistura de sensações, pela área próxima ao cemitério, espaço místico, visto por alguns como assustador e por outros como símbolo de tranquilidade.

A entrevista oral, no processo de rememoração, ressaltou como era conviver e vivenciar o período da construção da EFMM, o sentimento de pertença e, acima de tudo, o aspecto de descaso com que se trata os últimos resquícios de veracidade de um tempo que misturava sonho e realidade na idealização da construção da estrada, dos seus benefícios para constituição do bairro e para a cidade de Guajará-Mirim. Essas pessoas falam do fim do funcionamento da estrada como quem conta do fim de um sonho, saudosismo dos momentos e das pessoas que fizeram parte deste ciclo que marcou a memória individual e coletiva dos moradores do bairro Cristo Rei, conforme fragmentos de entrevistas apresentadas na Tabela 5. 


\section{Tabela 2 - Memórias afetivas dos entrevistados em relação à construção da EFMM}

\section{FRAGMENTOS DE REMEMORAÇÃO: TRABALHADORES \\ VERSOS E.F.M.M.}

" [...] eles trabalhavam com muita dificuldade no trem porque nunca deram muita atenção pra isso. $\mathrm{O}$ trem vivia descarrilhando, quebrando, até que ficou extinto e não tem mais nada e hoje não tem mais trilho, não protegeram essa estrada de ferro e hoje ficou só a saudade." (Entrevistada: A.N.S)

"Estava em construção, no tempo que a gente baixava do seringal, ainda o trem funcionava passava aí, aí depois quando eu vim morar já não funcionava, mas só era a cegonha que andava, aí depois foi parando arrancando os trilhos tudo e se acabou." (Entrevistada: A.B.)

"[...] Andei, andei de trem, eu ia daqui pra porto velho de trem, agente dormia no Abunã, do Abunã no outro dia que gente ia pra Porto Velho e de lá pra cá era a mesma coisa e depois que o trem coisou eu sempre ia pro bananeira, sempre ia pro bananeira eu ia de cegonha." (Entrevistada: E.S.S.)

"[..] eu tive um compadre que trabalhava na estrada de ferro, morreu trabalhando na estrada de ferro, [...] depois da segunda guerra foi que eles chegaram aqui em Rondônia, vieram como soldado da borracha achavam porque não tinham condição de voltar, mas, né ai ficaram tudo, construíram família e ficaram, e quem veio lá do nordeste não queria voltar mais, porque aqui ganhava dinheiro que dava bem de viver, antigamente era melhor do que hoje em dia porque tudo que você procurava aqui em Guajará-Mirim tinha [...].”(Entrevistado: M.I.M.)

"[...] meu pai [...] ele era maquinista, naquela época quando nós comecemos a trabalhar na estrada de ferro, principalmente eu, ele já era antigo na estrada de ferro [...] aí nós viemos pra cá já ajeitamos a locomotiva tudinho [...].” (Entrevistado: J.M.L.)

Fonte: Dados da pesquisa

A infraestrutura do bairro de características interioranas relembradas pelos sujeitos da pesquisa, inicia com a descrição de 
um lixão a céu aberto, sem ruas, apenas caminhos bem estreitos, e que em alguns momentos eles preferiam andar sob os trilhos do trem, por ser limpo de mata. No bairro não havia encanação para água potável, sendo assim, os moradores se adequavam com poço artesiano. Na época, só havia um poço natural, ao qual eles chamavam cacimba e a manutenção era feita pelos próprios moradores do bairro. Após muitos anos, o poder público começou a trabalhar para que as ruas fossem abertas e possibilitasse não apenas o acesso de bicicletas e carroças, mas também de carros. Aumentando o interesse pela localidade, tanto por ser um bairro localizado na parte central da cidade, quanto por ser um bairro mais acessível financeiramente, os moradores eram pessoas muito humildes que procuravam vilas, habitações que eram muito utilizadas na época, pela praticidade e pelo valor, pois a maioria, senão todas, era de madeira. A comunidade tinha em seu meio uma infinidade de dificuldades em infraestrutura.

Sobre este aspecto, abaixo, apresentamos fragmentos de entrevistas feitas com os moradores na Tabela 6.

\section{Tabela 3 - Infraestrutura do bairro Cristo Rei}

\section{HISTORICIDADE}

"Aqui só andava só de bicicleta, não passava carro, era só bicicleta, pois era só um caminhozinho. Morava muita gente, muitas famílias [...] até hoje existe marcas de que era um lixão [...] até hoje as residências são quase as mesmas só reformadas, mas os locais são os mesmos e não havia plantação" (Entrevistada: A.N.S).

"Bom quando eu vim morar mesmo aqui, aqui não tinha rua aqui só era um caminhozinho, aqui mesmo onde eu to era um lixão o lixão era aqui, ai o povo foram limpando foram fazendo casa ai o lixão acabou ai ficou só aquela ruazinha que andava só bicicleta ai depois que vieram e abriram a rua." (Entrevistada: A.B.). 
“[...] quando eu era mocinha ali era só um caminho que a gente ia lá pra casa da [...] era só essa rua aqui mesmo não tinha muita coisa aqui não.” (Entrevistada: E.S.S.).

"Aqui no tempo que nós era menino, aqui não tinha rua, e era contada as casa, nós andava por cima da linha, era um matagal só tinha uma entrada que caia aqui no lixão né, e a gente andava só por cima da linha porque tudo era limpo, não era cheio de mato na estrada de ferro." (Entrevistado: M.I.M.).

"Naquela época [...] quando nós chegamos aqui, aqui o bairro era pequeno, aqui não tinha essa rua aqui, era um matagal [...] a gente passava pela linha de ferro pra gente ir lá pro centro, [...] era uma lagoa, [...] a gente passava aqui no caminho, [...] ali a rua era a linha de ferro que a gente passava [...].”(Entrevistado: J.M.L.).

Fonte: Dados da pesquisa.

Os sujeitos da pesquisa, através das narrativas orais rememoram e descrevem o sentimento por morar às margens do rio, pela vivência que mantinham socialmente e culturalmente. Alguns deles advém de uma realidade rural e isoladas, em contato com rios e lagoas, viviam da agricultura, do extrativismo, da pesca para sua alimentação, da lavagem roupa, da quebra de pedras para venda, da retirada de planta medicinais e outros. Ao chegar no bairro Cristo Rei, reconhecia-o como um espaço natural, semelhante ao local de origem, outros acolhem o sentimento de pertencimento pela construção da EFMM às margens do rio, espaço de muitas dificuldades, mas onde viveram em plena felicidade. Eles se referem ao bairro como uma "grande família”, que em certos dias percorriam o caminho dos trilhos para alvoradas, festejos nas vizinhanças, quando não se reuniam para limpeza e beneficiamentos da área em que moravam. 
Na tabela 7, apresentamos alguns fragmentos de entrevistas que expressam alguns aspectos das identidades dos culturais dos moradores do bairro Cristo Rei:

\section{Tabela 4 - Fragmentos da relação dos moradores com o rio}

\section{MORADORES VERSUS RIO}

"A sensação de morar aqui [...] viver um pouco do que a gente vivia no lata também porque tinha acesso a rios, garapés e tinha acesso a estrada de ferro e aqui ficou um ponto certo porque podia pescar." (Entrevistada: A.N.S).

"Bom o rio também é muito poluído, [...] bem ali tem aquele esgoto e passa tudo pela praia, eu acho que essa água é contaminada." (Entrevistada: A.B.).

"Os menino tomavam banho tudo no rio, aprenderam a nadar no rio [...]." (Entrevistada: E.S.S.).

"Ao rio porque eu gosto de pescar né, eu quando não to fazendo nada eu acho melhor ta dentro do rio [...].”(Entrevistado: M.I.M).

Fonte: Dados da pesquisa

Na Tabela 8, logo abaixo, apresentamos fragmentos de entrevistas que comprovam a existência de mitos no bairro Cristo Rei: $\mathrm{O}$ bairro é cercado por uma cultura mística que envolve o rio, $\mathrm{o}$ cemitério, a mata e os trilhos da EFMM Os moradores recordam, com um sentimento de conflito, medo e entusiasmo, dos mitos construídos pelo imaginário popular ao longo dos anos, dentre eles, destaca-se a imagem de uma noiva, que aparecia no cemitério assustando aos que andam pelo bairro durante a noite. Na mata, o mito da Matinta Pereira, que muitos descrevem como pássaro que canta bem alto, e o sumiço ou morte de muitos ao longo das margens do rio e praia. Esses mitos mobilizam o sentimento e imaginário de quem mora no local. 


\section{Tabela 5 - O misticismo que envolve o bairro}

\section{CULTURA MISTICA}

"A história da noiva que aparecia em cima do muro do cemitério." (Entrevistada: A.N.S).

"[...] naquele tempo diziam que tinha mula sem cabeça, eu nunca vi, nem queria ver, que nem a Matinta Pereira, a Matinta Pereira era um pássaro [...] tinha gente que escutava aquele assobio e diziam que era a matinta pereira, e corria com medo [...].” (Entrevistado: M.I.M).

"[..] foi verdade [...] uma vez eu vinha [..] era de tardezinha [...] ai pra mim vinha uma mulher né, no trolho vestida de branco ai quando eu olhei pra trás não tinha mais a mulher no trolho [..].”(Entrevistado: J.M.L).

"Toda vida nessa praia o pessoal ia, sei que quase todo ano morria uma pessoa [...].” (Entrevistado: E.S.S.).

Fonte: Dados da pesquisa.

\section{CONSIDERAÇÕES FINAIS}

A realização da pesquisa apresentada, neste trabalho, proporcionou o conhecimento da realidade e das dificuldades enfrentadas pelos moradores do bairro Cristo Rei, que é situado em área ribeirinha urbana, no município de Guajará-Mirim, na fronteira Brasil-Bolívia.

Durante a pesquisa de campo, realizamos uma análise sobre as identidades sociolinguísticas e culturais que são marcas na fala dos moradores do bairro Cristo Rei e, então, tivemos a possibilidade de discutir e refletir sobre a importância da variação semânticolexical identificada na fala dos entrevistados, destacando fenômenos sociolinguísticos que constituem as identidades linguísticas dos moradores do bairro Cristo Rei. 
A partir da observação, das conversas informais e da realização de entrevistas, constatamos que os moradores mantêm os costumes e as tradições que trouxeram como "bagagem" dessa época falada com sentimento saudosista a respeito de toda história que acompanha a formação do referido bairro e que esses moradores mantêm um linguajar característico de pessoas advindas de áreas rurais-ribeirinhas e de pouca escolarização.

Por fim, enfatizamos que os dados coletados nesta pesquisa contribuirão para melhor compreensão do ecossistema linguístico e sociocultural do município de Guajará-Mirim(RO) e para a constituição de um banco de dados sobre os falares guajarámirenses.

\section{REFERÊNCIAS}

ABDALA JUNIOR, Benjamin. Fronteiras múltiplas, identidades plurais: um ensaio sobre mestiçagem e Hibridismo cultural. São Paulo: Senac, 2002.

\section{ASSOCIAÇÃO BRASILEIRA DE NORMAS TÉCNICAS. NBR} 15287: Informação e documentação - Projeto de Pesquisa Apresentação. Rio de Janeiro, 2011.

BAGNO, Marcos. Nada na língua é por acaso: por uma pedagogia da variação linguística. São Paulo: Parábola Editorial, 2007.

BORTONI-RICARDO, Stella Maris. Manual de sociolinguística. São Paulo: Contexto, 2014.

COELHO, Izete Lehmkuhl e outros. Para conhecer a sociolinguística. São Paulo: Contexto, 2015. 
EDGAR, Andrew; SEDGWINCK, Peter. Teoria cultural de A a Z. Trad. Marcelo Rolemberg. São Paulo: Ed. Contexto, 2003.

FERREIRA, Lucia M.A.; ORRICO, Evelyn G.D.. Linguagem, identidade, e memória social: novas fronteiras, novas articulações. Rio de Janeiro: DPEA, 2002.

FRAXE, Therezinha de Jesus Pinto. Cultura cabocla-ribeirinha: mitos, lendas e transcultural idade. São Paulo: Amablume, 2004.

HALBWACHS, Maurice. A memória coletiva. Trad. Beatriz Sidou. São Paulo: Vértice, 1990.

HALL, Stuart. Cultura e representação. Trad. Daniel Miranda e William Oliveira. Rio de Janeiro: Apicuri, 2016.

LARAIA, Roque de Barros. Cultura: um conceito antropológico. Rio de Janeiro: Jorge Zahar, 2011.

MOLLICA, Maria Cecilia; BRAGA, Maria Luiza. Introdução à sociolinguística: tratamento da variação. São Paulo: Contexto, 2012.

PORTELLI, Alessandro. História oral como arte da escuta. Trad. Ricardo Santiago. São Paulo: Letra e Voz, 2016. 
MEMÓRIA E DESAFIOS CONTEMPORÂNEOS DE POPULAÇÕES NEGRAS NA AMAZÔNIA SUL-OCIDENTAL BRASILEIRA

\author{
Joely Coelho Santiago ${ }^{65}$ \\ Rosália Aparecida da Silva ${ }^{66}$
}

\title{
INTRODUÇÃo
}

Há ainda lacunas a serem revisitadas nas histórias e culturas de populações negras ribeirinhas do Vale do Guaporé, região norte do estado de Rondônia e que está situada próxima da Bolívia e do Mato Grosso. Uma das possibilidades para conhecer mais sobre as comunidades e seus desafios contemporâneos é recorrer às memórias dos idosos.

Vó Rita dormia embolada com ela.

Vó Rita era boa, gostava muito dela e de todos nós.

Talvez ela só pudesse contar com o amor de Vó Rita, pois, de nossa parte, ela só contava com o nosso medo, com o nosso pavor.

Eu me lembro de que ela vivia entre o esconder e o aparecer atrás do portão. Era um portão velho de madeira, entre o barraco e o barranco, com algumas tábuas já soltas, e que abria para o beco escuro (Evaristo, 2017, p. 15).

65 Mestra em História e Estudos Culturais. Pesquisadora de comunidades ribeirinhas do Estado de Rondônia. E-mail: joelicoelhosantiago@live.com. ${ }^{66}$ Mestra em Letras pela Universidade Federal de Rondônia (UNIR). Integrante do Grupo de Estudos em Educação, Filosofia Tecnologias (GET/IFRO). E-mail: rosalia.silva@ifro.edu.br. 
O romance Becos da Memória inicia assim, remexendo memórias que Evaristo (2017) descreve como não sendo verdades, porém, por outro lado, não sendo mentiras. Escrito entre 1987/88, o texto foi publicado pela primeira vez somente 20 anos depois, apresentando ao público uma ficção de lembranças e esquecimentos da própria autora e de sua família, que ela resume enquanto "ficções de memória": "Entre o acontecimento e a narração do fato, há um espaço em profundidade, é ali que explode a invenção" (Evaristo, 2017, p. 11). Em outras palavras: "Ali busquei escrever a ficção como se estivesse escrevendo a realidade vivida, a verdade. Na base, no fundamento da narrativa de Becos está uma vivência, que foi minha e dos meus" (Evaristo, 2017, p. 11). Na trama narrativa de seu romance memorialista, sua escrita consegue reunir testemunhos e uma realidade social.

Saindo da literatura, passando para a análise da historiografia, e pensando na memória enquanto registro individual/coletivo que vai dar vazão às necessidades sociais, podemos ainda observar pelo viés da linguagem. Num mundo plurilíngue ${ }^{67}$, a história única sempre ficou oficialmente registrada e contada somente pelos "vencedores". O que vem paulatinamente recebendo novas inclusões de falas, de experiências e aprofundamento em estudos, abrindo possibilidades de percepções sobre o que era organizado como verdade incontestável de um fato. Dos agravantes que impediam essa multiplicidade científica estavam relações de poder, reflexo das sociedades em que se desenvolveram. Uma das vertentes dessa relação de disputa social pode ser encontrada nos estudos sociolinguísticos, quando tratam de preconceitos: “A história está repleta de provérbios ou de

67 "Haveria na superfície do globo entre 6.000 e 7.000 línguas diferentes e cerca de 200 países" (Calvet, 2013, p. 27). 
fórmulas pré-fabricadas que expressam preconceitos de cada época contra as línguas" (Calvet, 2013, p. 58).

E como a língua está inserida no contexto social, em meio a essa escala social de valores, também a história, sob a ótica eurocêntrica, foi analisada a partir de "grandes homens". Com isso, as trajetórias das populações negras e dos desprovidos de poder, da mesma maneira, permanecem desvalorizadas, marginalizadas e soterradas pela História e/ou historiografia. No poema "Perguntas de um trabalhador que lê", Bertolt Brecht ${ }^{68}$ faz o seguinte questionamento:

[...] O jovem Alexandre conquistou as Índias Sozinho?

César venceu os gauleses.

Nem sequer tinha um cozinheiro ao seu serviço?

Quando a sua armada se afundou Filipe de Espanha

Chorou. E ninguém mais?

Frederico II ganhou a guerra dos sete anos

Quem mais a ganhou?

Em cada página uma vitória.

Quem cozinhava os festins?

Em cada década um grande homem.

Quem pagava as despesas?

Tantas histórias

Quantas perguntas

${ }^{68} \mathrm{O}$ poema do poeta e dramaturgo alemão pode ser encontrado em diversos sites. Disponível em: <https://edisciplinas.usp.br/pluginfile.php/2201742/mod_ resource/content/1/POEMA\%20DE\%20BRECHT\%20\%28PERGUNTAS\%20 DE\%20UM\%20TRABALHADOR\%20QUE\%20L\%C3\%8A\%29.pdf>. Acesso em: 11 dez. 2020. 
Em solo nacional, um olhar único do fato pode ser encontrado quando se relembra a História do Brasil em relação ao propalado 13 de maio:

A libertação é registrada nesses livros como uma liberalidade e ato de bondade da princesa Isabel. A classe dominante se apropria até da história, que conta uma versão açucarada dos acontecimentos passados, ignorando as lutas do povo, elegendo heróis da elite e deixando de lado aqueles saídos do povo (Benedito, 2006, p. 15)

E as vozes que estavam silenciadas, vão começar a se fazer ecoar e serem ouvidas junto à sociedade. Durante a visita do Papa ${ }^{69}$ João Paulo II a Manaus, no Amazonas, em julho de 1980, o indígena Marçal de Souza, o Tupã-Y (Pequeno Deus), falou ao representante da igreja católica, no que ficou conhecida como "a voz do trovão": "Pouca gente imaginava que aquele franzino guarani, com um pouco mais de um metro e meio, banguela, pudesse, de improviso, sintetizar 500 anos de violência contra os povos indígenas” (Prezia, 2006, p. 15). Marçal foi assassinado três anos depois, em sua aldeia no Mato Grosso do Sul, e os acusados, anos depois, foram absolvidos.

Sobre o etnocídio a que os povos indígenas são historicamente subjugados, Munduruku (2016) dirá que é preciso conhecer o outro para poder respeitá-lo. “O Brasil - em sua história passada - cometeu muitos atos bárbaros contra esses povos, desvalorizando a beleza de sua ancestralidade” (Munduruku, 2016, p. 8), o que conforme o autor foi uma forma inventada para se

\footnotetext{
${ }^{69}$ Matéria "Visita de João Paulo II a Manaus completa 40 anos". Disponível em: $<$ www.acritica.com/channels/manaus/news/40-anos-da-visita-do-papa-joaopaulo-ii-a-manaus $>$. Acesso em: $11 \mathrm{dez} .2020$.
} 
apossar de riquezas, escravizar povos e destruir suas culturas e crenças.

E a partir desse contar a história sob outros pontos de vista e de outras visões tem revelado um novo mundo, com novas possibilidades, não mais dadas como única a ser acreditada. "A ideia de que os brancos podiam sair colonizando o resto do mundo estava sustentada na premissa de que havia uma humanidade esclarecida que precisava ir ao encontro da humanidade obscurecida" (Krenak, 2019, p. 11). E essas novas vozes que emergem, portanto, conseguem fazer uma crítica à "verdade" até então escrita, oficialmente, como a única possível. Similarmente, há um risco que permeia essa disputa: "Se as pessoas não tiverem vínculos profundos, com sua memória ancestral, com as referências que dão sustentação a uma identidade, vão ficar loucas neste mundo que compartilhamos" (Krenak, 2019, p. 14).

Para reverter essa constante, nesse caso, tratando-se das memórias e histórias das pessoas remanescentes de quilombos, sobretudo as narrativas das pessoas mais idosas, surge o coletar memórias como um recurso para a validação de preciosos dados históricos, até então desconhecidos e/ou pouco registrados. Este artigo busca observar mais atentamente memórias de povos situados em Rondônia: as populações negras do Vale do Guaporé.

\section{JUSTIFICATIVA}

É levado em consideração que as publicações humanas acerca das populações negras, excluídas e discriminadas, por exemplo, surgem como "uma via de compromisso com aqueles que não têm história oficializada” em que oportuniza e dá voz para a inclusão e o reconhecimento de grupos populacionais, antes silenciados e apagados (Meihy, 1996). Ao documentar as 
experiências desses grupos silenciados, a partir não mais de técnicas e teorias unicamente europeizantes, mas das histórias oral e pública, por exemplo, passa a ser capaz de fazer aflorar uma dimensão social mais ampla, como mostra Meihy (1991, p. 15): “A história oral, como tributária da história pública, se remete ao leitor comum, vigorando o princípio que privilegia o social como alvo do conhecimento".

Posto isso, o "emergir contemporâneo" de pessoas negras de comunidades remanescentes de quilombos do estado de Rondônia é visto sob outras óticas, a partir do trabalho de reconhecimento, demarcação e titulação das comunidades remanescentes de quilombos. Numa disputa social, que vem ocorrendo de maneira até discriminatória, reverberada inclusive por falas públicas do maior representante político ${ }^{70}$. Assim, o novo modo de pesquisar abre a questão de quem e quais são esses sujeitos de direitos, no sentido de tirar do lugar, de desestabilizar, de fazer emergir sujeitos não previstos no enredo ou projeto (Leite, 1998).

Se aos grupos negros e indígenas resultou o apagamento de suas memórias, como dito anteriormente, não obstante, as populações negras veem suas lutas longe de chegarem ao fim, visto que os ataques e o não reconhecimento, a partir de defensores de teorias conspiratórias adversas aos interesses dos remanescentes, são apoiados, amplamente, pelo atual Governo ${ }^{71}$. Em contrapartida,

${ }^{70}$ Krenak (2019, p. 31) comenta a força política eleita em 2018 dizendo que os povos indígenas há mais de 500 anos já estão fazendo a resistência a partir da expansão de sua subjetividade: "Ainda existem aproximadamente 250 etnias que querem ser diferentes uma das outras no Brasil, que falam mais de 150 línguas e dialetos”.

71 Parte de discurso proferido do então Presidente da República Jair Bolsonaro, em entrevista com Marcelo Godoi realizada em 2 de abril de 2017: 
a antropóloga Leite (2010) ainda afirma sobre o direito "quilombola" que a Constituição visa alcançar é o direito sobre o lugar, o direito não exclusivamente à terra ou às condições de produção, mas ao seu reconhecimento na ordem jurídica.

O silenciamento refletido nas pesquisas acadêmicas, de alguma maneira, serve para perpetuar a inferioridade, o racismo e a discriminação em que são postas, assim como, o comprometimento histórico da região, de maneira que seja imprescindível desmistificar a visão negativa e homogênea em que muitas pessoas têm a respeito das populações remanescentes de quilombos, uma vez que as populações negras, longe de terem sido apenas operários de enxada, a serviço da agricultura, desempenharam uma função civilizadora (Freyre, 2006).

Nacionalmente, vem ocorrendo pesquisas que fazem a trajetória histórica ganhar novos contornos. No livro Rebelião Escrava no Brasil, Reis (2019) analisa minúcias do Levante dos Malês no ano de 1835, na Bahia, a partir, especialmente, do que ficou registrado nos boletins de interrogatório policial e ajudam a demonstrar como era a sociedade baiana da época.

Movimentos como a Confederação do Equador e a Guerra dos Farrapos no Rio Grande do Sul - para citar poucos -, todos expressam a inquietação de classes e grupos sociais para os quais a Independência não parecia oferecer chances de uma vida melhor (Reis, 2019, p. 45)

\footnotetext{
“[...] pode ter certeza que se eu chegar lá (Presidência da República) não vai ter dinheiro pra ONG. Se depender de mim, todo cidadão vai ter uma arma de fogo dentro de casa. Não vai ter um centímetro demarcado para reserva indígena ou para quilombola." Disponível em: <http://infograficos.estadao.com.br/politica/ bolsonaro-um-fantasma-ronda-o-planalto/entrevista>. Acesso em: 2 dez. 2020.
} 
Na mesma linha de raciocínio de contribuição social, outros estudos vêm analisando e trazendo à tona pontos de vista diferentes da ótica eurocêntrica. Como as explorações em torno da historicidade das bases religiosas diversas no país no âmbito acadêmico e do fomento à pesquisa. $\mathrm{O}$ recorte de pesquisa de Parés (2011, p. 15) é sobre os povos jeje e o Candomblé na Bahia, dentro de um processo histórico e dinâmico, no qual busca: "Um dos problemas centrais desse trabalho é compreender a gênese e a manutenção de identidades étnicas dos africanos no Brasil”. Dialogando com essas inserções científicas regionais, abre-se caminho para conhecer melhor o lugar onde habitamos e dar os devidos créditos aos que constroem as histórias da região.

Nascimento (2011) corrobora acerca das diversas atividades que os escravizados realizaram, na época do Brasil Colônia, época em que inúmeros incertos de africanos foram trazidos à força, no processo de diáspora, amontoados em navios negreiros sem nenhuma ou pouca ventilação. Já nos engenhos de açúcar, no meio do caminho entre a casa grande e a senzala, os grupos escravizados prestaram serviços importantes à classe dominante, que se abasteceu com os lucros financeiros. Enquanto nação que foi a primeira a iniciar e a última a finalizar o escravismo, o Brasil e seus "senhores" lucraram muito, segundo Fiabani (2005, p. 21): “A economia escravista nacional produziu a mais rica gama de mercadorias coloniais de mão-de-obra servil: açúcar, arroz, café, charque, fumo, pau-brasil, ouro etc." Sendo seu trabalho usado nos centros urbanos e rurais e em praticamente toda a extensão do território brasileiro.

Durante a travessia nos navios negreiros, era comum um curto laço de amizade se firmar durante a travessia, entre os grupos, ao mesmo tempo em que milhares deles eram mortos ou morriam com fome, sede ou por terem sido contaminados com doenças e 
com os corpos dos mortos que apodreciam ao lado. Nos variados portos negreiros, em solo brasileiro, os africanos eram separados e colocados em filas para serem apreciados e comercializados pelos senhores de engenho. Aqueles escravizados que chegavam doentes ou muito magros, por exemplo, ficavam isolados e trancafiados numa espécie de galpão, onde recebiam água e pão, uma vez ao dia, até restabelecer sua saúde, para em seguida, serem postos à mostra nas praças de compra e venda de escravizados. E, mais uma vez, o escravizado seguia rumo incerto, acorrentados por mãos e pés para evitar e/ou dificultar a fuga.

Singularmente, visto que, aos grupos escravizados eram desenraizados e desbaratados de diversas partes do continente africano, e pouco permaneceu de seus reais nomes e/ou sobrenomes nativos, uma vez que em solo brasileiro eram proibidos de falar a língua materna. $\mathrm{E}$, além disso, o batismo religioso dava ao recém-chegado nomes e sobrenomes nacionalizados, e com isso, toda uma bagagem familiar era soterrada, guardada apenas em memória $^{72}$.

Para resistir, uma das formas de enfrentamento era a fuga, disso surgiam comunidades nas cidades e em áreas rurais, em localidades próximas ou de difícil acesso, existindo em praticamente todo território nacional. "No Brasil, essas comunidades de ex-cativos foram designadas de quilombos, mocambos e outras denominações [...]" (Fiabani, 2005, p. 23). Nessas organizações coletivas todos tentavam formas para sobrevivência e para manutenção da liberdade: “[...] os

\footnotetext{
${ }^{72}$ Projeto genocida que, em seu estudo sobre a historiografia, a cultura e a imigração de grupos provenientes das Antilhas, a historiadora Cledenice Blackman (2019) vai nomear como uma nova tentativa identitária imposta a essas populações, que se naturalizou com o passar do tempo.
} 
quilombolas praticaram a agricultura, extraíram metais preciosos, furtaram, coletaram, negociaram com a sociedade escravista [...]", o que levou a essa sociedade escravista gastar muito para destruir as comunidades quilombolas e muitos são os registros de lutas, como o do Quilombo dos Palmares, na região de Pernambuco, e que inclusive é relembrado na pessoa de um de seus líderes, Zumbi dos Palmares. Com data ${ }^{73}$ histórica relembrada no Brasil, faz-se referência ao Dia Nacional de Zumbi e da Consciência Negra ${ }^{74}$.

Para tanto, também é preciso pensar as regionalidades, as diferenças encontradas em cada espaço. Assim nasce a intenção deste artigo em se observar a realidade na Amazônia Sul-Ocidental Brasileira. Desse modo, acredita-se que proceder registros que enalteçam vozes marginalizadas por estruturas sociais e de poder, historicamente, contribuem para a compreensão da múltipla diversidade cultural das populações negras dos estados de Rondônia e de Mato Grosso.

\section{FUNDAMENTAÇÃO TEÓRICA E METODOLÓGICA}

Os grupos negros desbaratados, escravizados na Amazônia Sul-Ocidental Brasileira, tiveram mão de obra e corpos usados e explorados, largamente, nas lavras e edificações do Vale do Guaporé e afluentes, sob vigilância rigorosa e castigos físicos da elite colonizadora, resistiam das mais diversas formas ao regime escravocrata sendo "comum a fuga de escravos e o seu ajuntamento

73 Dia Nacional da Consciência Negra - 20 de novembro. Disponível em: $<$ https://almapreta.com/editorias/realidade/por-que-20-de-novembro-e-odia-da-consciencia-negra $>$. Acesso em: 11 dez. 2020.

${ }^{74}$ Lei n. 12.519, de 10 de novembro de 2011, que institui o Dia Nacional de Zumbi e da Consciência Negra. Disponível em: <www.planalto.gov.br/ccivil_03/ _ato2011-2014/2011/lei/112519.htm>. Acesso em: 11 dez. 2020. 
em quilombos, alguns dos que resistiram por longos períodos, como é o caso do Quariterê, que se manteve ativo por mais de meio século." (Teixeira; Lima, 2016, p. 24). Esses espaços eram, tal qual em outras localidades brasileiras, espaços de resistência à sociedade repressora, abrigando uma busca pela liberdade e sobrevivência, como também explica Fiabani (2005, p. 24): "O quilombo foi uma clara expressão de luta de classes na produção colonial”.

É importante mencionar que, neste nosso estudo, os colaboradores não são retratados como objetos de pesquisa e sim como atores e produtores centrais que refizeram e fazem suas contribuições na sociedade amazônica brasileira. Dessa forma, este estudo em tela contou com a participação de seis pessoas remanescentes de quilombolas, sendo dois dos colaboradores homens e quatro colaboradoras mulheres. Todos nascidos e criados no Vale do Guaporé, idosos, com faixa etária superior a 82 anos, assim sendo, são detentores de uma memória ímpar do contexto guaporense $^{75}$. O corpus relativo à contribuição das populações negras no Vale do Guaporé provém, também, da observação participante da pesquisadora que possui suas origens ligadas aos negros de Vila Bela-MT e Comunidade Remanescente de Quilombos de Pedras Negras-RO.

A pesquisa, bibliográfica e de campo, do tipo qualitativa, foi desenvolvida no período de setembro a dezembro de 2020. Assim sendo, o estudo foi norteado pelos seguintes questionamentos problematizadores: Quais as lutas e os desafios contemporâneos delineados pelas populações negras do Vale do Guaporé, a partir do

\footnotetext{
${ }^{75}$ Para a obtenção das narrativas orais, fora apresentado aos entrevistados o Termo de Consentimento Livre e Esclarecido (TCLE), cujo fora explicado pela pesquisadora e em seguida assinado em duas vias pelos colaboradores.
} 
"emergir" de seus remanescentes? De que maneira é possível garantir o reconhecimento e a validação de suas histórias, culturas e memórias herdados da cultura negra e ribeirinha?

\section{MEMÓRIA INDIVIDUAL E COLETIVA: ALGUMAS CONSIDERAÇÕES}

Consideramos necessário compreender o caráter social da memória enquanto um fenômeno social que traz em si a forma particular de inserção do indivíduo nos diversos espaços em que dele participou. Nessa perspectiva, foi possível a reconstrução, ainda que parcial, do percurso histórico-cultural trilhado pelas famílias negras do Vale do Guaporé no processo de reorganização de suas comunidades, após a escassez de pedras preciosas e o abandono da região, através de narrativas orais de indivíduos que participaram do espaço deste grupo, considerando estas narrativas enquanto uma expressão da memória construída coletivamente, como analisa Halbwachs (1990):

[...] nossas lembranças permanecem coletivas, e elas nos são lembradas pelos outros, mesmo que se trate de acontecimentos nos quais só nós estivemos envolvidos e com objetos que só nós vimos. É porque, em realidade, nunca estamos sós. Não é necessário que outros homens estejam lá, que se distingam materialmente de nós: porque temos sempre conosco e em nós uma quantidade de pessoas que não se confundem (Halbwachs, 1990, p. 162).

Com isso se vai tecendo a história a ser registrada por meio dessa memória coletiva. Hampaté Bâ (1982) corrobora ao analisar a prática da transmissão de conhecimentos nas tradições africanas em que a memória é mais desenvolvida por meio da tradição oral. Segundo o autor:

[...] nenhuma tentativa de penetrar a história e o espírito dos povos africanos terá validade a menos que se 
apoie nessa herança de conhecimentos de toda espécie, pacientemente transmitidos de boca a ouvido, de mestre a discípulo, ao longo dos séculos (Bâ, 1982, p. 167).

Neste sentido, compartilhamos da análise de Thompson (1992) no que diz respeito sobre a significância da memória coletiva e individual:

[...] a construção e a narração da memória do passado, tanto coletiva quanto individual, constituem um processo social ativo que exige ao mesmo tempo engenho e arte, aprendizado com os outros e vigor imaginativo. Nisto, as narrativas são utilizadas, acima de tudo, para caracterizar as comunidades e os indivíduos e para transmitir suas atividades (Thompson, 1992, p. 185).

As lembranças preservadas nas narrativas orais fazem parte da memória que se constitui pelo armazenamento de parte das práticas vivenciadas pelos indivíduos e grupos sociais, sendo um exercício de reconstrução e de ressignificação de eventos passados, por meio do qual os fatos lembrados são aqueles que marcaram a vida das pessoas e de sua coletividade (Fonseca, 2000). Nessa direção, Paul Gilroy (2017) analisa:

No período posterior à escravidão, a memória da experiência escrava é evocada em si mesma e utilizada como instrumento adicional, suplementar, com o qual construir uma interpretação distinta da modernidade. Que essas memórias invoquem ou não a lembrança de um terror que ultrapassa a apreensão do discurso ideal, gramatical, elas apontam no presente para uma transformação utópica da subordinação racial. (Gilroy, 2017, p. 154).

Em Bosi (1994) chama-nos a atenção essa possibilidade de estabelecer-se essa relação contínua do passado com o futuro, a partir da mediação que no presente é feita pela memória de 
indivíduos de idade avançada por meio da linguagem, prática bastante usada pelas populações tradicionais. Segundo a autora:

[...] há um momento em que o homem maduro deixa de ser um membro ativo da sociedade, deixa de ser um propulsor da vida presente do seu grupo: neste momento de velhice social resta-lhe, no entanto, uma função própria: a de lembrar. A de ser a memória da família, do grupo, da instituição, da sociedade (Bosi, 1994, p. 63).

Da mesma maneira, pode-se analisar os rumos que a tradição oral vem alcançando ao não escutar atentamente aos idosos: "[...] a sociedade capitalista desarma o velho mobilizando mecanismos pelos quais oprime a velhice, destrói os apoios da memória e substitui a lembrança pela história oficial celebrativa" (Chauí, 1994, p. 18). Corroborando com análise sobre esse apagar a memória dos idosos em benefício de uma memória oficial e esvaziada, Montenegro (2010) ressalta o quão limitado tem ficado a prática da tradição oral na transmissão de conhecimentos aos mais jovens, que na condição de passivos, ouvintes, em outros tempos, escutaria respeitosamente as palavras dos mais velhos, pois esses eram vistos como exemplos de vida a serem seguidos devido à experiência.

O autor analisa que os mais jovens, em dias atuais, distraemse com atividades diversas, sobretudo as tecnológicas. Em contraponto, esses limites apontados por Montenegro (2010) são insuficientes para impedir a potência e a riqueza de memória e as possibilidades de pesquisa com este recurso teórico-metodológico fundamental para reconstruirmos a história e as práticas socioculturais das populações negras do Vale do Guaporé, em Rondônia, no emergir ou significância contemporânea. 
POPUlAC̣ÕES NO VALE DO GUAPORÉ: BREVE REGISTRO HISTÓRICO E GEOGRÁFICO

De acordo com Meireles (1989), o Vale do Guaporé tem sua nascente "nos contrafortes da Serra dos Parecis, em Mato Grosso" (Meireles, 1989, p. 15). Em 1743 teve início a ocupação colonial no Rio Guaporé por jesuítas espanhóis e portugueses, que iniciaram a catequização aos povos nativos da região (Teixeira; Fonseca, 2001). Como em todas as áreas do Brasil, de modo particular no Vale do Guaporé e afluentes, os escravizados foram trazidos a força, no processo de diáspora negra, por bandeiras portuguesas para realizar trabalhos diversos na época do Brasil Colonial. Sobre esse aspecto, Bandeira (1988) analisa que:

[...] os pretos, na sua força de resistir, inscrevem no discurso branco o antidiscurso de sua invalidez, da sua fome prematura, empunhando bateias, lavando cascalhos, construindo a cidade, plantando e colhendo, moendo, fazendo melado, rapadura, açúcar e cachaça, farinhando, remando, fugindo, lutando, rezando e festejando (Bandeira, 1988, p. 79).

Submetidos ao trabalho escravo, torturas e castigos físicos de toda a sorte, os grupos escravizados tentavam fugas para locais de difícil acesso no interior da mata amazônica, e assim resistiam das mais diversas formas à escravidão. "A busca de esconderijo no mato, junto de outros companheiros, foi sempre a alternativa ousada na esperança de não serem capturados. Esses aglomerados de escravos vivendo nas matas eram os chamados "quilombos" (Volpato, 1993, p. 182).

Durante a segunda metade do século XVIII, eram comuns as fugas de escravos para os quilombos na tentativa de viverem em liberdade. Dos quilombos formados na região, o mais expressivo foi 
o "Quilombo do Quariterê, ou do Quariteté ou do Piolho, considerada a mais importante formação de quilombo em Mato Grosso pela consistência de sua organização" (Bandeira, 1988, p. 118).

O quilombo do Quariterê, ou Piolho, formou-se às margens do rio do mesmo nome - afluente da margem ocidental do Guaporé - a partir de escravizados negros e indígenas fugidos das minas auríferas do Mato Grosso, sendo invadido pela poderosa bandeira do Capitão-general João Costa Pinto, em 1770. Após a morte do líder do Quariterê, José Piolho, a Rainha Teresa, viúva, passou a administrar o local utilizando uma forma de governo específica, como enforcamento, castigos físicos, fraturas de ossos e o enterramento vivo aqueles que "desertassem" do quilombo (Bandeira, 1988).

Na organização do Quariterê, a Rainha Teresa era auxiliada por outras mulheres negras e mulheres indígenas. Na primeira destruição, em 1770, foram aprisionados mais de cem escravizados (79 negros, entre homens e mulheres, e 30 índios, entre homens e mulheres) levados acorrentados para Vila Bela. "Muitos morreram e muitos conseguiram evadir-se. [...]. Capturados, os quilombolas sofreram castigos cruéis em praça pública, expostos à curiosidade do povo, e foram marcados a ferro" (Bandeira, 1988, p. 119).

A invasão no Quariterê, em 1770, também, foi marcada pela captura e o suicídio da Rainha Teresa que, descontente com a destruição de seu quilombo e ter de render-se à dominação dos brancos, prefere tirar sua própria vida. Gesto de coragem e ousadia que fez de Teresa de Benguela tornar-se símbolo de luta e resistência para as mulheres afro-brasileiras.

Segundo Gomes (2015) a constituição dos quilombos era feita pelos homens, contudo a reorganização dos territórios ficava a 
cargo das mulheres. $\mathrm{O}$ autor chama-nos a atenção para as escassas notícias que se tem sobre as mulheres na reconstituição dos mocambos, visto que o papel das mulheres diante de ataques, armadilhas e arapucas foi de extrema relevância, pois segundo esse autor:

[...] cabia a elas esconder o máximo de grãos na cabeça - entre seus penteados - e escapar para as matas, o mais longe possível. A economia de um quilombo atacado era reconstituída exatamente a partir desses grãos. Outras indicações sugerem sua função religiosa de proteção dos quilombos ao entrarem em transe para adivinhar o momento e local dos ataques punitivos. Nos quilombos maiores, [...] as mulheres podiam estar representadas demograficamente. Seu papel na manutenção da família foi acompanhado da importância econômica na produção artesanal de utensílios e mesmo do enfrentamento diante das tropas escravistas (Gomes, 2015, p. 40).

Ao findar do século XVIII, o Vale do Guaporé vivencia um profundo estado de decadência e abandono dos colonizadores. Diante dessa inviabilidade econômica da região, a elite branca decide mudar para áreas mais prósperas nas cercanias de Cuiabá, deixando para trás seus escravizados à mercê da própria sorte. Reinventando-os a si mesmos e compartilhando saberes e práticas culturais com os outros grupos da região fronteiriça, os negros escravizados tornaram-se senhores do Vale do Guaporé, estabelecendo-se na região como agricultores e extrativistas.

No Vale do Guaporé, como podemos ver no mapa (Figura 1), localizam-se, em dias atuais, nove comunidades remanescentes de quilombos, são elas: Comunidade Forte Príncipe da Beira, Comunidade Laranjeiras, Comunidade Pedras Negras, Comunidade Rolim de Moura, Comunidade Santa Cruz, Comunidade Santa Fé, Comunidade Santo Antônio e Comunidade Tarumã. Destas, apenas 
a Comunidade Jesus localiza-se num afluente do Rio Guaporé, o Rio Miguel.

Segundo Gomes (2015), em outros anos, as comunidades remanescentes do estado de Rondônia somaram maiores números, contudo esses povoados vêm progressivamente vivenciando o despovoamento de seus moradores. A evasão dos remanescentes ocorre devido a diversos fatores, dentre eles a escassez de políticas públicas e a irregularidade da demarcação e titulação de terras ocupadas pelos remanescentes. Não obstante, somado a esses entraves, há a disputa pelas terras com fazendeiros, agropecuaristas e projetos de desenvolvimento, situações conflituosas que impedem que sejam feitos os trabalhos de demarcação e titulação das terras remanescentes de quilombos.

Abaixo, o mapa geográfico das populações negras do estado de Rondônia:

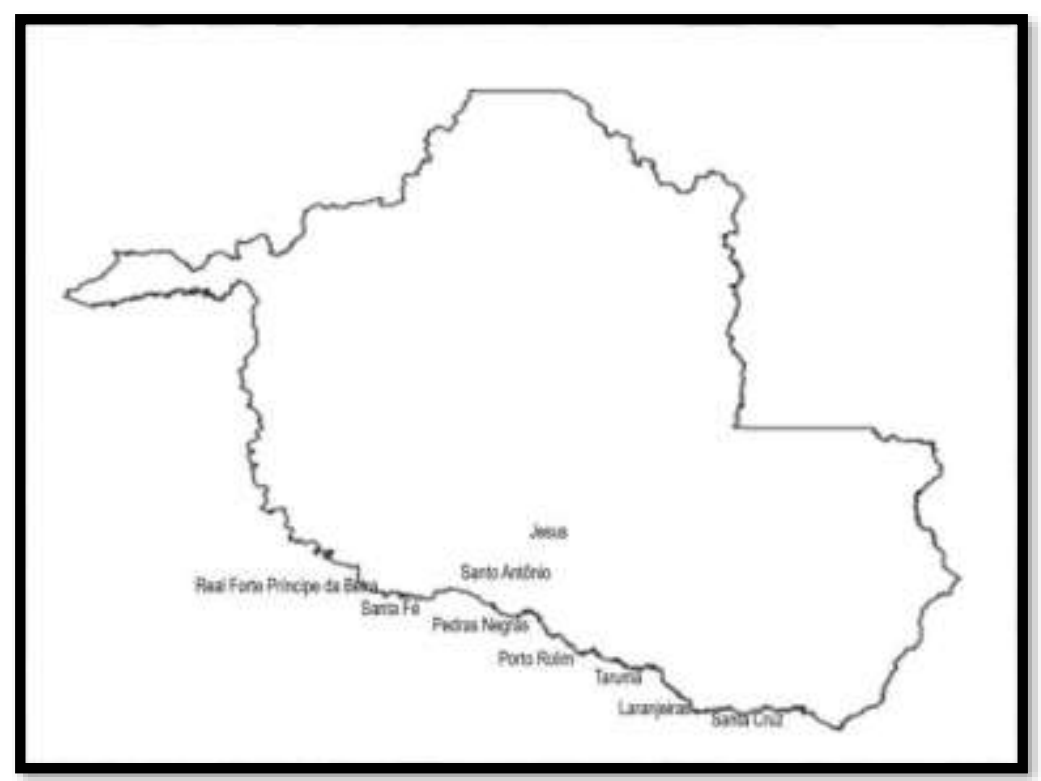

Figura 1: Fonte: Divisão Municipal e Hidrografia - Brasil (Adaptado), 2020 
Os remanescentes de populações negras no Vale do Guaporé lutam pela legalidade de suas terras ancestrais, resistentes aos variados discursos discriminatórios e racistas por defensores providos de total desconhecimento e falta de respeito às memórias e histórias desses grupos populacionais, que, por muito tempo foram excluídos da história e dos principais estudos acadêmicos, ainda, considerados pela religião dominante como seres incompletos e sem alma. De fato, precisa-se ressaltar a diversidade da fauna e da flora na região (registro fotográfico - Figura 2) que desde muito tempo atraiu o interesse de grupos que projetam a expansão do agronegócio, o que dificulta ainda mais o processo lento na bancada jurídica.

No que diz respeito à educação escolar na região guaporense, vale ressaltar que foi ofertada a partir do projeto socialista e catequético de Dom Francisco Xavier Rey, fim do século XIX até meados do século XX (Assunção, 2012). Dom Rey propiciou oportunidade a 31 meninas negras a educação primária no internato católico do município de Guajará-Mirim(RO) para exercer o serviço de Magistério e atividades diversas, como juízas de paz, conciliadores e enfermeiras.

“As filhas de Dom Rey", como ficaram conhecidas, adquiriram status de prestígio e poder no interior de suas comunidades remanescentes, destinadas antes desse projeto aos serviços considerados domésticos e aos trabalhos na mata amazônica, tidas como meras "auxiliares" dos homens, oportunizando-as o direito a voz, visto que em cada comunidade havia uma mulher no cargo de liderança, cargo este ocupado apenas pela figura masculina. E que assim como os religiosos, elas (professoras) eram respeitadas como autoridade nos povoados. Nesse contexto, entretanto, pouco mudou a realidade da educação 
escolar. Espaços precários, poucos ou nenhum material de recurso pedagógico acompanham os estudantes guaporenses.

Assim sendo, a partir da reconstituição da memória coletiva e individual, os colaboradores deste estudo demostraram em suas narrativas a importância da preservação de tradições herdadas dos seus antepassados, em que novos olhares e aprendizados são compartilhados com outros contingentes populacionais da região fronteiriça. Na culinária, por exemplo, isso se manifesta de forma peculiar, sendo comum encontrar na alimentação dos remanescentes migrantes no município de Guajará-Mirim(RO), por exemplo, comidas e bebidas típicas da cultura negra e ribeirinha, que apesar do diverso contato com práticas culturais diferentes das suas, ainda preservam traços ancestrais que nesse contexto, se tornam significantes para a manutenção e preservação da cultura afro-guaporense $\mathrm{e}^{76}$.

Enfatiza-se que as populações negras, sobretudo as mulheres, repassam de geração a geração, suas culturas, saberes e práticas na educação familiar, visto que, a educação das crianças ainda é vista como atividade destinada às mães e a um trabalho dito feminino, embora elas se dediquem a outras atividades ligadas ao universo masculino. Todos, homens e mulheres, contribuem de forma relevante no processo de formação e resistência das populações remanescentes de quilombos. Da mesma forma que colaboram na constituição identitária, histórica e cultural do município de Guajará-Mirim(RO), cujo desenvolvimento regional

\footnotetext{
${ }^{76}$ Dentre as comidas e bebidas típicas dos guaporesenses, destaca-se a paçoca e o massaco (feitos no pilão), o aluá e a chicha (feitos com milho), o biscoito de goma da mandioca e o bolo de arroz (feitos com arroz).
} 
é constituído por pessoas de várias nacionalidades, dentre elas, afroguaporenses, libaneses, japoneses, gregos e barbadianos.

Entretanto, no que diz respeito à estrutura da comunidade, ressalta-se que a situação de abandono e descaso em que resistem as comunidades remanescentes de quilombos em Rondônia é vasta. A exemplo disso, há comunidades como Santo Antônio do Guaporé, em que ainda não há energia elétrica, e para evitar a escuridão no período da noite os moradores custeiam com recursos do próprio bolso um motor de energia à base de combustível, cujo funcionamento ocorre das $18 \mathrm{~h}$ às $22 \mathrm{~h}$. Faltam maiores incentivos $\mathrm{e}$ projetos sociais que abarquem de forma mais humana o viver desses remanescentes que optam por continuar em suas comunidades ancestrais; faltam melhores oportunidades para os jovens, tanto no que diz respeito à parte educacional quanto na parte de trabalho $\mathrm{e}$ renda. E esta tem sido a justificativa para a evasão e o abandono de suas comunidades. Assim, a evasão de seus locais de origem na busca por essas e outras perspectivas melhores de vida, torna a migração uma alternativa de fuga às localidades mais prósperas e salubres, levando consigo suas culturas e aprendizados para as novas rotas.

Não obstante, também é importante mencionar que, assim como a população afro-guaporense, as populações indígenas da região do Vale do Guaporé, também são vítimas de discursos classicistas e preconceituosos de interesses adversos aos seus. Na área vivem vários povos, dentre eles, Jabuti, Macurap e Oro Wari ${ }^{77}$. Como lembra Krenak (2019, p. 23): "Todos nós sabemos que a cada ano ou a cada semestre uma dessas línguas maternas, um desses

77 FUNAI. Terras indígenas em Rondônia. Disponível em: $<$ http://ccr6.pgr.mpf.gov.br/documentos-e-publicacoes/terrasindigenas/terras-indigenas>. Acesso em: $6 \mathrm{dez} .2020$. 
idiomas originais de pequenos grupos que estão na periferia da humanidade, é deletada”. Havendo riscos eminentes para domínio dos territórios. Tratando sobre a concentração de terras, em estudo no estado de Rondônia, especificamente em projetos de assentamento de colonização rural (Projetos Jamari e Cujubim), Amaral (2007, p. 99) registra que "Os novos latifundiários são os mesmos espertos de sempre: políticos, advogados, industriais, funcionários públicos federais ou não, donos de madeireira etc." Dando mostras de quanto poder está na esteira dessa disputa por territórios para as várias comunidades e segmentos populacionais.

Visto que, também, na Amazônia Ocidental os povos indígenas tentam manter suas áreas da mesma forma que lutam pela legalização de suas terras junto a parceiros governamentais, somado aos trabalhos de antropólogos e historiadores, demandam olhar que os compreenda dentro de sua pluralidade cultural e de suas necessidades de vida plena.

\section{CONSIDERAÇõES FINAIS}

Este estudo objetivou investigar e registrar o emergir de vozes de remanescentes de quilombos do Vale do Guaporé, que por muito tempo foram postos à invisibilidade, e marginalizados pelo Estado e silenciados pela História, assim como suas conquistas, lutas e desafios no cenário político atual.

A análise oportunizou-nos ouvir narrativas e comparar registros bibliográficos a fim de analisar e registar parte de histórias das populações negras na Amazônia Sul-Ocidental Brasileira, numa região de fronteira entre o Brasil e a Bolívia. Há no cenário atual a luta de melhores projetos de leis e políticas públicas eficazes para suprir as estruturas essenciais à moradia e à vida digna, assim como, há luta para a legalização da posse coletiva de suas terras ancestrais. 
No caso da legalidade das terras remanescentes de quilombos, é importante ressaltar que os processos movimentam-se de maneira lenta no setor judiciário, enquanto os remanescentes assistem de "mãos atadas" a invasão e a ocupação de suas terras por fazendeiros, agropecuários e megaprojetos de desenvolvimento, vendo suas terras como campos lucrativos para promover o agronegócio, atitude essa que impacta de modo considerável a vida dessas populações tradicionais, defensoras da natureza.

Por conseguinte, este estudo não pretende esvaziar a luta social e política no atual cenário vivenciado pelas populações negras do Vale do Guaporé. Muito pelo contrário, é preciso dar voz a estes grupos silenciados e marginalizados. É preciso oportunizar melhor as crianças e os jovens que lá residem, para que possam competir de maneira igualitária com os estudantes urbanos, uma vez que os estudantes negros ainda estão em bastante diferença com os contingentes populacionais de classe média branca.

Não obstante, embora não seja este o lócus do estudo, contudo, é importante mencionar a dura realidade que os grupos indígenas vivenciam, que assim como os negros ainda estão postos à marginalidade, enfrentando racismo, discriminação e interesses adversos diante da expansão do agronegócio. Colocar essas vozes e memórias para o registro em pesquisas e estudos das universidades e do mundo acadêmico é uma lacuna ainda a ser mais explorada.

Por fim, esta pesquisa desafia-nos a mais estudos acerca dessa temática nos diferentes campos das Ciências Humanas, enquanto pesquisadores e pesquisadoras. De maneira que possamos problematizar a condição dos grupos desbaratados no tráfico negreiro, na época do Brasil Colônia, hoje emergentes no atual cenário político devido a extrema necessidade de garantia de 
demarcação de seus territórios, ativos e resistentes em suas comunidades afro-brasileiras.

Faz-se urgente fazer ecoar mais forte e mais vezes, nos diferentes espaços acadêmicos e da sociedade, o som dessas vozes múltiplas, minoritárias, marginalizadas, silenciadas e discriminadas por estruturas sociais, pelo discurso tido como verdadeiro, único e hegemônico, posto que, a História e o Estado ainda não reconheceram, de fato, a contribuição social dos grupos afrobrasileiros amazônicos, na formação da sociedade brasileira, precisando ser revisitadas e reconstituídas nesse território de fronteira.

\section{REFERÊNCIAS}

AMARAL, José Januário de Oliveira. Os latifúndios do INCRA. Porto Velho: Edufro, 2007.

ASSUNÇÃO, Izabel de Oliveira. Memórias de Monsenhor Francisco Xavier Rey: Dom Rey. São Paulo: Scortecci, 2012.

BANDEIRA, Maria de Lourdes. Território negro em espaço branco. São Paulo: Brasiliense, 1988.

BENEDITO, Mouzar. Luiz Gama: O libertador de escravos e sua mãe libertária, Luiza Mahin. São Paulo: Expressão Popular, 2006.

BOSI, Ecléa. Memória e sociedade: lembranças de velhos. 19. ed. São Paulo: Companhia das Letras, 1994.

BLACLKMAN, Cledenice. Do mar do Caribe à beira do Madeira: a comunidade antilhana de Porto Velho. Dissertação (Mestrado em História e Estudos Culturais). UNIR, Porto Velho, 2015. 
CALVET, Louis-Jean. Sociolinguística: Uma introdução crítica. São Paulo: Parábola Editorial, 2013.

EVARISTO, Conceição. Becos da memória. 3. ed. Rio de Janeiro: Pallas, 2017.

FIABANI, Aldemir. Mato, palhoça e pilão: $O$ quilombo, da escravidão às comunidades remanescentes [1532 - 2004]. São Paulo: Expressão Popular, 2005.

FREYRE, Gilberto. Casa-grande $\boldsymbol{E}$ senzala: formação da família brasileira sob o regime da economia patriarcal. 51. ed. São Paulo: Global, 2006.

FUNAI. Terras indígenas em Rondônia. (2009). Disponível em: $<$ http://ccr6.pgr.mpf.gov.br/documentos-e-publicacoes/terrasindigenas/terras-indigenas $>$. Acesso em: 20 de julho de 2019.

GILROY, Paul. O Atlântico negro. Modernidade e dupla consciência. São Paulo: Editora 34, 2001.

GODOI, M. Bolsonaro um fantasma ronda o Planalto. (2017). Recuperado de: <http://infograficos.estadao.com.br/politica/ bolsonaro-um-fantasma-ronda-o-planalto/entrevista $>$. Acesso em: set. 2020.

GOMES, F. dos S. Mocambos e quilombos: uma história do campesinato negro no Brasil. São Paulo: Claro Enigma, 2015.

HALBWACHS, Maurice. A memória coletiva. Trad. Beatriz Sidou. São Paulo: Centauro, 1990.

HAMPATÉ BÂ, Amadou. A tradição viva. In: Ki-Zerbo. J. História geral da África: metodologia e pré-história. São Paulo: Ática/Unesco, 1982. 
KRENAK, Ailton. Ideias para adiar o fim do mundo. São Paulo: Companhia das Letras, 2019.

LEITE, Ilka Boaventura. Humanidades insurgentes: conflitos e criminalização dos quilombos. In: ALMEIDA, Alfredo Wagner Berno de (Org.). Projeto nova cartografia social da Amazônia. Manaus: UEA Edições, 2010.

LEITE, Ilka Boaventura. Ética e estética na antropologia. Florianópolis: Programa de Pós-Graduação em Antropologia Social da UFSC, CNPQ, 1998.

MEIHY, José Carlos Sebe Bom. Canto de morte Kaiowá: história oral de vida. São Paulo: Loyola, 1991.

MEIHY, José Carlos Sebe Bom. Manual de história oral. São Paulo: Loyola, 1996.

MEIRELES, Denise Maldi. Guardiões da fronteira: Rio Guaporé, século XVIII. Vozes, 1989.

MONTENEGRO, Antonio Torres. História, metodologia, memória. São Paulo: Contexto, 2010.

NASCIMENTO, Abdias do. O genocídio do negro brasileiro: processo de um racismo mascarado. São Paulo: Perspectivas, 2016.

MUNDURUKU, Daniel. Coisas de índio: versão infantil. 24. ed. São Paulo: Callis Editora, 2016.

REIS, João José. Rebelião escrava no Brasil: A história do Levante dos Malês em 1835. 3. ed. São Paulo: Companhia das Letras, 2019.

TEIXEIRA, Marco Antonio Domingues; LIMA, Uilian Nogueira. Negros e indígenas no contexto da escravidão colonial no Vale do 
Guaporé. In: TEIXEIRA, Marco Antonio Domingues; LIMA, Uilian Nogueira (Orgs). Afros e amazônicos: estudos sobre o negro e o indígena na Amazônia - vol. III. Porto Velho: MC\&G Editorial, 2016.

THOMPSON, PAUL. A voz do passado: história oral. São Paulo: Paz e Terra, 1992.

VOLPATO, Luiza Rios Ricci. Cativos do sertão: vida cotidiana e escravidão em Cuiabá em 1850-1888. São Paulo: Editora Marco Zero; Cuiabá: Editora da Universidade Federal de Mato Grosso, 1993. 


\section{A Bíblia É A ESPADA do ESPÍRITO E A HaRPa CRISTÃ É O CANIVETE: O MOVIMENTO PENTECOSTAL E A SUA HINOLOGIA ${ }^{78}$}

Josué Passos de Melo ${ }^{79}$

\section{INTRODUÇÃo}

Este artigo é o resultado de um estudo sobre o Movimento Pentecostal e a sua hinologia, a partir leituras realizadas em obras narrativas cuja autoria pertence aos primeiros representantes do Movimento Pentecostal no Brasil.

Pretende-se, com isso, apresentar, no contexto da formação político-cultural da Amazônia, uma síntese do Movimento Pentecostal e a sua Hinologia, a partir da análise, na perspectiva da sociologia weberiana $(2002 ; 2007 ; 2010)$, Abumanssur (2005), e Mariano (1999); da análise sociológica da música, sobretudo da música de estratificação étnica, Du Bois (1999), Martin (2009); como suporte histórico nos servimos das obras de Alencar (2010; 2013), Hollenweger (1976); da perspectiva teológica, Allmen (2005), Bobsin (2002), Hahn (2011). Nos servimos, também, das obras de cunho narrativo Conde (2011; 1982), Araújo (2007; 2011), Vingren (1987; 2011) e Berg (2011).

78 Este artigo é parte da Dissertação intitulada "Louvor, Triunfalismo e Colonização no Movimento Pentecostal na Amazônia”, que foi apresentada como requisito para atender ao Programa de Pós-Graduação Stricto Sensu do Mestrado Acadêmico em História e Estudo Culturais, sob a orientação do Professor Dr. Júlio César Barreto Rocha.

${ }^{79}$ Mestre em História e Estudo Culturais da Universidade Federal de Rondônia (UNIR). 
Inicialmente, apresentaremos aspectos da história do Movimento Pentecostal no Brasil, descrevendo sua inserção na Amazônia e na cidade de Porto Velho. Em seguida, explicaremos a formação do cancioneiro do Movimento, que reúne sua hinologia, e a sua utilização como instrumento de carisma, de poder e de controle. A transferência da sede do poder central do ramo do Movimento Pentecostal representado pela Igreja Evangélica Assembleia de Deus, da Amazônia para o Sueste do País, também foi utilizada como elemento simbólico de poder.

Não foi intenção reunir nesse pequeno texto tudo que se pode pensar sobre canções litúrgicas, sobretudo do Movimento Pentecostal. Nem tampouco, foi intenção atribui juízo de valor, mas fomentar a pesquisa desse movimento religioso que começou no Brasil pela Amazônia.

\section{Movimento Pentecostal: DAS LAVOURAS NORTE- AMERICANAS AO VALE DO MADEIRA, SÍNTESE HISTÓRICA}

Entre as características do Movimento Pentecostal, a musicalidade é aquela que se destaca pela diversidade de ritmos e pela influência que esses ritmos exerceram na musicalidade em geral; principalmente a musicalidade do Pentecostalismo Negro, que se originou entre os afrodescendentes norte-americanos (Hollenweger, 1976, p. 19-20). O spiritual, o jazz, o blues, o country são ritmos cuja popularidade recebeu significativa contribuição desse ramo do Pentecostalismo, pois eram sempre cantados e/ou tocados nos cultos desse grupo.

O ritmo negro spirituals (Martin, 2009; Coletto, s.d.; Du Bois, 1999), foi um estilo musical praticado pelos escravos nas lavouras das grandes propriedades americanas. Servia como elemento de inspiração. As músicas eram cantadas e acompanhadas com 
movimentos corporais e palmas, cadenciados. Essas expressões foram reproduzidas pelos pentecostais nos cultos.

O Movimento Pentecostal surgiu nos Estados Unidos da América, no meio dos protestantes negros e brancos, simultaneamente, na primeira década do século XX. Por questões ligadas à segregação racial comum da sociedade americana, o Pentecostalismo branco foi atribuído à liderança do pastor Charles Fox Parham, enquanto o pentecostalismo negro à direção do pastor Josef Williams Seymour (Hollenweger, 1976, p. 18-19). Um movimento semelhante ao Movimento Pentecostal surgiu nas fileiras do Catolicismo Romano, também nos Estados Unidos da América, bem mais tarde, 1968, para ser mais exato (Mansfield, 1995).

O Pentecostalismo resgatou a crença nos dons mágicos e na habilidade de falar em idiomas não aprendidos pelos falantes, denominado "dons de línguas". Virtudes essas, conforme a crença, concedidas ao fiel pelo Espírito Santo, a fim de que ele consiga vencer as agruras do cotidiano e conseguir ser uma testemunha e propagador da ressurreição do Messias. Essas crenças eram comuns nos dias dos primeiros apóstolos de Jesus e, posteriormente, nos dias do apóstolo Paulo, conforme relatado no livro da Bíblia denominado dos Atos dos Apóstolos. Com a morte dos primeiros apóstolos e dos seus discípulos, século I e início do século II da Era Cristã, crê-se ter encerrado a manifestação desses dons. Esse ponto é defendido pelo Protestantismo Histórico que rejeitou esse aspecto das doutrinas defendidas pelo Movimento Pentecostal. Doutrinas essas defendidas por um segmento do Cristianismo com aspecto fundamentalista e não apenas "paramental" e litúrgico (Conde, 2011, p. 182). Contudo, é certo afirmar que as raízes do Movimento Pentecostal estão no solo do Protestantismo (Barrera, 2005, p. 79112). 
Os protestantes consolidaram sua presença e atuação no Brasil ainda no século XIX. O século XX iniciou e o Brasil já estava envolvido, há pelo menos uma década, com a realização da aspiração republicana (Basbaum, 1976, 1986). Contudo, o Brasil estava acontecendo no litoral. A Amazônia, porém, estava fora do eixo das decisões políticas dos dirigentes do Brasil.

Desde datas anteriores ao século XX já se perguntava: quem é o homem amazônico? (Lima, 1937). Qual o idioma falado pelo amazônida? (Freire, 2011). Foi nessa geografia cheia de interrogações que, em 1910, chegaram, assim como muitos outros, dois estrangeiros de nacionalidade sueca, mas, erradicados nos Estados Unidos da América, Daniel Berg e Adolph Gunnar Vingren. A vinda deles teve o propósito específico de evangelizar. Como representantes do Movimento Pentecostal, divulgar as doutrinas do pentecostalismo, era o propósito da pregação desses dois suecos (Hollenweger, 1976).

Para nos situarmos naquele contexto, se faz necessário recordar que, o Tratado de Comércio e Navegação, de 19 de fevereiro de 1810, celebrado entre a Coroa Portuguesa e a Inglaterra, no artigo XII, permitia a liberdade de culto aos ingleses residentes no Brasil, assim como tolerância com os seguidores de religiões que não eram católicas (Reily, 1993, p. 40). Não significava dizer todas as expressões religiosas acatólicas, mas, as confissões religiosas pertencentes ao Cristianismo. Ou seja, os protestantes estrangeiros das nações amigas de Portugal e Inglaterra que estavam no Brasil representando suas nações nos interesses delas nos aspectos econômicos e políticos. Esse Tratado não autorizava o proselitismo nem a construção de edifício em forma de templo religioso. Os protestantes podiam celebrar seus cultos apenas no ambiente doméstico. Este contexto foi modificado durante todo o 
século XIX, o que facilitou a inserção do Movimento Pentecostal no Brasil no início do século XX.

O Movimento Pentecostal que surgiu no Brasil teve em seu primórdio, na década de 1910, dois ramos distintos e foi representado por missionários estrangeiros europeus. Luigi Francescone representou um ramo e os suecos Daniel Berg e Adolph Gunnar Vingren, o outro. A Congregação Cristã no Brasil, denominação que se formou em torno da pregação de Luigi Francescone, um italiano da Província de Udine nascido em 1866 (Hahn, 2011, p. 382), que partiu dos Estados Unidos da América, depois de uma temporada nesse País, seu destino foi o Brasil, cujo objetivo maior era o de divulgar as doutrinas pentecostais para seus conterrâneos italianos residentes no Estado de São Paulo, região do Braz (Pellizzaro, 2005, p. 192). As suas reuniões eram todas proferidas no idioma Italiano (Hahn, 2011, p. 386). Somente começou a utilizar o idioma Português a partir de 1935 (Hahn, 2011, p. 386). O hinário desse grupo é chamado de Louvores a Deus e outro, Guia de Culto da Congregação (Hahn, 2011, p. 383) Esse ramo do Movimento Pentecostal possui características peculiares e merece uma pesquisa mais detida. Congregação Cristã no Brasil e a Igreja Evangélica Assembleia de Deus, segundo Alencar, (2013, p. 159) constituem a "Matriz Pentecostal Brasileira".

No ano de 1910, cem anos depois que o Tratado de Comércio e Navegação foi assinado, os representantes do Movimento Pentecostal sueco-americano Daniel Berg e Adolph Gunnar Vingren chegaram à Amazônia, mais precisamente a Belém do Pará. Bobsin (2002, p. 66) e Hollenweger (1976, p. 19) nos informam que esses missionários eram oriundos do grupo pentecostal branco, cujo líder Charles Fox Parham era partidário do movimento cuja ideologia era a segregação racial Ku-Klux-Klan. Na cidade de Belém do Pará deu-se a implantação da primeira fase daquela que, mais 
tarde, se tornou a Igreja Evangélica Assembleia de Deus (Alencar, 2010, p. 48).

Dessa base em Belém do Pará (Berg, 2011; Vingren, 2011), o Movimento Pentecostal foi exportado para toda a Amazônia e Nordeste (Conde, 2011); e depois para todo o Brasil (Vingren, 1987), num período em que o Brasil experimentava um êxodo rural em decorrência do declínio econômico (Hahn, 2011, p. 378) e as periferias das cidades formavam grande complexo de casebres e vielas. Nessas localidades edificaram-se templos e, expressivo número de adeptos oriundo dessa camada social, aderiu ao Movimento. Hahn (2011, p. 375) nos informa que: "O pentecostalismo descobriu nas massas esquecidas e analfabetas e nos adeptos do catolicismo popular um campo fértil para sua mensagem e métodos e obteve resposta.”.

No ano de 1922 - 28 de fevereiro de 1922 -, a Igreja Evangélica Assembleia de Deus foi oficializada na cidade de Porto Velho (Conde, 2011, p. 73). Foi a terceira denominação cristã a estabelecer-se nesse chão. O missionário representante da Igreja Evangélica Assembleia de Deus ao chegar a Porto Velho se deparou com igrejas cristãs que já haviam sido instaladas por aqui: a Igreja Católica Apostólica Romana e a Primeira Igreja Batista de Porto Velho.

John Paul Aenes foi aconselhado pelos líderes da Igreja Evangélica Assembleia de Deus em Belém a procurar seu próprio local de trabalho proselitista: "Você deve sair e tornar-se um pioneiro.” (Araújo, 2007, p. 5). Esse missionário chegou à cidade de Porto Velho no ano de 1921. Aliou-se ao senhor José Marcelino da Silva que já pertencia ao Movimento Pentecostal e era oriundo do Nordeste do Brasil, viera para Porto Velho à procura de emprego como pintor, que era a sua profissão. 
A partir da Igreja Evangélica Assembleia de Deus de Porto Velho, o Movimento Pentecostal difundiu-se, nos anos seguintes a 1922, até 1930, para localidades adjacentes: Generoso Ponce (atual Distrito de Jaci-Paraná), vilarejos localizados ao longo do Baixo Madeira até a fronteira com o Amazonas, município de GuajaráMirim onde estava situada a última estação da Estrada de Ferro Madeira Mamoré; no Acre, localizado a Oeste e além das fronteiras territoriais de Porto Velho. Com os processos migratórios a partir de 1970 e a criação de novos municípios no então Território Federal de Rondônia, a Igreja Evangélica Assembleia de Deus foi estabelecida em todas as localidades situadas no eixo da BR-364 e fora dela. Resultou em um grande crescimento dessa igreja em Rondônia. Esse processo de expansão da Igreja Evangélica Assembleia de Deus em Rondônia foi encabeçado pelo pastor Leonardo Severo da Luz, que liderou essa igreja de 1953 a 1980 (Silva, s.d.). Nas palavras do pastor Leonardo Severo da Luz: "Daí por diante, dia após dia, ano após ano, a obra do Senhor cresceu e se desenvolveu por toda a vasta região rondoniense, onde milhares de almas, remidas pelo sangue de Jesus, cantam louvores e glorificam o Nome que é sobre todo o nome" (Silva, s.d., p. 15).

A partir da década de 1970 outras denominações pentecostais se estabeleceram em Porto Velho: Igreja Pentecostal Deus é Amor; Igreja do Evangelho Quadrangular; Igreja de Deus Pentecostal do Brasil. Vale salientar que desde 1950, no Brasil, o Movimento Pentecostal começou a fragmentar-se. Grandes denominações se fragmentaram internamente (Alencar, 2013, p. 172), dividiram-se em pequenas igrejas pentecostais, formando mais tarde outras denominações também pentecostais. Evitar as divisões era uma preocupação dos primeiros pentecostais do Brasil (Jardilino, 1994, p. 36). Essas denominações, resultado das divisões 
internas, desenvolveram-se e expandiram-se para vários estados do Brasil.

Os estudiosos dessa temática dividem a inserção do Movimento Pentecostal no Brasil em "três ondas". A primeira iniciou-se no ano de 1911, com as igrejas Assembleia de Deus e Congregação Cristã do Brasil. A segunda iniciou-se nos idos da década de 1950 para 1960, na qual surgem denominações pentecostais que vieram dos Estados Unidos e outras, cujo surgimento se deu por fragmentação das primeiras denominações, principalmente da Igreja Evangélica Assembleia de Deus. Por fim, a terceira onda surgiu a partir da década de 1970, com o aparecimento de denominações pentecostais (Abumanssur, 2005, p. 116).

Na atualidade brasileira, verifica-se que há outros segmentos pentecostais, oriundos das denominações pentecostalistas mais tradicionais, que enfatizam como crença central, apenas as facilidades de acesso aos bens de consumo oferecidos pelo mercado, a troco de oferendas materializadas em moeda corrente: os assim denominados neopentecostais (Mariano, 1999).

O ideal de vida sem os sofrimentos é imaginado como um lugar onde o acesso aos bens de consumo, dos mais básicos aos mais ostentosos, é livre, conquanto que o interessado pague pelo acesso. Um produto manufaturado que o mercado lançar com a promessa de satisfação garantida, cujo acesso será determinado pelo poder econômico que o indivíduo possuir de adquiri-lo e, com isso, obter satisfação. Tal acesso determinará, também, o ideal de "paraíso" no imaginário desse novo crente pentecostal.

Assim como o modo de viver, de comer, de morar e as demais instâncias da vida social estão determinados pela cultura, economia e política, o modo de crer também está. $O$ céu é o lugar onde não 
existe inacessibilidade. Esse lugar de acessibilidade total não é para além do túmulo. É agora! (Mariano, 1999).

Todo esse imaginário de um mundo maravilhoso é expresso nas canções, coletadas em um hinário, que recebeu, depois de várias edições, o nome de Harpa Cristã. Contudo, é necessário considerar a diversidade flagrante no Pentecostalismo da maneira de ver o mundo e essa diversidade está muito presente na sua hinologia. Peixoto (2008, p. 115) sintetiza muito bem essa característica:

Enfim, o Pentecostalismo é um fenômeno multifacetado, que é pontuado por geradoras locais e externas, que recebe influências de períodos bastante conflitantes entre si. Desse modo a hinologia pentecostal transparece toda essa gama de situações e condicionamentos. Não pode escapar dessa realidade. É perceptível a permanência de temas que remontam aos princípios da institucionalização do cristianismo. Também se pode o desuso de assuntos outrora muito recorrentes. Em seus lugares vão surgindo letras mais adaptadas às exigências do cenário pós-moderno.

Não apenas o conteúdo das canções sofreu e sofre modificações, mas a parte da musicalização rítmica também foi e é influenciada pela modernidade, sobretudo pelo gosto musical, uma vez que o consumo das produções artísticas religiosas, não está restrito aos cultos, mas ao mercado de bens de consumo.

A hinologia do Movimento Pentecostal, no aspecto histórico da sua formação, será o tema com o qual no ocuparemos no tópico seguinte.

\section{Hinologia do Movimento Pentecostal}

A hinologia do Movimento Pentecostal segue o imaginário contido nas doutrinas desse Movimento. Esse imaginário é 
estruturado em canções e são entoadas nos cultos pelos pentecostais sempre acompanhadas por uma diversidade de instrumentos musicais próprios das camadas mais populares da sociedade brasileira de então. $\mathrm{O}$ crente pentecostal participa ativamente no culto cantando a sua fé, acompanhado por instrumentos musicais que a sua condição social lhe permite o acesso. Araújo (2011, p. 119) nos informa que "Nas primeiras décadas, alguns crentes tocavam instrumentos simples tais como violão, cavaquinho, acordeão, pandeiros e triângulos”.

Ao contrário desse cenário descrito acima, nos cultos das igrejas protestantes os ouvintes tinham participação limitada e controlada pelo dirigente e as canções entoadas eram acompanhadas por instrumentos mais elitizados como piano e violino tocados por profissionais. Allmem (2006, p. 188) afirma que na liturgia tradicional determinadas funções litúrgicas são especificas de homens, colocando assim as mulheres num grau ainda maior de passividade no culto em relação aos ouvintes masculinos. Allmen (2006, p. 190-193) apresenta três protagonistas da liturgia protestante: o pastor, que preside a celebração; o corpo diaconal com liturgia específica para esse grupo como auxiliar no ministério; e a comunidade que participa ouvindo o sermão, comungando das mãos do celebrante, orando, dizendo o amém, fazendo a confissão de fé, doando oferendas e cantando os hinos. Geralmente nas igrejas históricas existem corais bem-organizados e equipados com vozes profissionais. Diga-se de passagem, que apesar dessa formalidade litúrgica do Protestantismo, o Movimento Pentecostal, "Ou bem ou mal, ele influenciou todo o culto no país, tanto protestante como católico” (Hahn, 2011, p. 375).

Os pentecostais - dirigentes e ouvintes - participam, ativamente, como protagonistas no culto. Qualquer crente assistente do culto que estiver anonimamente no meio da multidão, 
seja homem ou mulher, pode, caso sinta-se inspirado pelo Espírito Santo, alçar sua voz e proferir profecias, revelações, exortações. É facultada, ainda, a participação com brado de "aleluia", "amém”, "glória a Deus" e uma extensa lista de expressões, em qualquer momento do culto (Hahn, 2011, p. 381). Aliás, tal procedimento é, insistentemente, motivado por quem estiver fazendo uso da palavra, que pode franqueá-la ao fiel contar seus testemunhos para todos ouvir (Hahn, 2011, p. 381). Além de que "Todos têm a oportunidade de se tornarem líderes” (Hahn, 2011, p. 379) de uma comunidade.

A hinologia do Movimento Pentecostal, em alguns círculos desse Movimento, principalmente os mais tradicionais, recebe um status sagrado de acordo com a forma dos pentecostais de qualificar seus objetos de culto. É comum expressões como "a Bíblia é a espada do Espírito e a Harpa é o canivete”. A Harpa Cristã, que se tornou hinário oficial da Igreja Evangélica Assembleia de Deus e de outras denominações pentecostais como a Igreja Pentecostal Deus é Amor, é o resultado final de um processo de catalogação de hinos desde os primeiros anos desse Movimento no Brasil. A primeira coletânea de hinos utilizada oficialmente pelas igrejas evangélicas existentes no Brasil no início do século XX foi o Psalmos e Hinos. Esse hinário foi publicado no Brasil em 1861, sob a responsabilidade do dos missionários da Igreja Congregacional, os escoceses Robert e sua esposa Sara Poulton Kalley (Araújo, 2011, p. 119).

Como escrevemos acima, Protestantes Históricos e Pentecostais divergem, doutrinariamente, quanto à contemporaneidade dos dons do Espírito Santo, como "falar em outras línguas”, principalmente. Ponto doutrinário esse (falar em outras línguas), que os pentecostais acreditam ser possível mediante o batismo com o Espírito Santo, é central na doutrina do Movimento Pentecostal Histórico. Logo, o hinário Salmos e Hinos, 
não contemplava esse aspecto da crença pentecostal. Não enfocava a "verdade pentecostal" nem o "fervor pentecostal" (Araújo, 2011, p. 119).

Os hinos, que passaram a ser utilizados e que eram traduções de hinários pentecostais suecos e americanos, atenderam às aspirações doutrinárias do núcleo pentecostal de Belém do Pará. Sobre este aspecto, Araújo (2011, p. 119) fez a seguinte declaração:

Muitos desses hinos expressavam uma temática que incluía a doutrina do revestimento de poder pelo batismo no Espírito Santo, ressaltava necessidade de devoção e santificação na vida do crente, e falava da iminente segunda vinda de Cristo e a esperança do crente fiel se encontrar logo com o Senhor na vida eterna.

A primeira coletânea era simples. Organizada pelo missionário sueco Adolph Gunnar Vingren em 1917, possuía 10 canções em inglês e 14 no idioma sueco. Essa pequena coletânea de 24 hinos aumentou para 194 canções, sob a organização, segundo Araújo (2011, p. 119), dos líderes pentecostais de Belém, “[...] cuja impressão ficou pronta em 6 de outubro de 1917.”

Dando prosseguimento à evolução da hinologia do Movimento Pentecostal, pelos idos dos anos de 1921, os responsáveis pela Igreja Evangélica Assembleia de Deus, no intuito de constituir uma coletânea de hinos que atendesse essa demanda teológica, apresentaram outro hinário denominado "Cantor Pentecostal" (Oliveira, 1997, p. 168; Araújo, 2011, p. 119). Esse hinário foi editado pelo senhor Almeida Sobrinho, na cidade de Belém do Pará, e era constituído com 44 hinos e 10 corinhos. O corinho na hinologia pentecostal é uma espécie de canção curta, geralmente, composto de quatro a cinco versos (podendo ser constituído por mais versos) e de uma frase apenas. Nessa época, 
Belém do Pará, na Região Amazônica, era o núcleo principal do Movimento Pentecostal no Brasil (Araújo, 2007, p. 342).

A Harpa Cristã, hinário com 100 canções oficialmente aprovadas (Araújo, 2007, p. 342), foi lançada ao comércio em 1922 na cidade de Recife estado de Pernambuco. Teve com editor o pastor Adriano Nobre e nessa edição a tiragem foi de mil exemplares. A distribuição foi autorizada pelo missionário sueco Samuel Nyström, que nesse período, exercia maior influência como líder nacional da denominação.

Percebe-se que a Igreja Evangélica Assembleia de Deus, núcleo da Amazônia, começou a perder força como influência nas principais decisões da denominação; e a Harpa Cristã foi determinante nesse processo de enfraquecimento. Nesse sentido, conforme Araújo (2007, p. 341): "Ela foi especialmente organizada com o objetivo de enlevar o cântico congregacional e proporcionar o louvor a Deus nas diversas liturgias da igreja: culto público, Santa Ceia, batismo, casamento, funeral e outras ocasiões especiais". Onde a Harpa Cristã estivesse sendo editada, ali seria o centro do poder na Igreja Evangélica Assembleia de Deus, de onde emanaria para as demais filiais espalhadas pelo Brasil.

No ano seguinte, 1923, uma nova edição da Harpa Cristã contendo 300 canções foi lançada na cidade do Rio de Janeiro. Nove anos depois, 1932, uma terceira edição foi colocada à disposição dos interessados, com uma coletânea de 400 hinos (Oliveira, 1997, p. 168). Todas essas edições da Harpa Cristã foram distribuídas sob a liderança de do sueco Samuel Nyström que teve direta participação na seleção e tradução dos hinos. Araujo (2007, p. 342) afirma que "Apesar de não ter perfeito conhecimento da língua portuguesa, ele traduziu, literalmente, diversas letras da riquíssima hinódia escandinava”. Conforme Araujo (2011, p. 118): “A música 
pentecostal, no início do movimento no Brasil, se dividia em música importada e em composições brasileiras”. Contudo, foi necessário efetuar uma readaptação, a fim de que pudesse haver harmonias entre letras e canções, tarefa realizada pelo pastor Paulo Leivas Macalão, que assumiu a posição de "principal elaborador e adaptador” da Harpa Cristã (Araújo, 2007, p. 342).

Analisando a questão do semianalfabetismo de Samuel Nyström, quanto a conhecer o idioma português, e ainda assim, conseguia fazer traduções, vemos uma espécie de justificativa pelo desprezo à racionalidade científica (Weber, 2002; 2007) em favor da valorização do conceito de "vocação" de Weber (2007). Nesse sentido, não é necessário saber plenamente o idioma português e os significados culturais que cada palavra carrega. $\mathrm{O}$ vocacionado recebeu ordem divina e está adaptado a ela (Weber, 2007, p. 73). Não é necessário, conforme Weber (2002, p. 42) apego ao racionalismo e ao intelectualismo científico, apenas, a interação com Deus o classifica como “enviados por Deus” (Berg, 2011).

A migração do poder central da Igreja Evangélica Assembleia de Deus, de Belém do Pará, Amazônia, para o Sudeste, exatamente para a cidade do Rio de Janeiro, passando, temporariamente, pelo Nordeste, se consolidou com a instalação da secretaria da Convenção Geral das Assembleias de Deus no Brasil (CGADB), órgão máximo da autoridade dessa denominação. Estrategicamente, nessa cidade (em prédios anexados), foi instalada a Casa Publicadora das Assembleias de Deus (CPAD), editora oficial da Igreja Evangélica Assembleia de Deus, que detêm o monopólio da edição, publicação e distribuição de literaturas em geral reconhecidas e autorizadas por essa denominação.

Nessa nova configuração geográfica, os líderes sediados no Rio de Janeiro, detinham em suas mãos os instrumentos de poder e 
controle: sede nacional, de onde emanavam as decisões relacionadas às doutrinas e demais ordenamentos; editora, com toda a autoridade para editar os periódicos oficiais tais como o jornal Mensageiro da Paz, revistas para as classes da escola dominical e toda a literatura autorizada da denominação. Nesse mosaico de obras literárias estava a Harpa Cristã. Alencar (2013, p. 218) nos informa que as disputas internas na Igreja Evangélica Assembleia de Deus são sempre presentes desde os primórdios. Essa posição estratégica colocou os pastores que atuavam nesses locais em posição privilegiada em detrimento daqueles que estavam mais distantes desse núcleo.

Citamos acima que a Harpa Cristã foi criada com o objetivo de mediar entre o crente e a divindade, cantando os louvores que nela estão organizados conforme temas, " $[. .$.$] nas diversas liturgias$ da igreja" (Araújo, 2007, p. 341). Salienta-se que o autor Araújo se refere à liturgia da Igreja Evangélica Assembleia de Deus. De acordo ainda, com Araújo (2007, p. 342), “[...] a Harpa Cristã atualizada em 1992, contendo 628 hinos, com uma nova sequência numérica distribuída em seis grupos temáticos". Esse mesmo instrumento litúrgico, que passou por diversos estudos e adaptações, durante todo tempo de sua existência, desde seus protótipos ancestrais, sua primeira edição em 1922 até sua edição definitiva com a ampliação para 640 canções, se tornou um instrumento de poder e controle. Conforme Araújo (2007, p. 342):

Surgiu assim, em 1996, a atual Harpa Cristã ampliada [...]. A Harpa Cristã tem sido o instrumento de consolidação nacional da hinologia pentecostal. Um dos motivos que colaborou para isso foi o fato de cada crente ter que possuir o seu próprio hinário e lavá-lo para a igreja, diferentemente das igrejas nos Estados Unidos, por exemplo, em que os templos é que possuem 
exemplares do hinário para os fiéis usarem em seus cultos (Destaque nosso.)

Nesse cenário, visto na perspectiva de Weber (2010), constata-se que o "carisma” a priori subjetivo foi substituído pelo “carisma” materializado na Harpa Cristã. De acordo com Weber (2010, p. 40) “o termo 'carisma' será entendido como referência a uma qualidade extraordinária de uma pessoa, prescindindo de que seja real, presumida ou suposta". No caso daquele que "reconhece" os hinos legitimamente pentecostais e "autoriza" a inclusão na Harpa Cristã é o detentor do "carisma” cedido por Deus e, por isso, pode emaná-lo para os crentes pentecostais, via Harpa Cristã. No caso da Igreja Evangélica Assembleia de Deus, o detentor do “carisma” era o pastor Samuel Nyström, que não apenas traduzia hinos para o idioma nacional ainda que "[...] não tivesse perfeito conhecimento da língua portuguesa, [...]” (Araujo, 2007, p. 342), mas determinava quais hinos fariam parte desse hinário. Samuel Nyström consolidava sua posição de liderança sobre os demais pastores estrangeiros e nacionais, inclusive sobre os pioneiros Berg e Vingren (Alencar, 2013, p. 152). Sua “vocação” estava manifestada no seu "trabalho" de conquistar a posição de liderança.

Não só as letras das canções eram determinadas por quem detinha o poder carismático, como também os instrumentos e as melodias passavam por esse processo de seleção e só depois eram autorizadas as suas execuções. A última edição da Harpa Cristã, com hinos organizados, seguiu uma "nova sequência numérica distribuída em seis grupos temáticos” (Araújo, 2007, p. 342). Até mesmo a natureza do evento deveria coincidir com a temática do hino. Era a autoridade que fazia a escolha das letras, da harmonia musical e da ocasião em que o hino seria cantado. 
Weber (2010, p. 67) nos informa que "Existe uma estreita relação entre a religiosidade mágica e a esfera estética” e utiliza-se "a música como meio de êxtase, exorcismo ou magia". Enquanto os protestantes analisados por Weber $(2007$, p. 95) acreditavam que garantiriam "salvação pelo trabalho", os pentecostais creem assegurar a salvação pelo louvor. Louvor esse, a partir da entoação dos hinos catalogados na Harpa Cristã.

Parece contraditório a Harpa Cristã ser apresentada como materialização do carisma, mesmo tendo sido submetida a uma racionalidade científica: a compilação, tradução, edição e demais fases da tipografia. Porém, Weber (2002, p 56) nos esclarece que "Tão somente o discípulo faz legitimamente o 'sacrifício do intelecto' em favor do profeta, como somente o crente faz em favor da Igreja”. Nesse caso, quem se ofereceu como cordeiro para ser imolado no altar profano da ciência linguística foi Paulo Leivas Macalão. Nyström sai ileso, afinal "pouco conhece o idioma português” e nem precisava conhecer para dizer o que é sagrado ou profano na hinologia, pois, "O sucesso no exercício dos dons valida o chamado de Deus" (Hahn, 2011, p. 379).

\section{CONSIDERAÇõES FINAIS}

O Movimento Pentecostal surgiu nos Estados Unidos no início do século XX, entre os fiéis pertencentes ao Protestantismo Histórico. Esse Movimento foi protagonizado por dois grupos étnicos distintos: o pentecostalismo branco e o pentecostalismo negro. Esse último grupo recebeu destaque pela sua musicalidade diversificada, constituindo, assim, uma característica peculiar. Tal musicalidade exerceu influência tanto na musicalidade religiosa como na não religiosa. 
O Movimento Pentecostal que surgiu no Brasil teve em seu primórdio, na década de 1910, dois ramos distintos e foi representado por missionários estrangeiros. Luigi Francescone representou um ramo e os suecos Daniel Berg e Adolph Gunnar Vingren, o outro.

No Sudeste, o ítalo-americano Luigi Francescone representou o ramo do pentecostalismo do qual surgiu a Congregação Cristã no Brasil, sediada na cidade de São Paulo, reduto dos migrantes italianos para os quais Francescone destinou sua empresa evangelizadora. Essa denominação, seu desenvolvimento, seu fundador e o povo que a integra, merecem uma pesquisa à parte, que não foi, portanto, objetivo desse estudo.

O outro ramo do Movimento Pentecostal, representado pelos missionários sueco-americanos Daniel Berg e Adolph Gunnar Vingren, estabeleceu-se na Amazônia, precisamente na cidade de Belém do Pará. A pregação desses missionários não tinha destinatários definidos. Pregavam para quem se dispusesse a ouvir. Assim, o Movimento cresceu entre o maior contingente populacional do Brasil: os menos favorecidos.

De Belém do Pará esse ramo do Movimento Pentecostal cresceu e se espalhou para todos os estados do Brasil, nas décadas seguintes a 1910. Em 1922, Paul John Aenes, representante da Igreja Evangélica Assembleia de Deus, chegou a Porto Velho. Iniciou-se, assim, a empresa evangelizadora dessa denominação, que abriu filial em todos os municípios desse Estado.

A doutrina do Movimento Pentecostal apresentava uma novidade em relação à ortodoxia do Protestantismo Histórico, que era o resgate da crença na contemporaneidade dos dons do Espírito Santo, principalmente no dom de falar em outras línguas desconhecidas e na aprendida. Esse dom carismático acreditavam 
os protestantes, cessou de ser concedido com a morte dos primeiros discípulos dos séculos I e II depois da morte de Jesus. O Movimento Pentecostal que nasceu em torno do resgate dessa crença, sistematizou a sua doutrina acrescentando esses tópicos, que foi, de forma veemente, rejeitada pelo Protestantismo Histórico, tanto a doutrina como os próprios adeptos do Movimento.

O Movimento Pentecostal que migrou para o Brasil, para divulgar suas doutrinas com esses acréscimos, utilizou a musicalidade, principalmente, a do Pentecostalismo Negro pelas suas características mais populares. O Movimento Pentecostal no Brasil, os dois ramos, se desenvolveram entre os pobres, considerando que a pregação dos missionários representantes encontrou aceitação, principalmente, entre as classes mais basilares da sociedade e residente nas periferias das cidades. A cultura musical desse extrato social foi assimilada pela denominação e utilizada nas várias liturgias da Igreja, semelhante às comunidades pentecostais negras dos Estados Unidos da América, que cantavam temas do seu cotidiano.

As canções contendo as doutrinas do Movimento Pentecostal foram catalogadas em hinários, cujo processo de formação durou quase um século, mudando de nomes e de locais de edição, organizadas conforme os temas litúrgicos e apresentada ao público na forma de livro cujo título é Harpa Cristã.

A Harpa Cristã, muito mais do que uma coletânea de hinos, é a materialização do "carisma" que confere poder e controle, conforme verifica-se na sociologia weberiana. É, também, a mediação entre o fiel que entoa louvores e Deus que recebe esses louvores que, por sua vez, foram aprovados por quem possui a autorização de Deus para determinar o que é sagrado e o que é profano. 


\section{REFERÊNCIAS}

ABUMANSSUR, Edin Sued. Os Pentecostais e a Modernidade. In: PASSOS, João Décio. Movimentos do Espírito: Matrizes, afinidades e territórios pentecostais (Org.). (Coleção Ecclesia 21). São Paulo: Paulinas. 2005.

ALENCAR, Gedeon Freire de. Assembleias de Deus: origem, implantação e militância (1911-1946). São Paulo: Arte Editorial, 2010.

. Matriz pentecostal brasileira: Assembleia de Deus 19112011. Rio de Janeiro: Novos Diálogos, 2013. Coleção Protestantismo e Sociedade

ALLMEN, J. J. Von. O culto cristão: teologia e prática. 2. ed. Tradução de Dirson Glênio Vergara dos Santos. São Paulo: ASTE, 2005.

ARAÚJO, Isael. Dicionário do movimento pentecostal. Rio de Janeiro: CPAD, 2007.

- 100 acontecimentos que marcaram a história das Assembleias de Deus no Brasil. Rio de Janeiro: CPAD, 2011.

BARRERA, Paulo. Matrizes protestantes do pentecostalismo. In: PASSOS, João Décio. Movimentos do Espírito: Matrizes, afinidades e territórios pentecostais (Org.). (Coleção Ecclesia 21). São Paulo: Paulinas. 2005.

BASBAUN, Leôncio. História sincera da República: das Origens a 1889. 5. ed. v. 1., Série $1^{a}$, Volume 6 - História. São Paulo: AlfaOmega, 1986. Coleção Biblioteca Alfa-Omega de Ciências Sociais

. História sincera da República: de 1889 a 1930. 5. ed. v. 2., Série $1^{\text {a }}$, Volume 10 - História). São Paulo: Alfa-Omega, 1966. Coleção Biblioteca Alfa-Omega de Ciências Sociais 
BERG, Daniel. Enviados por Deus: Memórias de Daniel Berg. Ilustração de Ivar W. Rodrigues. Rio de Janeiro: CPAD, 2011.

BOBSIN, Oneide. Correntes religiosas e globalização. Curitibanos/São Leopoldo: CEBI/PPL/IEPG, 2002.

COLETTO, Felipe Salomão H. Dal. Duas interpretações acerca do ritmo musical "Spirituals Negro" - do Sul dos Estados Unidos da América, de $\mathbf{1 7 9 0}$ a $\mathbf{1 8 3 0}$. Disponível em: $<$ www.historia.uff.br/nec/sites/default/files/Duas_interpretacoes _acerca_do_ritmo_musical_Spirituals_Negro_-_do_Sul_dos_Esta dos_Unidos_da_America_de_1790_a_1830.pdf > Acesso em: 12 maio 2017.

CONDE, Emilio. História das Assembleias de Deus no Brasil. Revisão de Glaucia Victer. Rio de Janeiro: CPAD, 2011.

. O testemunho dos séculos. 2. ed. Rio de Janeiro: CPAD, 1982.

DU BOIS, W.E.B. As Almas da gente negra. Tradução de Heloísa Toller Gomes. Rio de Janeiro: Lacerda Editores, 1999.

FREIRE, José Ribamar Bessa. Rio Babel: A história das línguas na Amazônia. 2. ed. Rio de Janeiro: Eduerj, 2011.

HAHN, Carl Joseph. História do culto protestante no Brasil. 2. ed. Tradução de Antonio Gouvêa Mendonça. São Paulo: ASTE, 2011.

HOLLENWEGER, Walter. El pentecostalismo: historia y doctrina. Buenos Aires: Editorial La Aurora, 1976. Coleção Biblioteca de Estudios Teologicos

JARDILINO, José Rubens L. As religiões do espírito: visão histórico-teológica do pentecostalismo na década de 30. Rio de Janeiro/São Paulo: ISER/CEPE, 1994.

LIMA, José Francisco de Araújo. A Amazônia, a terra e o homem: "Introdução à Anthropogeographia". 2. ed. (Série 5a - Brasiliana - 
Vol. 104. Biblioteca Pedagógica Brasileira). São Paulo: Companhia Editora Nacional, 1937.

MANSFIELD, Patti Gallagher. Como um novo pentecostes: relato histórico e testemunhal do dramático início da Renovação Carismática Católica. 3. ed. Tradução de Sérgio Luiz rocha Vellozo. Rio de Janeiro: Louva-a-Deus, 1995.

MARTIN, Denis-Constant. A herança musical da escravidão. 2009. Disponível em: <www.scielo.br/pdf/tem/v15n29/02.pdf> Acesso em: 12 maio 2017.

MARIANO, Ricardo. Neopentecostais: sociologia do novo pentecostalismo no Brasil. São Paulo: Loyola, 1999.

OLIVEIRA, Joanyr de. As Assembleias de Deus no Brasil: sumário histórico ilustrado. Rio de Janeiro: CPAD, 1997.

PEIXOTO, Esdras Gusmão de Holanda. Pentecostalismo e imaginário: rupturas e continuidade na hinologia pentecostal na passagem para a pós-modernidade. Dissertação de Mestrado, Orientador: Gilbraz de Souza Aragão, Universidade Católica de Pernambuco, 2008. Disponível em: <www.unicap.br/tede/ tde_arquivos/5/TDE-2010-05-03T153914Z-250/Publico/disserta cao_esdras_peixoto.pdf> Acesso em: 16 fev. 2017.

PELLIZZARO, Nilmar. Predestinados e santificados: considerações sobre a Igreja Congregação Cristã no Brasil. In: PASSOS, João Décio. Movimentos do espírito: matrizes, afinidades e territórios pentecostais (Org.). São Paulo: Paulinas. 2005. Coleção Ecclesia 21 REILY, Ducan Alexander. História documental do protestantismo no Brasil. São Paulo: ASTE, 1993.

SILVA, Amizael Gomes da. (Coord.). Igreja Assembleia de Deus: Os 75 anos de evangelismo em Rondônia - Jubileu de diamante. s.d. 
VINGREN, Ivar. Diário do pioneiro: Gunnar Vingren fundador das Assembleias de Deus no Brasil. Tradução de Ivar Vingren. Revisão Alexandre Coelho. Rio de Janeiro: CPAD, 2011.

. Despertamento apostólico no Brasil: resumo da missão pentecostal sueca no Brasil. 3. ed. Tradução de Ivar Vingren. Rio de Janeiro: CPAD, 1987.

WEBER, Max. Ciência e política. Duas vocações. Tradução de Jean Melville. São Paulo: Martin Claret, 2002. Coleção Obra Prima de cada Autor

. A Ética protestante e o espírito do capitalismo. Tradução de Pietro Nassetti. São Paulo: Martin Claret, 2007. Coleção Obra Prima de cada Autor

- Sociologia das religiões. Tradução de Claudio J. A. Rodrigues. São Paulo: Ícone, 2010. Coleção Fundamentos da Filosofia 


\section{FRAGMENTOS HISTÓRICOS DA EDUCAC̣ÃO TEOLÓGICA NO PENTECOSTALISMO BRASILEIRO NAS DUAS ÚLTIMAS DÉCADAS DO PERÍODO DA PRIMEIRA REPÚBLICA - 1910 A 1930: PRIMEIRAS TENTATIVAS METODOLÓGICAS}

Josué Passos de Melo

\section{INTRODUÇÃo}

Este artigo apresenta discussões sobre tópicos específicos do movimento pentecostal, sobretudo daquele pioneiro, iniciado na Amazônia nas duas últimas décadas do período da Primeira República - 1910 a 1930.

Pensar no tema fragmentos históricos da educação teológica no pentecostalismo brasileiro nos remete a um questionamento: quais foram as metodologias educacionais utilizadas na formação teológica dos quadros pastorais na primeira geração de pastores pentecostais no Brasil nas duas últimas décadas do período da Primeira República?

O estudo sobre os fragmentos históricos do movimento pentecostal brasileiro, surgido no Brasil no período da primeira República, disponíveis e acessíveis, é relevante porque é necessário investigar quais as metodologias de educação teológica eram utilizadas pelos primeiros pastores pentecostais e de que formas suas ideologias e doutrinas eram veiculadas.

Nossa pesquisa foi fundamentada na obra de Marc Bloch (2002), Michael De Certeau (2012) e Galvão e Lopes (2010), que orientam aspectos metodológicos específicos da pesquisa histórica, sendo que a última obra orienta a pesquisa em história da educação. Para determinar o tempo histórico, cronológico e social, no qual 
nossa pesquisa se deteve, utilizamos como referencial a obra de Leôncio Basbaum (1986) e a obra de Murilo e Carvalho (2007). Definimos o conceito específico pentecostalismo ou movimento pentecostal, de acordo com a obra de Oneide Bobsin (2002). O conceito protestante ou protestantismo, utilizamos a definição dos teólogos Duncan Reily (1992); Antônio Gouvêa Mendonça (1985); Emile G. Leonard (2002) e o conceito de religião, conforme Émile Durkheim (2003). Diversas obras foram consultadas e citadas nas referências.

Apresentamos, nesse artigo as nossas considerações, iniciando com um relato sobre o surgimento da Igreja Evangélica Assembleia de Deus no Brasil. Identificamos os fragmentos históricos nas obras que constituem o maior arcabouço bibliográfico reconhecido pela denominação Assembleia de Deus. No terceiro tópico apresentamos os referenciais teóricos sobre os quais construímos nossos argumentos. Em seguida descrevemos as metodologias utilizadas para a consecução da finalidade dos líderes pentecostais. Essas metodologias consistiam em fornecer ensino teológico aos pastores nos locais mais distantes da sede em Belém do Pará, a saber: os materiais impressos e as escolas bíblicas de obreiros.

Por fim, apresentamos nossas considerações como conclusão da pesquisa sobre o tema em que nos propusemos a estudar, sem maiores pretensões em esgotar o assunto, contudo, consideramos importante esse estudo, sobretudo do recorte cronológico aqui abordado, que poderá servir para abrir caminho para futuros pesquisadores que se interessarem pelo tema.

Os fragmentos históricos disponíveis e acessíveis nos permitiram concluir que os pioneiros do movimento pentecostal 
brasileiro, surgido no Brasil no período da primeira República, utilizavam como metodologias de educação teológica dos primeiros pastores pentecostais a veiculação de suas ideologias e doutrinas em revistas, jornais e nas escolas de obreiros que ocorriam anualmente.

\section{CONTRIBUições PARA UMA HistóRIA DA IGREJA EvangÉlica AsSEMbleia de DeUS No BRASIL}

Em razão de ter completado em 2011, oficialmente, cem anos de atuação no Brasil, a Igreja Evangélica Assembleia de Deus, maior expressão pentecostal nacional, promoveu expressiva propaganda das comemorações alusivas à data. Como parte dessas comemorações, houve o lançamento e relançamento de livros. Essas obras reconstituem a implantação e trajetória do movimento em solo brasileiro e, também, suas práticas e crenças doutrinárias. Segundo Durkheim (2003), esse arcabouço formado pelas práticas e crenças doutrinárias constitui a expressão concreta da fé.

A fim de nos situarmos no tempo e nos fatos históricos, faremos uma síntese dos fatos que constituem a gênese do Movimento Pentecostal no Brasil. Daremos especial ênfase na dinâmica histórica e no proselitismo, este último através dos elementos do colportismo, imprensa evangélica e escolas bíblicas.

\section{A GÊNESE DO MOVIMENTO PENTECOSTAL NO BRASIL}

Dois anos depois da chegada da família real portuguesa ao Brasil, no dia 19 de fevereiro de 1810, foi assinado o Tratado do Comércio e Navegação entre Portugal e Inglaterra. No artigo 12 desse Tratado, os ingleses e outros protestantes residentes no Brasil obtiveram a liberdade de cultuar livremente de acordo com os ritos 
de sua confissão de fé (Reily, 1993). Com isso, vários missionários americanos e europeus vieram para o Brasil, a fim de prestarem auxílio espiritual aos estrangeiros que aqui estavam cuidando dos interesses econômicos de sua nação e como imigrantes residentes definitivamente. (Leonard, 2002).

A partir da segunda metade do século XIX, no dia 10 de maio de 1855, chegou à cidade do Rio de Janeiro o missionário escocês Robert Reid Kalley (1809-1888). Ele empreendeu no Brasil, e para os brasileiros, a evangelização com o objetivo estritamente conversionista ao protestantismo (Leonard, 2002). Foi entre 1810 e 1910 que as denominações protestantes foram se estabelecendo em solo brasileiro.

Em mil novecentos e dez, cem anos após a assinatura do Tratado do Comércio e Navegação, chegaram ao Brasil dois missionários suecos: Daniel Berg e Adolph Gunnar Vingren. Estes suecos haviam ido aos Estados Unidos da América, motivados pelas ofertas de emprego na indústria americana que estava em crescimento. Naquele período (início do século XX), ocorreu pelo mundo notícias de que as igrejas protestantes americanas estavam experimentando manifestações que, cria-se ser do Espírito Santo (Jardilino, s.d.), conforme narrado na Bíblia, no livro de Atos dos Apóstolos, capítulo 2:

Chegou a festa de Pentecostes, e os crentes estavam todos reunidos em um só lugar. Repentinamente, veio do céu um som como de um vento muito forte e encheu toda a casa na qual estavam sentados. A seguir, viram o que pareciam línguas de fogo, que se separaram e pousaram sobre cada um deles. Todos ficaram cheios do Espírito Santo e começaram a falar línguas diferentes, conforme o Espírito os capacitava a falar (At. 2.1-6). 
A passagem dos suecos pelos Estados Unidos da América, possivelmente, tenha deixado marcas da piedade wesleyana neles. Assim é que Mariano (1999) defende como origem do pentecostalismo da Assembleia de Deus o "metodismo wesleyano" e o movimento da santidade dos negros americanos; cuja influência wesleyana foi expressiva, dando forte ênfase ao pietismo e ao emocional na forma de praticar a fé e de cultuar.

Daniel Berg e Adolph Gunnar Vingren partiram dos Estados Unidos da América no navio Clement (Conde, 1960). A dupla Chegou à cidade de Belém, Estado do Pará, em 19 de novembro de 1910 (Lima, 1991). Tinham como objetivo único a evangelização e o proselitismo em solo brasileiro (Berg, 1959). Conforme Bobsin (2002), Daniel Berg pertencia ao "pentecostalismo dos brancos" nos Estados Unidos da América, o que vai determinar a constituição patriarcal da denominação no Brasil.

O trabalho evangelístico e proselitista da dupla sueca teve como resultado a adesão de pessoas da cidade de Belém de tal forma que: "Através de uma pregação conversionista, de tom puritano, os novos crentes são levados a romper com os vícios, abandonando o tabaco, a cachaça e os jogos" (Bobsin, 2002, p. 72).

Daniel Berg e Adolph Gunnar Vingren pertenciam à Igreja Batista. Ao chegarem a Belém, foram recebidos pelo pastor batista Reverendo Eurico Nelson. Contudo, com algum tempo de convivência e devido às divergências teológicas (Reily, 1993), a dupla foi excluída da Igreja Batista.

Os dois membros expulsos foram acompanhados por dezessete pessoas daquela congregação e, juntos, fundaram a Igreja Evangélica Assembleia de Deus (Alencar, 2010), no dia 18 de junho de 1911, cuja sede situou-se à Rua Siqueira Mendes, número 
sessenta e sete, na cidade de Belém do Pará. Esse grupo de dezessete pessoas, oriundas da Igreja Batista de Belém, e os dois suecos perfaziam o efetivo da primeira Assembleia de Deus (Conde, 1960). Contudo, nas semanas seguintes, em decorrência das reuniões e da curiosidade de que eram objeto os estrangeiros, muitas pessoas se filiaram à nova forma de culto (Vingren, 1987).

Enquanto Daniel Berg trabalhava em uma empresa como fundidor a fim de prover sustento para ele e Gunnar Vingren, este aprendia o idioma português e, no período da noite, ensinava para Daniel Berg (Berg, 1959).

As primeiras ações para a expansão da empresa missionária, que essa dupla de suecos pentecostais pioneiros empreendeu nas selvas, cidades e vilas do vasto território que compõe o Estado do Pará, lograram êxito. A atividade de colportagem, que consistia na venda de exemplares da Bíblia, de porções do Novo Testamento e dos Evangelhos, foi a estratégia utilizada nos primeiros anos de divulgação da nova fé, resultando daí que: "Durante os primeiros três anos, o nosso irmão Daniel espalhou 2.000 Bíblias, 4.000 Novos Testamentos e 6.000 Evangelhos" (Vingren, 1987, p. 14). O patrocínio desse empreendimento foi obtido com os valores que Daniel Berg conseguiu juntar com o trabalho de fundição, cuja quantia era de 300 mil réis.

A implantação de comunidades da Assembleia de Deus em solo brasileiro, a partir do Estado do Pará, não ficou sem a oposição da Igreja Católica Apostólica Romana, que à época detinha a hegemonia religiosa no Brasil. Já as denominações protestantes sediadas em Belém apresentaram atitudes antagônicas em relação ao trabalho da Igreja Assembleia de Deus. O jornal Boas Novas, distribuído para todo o Brasil e Portugal, com 20 mil exemplares e 
27 páginas (Vingren, 1987), trazia muitas advertências contra os suecos e a "nova doutrina”. Até mesmo os atos sacramentais, como o batismo nas águas, eram realizados às altas horas da noite e em lugares e rios ermos (Vingren, 1973), em decorrência dos antagonismos sofridos.

Fica aqui o esclarecimento de que o Protestantismo é aquele segmento cristão formado pelas denominações, também reconhecidas como históricas, a saber: anglicanos, luteranos, batista, presbiterianos, metodistas, congregacionais, e as demais, cuja origem remonta ao período que a história convencionou a chamar da Reforma Protestante do século XVI (Reily, 1992; Mendonça, 1985; Leonard, 2002). Já os pentecostais são os grupos cuja matriz brasileira é formada pela Igreja evangélica Assembleia de Deus e Congregação Cristã no Brasil (Alencar, 2010; 2013).

As cidades e lugarejos do estado do Pará foram visitados por Daniel Berg, que organizou comunidades sob a liderança dos próprios nativos. Os caboclos e ribeirinhos pobres foram os primeiros a fazer parte da membresia da Assembleia de Deus. Os membros batizados que se mudavam para outros estados e outras regiões partiam com o objetivo, também, de iniciarem uma nova comunidade da Assembleia de Deus. Em decorrência das ações proselitistas, o trabalho se estendeu, sendo necessária a presença de um dos pastores, seja Vingren ou Berg, a fim de oficializar cada nova comunidade da Assembleia de Deus (Vingren, 1973, p. 74), de forma que: "[...] o pentecostalismo se inculturou no Brasil com mais rapidez do que o protestantismo de missão e imigração.” (Bobsin 2002, p. 74).

Nos anos que se seguiram até 1930, o movimento liderado por Berg e Vingren se expandiu e se fixou nas Regiões Norte e 
Nordeste do Brasil. Após esse período, o Sudeste e o Sul do Brasil se tornaram os territórios a serem alcançados pela empresa missionária da Assembleia de Deus. Era o fim da Primeira República e o início da Era Vargas com o advento do Estado Novo (Basbaum, 1986).

Alencar (2010) nos informa que a partir de 1930 a Assembleia de Deus se institucionalizou de maneira definitiva e passou a ser dirigida por pastores brasileiros. Estes primeiros vinte anos de trabalho da Assembleia de Deus foram classificados por esse mesmo autor como a "Primeira Fase: a implantação da 'seita' pentecostista” (Alencar, 2010). Contudo, Jardilino (s.d.) informa que a Assembleia de Deus só passou a ser pessoa jurídica em outubro do ano de 1946. Mariano (1999) localizou a Igreja Evangélica Assembleia de Deus como pertencente ao "pentecostalismo clássico", formado pelas denominações mais antigas, ou seja, pela Igreja evangélica Assembleia de Deus e a Congregação Cristã no Brasil.

No início do terceiro milênio, em específico no ano 2000, a Assembleia de Deus contava com 8.418.154 (oito milhões quatrocentos e dezoito mil e cento e cinquenta e quatro) adeptos. Esse contingente representava 32,12\% dos evangélicos do Brasil. A cidade de Porto Velho figurava em 2009 como a quarta capital onde a adesão ao pentecostalismo era maior com o percentual de 19,02\%. Ficava abaixo de Boa Vista-RR com 21.21\%, Belém-PA com 22,99\% e Rio Branco-AC com 28,43\%. Essa situação dava à Região Norte o status de ter a maior concentração de fiéis pentecostais do Brasil (Neri, 2011), cuja maior representação é a Igreja Evangélica Assembleia de Deus. 
De acordo com o Censo Demográfico do Instituto Brasileiro de Geografia e Estatística (IBGE, 2010), os evangélicos representam $22,1 \%$ da população. Dessa percentagem, mais da metade são evangélicos pentecostais e neopentecostais, ou seja, $13,3 \%$, ficando o restante distribuído entre evangélicos de missão (protestantismo histórico), com $4.0 \%$ e evangélicos não determinados $4.8 \%$.

A concentração de pentecostais e neopentecostais, conforme o IBGE (2010), é maior na Região Norte do Brasil, com 20,1\%. Em segundo lugar, ficou a Região Centro-Oeste com 16,6\%. Em terceiro lugar ficou a Região Sudeste com 14,3\%, a Região Sul ficou em quarto lugar com 10,9\% e em quinto e último lugar a Região Nordeste com 10,1\%.

Registra-se aqui, a existência da Congregação Cristã do Brasil, denominação que chegou ao Brasil também em 1910. De orientação Calvinista, foi fundada pelo ítalo-americano Louis Francescon. É a segunda maior igreja pentecostal (Lima, 1991).Em face da inexistência de registro (caso exista, não tivemos acesso) de que tenha contribuído para a educação teológica, essa denominação não será considerada nessa reflexão.

O Pentecostalismo deve ser tomado em nossa pesquisa pelo termo Pentecostal. Seguiremos a definição de Bobsin:

Não obstante sua diversidade interna e sua expansão nos mais diversos contextos socioculturais existentes no Brasil, o movimento pentecostal assume, a meu ver, as seguintes características: a) forte tradição oral, com destaque para a experiência religiosa emocional em detrimento da racionalidade ocidental; b) desenvolvimento em contextos urbanos, alcançando as camadas pobres da população; c) espontaneidade litúrgica, enfatizando o canto e a música, com ritmos 
populares; d) nas primeiras gerações, forte socialização dos meios de produção simbólicos; e) ênfase no Batismo do Espírito Santo, que distribui dons, destacando-se a glossolalia e a cura como selos de sua presença; f) desempenho de funções terapêuticas; g) ênfase na segunda vinda de Cristo e um suposto desinteresse pela política, embora apoiando quase sempre os setores políticos conservadores, principalmente suas grandes lideranças que divergem sempre mais de posturas de base; h) bastante hierárquico no plano institucional, compensando este verticalismo com uma "democracia" dos dons no plano espiritual; i) marcadamente antiecumênico, desferindo ataques contra o catolicismo santorial e o papa, além da concorrência entre iguais concorrência intrapentencostal (Bobsin, 2002, p. 65).

Essa definição é recente, considerando sua formulação e o início o movimento em estudo, mas define muito bem o pentecostalismo que se fixou no Brasil em 1910.

\section{FRAGMENTOS HISTÓRICOS PARA A EDUCAÇÃO TEOLÓGICA}

As denominações do protestantismo histórico trouxeram em seu programa missionário a educação teológica. Aqui no Brasil, conforme Mendonça (1984, p. 203): “A unidade teológica produziu, desde o início, franca colaboração entre os protestantes. Os presbiterianos colaboraram e receberam colaboração dos congregacionais, anglicanos do Rio e luteranos de Nova Friburgo”.

Existem várias obras que reconstituem a história da trajetória da educação teológica nas denominações históricas. Nossa intenção foi de nos prendermos nas fontes literárias que nos forneceram os "fragmentos" que comprovassem a existência de uma educação teológica no Movimento Pentecostal, ainda em seu início, no Brasil. 
Fernandes (2006, p. 97) nos adverte que, nos primeiros anos da Assembleia de Deus no Brasil, a educação teológica foi construída na informalidade. Os missionários suecos não olhavam com simpatia, a formação teológica com maior formalidade e estrutura. Daí, o incipiente investimento. Priorizou-se a experiência.

\section{FUNDAMENTAÇÃO TEÓRICA E METODOLÓGICA}

O conceito de fragmento histórico utilizado nesse trabalho é aquele segundo a definição construída por De Certeau (2010), que apresenta o cerne, o conteúdo ou ainda, o pedaço de verdade esquecido: "Este fragmento, pedaço duro, cortante e cortado faz proliferar o corpo da Saga judia [...]” (De Certeau, 2010, p. 307). De Certeau se refere à obra de Freud "Moisés e o monoteísmo" (2010, p. 301), utilizada para exemplificar como identificar fragmentos e vestígios na fonte histórica. Esses fragmentos são "pedacinhos de verdade" (De Certeau, 2010, p. 308).

Corroboram com De Certeau Lopes e Galvão (2010, p. 65), sobre o fragmento histórico como fonte, contudo, considerando seus limites, ao dizerem que:

O passado nunca será plenamente conhecido e compreendido. No limite, podemos apenas entender seus fragmentos. E ainda: certamente isso se dá por meio dos traços que foram deixados, dos vestígios não apagados.

Sobre a concepção de vestígio histórico, Bloch (2001, p. 72) informa que: "[...] vestígios do passado nos oferecem um acesso do mesmíssimo nível”. Se referindo às fontes arqueológicas materializadas no artefato Bloch (2001, p. 73) vai além, ao defender que: 
[...] os documentos materiais não são, longe disso, os únicos a possuir esse privilégio de poderem ser apreendidos de primeira mão. Ele conclui dizendo: Como primeira característica, o conhecimento de todos os fatos humanos no passado, da maior parte deles no presente, deve ser [...], um conhecimento através de vestígios.

Fundamentados e orientados nessa concepção de De Certeau e Bloch, realizamos a análise das narrativas dos escritos deixados por personagens que foram protagonistas da implantação da educação teológica do movimento pentecostal e ou estiveram próximos deles. Narrativas que se constituem como vestígios e fragmentos históricos.

No período da Primeira República, para atingir os objetivos educacionais, muito se utilizou de material impresso para construção do que veio a ser um sistema de alfabetização no Brasil. Mathieson (2013) nos informa que:

Compreender a educação no começo do século 20 no Brasil significa, em alguma medida, entender o processo de alfabetização da população. Assim, é por meio do ensino dos rudimentos da leitura, da escrita e dos cálculos que se configuram as orientações morais do projeto republicano de civilizar o povo. A escola, aos olhos da época, visava a erradicar a ignorância que grassava por todo o país. Buscava-se preparar a nação brasileira para a sedimentação da recente República (Mathieson, 2013).

A divulgação e acessibilidade ao ensino e doutrinamento, seja na educação laica ou teológica, superando o obstáculo da grande extensão territorial do Brasil e os escassos meios de transporte e comunicação, às instituições, poucas alternativas se apresentavam. Assim, conforme Mathieson (2013) 
A imprensa periódica pedagógica teve um papel fundamental no começo do século 20 ao projetar mudanças no campo educativo a partir, de um lado, da prescrição das ações escolares por meio da publicação dos seus artigos e, de outro, pelo debate geral das questões educacionais da época. A análise histórica, pela óptica da cultura escolar, permite compreender a gradual constituição histórica das instituições escolares, da formação de professores, das concepções pedagógicas, dos métodos de ensino. Pela leitura dos artigos da Revista de Ensino pode-se observar que neles perpassam concepções pedagógicas e visões de mundo aptas a transmitir parte da dimensão social da época estudada. Naquele momento, os artigos representavam um meio inovador e dinâmico de difusão dos temas abordados, sendo necessário que o leitor desse tipo de material já tivesse previamente algum conhecimento e prática sobre os assuntos educacionais (Mathieson, 2013).

E assim Basbaum (1986) distingue o período em que os marechais militares governaram o Brasil como Primeira República: "A república onde dominou sobretudo a espada [...]" (Basbaum, 1986, p. 46). Já o período em que o governo foi exercido por membros civis das oligarquias cafeeiras, esse historiador o chamou de: "2a República, a era do café e do PRP (Partido Republicano Paulista), o Partido em cujas mãos se encontravam a riqueza do país e em cujas terras vivia a maioria da população brasileira” (Basbaum, 1986, p. 46).

Carvalho (2007) concorda com Basbaum (1986) sobre a fase do "governo militar", mas identifica como Primeira República o período que foi da Proclamação, em 1889, até 1930, ano em que a administração do governo da República sai das mãos dos políticos de São Paulo e de Minas Gerais, representantes das oligarquias 
cafeeiras e pecuaristas, respectivamente, e passa para as mãos dos políticos do Rio Grande do Sul.

Para nos situar cronologicamente, adotamos o ponto de vista de Carvalho que aceita os primeiros quarenta e um anos do Brasil República (1889 - 1930), como Primeira República, também denominada “República Café com Leite”.

\section{Educação Teológica Pentecostal: Primeiras TENTATIVAS METODOLÓGICAS}

A educação teológica de natureza protestante é uma prática existente no Brasil desde o século XIX e foi trazida pelos primeiros pastores protestantes das igrejas históricas. Segundo Neto (1991, p. 17):

A educação teológica tem como uma das metas principais formar pastores, formar líderes, para dirigirem não só as comunidades locais, como também instâncias eclesiásticas onde os destinos das igrejas são decididos.

Tomaremos essa concepção para falar em nossa reflexão sobre educação teológica, cuja principal motivação era a formação e líderes clérigos para a consolidação das instituições religiosas em solo brasileiro. Conforme Jardilino (s.d., p. 81): "A linguagem teológica expressa na doutrina da conversão/santificação remonta a uma herança dos pais fundadores do pentecostalismo". Essa estrutura de discurso perdura até os dias atuais. O pastor é aquele que ensina e divulga a doutrina e, também, zela pela pureza do ensino e doutrinamento. 


\section{MATERIAIS IMPRESSOS}

Os materiais impressos representaram uma tecnologia significativa nas primeiras décadas do século $\mathrm{XX}$, sobretudo para a evangelização, apesar dos poucos recursos financeiros do movimento pentecostal e o alto custo com a impressão.

A seguir apresentaremos tópicos que resgatam historicamente, a utilização e materiais impressos no processo de formação de obreiros no pentecostalismo do início do século XX.

\section{Jornais}

Conforme afirmamos acima, o serviço de colportagem (Araújo, 2011) foi a metodologia utilizada pelos pastores Daniel Berg e Adolph Gunnar Vingren para se aproximarem das comunidades e das pessoas (Berg, 1959) e, assim, transmitirem a nova doutrina (Conde, 1960). Essa maneira de comercialização era comum no Brasil. Os negociantes de uma grande variedade de mercadorias: gêneros alimentícios, tecidos, ferramentas, etc. utilizavam esse método, e ficaram conhecidos por muitos nomes: mascates, regatão, caixeiro viajante e outros. O método da colportagem foi muito utilizado naquela época, pelos líderes da Assembleia de Deus (Araújo, 2011).

Como metodologia para capacitar os novos líderes locais das congregações da Assembleia de Deus, com suporte mínimo do conteúdo dos ensinos religiosos (Oliveira, 1998), e em face das grandes distâncias e da inexistência de educação teológica formal, foi utilizada a confecção e distribuição de jornais. Conforme Oliveira (1998, p. 148): 
A "Voz da Verdade", que circulava em Belém do Pará sob a responsabilidade de Almeida Sobrinho e João Trigueiro. Em seu número 1, em novembro de 1917, ele noticiava: "Os nossos irmãos Samuel Nyström e Daniel Berg em viagem evangelística que fizeram em seis igrejas da fé apostólica, no interior do estado, batizaram 90 pessoas".

O jornal Voz da Verdade, apesar de não ser oficial da Assembleia de Deus, foi utilizado para divulgação doutrinária, proselitismo e avisos em geral. Não se admitia artigo de caráter crítico ou polêmico (Araújo, 2011). O artigo, na primeira página, do primeiro número, em 1917, trazia o título: "Jesus é quem batiza no Espírito Santo e fogo" (Araújo, 2011, p. 124). Suspeita-se de que houve apenas um único número do jornal Voz da Verdade (Alencar, 2010).

Esse periódico teve duração de dois meses (Araújo 201). Foi substituído pelo jornal revista Boa Semente, lançado em janeiro de 1919 (Oliveira, 1998). Este, sim, era um periódico institucional, gerenciado e editado pela liderança da Assembleia de Deus: "Em dezembro de 1918, o irmão Vingren começou a editar a nossa primeira revista que se chamou 'A Boa Semente' e que se distribuía gratuitamente" (Vingren, 1987). Conforme Alencar (2010, p. 79), os temas de maiores expressões nesse periódico eram: "Compromisso, Evangelismo, Poesia, Apologia, Doutrina, Escatologia, Pessoa de Jesus Cristo, Conforto na Tribulação, Oração e Diversos”. O periódico Boa Semente tinha uma tiragem de três mil exemplares e, a partir de 1921, havia a publicação de três números ao ano (Vingren, 1987).

Adolph Gunnar Vingren era o nome mais importante do jornal revista, pois era o único que tinha formação adequada e 
superior em seminário teológico. Estudou no Seminário Batista Sueco, na cidade de Chicago, dos Estados Unidos da América (Alencar, 2010).

O jornal Revista A Boa Semente tinha como redatores os missionários Samuel Nyström, Nels Nelson e Plácido Aristóteles (Araújo, 2011). Na edição de janeiro de 1919, Adolph Gunnar Vingren publicou o artigo de sua autoria, cujo título foi: "O Batismo no Espírito Santo" (Mesquita, 2004, p. 19), tema principal da teologia pentecostal.

Com a transferência do missionário Adolph Gunnar Vingren para cidade do Rio de Janeiro, ele fundou, naquela cidade, o jornal Som Alegre, em novembro do ano de 1929 (Araújo, 2011). Esse periódico circulou até o ano de 1930 (Oliveira, 1998). O jornal tinha caráter, propriamente, para divulgação doutrinária, o que se conhece no meio evangélico como "evangelização".

Tem-se por certo que a criação do jornal Som Alegre foi em decorrência da divergência doutrinária entre Vingren e Samuel Nyström, em relação à aceitação do trabalho feminino na igreja (Araújo, 2011). Diga-se trabalho feminino na igreja a ordenação de mulheres como pastoras, o que não é aceito na Igreja Assembleia de Deus e em outras denominações evangélicas, até os dias de hoje.

Assim, surgiram no Brasil: "[...] dois jornais assembleianos num país com maioria analfabeta”. (Alencar, 2010, p. 78). Ficou o jornal Boa Semente sediado em Belém do Pará e o jornal Som Alegre sediado na cidade do Rio de Janeiro. O primeiro de caráter formativo e o segundo de caráter informativo (Araújo, 2011).

A criação do jornal Mensageiro da Paz, em 1930, como órgão oficial da Assembleia de Deus no Brasil, pôs fim às divergências, já 
que a direção do novo jornal ficou sob a responsabilidade dos missionários divergentes Adolph Gunnar Vingren e Samuel Nyström e a sede do jornal ficou no Rio de Janeiro (Vingren, 1987). A decisão de se criar um único jornal partiu da Convenção Geral das Assembleias de Deus (Daniel, 2004), cuja reunião ocorreu de 5 a 10 de setembro de 1930, na cidade de Natal, estado do Rio Grande do Norte (Araújo, 2011). A primeira edição do jornal Mensageiro da Paz foi publicada em dezembro de 1930 (Oliveira, 1998). A circulação desse jornal permanece até os dias atuais e em todo o Brasil, sendo um número editado mensalmente.

O Mensageiro da Paz reúne todas as características dos dois jornais que substituiu, acrescidas de outras que a modernidade e o crescimento geraram. É possível encontrar em suas páginas: doutrinas, notícias, avisos, convocações, apologias doutrinárias, mensagem proselitistas, anúncios comerciais, divulgação de livros, obituários, sermões, hinos, felicitações, etc. “[...], foi o principal fator de consolidação desta nascente igreja" (Alencar, 2010, p. 113). O referido autor (Alencar, 2010, p. 116) relaciona as seguintes "ênfases teológicas nos textos: Compromisso, Evangelismo, Poesia, Apologia Pentecostal, Doutrina, Escatologia, Pessoa de Jesus Cristo, Conforto na Tribulação e Oração".

\section{Revistas da Escola Dominical}

As revistas para escola dominical, tão utilizadas e difundidas até a atualidade, vinham como suplemento do jornal Boa Semente (Oliveira, 1998). Sobre essas publicações, Araújo (2011, p. 136) nos informa que:

O suplemento era destinado, a princípio, para aqueles membros da igreja considerados pelos 
missionários e pastores como "vocacionados" para serem os "novos pregadores/ensinadores", ou seja, os novos obreiros da causa da igreja - e do movimento pentecostal - nos primeiros anos de sua implantação em solo brasileiro.

A partir do segundo semestre do ano de 1938, os membros infantis da Assembleia de Deus, tiveram uma revista Lições Bíblicas específicas para essa faixa etária (Araújo, 2011).

Essa metodologia ainda é utilizada atualmente: "Esta realidade evidencia a importância das Lições Bíblicas, no que diz respeito à unidade doutrinária das Assembleias de Deus e à teologia ensinada no país" (Oliveira 1998, p. 168). O que foi ampliado é o alcance da revista que contempla, não apenas os obreiros, mas, toda membresia da Assembleia de Deus.

\section{EVENTOS PRESENCIAIS}

No início do século XX o acesso aos centros de maior concentração populacional era muito eficiente, sobretudo na Amazônia em decorrência das grandes distâncias e as precárias vias de acesso, que era predominantemente, pelas vias fluviais.

Contudo, eventos presenciais ocorriam anualmente no seio do movimento pentecostal: eram as escolas bíblicas de obreiros, tema de a nossa abordagem a seguir.

\section{As escolas bíblicas de obreiro}

O ensino teológico formal e institucionalizado na Igreja Evangélica Assembleia de Deus só ocorreu muito depois da Era Vargas, em 1958, com a fundação do Instituto Bíblico das Assembleias de Deus (IBAD). Porém, o debate sobre o ensino 
teológico já ocorria desde 1943 (Araújo, 2011). Segundo nos informa Oliveira (1998, p. 191):

Desde o início, as lideranças da igreja têm-se voltado para o ensino da Palavra de Deus. Antes das convenções nacionais, nas primeiras convenções nos estados - ocasião em que, ao lado do exame de questões doutrinárias e administrativas, pastores ministravam estudos das Escrituras - havia as Escolas Bíblicas.

A primeira escola bíblica de obreiro ocorreu em 1922. De 4 de março a 4 de abril. Nessa época, já havia pastores brasileiros ordenados, mas, sem instrução teológica suficiente. Essa prática de realizar escolas bíblicas, anualmente, foi a maneira de equacionar essa deficiência. Conforme Araújo (2011, p. 170):

Esses períodos de dias destinados a que obreiros participem de estudos bíblicos de curta duração, quando começaram a ser realizados, duravam um mês e tinham como propósito a formação bíblico-espiritual e ministerial dos participantes. Depois dessa fase de aprendizado o obreiro era liberado para o exercício pastoral. De maneira geral esses encontros eram destinados à oração e estudo da Bíblia.

Araújo (2011, p. 170) nos informa ainda, que: "As Escolas Bíblicas foram oficializadas pela Convenção Geral de 1943, no Rio de Janeiro, quando pastores debateram a necessidade de os obreiros receberem melhor preparo bíblico e teológico".

Na atualidade, a Igreja Assembleia de Deus, apesar de possuir vários seminários e faculdades, mantém a realização anual da Escola de Obreiros. Esses eventos servem também, para a divulgação e distribuição dos produtos da Casa Publicadora das Assembleias de Deus. 
Sobre as metodologias educacionais da Assembleia de Deus para o período em que estamos estudando, Alencar (2010, p. 135) afirma que: "[...] em 1917, ela usou o que havia de mais moderno na comunicação da época: o jornal impresso”. Acrescentamos a esse recurso tecnológico a revista Escola Dominical e a Escola Bíblica de Obreiro, evento presencial.

\section{CONSIDERAÇÕES FINAIS}

Neste trabalho, procuramos apontar fatos identificados como fragmentos históricos da educação teológica no Pentecostalismo brasileiro nas duas últimas décadas do período da Primeira República. Em seguida, numeramos, a partir dos fragmentos históricos apontados, as metodologias utilizadas na educação teológica no pentecostalismo brasileiro do período, ou seja, de 1910 a 1930.

Consultamos as obras produzidas pelos pioneiros do Movimento Pentecostal e as que foram elaboradas a partir delas. Nessas últimas constam algumas análises e explicações, que de modo sistemático, corroboram com a proposta do trabalho que apresentamos.

Constamos que os pioneiros do movimento pentecostal brasileiro, surgido no Brasil nas duas últimas décadas da Primeira República utilizavam como metodologias de educação teológica dos primeiros pastores pentecostais, veiculando suas ideologias e doutrinas em revistas, jornais e nas escolas de obreiros que ocorriam e ocorrem anualmente.

O primeiro jornal, o Voz da Verdade, nos primeiros sete anos da fundação da denominação Assembleia de Deus, teve curta duração. Não era produzido pela instituição e nem pelos missionários estrangeiros. Foi iniciativa de pastores brasileiros. $\mathrm{O}$ 
segundo jornal foi A Boa Semente. Periódico oficial da instituição e dirigido pelos missionários suecos. Sua sede ficava na cidade de Belém do Pará e era distribuído para o Norte e Nordeste do Brasil.

Enquanto o jornal Boa Semente, do Norte do Brasil, atendia toda a Amazônia, o jornal Som Alegre, sediado no Rio de Janeiro e dirigido por Gunnar Vingren, atendia às igrejas localizadas naquela região Sudeste/Sul do País.

A partir de 1930, resultado da decisão das maiores autoridades da Assembleia de Deus, os jornais Boa Semente e Som Alegre se fundiram para formar o jornal Mensageiro da Paz, periódico com edição mensal; que passou a ser distribuído para as igrejas da Assembleia de Deus localizada em todo o território nacional brasileiro.

Junto à distribuição dos jornais, havia a publicação da revista da escola dominical que cobre um espaço temporal de um trimestre. Começou vindo como encarte no jornal Boa Semente. Depois teve edição própria. De início o nome era Escola Dominicaes. Hoje carrega o título de Lições Bíblicas.

Aliados a esses materiais impressos, ocorriam as Escolas Bíblicas de Obreiros, anualmente. Nesses eventos os líderes estrangeiros se reunião para deliberarem os destinos da instituição. Aos pastores brasileiros era permitido acompanhar as orações e os estudos bíblicos. Na atualidade, a Escola Bíblica de Obreiro ocorre em data específica e com finalidade apenas educacional. As reuniões administrativas e deliberativas ocorrem nas assim, chamadas Convenções Estaduais e Convenções Gerais das Assembleias de Deus no Brasil.

As narrativas consultadas contribuíram para compreender o pensamento dos primeiros líderes do Movimento Pentecostal 
quanto à necessidade de viabilizar educação teológica aos pastores. Ainda foi possível identificar os registros de fatos históricos que revelam a preocupação dos líderes pioneiros desse Movimento, com a educação teológica daquela geração de pastores pentecostais. Além disso, apontam para fatos, que nessa pesquisa qualificamos como fragmentos históricos da educação teológica no pentecostalismo brasileiro no período estudado. Finalmente, enumeram, a partir dos fragmentos históricos apontados, as metodologias utilizadas na educação teológica no pentecostalismo brasileiro nas duas últimas décadas durante a primeira República.

\section{REFERÊNCIAS}

ALENCAR, Gedeon. As Assembleias de Deus: origem, implantação e militância (1911-1946). São Paulo: Arte Editorial, 2010.

. Matriz pentecostal brasileira: Assembleia de Deus 19112011. Rio de Janeiro: Novos Diálogos, 2013. Coleção Protestantismo e Sociedade

ARAUJO, Isael. 100 acontecimentos que marcaram a história das Assembleias de Deus no Brasil. Rio de Janeiro: CPAD, 2011.

. Dicionário do movimento pentecostal. Rio de Janeiro: CPAD, 2007.

BASBAUM, Leôncio. História sincera da República: de 1889 a 1930. 5. ed. São Paulo: Alfa-Ômega, 1986

BERG, Daniel. Enviados por Deus: memórias de Daniel Berg. Rio de Janeiro: CPAD, 1959.

BLOCH, Marc. Apologia da história: ou o ofício do historiador. Tradução André Telles. Rio de Janeiro: Zahar, 2001. 
BOBSIN, Oneide. Correntes religiosas e globalização. Curitibanos; São Leopoldo: Pastoral Popular Luterana; CEBI; IEPG, 2002.

CARVALHO, José Murilo de. A formação das almas: o imaginário da República no Brasil. Vol. 2. São Paulo: Cia da Letras, 2007.

CERTEAU, Michel de. A escrita da história. Tradução Maria de Lourdes Menezes; revisão Arno Vogel. 2. ed. Rio de Janeiro: Forense Universitária, 2012.

CONDE, Emílio. História das Assembleias de Deus no Brasil. Rio de Janeiro: CPAD, 1960.

DANIEL, Silas. História da convenção geral das Assembleias de Deus no Brasil: os principais líderes, debates e resoluções do órgão que mudou a face do movimento pentecostal brasileiro. Rio de Janeiro: CPAD, 2004.

DURKHEIM, Émile. As formas elementares da vida religiosa. Tradução Paulo Neves; revisão Eduardo Brandão. São Paulo: Martins Fontes, 2003.

FERNANDES, Rubeneide Oliveira Lima. Movimento Pentecostal, Assembleia de Deus e o estabelecimento da educação formal. Piracicaba: Unimep, 2006. Cap. 3, item 3.4.1, p. 97.

GALVÃO, Ana Maria de Oliveira; LOPES, Eliane Marta Teixeira. Território plural: a pesquisa em história da educação. São Paulo: Ática, 2010.

JARDILINO, José Rubens de Lima. As religiões do espírito: visão histórico-teológica do pentecostalismo na década de 30. Rio de Janeiro; São Paulo: ISER/CEPE, s.d. 
LÉONARD, Émille G. O protestantismo brasileiro. 3. ed. Tradução Linneu de Camargo Schützer. São Paulo: ASTE, 2002.

LIMA, Delcio Monteiro de. Os demônios descem do Norte. 5. ed. Rio de Janeiro: Francisco Alves, 1991.

MARIANO, Ricardo. Neopentecostais: sociologia do novo pentecostalismo no Brasil. São Paulo: Loyola. 1999.

MATHIESON, Louisa Campbell. Educação na Primeira República: alfabetização e cultura escolar na Revista de Ensino (1902-1910). Santa Maria, set./dez. 2013. História da Educação. Disponível em: <www.scielo.br/scielo>. Acesso em: 5 jun. 2014.

MENDONÇA, Antônio Gouvêa. O celeste porvir: a inserção do protestantismo no Brasil. São Paulo, SP, Paulinas. 1984.

MESQUITA, Antônio Pereira de (Editor). Mensageiro da paz: os artigos que marcaram a história e a teologia do Movimento Pentecostal no Brasil. Rio de Janeiro, RJ. CPAD. 2004 (Coleção Artigos Históricos volume 1).

NERI, Marcelo Cortês (coord.). Novo Mapa das Religiões. Rio de Janeiro, RO. FGV/CPS. 2011. Disponível em: <www.fgv.br/cps/religiao>. Acesso em: 7 set. 2013.

NETO, Luiz Longuini. Educação teológica contextualizada: análise e interpretação da presença da ASTE no Brasil. São Paulo: ASTE, 1991.

OLIVEIRA, Joanyr de. As Assembleias de Deus no Brasil: sumário histórico ilustrado. Revisão Judson Canto e Isael Araújo. 2. ed. Rio de Janeiro, RJ. CPAD. 1998. 
REILY, Duncan Alexander. História documental do protestantismo no Brasil. Segunda impressão revisada pelo autor. São Paulo: ASTE. 1993

VINGREN, Gunnar. Diário do pioneiro. Tradução de Ivar Vingren. Rio de Janeiro: CPAD. 1973.

VINGREN, Ivar. Despertamento apostólico no Brasil. 3. ed. Rio de Janeiro: CPAD. 1987. 
19

\title{
Catequese e ASSistencialismo no Vale do GUAPORÉ/MAMORÉ(RO), FRONTEIRA BRASIL-BOLÍVIA
}

\author{
Joely Coelho Santiago ${ }^{80}$ \\ Rosália Aparecida da Silva ${ }^{81}$ \\ Auxiliadora dos Santos Pinto ${ }^{82}$
}

\section{INTRODUÇÃo}

O presente artigo apresenta resultados de uma análise literária da obra Memórias de Monsenhor Francisco Xavier: Dom Rey, de autoria da escritora Izabel de Oliveira Assunção, destacando-se os elementos regionais, como as ações de catequese e assistencialismo implantadas durante o trabalho missionário pelo primeiro bispo do município de Guajará-Mirim(RO), Francisco Xavier Rey, popular Dom Rey.

$\mathrm{O}$ estudo da obra foi norteado pelos seguintes questionamentos: quais as principais características estéticocomposicionais da obra literária "Memórias de Monsenhor

${ }^{80}$ Mestra em História e Estudos Culturais/UNIR. Pesquisadora de comunidades remanescentes de quilombos do estado de Rondônia. Integrante no grupo de Estudos Interdisciplinares das Fronteiras Amazônicas (Geifa). Integrante no grupo de Estudos e Pesquisas Interdisciplinares Afros e Amazônicos (Gepiaa). Email: joelicoelhosantiago@live.com

81 Mestra em Letras/UNIR. Integrante do Grupo de Estudos em Educação, Filosofia Tecnologias (GET/IFRO) e do Grupo de Estudos Integrados sobre a Aquisição da Linguagem (GEAL/UNIR). E-mail: rosalia.silva@ifro.edu.br

82 Doutora em Letras/Ibilce/Unesp/SJRP. Vice-líder do grupo de Estudos Interdisciplinares das Fronteiras Amazônicas (Geifa). Integrante do Grupo de Pesquisa em Poesia Contemporânea de Autoria Feminina do Norte, Nordeste e Centro-Oeste (Gpfennco).E-mail: auxiliadorapinto@unir.br 
Francisco Xavier: Dom Rey"? De que forma as questões regionais se inserem na obra em epígrafe? Qual a importância da obra de Izabel de Oliveira Assunção para a constituição da Literatura regional/amazônica?

Para desenvolver o estudo, partimos das seguintes proposições: a produção literária da escritora regional Izabel de Oliveira Assunção contribui, de forma significativa, para a constituição da Literatura amazônica, visto que, há escassas produções que estudam esse contexto regional. Assim sendo, a obra “Memórias de Monsenhor Francisco Xavier: Dom Rey" pode ser classificada na vertente Literatura amazônica. Nela, as belezas naturais do Vale do Guaporé, Mamoré e afluentes, tanto do lado esquerdo como o do lado direito, aborda um contexto de fronteira (Brasil-Bolívia), e são retratadas na obra com riqueza de detalhes.

O tema central do livro está em expressar aspectos da formação religiosa, missionária, política e social, especificamente, do Vale do Guaporé e Mamoré, no contexto da Amazônia. Como também, Memórias de Monsenhor Francisco Xavier Rey: Dom Rey apresenta traços característicos da Literatura regional/amazônica e uma inter-relação entre a literatura e a história, a qual é apresentada a partir da reconstituição da memória individual e coletiva. É importante mencionar que, na obra em epígrafe, a memória é utilizada como um recurso estético-composicional.

A relevância do estudo desta temática justifica-se, porque no contexto regional ainda há poucas pesquisas no campo da Literatura regional/amazônica. Trata-se de uma obra relatoexperiência na região do Vale do Guaporé, Mamoré, uma das regiões mais exuberantes da Amazônia rondoniense, fronteira entre o Brasil e a Bolívia. Nesse sentido, o estudo da referida obra contribuirá para o registro e a valorização do trabalho realizado por 
Dom Rey em defesa das populações excluídas, dentre elas, a população indígena, migrante, boliviana, remanescente de quilombos e outras. Não obstante, a obra, também, contribuirá para a conscientização sobre a importância da preservação ambiental, uma vez que os moradores da região travam luta jurídica pela demarcação e titulação de suas terras; além de oferecer subsídios a pesquisadores que se dedicam a essa temática, de maneira que possa incentivar novos estudos sobre a vertente da Literatura amazônica e como suporte de informação à sociedade em geral.

O objetivo geral da pesquisa foi realizar uma análise literária na obra "Memórias de Monsenhor Francisco Xavier: Dom Rey", de autoria da escritora Izabel de Oliveira Assunção, destacando-se os elementos estético-composicionais da obra em estudo. Para atingir o objetivo geral, propusemos os seguintes objetivos específicos: Elaborar uma breve biografia da escritora Izabel de Oliveira Assunção; Identificar e analisar a característica da Literatura regional/amazônica da obra literária "Memórias de Monsenhor Francisco Xavier: Dom Rey”; Abordar, a partir da obra, questões relativas aos aspectos da formação religiosa, missionária, política e social, especificamente, no Vale do Guaporé, no contexto da Amazônia; Mostrar de que forma a obra ficcional contribui para o registro e valorização da história, da memória e das identidades culturais dos povos amazônicos, principalmente, a história dos povos que viveram/vivem no Vale do Guaporé, em Rondônia.

A pesquisa foi fundamentada pelos estudos de teóricos, destacando-se as obras dos seguintes autores: Halbwachs (2015), Bosi (2004; 2013), Loureiro (1997; 2014), Candido (2004, 2006), Perrot (1988), Souza (2014), Williams (1979), Bezerra (2012), dentre outros. De natureza descritiva, a pesquisa bibliográfica, foi desenvolvida no período de outubro a dezembro de 2020. Quanto a análise literária da obra Memórias de Monsenhor Francisco Xavier 
Rey: Dom Rey, ela foi feita a partir da elaboração de um roteiro contendo três partes, em que inicialmente estão breves considerações sobre literatura (s) e cultura. Na segunda, parte, retrata-se a vida e a obra de Izabel de Oliveira Assunção. E, por fim, a última parte traz a identificação e a análise das características estético-composicionais da obra em estudo.

Os resultados da pesquisa apontam a relevância da produção literária da escritora Izabel de Oliveira Assunção para a constituição da literatura regional/amazônica a partir de Memórias de Monsenhor Francisco Xavier Rey: Dom Rey.

\section{LITERATURA(S) E CULTURA: BREVES CONSIDERAÇÕES}

A Amazônia representa um universo de possibilidades diante de sua (bio)diversidade, sendo um bioma inserido em oito diferentes países além do Brasil (Bolívia, Colômbia, Equador, Guiana, Guiana Francesa, Peru, Suriname e Venezuela), e internamente chegando a nove estados brasileiros (Acre, Amapá, Amazonas, Mato Grosso, Pará, Rondônia, Roraima, Tocantins e Maranhão), na denominada Amazônia Legal ${ }^{83}$. Essa ligação local e global inserida em seu todo não seria diferente no tocante à sua literatura. De acordo com Loureiro (2014), no artigo intitulado "Mundamazônico: do local ao global", a Literatura amazônica apresenta uma estética singular:

[...] o amazônico da estética amazônica não é propriamente a forma: o amazônico da estética amazônica é aquilo que emerge dessa forma, é aquilo que emerge do

83 Amazônia Legal. Disponível em: <www.ibge.gov.br/geociencias/cartas-emapas/mapas-regionais/15819-amazonia-legal.html? $=\mathcal{E} \mathrm{t}=\mathrm{O}-\mathrm{que}-\mathrm{e}>$. Acesso em: 8 dez. 2020. 
vitral, é o ethos amazônico, é uma forma de amazonicidade que emerge da obra que você percebe mais como modo de sentir do que propriamente como modo de demonstração racional (Loureiro, 2014, p. 33).

O autor também afirma que na Amazônia temos a estética urbana e a estética rural:

[...] a estética urbana, que é aquela que tem mais diálogo com outras estéticas mais atualizadas em cada época”; e por sua vez: “[...] a estética ribeirinha, que tem traços perceptíveis: quando se anda ao longo dos rios, sabemos olhar as margens e ver o que nos revela. [...] (Loureiro, 2014, p. 35).

Entretanto, as discussões que envolvem os temas local/global são complexas e, muitas vezes, antagônicas. Alguns autores defendem que a estética amazônica é singular. Para outros, o que existe é uma literatura brasileira. Nesse sentido, no artigo intitulado "Literatura na Amazônia, ou Literatura amazônica?" Souza (2014) apresenta reflexões sobre os termos amazônico/regional, afirmando que esses conceitos são rótulos:

[...] O que precisamos é fugir do risco de nos deixarmos capturar em guetos, onde os parâmetros de recepção de nossas obras não são de excelência literária, mas fruto da condescendência porque somos pobres e moramos longe (Souza, 2014, p. 25).

Também é oportuno destacar as discussões apresentadas por Bezerra (2012), que ao falar sobre o sistema literário amazônico defende haver nele uma hibridez:

[...] as produções culturais na região amazônica não estão apenas ligadas à ideia de uma cultura letrada, das belas letras, das belas artes, buscando sempre 
elementos universalizantes, mas que as culturas amazônicas e, portanto, a sua produção e recepção artística são híbridas (Bezerra, 2012, p.3).

Corroborando as ideias de Bezerra (2012), Mendes (2011) ${ }^{84}$, no artigo "Literatura Amazônica" afirma que: "Discorrer a respeito da Literatura Amazônica constitui um desafio para qualquer estudioso do tema, pois todo assunto envolvendo a Amazônia tende a agigantar-se quando nos debruçamos sobre ele. [...]”. A partir das concepções apresentadas pelos autores, é possível afirmar que a Literatura Amazônica é constituída por símbolos e elementos que emergem do imaginário social, tendo, assim, características bem diversificadas.

Nessa direção, ao analisar o termo cultura, Gullar (1992) define, numa perspectiva mais geral, como o conjunto de práticas, das técnicas, dos símbolos e dos valores que se devem transmitir às novas gerações para garantir a reprodução de um estado de coexistência social. Para Williams (1979), o mundo construído, historicamente, pelas ações humanas é o lócus de geração de cultura. Trata-se de um processo social constitutivo que cria "modos de vida" específicos e diferentes, com ênfase nos processos social e material, sendo os sujeitos dotados de inteligibilidade e de consciência, que os tornam, também, produtores de vida. Nesta perspectiva, podemos entender "cultura" como um processo que se produz e se desenvolve nas relações de produção da vida material,

${ }^{84}$ Em palestra proferida no I Encontro Cultural da Fronteira Brasil/Bolívia, na Câmara Municipal de Guajará-Mirim (RO), em 9 abr. 2011. 
campo de conflitos e contradições, podendo se constituir como espaço de reprodução social.

Bosi (2013), em seu livro “Entre a Literatura e a História”, nos convida a refletir sobre alguns conceitos-chave para entendermos a relação entre Literatura e História. Para o referido autor "[...] uma coisa é a linguagem de comunicação, outra é a representação ou a expressão, que exige uma determinada construção" (Bosi, 2013, p. 222). Por sua vez, Antonio Candido (2004), no artigo "O direito à literatura", afirma que "[...] a eficácia humana é função da eficácia estética" e que, portanto, "o que na literatura age como força humanizadora é a própria literatura, ou seja, a capacidade de criar formas pertinentes" (Candido, 2004, p. 182).

Em suas palavras, na obra "Literatura e Sociedade", Candido (2006) afirma a necessidade de compreendermos a literatura como um todo indissociável, resultado de um tecido formado por características sociais distintas, porém complementares: Tudo faz parte de um "fermento orgânico" (Candido, 2006), no qual a diversidade se torna coesa e possibilita um estudo mais aprofundado e estruturado em bases históricas, sociológicas e críticas. Assim sendo, Candido (2006), afirma sobre o conceito de representação: “A arte, e, portanto, a Literatura é uma transposição do real par o ilusório por meio de uma estilização formal, que propõe um tipo arbitrário de ordem para as coisas, os seres, os sentimentos" (Candido, 2006, p. 62).

Dessa forma, podemos inferir que a Literatura, muitas vezes, serve de base para a construção das representações sociais ou históricas. Também podemos afirmar que a Literatura, além de ser um fenômeno estético, também se inter-relaciona com elementos sócio-históricos e culturais sendo, portanto, um construto existencial construído intencionalmente. Os pensamentos de Ecléa 
Bosi (2004) e de Maurice Halbwachs (2015) serão utilizados como base para análise das formações das memórias, coletivas ou individuais.

Nesse percurso de investigação, importa ressaltar a importância do texto literário como representação da construção estético-social que transcende a existência material de homens e mulheres a partir das experiências passadas, as quais concorrem para a construção das tradições, hábitos e costumes. E que podem determinar um modo de vida, reificadas na cultura e presentes no cotidiano da vida individual e coletiva dos sujeitos, em permanente ebulição com a modernidade, presentes no palco das relações sociais das famílias das comunidades guaporenses do estado de Rondônia.

Esse contexto de latência constitui ambiente privilegiado de produção de vida imaterial e ressignificação do mundo e das vidas. É um espaço de tensão, onde subsiste a dualidade relacional entre o tradicional e o moderno, campo fértil para aprofundamento das discussões em torno de novas perspectivas de vida, da história, da memória, da cultura e das identidades da região do Vale do Guaporé e afluentes.

\section{VIDA E OBRA DE IZABEL DE OLIVEIRA AsSUNÇÃo}

Nascida em 2 de julho de 1927, na localidade de Pau D’Óleo, região do Vale do Guaporé, Rondônia, Izabel de Oliveira Assunção foi aos seis anos estudar em Guajará-Mirim(RO), conduzida entre as crianças que compuseram o primeiro grupo organizado por Dom Rey. Tornou-se professora e passou a ser referência nas comunidades da região. Sua história está assim ligada ao local e ao global, do que deixou de legado na região, espaço de sua atuação e trabalho católico, como veremos nesta seção. 
No ano de 2012, Izabel de Oliveira Assunção lançou o livro intitulado Memórias de Monsenhor Francisco Xavier Rey: Dom Rey, que apresenta memórias da região fronteiriça, detidamente sobre o primeiro bispo de Guajará-Mirim: Francisco Xavier Rey, Dom Rey, como era carinhosamente chamado pelos moradores. Confiado pelo então Papa Pio XI à atuação missionária católica: "[...] uma das missões mais duras do mundo!" (Caravita; Arruda, 2002, p. 7). O representante religioso ocupou por um longo período o papel de maior representante eclesiástico da região, conquistando rápido a confiança das famílias guaporenses que clamavam por políticas públicas de educação, saúde e assistências afins de forma sistemática a esse ponto negligenciado pelo Estado.

Na obra, que contém 164 páginas e foi publicada pela Scortecci Editora no ano de 2012, a autora Izabel Assunção registra as memórias e as histórias do primeiro grupo de meninas educadas nas primeiras salas educacionais de Guajará-Mirim (RO), sob o olhar de Dom Rey:

Aos seis anos de idade, com o consentimento de meus pais, deixei minha casa em San Martin, Bolívia, juntamente com minha irmã Paula Gomes de Oliveira, também criança, para acompanhar Dom Rey em sua empreitada. Fui uma das primeiras alunas do Internato Santa Terezinha, fundando por ele em abril de $1933 \mathrm{em}$ Guajará-Mirim (Assunção, 2002, p. 15).

Nessa perspectiva, o trabalho de catequese e assistencialismo (típico dos jesuítas) de Dom Rey, com o consentimento das famílias, levou algumas de suas crianças (da região guaporense) para receber instruções em salas educacionais provisórias, no município de Guajará-Mirim(RO). Com o passar do tempo, após apoio financeiro de comerciantes locais, o missionário conseguiu edificar o Internato Santa Terezinha, em 1933. Neste 
local, havia uma equipe religiosa, formada por padres e irmãs católicos que davam instruções gerais às alunas internas, desde a maneira de vestir-se a atendimentos hospitalares de primeiros socorros. Assim, "As Filhas de Dom Rey" - como passaram a ser conhecidas - tornarem-se professoras, juízas de paz, conciliadoras e enfermeiras para atender os anseios das comunidades do Vale do Guaporé, Mamoré e afluentes, além de tornarem-se lideranças dentro de suas comunidades, nisto, observa-se um romper de cargos de poder ocupados até então apenas pelos homens.

Foi dessa maneira que Izabel de Oliveira Assunção ficou conhecida como Professora Izabel. Ela esteve entre as meninas (apenas duas não negras) levadas por Dom Rey para receber educação e instruções diversas, no Internato Santa Teresinha: “[...] do Rio Guaporé foram trazidas 30 meninas entre 7 e 14 anos de idade, após o que foram confiadas a Dona Emília Bringel Guerra (Dona Pretinha)" (Assunção, 2002, p. 33).

É importante mencionar que o Internato de ensino foi construído em 1932 e fundado no ano seguinte, em 30 de abril de 1933, com o início das aulas para 33 alunas internas. Depois, em 1935, passa a se chamar Instituto Nossa Senhora do Calvário até o encerramento de suas atividades escolares em 1976. Segundo Souza (2017), as Irmãs da Congregação de Nossa Senhora do Calvário aceitaram convite de Dom Rey, que passa a partir de 1935 a não coordenar mais diretamente a escola, deixando a tarefa às religiosas francesas. Contudo, todas as atividades eram supervisionadas pelo missionário. É importante mencionar que as irmãs calvarianas eram, em sua maioria, tal qual Dom Rey, francesas. E a partir do ano de 1976, o local passou a ser somente uma casa religiosa católica das irmãs do Calvário. 
Izabel de Oliveira Assunção foi a estudante mais nova da turma. No projeto de Dom Rey, depois de selecionadas, as crianças e adolescentes estudariam para retornarem às suas comunidades para lecionar, bem como, seriam dotadas de outros conhecimentos que poderiam ajudar suas famílias no dia a dia. Izabel foi para Guajará-Mirim junto com sua irmã Paula Gomes de Oliveira. Sendo assim, o grupo ficou conhecido como "As Filhas de Dom Rey" e Izabel integrou a primeira turma formada naquela escola, iniciando seus estudos em 1933.

Verifica-se o quanto a formação nos moldes da educação religiosa católica acompanhava a educação das estudantes daquela escola. Assim, as "Filhas de Dom Rey" eram ministradas, como já dito, para serem professoras, juízas de paz, conciliadoras e enfermeiras, portadoras de uma formação católica e cristã, como ficara registrado na historiografia e na memória individual e coletiva dos moradores mais idosos.

Em Dutra (2010, p. 108): "As primeiras professoras que atuaram na Instrução Pública no Vale do Guaporé foram os sujeitos principais de uma ação educadora de sucesso". O pesquisador fala ainda do espírito de liderança que "as filhas de Dom Rey" exerciam neste retorno às comunidades do Vale do Guaporé, exercendo, muitas vezes, o posto de conselheiras da comunidade, leitoras/escritoras de cartas e até prefeitas temporárias em substituição aos prefeitos ausentes.

Nascimento (2014) aborda a importância da atuação do líder religioso na educação e formação de professoras entre os anos 1930 e 1960. O estudo se dá sobre as escolas criadas por Dom Xavier Rey, entre as quais está a Escola de Santo Antônio, criada em 1945 e que tem por professora Izabel Assunção. Além dessa escola, podemos citar outras edificações educacionais em várias comunidades 
ribeirinhas, como a Pedras Negras, Laranjeiras e Santa Fé, além de postos de saúde, como nas localidades de Surpresa, Pedras Negras e Sagarana (Assunção, 2002).

Em 1947, a Professora Izabel é contratada pelo Governo e passa a exercer o magistério em diversas localidades do Guaporé, comunidades e distritos do então estado de Mato Grosso e, também, em Porto Velho no território do Guaporé. Em seguida, Izabel é transferida em 1964 para Guajará-Mirim, onde também atuou em vários estabelecimentos de ensino, a exemplo da Escola Batista Cepelos (já extinta). Isabel foi a primeira diretora da Escola Capitão Godoy. Aposenta-se em 1977.

É importante destacar que a professora Izabel, também, era bastante atuante nas igrejas católicas das localidades por onde passava. Foi devota e líder no Festejo do Divino Espírito Santo, uma das manifestações culturais mais fervorosas da região. De forma geral, essa atuação das "filhas de Dom Rey" é bastante reconhecida pelos moradores, até dias atuais. Na ocasião de falecimento da Professora Maria de Jesus Evangelista Assunção, em 2011:

Foi sepultada neste sábado, 1 de outubro, no cemitério "Santa Cruz", nesta cidade, a senhora Maria de Jesus Evangelista Assunção falecida na noite de sextafeira, aos 86 anos de idade. Viúva do agricultor Canuto Assunção, e mãe de seis filhos, era professora aposentada e fez parte do grupo de adolescentes que na década de 1930 passou a ser conhecido como "filhas de Dom Rey" (Albuquerque, 2011, s.p.).

Da mesma maneira, quando ocorreu o falecimento da Professora Izabel, em 11 de fevereiro de 2014, os jornais noticiaram: "Católica fiel, devota do Senhor Divino Espírito Santo, a professora Izabel deixa filhos, netos e bisnetos e uma grande lacuna na Igreja 
Católica de Guajará-Mirim onde atuou como evangelizadora durante longos anos" (Guajará Notícias, 2014, s/p.). Religiosa, ocupou o cargo de ministra da Eucaristia na Igreja do Divino Espírito Santo, em Guajará-Mirim, e atuava junto à Diocese do citado município, na antiga Congregação Filhas de Maria. Em 10 de abril de 2012, recebeu a Medalha de Mérito Marechal Rondon, que lhe foi concedida pelo Governo do Estado de Rondônia. Foi homenageada ainda com a Comenda do Mérito Acadêmico Magistrado José de Mello e Silva, outorgada pela Academia Guajaramirense de Letras (AGL). Nesta última, foi reverenciada como a professora "mais antiga do Vale do Guaporé e da cidade de Guajará Mirim” (Machado, 2012, s/p.).

A AGL também a teve como imortal, pois passou a ser parte da Academia após o lançamento de sua obra: "Recentemente ingressou na Academia Guajaramirense de Letras (AGL)” (Guajará Notícias, 2014, s/p.). A Professora Izabel, inclusive, estava escrevendo um segundo livro: "Ela trabalhava em uma nova obra sobre a vida do religioso que marcou a vida do povo guajarámirense com sua obra missionária” (Guajará Notícias, 2014, s/p.).

Sob as condições econômicas da qual vinham, em regiões sem escolas e com pais e mães analfabetos, a saída de casa e a separação temporária dos entes familiares eram necessárias para aprendizagem da leitura e da escrita. Izabel e as outras primeiras alunas que se tornaram, posteriormente, professoras pelas ações desenvolvidas por Dom Rey eram buscadas para contar histórias da experiência vivenciada por elas:

A professora Izabel também representou uma fonte confiável, por abordar a temporalidade do ensino católico e dela fazer parte como agente das temáticas aqui trabalhadas, como memória e formação de professoras, resultado de um movimento processual em busca da 
cidadania, identidade cultural e superação da pobreza (Nascimento, 2014, p. 60).

Eram fontes importantes para testemunhar a época. Porém, em pesquisas e abordagens literárias, ainda há pouco discutido sobre elas próprias, além dos registros relativos a suas funções profissionais e de líderes em suas comunidades, visto que, mesmo ocupando lugares de destaque, ainda continuam na invisibilidade. Segundo Perrot (1988), chama a atenção para a "reavaliação do poder das mulheres": “[...] num desejo análogo de inverter as perspectivas historiográficas tradicionais, de mostrar a presença real das mulheres na história mais cotidiana” (Perrot, 1988, p. 171). Portanto, espera-se o despertar de mais trabalhos acadêmicos como forma a suprir essa lacuna.

\section{ANÁLISE DA OBRA MEMÓRIAS DE MONSENHOR FRANCISCO XAVIER REY: DOM REY}

Neste tópico, faremos a apresentação e análise da obra “Memórias de Monsenhor Francisco Xavier Rey: Dom Rey” - de autoria da escritora Izabel de Oliveira Assunção. As análises em questão se darão, em grande medida, a partir da memória daqueles, neste caso, a autora em epígrafe, que dedicou sua vida a serviço dos excluídos, produzindo cultura:

Haveria, portanto, motivos para distinguir duas memórias, que chamaríamos, por exemplo, uma interior ou interna, a outra exterior - ou então uma memória pessoal e a outra, memória social. Mais exatamente ainda (e do ponto de vista que terminamos de indicar), diríamos memória autobiográfica e memória histórica. A primeira receberia ajuda da segunda, já que afinal de contas a história de nossa vida faz patê da história em geral. A segunda, naturalmente, seria bem mais extensa do que a 
primeira. Por outro lado, ela só representaria para nós o passado sob uma forma resumida e esquemática, ao passo que a memória da nossa vida nos apresentaria delem um panorama bem mais contínuo e mais denso (Halbwachs, 2015, p. 145).

Nesse particular, sobre a memória individual e coletiva, ancorado em Ecléa Bosi (2004), a partir da experiência de sujeitos que fizeram e fazem a história, a autora afirma:

[...] a memória permite a relação do corpo presente com o passado e, ao mesmo tempo, interfere no processo atual das representações. Pela memória, o passado não só vem à tona das águas presentes, misturando-se com as percepções imediatas, como também empurra, "desloca” estas últimas, ocupando o espaço todo da consciência. A memória aparece como força subjetiva ao mesmo tempo profunda e ativa, latente e penetrante, oculta e invasora. (Bosi, 2004, p. 46/47).

As "filhas de Dom Rey", a partir de seus ensinamentos e compartilhamentos de práticas de vida às famílias do Vale do Guaporé, sem dúvida, são uma memória viva do passado que, subsidiará o processo de descoberta dos fatos e versões não contados, mas que fizeram e fazem parte do cotidiano. Sendo assim, de acordo com Bosi, (2004, p. 55) na maioria das vezes, lembrar não é reviver, mas refazer, reconstruir, repensar, com imagens e ideias de hoje, as experiências do passado.

É oportuno contextualizar sobre o modelo de família formado na região em baile: o patriarcal. Mulheres e crianças mantinham-se ocupadas envoltas às plantações e colheitas, na procura de lenhas na mata, no abastecimento dos potes com água do rio; no trabalho com o pilão e o forno de barro, visto que os mais jovens acompanhavam os mais velhos nos serviços que eram 
exercidos tanto por homens quanto por mulheres, contudo, havia funções mais ligadas ao universo feminino como ser mãe, partejar e se responsabilizar pelos primeiros cuidados com os recém-nascidos.

Havia famílias chefiadas por mulheres, mães solos (mães que criam sozinhas seus filhos, sem a presença ou ajuda dos pais) ou viúvas, que iam para a mata amazônica e trabalhavam tanto quanto os homens. E mesmo as casadas, que iam para os trabalhos na mata eram vistas apenas como meras ajudantes dos homens. Sem vez e sem voz, elas ficavam responsáveis por todas outras atividades ligadas ao setor doméstico como lavar, cozinhar, varrer e fabricar as vestimentas dos familiares com os tecidos, chamados por "corte de pano", adquiridos com os vendedores locais, os chamados "regatões". Essas atividades, geralmente, eram realizadas somente pelas mulheres que na educação das crianças repassavam essas e outras ocupações, sobretudo às meninas, que seguiam do nascimento até o casamento acompanhando suas mães. $\mathrm{Na}$ educação familiar, as meninas eram educadas para serem do lar, uma boa esposa e boa mãe. Com isso, o trabalho doméstico era destinado às mulheres.

Destarte, numa região negligenciada pelo Estado e marginalizada pela sociedade, o trabalho de Monsenhor Dom Rey ganhou espaço e notoriedade, uma vez que proporcionava às famílias, sobretudo para as meninas, em sua maioria negras, melhores oportunidades de vida e de trabalho, longe do setor doméstico.

A representação dessa atuação local feminina, também, está nos trabalhos de primeiros socorros, numa região anteriormente atendida por benzedeiras e curandeiras, remanescentes de quilombolas $\mathrm{e}$ indígenas. As benzedeiras eram personagens conhecidas no Vale do Guaporé, principalmente, na época em que 
a região era bastante carente de médicos e a medicina oficial ainda não tinha alcançado a localidade.

No trabalho de práticas de cura não oficiais, as benzedeiras e/ou curandeiras estavam sempre disponíveis para atender aos pedidos de socorro físico ou espiritual dos moradores enfermos. Na atualidade, a arte de benzer, assim como a maneira específica de benzer de cada benzedeira, é uma ciência que está destinada a desaparecer dia após dia, visto que, elas (as benzedeiras e curandeiras), diferente de épocas passadas, deixaram de transmitir essa arte aos mais jovens.

Nesse processo histórico e de desenvolvimento social, as artes de benzimento e de curandeirismo foram sendo substituídas por trabalhos de saúde oficiais, ao passo em que os trabalhos assistencialistas religiosos foram ganhando espaço nas comunidades ribeirinhas da região, pois: “[...] as futuras professoras não foram preparadas somente para dar aulas, mas também para atuarem como enfermeiras de emergência, como aplicar injeção, curativos, primeiros socorros, etc., nas ocasiões necessárias.” (Assunção, 2002, p. 78).

Reinterpretando a nova religião dominante, mais precisamente a partir do final do século XIX, as famílias guaporenses seguiam às práticas ritualísticas de origem portuguesas e europeias. Vale a pena ressaltar que nessa época, a religião dominante (católica) era a instituição que auxiliava as populações empobrecidas no Vale do Guaporé e afluentes, que abandonadas numa região marcada com forte presença militar, padres e missionários, foram muitas vezes, apaziguadora entre grupos indígenas e colonizadores (Verdier, 2012).

A ação catequética imposta às populações no Vale do Guaporé pode ser justificada (para alguns) para a diminuição da 
atuação da cultura negra e indígena, a exemplo disso, os trabalhos das benzedeiras, o que resulta na perda da pureza de ritos da religião de matriz afro e/ou indígena, primeiramente cultuada pelos primeiros moradores. $O$ trabalho de revolução espiritual do missionário franciscano Dom Rey resultou às famílias colonizadas reinterpretar ritos católicos em torno de realização do pagamento de promessas em torno de santos, num sincretismo religioso. Assim, as famílias participavam de ritos católicos diversos, como batismos, crismas e cerimônias de casamentos, realizados em trabalhos de desobriga pelo Clero.

Nestas sendas, é importante mencionar outra justificativa atual, pelo qual as festas de santo vêm desaparecendo, na medida em que seus realizadores não transmitem o festejo aos mais jovens devido à interferência de novas denominações religiosas. Isso devese ao fato que os promesseiros (já idosos) falecem e, consequentemente, os familiares que permanecem vivos, mesmo que tenham recebido dos seus familiares o dever de continuar com a promessa, mostram-se desinteressados com a continuidade das promessas realizadas pelo familiar promesseiro falecido. Dentre essas festas não mais realizadas (de promesseiros falecidos), citamos: o de São Benedito, São Pedro e São Paulo, Nossa Senhora da Saúde e Nossa Senhora do Bom Parto.

Contudo, há uma festa que resiste no tempo e no espaço: o festejo do Divino, manifestação cultural, que ocorre há mais de cem anos, tendo iniciado em 1894 a partir de tradições portuguesas. Levado de Vila Bela da Santíssima Trindade-MT por um dos moradores da comunidade de Pedras Negras, Manoel Fernandes Coelho, que foi até Vila Bela, de canoa e remo, para pedir autorização do Bispo local para que a festa fosse realizada, também, no Vale do Guaporé.

Dom Rey foi o responsável pela revitalização da festa do Divino a partir de 1934, que passou a ser venerada por todos os 
moradores do Vale do Guaporé, "[...] Monsenhor fazia tudo de forma muito organizada. Com ele, tudo tinha que andar na linha, principalmente quando se tratava de religião" (Assunção, 2002, p. 58). A passagem do Divino é feita em peregrinação durante quarenta e cinco dias de Quaresma ${ }^{85} \mathrm{em}$ todo o Vale do Guaporé e Mamoré, tanto do lado brasileiro quanto do lado boliviano. Adultos e crianças, mulheres e homens seguem mantendo viva a festividade centenária que recebe todos os anos centenas de devotos e pesquisadores. Ainda nesta perspectiva, Dom Rey instituiu outras festas com preceito religioso, com base no calendário litúrgico da Igreja Católica:

O mês de maio, intitulado "Mês de Maria", era cheio de festividades. Iniciava com as noites de novenas para ofertarem flores a Maria. Na primeira noite, todas entravam em duas filas, fazendo a procissão das flores. Após a novena havia quermesse com valiosos prêmios e cada "noitário" (assim chamávamos na época), procurava fazer sempre mais animado que o outro. Monsenhor vibrava com esses acontecimentos, vendo que as filhas de Maria só lhe davam gosto. Havia também o apostolado da oração, que era formado por senhoras casadas e viúvas. Funcionava com reuniões às primeiras sextas-feiras do mês, com missa às 5:00 horas da manhã. Mesmo com este horário, elas eram assíduas e perseverantes. Também tinham uma Diretoria. Assim, tudo tinha mais ordem e organização. Monsenhor era incansável à frente desses movimentos (Assunção, 2002, p. 59-50).

${ }^{85}$ Substantivo feminino que significa dentro da liturgia religiosa: "Período de 40 dias compreendido entre a Quarta-Feira de Cinzas e o Domingo de Páscoa; quadragésima, quarentena”.

Disponível em: https://michaelis.uol.com.br/moderno-portugues/busca/portuguesbrasileiro/quaresma. Acesso em: 8 dez. 2020. 
Não obstante, Dom Rey edificou várias construções, também, no município de Guajará-Mirim, dentre elas: a Catedral Nossa Senhora Seringueiro (1958), padroeira do município; o Centro Catequético (1959); a Associação dos Vicentinos São Vicente de Paula (1956), que presta serviços de moradia e saúde a idosos abandonados; A segunda emissora de rádio mais antiga do estado de Rondônia (inicialmente transmitida na faixa AM 1260, e atualmente na faixa FM 88.7 $\mathrm{MHz}^{86}$ ): a "Rádio Educadora" (1963).

Assim sendo, a validação da memória da Professora Izabel de Oliveira Assunção, em sua obra literária "Memórias de Francisco Xavier Rey: Dom Rey” oportuniza-nos conhecer parte da memória, da cultura e da história do findar do século XIX e início do século XX. E assim como as "filhas de Dom Rey", o apóstolo é lembrado com muita saudade pelas famílias da região, visto que, muitas delas migraram para o citado município na perspectiva por melhores condições de vida e trabalho. Muitas famílias receberam, inclusive, doações de terrenos e alimentos da igreja, assim que migraram para a nova localidade.

O trabalho de Dom Rey recebe continuidade no ano de 1966, após ele tornar-se emérito da administração da Prelazia, conforme Assunção (2002, p. 90), “[...] o benemérito bispo deu toda sua vida em prol do serviço educacional e catequético, como também promoveu com capacidade o desenvolvimento cultural na região". E, dessa maneira, a Professora Izabel foi registrando a vida de Dom Rey e da região, deixando em forma de livro relatos dessa experiência individual/coletiva em que ela própria foi partícipe.

86 Disponível em: <www.rcr.org.br/cristosalvador/noticias/diocese/17-092018/inaugurao-da-frequncia-modulada-fm-887-rdio-educadora-histrico $>$. Acesso em: 8 dez. 2020. 


\section{CONSIDERAÇÕES FINAIS}

Este trabalho estudou a obra literária "Memórias de Monsenhor Francisco Xavier Rey: Dom Rey", de autoria de Izabel de Oliveira Assunção, que pode ser classificada na vertente da Literatura amazônica, pois, em seu enredo, destaca o trabalho de Dom Rey em prol da população desassistida do eixo Mamoré/Guaporé, na fronteira Brasil/Bolívia.

Izabel de Oliveira Assunção tornou-se professora e durante toda a sua vida dedicou-se ao trabalho educacional e também às questões religiosas, sendo, inclusive, uma das principais lideranças femininas da Irmandade do festejo regional do Divino Espírito Santo.

Os registros, em forma de livro, deixados pela Professora Izabel, ressaltam o quanto há perpetuação das memórias de Dom Rey, e que expressam aspectos da formação religiosa, missionária, política e social, especificamente, no Vale do Guaporé, no contexto da Amazônia. Assim, a partir do estudo da obra, foi possível abordar, questões relativas ao trabalho de Dom Rey nos vales Mamoré-Guaporé. Bem como, mostra-se o espaço geográfico de várias localidades por onde o trabalho catequético e assistencialista das "filhas de Dom Rey" alcançou, destacando elementos históricos e geográficos regionais, além da fauna e da flora e a integração/desajuste entre a sociedade e o meio ambiente.

Destacamos que a obra em questão contribui para a conscientização histórica da região para pesquisadores e futura geração, visto que, evidencia a memória, a cultura e a história dos povos amazônicos, principalmente, a história dos povos que viveram/vivem na região do Vale do Guaporé e afluentes, na fronteira Brasil-Bolívia. 
Os resultados da pesquisa apontam para a relevância da produção literária da escritora Izabel de Oliveira Assunção para a constituição da Literatura amazônica, e a análise da obra "Memórias de Monsenhor Francisco Xavier Rey: Dom Rey” surge como uma possibilidade de mostrar alguns aspectos dos trabalhos de catequese e de assistencialismo realizados pela Igreja Católica, na região amazônica, no século XX.

\section{REFERÊNCIAS}

ALBUQUERQUE, Lúcio. Falece em Guajará uma das 'filhas de Dom Rey'. Porto Velho, Gente de Opinião: 01/10/2011. Disponível em <www.gentedeopiniao.com.br/colunista/lucio-albuquerque/ falece-em-guajara-uma-das-filhas-de-dom-rey>. Acesso em: 3 out. 2020.

ASSUNÇÃO, Izabel de Oliveira. Memórias de Monsenhor Francisco Xavier Rey: Dom Rey. São Paulo: Scortecci, 2012.

BOSI, Alfredo. Entre a literatura e a história. São Paulo: Editora 34, 2013.

BOSI, Ecléa. Memória e sociedade: lembrança de velhos. 3. ed. São Paulo: SCHWARCZ, 2004.

BEZERRA, José Denis. "Literatura amazônica para quê?" Disponível em: https://portalclic.files.wordpress.com/2012/03/ literatura-amazonica-para-que-jose-denis-de-oliveirabezerra.pdf>. Acesso em: 5 dez. 2020.

CANDIDO, Antonio. Literatura e sociedade. 9. ed. Rio de Janeiro: Ouro Sobre Azul, 2006. 
CANDIDO, Antonio. O direito à literatura. In: Vários escritos. São Paulo: Duas Cidades: Ouro sobre Azul, 2004.

CARAVITA, Adriana; ARRUDA, Luiz Gomes. Dom Rey: O primeiro bispo de Guajará-Mirim - centenário de seu nascimento, 1902-2002. São Paulo, 2002.

DUTRA, Paulo Sérgio. Memórias de professoras negras no Guaporé: do silêncio à palavra. Cuiabá, 2010. Dissertação (Mestrado em Educação). Universidade Federal do Mato Grosso, Cuiabá, 2010.

GUAJARÁ NOTÍCIAS. Morre professora pioneira. GuajaráMirim: Site Guajará Notícias, 11 fev. 2014. Disponível em: https://www.guajaranoticias.com.br/noticia/25/page1/ler/7917. Acesso em: 20 dez. 2020.

HALBWACHS, Maurice. A memória coletiva. Tradução: Beatriz Sidou. 2. ed. São Paulo: Centauro, 2015.

MACHADO, Abnael. Em noite de gala a Academia Guajaramirense de Letras festejou os seus $\mathbf{3}$ anos de fundação. Porto Velho: Site Gente de Opinião, 27 ago. 2012. Disponível em: $<$ www.gentedeopiniao.com.br/colunista/abnael-machado/emnoite-de-gala-a-academia-guajaramirense-de-letras-festejou-osseus-3-anos-de-fundacao >. Acesso em: 20 dez. 2020.

NASCIMENTO, Sílvio Melo do. A escola de Dom Xavier Rey: história da formação de professoras no Vale do Guaporé, 2014. Dissertação (Mestrado em Educação) Universidade Federal de Rondônia, Porto Velho, 2014.

PAES LOUREIRO, João de Jesus. Cultura amazônica, uma poética do imaginário. Belém, Cejup, 1997. 
PERROT, Michelle. As mulheres ou os silêncios da história. Trad. Viviane Ribeiro. São Paulo: Edusc, 1988.

SOUZA, Cleicinéia Oliveira de. Entre o evangelho e o ensino rural: Educação feminina no instituto Nossa Senhora do Calvário (Vale do Guaporé/Guajará-Mirim/MT/RO 1933-1976). 2017. 164 f. Dissertação (Mestrado em Educação). Universidade Federal de Mato Grosso, Cuiabá, 2014.

VERDIER, Geraldo. Paixão pela Amazônia. Diocese de GuajaráMirim: uma igreja missionária. Brasília: CNBB, 2012.

WILLIAMS, Raymond. Marxismo e literatura. Tradução: Waltensir Dutra. Rio de Janeiro: Zahar, 1979. 


\title{
A METAMORFOSE ANIMAL E ESPACIAL EM MISTERIOS DE LA SELVA AMAZÓNICA
}

\author{
Edimilson de Sousa Macedo ${ }^{87}$ \\ João Pedro da Silva Antelo 88
}

\section{INTRODUÇÃO}

Este estudo visa apresentar uma análise do espaço como um recurso estético e de transformação na obra da escritora Gabby Cuellar, juntamente com os estudos da teoria animal. Dessa forma, pretendemos estudar a obra Misterios de la Selva Amazónica, de autoria da escritora boliviana Gabby Cuéllar Camacho.

A citada poetisa nasceu em Porto Suárez, em Santa Cruz de La Sierra, Bolívia, e foi educada na região do Beni, onde reside atualmente. Foi professora na Universidade da Amazônia em Guayaramérin, Beni, Bolívia. É membro da Sociedade de Escritores de Guayaramerín e conferencista em eventos literários e integrante do Diretório do Palácio da Cultura Dr. Aldo Bravo. Possui uma vasta produção literária: ensaios, contos e poemas. A obra Sortilégios de Guayaramerín, a qual analisamos nesta pesquisa, é composta por três partes: história, mitos e poesia.

O artigo em tela, além de apresentar conceitos para a questão das histórias míticas, fará uma abordagem do espaço, para evidenciar traços de mudanças que nele acontecem, bem como para

\footnotetext{
${ }^{87}$ Licenciado em Letras pela Universidade Federal da Paraíba- UFPB, mestrando em Estudos Literários da Universidade Federal de Rondônia.

88 Licenciado em Letras pela Universidade Federal de Rondônia - UNIR, mestrando do curso de Estudos Literários, pela mesma fundação. E-mail: pedroantelo179@gmail.com
} 
demostrar a metamorfose que ocorre em relação às personagens, que se transformam em animais. A análise não focará nas questões de verdade ou mentira que sempre recaí quando falamos do mítico, mas sim nas questões de transformação que, possivelmente, influenciaram essas histórias.

Pretendemos, também, fazer uma breve exposição sobre a constituição do imaginário amazônico. Com isso, situaremos o leitor/leitora, no contexto em que a obra foi construída, visto que a escritora utiliza-se de memórias para construir maior parte das histórias míticas presentes na obra em estudo.

As nossas principais interrogações, que motivaram essa pesquisa, procuraram na tessitura do referido artigo responder: quais as marcas de transformação ou metamorfose apresentadas na obra? e como tais discursos podem ser analisados pelo viés da teoria do espaço?

Estabelecemos como objetivo geral identificar e analisar elementos de transformação, mudança e metamorfose, presentes nas personagens e no espaço. Por conseguinte, estabelecemos, também, o seguinte objetivo específico: identificar, na obra em estudo, os elementos do estudo da teoria animalidade. Lestel (2007) assim apresenta:

A animalidade pertence aquela classe de ideias que dificilmente definimos com o rigor esperado, mas da qual não podemos legitimamente nos privar. A causa do nosso mal-estar e facilmente determinável: a animalidade designa uma classe de criaturas vivas, da qual o humano tenta se distinguir, ela não remete apenas a uma classe de seres, mas as relações que esta mantém com outras classes (p. 22). 
Dessa forma buscamos a aproximação dos seres humanos com os animais ou com animalidade. Também chamamos a atenção para o fato de que não menosprezamos ou fazemos juízo de valores sobre a relação entre humanos e não humanos. Para esse estudo, optamos em fazer um recorte da obra e analisar apenas duas histórias míticas, a primeira que a autora nomeia como "La Trigresa” e a segunda é a história da "Mujer Jaguar".

Dessa forma, para lograr êxito em nossas análises, utilizaremos como referencial teórico, Lestel (2007), com os estudos sobre "A Animalidade, o Humano e as "Comunidades Híbridas" e nas relações sobre o espaço vamos estudar com os estudos da Análise da Narrativa, focando o estuda no capítulo do espaço.

\section{O IMAGINÁRIO FANTÁSTICO AMAZÔNICO}

O amazônico da estética amazônica não é propriamente a forma: o amazônico da estética amazônica é aquilo que emerge do vitral, é o ethos amazônico, é uma forma de "amazonicidade" que emerge da obra e que você percebe mais como modo de sentir do que propriamente como modo de uma demonstração racional (Loureiro, 2014, p. 33).

A partir da concepção de Loureiro, podemos entender a Literatura Amazônica como aquela que nos causa diversas sensações, como aquele sentimento que nos atinge na medida em que fazemos a leitura, despertando nossas emoções. $\mathrm{O}$ autor também comenta sobre esses sentimentos que afloram da literatura amazônica e que a diferencia das demais literaturas produzidas no Brasil:

Eu me lembro um pouco de uma questão relativa a essa forma de conhecer pelo sentimento que está em 
Santo Agostinho quando ele fala de amor. E ele diz: "quando eu amo, eu sei tudo sobre o amor, mas quando eu quero falar dele eu já não sei mais nada.” Quando a gente sente, quando a gente percebe numa obra amazônica, a gente percebe tudo ali, pela emoção dessa recepção, pelo que emerge da forma dessa obra. Mas, às vezes, quando a gente quer explicar o que é o amazônico e a amazonicidade daquela forma, a gente não consegue muito, porque é mais algo para ser percebido e sentido do que propriamente para ser racionalizado e explicado (Loureiro, 2014, p. 33 e 34).

Dessa forma, podemos entender como a literatura produzida na Amazônia é rica e diversificada. $O$ verde e vasto mundo de águas e florestas, que constituem o grandioso cenário amazônico, povoado por uma imensidão de espécies (fauna e flora), faz com que, ainda hoje, a Amazônia mantenha sua aura mítica e misteriosa. O tempo não consegue apagar do imaginário popular esse traço mítico da floresta, ainda que tenha se passado cinco séculos dos primeiros registros e relatos dos viajantes e exploradores europeus que ocorreram na região no século XVI. Assim, a região amazônica ainda permanece no imaginário mundial, como um lugar de maravilhas, exotismos e deslumbramentos.

Neide Gondim, explica em seu livro A invenção da Amazônia (1994), cuja ideia central defende que a Amazônia não foi descoberta, tampouco construída, tendo surgido na realidade a partir da construção da Índia, fabricada pela historiografia grecoromana tendo como base relatos e narrativas dos peregrinos, missionários, viajantes e comerciantes (Gondim, 2019, p. 13). Desta forma a autora reconstrói os caminhos e apresenta a tradição estética e discursiva sobre a Amazônia, na qual predomina, o contraditório, o hiperbólico, e o paradoxo entre paraíso e inferno, um outro mundo, lugar de maravilhas, exotismos e 
deslumbramentos (embora a realidade por vezes contradiga tais relatos).

Gondim (2019), também estabelece a relação entre os povos nativos e o colonizador. Esses povos eram definidos como primitivos, incapazes de desenvolver-se plenamente em consequência do forte calor, lhes caracterizando como preguiçosos e indolentes, infantis e bestializados. Fato que de acordo com a autora, reverbera ainda hoje, na representação difundida e consolidada pelo sistema capitalista, segundo a qual, a Amazônia premiaria com riqueza aqueles que sobre ela trabalharem, ao contrário do que não fizeram os indígenas.

A representação hiperbolizada da Amazônia é uma tentação da qual quase ninguém escapa. Para a autora, essa representação edênica da natureza vem seguindo um efeito cascata que começou no imaginário medieval sobre o incompreensível oriente e desconhecida América. Talvez mais que a própria Amazônia, o que realmente impressiona seja a representação desse encontro/confronto. Esse imaginário fantástico universal impressionou todas as mentes, dos que passaram pela Amazônia e dos que dela só ouviram falar. Gondim (2019), ilustra sua argumentação com trechos dos livros e relatos que se mostram reveladores da invenção imaginária do que seja a Amazônia, ao tempo que nos oportuniza a dupla satisfação de ler literatura e ciência.

\section{RELAÇÕES, ESPAÇO E METAMORFOSE ANIMAL}

[...] O espaço é um agente produtor de sentidos, de forma que, para sua apreensão o percurso teórico a ser seguido deve ultrapassar os limites da noção de situar geograficamente a personagem na narrativa (Molina, 2016, p. 160). 
Partindo da epígrafe desta seção buscamos apresentar o espaço como um produtor de sentido, juntamente com as transformações ocorridas pelas personagens, visto que estamos falando de metamorfoses, ou seja, pessoas que por motivos míticos se transformam em animal. No caso das duas histórias que são apresentadas nesse trabalho.

Vale ressaltar que, ao estudar a transformação juntamente com o espaço, será um trabalho árduo, pois as pesquisas que refletem as metamorfoses são poucas e buscar essa relação com espaço é um estudo menor ainda. Para Barbiere (2009):

O espaço na narrativa, muito além de caracterizar os aspectos físico-geográficos, registrar os dados culturais específicos, descrever os costumes e individualizar os tipos humanos necessários à produção do efeito de verossimilhança literária, cria também uma cartografia simbólica em que se cruzam o imaginário, a história, a subjetividade e a interpretação. A construção espacial da narrativa deixa de ser passiva - enquanto um elemento necessário apenas à contextualização e pano de fundo para os acontecimentos - e passa a ser um agente ativo: 0 espaço, o lugar como um articulador da história. A percepção deste pela personagem e seu percurso dão ao leitor uma maior compreensão da constituição de ambos e ampliam as possibilidades de significação do texto (p. 105).

Assim podemos verificar que o espaço não é só a construção de uma cena para situar o leitor de algo que vai acontecer ele é dinâmico e influência na construção de sentidos. Dessa forma é esse espaço que estamos apresentando em nossas análises, visto que a transformação que ocorre com as personagens das histórias acontece também no espaço. 
Buscamos, nesse estudo, apresentar personagens maravilhosos, que prendem o leitor, que transformam-se e dessa forma surja um personagem no novo no antigo. Assim, Correia (2005), apresenta:

Em se tratando de personagens fictícias maravilhosas que se pode encontrar na literatura, os seres que encantam leitores povoam os mundos "reais" e possíveis. São muitos os seres que, de origem cultural diversa, de tempos históricos diferentes, se fazem presentes em literaturas dos mais variados países (p. 11).

Assim sendo, os personagens maravilhosos cativam o leitor de uma forma sem igual, pois os mistérios que eles apresentam são diversos e suas transformações despertam o interesse em conhecer essa aura mítica. As histórias objeto de análise neste artigo trazem como clímax do seu enredo essas transformações.

Contextualizando a primeira história mítica apresentada, trata-se de uma curandeira que vive na selva, sozinha. Este fato chama a atenção de curiosos, pois viver sozinho na selva é uma tarefa difícil, assim surge a "lenda", de que essa curandeira se transforma em jaguar quando precisa caçar, porém, note o excerto da obra:

Compungidos, se retiraron a su choza y al llegar, horrorizados vieron a salir de adentro, cuatro grandes jaguares que habían destrozado y esparcido por el piso sus escasas pertinências y los miraban en el son ataque. Desesperados, se arrojaron a la noria y allí se quedaron agarrados de la soga, por varias horas, hasta que calcularon que los felinos se habían no marchado (Camacho, 2019, p. $16)$.

Podemos notar em Misterios de la selva Amazónica, no conto a "La Mujer Jaguar" que, quando ela se transforma, o espaço que 
antes era pacífico e tranquilo ganha uma espécie de caos. Isso nos mostra que pensamos nos animais e os vemos como seres portadores do caos como apresenta (Lestel, 2007), afirma que: "A animalidade continua sendo um horizonte do homem, o da sua perda ou de uma fuga para fora de si mesmo. Ela é o resultado conjunto de uma história natural e de uma história cultural, mesmo que essa ideia não seja evidente, (p. 24)", ou seja, dessa forma notamos que animalidade em alguns textos é vista como algo ruim, de modo que fugir para uma transformação animal vire algo, como se desprender de regras e torna-se um ser pior.

Dessa forma, notamos o espaço que também foge para um lugar sem regras, um lugar "animalesco", como no fragmento: "cuatro grandes jaguares que habían destrozado y esparcido por el piso sus escasas pertinências y los miraban en el son ataque", (Camacho, 2019, p. 16). Podemos observar a desordem com que é visto o espaço. $O$ narrador sugere uma organização quando fala dos poucos pertences, intende-se que há uma ordem na cabana, ordem essa, quebrada pelos jaguares comandados pela curandeira.

Podemos observar, segundo Barbiere (2009), que, "o espaço está intimamente ligado à ação, aos personagens, ao enredo, ao tempo e a perspectiva narrativa (p. 108)", assim, reiteramos, que o espaço foi modificado a partir do momento em que a metamorfose ocorreu com curandeira. Correia (2005), afirma que:

É possível que a espécie dos jaguares teria sido a responsável por carregar a fórmula divina e todo poderosa. O que Tzinácan não menciona é que segundo o povo quiche (e outros povos), além do jaguar ser animal sagrado, os sacerdotes, magos, xamãs ou pajés nele se transformam (p. 29). 
Podemos observar que não são todas a pessoas capazes de se transformar em animais, como afirma Correia ao falar de Tzinácan, dessa forma podemos inferir que a transformação não se trata de algo que aconteça fora do controle, mas um meio de se fortalecer perante as adversidades. Podemos notar que a Curandeira sentiu-se pressionada pelas investidas dos rapazes que lhe observavam em sua casa: "Mama Justina... salió de cacería? Interrogo Juan. Ella los miró despectivamente y sin decir uma palavra procedióa desollar el venadito que traía", Camacho (2019), dessa forma observamos o comportamento a seguir de Mama Justina: "Fuera de aquí, muchachos!... No quiero verlos más merodeando por mi choza. Les daré uma lección nunca olvidarán”. Dessa forma notamos que essa transformação foi movida pela raiva, o que nos explicaria a bagunça no espaço anterior.

Cunha (2003), nos apresenta uma perspectiva interessante sobre o espaço:

Os cenários, invariáveis no espaço, transmudamse no tempo. Diante do homem errante, a natureza é estável; e aos olhos do homem sedentário que planeie submetê-la à instabilidade das culturas, aparece espontaneamente revolta e volúvel, surpreendendo-o por vezes, quase sempre afugentando-o e espavorindo-o (Cunha, 2003, p. 29).

Assim sendo, podemos notar que aqueles que tentaram impor sua cultura, acabaram por sendo afugentados. Por não entenderem de que forma me relaciono com as outras culturas. A metamorfose apresentada aqui não é só a do espaço ou personagens, é, também, das culturas, religiões, da forma como busco entender os outros seres vivos. 
Buscamos, nesse trabalho apresentar a metamorfose como traços de semelhança entre homens/animais, sobre essas semelhanças, Lestel (2007), afirma que:

A hominização não e tanto uma ruptura com a animalidade quanto uma mudança radical das relações entre hominalidades e animais. Parece surpreendente ver que, se o papel do artefato foi reavaliado no processo de hominização, o do animal ainda permanece muito subestimado. Da mesma forma que uma definição do humano que ignorasse totalmente $\mathrm{o}$ animal seria paradoxalmente incompleta, uma caracterização da animalidade independentemente do homem parece dificilmente pensável (p. 36).

Dessa forma podemos observar que a literatura tem um papel crucial nesse pensamento sobre o animal, pois está sempre buscando as similitudes, mesmo que na maioria das vezes os animais sejam vistos como serem inferiores, ou sempre sendo julgados por um viés maléfico, traços estes que na maioria das vezes não condiz.

Na próxima história mítica que apresentamos, falamos de Lidia, uma menina que após cair um coco em sua cabeça, entrou em um estado que os xamãs, da história, falaram em alma que deixa o corpo. Depois de alguns tratamentos, voltou a consciência com poderes curativos e de transformação. Assim note que a transformação que ocorre com Lidia é para ajudar os outros, como excerto:

"Lo que te ha passado no es corriente, es raríssimo que se presente la Madre-Jaguar” exclamó el chamán "ella te há elegido como su hija y te há traspassado su esencia mágica a través de su leche. Ahora podrás convertirte em jaguar las veces que quieras y además tendrás poderes curativos. Yo te ensenaré a usarlos, te quedarás conmigo y 
tu familia podrá llevarte algunos días de visita”. Así fue como Lidia se crió com ese curandero que la llevó a conocer a fomosos chamanes seminolas, hospis, mayas, animaras y amazónicos que le enseñaron a usar las hierbas y le abrieron la entrada al universo de los espíritus (Camacho, 2019, p. 10).

Podemos notar que a partir do momento que Lidia pode se transformar em jaguar o espaço que ela está, começa a ser todo modificado. Antes morava com os pais, agora irá morar com o xamã, só poderá ver os pais em visitas. Observamos também que a vida de Lidia agora não tem um paradeiro fixo, sempre mudando indo em várias localidades, ou seja, os espaços estão sempre se modificando.

Vale ressaltar que mesmo com poderes curativos, Lidia foi morta quando caçava em suas terras. Ou seja, o não entendimento dos animais e dos não humanos, nos tornam seres humanos maléficos que mata o que não conhece. Lestel (2007), afirma que:

Não é, portanto, por não possuirmos o conceito de certos fenômenos, ou por ser quase consenso que jamais disporemos desse conceito, que estamos bloqueados em nossas relações com os animais. Em outras palavras, é possível construir pontos de vista, planejar ações, gerar crenças e coordenar instituições em torno do incompreensível, de um incompreensível mais ou menos fechado, e certo, mas o qual não poderemos jamais acessar. É exatamente esse o caso da animalidade: não é possível descrever o conceito de animalidade, entretanto, esse não é um conceito que convém ser eliminado. $\mathrm{O}$ humano não possui uma concepção clara, sabia ou ingênua do que é a animalidade (p. 48).

Dessa forma, buscando compreender o animal que chegaremos a um denominador comum, ou seja, como desconhecemos seus hábitos, rotinas e seus meios de sobrevivência, 
subjugamos e acabamos por "matar" aquele ser, assim fazemos também com as culturas que não conhecemos.

\section{CONSIDERAÇÕES FINAIS}

Esta pesquisa objetivou apresentar alguns elementos das histórias míticas da obra Misterios de la Selva Amazónica, de Gabby Cuellar, em duas narrativas em que ocorrem a metamorfose, tanto nas personagens quanto no espaço e mostra uma breve descrição de como a região Amazônia é vista ou foi vista. Dessa forma compreender um pouco sobre os animais e os não humanos.

Identificamos, a partir da análise dos elementos do espaço e dos estudos animais, em histórias míticas que a autora, utiliza esses recursos estilísticos de metamorfose de personagens e espaço para construir o imaginário amazônico.

A partir da leitura e da análise das histórias, observamos que a temática da Amazônia tem forte influência para a escritora que é, notadamente, uma escritora engajada em apresentar as particularidades da história, da cultura e da literatura amazônica. Dessa forma apresentar a região pela voz de Gondim, 2019, se relacionando com Lestel (2007), juntamente com, Barbiere (2009), Cunha (2003), Molina (2016) e Correia (2005), nos mostram como o imaginário amazônico foi construído e como ele se relaciona com as histórias míticas aqui apresentadas.

Ressaltamos que a compreensão das narrativas analisadas exige do leitor alguns conhecimentos sobre as questões míticas, do estudo do espaço, do estudo animal e, também, do imaginário amazônico. A obra de Gabby Cuellar proporciona ao leitor uma reflexão sobre a produção literária brasileira produzida na Amazônia. Ao mesmo tempo que a literatura é local, ela é global, 
pois conforme afirma Loureiro (2014), "O mundamazônico é um mundo dentro do mundo".

Por fim, as análises, aqui apresentadas, não buscam responder aos questionamentos que surgem quando ocorre a leitura de tais histórias, principalmente quando se trata da região amazônica que é: "é verdade ou mentira?". O que foi pretendido, foi mostrar a forma como as histórias míticas fazem parte do espaço em que vivemos, a região amazônica, e nos ajudaram a compor este estudo.

\section{REFERÊNCIAS}

CAMACHO, Gabby Cuéllar. Misterios de la Selva Amazónica. Guayaramérin, Beni, Bolívia, 2019.

BARBIERI, Cláudia. Arquitetura Literária: sobre a composição do espaço narrativo. In.: BORGES FILHO, O. e BARBOSA, S. (Org.). Poéticas do espaço literário. São Carlos: Claraluz, 2009. p. 105126

GONDIM, Neide. A Invenção da Amazônia. 3. ed. Manaus: Valer, 2019. 340 p. Organização: Tenório Telles.

CORREIA, Heloisa Helena Siqueira. Revista

Abusões, n. 8, v. 8, Ano 5. Disponível em: <www.epublicacoes.uerj.br/index.php/ abusoes/article>. Acesso em: 13 fev. 2020.

LESTEL, Dominique. A Animalidade, o Humano e as Comunidades Hibridas. Pensar/escrever o animal. 2007.

LESTEL, Dominique. A animalidade, o humano e as "comunidades híbridas”. In: MACIEL, Maria Esther (org.) Pensar/escrever o 
animal - ensaios de zoopoética e biopolítica. Florianópolis: UFSC, 2011.

LOUREIRO, João de Jesus Paes. Mundamazônico: do local ao global. Revista Sentidos da Cultura. Belém, Pará. Jul-Dez/2014. <www.uepa.br>. Acessado em: 10 jan. 2020.

MOLINA, Maria de Fátima Castro de Oliveira. A hipertextualidade em O outro pé da sereia: uma escrita em palimpsesto. São José do Rio Preto, 2016. 


\section{INTRODUÇÃO}

A canoa vai cortando manso as águas turvas do remanso. A saudade vai remando na proa, comandando o rumo da canoa. (“Saudoso Fado”, Cortezão, 2018, p. 116)

A Literatura Amazônica ou de Expressão Amazônica lembra a metáfora das viagens, talvez porque a história da ocidentalização da Região Norte, como a do restante do país e do continente sul-americano, esteja ancorada nas viagens da era dos descobrimentos e das catequeses, fatos e histórias que nos chegaram pelos mares e oceanos. E nessas viagens identificam-se as marcas históricas do passado colonial e de outros processos de dominação dita "civilizatória" que apontam as muitas interferências externas que impõem à região um embate constante entre a visão moderna e a colonialista. Nessas viagens e nesses deslocamentos ocorrem fatos singulares da cultura local,

${ }^{89}$ Professora de Literatura Brasileira da Amazônia da FALE/UFPA. Mestre em Estudos Literários e Doutoranda do PPGL/UFPA. Jornalista, poeta e ensaísta. Publicou: História e Memória em Aruanda e Banho de Cheiro, Deus sobre todas as coisas, Escre(vi)vências \& Afetos, A Literatura Amazônica e a Cultura Regional, para além das salas de aula, Romanceiro da Floresta \& das Águas, Ensaio: 30 Fotos de Elzinha x 30 Letras Minhas entre outras publicações. Contatos:vmsalvarez58@hotmail.com ou alvarez@ufpa.br. 
da subalternização do "Outro" e também de resistência. Viajar para sobreviver, para garantir a subsistência, para ter acesso aos serviços públicos como a escola, o posto de saúde, o cartório, a delegacia - que parecem muito distantes do ribeirinho que se acostumou com o céu, a água e a floresta. Sair de seu lugar em busca de algo melhor, que lhe complete ou que se ofereça como um alento diante da vastidão e do isolamento. $\mathrm{E}$ os sonhos persistem na memória, no dormir e no despertar, apesar dos muitos deslocamentos que o amazônida é obrigado a fazer. Há imensas enchentes e inundações que rompem esses silêncios.

Há na Região Norte o ir e vir por meio das estradas que andam ${ }^{90}$, os rios, furos e igarapés que aparentemente poderiam limitar o caboclo, porém esse movimento lança-o em desafios diários, como pescar, remar, lancear, sempre com as viagens mediando o imaginário social desse ribeirinho. $\mathrm{O}$ amazônida sai de sua terra, mas esteja onde estiver estará corroído pela saudade; suas lembranças alimentarão seus sonhos de voltar, de se encontrar com/em um lugar imaginoso, vislumbrar as coisas que já se passaram e que não voltam mais.

Esses aspectos estão em conhecidíssimos escritores amazônicos, tais como, Márcio Souza, Dalcídio Jurandir, Benedicto Monteiro e Milton Hatoum. Contudo, há outros escritores que se identificam com a gente do Norte, mesmo que se lancem do isolamento à transnacionalidade, tomam para si o desafio de serem cidadãos do mundo. Todavia, as narrativas orais,

90 O poeta Ruy Paranatinga Barata escreveu os versos "Esse rio é minha rua/minha e tua mururé/ piso no peito da lua/deito no chão da maré/ pois é, pois é/ eu não sou de igarapé/ quem montou na cobra grande/ não se escancha em puraqué/", que se tornaram conhecidíssimos no Brasil pela interpretação de Fafá de Belém, e que se referem a esse mundo de água e ao desafio a ser vencido pelo ribeirinho, as enfrentar os rios e enchentes em seu dia a dia. 
os mitos, as lendas, os hábitos e os costumes amazônicos acompanham esses escritores: um pedaço deles fica na Amazônia e uma parte da região segue com eles, em suas andanças.

E essa metáfora da viagem também se dá com os que chegam à Amazônia e por ela se sentem encantados e como se diz nas terras do Norte - "mundiados" 91 - assim como a cobra grande e a uiara "hipnotiza suas presas". O prof. Dr. Joel Cardoso da Silva, ensaísta e professor de Literatura Brasileira da Amazônia, no magistral prefácio do livro A Literatura Amazônica e a cultura regional, para além das salas de aula, autoria de Alvarez (2021), assinala que a Amazônia é um contexto que, em aqui chegando, nos influencia, nos contagia, nos modifica, nos estrutura, nos forma. Diante de nosso olhar embevecido, os cenários se descortinam imensos: rios profundos e caudalosos; matas indevassáveis; vilarejos ribeirinhos entranhados na floresta; centros urbanos que se opõem à simplicidade rústica das margens; culturas, hábitos, falares, específicos de sobrevivência de seus moradores. É preciso se deixar reeducar para que, com novos olhares, aprendamos a ver, a sentir e apreender esse universo. Estar na Amazônia é vivenciar um Brasil diferente, específico, profundo em seus mistérios e incontestavelmente mágico. Com suas especificidades, a Amazônia representa um contexto múltiplo, abrangente e universal e, ao mesmo tempo, muitíssimo específico e particular. Imensa, desconhecida, com sua cultura diversificada, com seu rico imaginário, com suas crenças particulares, com seus personagens, com seus falares

${ }^{91}$ Mundiar = magnetizar, assombrar. Poder que o povo amazônida crê, possuem as cobras e as uiaras, de entorpecer o ânimo, abolir a vontade, aniquilar o instinto de proteção e de conservação. Vem do tupi mundiá, do guarani mondyi, significando tremer, espantar, causar medo (Miranda, 1968, p. $59)$. 
característicos, a Amazônia continua paradoxalmente próxima e distante (Cardoso, 2021, p. 16)

E nessa viagem para ler e estudar essas poéticas locais, que se localizam muito além das fronteiras regionais (pois se lançam ao global), algumas problemáticas revelam-se: o escritor nascido na Amazônia tem dificuldades para publicar suas obras, ainda porque a fala amazônica duela contra a sua própria invisibilidade, embate-se contra as marcas de um colonialismo que ainda está entranhado nas mentalidades e contra os estereótipos de ser um lugar considerado "exótico ou selvagem", mas mergulhado em muitos encantos, mitos e lendas. Há outros entraves: a ausência de obras referenciais que revelem o que é a Literatura da Amazônia; como entender que a grandeza da Amazônia, não é apenas territorial, mas também imensa em sua produção literária e cultural. E que há muitos escritores nos rincões amazônicos que falam de sua terra, de sua gente, de seus costumes, como forma de marcar territorialidades e identidades, porque a Amazônia é também plural.

E como não referir-se às viagens se um discurso amazônico se descortina sob a voz do exílio que vem da Espanha e de lá e daqui do Brasil entrecruzam-se outras vozes poéticas. Poeta "exilada” em Segóvia, mas impregnada pelo universo mítico e plural amazônico, a escritora Marta Cortezão tem se destacado pelos projetos culturais que desenvolve por meio das Tertúlias Virtuais, realizadas com mulheres poetas de todo o mundo. Tratase de um trabalho divulgado no Mulherio das Letras da Espanha e no canal da escritora Banzeiro Conexões. Porém, Marta também é 
poeta e se revela em Banzeiro ${ }^{92}$ Manso e no inédito livro de trovas Amazonidades Poéticas.

Este artigo fará essa viagem tentando entrecruzar o fazer poético presente nos mitos gregos e as musas clássicas, reinterpretadas pela ação das guerreiras icamiabas ${ }^{93}$, para revelar a fala de "Maria e de outras" mulheres caboclas e anônimas. Falarse-á do "jeito tupeba de ser", ao mesmo tempo lisonjeiro com dicção própria e "verdadeiramente amazônica". Discorrer-se-á sobre uma poética feminina libertadora, livre e louca, "para alçar voos sem limites". E nesses tantos banzeiros há "a fraqueza que nasce da força", "os revoltosos tormentos", que "desatam piracemas no olhar". Há ainda a viagem do "Odisseu errante”, "os descompassos da vida", "o vazio das incertezas", "a alma viandante" que se "perde em descaminhos" e que se projeta em "muitas sedes".

Há ainda o seu trajeto nas trovas e que marcam seus caminhos de uma intensa redescoberta de sua terra, movida pela separação, pelo olhar do exilado e pela imensa saudade.

${ }^{92}$ Banzeiro significa agitação das águas de um rio ou de um igarapé, na forma de ondas suaves ou violentas. (Oliveira, 2001, p. 23)

93 Segundo Luis Caldas Tibiricá (1984), Icamiabas ou iacamiabas (do tupi i + kama + îaba), significa "peito partido" ou "que não tem seio", sendo a designação dada à lenda de índias que teriam formado uma tribo de mulheres guerreiras. Compunham uma sociedade matriarcal, caracterizada por mulheres sem homens. Esta lenda teria dado origem, no século XVI, ao mito da presença das Amazonas na região Norte do Brasil. Embora seja uma lenda, as Icamiabas foram vistas pela esquadra de Orellana, em 1542, quando os espanhóis passavam pelo Espelho da Lua, região da atual cidade de Nhamundá, no Amazonas. Mitologia grega e a lenda local se fundem nas narrativas dos viajantes e originaram o nome do rio Amazonas, de onde deriva a região Amazônica e o estado do Amazonas. 
São as lembranças

mais simples e cotidianas

que dão à palavra saudade

um significado que transcende a matéria

se apropria da alma,

confunde e domina a razão.

embriaga o coração num sentimento profundo,

pleno de inesquecíveis recordações

colorindo, harmoniosamente, a vida

e nos reservando, ao mesmo tempo

inúmeras surpresas (“Saudade”, Cortezão, 2018, p. 54).

\section{DA AUTORIA FEMININA SINGULAR}

Sou do norte, terra de caboclo forte, que toma açaí, come piracuí, bodó assado e jaraqui, pirarucu $^{94}$ com chibé ${ }^{95}$, tucumã com café; que faz paneiro ${ }^{96}$ com cipó de ambé planta roça, faz farinha pra comer com pupeca de sardinha, enquanto a criançada corre e salta, colecionando coloridas joaninhas. ("Essência”, Cortezão, 2018, p. 96)

${ }^{94}$ Pirarucu: é o Arapaima gigas, grande peixe de escamas da Bacia Amazônica, que mede dois ou mais metros de comprimento, sendo por isso considerado o maior peixe de água doce do Brasil (Oliveira, 2001, p. 136).

${ }^{95}$ Chibé. Farinha d'água mui diluída em água. Che=mim, $y=$ água, $b e ́=$ para, segundo Barbosa Rodrigues. Vem de cheribé, o caldo, ou o meu caldo (Miranda, 1968, p. 22-23).

${ }^{96}$ Paneiro: cesto de talas de palmeira, com ou sem asas, muito utilizado na Amazônia para o transporte de frutas, legumes, etc. Há paneiros de vários tamanhos, sendo que os menores são usados como vasos para o plantio de mudas de pequeno e médio porte (Oliveira, 2001, p. 44). 
Em 2020, por ocasião do aniversário de Marta Cortezão, em 16 de setembro de 2020, Vânia Alvarez publicou em sua página na rede social, o poema intitulado No remanso do rio: $o$ caboclismo das águas, no qual a biografia e a produção literária da escritora e produtora cultural aparecem em destaque. $\mathrm{O}$ poema tenta historiar o trabalho de uma guerreira Icamiaba, do mesmo modo icônico que se conhece na Amazônia.

Hoje é aniversário dela

Professora poeta escritora

Ativista pelas coisas da Amazônia

Pode-se dizer... Uma Icamiaba

Mas também querida

Do bom humor

E crítica decidida contra

Os que não respeitam a Amazônia

Uma amiga feita de repente

de águas

de oceanos

de paneiros

de trançados

de trovas

de poesia...

Eu a conheci em 2019

Na Revista Pixé

E lá encontrei o lindo poema

"Fotografia" e nele se lê...

"Teu olhar decifrou-me os pensamentos;

o silêncio gritou feros desejos;

meu corpo te implorou atrevimentos,

paixão, insanos beijos e gracejos...

Vem, despe-me das vestes, dos tormentos..."

Ela é poeta da Literatura Amazônica

Nascida em Tefé, no Amazonas

Porém registrada em Uarini

Lugar onde viveu parte 
De sua infância

E comeu da melhor farinha ovinha

Feitas de grânulos

Caprichosamente torrados

No tacho da vida...

Minha amiga de poéticas é cidadã do mundo

Pois sonhos não permitem fronteiras

Conforme escreveu em "Primavera"...

"A chuva que molha

meu triste rosto agora

é a mesma que leva

os desencantos

correnteza afora."

Está em várias antologias

Nacionais e internacionais

Seu primeiro livro de poesias

É "Banzeiro Manso"

Onde se lê... "Enigma"

"Se nosso amor é tão sólido

por que me escorre pelos dedos?

A liquidez do teu sentimento

deságua em mim igual tormento..."

Ela é da Associação Brasileira de Escritores

e Poetas Pan-amazônicos - ABEPPA

Faz parte da Academia de Letras do Brasil

- Amazonas - ALB/AM

Em 2014 estreou com "Atreva-se"

Na revista "Subversa, literatura luso-brasileira"

E recebeu muitos elogios.

No poema No remanso do rio: o caboclismo das águas, fala-se de suas origens, do seu ativismo pelas coisas da Amazônia, da mistura de seu bom humor com a crítica (mais bem-humorada, que ferina), que é efetivado ao vivo, em cada Tertúlia Virtual que 
realiza. É das amizades que Cortezão cultiva com as poetas que ela "pesca" em muitos lugares, mulheres poetas que estão em todos os lugares do mundo.

Agora ela está em Segovia

Castilla y León Espanha

E de lá convoca um exército de poetas

Do Brasil

De Portugal

Da Europa

Do mundo

Para perto de si

E risca o céu de saudades

Com um "Raio de Luz"...

"Quando uma estrela riscar,

velozmente, o escuro do céu,

será a minha saudade a pintar

a dor insana de um coração, teu réu.”

E dia desses recebi uma mensagem de afetos

Para dividir experiências

E divulgar o que escrevo

No entanto minha amiga de poeticidades

Tem feito travessuras poéticas

E travessias literárias

Ela faz tantas coisas

E seu espírito irrequieto

Nos mergulha em Tertúlias

Festivais, Festas Poéticas, Vídeos

Poesia... muita poesia...

Dia desses recebi um telefonema

Do outro lado do mundo

Chegou uma voz doce

educada

delicada

bem humorada

E rimos de alguns poemas

E afinamos nossas poéticas

E li na "Simplicidade" dos versos... 
"Deixe o amor entrar

e fazer ninho no seu querer.

Deixe a alma transbordar

a vida acontecer.

(...)

Se jogue na corrente.

Abrace quando sinta afeto

sem os medos que ceifam mentes

e geram profundos desafetos.”

O poema No remanso do rio: o caboclismo das águas referese à trajetória de Marta, que sem perder a caboclice ${ }^{97}$, característica do amazônida, nunca foi tímida em seu poetar e em seus projetos culturais e literários. Sendo da Amazônia, Cortezão transformou-se em cidadã do mundo, porque sua terra natal tornou-se pequena para os projetos que ela sempre teve em mente. Mas nesse projetar-se para o mundo, a poeta sente-se fragmentada, corroída pelas lembranças e arma-se de uma imensa saudade. O livro Banzeiro manso é uma amostra desse ir e vir, dessa incompletude poética e dessa completude pessoal e humana.

Quem faz aniversário hoje

É Marta

E Marta é "senhora", "patroa"

É "dona de casa", "protetora do lar".

Vem do aramaico Martha

E se originou de marta, mar e mara

Ela está no novo testamento

Irmã de Lázaro e Maria

Está em Betânia

97 É o indivíduo resultante do cruzamento do branco com o índio. (Oliveira, 2001, p. 101.) Refere-se ao caboclo, tapuio ou mestiço que já adquiriu maneiras cortesãs, mas que não se exprime no nheengatu materno. A caboclice se refere ao modo de ser do caboclo ou as coisas a ele afeitas. (Miranda, 1969, p. 12 e 13). 
Entre os amigos de Jesus

Mas esta Marta é diferente...

Esta Marta nos diz

Em seu "Banzeiro Manso"

Desfilam (des)amores, flores,

Devaneios e a existência humana

Lendas e mitos greco-romanos

Folclores e costumes

Expressões das caboclices regionais

Hábitos e identidade

Pitadas de sutil bom humor

Um saudosismo telúrico

De quem partiu

Mas o coração ficou

Em sua terra natal...

É esse o compasso do "banzeiro manso"

Versos sem deixar de lado

A rebeldia e a intolerância

Contra preconceitos sociais

Marta é também Cortezão

E nos corteja de amores

Que nos tocam grandemente

"Meu primeiro inocente amor pesquei na cacimba

com isca de bucho de cuia

na água menina

que borbulhava

de dentro para fora

transbordando o coração

de paixão cunhatã.

Ele tinha os olhos negros

como o caroço de tucumã,

cheiro avassalador de umari,

voz sonora de Acauã,

pele suave de araçá-boi,

cabelo ruivo de espiga de milho,

de jenipapo carnuda boca.

Quando seu sorriso me via 
minha boca desejava beijo

igual chuva cai do céu

e fervilha sentimentos

na água menina!

Sempre o pescava à tardinha,

hora exata do encantamento.

O caniço viçoso exalava

o cheiro de amor verde escondido.

Era jogar a isca e o anzol fisgava

ligeiro meu amor primeiro... (...)”

É assim que caminha a poética de Marta Cortezão: falando de amores - de assumir-se mulher, doce e terna, mas incisiva, que se revela poeta e tocada pelo visível silenciamento, que o cânone impõe às poetas na literatura brasileira. Marta volta-se para os amores nascidos "nas águas meninas", paixões que remetem às ancestralidades dos povos indígenas, caboclos, ribeirinhos, mestiços, ancestralidade feminina das icamiabas. E o universo das frutas, das águas e da floresta emerge "fervilhando em sentimentos" femininos, revelando os hábitos vividos pela menina de Tefé, no Amazonas, mas pontuando a poética madura da mulher projetada do local ao global.

Hoje é aniversário da Marta Cortezão

A quem quero confessar:

Fui fisgada na poética

Como "água da cacimba"

E estou impregnada

De perfumes como o do "Umari"

Do "araçá- boi"

E aceito, ansiosa,

Que viajaremos "muitas águas"

E ficaremos, mesmo,

Encantadas com o canto da Iara!

Felicidades Marta Cortezão

Ave, poeta do mundo! 
Estamos no Pará e no mundo

Enfeitiçados pelo teu canto poético.

(Alvarez, 16/09/2020)

\section{DA DIVULGAÇÃo CULTURAL E DA POÉTICA PARTILHADA}

Levando dentro o amor e o orgulho de ser amazônida.

Força que move o coração desta

Mulher que por isso, se sente Imensa!

(“Encontro”, Cortezão, 2018, p. 113)

Estes versos do poema "Encontro" mostram “a imensidão e o amor” pela educação literária, pela mediação de leituras e pela defesa da literatura e da cultura que move Marta Cortezão. Além de generosa com os amigos e preocupada com a literatura e a cultura, a escritora é "mulher dos mil instrumentos" quando o assunto é o letramento, por meio da literatura e da cultura. A escritora tem participado de inúmeros eventos que divulgam a literatura, a produção cultural e a poesia feminina. Entre eles destacam-se Essas Mulheres, projeto realizado através do Blog Tabacaria e idealizado por Sidnei Manoel Ferreira, que foi ao ar em 09/11/2020. Criou o coletivo Mulherio das Letras Espanha e tem sido articuladora do Mulherio das Letras União Europa, contando com Mulheres de Letras de Portugal, Suíça, Bélgica, Espanha, Alemanha, Dinamarca, Áustria, África e Itália. Idealizou o bate-papo literário com vários escritores, inclusive com Simon Oliveira (autor de O Trem das Almas), de Rondônia; o bate-papo com a pesquisadora da "causa indígena" Carina Oliveira. Ela também conversou com Nathan Sousa, Prêmio UBE e finalista do Prêmio Jabuti (2015) e inúmeros(as) escritores(as), poetas e artistas. 
Participou do painel Vozes Femininas e Diáspora Brasileira na Espanha, no II Encontro Virtual Mulherio Portugal, realizado em 28/09/2020. Engajou-se em vários grupos internacionais para apoiar uma "amiga escritora", iniciativa do Mulherio das Letras Portugal, que assiste com a compra de livros e com likes, compartilhamentos, financiamentos coletivos, indicações, recomendações, comentários e outras participações com o objetivo de divulgar o trabalho literário de mulheres brasileiras pelo mundo. Ela também participou do evento $V$ Transfronteiras - Epistemologias, Culturas e Vozes Interdisciplinares, evento organizado pelo PPGICH/UEA/Tefé), em 22 de outubro de 2020. Fez parte do I Simpósio de Poesia Contemporânea de autoria Feminina do Norte, Nordeste e Centro-Oeste/Simpfennco, realizado pelo Grupo de Pesquisa Gpfennco da Universidade de Rondônia, em 30 de outubro de 2020. Incentivou e criou por meio do Mulherio das Letras Espanha, a realização do Estou a fim de Poesia e A Poética que abraça, com escritoras como Cida Ajala (SP), em 25 de novembro de 2020. Participou do I Encontro Regional do Mulherio Nísia Floresta, uma roda de diálogo do Mulherio das Letras sem Fronteiras, com a participação do Mulherio das Letras EUA, do Mulherio das Letras Mato Grosso, que se realizou em 28 de novembro de 2020.

Além dos eventos que incentiva, participa ou idealiza, a escritora também criou o projeto Tertúlias Virtuais, que tem despertado a admiração de muitos, conforme nos revela Sidnei Manoel Ferreira, do Blog Tabacaria: "a Tertúlia Virtual é um verdadeiro espetáculo de amor à poesia, de entrega à inspiração e ao talento de tantas poetas maravilhosas. Parabéns, Marta Cortezão!". Os convites feitos são sempre afetuosos: “É com essa plêiade de luz que celebraremos o lançamento dos livros de Janete Manacá! Esperamos vocês com amor e poesia!”. A generosidade de Marta Cortezão tem uma função muito além do que se imagina: ela incentiva as pessoas, as acolhe e dá a essas mulheres uma 
oportunidade de ouvir outras escritoras e serem ouvidas. Não é de estranhar que muitas se emocionem e chorem, ou agradeçam a participação nas Tertúlias.

Tudo na vida tem uma razão de ser. Nada acontece por acaso. Em 2019 depois de muito tempo sem escrever uma linha sequer quis homenagear um grande amigo então escrevi a minha primeira poesia. Desde então, tomei gosto e nunca mais parei. $\mathrm{E}$ as coisas foram acontecendo. Que maravilha! Deus colocou tantas pessoas espetaculares que vieram para enriquecer o meu cotidiano, a minha vida. Obrigada Marta Cortezão pela sua benevolência. É uma oportunidade ímpar. Meu coração gentilmente agradece. Espero ansiosa por este momento. Convido meus amigos para este lindo e maravilhoso momento de minha vida!

Em 27 de setembro de 2020, Marta Cortezão explicou aos seus leitores o objetivo das Tertúlias Virtuais.

Sou Marta Cortezão, nasci em Tefé, no Amazonas/ BR, mas vivo em Segovia/ Espanha há alguns anos. Tenho realizado várias "loucuras poéticas", com a ajuda de muitos amigos e amigas da Literatura e das Artes como um todo; o Tertúlia é um desses momentos de loucura que venho vivenciando através da partilha poética. $O$ projeto tem como peculiaridade criar elos poéticos e destacar engenho e arte de mulheres de vários lugares desse mundo, proporcionando, por meio de um delicioso banquete de leitura de poemas e poesias, o prazer da troca poética (Cortezão, 27/09/2020).

Confirma-se que as Tertúlias são movidas pela paixão de revelar os talentos de escritoras e de poetas brasileiras e o compromisso da escritora amazonense com a fala feminina que já aparecia em sua poética desde Banzeiro manso como a voz que falava em nome das guerreiras icamiabas. 
Lá se vão as grandes heroínas

vestidas de aparente resignação.

mas são o sustentáculo da família

na honrada e dura lida pelo pão.

São fortes e atrevidas essas Marias,

Marias que tecem o fio do destino.

Em meio ao rebojo das calmarias,

o suor rola pelo rosto destemido.

(“Tenras lições”, Cortezão, 2018, p. 115)

Devido o sucesso das Tertúlias, Cortezão passou a escrever uma coluna na Revista Ser MulherArte, na qual a autora produz textos que falam da importância desses encontros. Na crônica de crítica literária publicada em 27/11/2020, a escritora revela algumas de suas preocupações e que movem o seu maravilhoso trabalho de divulgação da produção de mulheres:

[...] qual é o lugar da mulher na atual sociedade? Como estamos construindo este conceito historicamente e culturalmente? Por que é importante discutir acerca do gênero? Por que dizer-se feminista provoca tantos desafetos? Sempre é tempo de despir-nos das velhas amarras da ignorância e buscar entender o real significado do Feminismo que, em poucas palavras, nada mais é que um movimento social, não sexista, liderado por mulheres e que reivindica equanimidade jurídica, política e social entre homens e mulheres. Se nos debruçarmos a estudar o Feminismo, encontraremos inúmeras histórias de lutas de grandes mulheres inspiradoras que nos abriram passo para exercer o nosso grito de liberdade. Já não há como tapar os ouvidos a estas vozes que ecoam cada vez mais alto e, harmoniosamente, alavancadas pelas múltiplas inquietudes que nos movem no mundo (Cortezão, 11/2020) 
A escritora amazonense afirma que nas Tertúlias as discussões são saudáveis e poéticas e têm reunido mulheres do Brasil e do mundo e suas poéticas são discutidas ou publicadas num espaço sem fronteiras. Cortezão refere-se à transgressão, ao terreno de possibilidades que o mergulhar no texto poético feminino proporciona.

Autoras que fazem da linguagem poética o território simbólico de combate e de transgressão literária, "um lugar que não é o espaço natural, mas o espaço-tempo habitado pelo sujeito poético" (BOSI, 2003, p. 285), terreno das possibilidades. É importante ressaltar que, na criação do texto poético, o fazer literário se origina no mergulho interior de "uma dialética da lembrança pura e memória social; de fantasia criadora e visão ideológica da História; de percepção singular das coisas e cadências estilísticas herdadas no trato com pessoas e livros." (Bosi, 2003, p. 278). Não se trata apenas do que o sujeito poético observa/filtra no/do seu exterior, mas do diálogo que trava com sua bagagem interior e o mundo lá fora. Vargas Llosa também se une a este pensamento quando afirma que "o que se viveu é a fonte que irriga a ficção" (Llosa apud Sena, 2020, p. 61) (Cortezão, 11/2020).

No entanto, a cronista literária não está distante de vislumbrar sua própria produção poética. Ao falar da poética de suas amigas e convidadas, Cortezão também se refere à inquietude, à afetividade, ao erotismo poético, temas que são transgressões para a mulher diante de uma história das mulheres, escritas por homens, uma das marcas opressoras da sociedade patriarcal. $\mathrm{O}$ discurso feminino é de empoderamento, no qual diversos tabus são questionados, preconceitos e representações são desmistificados. Essa é a marca de Cortezão que afina o pensar das Tertúlias com o pensamento de Simone de Beauvoir e o poema "Dona de mim", escrito nas lonjuras do tempo, conforme 
assinala a poeta: "É a escrita tábua de salvação, resistência e transgressão, é também linguagem simbólica que liberta corpo e mente da violência do silenciamento, dos flagelos da invisibilidade social e por que não da cruel sina de apêndice do homem?”

A escolha foi minha:
abracei a loucura
sem preocupações futuras.
Sou Eva, amiga da sábia serpente
que me ensinou o pecado
e as rudezas de um mundo doente.
Sou mulher livre
para amar a loucura
sou mulher louca
para alçar voo sem limites
sou mulher viva
para viajar aventuras
sou despenhadeiro
para aventurar-me aladamente.

Sou dona de mim

Para fazer diabruras.

(“Dona de mim”, Cortezão, 2018, p. 72)

As Tertúlias Virtuais surgiram como lives em um período de isolamento e de lockdown e representam essa possibilidade de fazer amigos, de mobilizar o mundo para a importância do letramento literário e divulgar a obra de mulheres consagradas ou não, e passam a ter um fundo social e de educação literária inclusiva.

Esta voz feminina na poesia que, assumindo-se sujeito pelo poder da palavra, (re)inventa sua (re)existência quando diz sobre os outros e as outras presentes no ambiente a sua volta e/ou ainda em espaços, cujos olhares e cujas vozes esgueiram-se por alcançar. Além de escancarar seu mundo interior, esses corações poetas sangram aquele grito que reverbera com 
ousadia e ainda revela as tantas vozes silenciosas e silenciadas pelas concepções ideológicas estruturais que teimam em definir um lugar próprio da mulher na sociedade. São estas vozes, são estes olhares, oriundos das margens do não-lugar, que se dirigem à trilha do "para além do não-silenciamento", decididos a tomar as rédeas do discurso poético e (re)ocupar os lugares que os padrões tradicionais de poder, dia a dia, lhes vêm negando. São estas vozes e estes olhares, no feminino, que (re)contam o contexto histórico-social vivido e que através da palavra se (re)vestem de humanidade para externar aquilo que é humano e que humaniza. É deste viés marginal que a poesia também se alimenta como gênero poético, inspirando denúncia e liberdade, dois tênues fios que pendem dos corações poetas, através das singulares vozes e subjetivos olhares, com o intuito de descortinar invisibilidades. Quando estas autoras falam de si mesmas, estão também ressignificando-se e comungando do ato poético de existir pela palavra (Cortezão, 06/12/ 2020).

\section{DA POÉTICA COM JEITO TUPEBA}

Eu que já viajei tantas águas, que conheço os segredos do rio profundo, o canto da Iara, ${ }^{98}$

os mistérios e encantamentos do Boto ${ }^{99}$ sedutor e da Boitatá, a cordialidade do Tucuxi, o arrepio do canto da mata...

Sou incapaz de conhecer teu dissimulado riso de louca Mona Lisa!

\footnotetext{
${ }^{98}$ Iara: formosa mulher de voz encantadora, cativante, que vive nos rios e lagos. Está presente na religião indígena com a 'senhora' que é a uiara (Miranda, 1969, p. 42).

${ }^{99}$ Boto: ente mitológico que costuma aparecer como um rapaz bonito, usando bengala e chapéu para seduzir as moças (Oliveira, 2001, p. 63).
} 
Para se falar em Literatura Amazônica é necessário compreender a Amazônia, além de considerar que existe uma cultura e uma literatura próprias da região, pois essa discussão transita pela ancestral relação entre o local e o universal. Quanto à temática da Literatura Amazônica, Romário Aires (2015) referese à necessidade de fazer dialogar o local com o global e assinala que: percebe-se que não é de hoje que os embates entre o local e o universal se suscitam no campo literário. Na ânsia de resguardar sua identidade, os povos exaltam suas singularidades, a fim de serem considerados, na pluralidade de suas culturas, em contraponto a outras manifestações culturais (Aires, 2015, p. 130).

Assim, volta-se o olhar para uma literatura, que tem origem nesses rincões e surge pela voz dos narradores e poetas; uma literatura da Amazônia: que seja referência para os de fora, mas que seja referência também para os de dentro. Sem dúvida uma literatura da Amazônia ou de expressão amazônica que venha problematizar a não restrição do olhar ao local, ao particular, e, sim, tomar o local e o universal, aproximando a literatura, a cultura regional e a do mundo, questionando os processos colonizatórios e os midiáticos que professam ideologias de homogeneização, particularidades mais relacionadas a questões político-ideológicas do que estéticas, que a todo custo tentam oprimir e calar os amazônidas.

Há uma literatura que fala de problemas universais, mas também dos rios, da floresta, da gente amazônica, suas belezas, costumes, hábitos e de seus conflitos. Há uma Amazônia, cujos temas perpassam pela destruição da cultura ancestral, pelos desastrados projetos de devastação que prometeram trazer o progresso e por temáticas que identificam escritores engajados 
nessas lutas. Entretanto, há outras questões que devem ser suscitadas.

Na publicação Literatura Brasileira da Amazônia: Roteiros \& Estudos, assinada por Vânia Alvarez (2018, p. 28), percebe-se que é possível distinguir alguns aspectos caracterizadores da Literatura Brasileira da Amazônia: a) na Literatura da Amazônia, há uma produção que se realiza entre o isolamento do homem amazônico e o projetar-se na vastidão territorial de outros cenários locais e globais; b) a Literatura da Amazônia reflete a cultura híbrida que amealhou para si, elementos da vida/cultura indígena, negra, cabocla e estrangeira/europeia, como traços de populações que viviam ou que se instalaram na Amazônia, no decorrer de sua história; c) na Literatura da Amazônia, o universal dialoga com o local, mas sem ser eminentemente regional, exótico ou folclórico; d) Há nos escritores amazônicos aproximações com o cânone ocidental e suas formulações estéticas, sociais e culturais, dialogando perfeitamente; e) a Literatura da Amazônia transita entre a tradição e a modernidade, em amplos processos de ressignificações, de pluralidade e de aculturamentos; f) a Literatura da Amazônia realiza-se no "entre-lugar", no entremeio, localizando-se em assinalar a existência de uma Amazônia real e uma Amazônia mítica; g) faz-se uma Literatura da Amazônia que mesmo sob a intervenção do explorador, realiza-se na "contrainvestida” de uma Amazônia devastada, 'derruída', para ser sinônimo de resistência cultural; e h) a Literatura da Amazônia reflete a identidade em permanente movimento de construção/desconstrução, visando enquadrar-se em um contexto moderno e pós-colonial.

A poética de Marta Cortezão tem ligação profunda com esses caracteres e com o município de Tefé, no Amazonas, região habitada antes da colonização pelas tribos Tupebas ou Tapibas. $\mathrm{O}$ traço marcante da cultura Tupeba é a valorização dos costumes 
ameríndios e da cultura cabocla local. A produção de farinha de mandioca e a pesca do tambaqui e do pirarucu estão entre as atividades econômicas principais.

Para Rogel Samuel (2018), que escreveu o prefácio de Banzeiro manso é a própria poeta quem define o "Jeito tupeba de ser", ou seja, um ar lisonjeiro, um sorriso faceiro, o discurso de poesia forte e feliz, amazônica, a fala de cunhantã, a voz das icamiabas, dos curumins e dos mistérios e segredos do muiraquitã. Essa poética é a representação da doçura da alma cabocla e tudo que ela tem.

A compreensão de que a poética de Marta Cortezão referese a um mundo caboclo está fundada em Fábio Castro (2013) que definiu que o caboclo pode ser o que vem da floresta, mas é também "o filho do homem branco", porém trata-se de uma forma de representar, modernamente, o que significa ser o homem amazônico. O caboclo é o resultado do campesinato amazônico pós-indígena, que revelou um tipo humano em busca constante de definir a sua própria identidade. Para Castro (2013) o lugar social do caboclo o coloca em uma longa tradição segregatória, de luta pela sobrevivência, na tentativa de participação ativa na produção regional, deslocado da maioria dos projetos desenvolvimentistas, sendo obrigado a viver entre a ideologia de uma vida de encantos e a de grandes dificuldades. A poeta anota em suas "Caboquices" que há coisas boas: a gostosa culinária, a farinha, o vinho de açaí, a rede para se embalar e dar cochilos certeiros. Mas também em Monólogo do Tapiri há o duro trabalho da roça; o perigo da malária; as embarcações que exigem grande força de trabalho; o atravessador que quer comprar a produção do caboclo por preços baixos, e aumentar os preços do "açúcar, café, arroz, feijão"; a vida sofrida; a falta de escolas para as crianças ribeirinhas e o círculo vicioso de terem suas vidas mantidas "pelo cabo da enxada". Há 
também a falta de energia elétrica, a água que vem da cacimba para o pote; para o ribeirinho é da fraqueza que nasce a força.

O imaginário amazônico está presente, por exemplo, no poema "Dos medos": o medo de visagem, o medo de ser levada pelo Curupira, o Boto namorador, a Matinta que vem atrás de tabaco, o canto noturno do Bacurau, o canto agourento do Acauã, o berro do Mapinguari, o sapo Cururu Tei-Tei, o despertar da Cobra Grande, a Mãe-d’Água e a Mãe do Corpo. No poema "Súplica a Iara" há o pedido para morar no reino encantado das águas, onde não haverá pranto, mágoa, lamentos, dores, dificuldades, sendo o caminho para a redenção e para a ressignificação da vida e uma forma para "fugir deste mundo doente".

A representação da língua do caboclo está presente no poema "Festejo": os "zóio" são duas "porongas ${ }^{100 " ; ~ " o ~ j i r a u ” ~ q u e ~}$ substitui a pia; "o peguemo a rabeta”; "a boniteza da cunhã"; "o tremelique nas canela”; e outras expressões desse universo "marchemo zimpado", "apalpar aquela cintura"; "o cheiro no cangote"; "ela, arisca", se afastou num "pinote"; o jeito "vexado"; a risada "azeda que nem bacuri"; e a metáfora social cabocla: "a desfeita dói igual dor de dente". No poema "Farinhada", a poeta descreve o passo a passo para se produzir a farinha de mandioca e os seus derivados: o tucupi, a goma branquinha, a tapioquinha, $\mathrm{o}$ beiju de goma. E nesse poema surgem os apetrechos do trabalho do caboclo: o tipiti, a gangorra para espremer a massa, a peneira, a gamela, o remo ou tarubá, além de outros hábitos que seguem

\footnotetext{
${ }^{100}$ Poronga: espécie de lamparina que os seringueiros ou os pescadores usam na cabeça para percorrer as estradas da seringa na floresta amazônica, ou para 'lancear' no escuro. Feita a partir de latas de óleo, o seu combustível mais frequente é o querosene, e apresenta uma aba que impede que ela apague com o vento (Miranda, 1968, p. 71).
} 
aquele 'ritual': o banho na cacimba, a pesca do jaraqui e a curuminzada sentada no chão do tapiri. A voz cabocla também esta aderida à natureza que se antropoformiza, em uma abordagem telúrica, como nos poemas "A um taperebazeiro" e em "Remanso". Destaque a criação do verbo "taperebar”, referente às lembranças e as brincadeiras de criança que viveu nesse ambiente amazônico. A linguagem cabocla está bem representada no hábito de contar 'causos' e histórias como no poema "Desculpa esfarrapada”.

Em todo esse universo poético, há o toque autobiográfico que revela os motivos do exílio e da ida para outro país. No poema "Escolhas", a autora revela a opção pela felicidade, enfrentando os medos; o deixar para trás os fardos; as perseguições por inveja; porém, o coração de exilada parece entrecortado pelos "espinhos da saudade”; embora o sacrifício de exilar-se seja necessário para inaugurar outra fase da vida. E novamente se repete a metáfora da viagem, como no poema "Rito": "Eu que já viajei tantas águas, /que conheço tantos segredos”. Na temática do amor, o toque autobiográfico se revela como no poema "Dos amores": amor que se "pesca na cacimba", ou que tenha o cheiro do amor escondido, em "um tempo curumim."

Assinale-se que na poética de dicção cabocla de Cortezão há aproximações entre o cânone ocidental em suas formulações estéticas, sociais, culturais e essas influências dialogam com a ambiência amazônica. No poema "Exército Tupeba" há a menção do deus Hélio, que "desperta sua dourada baía de espelhos”. No poema "Baía Tupé”, a poeta realiza o encontro entre Hélio e Diana, nos amores que desaguam no rio Negro. A presença da literatura grega, em seu processo de construção poiética intertextual está em "Olimpo da saudade”, e de cada deus haverá a adaptação ou a transformação nessa ambiência amazônica: "a saudade tem os pés 
alados de Hermes”; “é sábia como Minerva”; e em todos os deuses do Olimpo há uma perfeita correspondência transformadora: o cânone ocidental universal dialoga perfeitamente com o local.

Outra característica que identifica sua poética como Literatura da Amazônia, em toda a peculiaridade, refere-se ao lançar-se do isolamento amazônico à vastidão territorial, tendo a saudade como fator que reconstitui a visão do degredado. No poema "Alada Saudade", se os olhos se fecham haverá um encontro com "a encantada terra Tupeba". Essa brasilidade amazônica repete-se em "Sangue Tapiba", no qual a poeta fala de sua aldeia como referência poética para o seu processo de criação. Destaque-se que a poética de Cortezão alimenta-se do imaginário amazônico para projetar-se para "fora" do isolamento das cidades ribeirinhas, lançar-se do local ao global, como no poema "Rebojo", cuja intenção poética é reinventar elementos do "banzeirando saudade", aliando-as às referências do "Velho Mundo".

No poema "Voltas", o laborar poético reflete os processos de aculturação e de hibridização, presente na poética de Cortezão: “a índia morena /que é belo anjo", a natureza como religião, a presença da "cruz", que serve para curar o desalento. Essa "Cabocla" de "tez Tupé", se mantém viva e miscigenada como forma de resistência. Assim, a poética viaja entre a Amazônia mítica e a Amazônia real, e esses "entremeios" ou "entre-lugares" servem para "curar a dor" do degredado, do exilado, "libertando do medo e do funesto cansaço".

Esse canto do exilado bebe nas fontes do romantismo nacional e se projeta em um modernismo paródico, aproximando o poema "Canção Tupeba" da "Canção do Exílio", de Gonçalves Dias. Esse exercício moderno de parodiar e reinventar outras 'falas e discursos' demonstra que a poética de Cortezão transita entre a tradição e a modernidade, mostrando a perfeita aproximação da poética amazônica com a tradição ocidental: "Minha terra, de 
palmeira, tem o zau: / piassaba, jarina, bacaba, buriti, patuá, / pupunha, babaçu, tucumã, açaí e o escambau / Ach'é pouco lugar pra sabiá cantar por lá," porém sem deixar de ser a afirmação de uma escrita pós-colonial.

Nesse universo poético anota-se ainda uma identidade cabocla em permanente movimento de construção e de desconstrução: a dor do degredado reconstrói cenários, cenas da infância, hábitos cotidianos como as conversas na calçada, o café com pão quentinho, "as matronas com sua peculiar sabedoria", as conversas nas portas, as histórias de encantamento e todo um imaginário caboclo que contrasta com "a vida na velha aldeia", no poema "Noites Ega", com o cenário do "Velho Mundo". As brincadeiras de infância retornam como uma forma de reconstituir esse passado que não volta mais, assim como ocorre no poema "Manso Amor".

E assim se inventa a arte da amazonense, conforme assinala Rogel Samuel: "a arte poética de Marta Cortezão, arte viva vinda do tapiri, com muita cultura"; (...) uma "poética da vida ribeirinha e do amor, do cântico cabôco que são duas porongas alumiando o escuro desse mundão." (Samuel, 2018, p. 12).

\section{DAS TROVAS AMAZÔNICAS}

Com a vara de trovar descaniçou caboquices nas águas de rebojar caprichos e gaiatices (Cortezão, 2021, p. 54).

É possível ler em um antigo livro de trovas que desde os índios Tupinambás já se prezavam os grandes músicos que, ao seu modo, cantavam quadrinhas populares e muitos ouvintes guardavam na memória. Os músicos faziam motes de improviso e 
suas voltas acabavam na consoante do fim do mote. Entre os indígenas, os músicos e os trovadores eram muito estimados, e por onde quer que passassem eram bem recebidos, alimentados e agasalhados, e muitos atravessaram até mesmo o território de tribos contrárias, sem que seus 'inimigos' lhes fizessem qualquer mal. Essas anotações pertencem ao colonizador Gabriel Soares de Sousa e estão assentadas no Tratado Descritivo do Brasil, cap. X, escrito em 1587. Será então verdade que se antes já valorizávamos nossos trovadores, imagine-se o que ocorreu com a chegada dos portugueses, considerada uma gente namoradeira e saudosa - e eles se revelaram profusos e admirados poetas e trovadores? (Peixoto, 1919, p. 23 e 24).

No entanto, as trovas portuguesas divergem das brasileiras: no país anotaram-se as contribuições dos aborígenes e dos africanos e em Portugal as origens estão em corações femininos saudosos e desejosos da volta dos amados que seguiram para o 'fossado' ou para as aventuras de Além-Mar, sob a proteção dos Reis de Leão, Castela, Portugal e dos Impérios marítimos. E dessa "saudade dolorida" surgiram as quadrinhas ou trovas que falam do mar e da partida do amado que tarda. O Trovadorismo está na base do primeiro movimento relevante da música e da poesia, que surgiu na Península Ibérica e que era acompanhada por instrumentos musicais.

Contudo, há grandes diferenças nessa poesia popular feita no Brasil, cujo tema principal é o amor, e toda a sua verve em sua amplitude de visões: amor paixão, amor pela natureza, amor pelo povo, amor pela cultura local, amor pelos costumes, amor pela poesia popular - e todas as demais formas de amor que o crítico literário Afrânio Peixoto (1919) assinalou no início do século XX, em sua publicação sobre trovas brasileiras. 
O tema da poesia popular, aqui e alhures, é o único deveras interessante da vida - é o amor. Pelo menos o dominante. O que sobra é caso fortuito - ironia de acaso, troca de chistes, lástima de infelizes, avisos de experiência - que servem apenas de entremeio. $\mathrm{O}$ amor dá para tudo, porque as cambiantes de alma ou de coração são infinitas da mesma paixão, que nunca foi ou será igual a si mesma, desde que há viventes que a sofrem e por ela conhecem o inferno, e por ela atingem também o único céu que nos é dado conhecer neste mundo. Poder-se-ia compor uma enciclopédia amorosa apenas com as trovas populares, antologia de divina inspiração, pela franqueza do sentimento, pela simplicidade de expressão, a deixar longe e descoloridos os nossos poemas mais celebrados (Peixoto, 1919, p. 27).

Segundo Peixoto (1919), as trovas por ele coletadas eram todas anônimas e estavam guardadas no imaginário popular e na memória de muitos. A base dessas trovas era o dito popular: "quem canta, seus males espanta". Em seguida, o pesquisador cataloga as trovas a partir de seus temas: falar de seu próprio canto, o chiste e os gracejos, o caráter do povo, os costumes, além da sabedoria popular para as mais diversas situações do cotidiano.

Afonso Piliackas Junior (2004) assinala que o trovador articula verbalmente nas trovas suas rimas e o desfecho dos seus versos também se realiza no ato da fala. Antes esses trovadores passam por um processo de aprendizagem, memorizando versos, ditos populares, rimas chegadas pela tradição oral, até que surjam as trovas ou quadrinhas. Nesse jogo de criação, existem "regras" que o trovador deve obedecer (Piliackas Jr., 2004, p. 12). Uma quadra rimada deve ter esquema métrico fixo $\mathrm{ABAB}$, com sete sílabas poéticas, o que demonstra não ser tão fácil executar com maestria a arte de trovar. 
Existe na Amazônia uma forte tradição de trovar que se transmuda e se revela nos cordelistas, que vindos do Nordeste na época do boom da borracha, em cidades ribeirinhas se aclimataram e fizeram história. O professor, poeta e escritor paraense Antonio Juraci Siqueira ressalta que algumas trovas apareceram na Ilha de Marajó, na forma de Literatura de Cordel e nos folhetos rústicos que chegavam à cidade de Cajari, no município de Afuá, e com esses folhetos, ele aprendeu a ler e se tornou poeta e contador de histórias. Assim, as trovas e o cordel têm sido utilizados para alfabetizar, para mediar leituras e para despertar o gosto de ler e de declamar em muitos curumins e cunhantãs da Amazônia. Juraci define o significado da trova e sua importância na Literatura da Amazônia: poesia popular, a voz bem-humorada do povo, a cadência musical poética que lembra diversão e as coisas simples da vida e de nossa gente (Alvarez, 2018, p. 233). Porém, esse é um perfil dos escritores amazônicos que ainda precisa ser estudado e explorado pela crítica literária sobre a Literatura Brasileira da Amazônia.

Nesse sentido, a viagem pelos encantos do que Marta Cortezão tem produzido, reserva um capítulo especial para o universo das trovas, no qual se relembram os muitos significados que sua poética possa ter, incluindo o deslocamento em duplo pertencimento e a complexidade de múltiplas identidades:

[...] a cultura passa a funcionar como mediadora na construção da identidade de um indivíduo, representando uma teia de significados que acaba se amarrando ao falante para que ele consiga produzir sentidos e se significar como sujeito na sociedade em que vive, assim adquirindo a linguagem, a educação, os valores, as normas e as representações simbólicas. [...] Já o indivíduo em deslocamento tem duplo pertencimento, identidades múltiplas em embate constante, aquela que influencia e aquela que é influenciada pela cultura do 
país que o acolhe, traduzindo toda a complexidade da relação local-global. É o caso de Marta Cortezão, em que seu exílio se faz íntimo e instável na representação negociada a cada dia, dentro desse mundo de trânsitos contínuos e de seres em deslocamentos infinitos. Marta leva seu canto amazônico como parte da alma e de seu estado de espírito. Seus pés tocam o chão, mas suas mãos fazem escorrer pelos dedos versos escritos em redondilha maior, na tentativa de trazer a localidade de origem ao seu universo europeu. É o que alimenta sua identidade em deslocamento, essa voz interiorana que se faz maior, que sai das entranhas, com a força de uma reinvenção de si mesma, buscando em suas origens parte da pessoa que ela é (Godinho, 2021, p. 5 e 6).

Pertencendo à literatura oral e ao folclore, as trovas escritas por Cortezão vêm completar as influências portuguesas e populares de sua poética. Suas trovas, recheadas da sabença popular, revelam a marca do pensar coletivo do amazônida, que não dispensa uma boa pilhéria, e que se revela intangível em sua simplicidade cabocla.

Celebração do Divino
tem derrubação do mastro!
Teu amor foi Dom Girino:
triste sina... virou sapo!

Se a carne tem tapuru, é só colocar de molho que eles bóiam um por um.

Deixe de frescura, moço!

Nessa poesia popular, de ritmo cantante, há os muitos encantos que estão nas quadrinhas populares achegadas ao cordel e ao que Marta Cortezão guardou em sua memória e que no tempo presente divide com os seus leitores. 
Quando caniçava as águas, e me remava de rios, sacava-me o vento a saia na fértil relva de cios.

Teci inúmeras peneiras, dois tupés, um tipiti e uma atrevida maneira de trazer-te para mim.

No riso, todos os sóis que abrasam louca manhã, na pele ardente, lençóis;

no beijo, febre terçã.

O livro Amazonidades Poéticas traz quadrinhas vindas de um universo telúrico, que não despreza também o sensualismo caboclo.

Amazonidades poéticas é um livro marcadamente telúrico. Ou melhor, fluviolírico. Pois se trata, antes de tudo, de uma poética dos rios e das águas (hidrolíricas). Águas, cujas forças impulsionam o belo e perene barco da poesia. Percorrer as cinco partes que compõe a obra, que se coadunam e se complementam, é percorrer, também, um itinerário singular da Amazônia. Não a Amazônia das metrópoles efervescentes, porém, a Amazônia dos ribeirinhos, indígenas e caboclos. Um traço importante da poesia de Marta é o viés sensual, que pode ser evidenciado, de modo geral, em todo o livro, expresso sobremodo em Dos acesumes. O rio assume uma personificação do amor: "rio de perene amor", "o rio exala paixão”. Neste sentido, o rio torna-se um eloquente símbolo lúbrico, másculo: "braço de rio lascivo, morno, fogoso”. Aliás, que magnífica analogia, o do encontro das águas como a "cópula dos rios Negro e Solimões”. Assim, em toda a obra, nos deparamos com imagens que nos remetem à sensualidade: "sonhos em cio", "masturbarme de vícios”, "vaginar pensamentos”, “vulvas sedentas”, 
“falo afoito do vento", "ritmo ereto”, “cabaço”, etc. É a quentura (os acesumes) da Amazônia "natural" transfigurada na própria sensualidade humana (Melo, 2021, p. 11 e 12).

A rica culinária amazônica se instala e aparece nas trovas de Cortezão com sugestivo título de Das comilanças. Entretanto, outros elementos desse universo caboclo também aparecem em suas trovas.

Nos pés, a monstra peconha, no chão, um baita dum cacho, açaí roxo no tacho, vinho mais fome medonha.

Carne de anta no sol, beijus assando no forno.

Dia animado que só e o ajuri pegando fogo!

Na goela, monstra espinha, pacu cozido no prato, escarro e muita farinha: caboco fica vexado.

Opondo-se ao frenesi contemporâneo que chega às cidades, o mundo das amazonidades ribeirinhas (refletida nas trovas) traz a calma dos rios, das cidades pequenas marcadas por 'leseiras' e por 'mormaços', que imprimem à vida um ritmo próprio.

Das barrancas do meu Norte, trago todas as bonanças.

Quando o peito aperta forte, abro o pote das lembranças.

Sentado àquela varanda, 
beijava o rio que corria com seu olhar delirante alvorecendo magia.

O cotidiano do caboclo e o imaginário amazônico das lendas/mitos, que fazem parte desse mundo dos encantados, são assuntos das trovas de Marta Cortezão.

Diacho, deixe de bestagem!

Chega já de teimosura!

Quem caçoa de visagem

acaba vendo misura!

E foi de vento caído

que o bruguelo amofinou

mas foi com reza benigna

que a benzedeira o curou.

Vá caçar o que fazer!

Desapareça, carniça!

Cape o gato, pegue o beco, bicho podre de preguiça!

\section{CONSIDERAC̣ÕES FINAIS}

Ao estudar a obra de Marta Cortezão algumas questões vieram à tona e que precisam ser colocadas em discussão. Faz-se necessário considerar que há um imaginário peculiar que é a essência e razão de ser de sua poética: "Homem e rio se fundem na geografia amazônica, vivendo numa comunhão mítica, uma amálgama de sentidos, em um lugar onde a água é o verdadeiro sangue da mãe terra.” (Carvalho, 2014, p. 221).

Este artigo representa uma pequena viagem pela Literatura e pela Cultura da Amazônia com a intenção de contribuir para que não se tenha mais a ideia equivocada de que a Amazônia é terra homogênea, pois que nela, há diferentes formas de vida, há a pluralidade de seus habitantes e a diversidade deve ser respeitada. 
Comprova-se o que ensinou o mestre Antonio Cadido: "a literatura é um direito humano", mesmo que as pessoas estejam isoladas contra a sua vontade, o trabalho de divulgação da Marta Cortezão tem cumprido seu papel social de mediar leituras, incentivar o letramento literário e tirar a poética de muitas mulheres da invisibilidade.

E Marta Cortezão segue sendo essa Icamiaba, modelo das mulheres guerreiras que Betty Mindlin (1996) conheceu realmente nas regiões remotas do Amazonas e do Xingu, nas tribos dos Macurap, Aruá, Ariká e Suruí: as mulheres sem maridos que preferiram a liberdade e a independência, mesmo à custa da renúncia de prazeres, mas que se revelaram como mulheres autônomas, lutaram contra um modelo patriarcal de comportamento e inauguraram a liberdade e a plenitude em suas vidas (Mindlin, 1996, p. 313).

Entende-se que o mito das Icamiabas pode ser simbolicamente a representação da mulher que procura seu espaço na sociedade e que pensa que para conquistá-lo e mantêlo não irá precisar de mais ninguém. As Icamiabas são as mulheres modernas, que trabalham e a cada dia lutam para manter o seu espaço no mercado de trabalho e que muitas vezes cuida sozinha da família - sendo pai e mãe - representando um novo grupo familiar (Sá; Dutra, 2012, p. 4-5).

Ao ler a obra de Marta Cortezão não há como não associar ao que o escritor paraense João de Jesus Paes Loureiro (1995, p. 68) enfatizou sobre a cultura amazônica: há um mundo povoado de seres, signos e fatos. É um mundo de pescadores, índios e pequenos agricultores, coletores de sementes, exploradores de madeira, apanhadores de açaí, que vivem em casas humildes e adotaram para si um viver contemplativo e devaneante, diante da grandiosidade dos cenários e do isolamento em que vivem. E há um grande número de escritores que são porta-vozes e intérpretes 
desse mundo de gente 'quase sem voz' e que vive nesse universo ao mesmo tempo real e mítico.

Lembrem-se as palavras de Alonso Tôrres Freire (2005, p. 1), ao afirmar que há um Brasil que se precisa 'descobrir', porque o Brasil não é só o litoral, o Brasil é também a Amazônia.

Em um rápido passeio pela literatura que chamamos de brasileira, parece haver uma lacuna muito grande em relação a outras regiões do país. [...] aos poucos, junto com a ocupação sistemática do interior do país, também foi se construindo um sistema literário produção, circulação e leitura regulares - referente ao que faz no litoral e nos centros tradicionais de cultura; uma literatura preocupada em representar facetas diferentes daquelas com as quais estamos mais familiarizados. Todavia, encontra-se uma intensa vida literária fora desses âmbitos mais conhecidos, uma literatura que vai representar ficcionalmente os conflitos específicos da ocupação da região vasta que é a Amazônia, com dois grandes limites: de um lado o rio enorme e de outro a grande floresta. (...) Ao final desse brevíssimo passeio pela literatura nacional, vamos descobrir que precisamos redescobrir continuamente o nosso país ou, como dizem os versos da canção de Milton Nascimento e Fernando Brant, que - "o Brasil não é só litoral / é muito mais é muito mais do que qualquer zona sul."

E nas plagas amazônicas existe uma intensa e grandiosa produção literária e cultural que precisa ser descoberta por muitos e a obra de Marta Cortezão é um belíssimo exemplo disso!

\section{REFERÊNCIAS}
ALVAREZ, V.M.S. A literatura amazônica e a cultura regional, para além das salas de aula. Bragança: Pará.grafo, 2021. 
. Aspectos da poética contemporânea brasileira. Estudos \& Antologia. Belém: UFPA/ILC/FALE/LABIC, 2020.

. Literatura Brasileira da Amazônia. Roteiros \& Estudos. Belém: UFPA/ILC/FALE/LABIC, 2020.

CARVALHO, N.C. Caleidoscópio do imaginário ribeirinho amazônico. Instrumento: Revista Est. Pesq. Educ. Juiz de Fora, v. 16, n. 2, jul./dez, 2014.

CORTEZÃO, M. Banzeiro manso. Gramado: Porto de Lenha, 2017.

Amazonidades poéticas. Cultura e Identidade. Inéditos, 2021.

MINDLIN, B. As amazonas ou icamiabas. Revista Índios. Temas e problemas. São Paulo: UFAL/ IAMÁ, set. 1996, p. 301-313.

MIRANDA, V.C. Glossário paraense. Belém EDUFPA, 1969.

OLIVEIRA, M. O. E. Vocabulário terminológico cultural da Amazônia Paraense. V.1. Belém: EDUFPA, 2001.

PEIXOTO, A. Trovas brasileiras. Rio de Janeiro: Livraria Francisco Alves, 1919.

Sá, G.O.; DUTRA, M.G.E. Mulheres na mitologia: uma análise de personagens míticos da cultura amazônica. Revista Manoá. Manaus, Online, 2012.

PILIACKAS JR, A.M. A trova e as suas relações com o chiste. Porto Alegre: UFRGS/PPPD, fev. 2004, dissertação de mestrado. 


\title{
A DESCOLONIZAC̣ÃO EM GALVEZ, IMPERADOR DO ACRE, MÁrCiO SOUZA E O DISCURSO IRÔNICO DA FACE DO \\ COLONIZADOR
}

\author{
João Pedro da Silva Antelo ${ }^{101}$ \\ Mara Genecy Centeno Nogueira ${ }^{102}$
}

\section{INTRODUÇÃO}

\author{
"Além do equador \\ tudo é permitido" \\ Provérbio \\ quinhentista \\ português \\ "Nem tudo" \\ Luis Gálvez, deposto \\ (Souza, 1946, p. 7).
}

Este trabalho visa apresentar uma análise dos discursos do colonizador, presentes na obra literária Galvez, imperador do Acre do escritor Márcio Souza. Vale salientar que as obras, do referido autor, apresentam uma linha tênue entre a história e ficção, artificio que deixa a sua produção literária ainda mais interessante.

\footnotetext{
101 Discente do Mestrado Acadêmico em Estudos Literários da Universidade Federal de Rondônia (UNIR).

${ }_{102}$ Professora Adjunta do Departamento de História da Universidade Federal de Rondônia e do Programa de Pós-Graduação Mestrado Acadêmico em Estudos Literários.
} 
O romance Galvez, imperador do Acre foi a estreia de Márcio Souza na literatura. A essência do romance está na etapa de construção da obra, pois podemos identificar o processo colonizador na época da chamada "Revolução acreana" marcada pela disputa do "ouro branco" da Amazônia ou mais precisamente pela extração, manipulação e comercialização da borracha. $\mathrm{O}$ referido romance tem sua relevância para o contexto regional, uma vez que denota os conflitos que marcaram a disputa entre Brasil e Bolívia, em torno do que hoje denominamos de estado do Acre, além de contribuir para o exercício reflexivo em torno do processo colonizador que se instaurou na Amazônia.

O artigo em tela, além de apresentar conceitos focados no processo colonizador da região amazônica, procurou evidenciar expressões como; “a amazonicidade”, que para Loureiro (2014) é algo mais para ser sentido do que para ser descrito, ou seja, é um sentimento que se tem pela Amazônia. Buscou-se ainda enfatizarmos os recursos estéticos utilizados no processo composicional do referido autor, que dentre eles, a ironia que possui um papel fundamental na obra.

As nossas principais interrogações pesquisadoras procuraram na tessitura do referido artigo responder: quais as marcas do discurso colonizador apresentadas na obra? e como tais discursos podem ser analisados pelo viés pós-colonialista?

Estabelecemos como objetivo geral identificar e analisar elementos do processo colonizador da/na região amazônica. Por conseguinte, estabelecemos, também, os seguintes objetivos específicos: identificar, na obra em estudo, os elementos da amazonicidade e da ironia na obra Galvez, imperador do Acre.

Dessa forma, para lograr êxito em nossas análises, utilizaremos como referencial teórico os autores do pós-colonial e decolonial, entre eles: Dussel (1992), Said (1995), Aníbal 
Quijano (2000) e Mignolo (2012) dentre outros. Para análise dos elementos amazônicos, a pesquisa dialogará com os seguintes teóricos: Loureiro (2014) e Souza (2014) que abordam os aspectos da amazonicidade e Bataille (1987) que apresenta um estudo sobre o erotismo. Ressaltamos que esse diálogo visa aprofundar nossas análises para o processo descolonizador da obra em estudo.

\section{O DISCURSO COLONIZADOR NA OBRA GALVEZ, IMPERADOR DOACRE}

Podemos notar na produção literária de Márcio Souza uma preocupação com a região amazônica. Ele apresenta com detalhes as características desse lugar, a beleza do povo e da cultura aqui existente. Por isso, que, quando falamos da produção literária de Márcio Souza, a crítica social e o pós-colonialismo estão presentes desde a sua primeira obra literária, Galvez, imperador do Acre, que traz em sua temática aspectos das teorias pós-coloniais, tais como, a apresentação do genocídio de povos e, por conseguinte, da cultura da região amazônica. É ressaltado, também, mas de forma irônica, o descaso que do colonizador em relação à Amazônia, como podemos notar neste artigo. Outra característica presente, no referido romance, é a face do colonizado que muitas vezes é tratado como um ser aculturado ou um não ser.

Como já ressaltado, o artigo se propõe a fazer uma análise voltada para as questões pós-coloniais apresentadas por Márcio Souza na obra Galvez, imperador do Acre, à luz dos teóricos: Said (1995), Quijano (2000), Dussel (1993) e Mignolo (2012) dentre outros. Dessa forma as questões ideológicas trazidas pelo autor serão apresentadas e ganharão sustentabilidade em nossas análises. Retornamos a epígrafe para apresentar a ironia que está presente no romance em tela, recurso este, que podemos 
apresentar como, estético descolonial, assim como apresenta, Mignolo (2012, p. 32), que conceitua a estética descolonial:

La palavra aesthesis, que se origina en el griego antiguo, es aceptada sin modificaciones en las lenguas modernas europeas. Los significados de la palabra giran en torno a vocablos como "sensación", "proceso de percepción”, "sensación visual", sensación gustativa” o "sensación auditiva”. De ahí que el vocablo synaesthesia se refiera al entrecruzamiento de sentidos y sensaciones, y que fuera aprovechado como figura retórica en el modernismo poético/literário. A partir del siglo XVII, el concepto aesthesis se restringe, y de ahí en adelante pasará a significar "sensación de lo bello". Nace así la estética como teoria, y el concepto de arte como práctica. [...] Esta operación cognitiva contituyó, nada menos, la colonización de la aesthesis por la estética; puesto que si es un fenómeno común a todos los organismos vivientes com sistema nervioso, la estética es una versión o teoria particular de tales sensaciones relacionadas con la belleza.

Podemos notar que para Mignolo (2012) a palavra estética tem o seu sentido modificado a partir do século XVII, ou seja, no processo colonizador. Na essência a palavra significava sensação, aquilo que causava impacto, seja no leitor, seja no apreciador de alguma arte. Porém a partir da colonização da palavra aesthesis, o sentido foi completamente subvertido e passou a significar beleza. Márcio Souza aproveitando desse feeling de autor, traz uma nova interpretação, uma vez que descontrói seu romance ao escrever em forma de folhetim e a apresentar um protagonista fanfarrão, que não possui nada além de sorte. Ou seja, se pensarmos na ideia de beleza segundo o sentido colonizador da palavra estética, o romance de Galvez, imperador do Acre é um romance feio, e sim, era isso que o autor procurava para iniciar o processo descolonizador que está intrínseco no romance. 
No decorrer da narrativa podemos notar que a estética decolonial está presente e é muito importante para a obra. Notamos esses aspectos decoloniais repetidas vezes no decorrer da leitura. Além da estética decolonial, notamos também outras abordagens, que enriquecem o romance e nos fazem refletir. Podemos analisar a obra com outras lentes e por meio delas, evidenciar o encobrimento das classes baixas ou dos seres nativos da Amazônia que são evidenciados muitas vezes como pessoas sem culturas e as vezes comparados a "seres manipulados por alienígenas", como notamos no fragmento a seguir:

Deglutindo os fofos biscoitos, Sir Henry me ofereceu suas teses. "Quando lhe disserem que em Manaus, grunhiu Sir Henry, que o Teatro Amazonas é obra de um obscuro governador, não acredite. Isso é fruto da ignorância dos nativos. Estamos certo, Mister Aria, que os extraterrestres existem e que o Teatro Amazonas é uma de suas marcas. A concepção de que o Teatro Amazonas é um artefato espacial é exclusivamente racional, isto é, a intervenção no meio da jungle equatorial é produto de seres inteligentes. [...], (Souza, 1946, p. 86 e 87).

Notamos como foi construída a visão do colonizador, sobre as pessoas que habitam a região amazônica. São consideradas seres sem inteligências e cultura. A forma irônica como isso é colocado no texto é muito importante, pois denota a ironia, uma das principais marcas do romance. Tal marca pode ser evidenciada no romance quando um dos personagens diz que é mais fácil um extraterrestre pousar na região amazônica, do que o colonizador achar possível que os nativos tenham inteligência suficiente a ponto de construir uma obra da grandeza do Teatro Amazonas. 
A ironia presente no romance evidencia uma das marcas colonizadora que era a de encobrir e não descobrir o traço do colonizado, como nos explica Dussel (1993, p. 52),

La conquista, es un proceso militar, práctico, violento que incluye dialécticamente al otro como, "lo Mismo”. El otro, en su distinción, es negado como otro y es obligado, subsumido, alienado a incorporarse a la totalidad dominadora como cosa, como instrumento, como oprimido, como "asalariado" (en las futuras haciendas), o como africano esclavo (en los ingenios de azúcar $\mathrm{u}$ otros productos tropicales). La subjetiviad dét "conquistador", por su parte, se fue constituyendo, desplegando lentamente en la práxis.

Podemos observar que Dussel (1993) ressalta como funciona o processo de colonização da cultura “inferior", primeiro o colonizador infere para os colonizados que a cultura que eles possuem não é cultura, depois oprimem, obrigam, fazem com que o Outro se sinta inferior e a partir disso, começa o processo de encobrimento dos nativos que passam a ter corpos subjugados e sua cultura oprimida. É isso que nos mostra Dussel ao analisar o processo de colonização.

Podemos imaginar o quão foi dificultoso o processo de imposição do "quase" abandono da cultura do nativo. Quando inferimos o quase abandono das bases culturais das populações pré-cabralianas, queremos enfatizar que o processo colonizador foi um processo de mão dupla, e que por fezes o cenário que se construiu foi o de resistência por parte dos nativos. Desde da fase do "descobrimento" fica evidente que o que era para ser um encontro de culturas, se transformou em desencontros/confrontos, onde a cultura nativa não soube ser vista pelo olhar estrangeiro. Porém, o indígena mesmo na 
condição de sujeito assujeitado, conseguiu encontrar brechas para manter sua base cultural viva.

Na obra analisada, percebemos o descaso do colonizador em relação aos indígenas, uma vez a narrativa apresenta que por qualquer motivo fútil, eram assassinados. Notemos que no fragmento apresentado a seguir, um cientista europeu busca explicações para uma cerimônia indígena, porém a forma irônica e as crueldades apresentadas por ele exemplifica bem a forma como colonizador via o colonizado:

\section{Em Nome da Ciência:}

Jantei com sir Henry, e Justine, incansável frequentadora do vapor do cientista, me contou que havia curiosas peças trazidas do alto do Rio Negro. Depois do jantar, Sir Henry me ofereceu uma completa visita ao camarote onde estavam guardadas as preciosas relíquias. E relíquias o eram na realidade, pois o meu caro cientista guardava, em vidros de formol, cerca de vinte amostras de genitálias masculinas extraídas de índios do Vaupés (Souza, 1946, p. 122).

Observe que a composição dessa narrativa é muito forte. Parece ser algo de outro mundo, afinal está se referindo a um genocídio com justificativa na ciência. Porém, podemos observar essa crueldade com relação à religião, à cor da pele e gênero. Mas, na obra, o autor apresenta de forma irônica o que ameniza a crueldade e a revolta que o leitor sente o excerto. $\mathrm{O}$ nativo passa a ser apenas um objeto. É um condenado, simplesmente, por ser ele. Sobre essa questão Fanon (1968, p. 31), afirma que:

A discussão do mundo colonial pelo colonizado não é um confronto racional de pontos de vista. Não é um discurso universal, mas a afirmação desenfreada de uma singularidade admitida como absoluta. $\mathrm{O}$ mundo colonial é um mundo maniqueísta. Não basta ao colonizador limitar fisicamente, com o auxílio de sua 
polícia e de sua gendarmaria, o espaço do colonizado. Como que para ilustrar o caráter totalitário da exploração colonial, o colonizador faz do colonizado uma espécie de quintessência do mal. A sociedade colonizada não é apenas descrita como uma sociedade sem valores. Não basta ao colonizador afirmar que os valores desertaram, ou melhor, jamais habitaram, o mundo colonizado. O indígena é declarado impermeável à ética, ausência de valores, como também negação dos valores. É, ousemos confessá-lo, o inimigo dos valores. Neste sentido, é o mal absoluto. Elemento corrosivo, que destrói tudo o que dele se aproxima, elemento deformador, que desfigura tudo o que se refere à estética ou à moral, depositário de forças maléficas, instrumento inconsciente e irrecuperável de forças cegas.

A partir da concepção apresentada por Fanon (1968), podemos inferir que para o colonizador, o indígena é a representação da face da maldade e, para isso precisa ser educado aos moldes do colonizador merecendo todo o castigo possível, pois não se enquadra nos padrões pré-definidos pelo sistema de colonização. Dessa forma, verificamos que Márcio Souza, apresenta essa questão por estética, mas não é só isso, ele traz essa temática para nos fazer pensar nas crueldades sofridas pelos povos colonizados, ou seja, as barbáries sofridas pelos nossos antepassados.

Se observarmos a obra, Galvez, imperador do Acre, o protagonista não é cruel, está apenas observando todas as crueldades e opressões que sofrem os colonizados. Esse recurso utilizado pelo autor insere o leitor como confidente de um protagonista aquém. Ou seja, é para mostrar que se nada for feito as coisas continuam na mesma. Podemos trazer essa questão proposta por Márcio Souza para os dias atuais. Isso é o que nos explica Quijano (2000), quando fala das questões políticas. 
Colonialidade é um conceito diferente de, ainda que vinculado a Colonialismo. Este último refere-se estritamente a uma estrutura de dominação/exploração onde o controlo da autoridade política, dos recursos de produção e do trabalho de uma população determinada domina outra de diferente identidade e cujas sedes centrais estão, além disso, localizadas noutra jurisdição territorial. Mas nem sempre, nem necessariamente, implica relações racistas de poder" (Quijano, p. 6).

Dessa forma, a invasão, ao que hoje denominamos de território acreano, por Galvez que tomou tal território sem dificuldades, sugerindo que na região amazônica as terras não tinham dono. Ao fazer isso, impôs normas e relações políticas que serviram para inferiorizar o Outro e mantê-lo prisioneiro de um sistema.

A amazonicidade como discurso do colonizador é apresentada de forma subvertida. Tal termo é definido por Loureiro (2014), como sendo um sentimento que se tem pela Amazônia, porém podemos notar que a forma irônica como é construída a visão do colonizador em relação ao território colonizado é contrária à definição de Loureiro. No romance, o narrador, subverte esse sentido e apresenta um discurso pejorativo. Para a personagem o ambiente amazônico é totalmente inóspito e selvagem e que, portanto, só é digno de possuí-lo a "pessoa que possui cultura”. Dessa forma Loureiro (2014, p. 33), afirma que:

O amazônico da estética amazônica não é propriamente a forma: o amazônico da estética amazônica é aquilo que emerge do vitral, é o ethos amazônico, é uma forma de "amazonicidade" que emerge da obra e que você percebe mais como modo de sentir do que propriamente como modo de uma demonstração racional (p. 33). 
Utilizaremos a afirmação de Loureiro (2014) para falar da amazonicidade na obra de Márcio Souza, que traz essa questão muito explícita, porém mascarada pelo discurso do colonizador. Em toda obra podemos notar que as paisagens amazônicas são marcas presentes e evidenciadas. Esse recurso na descrição do autor é muito importante, pois é subvertido, ou seja, o autor fala da Amazônia, porém de forma que sua cultura seja rebaixada, que suas qualidades sejam sufocadas por um colonizador que não conhece e não gosta da região.

Esse discurso é encontrado em vários momentos da obra, porém separamos um fragmento que ajudará o leitor na compreensão do descaso com que o colonizador tem com o clima e o ambiente amazônico,

Trinta graus. Manchas de água evaporavam das paredes como restos mortos de chuva. Eu olhava pela janela a rua movimentada, os bondes atravessando os paralelepípedos cor de vinho. Mulheres com chapéus extravagantes flanavam de braços com seus homens. A cidade coruscava de eletricidade. Prédios vitorianos ou manuelinos? Uma igreja inacabada e uma praia de lama fétida. Eu estava há um mês em Manaus. Sem problemas (Souza, 1946, p. 106-107).

Podemos observar no excerto acima que o narrador denota um discurso colonizador. A cidade por ele apresentada era um misto de moderno com arcaico. Por mais que o progresso advindo do Centro (Europa) para a periferia (América) a população de desvalidos era incapaz de usufruir. Destacamos ainda, que a narrativa não enaltece nada da região, até mesmos os prédios construídos ou em construção eram duvidosos, tendo em vista que não se sabia a que representação arquitetônica eles se enquadravam: vitoriana ou manuelinas? Perguntava-se o 
interlocutor. Por outro lado, as lentes do narrador não o deixavam ver outras belezas como a florestas, rios e os próprios nativos com suas singularidades.

Portanto, a partir das concepções apresentadas, podemos inferir que na obra Galvez, imperador do Acre, o discurso do colonizador é forte. A obra está carregada de estereótipos, a ponto de na condição de leitor, perguntarmos frequentemente se o que liamos era ficcional ou real. Esse é o motivo que podemos afirmar que no referido romance, a fronteira entre ficcional e o real é bastante tênue, uma vez que a história é confundida com a realidade e vice-versa, o que torna a leitura prazerosa e complexa para ser estudada.

\section{CONSIDERAÇÕES FINAIS}

Esta pesquisa objetivou apresentar alguns elementos do discurso do colonizador na obra literária Galvez, imperador do Acre, do escritor Márcio Souza.

Identificamos, a partir da marca do discurso colonizador que os recursos estilísticos utilizados pelo escritor no processo composicional, demonstram o quanto ele estava, no ato da escrita, engajado em transmitir aos seus leitores os aspectos de cultura amazônida, e como isso foi visto pelo colonizador na disputa pelo “ouro branco” na chamada Revolução Acreana.

Em relação à presença de elementos irônicos na obra do referido autor, salientamos que o escritor possui uma vasta habilidade na utilização deste recurso estético, pois a forma como ele utiliza a ironia em suas composições literárias, torna a leitura muito agradável e atraente. Márcio Souza satiriza um colonizador, na perspectiva de um protagonista fanfarrão que deixa a sorte guiar o seu caminho. 
A partir da leitura e da análise da obra em epígrafe, observamos que a temática da amazonicidade tem forte influência para Márcio Souza. Ele é historiador e literato, é notadamente, um escritor engajado em apresentar as particularidades da história, da cultura e da literatura amazônica.

Ressaltamos que a compreensão da análise da obra exige do leitor alguns conhecimentos sobre as questões da descolonização. A obra de Márcio Souza proporciona ao leitor uma reflexão sobre a produção literária brasileira produzida na Amazônia. Dessa forma, poderemos entender como aconteceu o processo de colonização da Amazônia e buscar, de forma mais efetiva uma evidenciação da cultura que existia aqui, antes de todo esse processo esmagador que chamam de "progresso".

Por fim, para mostrar que esse processo foi violento, traremos um último fragmento da obra que evidencia o quanto o colonizador era violento e capaz de tudo: "A classe dominante não se envergonha de nada". "Ser violento nos trópicos é uma questão de humor" (Souza 1946 p. 151), assim evidenciamos ainda mais o discurso violento e autoritário do colonizador.

\section{REFERÊNCIAS}

DUSSEL, Enrique. 1492: O encobrimento do outro: o mito da modernidade. Conferências de Frankfurt. 1992.

FANON, Frantz. Os condenados da Terra. Rio de Janeiro: Civilização Brasileira, 1968.

LOUREIRO, João de Jesus Paes. Mundamazônico: do local ao global. Revista Sentidos da Cultura. Belém-Pará. Jul-Dez/2014. <www.uepa.br>. Acesso em: 10 jul. 2019.

MIGNOLO, W. D. Aiesthesis decolonial. Calle 14. Revista de Investigación en el Campo del Arte, 4(4), 10-25. Disponível em: 
$<$ https://doi.org/10.14483/21450706.1224>. Acesso em: 7 jul. 2019.

QUIJANO, Aníbal. Colonialidade do Poder e Classificação Social. In: Epistemologias do Sul. 2000.

SAID, Edward. Cultura e imperialismo. São Paulo: Companhia das Letras. 1995

SOUZA, Márcio. Galvez, imperador do Acre. 17. ed. São Paulo: Marco Zero, 1995.

. Literatura na Amazônia, ou literatura amazônica? Revista Sentidos da Cultura. Belém-Pará. Jul-Dez/2014. <www.uepa.br>. Acesso em: 15 jul. 2019. 


\title{
AS NARRATIVAS NAVEGANTES NAS ÁGUAS DO MAMORÉ: OS ENCANTAMENTOS NA VOZ DOS RIBEIRINHOS
}

\author{
Daiane de Castro Eurico ${ }^{103}$ \\ Ester Chao Ojopi Simo ${ }^{104}$ \\ Márcia Dias do Santos ${ }^{105}$
}

\section{INTRODUC̣ÃO}

Este artigo apresenta resultados de uma pesquisa realizada em comunidades ribeirinhas bolivianas que se situam às margens do rio Mamoré, fronteira com o Brasil. Comunidades essas que têm seu cotidiano determinados pelos períodos de chuva/sol, cheias/vazantes dos rios, pelo dia e pela noite. Concebem um modo de vida constituída pelo extrativismo vegetal ou animal, vivendo em função dos produtos das florestas e rios. São comunidades de profunda relação com a natureza que faz com que a crença em seres sobrenaturais influencie nas atividades de caça ou pesca ribeirinha.

As pretensões das investigações foram perscrutar quais narrativas navegavam pelo rio Mamoré, bem como promover o

103 Graduada em Língua Portuguesa e suas respectivas literaturas pela Fundação Universidade Federal de Rondônia - Departamento Acadêmico de Ciências da Linguagem - Campus de Guajará-Mirim.

104 Graduada em Língua Portuguesa e suas respectivas literaturas pela Fundação Universidade Federal de Rondônia - Departamento Acadêmico de Ciências da Linguagem - Campus de Guajará-Mirim.

${ }^{105}$ Doutoranda em Estudos Literários pela Universidade Federal de Uberlândia (UFU). Docente da Fundação Universidade Federal de Rondônia Departamento Acadêmico de Ciências da Linguagem - Campus de GuajaráMirim. 
registro de lendas e mitos orais e analisá-los, considerando o encantamento presente nas histórias, e assim verificar como os povos que vivem às margens do rio são influenciados por elas.

Partimos do conceito de que tais narrativas constituem o patrimônio imaterial, tanto para a Bolívia quanto para o Brasil, pois, nesses espaços, as fronteiras são navegantes e os contatos fazem com que elementos culturais transitem de um lado ao outro do rio e assim, ao registrá-las, podemos conhecer e divulgar narrativas que possam/devem fazer parte do acervo das literaturas orais/escritas de países de fronteiras que, de modo geral, ainda não se revelam de maneira muito significativa.

As histórias foram coletadas em uma expedição que fizemos na qual viajamos em um barco, sete dias, subindo o rio Mamoré. Estávamos em grupo de 29 pesquisadores do Brasil e da Bolívia. Fizemos várias paradas nas comunidades ribeirinhas do território boliviano até chegarmos ao distrito de Surpresa, uma comunidade brasileira que pertence à Microrregião GuajaráMirim e à Mesorregião Madeira-Guaporé.

As histórias narradas foram registradas de acordo com alguns elementos que suscitavam o diálogo entre o pesquisador e o interlocutor. Sendo assim, o diálogo aproximava-se direcionado para questões sobre histórias do local, relatos de experiências, narrativas (mitos ou lendas) que se apresentavam com elementos da natureza, ou seja, história do rio, da floresta, ou também as histórias que avós, pais contavam para seus filhos ou netos, durante a noite, para que eles fossem dormir ou para que não saíssem de casa no período noturno.

Acerca do registro de narrativas orais, Busatto (2008, p. 87) afirma que

Recuperar o conto de literatura oral é também perpetuar a nossa cultura e a nossa história. Se cito com frequência o conto de fadas e o mito é por acreditar que eles 
são uma via de acesso ao nosso ser, porém há nas lendas regionais e causos populares um conhecimento que não deve ser desprezado, pois eles indicam a produção cultural de um povo, suas crenças, temores e anseios íntimos. Seja qual for a categoria do conto que você pesquise ele será sempre bemvindo, pois estaremos contribuindo para sua permanência.

Assim, podemos afirmar que a temática apresentada será relevante aos estudos de produções de literatura oral em regiões fronteiriças na América Latina, pois trará em evidência as narrativas navegantes do Mamoré na fronteira Brasil/Bolívia, destacando as contribuições culturais da tradição oral que se entremeiam e tecem uma relação entre o local e o global nas produções universais, revelando um mundo maravilhoso, encantado e mágico das margens de rios.

\section{A LiTERATURA ORAL NA CONSTITUIC̣ÃO DE IDENTIDADE DAS COMUNIDADES}

O contar histórias que se ouviu deflui de uma dimensão imaginativa, memorialista e oral dos povos de todas as culturas. Essas práticas em comunidades pequenas, nessa pesquisa consideradas as ribeirinhas do rio Mamoré, ainda são bem comuns.

Muitas narrativas, carregadas de simbologias, navegam pelos rios de comunidades que vivem às margens e são levadas pelas águas caudalosas com profundas marcas de identidade que determinam "jeitos" de enxergar o mundo e aprender o outro e a si mesmo.

Munida de elementos encharcados pela memória coletiva, a literatura oral desses povos deságua em forma de folclore também conseguindo fluir e se tornar uma produção estéticoliterária, pois essa passa a possuir uma prática significativa de sentidos coletivos como àquelas já registradas. 
Acerca do termo folclore, Cascudo (1984, p. 24) define que o folclórico possui alguns elementos que o caracteriza, tais como: a) antiguidade; b) persistência; c) anonimato; d) oralidade. $\mathrm{O}$ autor ainda afirma que, para ser folclórico, uma dança, canto, anedota, contos não podem ter definições cronológicas de surgimentos, desse modo, essa produção navega pelo tempo e perpassa pelas perdas e acréscimos da memória coletiva de determinada comunidade "O folclórico decorre da memória coletiva, indistinta e contínua” (Cascudo, 1984, p. 24).

No documento Recomendação sobre a salvaguarda da cultura tradicional e popular, na Conferência Geral da Unesco $25^{\text {a }}$ Reunião, ocorrida em Paris, 15 de novembro de 1989, sobre o termo essas produções tradicionais, a Unesco em 1989 assim postula:

A cultura tradicional e popular é o conjunto de criações que emanam de uma comunidade cultural fundada na tradição, expressas por um grupo ou por indivíduos e que reconhecidamente respondem a expectativas da comunidade enquanto expressão de sua identidade cultural e social; as normas e os valores se transmitem oralmente, por imitação ou de outras maneiras. Suas formas compreendem, entre outras, a língua, a literatura, a música, a dança, os jogos, a mitologia, os rituais, os costumes, o artesanato, a arquitetura e outras artes. ${ }^{106}$

Para Stuart Hall (1977), teórico que fundou junto Richard Hoggart e Raymond Williams, a escola de pensamento hoje denominado Estudos culturais britânicos ou a escola Birmingham dos Estudos Culturais, a identidade cultural de determinada

106 Disponível em <www.portaldoconhecimento.gov.cv/bitstream/ 10961/238/4/Anexo\%203\%20-\%20Doctos\%20Unesco.pdf >. Acesso em: 15 dez. 2020. 
sociedade se traduz pelos aspectos étnicos, raciais, linguísticos, religiosos e, acima de tudo, nacionais (Hall, 1977, p. 8). Nesse sentido, podemos afirmar que todas as narrativas que (re)existem na memória dos ribeirinhos das comunidades visitadas guardam e (re)criam em seus espaços um eixo vital de qualquer comunidade em torno dos sentidos estabelecidos e que passam a existir e se consolidar por meio das verossimilhanças constituídas nas narrativas.

Essas narrativas, como percebemos, navegam de uma comunidade à outra, chegam carregadas dos espantos, dos encantos que esses espaços fazem gerar. O "navegar no rio” em si já é uma contribuição para a construção do imaginário, como nos descreve Loureiro em seu artigo intitulado "Mundamazônico: do local ao global":

Uma situação tipificadora desse vir-de-bubuia é quando o caboclo, na descida do rio, ao invés de permanecer remando, amarra sua canoa em um marapatá ou periantã, pequenas ilhas de terra caída das margens dos rios que seguem flutuantes boiando na correnteza. Amarrando a canoa em alguma raiz, árvore que se manteve ou capim resistente, o canoeiro pode parar de remar levado pela ilhota flutuante, ou mesmo tronco de árvore arrastada pela correnteza, enquanto fica livre para "pensar na vida”. Elaborar as narrativas, míticas ou não, de seu imaginário (Loureiro, 2014, p. 37)

Essa relação entre homem e natureza, considerada para Loureiro característica do homem amazônico, contribui para a “inundação da bacia semântica do imaginário”. Uma atitude denominada por esse autor de “dibuísmo" (Loureiro, 2014, p. 37), ou seja, um modo fenomenológico transacional que possibilita que o homem usufrua da natureza, porém em estado de relação recíproca e aglutinadora e assim promova um enriquecimento da cultura enquanto a cultura o enriquece. 
Loureiro (2014) ainda acrescenta que este estado de dibuísmo "é uma estratégia no comportamento do homem ruralribeirinho da Amazônia” que se afasta de um conceito de ócio ou preguiça e que permite ao corpo estar em processo de devaneio criativo.

São nas vozes desses sujeitos também que as narrativas chegam, permanecem e se transformam nas comunidades ribeirinhas. Entre as águas caudalosas do rio, entre as árvores das florestas que contam e escondem as histórias, esses espaços se tornam mediadores para a consciência imaginativa. Na mata, estão escondidos os duendes, personagens míticos muito comuns em todas as comunidades visitadas, os pássaros encantados, os espíritos, etc. Do rio, vêm as grandes cobras, as luzes misteriosas e assombrosas. Na obra A poética do espaço, Bachelard nos apresenta, nas palavras de Marcault e Thérèse Brosse, a imposição criativa que a floresta exerce nos seres: "A floresta sobretudo, com o mistério de seu espaço indefinidamente prolongado para além do véu de seus troncos e folhas, e espaço velado para os olhos, mas transparente à ação é um verdadeiro transcendente psicológico" (Bachelard, 1993, p. 191).

Nas narrativas dessas comunidades há uma linha tênue entre o visível e invisível, palpável e a abstração, o natural e o espiritual. Essa vivência mística é fundamental para os sujeitos que estão envoltos pela mata e rio.

Tal como um círculo, essa relação homem/natureza é estabelecida de diferentes modos em diferentes culturas, mas que se imbricam nas simbologias. A relação do homem com a água nos é apresentada em várias sociedades. Para Diegues (2007, p. 1)

Em muitas sociedades chamadas "primitivas" a água doce das fontes, dos riachos e rios é símbolo de vida ao passo que as águas do mar simbolizam o perigo e a 
morte. Ambas são habitadas por seres sobrenaturais que as protegem, como Oxum, orixá das águas nos cultos afro-brasileiros, a Mãe d'água entre os caboclos da Amazônia, Yemanjá, mãe dos peixes, as sereias e os monstros marinhos. As águas das nascentes simbolizam a pureza e a inocência e por isso devem ser especialmente respeitadas, sob pena de graves castigos.

O homem ribeirinho do Mamoré estabelece com o rio uma relação de elemento personificado. Para o rio, é transportada uma materialidade para além da liquidez de suas águas. Essa personificação justifica as figuras que a ele são relacionadas: o rio é companhia, é esconderijo, é mistério. Essa relação é própria do homem que vive nesse espaço ribeirinho-rural, considerando que em espaços urbanos o rio é fonte conflitiva e política que gera muitas vezes dimensões bem diferentes para essa sociedade, podendo delimitar espaços geográficos, ser gerador de conflitos sociais e econômicos ou ainda ser fonte de poluição.

Sendo assim, o que faz com que esses cenários sejam fontes inspiradoras de produção de narrativas é exatamente o sujeito ribeirinho estar imbricado com esse imaginário e sua pertença a esses espaços. Essas produções são compreendidas e promovidas por esse encantamento. Sobre essa “criação”, aportamo-nos em Almeida e Queiroz (2004) na obra Captura da Voz: as edições das narrativas orais no Brasil que assim indicam, considerando o que Cascudo também aponta em relação à produção dos contos tradicionais, com suas origens na oralidade, que as combinações dessas produções são indefinidas, mas com fios, morfologias afins. No entanto, "A ciência popular vai dispondo-os diferentemente. E são incontáveis e com a ilusão da originalidade" (Cascudo, p. 23 apud Almeida; Queiroz, 2004, p. 71).

O que sabemos é que todos os grandes textos escritos no Ocidente são reprises das tradições orais e o que vamos 
percebendo nas comunidades visitadas é que as narrativas encontradas também carregam essas marcas. As histórias vão se entrecruzando, mas com vozes de narradores orais que exercem papéis de destaque nesses lugares, pois são eles os contadores das histórias que o povo ouve e que ora marcam-se como narradores, ora como personagens da história narrada.

\section{AS COMUNIDADES VISITADAS: ENTRE O OUVIR E O REGISTRAR}

Ao contar uma história seja um relato de um fato vivido, ouvido, imaginado, requer um exercício de memória pelo narrador e o de escuta para o interlocutor.

Para Campbell:

Quando a história está em sua mente, você percebe sua relevância para com aquilo que esteja acontecendo em sua vida. Isso dá perspectiva ao que lhe está acontecendo. Com a perda disso, perdemos efetivamente algo, porque não possuímos nada semelhante para pôr no lugar (Campbell, p. 15, 1991).

As narrativas orais, embora se apresentem, na maioria das vezes com elementos fabulosos, fantásticos, misteriosos, são guardadas na memória e se entrecruzam com as experiências vivenciadas pelo narrador, neste caso, o homem ribeirinho. Acerca disso, Barbosa (2011) nos esclarece que

Narrativas orais, mais do que o relato de um fato, onde aparecem personagens enigmáticos, seres que habitam lugares comuns como os rios e as matas, são narrativas da vida [...] são também histórias de vida. São tesouros semeados na mente de quem um dia as ouviu. São relatos, memória e poesia contados e cantados pelas vozes poéticas de homens e mulheres simples, pescadores, lavradores, seringueiros que, com a mesma 
habilidade com que tecem as malhadeiras, peneiras e tipitis, contam/tecem os causos que ouviram, que também presenciaram, e fazem questão de dizer “Aconteceu comigo!" e, por isso, deles são também personagens (Barbosa, 2011, p. 11).

Essas memórias são alimentadas por esses fatos e assim transmitidas e acrescentadas tanto pelo ouvinte/interlocutor, como também pelo recontar das narrativas, seguindo a máxima do provérbio "Quem conta um conto, aumenta um ponto”.

Barbosa (2001, p. 68) ainda acrescenta que

Ao contar o que viu/viveu nas suas idas e vindas das atividades nos rios e nas matas, o contador volta-se a um passado marcado na memória e que se torna presente no momento em que tece o seu relato. Contar causos é (re)viver o passado e misturá-lo ao presente. As imagens do visto e do vivido passam a ter sentido porque o contador alia ao seu repertório de experiências passadas às experiências presentes.

Nas comunidades visitadas, a contação e registros das narrativas se deu pela metodologia da história oral. Primamos por ouvir o narrador/contador falar de sua vida como ribeirinho, sua história pessoal, em saber como chegou àquele lugar. Desse modo, estabeleceu-se uma relação de aproximação entre pesquisadores e sujeitos da pesquisa de modo que as ações entre o ouvir e o registrar aconteceram de forma respeitosa e cordial.

A concepção de vida dessa população é caracterizada pelo conhecimento de mundo ao longo dos anos e por meio da transmissão oral. São comunidades constituídas com agrupamentos familiares de 20 a 40 famílias, que vivem em condições de vida bem simples, com habitações na sua maioria de alvenaria, mas ainda há comunidades menores que vivem em 
casas de madeira e até mesmo de palha e muitas sequer contêm assoalhos.

A iluminação é realizada pelo uso de lamparinas, e para dormir à noite utilizam mosquiteiros. Isolados do mundo midiático, os ribeirinhos do sexo masculino passam a maior parte do seu tempo no trabalho da roça, agricultura ou caça, já as mulheres ficam encarregadas de cuidar dos filhos e dos serviços domésticos, e as crianças a partir dos 5 anos passam a maior parte do dia na escola.

Nesse contexto é que ouvimos diversas narrativas orais e somadas a vozes, também percebemos os gestos quando o contador/narrador apontava para o rio, para a mata, indicava partes do próprio corpo, expressões faciais, alteração da voz, emitia sons que imitavam pássaros, bichos. Tais fatores, de acordo com Heller (1993, p. 73) contribuem para

[...] dar sentido significa mover os fenômenos, as experiências e similares, para dentro de nosso mundo; significa transformar o desconhecido em conhecido, o inexplicável em explicável, bem como reforçar ou alterar o mundo por ações significativas de diferentes proveniências.

Quando ouvimos as narrativas, com todos os recursos que são próprios de um contador de histórias nas comunidades, foi provocado em nós o sentimento de vivência da experiência narrada. É como se uma roda de contação de história tivesse sido criada para nós e ali, deliramos junto aos demais, sentindo cada fato narrado como se fosse uma experiência nossa, pois muitas histórias foram contadas à luz de lamparina, no iniciar da noite, ou próximo às matas, confirmando o que indica Bosi (1994, p. 90) "A arte de narrar é uma relação alma, olho e mão: assim transforma o narrador sua matéria, a vida humana”. 


\section{AS NARRATIVAS NAVEGANTES}

Nas comunidades ribeirinhas visitadas, como nos demais lugares em que os trânsitos da palavra se dão mais de forma oral que escrita, a tradição oral se apresenta de diferentes formas, em diferentes contextos, ou seja, elas se traduzem em contos populares, estórias encantadas ou fantásticas, lendas, adivinhações e canções populares. Augel (2010) afirma que

Todas essas expressões são tipos de discursos que se fixam, primeiramente pela via oral, pelo instrumento da palavra falada. Costumamos chamar a esse conjunto de conhecimentos tradicionais de literatura oral. Vários autores, entretanto, em vez dessa designação, preferem referir-se à oralidade, à tradição oral, ou mais recentemente, oralitura (Augel, 2010, p. 2)

Para a autora, essas produções além de servirem como produções estéticas para posteriores escritas e registros são vias para que os textos ganhem vivacidade. Ela ainda acrescenta que “através dessas variadas vozes, é possível conhecer-se muito de um povo: sua organização familiar, relações de trabalho, os conflitos sociais, as relações com o sagrado” (Augel, 2010, p. 2).

As narrativas descritas foram contadas pelos moradores, na língua castelhana e traduzidas para o português e inseridas à estrutura formal do texto.

A seleção dessas narrativas ocorreu de modo que as histórias que registramos apresentam elementos da natureza, do rio, encantamentos e mistérios, como também, apresentam expressões que são marcas das narrativas de origens orais, tais como: "Existe uma lenda/ Havia uma família/ Em certa hora etc." Desse modo, produções orais desses espaços de fronteiras podem indicar elementos simbólicos que seguem um fio condutor de 
produção e refletem a identificação que os sujeitos têm com seus lugares.

\section{Narrativa 1 - A luz que vem do rio}

Existe uma lenda na comunidade que é contada pelos pescadores que dizem que quando saem para pescar no rio, depois de uma certa distância eles veem uma luz saindo de dentro do rio que foca direto nas pessoas que estão pescando, mas nenhum deles se prontificam a verificar o que é aquela luz. Rapidamente eles retornam para o solo. E quando eles retornam a luz que focava neles volta para o rio e some.

\section{Narrativa 2 - O duende da floresta}

Havia uma família com dez pessoas que moravam na comunidade, dentre eles, tinha um menino que gostava de tomar banho na beira do igarapé. Certa tarde, o menino e sua irmã caçula foram tomar banho no rio. Chegando perto, avistaram um garoto em pé, vestido de branco pedindo que os acompanhassem. Assim eles o fizeram. Saíram conversando, distraídos, e quando perceberam, já era noite e estavam perdidos e o menino de branco havia sumido. Ficaram abandonados em cima de um tronco de babaçu e começaram a chorar de medo.

Enquanto isso, a família estava desesperada e aflita com medo que acontecesse o pior. Os amigos se mobilizaram e foram à procura das crianças no meio da mata. No outro dia, conseguiram encontrar. Muitos acreditam que foi o duende que apareceu e os levou para a floresta. Desde então, as famílias cuidam para que seus filhos não andem sozinhos e nem se afastem com medo que o duende os leve.

\section{Narrativa 3 - A moça que foi levada pelo duende}

Certa vez, existia uma família que criava sua única filha formosa que sempre gostava de brincar e falar sozinha. Os pais 
não se importavam com a situação, até que um dia ela veio em direção a eles e disse:

- Mãe eu tenho um amiguinho que sempre me acompanha e que gosta muito de conversar comigo.

A mãe pergunta: - Cadê eu não estou vendo nada? - E a manda ir para o quarto.

O tempo passou e os pais foram trabalhar no campo levando a menina junto, eles não perceberam em que momento a filha desapareceu. Os dias passam, e só após seis dias acabam encontrando a menina muito debilitada. Os pais muito aflitos perguntam o que aconteceu, ela diz que seguiu o amiguinho duende e que era ele quem lhe dava de comer todos os dias. A menina ficou muito doente e transtornada e três dias depois faleceu. Todos acreditam que foi o duende que veio buscar o espírito dela.

\section{Narrativa 4 - Casa mal-assombrada}

Um menino morava com sua família na comunidade de San Roque e sempre gostou de caçar na Floresta. Certa noite, ele convida um amigo para ir caçar juntos, durante a caminhada, eles escutam alguém gritando, os dois ficam desconfiados com aqueles gritos e se sentam no tronco de uma árvore, o companheiro do menino disse que não era nada e deduz que é um canto de um pardal.

Decidiram se aproximar para verificar de onde vem aquele grito, quanto mais eles se aproximavam, mais os gritos aumentavam com rouquidão, quando de repente se deparam com uma casa abandonada perto de um riacho. Avistaram de longe algo estranho e muito feio que sacudia os pés tentando cruzar o riacho. Os dois ficaram com muito medo e saíram correndo sem olhar para trás. 
No outro dia, eles voltaram levando outros amigos, mas não encontraram ninguém, contudo viram algumas pisadas em formato estranho e arranhões na porta. Vendo isso, outros meninos afirmaram que já tinham ouvido os mesmos barulhos e disseram que a casa é mal-assombrada, pois é rodeada de demônios e espíritos malignos.

\section{Narrativa 5 - Os meninos que viraram passarinhos}

Existia uma mulher solteira que tinha dois filhos. Essa mulher conheceu um homem que queria casar com ela, mas não aceitava os filhos que ela tinha. Então ele disse a ela que só casaria, se ela abandonasse os filhos. Ela pegou seus dois filhos e os levou até o monte, onde os abandonou, deixando-os sozinhos, retornando para casa, e assim, pôde se casar com o homem que ela amava.

Os dois meninos tentaram voltar para casa, mas não encontraram uma forma de sair dali. Foi então que apareceu a Virgem Maria e os transformou em passarinhos, 'UARRORRO', e os nomeou de João e Juan e assim eles voaram, voaram, voaram.

\section{Narrativa 6 - $O$ espírito da vovó}

Em uma certa hora que todo mundo está dormindo, escutase uma pessoa galopando em um cavalo pelas redondezas da comunidade, os cachorros ficam latindo eufóricos. Escuta-se como se uma pessoa descesse do cavalo colocando os pés bem firmes no chão, mas quando os moradores saem para fora para verificar o que é, não encontram nada além de nada.

Dizem que em uma casa, na comunidade, morava uma menina com um parente. Essa menina disse que estava se sentindo muito mal porque o espírito da sua avó estava incorporando nela. Levaram-na então para os curandeiros que existia na comunidade, 
até que ela melhorou do mal-estar. Desde então, eles escutam esse barulho na comunidade e ele se intensifica nos períodos da chuva.

\section{OS ENCANTAMENTOS DA NARRATIVA}

A realidade é tecida de uma intrínseca rede de signos (Cunha, 2009, p. 85). Desse modo vão se construindo os sentidos, considerando as relações históricas, sociais, políticas e aqui também consideradas as geográficas.

De modo sucinto, destacaremos alguns elementos das narrativas, pois, ao ouvirmos os moradores, observarmos os lugares visitados, a relação com as histórias, tivemos uma pequena possibilidade de compreender esses processos de construção, bem como os elementos contidos em cada narrativa.

A narrativa 1 A luz que vem do rio nos apresenta um elemento misterioso que é a Luz que aparece e desaparece, sendo este fato revelado e temido pelos pescadores. Nenhum dos pescadores sabe o que significa essa luz, porque ninguém se atreveu a ir lá para saber o que é e de onde ela sai. A comunidade tem muito medo dessa luz e quando as pessoas vão pescar, já levam consigo o sentimento de que qualquer sinal da luz é para irem embora, pois pode surgir uma sucuri do rio.

As narrativas $2 \mathrm{O}$ duende da floresta e 3 A moça que foi levada pelo duende apresenta um personagem comum nas histórias de todas as comunidades visitadas: $\mathrm{o}$ duende. Percebemos que para evitar que as crianças saiam para a floresta sozinhas sempre utilizam a figura do duende. As duas narrativas apresentadas revelam esse fato. Há nesse personagem mítico a mesma função que muitos outros contos de tradição apresentam, ou seja, contos populares que sugerem um certo perigo ao se afastar de casa. Esses se aproximam do que Consiglieri Pedroso, 
de acordo com Cascudo (1984, p. 259) vai classificar nos contos escritos, de história da Carochinha.

Os duendes, para alguns teóricos, são criaturas mitológicas que aparecem em várias histórias do folclore europeu. Apesar de sua origem não ser completamente conhecida, o mais provável é que os duendes tenham surgido junto com elfos, anões e outros seres obscuros em lendas da mitologia celta e escandinava, em países como Inglaterra, Noruega e Suécia. ${ }^{107}$

Na obra Breve diccionário etmológico da la lengua castelhana, de Juan Corominas, o conceito de duende assim é descrito: "espíritu travieso que se aparece fugazmente, por lo comum. "El espiritu que se cree el habita en una casa” (1987, p. 222). Muitos moradores das comunidades visitadas temem a figura do duende e afirma veementemente que já viram vários.

Na narrativa 4 Casa mal-assombrada, podemos observar traços comuns a narrativas do mesmo universo "caçar na Floresta"; "durante a caminhada, eles escutam alguém gritando"; "Avistaram de longe algo estranho"; "Os dois ficaram com muito medo e saíram correndo sem olhar para trás"; "viram algumas pisadas em formato estranho e arranhões na porta". Nessa narrativa, podemos ver elementos que se aproximam das histórias de lobisomem no Brasil. Não há nelas figuratividade de lições de moral para a comunidade, mas sua função, conforme observamos, é para amedrontar, prender a atenção de quem está ouvindo e é uma história para ser contada à noite.

$\mathrm{Na}$ narrativa 5 Os meninos que viraram passarinhos podemos identificar a figura da Virgem Maria, o que aproxima a história dos contos de encantamento, que conforme nos esclarece

107 Disponível em: <https://super.abril.com.br/mundo-estranho/o-que-saoduendes/>. Acesso em: 20 dez. 2020. 
Cascudo (1984, p. 263) "a personalização do velho e da velha se materializam sempre os extremos espirituais. É o bruxo, a feiticeira ou Nossa Senhora”. Na narrativa, os meninos, rejeitados pela mãe, são abandonados e por intervenção da mãe de Jesus, Virgem Maria, eles viram pássaros. Devido a essa narrativa, os passarinhos são denominados 'UARRORRO' pelos moradores da comunidade e se tornaram sagrados.

No dicionário de La Lengua Castellana, de Dr. Rodolfo Oros, (p. 72), não nos é apresentada a palavra 'UARRORRO', todavia aparece "arrorró" que significa "canciona de cuna" ou seja canção de ninar. Há várias versões de canções de ninar nas quais aparecem Arrorró, como nos apresenta Cerrilo Torremocha (2005, p. 53)

Arrorró mi nene/Arrorró mi sol/Arrorró pedazo/De mi corazón (Versão espanhola);

Arrorró mi niño/Arrorró mi sol/Arrorró pedazo/De mi corazón (Versão mexicana);

Arrorró, arrorró/a mi ninõ duermo yo/ pero él no me quiere oir/y yo me quiero dormir/arrorró, arrorró/mi niño ya se durmió (Versão colombiana).

Diante dessa constatação, podemos associar essa narrativa a relações singelas, sublimes e que acontecem no campo da maternidade, já que, esse pássaro aparece nas cantigas de ninar dos países acimas citados que tem como aproximação a língua castelhana.

Na Narrativa 6 O espírito da vovó também encontramos a mesma ocorrência do conto 4 , há um mistério sombrio em torno da narrativa. $\mathrm{O}$ espírito de uma velha, na narrativa denominada vovó, assusta as pessoas na comunidade. Podemos perceber que ela chega montada a um cavalo, pois se ouve as patas do cavalo a galopar pela comunidade e isso ocorre na época das chuvas, época 
em que eles têm que ficar em casa, trancados, pois não podem sair. Então, junto com o barulho da chuva na mata, do vento, da sensação de que as águas estão subindo, tem-se a intuição de que o espírito da vovó está ali rondando a comunidade.

Esse espírito é atribuído a uma pessoa que não pertence à comunidade, conforme podemos observar na narrativa: "Diz-se que em uma casa na comunidade morava uma menina com um parente. Essa menina disse que estava se sentindo muito mal porque o espírito da sua avó estava incorporado nela”. Outro fato a ser considerado na narrativa é o aparecimento da figura do curandeiro que, em poucas narrativas aparecem, "Levaram-na então para os curandeiros que existia na comunidade, até que ela melhorou do mal-estar".

Essas narrativas abrangem vários elementos do maravilhoso, fantástico que são carregados de simbologias para cada comunidade. Tais histórias contribuem para agregação de sentidos na memória coletiva desses lugares, frutos de uma tradição oral, que transmite valores relacionados aos aprendizados do cotidiano e que como afirma Bâ (1982) não são aprendizados sistemáticos, mas "ligados às circunstâncias da vida" e que ficam gravados profundamente nas memórias de quem as ouve.

\section{CONSIDERAÇÕES}

A fronteira Brasil/Bolívia no Mamoré apresenta, como em outras fronteiras dos países latino-americanos características plurais em decorrência das diversas influências étnico-culturais. Assim, as narrativas registradas estabelecem relação com as demais já conhecidas por outros povos.

As histórias são delineadas pelos embates entre o real/irreal, verdade/ilusão e tendem a transitar pelo campo 
metafórico de mensagens subliminares dentro das comunidades, alicerçando-as a compreender e transmitir o conceito de coletivo que subjaz na consciência e memória afetiva dos povos.

Podemos destacar a figura de quem narra as histórias da comunidade, bem como seu domínio do fio da narrativa e o encantamento que se provoca aos que ouvem. Há na linguagem simples do cotidiano, no movimento, na verdade que se transpõe ao enredo, uma magia que emoldura as cenas.

Vale salientar que nos apresentaram um amplo repertório de narrativas, que podemos afirmar que ainda está à mercê de registros, considerando a frágil produção e registro da literatura na fronteira Brasil/Bolívia do Mamoré.

Percebemos, nessas narrativas dos ribeirinhos da fronteira Brasil-Bolívia do Mamoré produções constituídas de sentidos próprios, nas quais símbolos e imagens traduzem um modo de ser, agir e re (existir) nesses espaços.

Essas histórias são parte de um patrimônio imaterial desses povos que refletem uma forma de se articular com o mundo ao seu redor: os mistérios das águas, da floresta, da noite e por meio delas conseguem transpor um mundo de magia e encantamento revelando uma identidade ribeirinha e que, ao mesmo tempo, está interligada a um espaço transitório de chegadas e partidas de memórias, histórias e culturas que navegam pelas águas do rio.

\section{REFERÊNCIAS}

ALMEIDA, Maria Inês de; QUEIROZ, Sônia. Na captura da voz as edições das narrativas orais no Brasil. Belo Horizonte: Autêntica, 2004.

AUGEL, Moema Parente. Abdulai Sila: uma visão crítica de Guimé Bissal. In: SECCO, Carmen Tindó; SEPÚLVEDA, Maria do Carmo; 
SALGADO, Maria Teresa. África $\boldsymbol{E}$ Brasil: letras em laço. Vol. São Caetano do Sul: Yendis, 2010.

BÂ, Amadou Hampâté. A tradição vida. In: Ki-zerbo, Joseph (org.) Histórias da África. São Paulo: Ática; Paris; Unesco, 1982.

BARBOSA, Joaquim Onésimo Ferreira. Narrativas orais: performance e memória. Dissertação. Manaus: UFAM, 2011. 143 f.; il. color. Disponível em: <https://tede.ufam.edu.br/bitstream/ tede $/ 2340 / 1 /$ Disserta $\% C 3 \% A 7 \% C 3 \% A 30 \% 20-\% 20 J o a q u i m \%$ 20On\%C3\%A9simo\%20Ferreira\%20Barbosa.pdf >. Acesso em: 22 dez. 2020.

BOSI, Ecléa. Memória e Sociedade. Lembrança de velhos. 14. ed. São Paulo: Companhia das Letras, 1994.

BUSSATO, C. Contar e encantar: pequenos segredos da narrativa. 5. ed. Petrópolis: Vozes, 2008.

CANDIDO, Antonio. Literatura e cultura de 1900 a 1945. In: . Literatura e sociedade. 5. ed. Rio de Janeiro: Ed. Nacional, 1980. p. 109-138.

CASCUDO, Luis da Camara. Literatura oral no Brasil. 3.ed. Belo Horizonte: Itatiaia, 1984.

- Dicionário do folclore brasileiro. Rio de janeiro: Publicação S/A. CEJUP, 1995.

CERRILLO TORREMOCHA, Pedro C. La voz da la memória: estudio sobre él cancioneiro popular infantil - Cuenca. Ediciones de la universidade de Castilla - La Mancha, 2005.

CHARTIER, R.; CAVALLO, G. História da leitura no mundo ocidental. São Paulo: Ática, 1998. 
COROMINAS, Juan. Breve diccionário da la lengua castellana. Madri: Gredos S\&A, 1987.

CUNHA, Maria Zilda da. Na tessitura dos signos contemporâneos: novos olhares para a literatura infantil e juvenil. São Paulo: Humanitas, 2009.

DAVID, Ricardo Santos. A literatura entre fronteiras: um estudo pela perspectiva semiótica de greimas. Disponível em: $<$ http://erevista.unioeste.br/index.php/linguaseletras/article/view/1692 9>. Acesso em: 20 dez. 2020.

DIEGUES, Antônio Carlos. Água e cultura nas populações tradicionais brasileiras. <http://nupaub.fflch.usp.br/sites/ nupaub.fflch.usp.br/files/color/simbolagua.pdf $>$. Acesso em: 20 de fev. 2019.

HELLER, Agnes. Uma teoria da história. Tradução Dilson Bento de Faria Ferreira Lima. Rio de Janeiro: Civilização Brasileira, 1993.

KUPSTAS, Márcia. Literatura, arte e cultura. São Paulo: Ática, 1988.

LOUREIRO, João de Jesus. A cultura amazônica: uma poética do imaginário. Belém: Cejup, 1994

. Mundamazônico: do local ao global. Revista Sentidos da Cultura, Belém-Pará. v.1.n. 1. Jul-dez/2014.

LOUREIRO, Violenta Refkalesfky. Amazônia: estado-homemnatureza. Belém: Cejup, 1992.

LIMA, Abnael Machado. Pequeno ensaio sobre as lendas e folclore de Rondônia. Porto Velho: Fundação Cultural de Rondônia, 1987. 
MOISÉS, M. Dicionário de termos literários. São Paulo: Cultrix, 1978.

OROZ, Rodolfo. Diccionario de la lengua castellana. 10. ed. Santiago do Chile: Editorial Universitária, 2005.

PORTELLI, A. Tentando aprender um pouquinho: algumas reflexões sobre a ética na história oral. Projeto História. São Paulo, 1997. 


\title{
O FEMININO NA OBRA NIKETCHE: UMA HISTÓRIA DE poligamia, de Paulina Chiziane
}

\author{
Jéssica Vivilane Pereira Freitas ${ }^{108}$ \\ Maria Viviane Pereira Freitas ${ }^{109}$ \\ Lisiane Oliveira e Lima Luiz ${ }^{110}$
}

\section{INTRODUÇÃo}

Abordar questões sobre a figura feminina foi e continua sendo um complexo campo em discussão, longe de ser solucionado, uma vez que a própria sociedade ao longo dos anos por meio do seu discurso contribuiu de forma direta ou indireta na disseminação de um pensamento machista perante o papel da mulher na sociedade, visto como natural, sendo repassado de geração a geração.

Ratificando a ideia de que a mulher era notada socialmente por meio do espaço familiar, filhos, marido e os afazeres domésticos, ou seja, não tinha o direito de expressão e muito

${ }^{108}$ Graduada em Letras Português e suas respectivas literaturas pela Fundação Universidade Federal de Rondônia, campus de Guajará-Mirim.

${ }^{109}$ Graduada em Letras Português e suas respectivas literaturas pela Fundação Universidade Federal de Rondônia, campus de Guajará-Mirim.

110 Doutoranda em Estudos Literários pela Unemat. Mestre em Estudos Literários pela Fundação Universidade Federal de Rondônia. Graduada em Letras pela Fundação Universidade Federal de Rondônia. Membro do Grupo de Pesquisa Literaturas de Língua Portuguesa (Lilipo), do Grupo de Estudos Teóricos e Literários (Gestelit) e do Grupo de Pesquisa em Poesia Contemporânea de Autoria Feminina do Norte, do Nordeste e do Centro-Oeste do Brasil (Gepefennco).E-mail:lisiane.oliveira@unemat.br 
menos de realização dos seus desejos pessoais, fazendo com que a mulher ocupasse um papel restrito ao lar. Porém, embora a figura feminina tenha assumido um papel secundário aos olhos da sociedade, aos poucos as mulheres foram tecendo forças para lidar com a submissão na qual eram diariamente expostas não só pelo marido, mas também pela sociedade.

Em geral, a literatura em sua amplitude é uma das áreas das ciências humanas que tem muito a contribuir para o campo de pesquisas tendo-se como objeto de estudo as produções literárias, junto às quais nos deparamos com elementos imaginários e reais envolvendo os escritores, que se adaptam aos mesmos de acordo com a sua subjetividade, tornando um texto um produto enriquecedor, tomados não apenas como uma narrativa, mas uma manifestação de sentimentos, emoções, angústias, conflitos e, sobretudo, insatisfação social e, muitas vezes, políticas; problemas esses fazendo surgir a literatura como uma fonte de expressão e denúncia.

A literatura, por si só, não tem existência, precisando de um público que se veja nos textos que são produzidos o retrato da sua própria vida. Assim sendo, por mais que a mesma seja identificada acentuadamente pelo lado da ficção do que realisticamente, faz referência ao cotidiano de muitas pessoas em situações que já viveram ou pela qual estão passando, desvelando um mundo que se encontra com outros de uma maneira dinâmica.

Trabalhar Literaturas Africanas de Língua Portuguesa é mostrar o grande universo literário de um povo, que ao longo do processo histórico ficou à margem da sociedade, em segundo plano e que não foi valorizado, apesar da grande riqueza cultural existente.

Ao estudarmos as Literaturas Africanas de Língua Portuguesa estamos fazendo também um resgate da história de pessoas, entre o período colonial e pós-colonial, que lutaram bravamente pela sua independência. 
A cultura africana até pouco tempo não era vista com bons olhos, notando-se apenas os aspectos negativos, em que muitos pontos eram censurados ou nem mencionados. Mas, os estudos literários que se debruçam sobre a cultura e a literatura africana as tornam mais relevantes face às demais. O povo africano (ou os povos que compõem o continente africano) tem muito a nos ensinar a partir de suas histórias de lutas, principalmente na busca pela emancipação política e social, na qual a participação da mulher era mínima e no universo literário praticamente escasso.

Nesse sentido, destacar a obra de Paulina Chiziane, uma literatura moçambicana é enfatizar a luta pela valorização de uma cultura e uma voz feminina, que não tinha liberdade de expressão, em uma sociedade machista na qual o homem ditava as regras e a mulher apenas obedecia.

Destacar a cultura moçambicana é trazer à tona a realidade vivenciada pelos povos de Moçambique, que tiveram um longo período marcado por lutas amarguras, intensos sofrimentos, o que fez com que a vida dos indivíduos fosse movida por uma incessante busca pelo reconhecimento.

Desse modo, a relevância de se trabalhar o feminino com ênfase na obra de Paulina Chiziane, escritora moçambicana, remete tanto a uma importância social como pessoal. No campo social esta temática estimula o pensamento crítico e reflexivo, pois falar sobre a questão feminina gera questionamentos, pois ainda se evidenciam os discursos e práticas machistas, como na frase: "lugar da mulher é dentro de casa cuidando dos filhos e do marido", ou "a obrigação da mulher é cuidar da boa educação dos filhos e mediar o sucesso profissional do marido". O desenvolvimento destas temáticas faz com que a própria mulher passe a refletir a sua própria existência de uma forma mais consistente.

No campo pessoal, a oportunidade de debater assuntos como estes, que promovem socialmente muitos questionamentos, 
nos faz conhecer um pouco mais sobre o percurso histórico das mulheres africanas e suas conquistas.

A pesquisa foi subsidiada pelas teóricas Rocha-Coutinho (1994) e Perrot (2008), em especial, que deram suporte no decorrer do desenvolvimento do trabalho. Na obra destas autoras destaca-se a figura feminina e suas histórias vivenciadas ao longo dos séculos. Há uma questão a investigar nesta pesquisa é: como são abordadas as várias questões sociais vivenciadas em Moçambique com ênfase na subalternidade feminina no livro de Paulina Chiziane Niketche: uma história de poligamia? A relevância desta obra na primeira mulher a escrever um romance, em uma época em que praticamente não havia mulheres no universo literário.

Assim sendo, o trabalho pretende investigar as contribuições dessa obra para a vida das pessoas, em especial das mulheres, e para o campo da Literatura Africana, norteada pelos seguintes objetivos específicos: conhecer o percurso histórico da autora Paulina Chiziane, identificar a forma como a mulher era tratada na sociedade/cultura moçambicana e refletir sobre a condição da mulher por meio da referida obra.

\section{BREVE BIOGRAFIA DA ESCRITORA PAULINA CHIZIANE}

Paulina Chiziane, de origem camponesa, nasceu no dia 14 de junho de 1955, em Majancaze, província de Garza, pertencente ao sul de Moçambique. Na infância, quando criança deslocou-se para Lourenço Marques para estudar, quando passou a vivenciar em seu dia a dia as histórias relatadas pelas pessoas sobre as consequências geradas pelo colonialismo - injustiças, segregações sociais e, principalmente, exploração de toda ordem, da econômica e laboral à sexual.

Essa autora produziu quatro romances. Ela não se considera, rigorosamente, uma escritora, título que ela nega, 
definindo-se apenas como uma contadora de histórias, inspirando-se nos relatos escutados em volta de uma fogueira. Começou a percorrer pelo universo literário em 1984, com a publicação de contos, quando vivia e trabalhava na província da Zambézia (Tedesco, 2008).

Além das questões sociais abordadas em suas obras, nasce em suas narrativas outra identidade, que vai constituindo-se ao longo de quatro narrativas, a autonomia feminina, com o intuito de demostrar a insatisfação sofrida pelas mulheres devido às questões patriarcais. Porém, embora seja reconhecida por obras que têm como protagonista a mulher, deixa claro que é uma inquietação que surge de forma particular e não como um movimento feminista (Tedesco, 2008). Sobre essa questão, a escritora aponta:

Falar sobre as vivências de mundo, não significa ser feminista ou machista, escrevo aquilo que acho que preciso escrever apenas isso. Mas, quanto à condição de mulher, sinto uma emoção, que faz com que eu comece escrever até tornar-se um livro. Contudo, a maioria das pessoas define como uma escrita feminina, talvez pela simples razão da mulher não se fazer presente no universo literário (Chiziane apud Tedesco, 2008, p. 28).

Desse modo, conforme a descrição da fala da escritora Paulina Chiziane fica explicito que as suas produções têm como base as situações da vida diária das pessoas, ou seja, acontecimentos marcantes, deixando claro que suas inquietações surgem de maneira particular, escreve aquilo que toca o mais íntimo do seu ser, escrevendo em sua condição de mulher sem medo, rompendo barreiras no universo literário.

As obras de autoria de Paulina Chiziane apresentam a dualidade entre o Sul e o Norte de Moçambique. Em uma 
entrevista publicada por Juliana Gonçalves, Paulina Chiziane aponta:

Considero meu país um lugar virgem, ainda não foi escrito, o acesso à escrita é muito limitado. A nossa independência é muito recente, apenas 40 anos. E mulheres que tenham experiência e gostem de escrever ainda são poucas... A literatura é arma para desconstruir toda a mentira histórica que vem sendo reproduzida em todas as bibliotecas do mundo sobre nós, africanos (Gonçalves, 2016, p. 1).

Perante a fala da escritora no decorrer da entrevista fica explicito que a participação da mulher no espaço literário, ainda é uma questão escassa, principalmente, em Moçambique um país que recentemente viveu situações conflituosas de exploração e dominação portuguesa. $\mathrm{O}$ fato de ter se tornado escritora foi sem dúvidas uma quebra de paradigmas. As obras de Paulina Chiziane são provocativas. A mesma salienta que não é uma escritora feminista, apenas sente-se motivada a escrever sobre os acontecimentos que a rodeiam.

Essa voz provocativa trouxe à tona vivência de pessoas e a maioria histórias de mulheres, assuntos esses que até então não eram discutidos, pois não havia interesse em abordar sobre a submissão das mulheres.

\section{O CONTEXTO HISTÓRICO FEMININO}

Durante os últimos anos observou-se um elevado número de mulheres com participação na vida social, aos poucos elas vêm conquistando o seu espaço, principalmente em relação à sua carreira profissional, ocupando até mesmo cargos de grande prestígio, que até então eram ocupados apenas por homens. Porém, embora as mudanças tenham sido significativas, tendo em vista o contexto social, a desigualdade entre homens e mulheres 
faz-se muito presente, pois ainda encontram-se mulheres que ocupam as mesmas posições trabalhistas, entretanto continuam recebendo menos.

As transformações pela qual o gênero feminino tem alcançado deve uma parcela aos movimentos feministas iniciado nos Estados Unidos e em outros países, como também às pesquisas desenvolvidas ao longo do tempo que passaram a modificar o modo de pensar de muitas pessoas, surgindo dessa maneira os estudos sobre a figura da mulher. Nesse sentido, Rocha-Coutinho destaca:

No bojo destas descobertas está, ainda que de forma implícita, a rejeição da antiga ideia de que a biologia constrói homens e mulheres, isto é, de que há alguma forma de determinismo biológico funcionando no mundo e de que esta força seria a principal responsável pela diferença sexual. Os novos pesquisadores enfatizam os elementos culturais, sociais, políticos e econômicos que influenciam o comportamento social e criam padrões específicos de relações entre homens e mulheres (Rocha-Coutinho, 1994, p. 14).

As mulheres durante muito tempo estavam restritamente limitadas ao espaço familiar, símbolo de mulher perfeita, tendo função de administrar todos os trabalhos domésticos e a plena educação dos filhos e o zelo ao marido. Conforme RochaCoutinho (1994, p. 19): "Nem vítimas, nem algozes, acreditamos que as mulheres ao longo dos anos foram tecendo modos de resistência a esta opressão masculina, formas de exercer um certo controle sobre suas vidas a despeito de uma situação social tão adversa". Compreende-se assim, que a mulher no decorrer da história aos poucos foram criando, tecendo a sua história e formas de resistência. 
De acordo com a obra de Coutinho Minha História das Mulheres (1994) a submissão feminina se dá devido alguns fatores entre os quais podemos elencar três pontos: $O$ primeiro ponto é a tradição patriarcal, em que coloca as mulheres sob a sombra do homem. A mulher casada dependia do marido, quando solteira vivia sob as ordens do pai, tal situação atrelada, principalmente por discursos disseminados pela própria sociedade, que ao longo dos anos criou estereótipos tanto em relação ao homem, quanto para a mulher, na qual o homem principal membro da família deveria trabalhar fora para sustentar os filhos e a esposa, enquanto a mulher deveria zelar pelos cuidados domésticos, suprindo as necessidades dos filhos e do esposo, uma figura amorosa, sensível e delicada.

Aos homens passa a caber o espaço público da produção, das grandes decisões e do poder, e às mulheres é, então, atribuída a responsabilidade da reprodução, em todas as suas formas, no seio da família. Seu trabalho como "reprodutora é naturalizado e à mulher passa a caber a execução e a supervisão de uma série de tarefas conhecidas como "trabalho doméstico" que se realizam no âmbito da unidade familiar (Rocha-Coutinho, 1994, p. 32-33).

De maneira geral durante esse período a separação entre homens e mulheres era notavelmente marcante, a figura feminina tendo como prioridade o espaço doméstico e para o homem sua carreira profissional bem-sucedida.

O segundo ponto é a condição biológica, pois a própria condição de ser mulher fez com que desde sempre a mulher fosse vista como reprodutora, instruída desde cedo para ser uma boa mãe e dona de casa, responsável pelo desenvolvimento integral dos filhos. Dessa forma, a mulher não podia realizar-se pessoalmente, por exemplo, se tivesse interesse em fazer um curso 
superior, podia estudar, no entanto, até o momento que não fosse casada, pois após o casamento a mulher era praticamente obrigada a abandonar os estudos para cuidar do filho e do esposo, como podemos observar no trecho abaixo:

A educação das meninas permaneceu por longo tempo atrasada com relação aos meninos. Uma vez que a ela era destinado o papel de mãe e esposa, a menina tinha acesso quase que unicamente ao ensino elementar. Até mesmo com relação a leitura e escrita, de acordo com Luccok (1820), o ensino para as mulheres "não devia ir além de orações, porque seria inútil para mulher, nem tão pouco deveriam elas escrever, como era sabiamente ressaltado, a fim de que não fizessem um mau uso da arte (Rocha-Coutinho, 1994, p. 79).

Como nota-se, o fato de ser mulher fez com que sempre fosse preparada da melhor forma possível para o casamento, toda a sua educação era baseada em instruções domésticas, privando a sua participação social, nem era relevante para uma mulher seguir uma carreira nos estudos, já que só era bem-vista por meio do casamento, mulheres escritoras mal se ouvia falar.

O último ponto destacado pela teórica é a dependência financeira, pois a condição de não poder exercer uma participação no espaço público, ou seja, fora de casa, enfatizava cada vez mais uma dependência, pois durante anos, uma mulher que fosse trabalhar fora do espaço doméstico não era vista com bons olhos pela sociedade, sendo que o objetivo era contribuir para o sucesso do marido.

Em geral, a história da figura feminina perpassa por uma ideologia maçante da mulher como um símbolo da perfeição devendo ser sempre obediente, opinando apenas no ambiente familiar, não havia uma preocupação com a carreira profissional 
feminina, cuidar da família era suficiente para que a mulher se sentisse realizada.

\section{A SUbMisSÃo FEMININA VIVENCIADA PELA PERSONAGEM RAMI NA NARRATIVA NIKETCHE: UMA HISTÓRIA DE POLIGAMIA}

Romance narrado em primeira pessoa, se passa entre o Norte e o Sul de Moçambique, história vivida pela protagonista Rosa Maria conhecida como Rami, que vive o drama da poligamia. Rami durante muitos anos não havia dado importância para os namoricos do marido, vivido pelo personagem Tony, mas após assumir a posição de chefia de uma delegacia, a história tomou novos rumos, pois Tony raramente aparecia em casa, e quando aparecia não dava atenção nem para a mulher e nem para os seus cinco filhos.

Diante de tal situação, Rami decide questionar sobre o comportamento do marido, que reage sempre de forma ríspida. Então, ela resolve procurar as concubinas do esposo, conhecidas pelos seguintes nomes: Julieta, Luísa, Mauá e Saly. Ao encontrálas foi praticamente agredida por todas, por tomar satisfação, saindo fisicamente e moralmente deprimida, pois tentava entender o que havia nelas que fazia com que Tony a deixasse abandonada, solitária, na mais profunda tristeza. Mas, ao longo da história Rami vai aproximando-se de cada uma, mesmo com mágoas e com o sentimento da traição passa a conhecer a vida de cada uma delas.

A primeira era Julieta (monumento de erro e perdão), foi a amante que Tony mais enganou, conheceu-a bem jovem, dizia ser um homem solteiro e no decorrer desse tempo Julieta estava no quinto filho. Luísa era a terceira, uma beleza que resplandecia, a mais desejada por Tony. Saly boa de cozinha e por último a recém- 
conquistada Mauá, a franguinha. Após encontrar todas as amantes, Rami resolve mostrar publicamente os casos do marido no dia em que ele completaria 50 anos, reunindo todas as mulheres com as mesmas vestimentas, assim como os filhos. Tony sentiu-se afrontado pela revelação em público. Rami mesmo movida pelo sentimento da traição conquista a confiança de cada uma, considerada como a rainha mãe, a primeira esposa, passa a determinar os dias da semana em que Tony faria companhia a cada uma e a maneira como deveriam cuidar dele.

Com tal situação, Rami encontra forças e passa a ser uma grande estimuladora na transformação da vida dessas mulheres que viviam submissas pela falta de condições financeiras, pois estavam com Tony não por amor e sim pela sobrevivência, porque a maioria delas vieram de situações cruéis como: estupros, humilhações, perseguições e encontrando em Tony uma forma para sobreviver. E a partir desses relatos, Rami incentiva cada uma a reconstruir sua vida, conquistando sua independência financeira. Desse modo, cada uma começou a buscar novos caminhos, uma começou a vender roupas, a outra vinhos, e assim aos poucos foram tornando-se independentes e Tony ficando em segundo plano. Todas seguiram um outro destino. Rami permanece, mas somente no final da História liberta-se do sentimento que tinha pelo marido. Tony reconhece que Rami era a única que o amava, mas que pelos acontecimentos já não acreditava em mais nada que ele falasse, terminando Tony em profunda solidão.

Uma das primeiras passagens da obra que marca a submissão e a dependência da mulher, é quando o filho de Rami, vivido pelo personagem Bentinho, brincando na rua da sua casa derruba uma fruta no carro do vizinho. É justamente nesse momento que Rami dá-se conta da falta tão marcante do marido quando tem que dar explicações ao dono do carro, pois a voz da 
mulher não tinha validade como a do homem, sendo evidenciado no fragmento abaixo:

Deixo o Bentinho e vou à rua. O proprietário do carro está bravo como uma fera. Esperava que ele me esmagasse, mas nem piou. É daqueles que falam fino e não agridem as mulheres. Aproximo-me e peço perdão em nome do meu filho. Digo-lhe que o meu marido, o Dr. Tony, comandante da polícia, irá resolver o problema. Ele diz que sim, mas sinto que não acredita em mim. Qual é o homem de bem que acredita nas palavras de uma mulher desesperada? (Chiziane, 2004, p. 11-12).

Diante de tal fragmento, percebe-se a falta da expressão feminina em meio a um cenário, quase que totalmente patriarcal, mulheres essas que se casavam e ficavam sob as rédeas do controle do esposo. É a partir do acontecimento e do relato de outras mulheres que tentam consolá-la, queixando-se da mesma questão, o abandono do marido, uns que partiram e não mais retornaram e outros que deixaram suas esposas por outras concubinas mais jovens. E nesse vai e vem de lamentações, Rami começa a refletir sobre os seus vinte anos de casamento e dos quais apenas dois foi em harmonia, da menina bela e charmosa que foi apagando-se com o passar do tempo pela angústia e decepção, ocasionada pelo tratamento do marido, como aponta:

Não consigo aceitar a ideia de ser rejeitada. Eu, Rami, mulher bela, Eu, mulher inteligente. Fui amada. Disputada por vários jovens do meu tempo. Causei paixões incendiárias. De todos os que me pretenderam escolhi o Tony, o pior de todos, que na altura julgava ser o melhor. Vivi apenas dois anos de felicidade completa num total de vinte e tantos anos de casamento (Chiziane, 2004, p. 14).

Registros históricos denotam que a mulher era ideologicamente vista à margem do seu marido, ou seja, sua 
identidade existia mediante a existência masculina, pela criação dos filhos e pelos cuidados com lar, fora isso ela era pouco notada, sua existência era medida pelo esposo, negando o seu próprio ser. De acordo com o processo histórico não havia para a mulher o direito à liberdade pessoal, profissional, sexual, totalmente privada dos prazeres da vida, anulava a si própria para satisfazer as necessidades da família e principalmente do marido. Podemos evidenciar tal ideologia na narrativa de Paulina Chiziane:

Obedecer, sempre obedeci. As suas vontades sempre fiz. Dele sempre cuidei. Até as suas loucuras suportei. Vinte anos de casamento é um recorde nos tempos que correm. Modéstia à parte, sou a mulher mais perfeita do mundo. Fiz dele o homem que é. Dei-lhe amor, dei-lhe filhos com que ele se firmou nesta vida. Sacrifiquei os meus sonhos pelos sonhos dele. Dei-lhe a minha juventude, a minha vida. Por isso afirmo e reafirmo, mulher como eu, na sua vida, não há nenhuma! Mesmo assim, sou a mulher mais infeliz do mundo. Desde que ele subiu de posto para comandante da polícia e o dinheiro começou a encher as algibeiras, a infelicidade entrou nesta casa. Os seus antigos namoricos eram como chuvas miúdas caindo sobre os guarda-chuvas, não me atingiam (Chiziane, 2004, p. 14).

Nesse sentido, a mulher tinha como papel fundamental satisfazer as necessidades do cônjuge, no geral de toda a família, enquanto a sua identidade feminina ficava a mercê de uma sociedade totalmente patriarcal, que defendia o homem como membro principal do lar, que ditava todas as regras de convívio, fazendo com que a figura feminina tivesse um espaço muito restrito, uma verdadeira anulação, não havia na mulher quase nenhum tipo de realização, viviam em função dos outros, ideia embutida por uma sociedade patriarcal, que disseminou ao longo do tempo uma visão muito pejorativa em relação à mulher. 
Enquanto ao homem cabem todos os privilégios da vida, inclusive sexuais como demostra na obra, em que o personagem polígamo Tony mantém relações extraconjugais com outras mulheres, pois conforme a sociedade patriarcal de Moçambique, quanto mais mulheres um homem possuía mais prestígio social adquiria:

O coração do meu Tony é uma constelação de cinco pontos. Um pentágono. Eu Rami, sou a primeiradama, a rainha mãe. Depois vem a Julieta, a enganada, ocupando o posto de segunda dama. Segue-se a Luísa, a desejada, no lugar de segunda dama. A Saly, a apetecida, é a quarta. Finalmente a Mauá Sualé, a amada, a caçulinha, recém-adquirida. O nosso lar é um polígono de seis pontos. É polígamo. Um hexágono amoroso (Chiziane, 2004, p. 58).

Como se vê, diferentemente da mulher, o homem podia ter uma vida sexual extraconjugal, sem cobranças, como elenca Rocha-Coutinho na citação abaixo:

O homem, ao contrário da mulher, devia ter agitada vida sexual antes do casamento, mantendo relações que, na maioria das vezes, continuavam após a união conjugal, geralmente com mulheres das camadas sociais pobres (escravas, empregadas, prostitutas). Ao marido era não só permitida, mas também muitas vezes incentivada pelo modo vedado-como forma de reforçar sua virilidade perante a sociedade-, a manutenção de amantes eventuais e fixas, prática que ainda permanece em alguns lugares do Brasil, especialmente no interior (Rocha-Coutinho, 1994, p. 86).

Em consonância com a teórica Rocha-Coutinho verifica-se o machismo e a dominação masculina sob a mulher, tudo permitido ao homem e quase nada a mulher, enquanto saíam em busca de outros romances, a figura feminina deveria estar em casa 
cuidando dos filhos e dos afazeres domésticos, assim acontece na narrativa. Rami, uma excelente esposa, dedicada ao lar e aos filhos, casou-se seguindo os preceitos religiosos, porém após cinco anos de casamento, começou a notar a ausência do marido que mal aparecia em casa, e quando estava, era por pouco tempo, mantinha relações com outras mulheres, gerando outras famílias.

Na visão do personagem Tony era uma prática normal ter várias concubinas e a mulher deveria servi-lo da melhor maneira possível, como podemos evidenciar no trecho abaixo:

Devem servir o vosso marido de joelhos, como a lei manda. Nunca servi-lo na panela, mas sempre em pratos. Ele não pode tocar na loiça nem entrar na cozinha. Quando servirem a galinha, não se esqueçam das regras. Aos homens se servem os melhores nacos: as coxas, o peito, a moela. Quando servirem carne de vaca, são para ele os bifes, os ossos gordos com tutano. É preciso investir nele, tanto no amor como na comida. $\mathrm{O}$ seu prato deve ser o mais cheio e o mais completo, para ganhar mais forças e produzir filhos de boa saúde, pois sem ele a família não existe (Chiziane, 2004, p126).

Podemos evidenciar neste fragmento que em tudo a mulher ficava em segundo plano, vivia praticamente a serviço do marido, inteiramente à disposição em todo momento que precisasse, suas vontades como mulher não existiam, até os melhores pratos como vimos era destinado a eles, já que como mencionado na narrativa, “o cabeça da família”, portanto, deveria alimentar-se bem e para mulheres sobravam os ossos. A mulher como a própria obra enfatiza era privada de quase todas as questões sociais:

Nas nossas tradições as mulheres não têm direito a voto; de resto, na aristocracia não se vota, mas as mulheres adquirem algum estatuto. Só ganha estatuto 
aquela que sabe partilhar o marido, que ultrapassou ciúme, que preserva os valores da tradição, que cumpre tudo o que a lei manda. Ganha muito mais prestígio aquela que sugere ao marido um novo casamento e ajuda a escolher a nova esposa (Chiziane, 2004, p. 131).

Fica nítido que a mulher até alguns anos não tinha direito de participação nas questões sociais, restrita ao espaço familiar, não tinha o direito de opinar, literalmente submissa às decisões tomadas pelo marido, sem voz e nem vez.

Por acaso temos direito à palavra? E por mais que a tivéssemos, de que valeria? Voz de mulher serve para embalar as crianças ao anoitecer. Palavra de mulher não merece crédito. Aqui no sul, os jovens iniciados aprendem a lição: confiar numa mulher é vender a tua alma. Mulher deve ouvir, cumprir, obedecer (Chiziane, 2004, p. 154).

As mulheres retratadas na história demostram uma insatisfação de ter que viver supervisionada pela sociedade e principalmente pelo marido, pois não podiam demostrar um ser insatisfeito, sua palavra não tinha credibilidade, em suma não eram ouvidas, nessa linhagem de pensamento Rocha-Coutinho ressalta:

Às mulheres caberia, o comando da casa e a educação dos filhos, atividades que deveriam exercer com perfeição: uma casa limpa e bem arrumada e filhos bem-educados davam um status todo especial. Dela também dependia, em grande parte, como vimos o sucesso do marido. Um ditado muito comum no Brasil, por exemplo, afirma que "Por trás de um grande homem existe sempre uma grande mulher.” A atuação da mulher no mundo público deveria se dar apenas indiretamente, através dele ou, mais tarde, através do sucesso dos filhos, uma vez que seu reino era sua casa. Afinal, ela era a "rainha do lar". Além disso, sua cabeça delicada não 
deveria e não poderia se ocupar dos complicados problemas lá fora (Rocha-Coutinho, 1994, p. 103).

Nesse contexto, a manifestação da visão feminina era quase inexistente, como podemos observar na obra de Chiziane, mesmo que a mulher tentasse expor sua opinião, praticamente ninguém dava atenção, assim como a descrição de RochaCoutinho, que o sucesso delas se dava apenas no espaço familiar, ao contrário disso a mulher fora de casa não tinha voz, evitando sair até mesmo sozinha de casa, para não ser vista com maus olhos pela sociedade.

\section{CONSIDERAÇÕES FINAIS}

Ao término do estudo referente a história das mulheres com ênfase na obra "Niketche: uma história de poligamia", da escritora moçambicana Paulina Chiziane, podemos verificar que a figura feminina ao longo da história passou por um vasto processo, tanto em relação à questão social, como a própria identidade. Social, porque durante muito tempo era vista como sexo frágil e melancólico, sem vez, um ser passivo, vivendo sobre as rédeas do esposo, tendo como principal função e até mesmo como única, zelar pelo bem-estar da família. Pensamento esse se propagou pela sociedade, "lugar de mulher é dentro de casa", cuidando dos filhos e do marido, as mulheres em sua grande maioria não podiam realizar nenhuma atividade fora do espaço doméstico, apenas com a permissão do marido, principalmente as casadas, que não podiam sair de casa sem a figura do esposo, caso contrário era vista com maus olhos, sendo alvo de julgamentos.

Mulheres no universo literário eram praticamente inexistentes, não havia incentivo para as mesmas seguirem carreira, não sendo viável a mulher ter um destaque intelectual superior ao homem, o ideal era sempre a figura masculina ter 
maior destaque, uma vez que era designado pela sociedade como o cabeça da família, o grande responsável pelo sustento da família, aquele que deveria ter sucesso na vida profissional, se nada saísse como o planejado a culpa era da mulher, que também deveria ser a mediadora do bom desempenho profissional do marido, assim também ocorria com a educação dos filhos, que se algo no desenvolvimento não estava bem a culpa era da mãe.

É dessa forma que a mulher era vista pela sociedade, sua voz de comando restrita ao lar, embora a última palavra fosse sempre a do homem. Porém, sendo importante ressaltar que de forma alguma o estudo tem como meta apresentar a mulher como sendo uma vítima dessa história, até porque com o passar do tempo as mulheres foram tecendo dentro do pouco espaço algumas formas de resistência.

Com a pesquisa observou-se que a obra de Paulina Chiziane retrata bem as histórias das mulheres que eram preparadas para ser uma boa esposa e aos homens tudo era permitido, inclusive ter relacionamentos extraconjugais, o que era considerado símbolo de virilidade. Já a mulher que ousasse tal prática era condenada por toda a sociedade, pois deveria ser recatada e pura, longe de práticas vistas como pecaminosas. E nesse vasto cenário, o homem foi exercendo diversas formas de dominação, como retrata a narrativa, mulheres que eram rotineiramente violentadas, abusadas e maltratadas. Tudo deveria ser com o consentimento do marido ou do pai. As mulheres serviam apenas como reprodutoras, que deveriam dar à luz a filhos saudáveis e futuramente bem-sucedidos na vida. Isso fica evidente na história da personagem Rami que vive um eterno dilema. Após o casamento, vivia praticamente em função do marido, fazia de tudo para agradá-lo e mesmo assim foi traída. No entanto, retirou do sofrimento forças para enfrentar o marido que 
ficou demasiadamente furioso quando a sua esposa decide revelar as demais amantes para a sociedade.

Durante a narrativa identificamos que as mulheres que eram submissas ao personagem Tony submetiam-se pela falta de independência financeira. Isso fazia com que as mulheres aceitassem a condição de amante, pois suas histórias advinham de um sofrimento intenso, encontrando em Tony uma forma de sobrevivência, pois como mostra a história quando aos poucos conquistaram seu espaço, ele já não fazia mais falta sendo pouco notado, porque não mais dependiam dele para viver.

Contudo, a pesquisa de acordo com a história percorrida pela figura feminina, a narrativa e o objeto de estudo fica evidente que o pensamento machista em relação à mulher é extremamente evidente nos dias atuais, propagado até mesmo por diversas mulheres, que tomaram para si a obrigação que mesmo trabalhando fora é seu dever cuidar da casa, já que o marido trabalha muito e não pode se estressar com os afazeres domésticos. Em suma, as diversas formas de dominação feminina está longe de ser resolvida, uma vez que desde sempre se criou essa identidade para a figura feminina, lembrando que tal ideologia é uma questão social e não natural.

\section{REFERÊNCIAS}

CHIZIANE, Paulina. Niketche: uma história de poligamia. São Paulo: Companhia das Letras, 2004.

JULIANA, Gonçalves. A escrita sagrada da romancista moçambicana Paulina Chiziane. São Paulo, 21 de setembro, 2016. Disponível em: <https://brasildefato.com.br $>$. Acesso em: 25 nov. 2019. 
PERROT, Michelle. Minha história das mulheres. São Paulo: Contexto, 2008.

ROCCO, Roberto Morozzo dela. A paz: como Moçambique saiu da guerra. Ebook: <www.livrariacultura.com.br/p/ebooks/ historia/a-paz-como-mocambique-saiu-da-guerra-111764834>. Acesso em: 5 jun. 2019.

ROCHA-COUTINHO, Maria Lúcia. Tecendo por de trás dos panos: a mulher brasileira nas relações familiares. Rio de Janeiro: Rocco, 1994.

SANTILLI, Maria Aparecida. Estórias africanas. São Paulo: Ática, 1985.

TEDESCO, Maria do Carmo Ferraz. Narrativas da Moçambicanidade: os romances de Paulina Chiziane e Mia Couto e a reconfiguração da identidade nacional. Brasília, 2008. 